TEHNOLOŠKO-METALURŠKI FAKULTET

Milena G. Žuža

RAZVOJ IMOBILISANIH SISTEMA SA

PENICILIN-ACILAZOM IZ ESCHERICHIA

COLIZA DOBIJANJE POLUSINTETSKIH

PENICILINA

Doktorska disertacija

Beograd, 2012. 
UNIVERSITY OF BELGRADE

FACULTY OF TECHNOLOGY AND METALLURGY

Milena G. Žuža

\section{DEVELOPMENT OF IMMOBILIZED \\ SYSTEMS WITH PENICILLIN ACYLASE \\ FROM ESCHERICHIA COLI FOR PRODUCTION OF SEMISYNTETIC PENICILLINS}

Doctoral Dissertation

Belgrade, 2012. 


\section{MENTOR:}

Dr Zorica Knežević-Jugović, vanredni profesor,

Tehnološko-metalurški fakultet, Univerzitet u Beogradu

\section{ČLANOVI KOMISIJE:}

Dr Slavica Šiler-Marinković, redovni profesor,

Tehnološko-metalurški fakultet, Univerzitet u Beogradu

Dr Bojana Obradović, redovni profesor,

Tehnološko-metalurški fakultet, Univerzitet u Beogradu

Dr Mirjana Antov, redovni profesor, Tehnološki fakultet, Univerzitet u Novom Sadu

DATUM ODBRANE: 
Sa velikim zadovoljstvom želim da se zahvalim profesorki dr Zorici KneževićJugović, pod čijim rukovođenjem je urađen ovaj rad, na nesebičnoj pomoći, divnoj saradnji, zalaganju, sugestijama i uloženom trudu tokom izrade i pisanja disertacije.

Neizmerno hvala profesorki dr Bojani Obradović na velikoj pomoći, razumevanju, strpljenju, predlozima i podršci koji su omogućili da disertacija poprimi konačan oblik.

Profesorki dr Slavici Šiler-Marinković zahvaljujem na korisnim savetima, interesovanju i sugestijama tokom izrade ove doktorske disertacije.

Zahvaljujem se profesorki dr Mirjani Antov na plodonosnoj saradnji i savetima koji su doprineli izradi ove disertacije.

Dr Nenadu Milosaviću zahvaljujem na korisnim idejama, zalaganju, konstruktivnoj saradnji i učestvovanju u pojedinim delovima rada.

Zahvaljujem se Ministarstvu nauke za stipendiranje mojih doktorskih studija.

Mojoj porodici se zahvaljujem na bezgraničnoj podršci koju su mi pružali u toku izrade ove doktorske disertacije. 


\section{Razvoj imobilisanih sistema sa penicilin-acilazom iz Escherichia coli za dobijanje polusintetskih penicilina}

\section{Rezime}

Osnovni cilj ove doktorske disertacije je bio optimizacija postupka dobijanja 6aminopenicilanske kiseline primenom imobilisane penicilin-acilaze iz E. coli. Pri tome je razmatrana reakcija hidrolize prirodnog penicilina G do 6-APA katalizovane slobodnom i imobilisanom penicilin-acilazom. Da bi se realizovao postavljeni cilj bilo je potrebno izvršiti izbor nosača i metode za imobilizaciju enzima, optimizovati postupak imobilizacije enzima sa aspekta mase vezanog enzima i prinosa aktivnosti, okarakterisati dobijeni biokatalizator $\mathrm{i}$ ispitati razlike u kinetičkim parametrima slobodne i imobilisane penicilin-acilaze, izabrati odgovarajuće reaktorsko rešenje za izvođenje reakcije sa imobilisanim enzimima $\mathrm{i}$ ispitati operativnu stabilnost sistema.

U prvom delu rada je izvršena karakterizacija slobodne penicilin-acilaze iz Escherichia coli $\mathrm{i}$ ispitana su njena katalitička svojstva u reakciji hidrolize penicilina G kao referentnom sistemu. Ova karakterizacija je bila neophodna da bi se utvrdile razlike u delovanju slobodnog i imobilisanog enzima. U tom cilju utvrđen je sadržaj proteina u komercijalnom enzimskom preparatu, specifična aktivnost, $\mathrm{pH}$ i temperaturni profil, termalna stabilnost, kao i vrednosti kinetičkih konstanti, i to Mihaelisove konstante i maksimalne brzine reakcije. Isto tako, ispitan je uticaj inhibicije supstratom u višku i proizvodima reakcije na brzinu reakcije u sistemu sa slobodnim enzimom i u tom cilju je određena vrsta inhibicije i vrednosti konstanti inhibicije.

U drugom delu rada osnovni cilj istraživanja je bio usmeren na stabilizaciju enzima različitim postupcima. Pri tome je ispitano nekoliko postupaka hemijske imobilizacije enzima na različitim prirodnim i sintetskim polimerima (Sepabeads sa različitim funkcionalnim grupama i hitozan), kao i postupak imobilizacije prethodno hemijski modifikovanog enzima. U radu je ispitana mogućnost direktnog vezivanja penicilin-acilaze preko amino grupa u molekulu za epoksidne grupe nosača, zatim vezivanje enzima za nosač koji je prethodno aktiviran glutaraldehidom ili vezivanje 
prethodno modifikovanog enzima za nosače sa amino grupama. Hemijska modifikacija enzima je izvedena pomoću dialdehidnih derivata prirodnih polisaharida (skroba i alginata) koji su prethodno dobijeni oksidacijom perjodatnom metodom. Ovako dobijeni glikozilovani enzim se vezao za amino-nosače preko uvedenih aldehidnih grupa koje nisu od esencijalnog značaja za njegovu aktivnost.

U slučaju svih primenjenih metoda imobilizacije, dobijeni biokatalizatori su bili u potpunosti okarakterisani za primenu $\mathrm{u}$ reakciji hidrolize penicilina $\mathrm{G}$ i upoređeni sa referentnim sistemom sa slobodnim enzimom. Određene su mase vezanog enzima na nosaču, specifične aktivnosti, prinosi imobilizacije, $\mathrm{pH}$ i temperaturni profili, termalne stabilnosti i mogućnosti ponovljenih upotreba. Ispitana je i kinetika reakcije i efekti inhibicije supstratom i proizvodima reakcije penicilin-acilazom imobilisanom na hitozanskim mikročesticama i na osnovu dobijenih rezultata izveden je odgovarajući kinetički model za slobodan i imobilisan enzim.

S obzirom da je za optimizaciju enzimskog postupka hidrolize penicilina G, pored izbora nosača i metode za imobilizaciju enzima, potrebno podesiti i procesne parametre $\mathrm{i}$ način izvođenja procesa, izabrati konfiguraciju i odgovarajući režim rada bioreaktora, za penicilin-acilazu imobilisanu na hitozanske mikročestice ispitana je početna kinetika hidrolize penicilina $\mathrm{G}$ u dva reaktorska sistema: protočnom bioreaktoru sa pakovanim slojem čestica biokatalizatora i protočnom bioreaktoru sa pakovanim slojem sa recirkulacijom reakcione smeše. Na dobijene kinetičke rezultate primenjeni su različiti kinetički modeli koji uzimaju u obzir različite vrste inhibicije.

Na osnovu nekih dostupnih podataka u literaturi, može se zaključiti da je u okviru ove teze razvijeno nekoliko imobilisanih sistema sa penicilin-acilazama koji imaju istog reda veličine ili čak veću efikasnost od komercijalnih imobilisanih sistema u pogledu aktivnosti, operativne stabilnosti i prostorno-vremenskog prinosa reaktora. Time ova doktorska teza predstavlja značajan praktičan doprinos ovoj problematici. Takođe, rezultati ove teze doprinose razumevanju mehanizama i kinetike hidrolize penicilina $\mathrm{G} \mathrm{u}$ različitim sistemima sa imobilisanom penicilin-acilazom, naročito vrstama i efektima inhibicije, kao i optimizaciji konfiguracije i odgovarajućeg režima rada bioreaktora. 
Ključne reči: penicilin-acilaza, imobilizacija, Sepabeads nosači, modifikacija enzima, hitozanske mikročestice, enzimska biokataliza, kinetika, bioreaktori

Naučna oblast: Hemija i hemijska tehnologija

Uža naučna oblast: Biohemijsko inženjerstvo i biotehnologija

\section{UDK:}




\title{
Development of immobilized systems with penicillin acylase from Escherichia coli for production of semisyntetic penicillins
}

\begin{abstract}
The aim of this work was the optimization of 6-aminopenicillanic acid obtaining procedure by using immobilized penicillin acylase from E. coli. The reaction of penicillin $\mathrm{G}$ hydrolysis to 6-APA catalyzed by free and immobilized penicillin acylase was considered. In order to realize the set aim, it was necessary to make a choice of carriers and methods for immobilization of the enzyme, to optimize enzyme immobilization procedure in terms of enzyme loading and activity yield. Also, the obtained biocatalysts were characterized and the differences in kinetic parameters of free and immobilized penicillin acylase were examined. An appropriate reactor solution for performing the reaction with the immobilized enzyme and the operational stability of the system were examined.
\end{abstract}

In the first part of the thesis free penicillin acylase (PAC) from Escherichia coli was characterized and its catalytic properties were studied in the reaction of hydrolysis of penicillin $G$ as a reference system. This characterization was necessary in order to determine the differences in the activities of the free and immobilized enzyme. Therefore, the protein content in the commercial enzyme preparation, specific activity, $\mathrm{pH}$ and temperature profile, thermal stability and the values of kinetic constants (Michaelis constant and maximal reaction rate) were determined. Likewise, the inhibition of PAC activity by substrate and reaction products (6-aminopenicillanic acid and phenylacetic acid) in the system with free enzyme was studied and types of inhibition and inhibition constant values were determined.

In the second part of the thesis the research has been focused on stabilizing the enzyme by different procedures. In with this aim, several procedures of chemical immobilization of the enzyme on various natural and synthetic polymers (Sepabeads with different functional groups and chitosan), as well as immobilization of the previously chemically modified enzyme were studied. In addition, possibilities of direct binding of 
penicillin acylase by amino groups in the enzyme to the epoxy groups of the carriers, the binding of the enzyme to the carriers activated with glutaraldehyde, as well as binding of the previously modified enzyme to the carriers with amino groups were investigated. The chemical modification of the enzyme was carried out using dialdehyde derivatives of natural polysaccharides (starch and alginate) that had been previously obtained by periodate oxidation method. The modified enzyme bound to the amino carriers by introduced aldehyde groups that were not essential for its activity.

In the case of all applied immobilization methods, resulting biocatalysts were fully characterized for use in the reaction of hydrolysis of penicillin $\mathrm{G}$ and compared to the reference system with the free enzyme. In this regard, enzyme loadings on carriers, specific activities, enzyme coupling yields, $\mathrm{pH}$ and temperature profiles, thermal stabilities and possibilities of reuse were studied.

Reaction kinetics and effects of inhibition by substrate and reaction products on penicillin acylase immobilized on chitosan microbeads were studied. On the basis of the obtained results, appropriate kinetic models for the free and immobilized enzyme were derived.

In addition to the choice of carrier and immobilization method, optimization of enzymatic hydrolysis of penicillin $G$ requires determination of process parameters and the regime including the appropriate bioreactor configuration. With this aim, the initial kinetics of hydrolysis penicillin G by PAC immobilized on chitosan microbeads was studied in two reactor systems: packed-bed with and without recirculation. The obtained kinetic results were analyzed using various kinetic models that consider the different types of inhibition.

Compared to data available in the literature, it can be concluded that within this thesis were developed several systems with immobilized penicillin acylase that had the same or even higher efficiency than commercial immobilized system in terms of activity, operational stability and space-time yield of reactor. Therefore, this thesis represents a significant practical contribution to this issue. Also, the results of this thesis contribute to the understanding of mechanisms and kinetics of hydrolysis of penicillin $G$ in different systems with immobilized penicillin acylase, especially the types and effects of 
inhibition, as well as optimization of the configuration and the corresponding modes of bioreactors.

Keywords: penicillin acylase, immobilization, Sepabeads carriers, enzyme modification, chitosan microbeads, enzyme biocatalysis, kinetics, bioreactors

Scientific area: Chemistry and Chemical Technology

Major area: Biochemical Engineering and Biotechnology

\section{UDK:}




\section{SADRŽAJ}

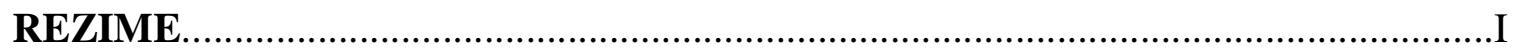

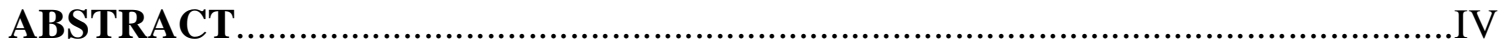

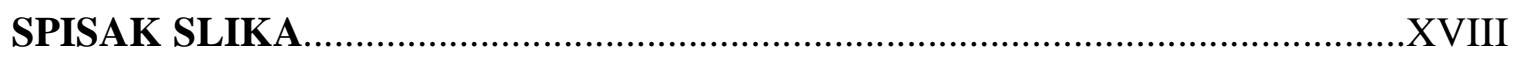

SPISAK TABELA

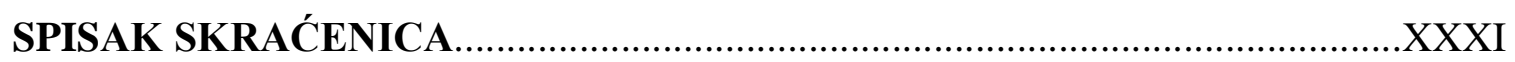

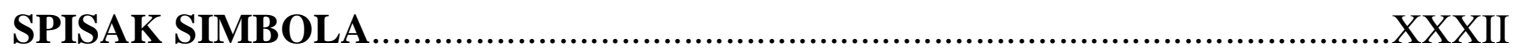

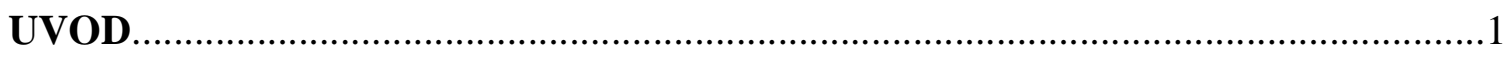

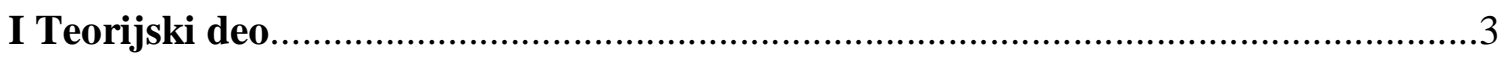

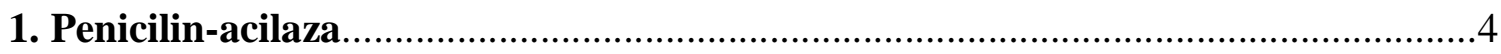

1.1. Osnovna svojstva penicilin-acilaza, poreklo i klasifikacija.........................4

1.2. Mehanizam delovanja penicilin-acilaze...................................................

1.3. Mehanizam delovanja penicilin-acilaze iz E.coli: kristalografski uvid X-

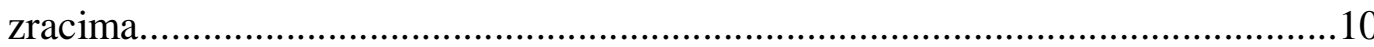

1.4. Kinetika enzimske hidrolize penicilina G............................................20

1.5. Specifičnost penicilin-acilaze prema supstratu i njena primena....................22

1.5.1. Specifičnost PAC iz Esherichia coli prema supstratu....................22

1.5.2. Specifičnost penicilin-acilaze iz Achromobacter sp. CCM 4824....24

1.6. Uticaj $\mathrm{pH}$, temperature i koncentracije supstrata na aktivnost enzima PAC..27

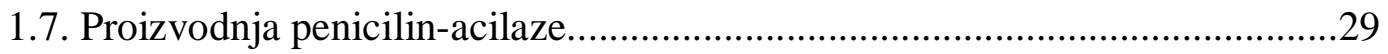

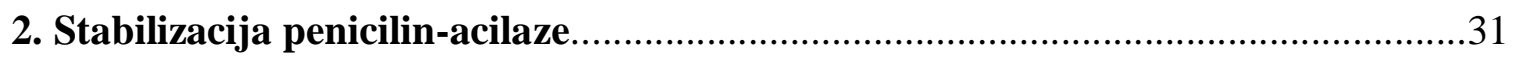

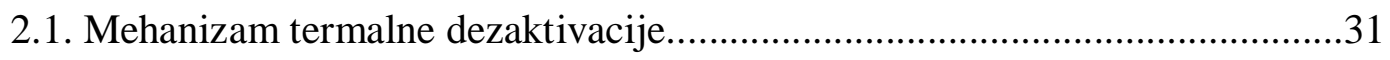

2.2. Stabilizacija penicilin-acilaze dodatkom različitih aditiva...........................33

2.3. Stabilizacija penicilin-acilaze hemijskom modifikacijom enzima.................34

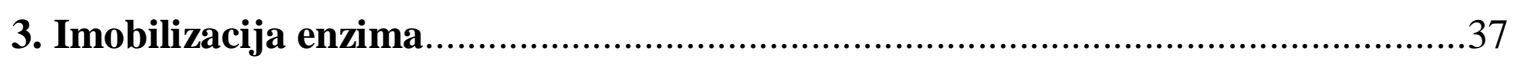

3.1. Definicija imobilizacije, razlozi zbog kojih se vrši imobilizacija...................37

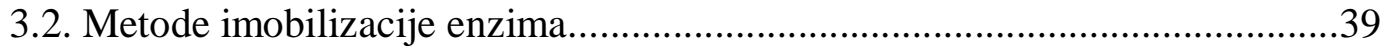




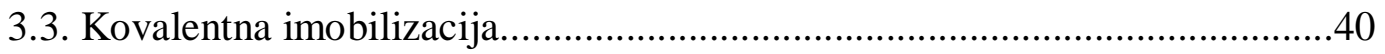

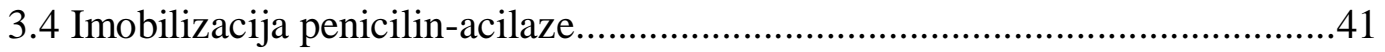

3.4.1. Eupergit $\mathrm{C}$ kao nosač za imobilizaciju enzima.................................42

3.4.1.1. Eupergit: hemijski sastav...................................................

3.4.1.2 Imobilizacija penicilin-acilaze na Eupergit.....................................43

3.4.1.3 Difuzione limitacije u Eupergitu C......................................44

3.4.2. Sepabeads kao nosač za imobilizaciju enzima...................................46

3.4.2.1. Sepabeads hemijski sastav i osnovna svojstva.......46

3.4.3. Amberlit XAD-7 kao nosač za imobilizaciju PAC............................50

3.4.4.Prirodni polisaharidi kao nosači za imobilizaciju penicilin-acilaze. 52

3.4.4.1. Agaroza kao nosač za imobilizaciju PAC.........................52

3.4.4.2. Smeštanje u želatin...........................................................53

3.4.4.3. Hitozan kao nosač za imobilizaciju enzima......................53

3.4.4.3.1. Imobilizacija penicilin-acilaze na hitozanskim

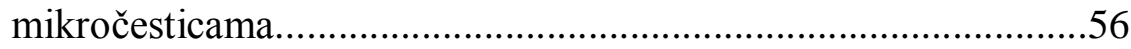

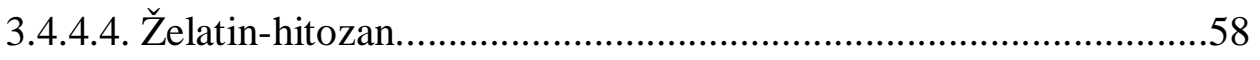

3.4.5. Biospecifična imobilizacija na Konkanavalin A nosaču......62

3.4.5. Biospecifična imobilizacija PAC na Konkanavalin A nosaču..........61

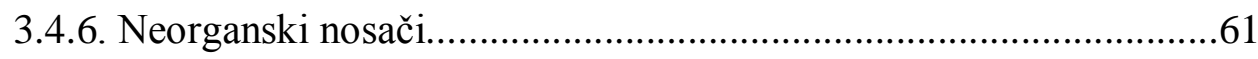

3.4.6.1. Modifikovani nosači na bazi silicijum-dioksida................61

3.4.6.2. Smeštanje u matriks silicijum-dioksida..........................................63

3.4.6.3. Imobilizacija na molekulskim sitima............................................64

3.4.6.3.1. Raslojeni zeoliti kao nosači za imobilizaciju PAC . .64

3.4.6.4. Lipidni biokompozitni filmovi na neorganskim

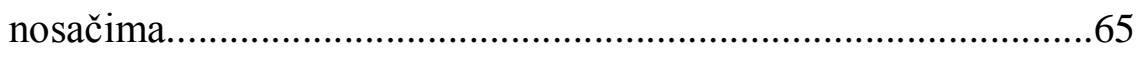

3.4.7. Imobilizacija penicilin-acilaze bez nosača..........................................66

3.4.7.1. Umreženi enzimski kristali........................................................67

3.4.7.2. Umreženi enzimski agregati............................................68

3.4.7.2.1. Umreženi enzimski agregati penicilin-acilaze kao katalizatori sinteze polusintetskih antibiotika.....................70 
3.4.7.2.2. Sinteza ampicilina u mikrovodenim sistemima organskih rastvarača................................................. 70

3.4.8. Tehnike imobilizacije u razvoju.............................................. 71

3.4.8.1 Integrisano prečišćavanje i imobilizacija penicilin-

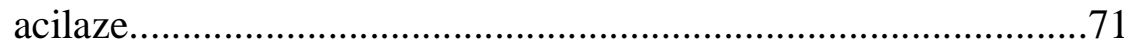

3.4.8.2. Kovalentno vezivanje penicilin-acilaze za temperaturno

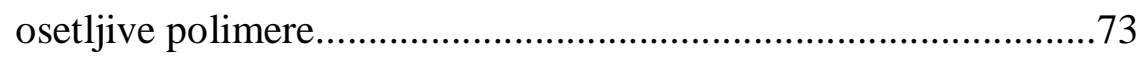

3.4.8.3. Magnetna biokatalizatorska zrna.......................................... 75

3.4.8.4. Termodijaliza kroz katalitičku membranu.......................76

3.4.8.5. Katalitički elektro-membranski reaktor.........................78

3.4.9. Separacija proizvoda reakcije u sistemu sa imobilisanim enzimom.

4. Bioreaktori za procese sa imobilisanim biokatalizatorima .84

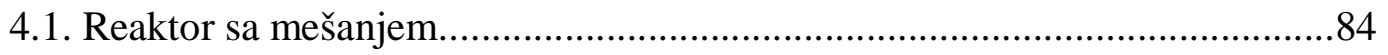

4.2. Reaktor sa pakovanim slojem..........................................................86

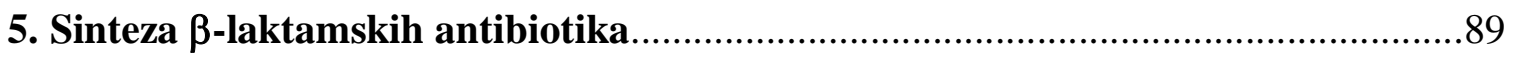

5.1 Hemijska struktura prirodnih i polusintetskih penicilina i načini njihovog

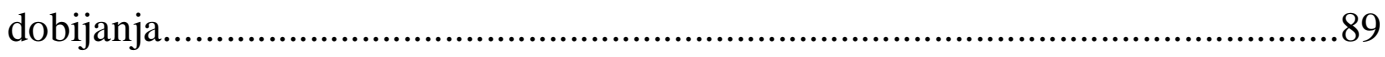

5.2.Termodinamički kontrolisana sinteza...................................................92

5.3. Kinetički kontrolisana reakcija sinteze polusintetskih antibiotika................94

5.4. Mehanizam enzimske sinteze $\beta$-laktamskih antibiotika............................96

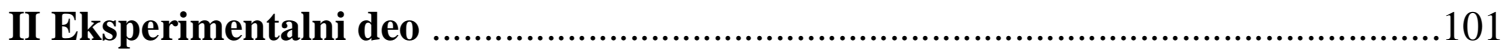

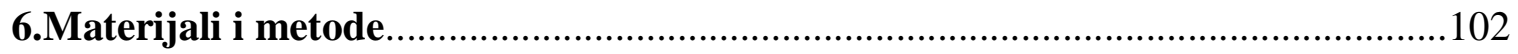

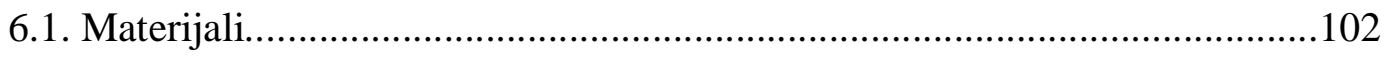


6.2. Metode. 104

6.2.1. Karakterizacija slobodne penicilin-acilaze.................................104

6.2.1.1. Određivanje sadržaja proteina metodom Loriju (Lowry).................................104

6.2.1.2. Određivanje aktivnosti slobodne penicilin-acilaze

.105

6.2.1.3. Određivanje uticaja temperature na aktivnost slobodne penicilin-acilaze

6.2.1.4. Određivanje uticaja $\mathrm{pH}$ na aktivnost slobodne penicilinacilaze.

107

6.2.1.5.Određivanje termostabilnosti slobodne penicilinacilaze 108

6.2.1.6. Određivanje kinetičkih konstanti slobodne penicilinacilaze 109

6.2.1.6.1. Određivanje konstanti inhibicije supstratom $\mathrm{u}$ višku.

6.2.1.6.2. Određivanje konstanti inhibicije 6-amino penicilanske i fenilsirćetne kiseline. 110

6.2.2. Imobilizacija penicilin-acilaze na komercijalne polimetakrilatne Sepabeads nosače

6.2.2.1. Imobilizacija penicilin-acilaze na Sepabeads EC-EP.....111 6.2.2.2. Imobilizacija penicilin-acilaze na Sepabeads EC-EA i Sepabeads EC-HA. 112

6.2.2.3. Određivanje stepena hidrofobnosti nosača 113

6.2.2.4. Određivanje aktivnosti imobilisane penicilinacilaze 113

6.2.2.5. Određivanje uticaja temperature na aktivnost imobilisane penicilin-acilaze. 114 6.2.2.6. Određivanje uticaja $\mathrm{pH}$ na aktivnost imobilisane penicilinacilaze 114

6.2.2.7. Određivanje termostabilnosti imobilisane penicilinacilaze. 115 
6.2.3. Karakterizacija i imobilizacija penicilin-acilaze modifikovane derivatima polisaharida

6.2.3.1. Modifikacija penicilin-acilaze derivatima polisaharida 115

6.2.3.2. Oksidacija enzima modifikovanog polisaharidima. .116

6.2.3.3. Određivanje sadržaja aktiviranog polisaharida u konjugatu PAC.

6.2.3.4. Određivanje uticaja temperature na aktivnost modifikovane penicilin-acilaze. 118

6.2.3.5. Određivanje uticaja $\mathrm{pH}$ na aktivnost modifikovane penicilin-acilaze. .118

6.2.3.6. Određivanje stabilnosti modifikovane penicilinacilaze 118

6.2.3.7. Imobilizacija modifikovane penicilin-acilaze na komercijalne Sepabeads EC-HA i Sepabeads EC-EA nosače.....119

6.2.3.8. Određivanje aktivnosti modifikovane i imobilisane

penicilin-acilaze

6.2.3.9. Određivanje uticaja temparature na aktivnost modifikovane i imobilisane penicilin-acilaze .121

6.2.3.10. Određivanje uticaja $\mathrm{pH}$ na aktivnost modifikovane i imobilisane penicilin-acilaze

6.2.3.11. Određivanje stabilnosti modifikovane imobilisane penicilin-acilaze.

6.2.4. Imobilizacija penicilin-acilaze na hitozanske mikročestice dobijene elektrostatičkom ekstruzijom.

6.2.4.1. Priprema i aktivacija hitozanskih mikročestica.....

6.2.4.2. Imobilizacija penicilin-acilaze na hitozanskim mikročesticama. 
6.2.4.3. Određivanje aktivnosti imobilisane penicilin-acilaze.....125

6.2.4.4. Titracija aktivnog položaja.........................................125

6.2.4.5. Karakterizacija hitozanskih mikročestica......................126

6.2.4.6. Određivanje uticaja temperature na aktivnost imobilisane

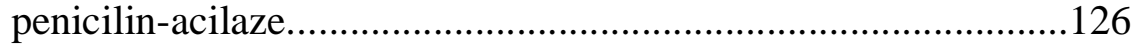

6.2.4.7. Određivanje uticaja $\mathrm{pH}$ na aktivnost imobilisane penicilinacilaze

6.2.4.8. Operativna stabilnost imobilisane penicilin-acilaze

6.2.4.9. Određivanje kinetike otpuštanja enzima sa hitozanskih mikročestica.

6.2.4.10. Određivanje kinetičkih konstanti imobilisane penicilinacilaze. 128

6.2.4.10.1. Određivanje konstanti inhibicije supstratom u višku.

6.2.4.10.2. Određivanje konstanti inhibicije 6-amino penicilanske i fenilsirćetne kiseline. 128

6.2.4.11. Određivanje brzine reakcije u reaktoru sa pakovanim slojem

III Rezultati i diskusija.

7. Karakterizacija slobodne penicilin-acilaze

7.1. Ispitivanje sadržaja enzima u komercijalnom enzimskom preparatu. 132

7.2. Ispitivanje specifične aktivnosti slobodne penicilin-acilaze

7.3. Ispitivanje uticaja temperature na aktivnost slobodne penicilin-acilaze

7.4. Ispitivanje uticaja $\mathrm{pH}$ vrednosti na aktivnost slobodne penicilin-acilaze.....134

7.5. Ispitivanje stabilnosti slobodne penicilin-acilaze.....

7.6. Ispitivanje početne kinetike hidrolize penicilina G slobodnom penicilin-acilazom u šaržnom sistemu.....................................................136

7.6.1. Ispitivanje inhibicije supstratom u višku 136 
7.6.2. Ispitivanje početne kinetike u prisustvu proizvoda reakcije.

7.6.2.1. Ispitivanje uticaja početne koncentracije

6-aminopenicilanske kiseline na početnu brzinu reakcije.

7.6.2.2. Ispitivanje uticaja početne koncentracije

fenilsirćetne kiseline na početnu brzinu reakcije.

7.6.3. Kinetički izraz za reakciju katalizovanu slobodnom

penicilin-acilazom u šaržnom sistemu

Zaključak

\section{Imobilizacija penicilin-acilaze na komercijalne polimetakrilatne Sepabeads}

nosače.

8.1. Imobilizacija penicilin-acilaze na Sepabeads EC-EP

8.1.1. Ispitivanje uticaja uslova imobilizacije na svojstva imobilisane penicilin-acilaze na Sepabeads EC-EP.

8.1.2. Ispitivanje uticaja temperature na aktivnost penicilin-acilaze imobilisane na Sepabeads EC-EP

8.1.3. Ispitivanje uticaja $\mathrm{pH}$ na aktivnost penicilin-acilaze imobilisane na Sepabeads EC-EP

8.1.4. Ispitivanje uticaja imobilizacije penicilin-acilaze na Sepabeads EC-EP na stabilnost biokatalizatora

8.2. Imobilizacija penicilin-acilaze na Sepabeads EC-EA i Sepabeads EC-HA

8.2.1. Ispitivanje uticaja uslova imobilizacije na svojstva imobilisane penicilin-acilaze na Sepabeads EC-EA i Sepabeads EC-HA

8.2.2. Ispitivanje uticaja temperature na aktivnost penicilin-acilaze imobilisane na Sepabeads EC-EA i Sepabeads EC-HA

8.2.3. Ispitivanje uticaja $\mathrm{pH}$ na aktivnost penicilin-acilaze imobilisane na Sepabeads EC-EA i Sepabeads EC-HA

8.2.4. Ispitivanje uticaja imobilizacije penicilin-acilaze na Sepabeads EC-

EA i Sepabeads EC-HA na stabilnost biokatalizatora. 164

Zaključak. 


\section{Karakterizacija i imobilizacija penicilin-acilaze modifikovane derivatima polisaharida.

9.1. Karakterizacija i imobilizacija penicilin-acilaze modifikovane derivatom skroba

9.1.1. Imobilizacija penicilin-acilaze modifikovane derivatom skroba po metodi 1

9.1.1.1. Imobilizacija penicilin-acilaze modifikovane derivatom skroba na Sepabeads EC-EA i Sepabeads EC-HA po metodi 1..170 9.1.1.1.1. Ispitivanje uticaja uslova imobilizacije na svojstva skrob-penicilin-acilaze imobilisane na Sepabeads EC-EA i Sepabeads EC-HA po metodi 1 170 9.1.1.1.2. Ispitivanje uticaja temperature na aktivnost skrob-penicilin-acilaze imobilisane na Sepabeads EC-EA i Sepabeads EC-HA po metodi 1. 174

9.1.1.1.3. Ispitivanje uticaja $\mathrm{pH}$ vrednosti na aktivnost skrob-penicilin-acilaze imobilisane na Sepabeads EC-EA i Sepabeads EC-HA po metodi 1. 176

9.1.1.1.4. Ispitivanje uticaja imobilizacije skrob-penicilinacilaze (metoda 1) na stabilnost biokatalizatora .178

9.1.2. Karakterizacija penicilin-acilaze modifikovane derivatom skroba. .180

9.1.2.1. Ispitivanje uticaja temperature na aktivnost penicilinacilaze modifikovane derivatom skroba po metodi 2 181 9.1.2.2. Ispitivanje uticaja $\mathrm{pH}$ na aktivnost penicilin-acilaze modifikovane derivatom skroba po metodi 2 . 182

9.1.2.3. Ispitivanje uticaja modifikacije penicilin-acilaze derivatom skroba na stabilnost biokatalizatora po metodi 2 . 183 
9.1.3. Imobilizacija penicilin-acilaze modifikovane derivatom skroba po metodi 2 .

9.1.3.1. Imobilizacija penicilin-acilaze modifikovane derivatom skroba na Sepabeads EC-EA i Sepabeads EC-HA po metodi 2..185

9.1.3.1.1. Ispitivanje uticaja uslova imobilizacije na svojstva skrob-penicilin-acilaze imobilisane na Sepabeads EC-EA i Sepabeads EC-HA po metodi 2.........................186 9.1.3.1.2. Ispitivanje uticaja temperature na aktivnost skrob-penicilin-acilaze imobilisane na Sepabeads EC-EA i Sepabeads EC-HA po metodi 2 .

9.1.3.1.3. Ispitivanje uticaja $\mathrm{pH}$ vrednosti na aktivnost skrob-penicilin-acilaze imobilisane na Sepabeads EC-EA i Sepabeads EC-HA po metodi 2 .

9.1.3.1.4. Ispitivanje uticaja imobilizacije skrob-penicilinacilaze (metoda 2) na stabilnost biokatalizatora

9.2. Karakterizacija i imobilizacija penicilin-acilaze modifikovane derivatom alginata 195

9.2.1. Karakterizacija penicilin-acilaze modifikovane derivatom alginata po metodi 2 195

9.2.1.1. Ispitivanje uticaja temperature na aktivnost penicilinacilaze modifikovane derivatom alginata po metodi 2. .196

9.2.1.2. Ispitivanje uticaja $\mathrm{pH}$ na aktivnost penicilin-acilaze modifikovane derivatom alginata po metodi 2 ... 197

9.2.1.3. Ispitivanje uticaja modifikacije penicilin-acilaze derivatom alginata na stabilnost biokatalizatora po metodi 2 . .198

9.2.2. Imobilizacija penicilin-acilaze modifikovane derivatom alginata po metodi 2 . 199 
9.2.2.1. Imobilizacija penicilin-acilaze modifikovane derivatom alginata na Sepabeads EC-EA i Sepabeads EC-HA po metodi 2.

9.2.2.1.1. Ispitivanje uticaja uslova imobilizacije na svojstva alginat-penicilin-acilaze imobilisane na Sepabeads EC-EA i Sepabeads EC-HA po metodi 2.........................200 9.2.2.1.2. Ispitivanje uticaja temperature na aktivnost alginat-penicilin-acilaze imobilisane na Sepabeads EC-EA i Seapabeads EC-HA po metodi 2.....................................203 9.2.2.1.3. Ispitivanje uticaja $\mathrm{pH}$ vrednosti na aktivnost alginat-penicilin-acilaze imobilisane na Sepabeads EC-EA i Sepabeads EC-HA po metodi 2. .205

9.2.2.1.4. Ispitivanje uticaja imobilizacije alginat-penicilinacilaze (metoda 2) na stabilnost biokatalizatora...............206

9.3. Poređenje biokatalizatora na bazi modifikovanih PAC..........................208

Zaključak.

\section{Imobilizacija penicilin-acilaze na hitozanske mikročestice dobijene

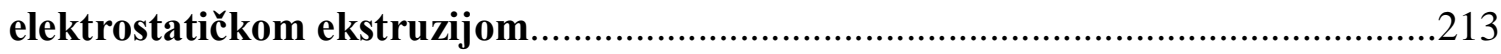

10.1. Optimizacija imobilizacije penicilin-acilaze korišćenjem elektrostatičke

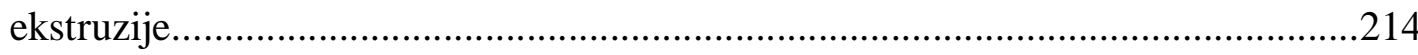

10.2. Karakterizacija penicilin-acilaze imobilisane na hitozanske mikročestice.....217 10.3. Ispitivanje uticaja uslova imobilizacije na svojstva penicilin-acilaze imobilisane na hitozanske mikročestice.

10.4. Ispitivanje uticaja koncentracije glutaraldehida

10.5. Ispitivanje uticaja temperature na aktivnost penicilin-acilaze imobilisane na hitozanske mikročestice. .227

10.6. Ispitivanje uticaja $\mathrm{pH}$ na aktivnost penicilin-acilaze imobilisane na hitozanske mikročestice. .228

10.7. Ispitivanje stabilnosti penicilin-acilaze imobilisane na 
hitozanske mikročestice nakon višekratne upotrebe. .229

10.8. Ispitivanje kinetike otpuštanja penicilin-acilaze iz mikročestica

.230

10.9. Ispitivanje početne kinetike hidrolize penicilina $G$ penicilin-acilazom imobilisanom na hitozanske mikročestice $u$ šaržnom sistemu.

10.9.1. Ispitivanje inhibicije supstratom u višku.......................231

10.9.2. Ispitivanje početne kinetike u prisustvu proizvoda reakcije........236

10.9.2.1. Ispitivanje uticaja početne koncentracije

6-aminopenicilanske kiseline na početnu brzinu reakcije. .236

10.9.2.2. Ispitivanje uticaja početne koncentracije

fenilsirćetne kiseline na početnu brzinu reakcije.

10.9.3. Kinetički izraz za reakciju katalizovanu slobodnom i imobilisanom penicilin-acilazom u šaržnom sistemu .242

10.10. Ispitivanje kinetike hidrolize penicilina $G$ penicilin-acilazom imobilisanom na hitozanske mikročestice u reaktoru sa pakovanim slojem. .243

10.10.1. Ukupni model kinetike sa inhibicijom..................................243

10.10.2. Model kinetike prvog reda................................................246

10.11. Ispitivanje kinetike hidrolize penicilina $G$ penicilin-acilazom imobilisanom na hitozanske mikročestice u reaktoru sa pakovanim slojem sa recirkulacijom.....248 10.11.1. Model kinetike hidrolize u sistemu sa recirkulacijom.............249

Zaključak .253

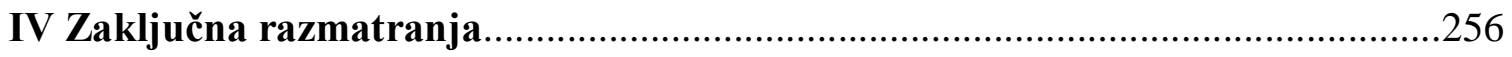

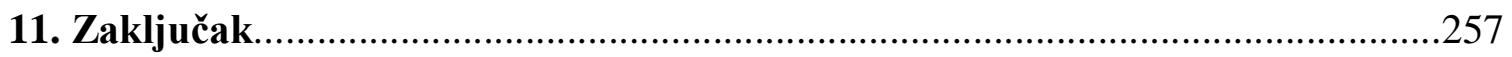

LITERATURA

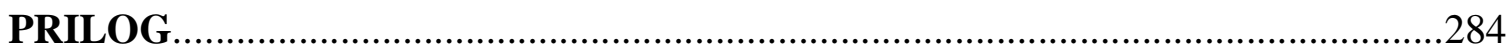




\section{SPISAK SLIKA}

Slika 1.1. Hidrolize penicilina $\mathrm{V}$, penicilina $\mathrm{G}$ i ampicilina odgovarajućim enzimima.....5

Slika 1.2. Hidroliza penicilina $G$ penicilin-acilazom..................................................6

Slika 1.3. Predloženi mehanizam za hidrolizu penicilina G. Tačkaste linije predstavljaju

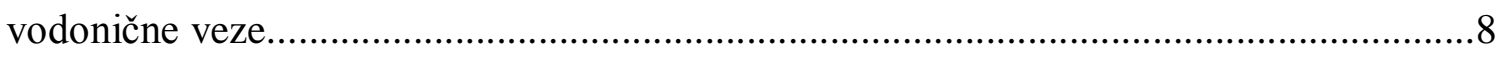

Slika 1.4. Šematski prikaz intermedijarnog stupnja hidrolize PenG...............................11

Slika 1.5. Sredina aktivnog mesta u PAA-PAC kompleksu........................................12

Slika 1.6. Izgledi kompleksa enzima sa različitim ligandima (a) sa phidroksifenilsirćetnom kiselinom i (b) sa m-nitrofenilsirćetnom kiselinom. Na slici su prikazane elektronska gustina i bitne interakcije unutar vezujućeg mesta enzima. Elektronska gustina je konturisana na $1 \sigma$ na $2 \mathrm{~F}_{\mathrm{o}}-\mathrm{F}_{\mathrm{c}}$ mapi na kojoj su prikazani i molekuli vode (obeleženi sa Wat) koji stupaju u interakciju sa ligandom.................................15 Slika 1.7. (a) Prostorni izgled preklopljenih struktura p-hidroksifenilsirćetne kiseline iz podgrupe 1 (bela) i p-nitrofenil-sirćetne kiseline iz podgrupe 2 (crna) i interakcije koje stvara svaki ligand. (b) Preklopljeni položaj liganada prikazan pod (a) znatno uvećan....16 Slika 1.8. Prikaz ostataka $\alpha-131$ do $\alpha-146$ unutar heliksa.............................................17 Slika 1.9. Trodimenzionalni izgled konačne $2 \mathrm{~F}_{\mathrm{o}}-\mathrm{F}_{\mathrm{c}}$ mape (obojena $\mathrm{u}$ crveno) elektronske gustine konturisan na $1 \sigma$ za kompleks penicilin G-modifikovana penicilin-acilaza. Slika je stvorena koristeći QUANTA sistem.

Slika 1.10. Trodimenzionalni izgled mape elektronske gustine PGSO vezanog za aktivno mesto u kompleks DIVLJI TIP-PGSO. $2 \mathrm{~F}_{\mathrm{o}}-\mathrm{F}_{\mathrm{c}}$ mapa je obojena u plavo i konturisana na $1 \sigma$ nivo. Jasnoće radi, elektronske gustine oko atoma proteina su izostavljene. .19

Slika 1.11. Grafičko predstavljanje mehanizma ukupne reakcije enzimske hidrolize PenG. Indeksi f i r se odnose na direktnu i povratnu reakciju.

Slika 2.1. (a) Uvođenje dialdehidnih grupa u glukozne ostatke dekstrana perjodatnom metodom (b) Modifikacija proteina dialdehid-dekstranom. $\mathrm{H}_{2} \mathrm{~N}-\mathrm{R}$ predstavlja protein...36 Slika 3.1. Osobine imobilisanih enzima su određene kombinacijom svojstava enzima i nosača. .38

Slika 3.2. Struktura Eupergita C i penicilin-acilaze vezane kovalentno višestrukim vezama 
Slika 3.3. Hidroliza penicilina G: brzina reakcije i pH gradijenti u česticama Eupergita C; (__ nepuferovana i (- - -) sa $200 \mathrm{mM}$ fosfatnim puferom.......................................45

Slika 3.4. Mikroskopski izgled čestice Sepabeads EC- nosača.....................................46

Slika 3.5. Šematski prikaz imobilizacije enzima na Sepabeads EC-EP nosač..................47

Slika 3.6. Postupak imobilizacije enzima na nosače sa amino grupama glutaraldehidnom metodom.

Slika 3.7. Perjodatna metoda vezivanja enzima za nosač..........................................50

Slika 3.8. Aktivacija Amberlita XAD-7 i kovalentno vezivanje penicilin-acilaze............51

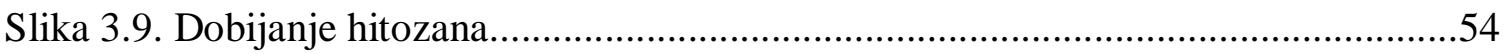

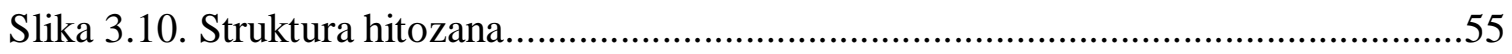

Slika 3.11. Postupak imobilizacije PAC glutaraldehidnom metodom............................57

Slika 3.12. 3D struktura PAC. Plavom bojom su predstavljeni ostaci lizina....................58

Slika 3.13. Gustina aktivnog položaja Assemblase-a i njegovih prosejanih frakcija........60

Slika 3.14. Šema imobilizacije penicilin-acilaze; na silicijum-dioksidu modifikovanim oksiranom (a) i aminopropil silicijum-dioksidu.

Slika 3.15. Aktivacija aminopropilsilicijum-dioksida i kovalentno višetačkasto vezivanje

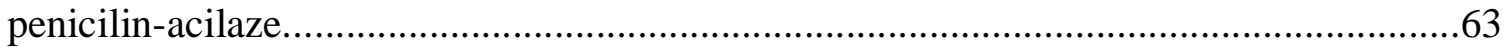

Slika 3.16. Kovalentna imobilizacija penicilin-acilaze na raslojenom zeolitu ITQ-6......65

Slika 3.17. Šematsko predstavljanje adsorpcije penicilin-acilaze na lipidnom filmu.......66

Slika 3.18. Poređenje formiranja umreženih enzimskih agregata (CLEAs) u odnosu na umrežene enzimske kristale (CLECs) .68

Slika 3.19. Aktivnost penicilin-acilaze-CLEAs pri hidrolizi penicilina G. Precipitanti: amonijum-sulfat (A-CLEA), terc-butil alkohol (T-CLEA), i PEG 8000 (P-CLEA); CLE je dobijen umreženim vezivanjem penicilin-acilaze u rastvoru. .69

Slika 3.20. Integrisano prečišćavanje i kovalentna imobilizacija penicilin-acilaze...........73

Slika 3.21. Vezivanje penicilin-acilaze za poliNIPAM- termoosetljivi polimer...............74

Slika 3.22. Šematski prikaz membranskog reaktora. Protok rastvarača je od tople ka hladnoj strani. .77

Slika 3.23. Aktivacija membrane na bazi poliakrilamida i kovalentno vezivanje penicilinacilaze. .78 
Slika 3.24. Princip rada elektro-membranskog reaktora (a) reakcija u jonskom obliku koja se odvija u reaktoru (b) pokretanje jona pod primenjenim pozitivnim (c) i negativnim (d)

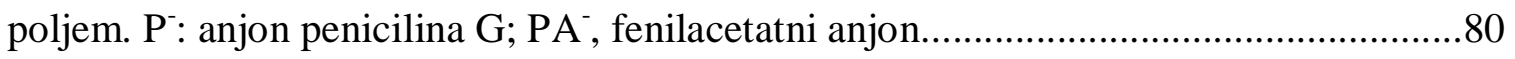

Slika 3.25. Brzina reakcije hidrolize penicilina $\mathrm{G}$ u zavisnosti od gustine struje...............80 Slika 3.26. Sadržaj i aktivnost PAC imobilisane na silikatu sa mikročesticama i monolitnom silikatu (1) PAC imobilisana na aminopropil-silikatu mikročestica (2) PAC imobilisana na epoksi-silikatu mikročestica (3) PAC imobilisana na aminopropilmonolitnom silikatu. (4) PAC imobilisana na epoksi-monolitnom silikatu.......................82 Slika 3.27. Hromatogram penicilina $\mathrm{G}\left(1 \mathrm{mg} / \mathrm{cm}^{3}\right)$ na PAC epoksi-mikročesticama

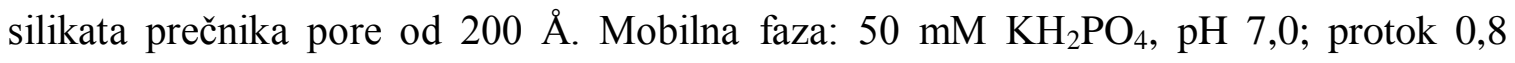
$\mathrm{cm}^{3} / \mathrm{min}$; detekcija na $225 \mathrm{~nm}$. Faktor zadržavanja za 6 -APA je 0,52 i za PAA je 23,08 . .83

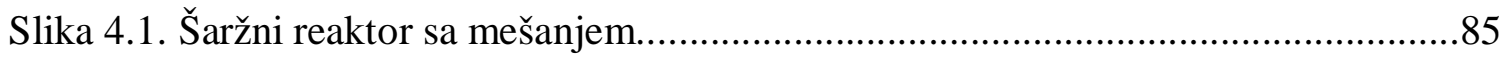

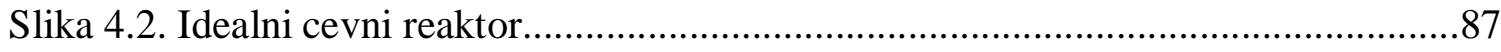

Slika 5.1. Šematski prikaz strukture jezgra penicilina....................................................89

Slika 5.2. Termodinamički kontrolisana sinteza polusintetskih penicilina, katalizovana penicilin-acilazom (PAC)......................................................................................93

Slika 5.3. Kinetički kontrolisana sinteza. PAC se ponaša kao transferaza (za sintezu) i kao hidrolaza, promovišući dve neželjene bočne reakcije (hidrolizu 1, bočnog lanca acil donor derivata, i hidrolizu 2, antibiotika). Na primer, u sintezi ampicilina $\mathrm{R}_{1}-\mathrm{COOH}={ }_{\mathrm{D}}-(-$ -)-fenilglicin ( $\mathrm{PG}$ ); za amoksicilin, $\mathrm{R}_{1}-\mathrm{COOH}=\mathrm{p}-\mathrm{OH}_{-\mathrm{D}}-(--)-\mathrm{PG}$, itd. Acil donor derivat

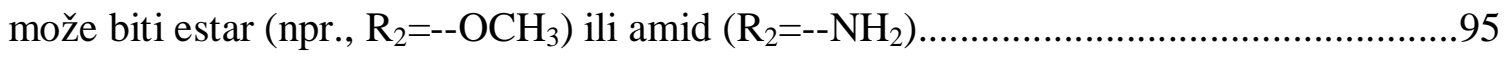

Slika 5.4. Šema mehanizma enzimske sinteze $\beta$-laktamskih antibiotika. Istaknuti deo slike ukazuje na korake koji nisu usaglašeni u literaturi....................................................98

Slika 6.1. Standardna kriva za određivanje koncentracije enzima $(210 \mathrm{~nm}) \ldots \ldots \ldots \ldots \ldots \ldots . . .113$

Slika 6.2. Standardna kriva za određivanje sadržaja aktiviranog skroba $(490 \mathrm{~nm})$........117

Slika 6.3. Standardna kriva za određivanje sadržaja aktiviranog alginata $(490 \mathrm{~nm})$.......118

Slika 6.4. Standardna kriva za određivanje koncentracije enzima PAC modifikovana

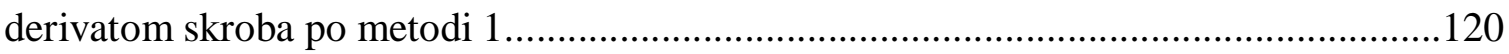

Slika 6.5. Standardna kriva za određivanje koncentracije enzima PAC modifikovana

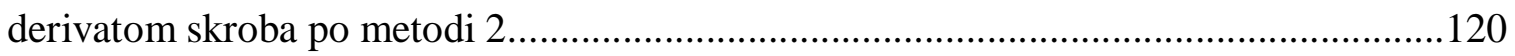


Slika 6.6. Standardna kriva za određivanje koncentracije enzima PAC modifikovana derivatom alginata.

Slika 6.7. Šematski prikaz eksperimentalne aparature za dobijanje hitozanskih mikročestica: (1) rastvor hitozana se propušta pumpom (2) kroz iglu $21 \mathrm{G}$ (3) povezanu sa generatorom visokog napona (4). Dobijene kapi se skupljaju u gelirajućem rastvoru 10\% natrijum-tripolifosfata (TPP) (5) koji se meša na mešalici (200 rpm) (6)

Slika 6.8. Šema bioreaktorskog sistema sa pakovanim slojem bez recirkulacije tečnosti (protok a) i sa recirkulacijom tečnosti (protok b): R: reaktor sa pakovanim slojem; RR: rezervoar sa reaktantima; PR: rezervoar sa proizvodima; P: pumpa. 130

Slika 7.1. Zavisnost aktivnosti PAC izražene u IU od mase enzima u komercijalnom enzimskom preparatu izražene u mg.

Slika 7.2. Zavisnost relativne aktivnosti PAC od temperature (reakcioni uslovi: radna koncentracija enzima od $0,06 \mathrm{~cm}^{3} / \mathrm{cm}^{3}$ i supstrata od 2,0\% (w/v) PenG u $0,1 \mathrm{M}$ fosfatnom puferu $\mathrm{pH} 7,92$ na $37^{\circ} \mathrm{C}$ ).

Slika 7.3. Zavisnost relativne aktivnosti PAC od pH vrednosti. Uslovi reakcije: $37^{\circ} \mathrm{C}, 3$ min, 0,1M puferi: acetatni puferi ( $\mathrm{pH} 4,5 \mathrm{i} \mathrm{pH} \mathrm{5,5),} \mathrm{fosfatni} \mathrm{puferi} \mathrm{(} \mathrm{pH} 6,2, \mathrm{pH} 7,3$ i pH 7,9) i tris/ $\mathrm{HCl}$ puferi ( $\mathrm{pH} 8,6$ i pH 9,3).

Slika 7.4. Zavisnost relativne aktivnosti PAC od vremena na $50{ }^{\circ} \mathrm{C}$. PAC se termostatira na $50{ }^{\circ} \mathrm{C}$ u različitim vremenskim periodima, a zatim se ispituje aktivnost tretiranog enzima u standardnoj reakciji. Uslovi reakcije: $0,1 \mathrm{M}$ natrijum-fosfatni pufer $(\mathrm{pH}=7,92)$, $\mathrm{t}=37^{\circ} \mathrm{C}, 3 \mathrm{~min}$. 136

Slika 7.5. Zavisnost relativne brzine reakcije katalizovane slobodnom PAC od koncentracije Pen G. Reakcioni uslovi: koncentracija Pen G od 0,01 do 0,24 M, koncentracija enzima $0,006 \mathrm{~cm}^{3} / \mathrm{cm}^{3}, 0,1 \mathrm{M}$ natrijum-fosfatni pufer $\mathrm{pH} 7,92$, temperatura $37^{\circ} \mathrm{C}$.

Slika 7.6. a) Zavisnost početne brzine reakcije katalizovane slobodnom PAC od koncentracije Pen G. Reakcioni uslovi: koncentracija Pen G od 0,01 do 0,1 M, koncentracija enzima $0,006 \mathrm{~cm}^{3} / \mathrm{cm}^{3}, 0,1 \mathrm{M}$ natrijum-fosfatni pufer $\mathrm{pH} 7,92$, temperatura $37^{\circ} \mathrm{C}$ b) Lajnviver-Berkov dijagram recipročnih vrednosti početne brzine hidrolize Pen G i koncentracije supstrata za reakciju katalizovanu slobodnom PAC. Dijagram je određen na osnovu vrednosti prikazanih na slici 7.6 a) .138 
Slika 7.7. a) Zavisnost početne brzine reakcije katalizovane slobodnom PAC od koncentracije Pen G. Reakcioni uslovi: koncentracija Pen G od 0,12 do 0,24 M, koncentracija enzima $0,006 \mathrm{~cm}^{3} / \mathrm{cm}^{3}, 0,1 \mathrm{M}$ natrijum-fosfatni pufer $\mathrm{pH} 7,92$, temperatura $37{ }^{\circ} \mathrm{C}$ b) Zavisnost recipročne vrednosti početne brzine reakcije od koncentracije supstrata u slučaju slobodne PAC. Dijagram je određen na osnovu vrednosti prikazanih na slici 7.7 a).

Slika 7.8. Uticaj koncentracija inhibitora 6-APA na zavisnost početne brzine reakcije od koncentracije Pen G za slobodnu PAC. Uslovi odigravanja reakcije: koncentracija Pen G od 0,01 do $0,08 \mathrm{M}$, koncentracija inhibitora 6-APA od $1 \%$ do $2 \%, 3 \min ., 37^{\circ} \mathrm{C}, 0,1 \mathrm{M}$ natrijum-fosfatni pufer $(\mathrm{pH} 7,92)$.

Slika 7.9. Lajnviver-Berkov dijagram za slobodnu PAC u slučaju 6-APA kao inhibitora.

Slika 7.10. Zavisnost nagiba iz Lajnviver-Berkovog dijagrama od koncentracije inhibitora (6-APA) za slobodnu PAC.

Slika 7.11. Uticaj različitih koncentracija inhibitora PAA na zavisnost brzine reakcije od koncentracije Pen G za slobodnu PAC. Uslovi odigravanja reakcije: koncentracija Pen G od 0,01 do $0,08 \mathrm{M}$, koncentracija inhibitora PAA od $1 \%$ do $2 \%, 3$ min., $37^{\circ} \mathrm{C}, 0,1 \mathrm{M}$ natrijum-fosfatni pufer $(\mathrm{pH} 7,92)$. 144

Slika 7.12. Lajnviver-Berkov dijagram za slobodnu PAC u slučaju PAA kao inhibitora. .144

Slika 7.13. Zavisnost nagiba iz Lajnviver-Berkovog dijagrama od koncentracije inhibitora (PAA) za slobodnu PAC. 145

Slika 8.1. Sepabeads EC-EP nosač 149

Slika 8.2. Uporedni dijagram zavisnosti mase vezane $\mathrm{PAC}\left(\mathrm{P}_{\mathrm{g}}\right)$ od početne koncentracije PAC $\left(c_{o}\right)$ i masenog prinosa imobilizacije $\left(\eta_{\text {enz }}\right)$ od početne koncentracije PAC $\left(c_{o}\right)$. Uslovi imobilizacije: $0,5 \mathrm{~g}$ Sepabead EC-EP nosača, $48 \mathrm{~h}, 25^{\circ} \mathrm{C}, 1,25 \mathrm{M}$ kalijum-fosfatni pufer $(\mathrm{pH} 8,0)$.

Slika 8.3. Uporedni dijagram zavisnosti aktivnosti imobilisane PAC $\left(\mathrm{A}_{\mathrm{IE}}\right)$ od mase vezane PAC $\left(\mathrm{P}_{\mathrm{g}}\right)$ i prinosa aktivnosti $\left(\eta_{\text {akt }}\right)$ od mase vezane PAC $\left(\mathrm{P}_{\mathrm{g}}\right)$. Uslovi imobilizacije: 0,5 g Sepabeads EC-EP nosača, $48 \mathrm{~h}, 25^{\circ} \mathrm{C}, 1,25 \mathrm{M}$ kalijum-fosfatni pufer $(\mathrm{pH} 8,0)$ 
Slika 8.4. Zavisnost relativne aktivnosti (RA) imobilisane PAC od temperature (t). Uslovi reakcije: $0,1 \mathrm{M}$ natrijum-fosfatni pufer $(\mathrm{pH} 7,92), 3 \mathrm{~min}$.

Slika 8.5. Zavisnost relativne aktivnosti (RA) imobilisane PAC od $\mathrm{pH}$ vrednosti. Uslovi reakcije: $37{ }^{\circ} \mathrm{C}, 3 \mathrm{~min}, 0,1 \mathrm{M}$ puferi: acetatni puferi ( $\mathrm{pH}$ 4,5 i pH 5,5), fosfatni puferi ( $\mathrm{pH} 6,2, \mathrm{pH} 7,3$ i pH 7,9) i tris/HCl puferi ( $\mathrm{pH} 8,6$ i pH 9,3). .154

Slika 8.6. Zavisnost relativne aktivnosti PAC imobilisane na Sepabeads EC-EP i slobodne PAC od vremena. Biokatalizatori se termostatiraju na $50^{\circ} \mathrm{C}$ u različitim vremenskim periodima, a zatim se ispituje aktivnost tretiranih biokatalizatora $\mathrm{u}$ standardnoj reakciji. Uslovi reakcije: $0,1 \mathrm{M}$ natrijum-fosfatni pufer $(\mathrm{pH}=7,92), \mathrm{t}=37^{\circ} \mathrm{C}, 3$ $\min$. 155

Slika 8.7. Sepabeads EC-EA i Sepabeads EC-HA nosači. .156

Slika 8.8. Uporedni dijagram zavisnosti mase vezane PAC $\left(\mathrm{P}_{\mathrm{g}}\right)$ i masenog prinosa imobilizacije $\left(\eta_{\text {enz }}\right)$ od početne koncentracije PAC ( $\left.c_{o}\right)$ za a) Sepabeads EC-EA i b) Sepabeads EC-HA. Uslovi imobilizacije: 0,5 g nosača, 20 h, $25^{\circ} \mathrm{C}, 20 \mathrm{mM}$ kalijumfosfatni pufer $(\mathrm{pH} \mathrm{8,0)}$. 157

Slika 8.9. Uporedni dijagram zavisnosti aktivnosti imobilisane PAC $\left(\mathrm{A}_{\mathrm{IE}}\right)$ i prinosa aktivnosti $\left(\eta_{\mathrm{akt}}\right)$ od mase vezane PAC $\left(\mathrm{P}_{\mathrm{g}}\right)$ za a) Sepabeads EC-EA i b) Sepabeads ECHA . Uslovi imobilizacije: 0,5 g Sepabeads EC-EA nosača, 20 h, $25^{\circ} \mathrm{C}, 20 \mathrm{mM}$ kalijumfosfatni pufer $(\mathrm{pH} \mathrm{8,0)}$.

Slika 8.10. Zavisnost relativne aktivnosti (RA) imobilisane PAC od temperature za a) Sepabeads EC-EA i b) Sepabeads EC-HA. Uslovi reakcije: 0,1 M natrijum-fosfatni pufer $\mathrm{pH}$ 7,92, 3 min. 161

Slika 8.11. Zavisnost relativne aktivnosti (RA) imobilisane PAC od pH vrednosti za a) Sepabeads EC-EA i b) Sepabeads EC-HA. Uslovi reakcije: $37{ }^{\circ} \mathrm{C}, 3 \mathrm{~min}, 0,1 \mathrm{M}$ puferi: acetatni puferi ( $\mathrm{pH} 4,5 \mathrm{i} \mathrm{pH} 5,5$ ), fosfatni puferi $(\mathrm{pH} 6,2, \mathrm{pH} \mathrm{7,3} \mathrm{i} \mathrm{pH} \mathrm{7,9)} \mathrm{i} \mathrm{tris/HCl}$ puferi (pH 8,6 i pH 9,3). 163

Slika 8.12. Zavisnost relativne aktivnosti PAC imobilisane na Sepabeads EC-EA i slobodne PAC od vremena za a) Sepabeads EC-EA i b) Sepabeads EC-HA. Biokatalizatori se termostatiraju na $50^{\circ} \mathrm{C}$ u različitim vremenskim periodima, a zatim se ispituje aktivnost tretiranih biokatalizatora u standardnoj reakciji. Uslovi reakcije: $0,1 \mathrm{M}$ natrijum-fosfatni pufer $(\mathrm{pH}=7,92), \mathrm{t}=37^{\circ} \mathrm{C}, 3 \mathrm{~min}$. 164 
Slika 9.1. Uporedni dijagram zavisnosti mase vezane skrob-PAC po metodi $1\left(\mathrm{P}_{\mathrm{g}}\right)$ od početne koncentracije enzima $\left(c_{o}\right)$ i masenog prinosa imobilizacije $\left(\eta_{\text {enz }}\right)$ od početne koncentracije enzima $\left(\mathrm{c}_{\mathrm{o}}\right)$ za a) Sepabeads EC-EA i b) Sepabeads EC-HA. Uslovi imobilizacije: 0,5 g Sepabeads EC-EA nosača, 48 h, $8{ }^{\circ} \mathrm{C}, 50 \mathrm{mM}$ natrijum-acetatni pufer $(\mathrm{pH} 5,0)$

Slika 9.2. Zavisnosti aktivnosti imobilisane skrob-PAC $\left(\mathrm{A}_{\mathrm{IE}}\right)$ i prinosa aktivnosti $\left(\eta_{\mathrm{akt}}\right)$ od mase vezanog enzima $\left(\mathrm{P}_{\mathrm{g}}\right)$ po metodi 1 za a) Sepabeads EC-EA i b) Sepabeads EC-HA. Uslovi imobilizacije: 0,5 g Sepabeads EC-EA nosača, 48 h, $8{ }^{\circ} \mathrm{C}, 50 \mathrm{mM}$ natrijumacetatni pufer $(\mathrm{pH} 5,0)$. 173

Slika 9.3. Zavisnost relativne aktivnosti (RA) imobilisane skrob-PAC po metodi 1 od temperature za a) Sepabeads EC-EA i b) Sepabeads EC-HA. Uslovi reakcije: 0,1 M natrijum-fosfatni pufer ( $\mathrm{pH} 7,92), 3 \mathrm{~min}$. 175

Slika 9.4. Zavisnost relativne aktivnosti imobilisane skrob-PAC po metodi 1 od $\mathrm{pH}$ vrednosti za a) Sepabeads EC-EA i b) Sepabeads EC-HA. Uslovi reakcije: $37{ }^{\circ} \mathrm{C}, 3 \mathrm{~min}$, 0,1 M puferi: acetatni puferi ( $\mathrm{pH} 4,5$ i pH 5,5 ), fosfatni puferi ( $\mathrm{pH} 6,2, \mathrm{pH} 7,3$ i pH 7,9) i tris/ $\mathrm{HCl}$ puferi ( $\mathrm{pH} 8,6$ i $\mathrm{pH} 9,3)$.

Slika 9.5. Zavisnost relativne aktivnosti slobodne, konvencionalno imobilisane i imobilisane skrob-PAC na a) Sepabeads EC-EA i b) Sepabeads EC-HA po metodi 1 od vremena. Biokatalizatori se termostatiraju na $50{ }^{\circ} \mathrm{C}$ u različitim vremenskim periodima, a zatim se ispituje aktivnost tretiranih biokatalizatora u standardnoj reakciji. Uslovi

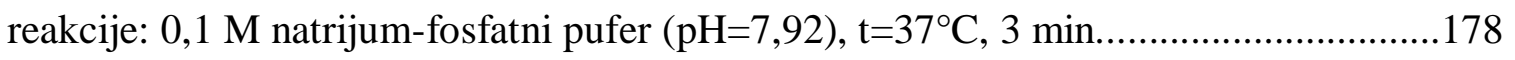

Slika 9.6. Šematski prikaz modifikacije PAC skrobom............................................... 180

Slika 9.7. Zavisnost relativne aktivnosti (RA) skrob-PAC od temperature(t). Uslovi reakcije: $0,1 \mathrm{M}$ natrijum-fosfatni pufer $(\mathrm{pH}=7,92), 3 \mathrm{~min}$.

Slika 9.8. Zavisnost relativne aktivnosti skrob-PAC od pH vrednosti. Uslovi reakcije: 37 ${ }^{\circ} \mathrm{C}, 3$ min, 0,1 M puferi: acetatni puferi ( $\mathrm{pH} 4,5$ i pH 5,5 ), fosfatni puferi ( $\mathrm{pH} 6,2, \mathrm{pH}$ 7,3 i $\mathrm{pH} 7,9)$ i tris/ $\mathrm{HCl}$ puferi ( $\mathrm{pH} 8,6$ i pH 9,3). 183

Slika 9.9. Zavisnost relativne aktivnosti skrob-PAC i slobodne PAC od vremena. Biokatalizatori se termostatiraju na $50^{\circ} \mathrm{C}$ u različitim vremenskim periodima, a zatim se ispituje aktivnost tretiranih biokatalizatora u standardnoj reakciji. Uslovi reakcije: $0,1 \mathrm{M}$ natrijum-fosfatni pufer $(\mathrm{pH}=7,92), \mathrm{t}=37^{\circ} \mathrm{C}, 3 \mathrm{~min}$. 
Slika 9.10. Uporedni dijagram zavisnosti mase vezane skrob-PAC po metodi $2\left(\mathrm{P}_{\mathrm{g}}\right) \mathrm{i}$ masenog prinosa imobilizacije $\left(\eta_{\text {enz }}\right)$ od početne koncentracije enzima $\left(c_{o}\right)$ za a) Sepabeads EC-EA i b) Sepabeads EC-HA. Uslovi imobilizacije: 0,5 g nosača, $48 \mathrm{~h}, 8{ }^{\circ} \mathrm{C}$, $50 \mathrm{mM}$ natrijum-acetatni pufer $(\mathrm{pH} 5,0)$.

Slika 9.11. Uporedni dijagram zavisnosti aktivnosti imobilisane skrob-PAC po metodi 2 $\left(\mathrm{A}_{\mathrm{IE}}\right)$ i prinosa aktivnosti $\left(\eta_{\mathrm{akt}}\right)$ od mase vezane PAC $\left(\mathrm{P}_{\mathrm{g}}\right)$ za a) Sepabeads EC-EA i b) Sepabeads EC-HA. Uslovi imobilizacije: 0,5 g nosača, 48 h, $8{ }^{\circ} \mathrm{C}, 50 \mathrm{mM}$ natrijumacetatni pufer $(\mathrm{pH} 5,0)$. 188

Slika 9.12. Zavisnost relativne aktivnosti skrob-PAC imobilisane na a) Sepabeads EC-EA i b) Sepabeads EC-HA po metodi 2 od temperature. Uslovi reakcije: 0,1 M natrijumfosfatni pufer ( $\mathrm{pH}=7,92), 3 \mathrm{~min}$.....

Slika 9.13. Zavisnost relativne aktivnosti skrob-PAC imobilisane po metodi 2 na a) Sepabeads EC-EA i b) Sepabeads EC-HA od pH vrednosti. Uslovi reakcije: $37{ }^{\circ} \mathrm{C}, 3$ min, 0,1M puferi: acetatni puferi ( $\mathrm{pH} 4,5 \mathrm{i} \mathrm{pH} 5,5$ ), fosfatni puferi ( $\mathrm{pH} 6,2, \mathrm{pH}$ 7,3 i pH 7,9) i tris/HCl puferi ( $\mathrm{pH} 8,6 \mathrm{i} \mathrm{pH} \mathrm{9,3).}$

Slika 9.14. Zavisnost relativne aktivnosti slobodne, konvencionalno imobilisane i imobilisane skrob-PAC na a) Sepabeads EC-EA i b) Sepabeads EC-HA po metodama 1 i 2 od vremena. Biokatalizatori se termostatiraju na $50{ }^{\circ} \mathrm{C}$ u različitim vremenskim periodima, a zatim se ispituje aktivnost tretiranih biokatalizatora u standardnoj reakciji. Uslovi reakcije: $0,1 \mathrm{M}$ natrijum-fosfatni pufer $(\mathrm{pH}=7,92), \mathrm{t}=37^{\circ} \mathrm{C}, 3 \mathrm{~min}$. 194

Slika 9.15. Zavisnost relativne aktivnosti alginat-PAC od temperature. Uslovi reakcije: $0,1 \mathrm{M}$ natrijum-fosfatni pufer $(\mathrm{pH}=7,92), 3 \mathrm{~min}$. 196

Slika 9.16. Zavisnost relativne aktivnosti alginat-PAC od $\mathrm{pH}$ vrednosti. Uslovi reakcije: $37{ }^{\circ} \mathrm{C}, 3$ min, 0,1 M puferi: acetatni puferi ( $\mathrm{pH} 4,5$ i pH 5,5 ), fosfatni puferi ( $\mathrm{pH} 6,2, \mathrm{pH}$ 7,3 i pH 7,9) i tris/HCl puferi ( $\mathrm{pH} 8,6$ i pH 9,3). .197

Slika 9.17. Zavisnost relativne aktivnosti alginat-PAC od vremena. Alginat-PAC se termostatira na $50{ }^{\circ} \mathrm{C}$ u različitim vremenskim periodima, a zatim se ispituje aktivnost tretirane alginat-PAC u standardnoj reakciji. Uslovi reakcije: 0,1 M natrijum-fosfatni pufer $(\mathrm{pH}=7,92), \mathrm{t}=37^{\circ} \mathrm{C}, 3 \mathrm{~min}$.

Slika 9.18. Uporedni dijagram zavisnosti mase vezane alginat-PAC po metodi $2\left(\mathrm{P}_{\mathrm{g}}\right) \mathrm{i}$ masenog prinosa imobilizacije ( $\left.\eta_{\text {enz }}\right)$ od početne koncentracije enzima $\left(c_{o}\right)$ za a) 
Sepabeads EC-EA i b) Sepabeads EC-HA. Uslovi imobilizacije: 0,5 g nosača, 48 h, $8{ }^{\circ} \mathrm{C}$,

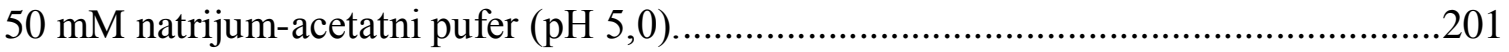

Slika 9.19. Uporedni dijagram zavisnosti aktivnosti imobilisane alginat-PAC po metodi 2 $\left(\mathrm{A}_{\mathrm{IE}}\right)$ i prinosa aktivnosti $\left(\eta_{\text {akt }}\right)$ od mase vezane PAC ( $\left.\mathrm{P}_{\mathrm{g}}\right)$ za a) Sepabeads EC-EA i b) Sepabeads EC-HA. Uslovi imobilizacije: $0,5 \mathrm{~g}$ nosača, $48 \mathrm{~h}, 8{ }^{\circ} \mathrm{C}, 50 \mathrm{mM}$ natrijumacetatni pufer $(\mathrm{pH} 5,0)$. 202

Slika 9.20. Zavisnost relativne aktivnosti alginat-PAC imobilisane na a) Sepabeads ECEA i b) Sepabeads EC-HA po metodi 2 od temperature. Uslovi reakcije: 0,1M natrijumfosfatni pufer ( $\mathrm{pH}=7,92), 3 \mathrm{~min}$. .204 Slika 9.21. Zavisnost relativne aktivnosti imobilisane skrob-PAC po metodi 2 na a) Sepabeads EC-EA i b) Sepabeads EC-HA od pH vrednosti. Uslovi reakcije: $37^{\circ} \mathrm{C}, 3$ min, 0,1 M puferi: acetatni puferi ( $\mathrm{pH}$ 4,5 i pH 5,5), fosfatni puferi ( $\mathrm{pH} 6,2, \mathrm{pH}$ 7,3 i pH 7,9) i tris/HCl puferi ( $\mathrm{pH} 8,6$ i pH 9,3).. 205 Slika 9.22. Zavisnost relativne aktivnosti slobodne, konvencionalno imobilisane i imobilisane skrob-PAC i alginat-PAC po metodi 2 na a) Sepabeads EC-EA i b) Sepabeads EC-HA od vremena. Biokatalizatori se termostatiraju na $50{ }^{\circ} \mathrm{C}$ u različitim vremenskim periodima, a zatim se ispituje aktivnost tretiranih biokatalizatora $\mathrm{u}$ standardnoj reakciji. Uslovi reakcije: $0,1 \mathrm{M}$ natrijum-fosfatni pufer $(\mathrm{pH}=7,92), \mathrm{t}=37^{\circ} \mathrm{C}, 3$ $\min$. 207

Slika 10.1. a) i c) SEM mikrograf hitozanskih mikročestica (skala 20 i $50 \mu \mathrm{m}$, redom) b) i d) SEM mikrograf umreženih hitozanskih mikročestica sa imobilisanom PAC (skala $20 \mathrm{i}$ $50 \mu \mathrm{m}$, redom). .218

Slika 10.2. Uporedni FT-IR spektar a) prirodni hitozan (kriva a), hitozan aktiviran 1\% glutaraldehidom (kriva b) i hitozan aktiviran 9\% glutaraldehidom (kriva c) i b) prirodan hitozan (kriva a), hitozan aktiviran 9\% glutaraldehidom (kriva c) i imobilisana PAC na hitozan aktiviran 9\% glutaraldehidom (kriva d)..... .219 Slika 10.3. Uticaj sadržaja enzima u rastvoru za imobilizaciju na količinu i aktivnost imobilisanog enzima. .221 Slika 10.4. Uticaj sadržaja enzima u rastvoru za imobilizaciju na maseni prinos imobilizacije i prinos aktivnosti. 
Slika 10.5. Zavisnost količine katalitički kompetentnih aktivnih centara koji su se vezali za hitozan od početne količine aktivnih centara u rastvoru za imobilizaciju. .223 Slika 10.6. Uticaj koncentracije glutaraldehida na aktivnost imobilisane PAC i masu vezane PAC (Količina enzima u rastvoru za imobilizaciju je bila $256 \mathrm{U} / \mathrm{g}$ suvih hitozanskih mikročestica dobijenih pod optimalnim uslovima elektrostatičkom

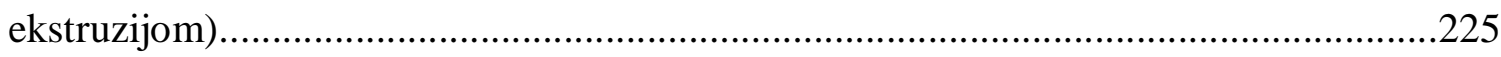

Slika 10.7. Uticaj koncentracije glutaraldehida na prečnik mikročestica..........................225 Slika 10.8. Zavisnost relativne aktivnosti PAC-Hit-GA-1 i PAC-Hit-GA-9 od temperature. Uslovi reakcije: $0,1 \mathrm{M}$ natrijum-fosfatni pufer $(\mathrm{pH}$ 7,92), $3 \mathrm{~min}$. Maksimalna vrednost aktivnosti pri određenoj temperaturi je predstavljala $100 \%$.........227 Slika 10.9. (a) Zavisnost relativne aktivnosti PAC-Hit-GA-1 i PAC-Hit-GA-9 pH vrednosti. Uslovi reakcije: $37{ }^{\circ} \mathrm{C}, 3 \mathrm{~min}$. Maksimalna vrednost aktivnosti pri određenoj

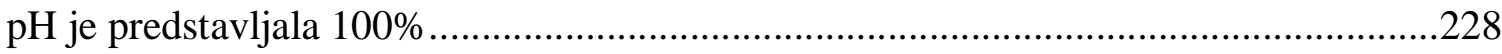

Slika 10.10. Relativna aktivnost kao funkcija broja ciklusa $\left(37{ }^{\circ} \mathrm{C}, 1 \mathrm{~h}\right.$-ciklus, $200 \mathrm{mg}$ biokatalizatora, pH 7,92, 100 i 400 rpm). .229

Slika 10.11. Procenat otpuštanja PAC $\left(37{ }^{\circ} \mathrm{C}, 400 \mathrm{rpm}\right)$ za PAC-Hit-GA-1 i PAC-HitGA-9. 231

Slika 10.12. Zavisnost relativne brzine reakcije od koncentracije Pen .232 Slika 10.13. a) Zavisnost početne brzine reakcije katalizovane slobodnom PAC i hitozanPAC od koncentracije Pen G. Reakcioni uslovi: koncentracija Pen G od 0,01 do 0,12 M, koncentracija enzima $0,006 \mathrm{~cm}^{3} / \mathrm{cm}^{3}$ ili $0,1 \mathrm{~g}$ imobilisane PAC, $0,1 \mathrm{M}$ natrijum-fosfatni pufer $\mathrm{pH} 7,92$, temperatura $37^{\circ} \mathrm{C}$ b) Lajnviver-Berkov dijagram recipročnih vrednosti početne brzine hidrolize Pen G i koncentracije supstrata za reakciju katalizovanu slobodnom PAC i hitozan-PAC. Dijagram je određen na osnovu vrednosti prikazanih na slici 10.13 a). .233

Slika 10.14. a) Zavisnost početne brzine reakcije katalizovane imobilisanom PAC od koncentracije Pen G. Reakcioni uslovi: koncentracija Pen G od 0,18 do 0,24 M, 0,1 g imobilisane PAC,, 0,1 M natrijum-fosfatni pufer $\mathrm{pH} 7,92$, temperatura $37^{\circ} \mathrm{C}$ b) Zavisnost recipročne vrednosti početne brzine reakcije od koncentracije supstrata u slučaju 
imobilisane PAC. Dijagram je određen na osnovu vrednosti prikazanih na slici 10.13 a). 235

Slika 10.15. Uticaj različitih koncentracija inhibitora 6-APA na zavisnost brzine reakcije od koncentracije Pen G za imobilisanu PAC. Uslovi odigravanja reakcije: koncentracija Pen $\mathrm{G}$ od 0,01 do $0,08 \mathrm{M}$, koncentracija inhibitora 6-APA $1 \%$ do $2 \%, 3 \mathrm{~min}$., $37^{\circ} \mathrm{C}, 0,1 \mathrm{M}$ natrijum-fosfatni pufer $(\mathrm{pH} 7,92)$. 237

Slika 10.16. Lajnviver-Berkov dijagram za imobilisanu PAC u slučaju 6-APA kao inhibitora. .238

Slika 10.17. Zavisnost nagiba iz Lajnviver-Berkovog dijagrama od koncentracije inhibitora (6-APA) za imobilisanu PAC. .238

Slika 10.18. Uticaj različitih koncentracija inhibitora PAA na zavisnost brzine reakcije od koncentracije Pen G za imobilisanu PAC. Uslovi odigravanja reakcije: koncentracija Pen $\mathrm{G}$ od 0,01 do $0,08 \mathrm{M}$, koncentracija inhibitora PAA od $1 \%$ do $2 \%, 3 \mathrm{~min} ., 37^{\circ} \mathrm{C}, 0,1 \mathrm{M}$ natrijum-fosfatni pufer $(\mathrm{pH} 7,92)$. 240

Slika 10.19. Lajnviver-Berkov dijagram za imobilisanu PAC u slučaju PAA kao inhibitora.

Slika 10.20. Zavisnost nagiba iz Lajnviver-Berkovog dijagrama od koncentracije inhibitora (PAA) za imobilisan enzim. 241

Slika 10.21. Zavisnost koncentracije penicilina $G$ od vremena $u$ ICR određena eksperimentalno i primenom modela sa inhibicijom. .245

Slika 10.22. Zavisnost $\ln [\mathrm{S}] /\left[\mathrm{S}_{0}\right]$ od vremena.... .247

Slika 10.23. Zavisnost koncentracije supstrata od vremena $\mathrm{u}$ ICR određena eksperimentalno, primenom modela sa inhibicijom i modela 1. reda...........................248

Slika 10.24. Reaktor sa pakovanim slojem sa recirkulacijom. .249

Slika P-7.1. Standardna kriva sadržaja BSA proteina u rastvoru određena metodom po Loriju. 284 


\section{SPISAK TABELA}

Tabela 1.1. Mikrobiološki izvori penicilin-acilaze..................................................

Tabela 1.2. Konstante inhibicije (dobijene vrednosti \pm standardna devijacija) za fenilsirćetnu kiselinu i njene derivate sa penicilin-acilazom.

Tabela 1.3. Uticaj strukture supstrata na brzinu hidrolize i stereohemijsku

selektivnost.

Tabela 1.4. Specifičnost prema supstratu penicilin-acilaze (PAC) i ampicilin acilaze

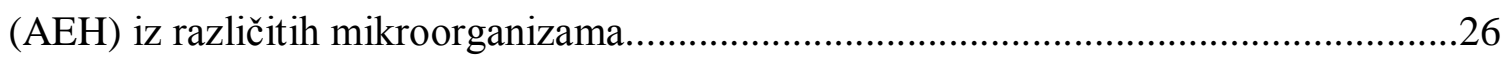

Tabela 5.1. Različiti penicilini u zavisnosti od R ostatka...........................................90

Tabela 7.1. Vrednosti $V_{\mathrm{M}}, K_{\mathrm{M}}$, konstante inhibicije i kritične koncentracije penicilina $\mathrm{G}$, konstante inhibicije u slučaju 6-APA i PAA kao inhibitora.......................................145

Tabela 8.1. Vrednosti kinetičkih konstanti dezaktivacije za slobodan enzim i PAC imobilisane na Sepabeads EC-EA i Sepabeads EC-HA nosačima...

Tabela 9.1. Vrednosti kinetičkih konstanti dezaktivacije za slobodan enzim i PAC i skrob-PAC (metoda 1) imobilisane na Sepabeads EC-EA i Sepabeads EC-HA nosače.

Tabela 9.2. Pregled literaturnih vrednosti specifične aktivnosti hemijski modifikovanih enzima dobijenih za različite enzime $u$ poređenju sa rezultatima dobijenim $u$ ovom radu.

Tabela 9.3. Pregled literaturnih vrednosti faktora stabilizacije $(\mathrm{F})$ hemijski modifikovanih enzima na različitim temperaturama.

Tabela 9.4. Vrednosti kinetičkih konstanti dezaktivacije za slobodan enzim i skrob-PAC imobilisane na Sepabeads EC-EA i Sepabeads EC-HA nosače po metodi 2.

Tabela 9.5. Vrednosti maksimalne mase vezanog enzima i masenih prinosa imobilizacije (za početnu koncentraciju enzima od $0,14 \mathrm{mg} / \mathrm{cm}^{3}$ i srednje vrednosti)......................208

Tabela 9.6. Vrednosti aktivnosti i prinosa aktivnosti imobilisane modifikovane PAC...209 Tabela 9.7. Optimalne $\mathrm{pH}$ vrednosti modifikovane i imobilisane PAC .210 
Tabela 9.8. Parametri modela dobijeni na osnovu kinetičkog modela inaktivacije prvog reda (jednačine 5.1. i 5.2.) slobodne PAC, konjugata PAC, konvencionalno imobilisane PAC i imobilisanih konjugata PAC po metodama 1 i 2 ..................................................211 Tabela 10.1. Uticaj primenjenog napona $(U)$, rastojanja elektrode $(h)$ i koncentracije hitozana $\left(C_{\mathrm{p}}\right)$ na prečnik hitozanskih čestica $\left(d_{\mathrm{p}}\right)$, maseni prinos imobilizacije $\left(\eta_{\mathrm{enz}}\right)$ i prinos aktivnosti $\left(\eta_{\text {akt }}\right)$ (dobijeni optimalni uslovi su podebljani)...................................215 Tabela 10.2. Rezultati imobilizacije PAC na hitozanske čestice aktivirane sa $1 \%$ glutaraldehidom pri različitom sadržaju enzima)....................................................224 Tabela 10.3. Vrednosti $V_{\mathrm{M}}, K_{\mathrm{M}}, K_{\mathrm{s}}$, kritične koncentracije penicilina $\mathrm{G}$ pri kojima dolazi do inhibicije, konstante inhibicije u slučaju 6-APA $\left(K_{\mathrm{iA}}\right)$ i PAA $\left(K_{\mathrm{iB}}\right) \cdot$ kao inhibitora za slobodnu i na hitozanske mikročestice imobilisanu PAC...............................................2242 Tabela 10.4. Vrednosti konstante $\mathrm{K}\left(k=3 \cdot 10^{-4} \mathrm{~s}^{-1}\right)$ i koncentracije pencilina $\mathrm{G}$ (eksperimentalne vrednosti i vrednosti dobijene na osnovu ukupnog modela)...... .252 


\section{SPISAK SKRAĆENICA}

\begin{tabular}{|c|c|}
\hline 6-APA & 6-aminopenicilanska kiselina \\
\hline 7-ACA & 7-aminocefalosporinska kiselina \\
\hline 7-ADCA & 7-dezacetoksicefalosporinska kiselina \\
\hline Amp & ampicilin \\
\hline Amx & amoksicilin \\
\hline Arg & arginin \\
\hline Asp & asparaginska kiselina \\
\hline Ceph & cefaleksin \\
\hline CLEC & umreženi enzimski kristali \\
\hline DAOC G & deacetoksicefalosporin $\mathrm{G}$ \\
\hline DAOC V & deacetoksicefalosporin $\mathrm{V}$ \\
\hline GA & glutaraldehid \\
\hline ICR & idealni cevni reaktor \\
\hline NIPAB & 6-nitro-3-fenilacetilamidobenzenska kiselina \\
\hline $\mathrm{P}$ & pumpa \\
\hline PAA & fenilsirćetna kiselina \\
\hline PAC & penicilin-acilaza \\
\hline PDAB & p-dimetilaminobenzaldehid \\
\hline Pen $\mathrm{G}$ & penicilin $\mathrm{G}$ \\
\hline Pen V & penicilin $\mathrm{V}$ \\
\hline PGME & fenilglicinmetil estar \\
\hline Phe & fenilalanin \\
\hline PMSF & fenilmetilsulfonilfluorid \\
\hline PR & rezervoar produkata reakcije \\
\hline $\mathrm{RR}$ & rezervoar reaktanta \\
\hline SEM & skenirajući elektronski mikroskop \\
\hline Ser & serin \\
\hline $\mathrm{TPP}$ & natrijum-tripolifosfat \\
\hline Tyr & tirozin \\
\hline
\end{tabular}




\section{SPISAK SIMBOLA}

A preostala enzimska aktivnost u vremenu t IU

$A_{\mathrm{SE}} \quad$ aktivnost slobodnog enzima IU

$\mathrm{c}_{\mathrm{GA}} \quad$ koncentracija glutaraldehida w/v

$C_{\mathrm{p}} \quad$ koncentracija hitozana $\%$

d prečnik kapi $\mathrm{m}$

$\begin{array}{lll}d_{0} & \text { prečnik kapi pri } U=0 & \mathrm{~m}\end{array}$

$d$ c unutrašnji prečnik igle m

$d_{\mathrm{M}} \quad$ prečnik mešalice m

$F \quad$ faktor stabilizacije

f stepen hidrofobnosti

$F_{\mathrm{M}} \quad$ molski protok reakcione smeše $\mathrm{mol} / \mathrm{s}$

$g \quad$ gravitaciono ubrzanje $\mathrm{m} / \mathrm{s}^{2}$

$h \quad$ rastojanje između elektroda m

$K \quad$ konstanta brzine prvog reda $\mathrm{s}^{-1}$

$k \quad$ konstanta brzine reakcije u idealnom cevnom reaktoru $\quad \mathrm{s}^{-1}$

$k_{1} \quad$ konstanta brzine reakcije razlaganja penicilina

$\mathrm{u}$ šaržnom reaktoru $\quad \mathrm{s}^{-1}$

$k_{\mathrm{D}} \quad$ konstante brzine dezaktivacije $\mathrm{s}^{-1}$

$k_{\mathrm{g}} \quad$ parametar uticaja geometrije na proces formiranja kapi

$K_{\text {iA }} \quad$ konstanta nekompetitivne inhibicije $\quad \mathrm{M}$

$K_{\text {iB }} \quad$ konstanta kompetitivne inhibicije $\quad \mathrm{M}$

$\begin{array}{lll}K_{\mathrm{M}} & \text { Mihaelis-Mentenova konstanta } & \mathrm{M}\end{array}$

$K_{\mathrm{S}} \quad$ konstanta inhibicije supstratom u višku $\quad \mathrm{M}$

$m_{\mathrm{E}} \quad$ masa enzimskog preparata $\quad \mathrm{g}$

$m_{\mathrm{P}} \quad$ masa polisaharida g

$n$ brzina rotacije $\mathrm{s}^{-1}$

$\mathrm{n}_{\mathrm{o}} \quad$ količina otpuštenog enzima $\%$ 


\begin{tabular}{|c|c|c|}
\hline$n_{\mathrm{ac} 0}$ & početna količina aktivnih centara enzima unetih pri imobiliz & $\mu \mathrm{mol} / \mathrm{g}$ \\
\hline$n_{\text {aclE }}$ & količina aktivnih centara određena na imobilisanom enzimu & $\mu \mathrm{mol} / \mathrm{g}$ \\
\hline $\mathrm{Np}$ & faktor snage & - \\
\hline$P$ & snaga & $\mathrm{W}$ \\
\hline$[P]$ & koncentracija 6-aminopenicilanske kiseline & M \\
\hline$P_{0}$ & mase enzima u početnom rastvoru za imobilizaciju & $\mathrm{g} / \mathrm{g}$ \\
\hline$P_{\mathrm{g}}$ & mase vezanog enzima & $\mathrm{g} / \mathrm{g}$ \\
\hline$[Q]$ & koncentracija fenilsirćetne kiseline & M \\
\hline $\mathrm{R}$ & prečnik čestica & $\mathrm{m}$ \\
\hline RA & relativna aktivnost & $\%$ \\
\hline $\mathrm{RB}$ & relativna brzina reakcije & $\%$ \\
\hline $\operatorname{Re}$ & Rejnoldsov broj & - \\
\hline$[S]$ & koncentracija supstrata (penicilina $\mathrm{G}$ ) u trenutku $\mathrm{t}$ & M \\
\hline \multirow[t]{2}{*}[S_{0}]{} & početna koncentracija supstrata (penicilina G) & \\
\hline & $\mathrm{u}$ početnom trenutku $t=0$ & M \\
\hline$S A_{\mathrm{IE}}$ & specifična aktivnost imobilisanog enzima & $\mathrm{IU} / \mathrm{g}$ \\
\hline$S A_{\mathrm{SE}}$ & specifična aktivnost slobodnog enzima & $\mathrm{IU} / \mathrm{g}$ \\
\hline$S_{\mathrm{E}}$ & sadržaj enzima u rastvoru za imobilizaciju & $\mathrm{U} / \mathrm{g}$ \\
\hline$T$ & temperatura & ${ }^{\circ} \mathrm{C}$ \\
\hline$t$ & vreme & $\mathrm{s}$ \\
\hline$t_{D}$ & vreme trajanja početne lag faze & $\mathrm{h}$ \\
\hline$t_{1 / 2}$ & poluvreme dezaktivacije & $\mathrm{s}$ \\
\hline$U$ & primenjeni napon & $\mathrm{V}$ \\
\hline$U_{\mathrm{cr}}$ & kritični napon & $\mathrm{V}$ \\
\hline$V$ & zapremina & $\mathrm{M} / \mathrm{s}$ \\
\hline$V_{\mathrm{M}}$ & maksimalna vrednost početne brzine reakcije & $\mathrm{M} / \mathrm{s}$ \\
\hline
\end{tabular}


Grčka slova

$\begin{array}{lll}\gamma_{0} & \text { površinski napon } & \mathrm{N} / \mathrm{m} \\ \varepsilon_{0} & \text { dielektrična konstanta vazduha } & \mathrm{C}^{2} / \mathrm{Nm}^{2} \\ \eta_{\mathrm{akt}} & \text { prinos aktivnosti } & \% \\ \eta_{\mathrm{enz}} & \text { maseni prinos imobilizacije } & \% \\ v & \text { kinematska viskoznost } & \mathrm{m}^{2} / \mathrm{s} \\ v & \text { zapreminski protok } & \mathrm{m}^{3} / \mathrm{s} \\ v_{\mathrm{i}} & \text { početna brzina reakcije } & \mathrm{M} / \mathrm{s} \\ \rho & \text { gustina } & \mathrm{kg} / \mathrm{m}^{3} \\ \tau_{\mathrm{C}} & \text { vreme zadržavanja reakcione smeše u } & \\ & \text { idealnom cevnom reaktoru } & \mathrm{s} \\ \tau_{\mathrm{M}} & \text { vreme zadržavanja reakcione smeše u } & \\ & \text { rezervoaru sa idealnim mešanjem } & \mathrm{s}\end{array}$




\section{UVOD}

Penicilin-acilaza je jedan od najvažnijih industrijskih biokatalizatora koji se koristi u enzimskoj proizvodnji 6-aminopenicilanske kiseline (6-APA), industrijskog $\beta$ laktamskog intermedijara. Takođe, primenjuje se i u enzimskoj proizvodnji polusintetskih $\beta$-laktamskih antibiotika. Na godišnjem nivou enzimskim putem proizvodi se oko 20000 tona 6-APA, tako da je jasno da se radi o značajnom industrijskom procesu. S obzirom da je efikasno obnavljanje i ponovno korišćenje biokatalizatora preduslov za održivi proces, mnogo pažnje je posvećeno imobilizaciji penicilin-acilaze.

Polusintetski penicilini, pored cefalosporina, predstavljaju osnovnu grupu $\beta$ laktamskih antibiotika i spadaju u jedne od najkorišćenijih faramaceutskih preparata zbog širokog spektra dejstva i velike hemijske stabilnosti. Polusintetski antibiotici, ne pokazuju samo bolja svojstva kao što su povećana stabilnost, smanjena rezistencija mikroorganizama, lakša apsorpcija, već izazivaju i znatno manje sporednih efekata u poređenju sa prirodnim penicilinima.

Hemijski procesi hidrolize prirodnog penicilina se odvijaju na niskim temperaturama (niže od $-30{ }^{\circ} \mathrm{C}$ ) pod strogo anhidrovanim uslovima u prisustvu organskih rastvarača i uz obaveznu zaštitu bočnih grupa da bi se izbeglo stvaranje sporednih proizvoda. Zbog toga se hemijski proces odvija dvostepeno uz znatno veću potrošnju skupih hemijskih reagenasa koji dovode do stvaranja toksičnog otpada i zagađenja životne sredine. Pored toga, zbog neselektivnosti hemijskog katalizatora, troškovi separacije i prečišćavanja proizvoda su veći, dok je njegov kvalitet značajno manji. Nasuprot ovome, enzimska hidroliza penicilina $\mathrm{G}$ se odvija pod blagim uslovima $\mathrm{u}$ vodenom rastvoru u slabo alkalnoj sredini $\left(\mathrm{pH} 7,9 ; \mathrm{t}=37^{\circ} \mathrm{C}\right)$. Zahvaljujući velikoj katalitičkoj aktivnosti i specifičnosti enzima nepotrebna je zaštita karboksilnih grupa u $\beta$-laktamskom jezgru, smanjen je rizik od racemizacije supstrata i odvijanja sporednih reakcija i nije potrebno dodavati toksične organske rastvarače koji se upotrebljavaju u konvencionalnim hemijskim procesima. Kao katalizator u enzimskim reakcijama koristi se slobodna ili imobilisana penicilin-acilaza mikrobnog porekla. 
$\mathrm{Na}$ osnovu pregleda velikog broja radova i patenata u ovoj oblasti može se zaključiti da se radi o izuzetno aktuelnoj problematici i da se penicilin-acilaze već dugo ispituju i uspešno koriste kao katalizatori u proizvodnji polusintetskih antibiotika. Za ove enzimske procese $u$ razvijenim zemljama primenjeni su različiti sistemi i postrojenja, neki od njih i do nivoa komercijalne upotrebe. U tehnološkom smislu poseban značaj ima primena imobilisanih penicilin-acilaza na različitim nosačima čime se omogućava višekratna upotreba biokatalizatora, olakšana separacija finalnog proizvoda i kontinualno izvođenje reakcije u različitim reaktorima.

Razvoj efikasnog imobilisanog sistema sa penicilin-acilazom je veoma složen problem jer u toku imobilizacije može doći do neželjenih gubitaka aktivnosti enzima usled pretrpljenog hemijskog tretmana, a u toku izvođenja reakcije sa imobilisanim enzimom u ovim heterogenim sistemima obično dolazi do dodatnih gubitaka aktivnosti enzima usled difuzionih limitacija. Pored toga, vrsta nosača može značajno da utiče na raspodelu supstrata, proizvoda i protona vodonika u sistemu, a usled toga i na svojstva imobilisanog enzima kao što su aktivnost, specifičnost, $\mathrm{pH}$ i temperaturni profil, kinetička svojstva, inhibitorni efekti, stabilnost i druga. Naročito značajni pri izvođenju reakcije hidrolize penicilina $\mathrm{G}$ mogu da budu efekti raspodele 6-APA između nosača i rastvarača jer navedeni proizvod može da deluje kao kompetitivni inhibitor na enzim i da dovede do promene $\mathrm{pH}$ vrednosti u sistemu. Zbog toga, izbor postupka i nosača za imobilizaciju moraju biti pažljivo optimizovani.

Osnovni cilj ove doktorske disertacije je bio optimizacija postupka dobijanja 6aminopenicilanske kiseline primenom imobilisane penicilin-acilaze iz E. coli. Pri tome je razmatrana reakcija hidrolize prirodnog penicilina $G$ do 6-APA katalizovane slobodnom i imobilisanom penicilin-acilazom. Da bi se realizovao postavljeni cilj bilo je potrebno izvršiti izbor nosača i metode za imobilizaciju enzima, optimizovati postupak imobilizacije enzima sa aspekta mase vezanog enzima i prinosa aktivnosti, okarakterisati dobijeni biokatalizator $\mathrm{i}$ ispitati razlike $\mathrm{u}$ kinetičkim parametrima slobodne i imobilisane penicilin-acilaze, izabrati odgovarajuće reaktorsko rešenje za izvođenje reakcije sa imobilisanim enzimima i ispitati operativnu stabilnost sistema. 


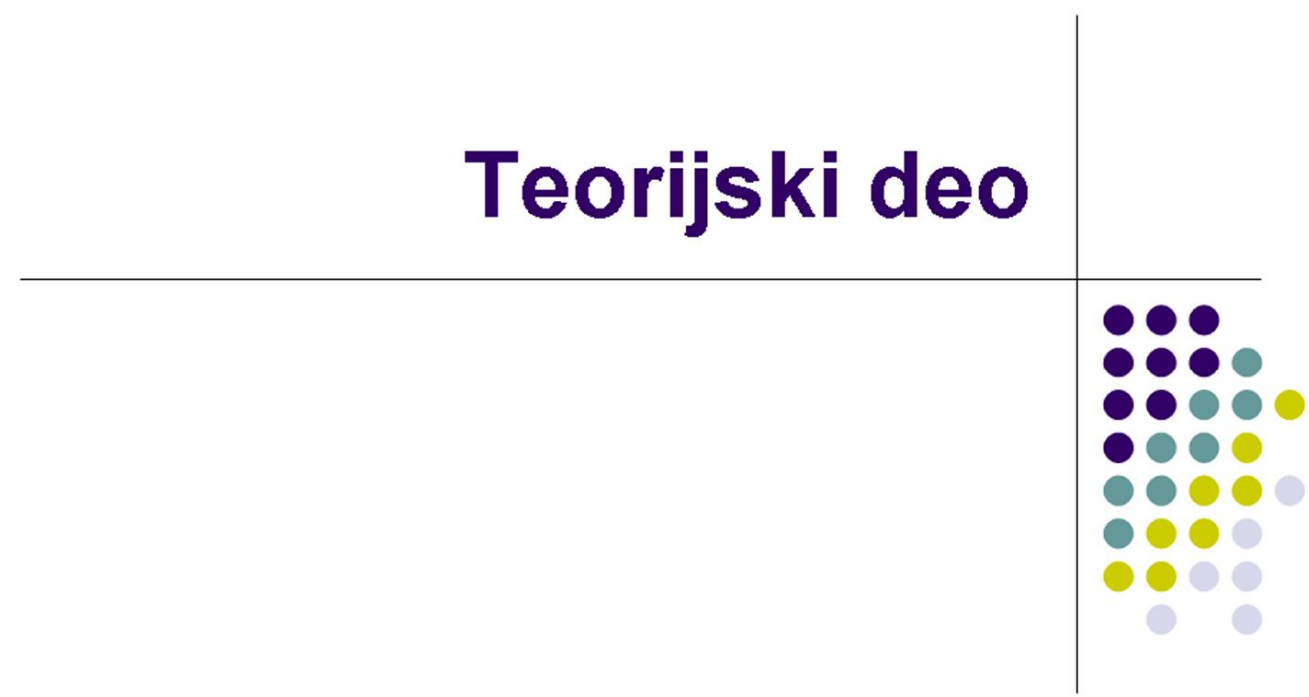




\section{PENICILIN-ACILAZE}

Penicilin-acilaze (penicilin-amidohidrolaze, EC 3.5.1.11) su ključni enzimi koji se koriste $\mathrm{u}$ industrijskoj proizvodnji $\beta$-laktamskih antibiotika. Penicilin-acilaza hidrolizuje bočni lanac penicilina $\mathrm{G}$ i srodnih $\beta$-laktamskih antibiotika oslobađajući 6aminopenicilansku kiselinu (6-APA). Ova kiselina je osnovni prekursor sinteze polusintetskih penicilina, pa zauzima centralno mesto u njihovoj industrijskoj proizvodnji [1]. Kako je sa aspekta razvoja efikasnog imobilisanog enzima neophodno poznavanje strukture enzima, mehanizma reakcije kao i strukture aktivnog centra enzima, u narednom poglavlju izneće se osnovna svojstva ovih enzima.

\subsection{Osnovna svojstva penicilin-acilaza, poreklo i klasifikacija}

Penicilin-acilaze su, dakle, industrijski enzimi koji se prvenstveno koriste kao biokatalizatori u reakciji hidrolize prirodnih penicilina [2]. Uglavnom se koristi penicilin $\mathrm{G}$ acilaza (u literaturi se javljaju skraćenice PAC ili PGA) dobijena iz Escherichia coli ATCC 11105, Bacillus megaterium ATCC 14945 i njihovih mutanata. Proizvodi se i rekombinantni enzim tako što se geni koji kodiraju PAC kloniraju iz različitih bakterijskih vrsta $\mathrm{i}$ zatim se vrši njihova hiperekspresija sa značajnim poboljšanjem u transkripciji, translaciji i post-translatornim modifikacijama usled čega se dobija enzim boljih svojstava i u većem prinosu. Pored toga, enzim se može na različite načine modifikovati da bi se postigla njegova konformaciona stabilnost i željena svojstva [1].

Penicilin-acilaza je prisutna u raznovrsnim mikroorganizmima uključujući Gramnegativne i Gram-pozitivne bakterije, filamentozne gljive i kvasce. Predloženo je da metod klasifikacije penicilin-acilaza bude zasnovan na njihovoj specifičnosti prema supstratu (slika 1.1):

- $\quad$ enzimi tipa I prvenstveno hidrolizuju fenoksimetilpenicilin (PenV);

- $\quad$ enzimi tipa II prioritetno deluju na benzilpenicilin (PenG), iako oni pokazuju širi opseg specifičnosti; 
- $\quad$ enzimi tipa III hidrolizuju ampicilin (D- $\alpha$-aminobenzilpenicilin) [3].

Enzimi tipa I

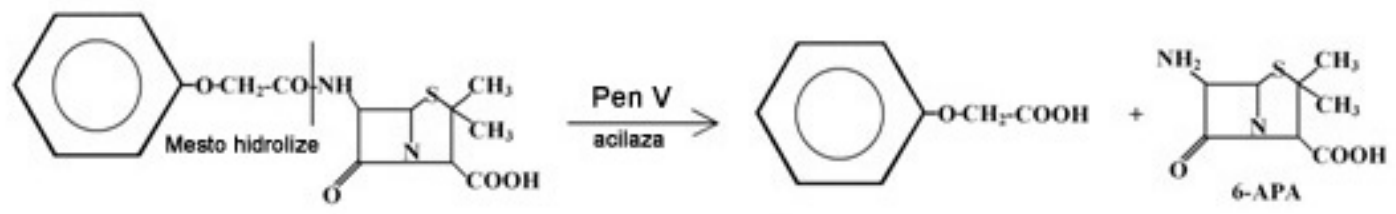

Enzimi tipa II
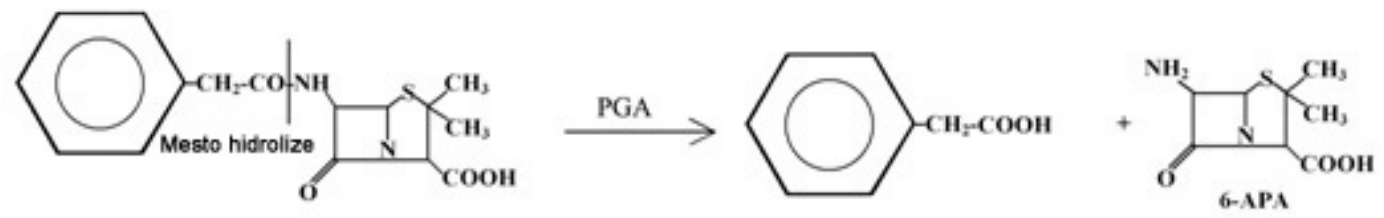

Enzimi tipa III

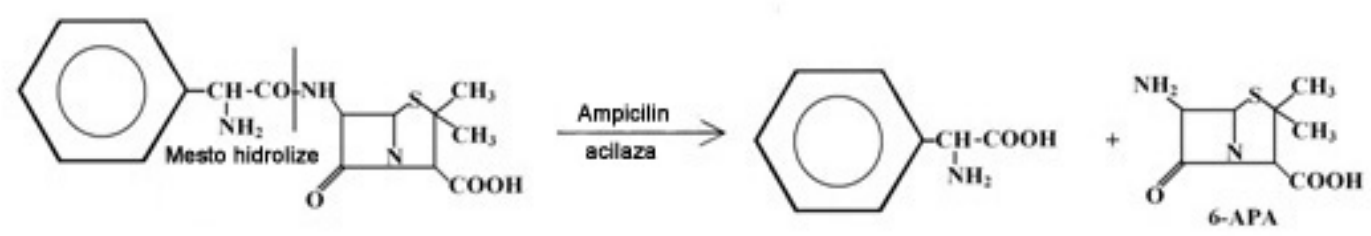

Slika 1.1. Reakcije hidrolize penicilina $V$, penicilina $G i$ ampicilina odgovarajućim enzimima [4]

Pošto cena 6-APA direktno utiče na profitabilnost proizvodnje polusintetskih penicilina, neprestano se ulažu napori da bi se unapredila tehnologija proizvodnje 6aminopenicilanske kiseline. Imobilisana PAC je većim delom uključena u ovaj proces, što obuhvata $88 \%$ svetske proizvodnje 6-APA, dok se ostatak proizvodi pomoću imobilisane penicilin $\mathrm{V}$ acilaze [5]. Kako je cena penicilina $\mathrm{V}$ prosečno za 10-15\% viša od cene penicilina G, PenG predstavlja prioritetan supstrat za proizvodnju 6aminopenicilanske kiseline (slika 1.2) [6]. Zbog toga, naročito velika pažnja je usmerena na primenu i imobilizaciju penicilin-acilaza tipa II koje deluju na penicilin G. 


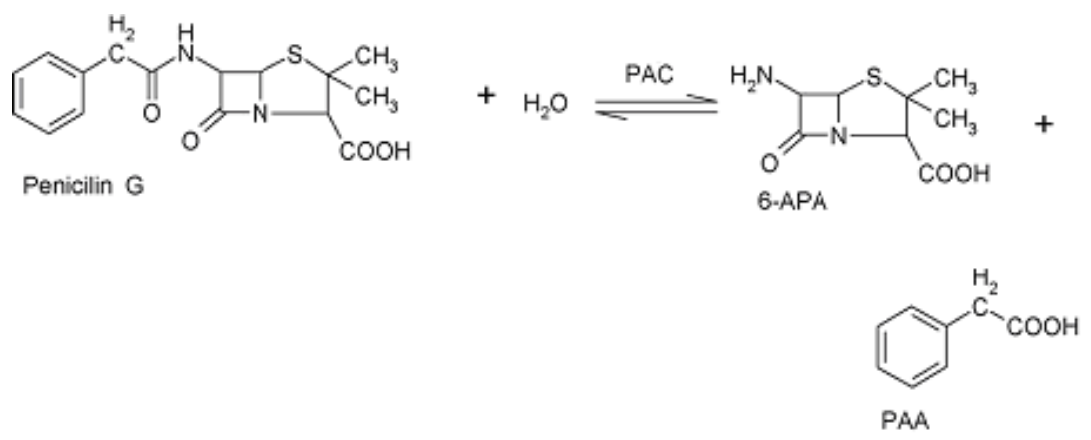

Slika 1.2. Hidroliza penicilina G penicilin-acilazom [7]

Iako nije proteaza, penicilin-acilaza ima veliki afinitet prema različitim amidima, pri čemu je mehanizam njenog dejstva sličan kao u slučaju estara. Penicilin-acilaza je takođe korisna za razdvajanje alkohola, $\beta$-hidroksi- $\alpha$-amino kiselina, $\beta$-amino kiselina, i za zaštitu fenilacetil grupe u sintezi peptida. Osim toga, PAC može da vrši razdvajanje racemskih smeša hiralnih jedinjenja $\mathrm{i}$ ispolji umerenu do odličnu sposobnost stereohemijskog razlikovanja među odgovarajućim enantiomerima u hidrolitičkom raskidanju fenil-acetil grupe iz $\alpha$-aminoalkilfosfornih kiselina, $\alpha$-, $\beta$ - i $\gamma$-amino karboksilnih kiselina, šećera, amina, peptida i estara fenilsirćetne kiseline [8].

Penicilin-acilaza iz Gram-negativnih bakterija kao što su Escherichia coli, Kluyvera citrophila, Providencia rettgeri (ranije poznata kao Proteus rettgeri) i Alcaligenes faecalis se akumulira u periplazmatičnom prostoru (intracelularni, periplazmatični enzimi), dok se penicilin-acilaza iz Gram-pozitivnih bakterija kao što su Arthrobacter viscosus i Bacillus megaterium izlučuje iz ćelija u spoljašnju sredinu (ekstracelularan enzim). Zabeleženo je da je nedavno dobijena intracelularna penicilinacilaza iz vrste Bacillus sp. (tabela 1.1.) [9-15]. 
Tabela 1.1. Mikrobiološki izvori penicilin-acilaze (PAC) [9-15]

\begin{tabular}{llcc}
\hline \multicolumn{1}{c}{ Organizam } & \multicolumn{1}{c}{ Lokacija enzima } & \multicolumn{2}{c}{ Proteinske subjedinice } \\
\cline { 3 - 4 } & & $\alpha(\mathrm{kDA})$ & $\beta(\mathrm{kDa})$ \\
\hline Escherichia coli & Periplazmatični prostor & 23,8 & 63,4 \\
Kluyvera citrophila & Periplazmatični prostor & 23,6 & 61,7 \\
Providencia rettgeri & Periplazmatični prostor & 23,7 & 62,2 \\
Alcaligenes faecalis & Periplazmatični prostor & 23,0 & 62,7 \\
Arthrobacter viscosus & Ekstracelularni & 24,3 & 61,4 \\
Bacillus megaterium & Ekstracelularni & 24,2 & 61,4 \\
Bacillus sp. & Intracelularni & Nije određeno \\
\hline
\end{tabular}

Osobine penicilin-acilaza kao što su aktivnost, termostabilnost, specifičnost prema supstratu zavise od njihovog porekla.

Iako još uvek nije potpuno jasna uloga koju ima ovaj enzim u bakterijama, navodi se da je on uključen u razgradnju fenilacetilovanih jedinjenja zbog stvaranja fenilsirćetne kiseline, koja može da posluži ćeliji kao izvor ugljenika kada se bakterija nađe pod nepovoljnim spoljašnjim uslovima sredine [2]. Takođe, primećeno je da je pac gen kojim je kodiran ovaj enzim u Escherichia coli lociran u blizini grupe gena koji kodiraju enzime uključene u degradativni put 4-hidroksifenilsirćetne kiseline, što navodi na to da bi PAC mogla biti uključena u snabdevanje ćelije fenilacetatnim jedinjenjima koja mogu biti uvedena u neke metaboličke procese [16].

\subsection{Mehanizam delovanja penicilin-acilaze}

PAC je heterodimer, odnosno protein koji se sastoji iz manje $\alpha$-subjedinice i veće $\beta$-subjedinice, koje su formirane obradom prekursora proteina. Član je familije, $N$ terminalnih nukleofilnih hidrolaza (Ntn), klase enzima koji imaju zajednički nabor oko aktivnog centra i sadrže ostatke jedne od aminokiselina, serina, cisteina ili treonina na $N$-terminalnom položaju koji učestvuje u katalitičkoj aktivnosti enzima [17]. 
Ovaj enzim ima dva vezujuća mesta u aktivnom centru: acil-vezujuće mesto, koje služi za vezivanje fenilsirćetne kiseline ili njoj srodnih jedinjenja, i nukleofilvezujuće mesto, koje služi za vezivanje 6-aminopenicilanske kiseline ili nekog drugog nukleofila. Jedinstvena osobina ovog enzima je da u katalitičkom centru ima samo jednu aminokiselinu i to ostatke serina na $N$-terminalnom kraju koji se nalazi na $\beta$ subjedinici.

Reakcioni mehanizam PAC uključuje formiranje kovalentno vezanog intermedijara i sličan je dobro poznatom reakcionom mehanizmu serinskih proteaza (slika 1.3) [18].

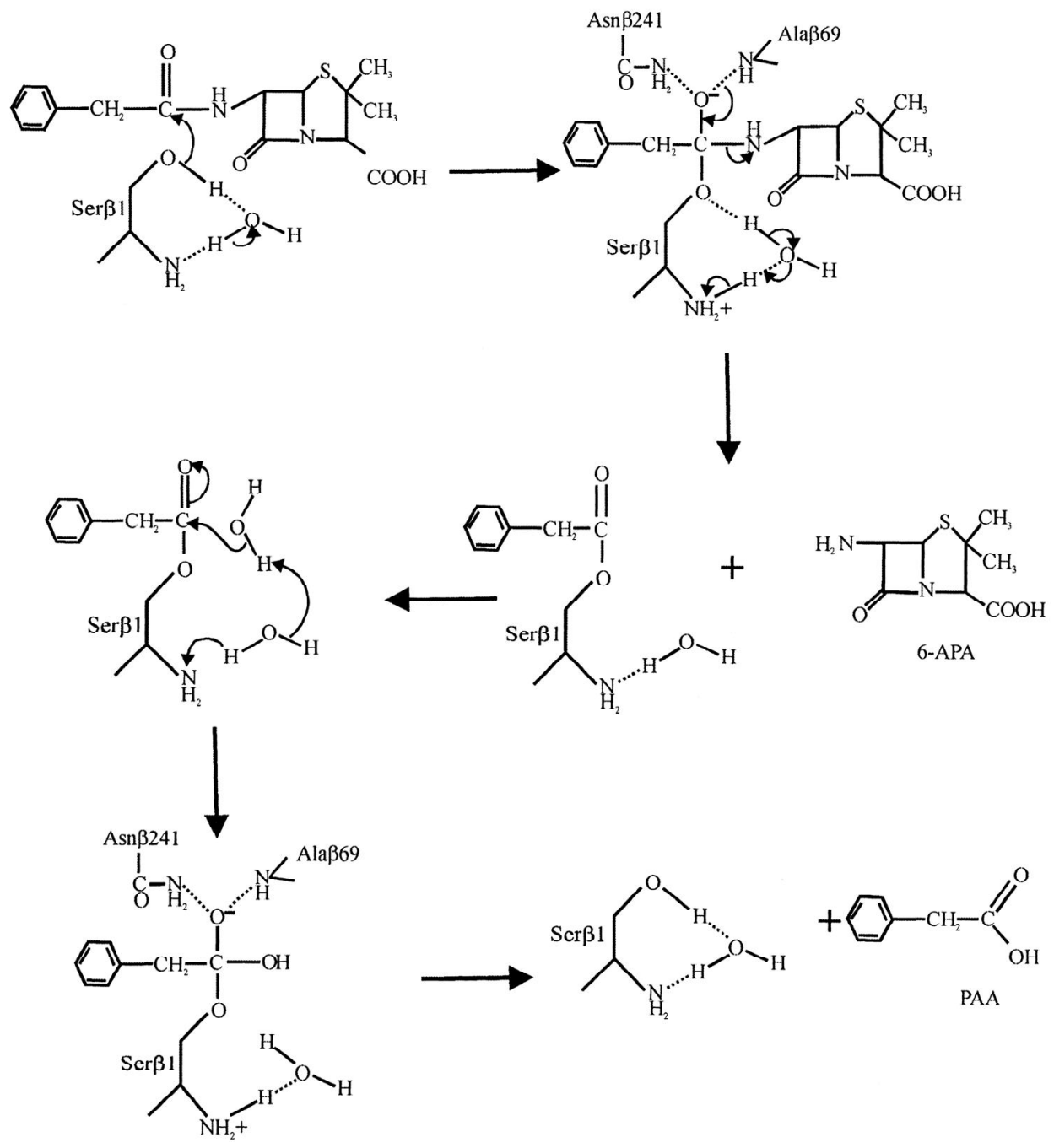

Slika 1.3. Predloženi mehanizam za hidrolizu penicilina G. Tačkaste linije predstavljaju vodonične veze [18] 
Dejstvo enzima počinje nukleofilnim napadom $\mathrm{OH}$ grupe $\mathrm{N}$-terminalnog ostatka serina (Ser) na karbonilni ugljenikov atom amidne ili estarske veze. U tom pogledu sličan je serinskim proteazama, ali umesto katalitičkog trojstva (ostaci tri aminokiseline u katalitičkom centru), koje je karakteristično za serinske proteaze, karakteristika ovog enzima je postojanje samo jedne aminokiseline kao katalitičkog aktivnog centra: Ser $\beta 1$, koja ima hidroksilnu grupu čiji nukleofilni karakter pojačava terminalna amino grupa. Prema tome, ovaj enzim može da se klasifikuje kao N-terminalna nukleofilna hidrolaza [19].

Nakon napada aktivnog nuleofilnog mesta na karbonilni ugljenikov atom amidne veze, formira se kovalentno vezani acil-enzim intermedijar preko tetraedarskog prelaznog stanja u kome je negativno naelektrisan oksianjon naknadno stabilizovan vodoničnim vezama sa ostacima asparagina (Asn $\beta 241$ ) i alanina (Ala $\beta 69$ ), koji čine sastavne delove oksianjonske šupljine [18]. Nakon isključenja odlazeće grupe sa aktivnog mesta, acil-enzim se deaciluje vodom ili nekim drugim nukleofilom, dajući krajnji transacilacioni produkt i slobodni enzim.

Enzim PAC isto tako može da se koristi za proizvodnju polusintetskih $\beta$ laktamskih antibiotika, pri čemu enzim ovde katalizuje kondenzaciju acil-grupe i molekula 6-aminopenicilanske kiseline. U ovakvoj reakciji kondenzacije, aktivirani acil-donor, koga obično predstavlja amid ili metilestar fenilsirćetne kiseline kao njen derivat, acetiluje enzim na serin-aktivnom mestu, uz oslobađanje amonijaka ili metanola kao odlazeće grupe. Rezultujući acil-enzim se tada deaciluje $\beta$-laktamskim nukleofilom kao što je 6-aminopenicilanska kiselina (6-APA) ili 7dezacetoksicefalosporinska kiselina (7-ADCA), dajući pri tome polusintetski penicilin ili cefalosporin [20].

Industrijski značaj PAC je podstakao istraživanja koja se tiču njegove strukture i katalitičkog delovanja. Koriste se dva glavna pristupa: kristalografska strukturalna analiza pomoću X-zraka (obično u prisustvu liganda) i proučavanje kinetike enzimske reakcije u prisustvu inhibitora. U svakom slučaju, proučavaju se enzimi dobijeni pomoću prirodnih i mutiranih mikroorganizama. U literaturi postoje mnoga saglasna mišljenja u pogledu katalitičkog mehanizma PAC, koja se uglavnom tiču početnih elementarnih koraka, to jest acilacije Ser $\beta 1$. Pri hidrolizi penicilina deacilujući agens je voda. 
Kristalna struktura kompleksa enzima PAC iz E.coli i različitih bočnih lanaca kao liganada je prikazana u velikom broju radova [18, 21-25].

\subsection{Mehanizam delovanja penicilin-acilaze iz E.coli: uvid rentgen kristalografijom}

Jedna od najviše proučavanih penicilin-acilaza je penicilin-acilaza iz E.coli. Utvrđeno je da je enzim heterodimer koji se sastoji iz dve subjedinice. $\alpha$-Subjedinica ima 209, a $\beta$-subjedinica ima 557 aminokiselinskih ostataka. Aktivni položaj se nalazi na dnu konične depresije koju formiraju ostaci ovih čvrsto spojenih subjedinica. E.coli produkuje aktivnu PAC ( $86 \mathrm{kDa})$ koja se akumulira u periplazmatičnom prostoru i nastaje iz jedinog neaktivnog prekursora enzima koji ima 26-aminokiselinsku signalnu transportnu sekvencu. Naime, poznato je da je za transport sintetisanog neaktivnog prekursora enzima $\mathrm{u}$ periplazmatičan prostor kroz membranu potrebna signalna sekvenca. Nakon transporta, ova sekvenca se uklanja usled dejstva periplazmatičnih proteaza i formira se aktivni oblik enzima [26].

Daglbi (Duggleby) i saradnici (1995) su prvi predstavili kristalnu strukturu PAC

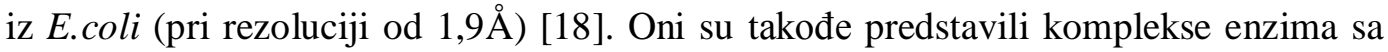
fenilsirćetnom kiselinom (PAA) i fenilmetilsulfonil-fluoridom (PMSF) (pri rezoluciji $2,5 \AA ̊)$, koji se kovalentno vezuju za Ser $\beta 1$ po ugledu na tetraedarski poluacetalni intermedijar. Autori su predložili da se, dok traje proces hidrolize penicilina, nakon nukleofilnog napada $\mathrm{O} \gamma$ na karbonilni $\mathrm{C}$ atom amidne veze molekula penicilina formira acil-enzim intermedijar. Dobijeni oksianjon se dodatno stabilizuje atomom $\mathrm{N} \delta$ iz Asn $\beta 241$, oslanjajući se na NH iz Ala $\beta 69$ i Gln $\beta 23$ (slika 1.4) [18].

Alkema (Alkema) i saradnici (2000) su predložili da se azotov atom iz Gln $\beta 23$ vodoničnim vezama, preko molekula vode, drži za karbonilni kiseonikov atom fenilsirćetne kiseline (PAA) [22]. Slika 1.5. pokazuje detalje ligand-vezujućeg "džepa" iz kristalne strukture kompleksa fenilsirćetne kiseline i enzima (PAA-PAC). Ovde je PAA prikazana u "lopta-štap"obliku. Važni aminokiselinski ostaci u vezujućem mestu enzima su istaknuti u vidu štapića [21]. Mreža predstavlja površinu enzima pristupačnu molekulima rastvarača ukazujući na komplementarnost oblika ovog aktivnog mesta u obliku malog džepa sa fenilsirćetnom polovinom i proračunata je pri ispitivanju na 
radijusu od $1 \AA$. Može se videti da je ovaj bočno lančano-vezujući džep oivičen pretežno ostacima aromatičnih aminokiselina i hidrofobnim bočnim lancima [21].

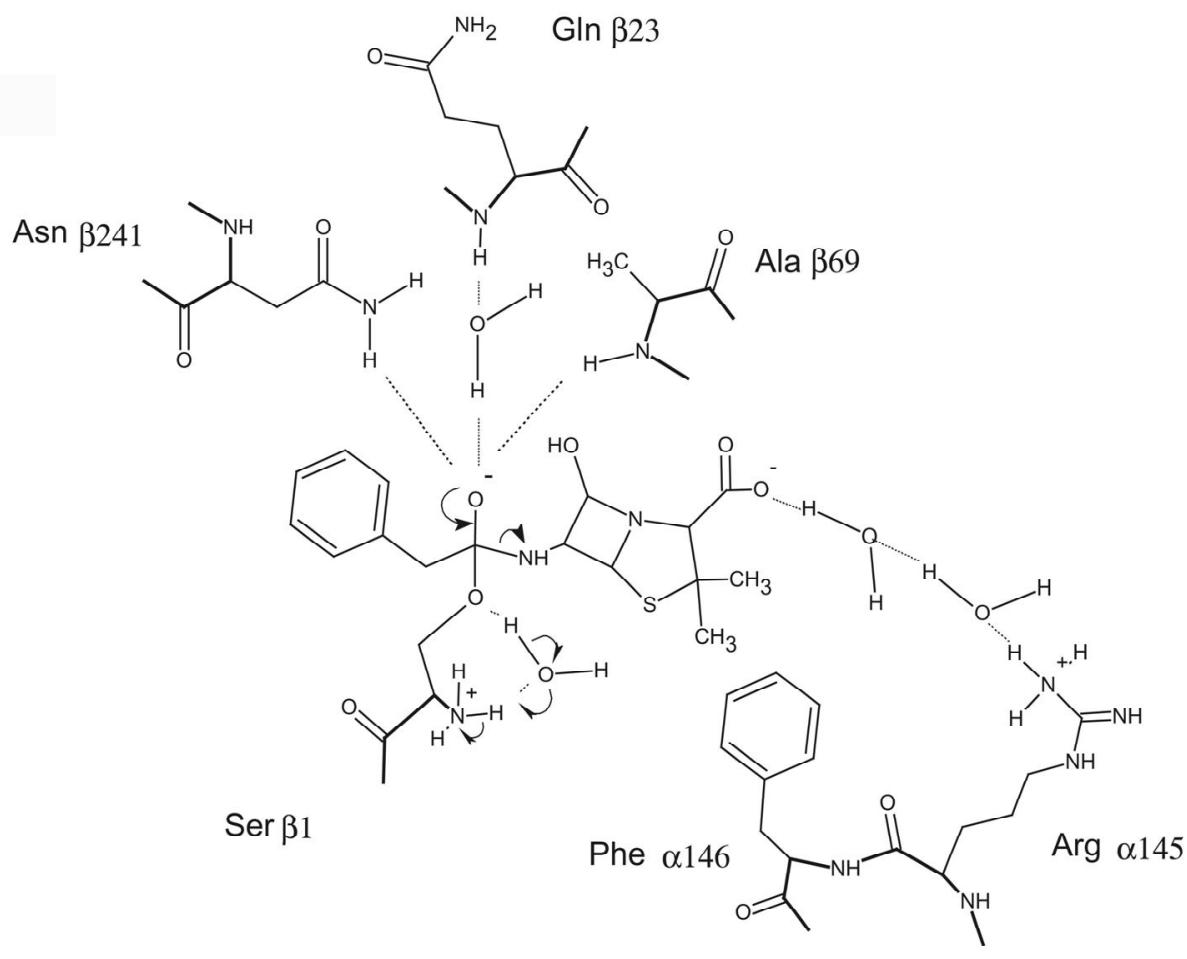

Slika 1.4. Šematski prikaz intermedijarnog stupnja hidrolize PenG. Slika opisuje interakciju Arg a145 sa karboksilnom grupom $\beta$-laktamskog dela molekula. Veze prikazane debelim linijama ukazuju na kostur enzima [22] 


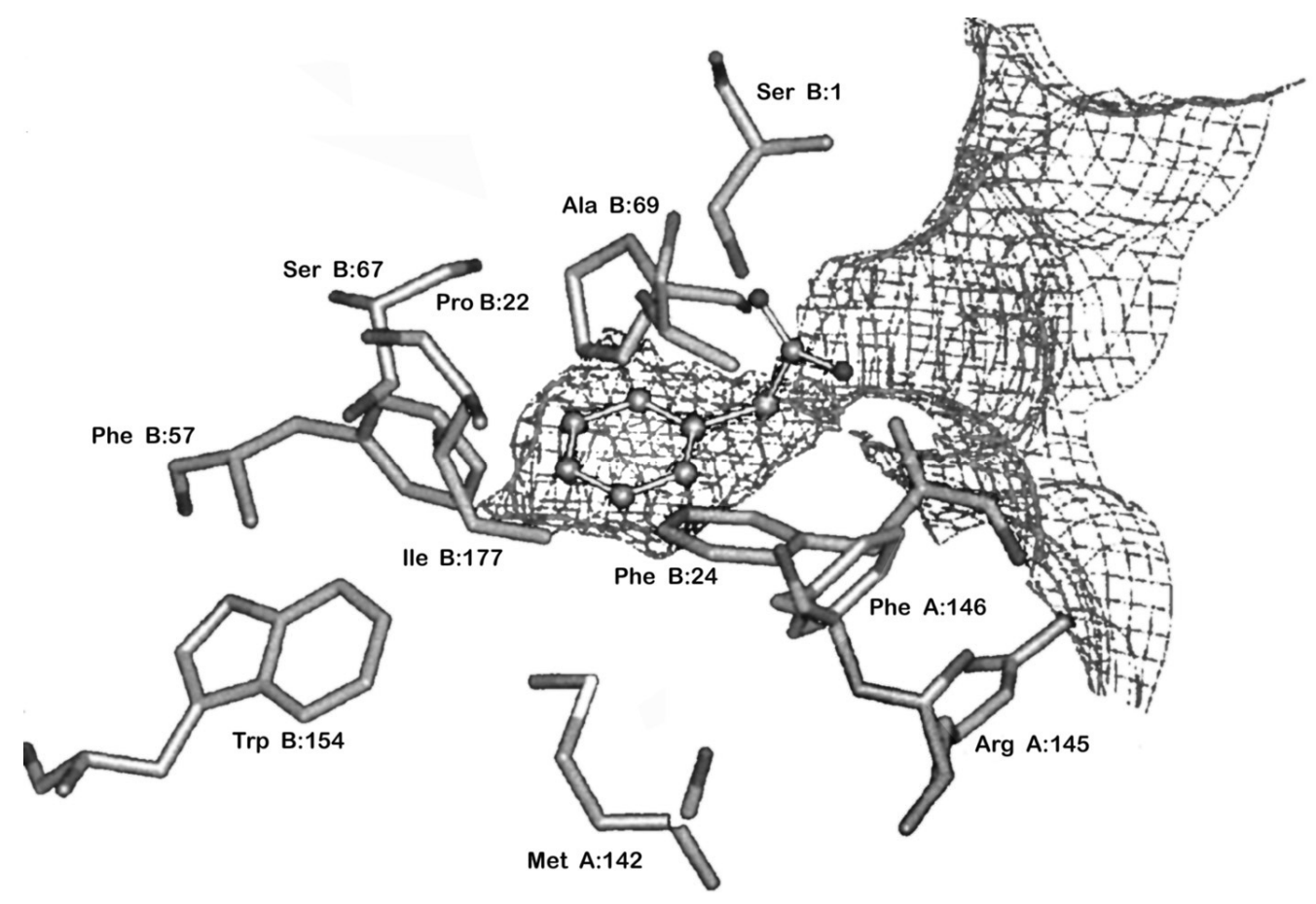

Slika 1.5. Sredina aktivnog mesta u PAA-PAC [21]

Don (Done) i saradnici (1998) su ispitivali specifičnost penicilin-acilaze prema različitim derivatima fenilsirćetne kiseline da bi utvrdili mehanizam stvaranja enzimligand kompleksa i strukturu vezujućeg mesta enzima. Poznato je da je fenilsirćetna kiselina, kao jedan od proizvoda hidrolize penicilina $G$, inhibitor samog enzima, tako da se radi o stvaranju enzim-inhibitor kompleksa. Dakle, autori su ispitivali strukturu enzima na osnovu kinetičke analize uz pomoć inhibitora različite veličine molekula $\mathrm{i}$ odredili strukture kompleksa enzima sa svakim od ovih jedinjenja kristalografijom Xzracima (slika 1.6). Oni su izmerili relativne stepene inhibicije enzima za svako jedinjenje koristeći analizu kompetitivne inhibicije (tabela 1.2). Autori su zabeležili konformacijske promene koje nastaju nakon vezivanja različitih derivata fenilsirćetne kiseline za PAC iz E.coli. Što je afinitet enzima prema inhibitoru veći, odnosno što je vezivanje jače, konstanta inhibicije je manja [21]. Na osnovu ispitivanja, jedinjenja analogna fenilsirćetnoj kiselini se mogu podeliti na dve različite grupe.

Podgrupu 1 čine jedinjenja koja pri vezivanju za enzim ne menjaju njegovu nativnu konformaciju, jedinjenja koja pripadaju ovoj grupi su tiofensirćetna kiselina, 
PAA, fenol i p-hidroksifenilsirćetna kiselina. Ovi ligandi zauzimaju sličan položaj pri vezivanju u kome njihove karboksilne grupe ostaju unutar vezujućeg džepa. U svim ovim slučajevima nije uočeno da dolazi do formiranja niti jedne vodonične veze iz supstituenta na fenolnom prstenu i prsten je čvrsto upakovan naspram bočnog lanca Phe $\alpha 146$.

Podgrupu 2 čine jedinjenja koja pri vezivanju indukuju konformacijsku promenu enzima: Arg $\alpha 145$ i Phe $\alpha 146$, koji igraju važnu ulogu u interakciji sa $\beta$ laktamskim jezgrom, premeštaju se prema rastvaraču, u otvorenu konformaciju. Ova dva ostatka leže na kraju 16-aminokiselinskog $\alpha$-heliksa ( $\alpha$-131 do $\alpha$-146), koji nije posebno pogođen njihovim velikim pomeranjem. U ova jedinjenja spadaju $\mathrm{m}$ nitrofenilsirćetna, 3,4-dihidroksifenilsirćetna, 2,5-dihidroksifenilsirćetna i $p$ nitrofenilsirćetna kiselina. Ovi ligandi nakon vezivanja za enzim imaju karboksilnu grupu isturenu iz vezujućeg džepa prema rastvaraču u odnosu na ligande iz podgrupe 1 . Kao rezultat tog isturenja, ligandi podgrupe 2 su manje sposobni da formiraju vodonične veze preko svojih karboksilnih grupa. Sva četiri liganda su još uvek sposobna da formiraju vodonične veze sa $\mathrm{O} \gamma$ iz Ser $\beta 1$, ali u svim slučajevima je izostavljeno vodonično vezivanje sa $\mathrm{N}$ atomom glavnog lanca iz Ala $\beta 69$ i jedino $m$ nitrofenilsirćetna kiselina i 3,4-dihidroksifenilsirćetna kiselina održavaju veze sa $\mathrm{N} \delta$ iz Asp $\beta 241[19,21]$.

Generalno, rezultati dobijeni za kinetičke konstante inhibicije se slažu sa sternom veličinom liganada koja se upoređuje sa veličinom, oblikom i hemijskim karakteristikama ovog vezujućeg džepa enzima. Može se zaključiti da se usled dodavanja supstituenata u prsten postiže slabije vezivanje enzima sa ligandom u odnosu na fenol, tiofensirćetnu kiselinu ili PAA. Supstituenti stvaraju sterne smetnje i ometaju hidrofobne interakcije koje doprinose vezivanju liganda. Uopšteno, može se videti da se voluminozniji $\mathrm{NO}_{2}$-supstituisan ligand (inhibitor) slabije vezuje nego njemu ekvivalentno $\mathrm{OH}$-supstituisano jedinjenje, sa izuzetkom $m$-nitrofenilsirćetne kiseline koja se jače vezuje nego $m$-hidroksifenilsirćetna kiselina. Rezultati pokazuju da se disupstituisana jedinjenja najslabije vezuju za enzim jer najviše narušavaju hidrofobne interakcije [21]. 
Tabela 1.2. Konstante inhibicije (dobijene vrednosti \pm standardna devijacija) za fenilsirćetnu kiselinu i njene derivate sa penicilin-acilazom [21]

\begin{tabular}{|c|c|}
\hline Jedinjenje & $\mathrm{K}_{i}(\mathrm{mM})$ \\
\hline Tiofensirćetna kiselina $^{\text {a }}$ & $0,049 \pm 0,011$ \\
\hline Fenol $^{\mathrm{a}}$ & $0,082 \pm 0,020$ \\
\hline Fenilsirćetna kiselina ${ }^{a}$ & $0,098 \pm 0,013$ \\
\hline p-Hidroksifenilsirćetna kiselina ${ }^{a}$ & $0,107 \pm 0,021$ \\
\hline m-Nitrofenilsirćetna kiselina & $0,189 \pm 0,021$ \\
\hline o-Hidroksifenilsirćetna kiselina & $0,783 \pm 0,225$ \\
\hline o-Nitrofenilsirćetna kiselina & $1,65 \pm 0,30$ \\
\hline p-Nitrofenilsirćetna kiselina ${ }^{a}$ & $2,32 \pm 0,40$ \\
\hline m-Hidroksifenilsirćetna kiselina & $2,49 \pm 0,56$ \\
\hline 3,4-Dihidroksifenilsirćetna & $3,13 \pm 0,99$ \\
\hline \multicolumn{2}{|l|}{ kiselina $^{a}$} \\
\hline 2,5- Dihidroksifenilsirćetna & $5,85 \pm 3,77$ \\
\hline kiselina $^{a}$ & \\
\hline
\end{tabular}

Svi ligandi se vezuju za enzim tako što fenilni ostatak intereaguje sa hidrofobnim vezujućim mestom enzima, dok im se karboksilna grupa orijentiše prema rastvaraču, blizu katalitičkog serinskog ostatka.

Rezultati eksperimenata inhibicije sa strukturama odgovarajućih kompleksa pokazuju da ligandi podgrupe 1 imaju male vrednosti $K_{\mathrm{i}}$ i smatra se da se bolje vezuju od onih iz podgrupe 2. Odstupanje u vidu anomalije se javlja u slučaju $m$ nitrofenilsirćetne kiseline koja po svemu sudeći spada u podgrupu 2, ali je njena $K_{\mathrm{i}}$ vrednost mala. Ovo se objašnjava pojačanim interakcijama između proteina i liganda u vidu vodonične veze između meta-položaja na aromatičnom prstenu i $\mathrm{O}$ atoma Ser $\beta 1$ [21]. 

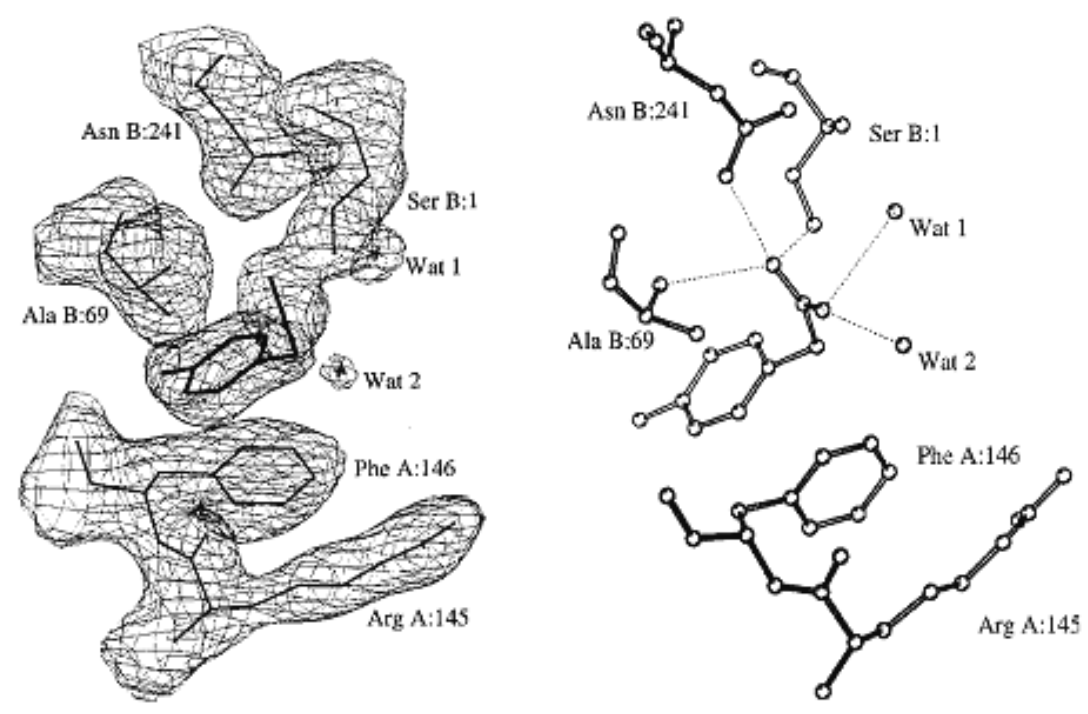

(a)
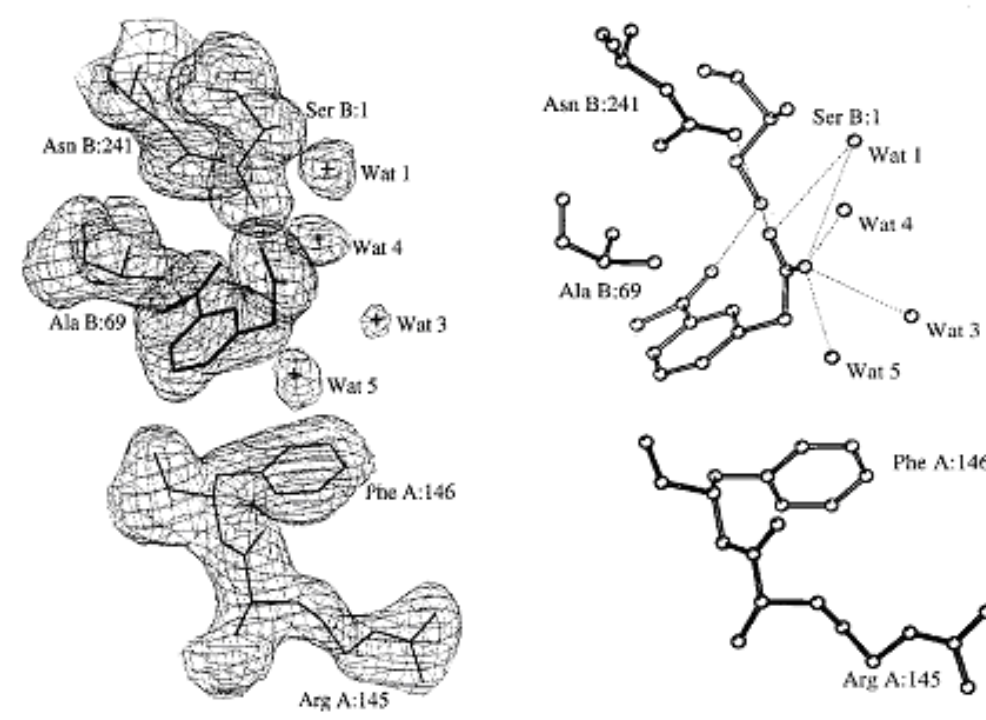

(b)

Slika 1.6. Izgledi kompleksa enzima sa različitim ligandima (a) sa phidroksifenilsirćetnom kiselinom i (b) sa m-nitrofenilsirćetnom kiselinom. Na slici su prikazane elektronska gustina $i$ bitne interakcije unutar vezujućeg mesta enzima. Elektronska gustina je prikazana na 1 $\sigma$ na $2 F_{o}-F_{c}$ mapi na kojoj su prikazani $i$ molekuli vode (obeleženi sa Wat) koji stupaju u interakciju sa ligandom [21]

Predstavljene preklopljene strukture kompleksa ističu činjenicu da $p$ hidroksifenilsirćetna kiselina ne izaziva značajna pomeranja u okolini proteina za koga 
se vezala (slika 1.7). U ovako nativnoj konformaciji, Arg $\alpha 145$ i Phe $\alpha 146$ proteina su sposobni da grade vodonične veze sa $\mathrm{OH}$ grupom Tyr $\beta 41$ i kiseonikom glavnog lanca Phe $\beta 24$ preko tri molekula vode. Ako bi $p$-nitrofenilsirćetna kiselina kao ligand bila u mogućnosti da zauzme isti položaj kakav zauzima $p$-hidroksifenilsirćetna kiselina, došlo bi do sternih smetnji između para- $\mathrm{NO}_{2}$ grupe i bočnog lanca Ser $\beta 67$. Da bi se ovo izbeglo, ligand se premešta u položaj dalje od vezujućeg džepa i usled sternih smetnji između Phe $\alpha 146$ i - $\mathrm{CH}_{2}$ grupe liganda, bočni lanac se pomera na niže za $3,5 \AA$ što dovodi do toga da peptidna veza između ostataka Arg $\alpha 145$ i Phe $\alpha 146$ obrazuje drugačiji ugao (slika 1.8) [21].

(a)
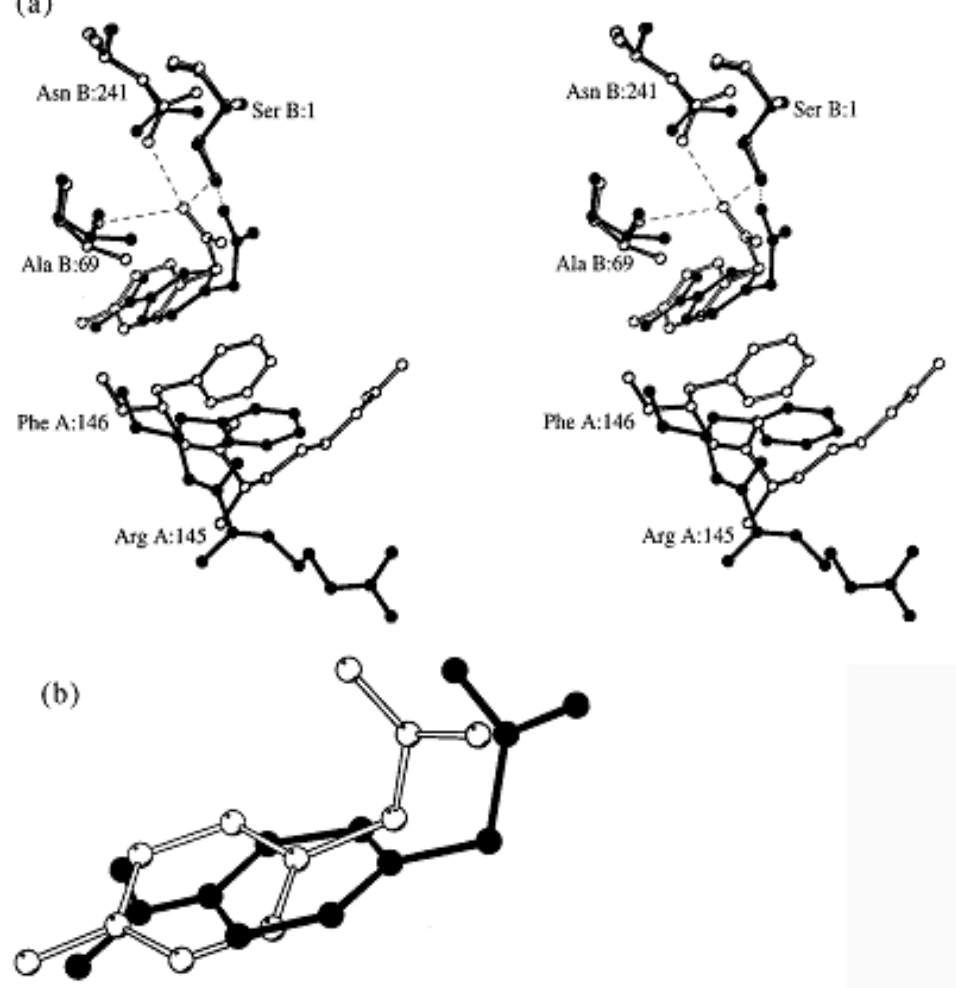

Slika 1.7. (a) Prostorni izgled preklopljenih struktura p-hidroksifenilsirćetne kiseline iz podgrupe 1 (bela) i p-nitrofenil-sirćetne kiseline iz podgrupe 2 (crna) i interakcije koje stvara svaki ligand. Vodonične veze za p-nitrofenilsirćetnu kiselinu su prikazane tačkastim linijama, a vodonične veze za p-hidroksifenilsirćetnu kiselinu su prikazane isprekidanim linijama. (b) Preklopljeni položaj liganada prikazan pod (a) znatno uvećan [21] 


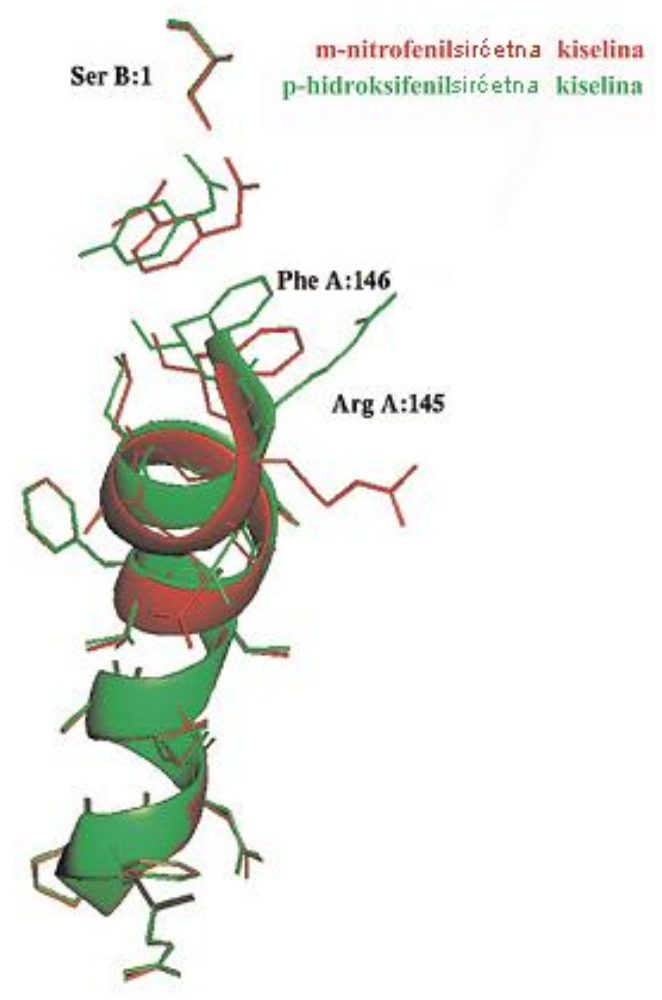

Slika 1.8. Prikaz ostataka $\alpha-131$ do $\alpha-146$ unutar heliksa. Veliko pomeranje koje se javlja u bočnim lancima $\alpha-145$ i $\alpha$-146 utiče jedino na nekoliko ostataka na $C$ terminalnom kraju heliksa [21]

Kao što se može zaključiti, veliki broj radova u literaturi se odnosi na proučavanje kristalne strukture kompleksa enzima i različitih derivata fenilsirćetne kiseline, koja je proizvod reakcije hidrolize penicilina G. Međutim, veoma malo podataka se može naći u literaturi o stvaranju kompleksa enzima i supstrata pri hidrolizi, odnosno jedinjenja sa $\beta$-laktamskim jezgrom. Razlog je što je rastvorljivost penicilin-acilaze i ovih jedinjenja slična, pa je njihova ko-kristalizacija otežana, kao i potapanje kristala enzima sa ovim jedinjenjima. Da bi se prevazišao ovaj problem, konstruišu se modifikovani enzimi metodama proteinskog inženjerstva (mutageneza usmerena položajem) koji imaju drugačiju rastvorljivost od nemodifikovanih enzima i supstrata ili se modifikuju supstrati, dok se enzim kristališe u neizmenjenom obliku. Tako, je penicilin-acilaza iz E.coli modifikovana pomoću mutageneze usmerene položajem [22]. Nakon toga, kristali enzima su potopljeni rastvorom penicilina G i izvršena je analiza strukture. Nađeno je da je penicilin G indukovao pomeranje Arg 
ג145 i Phe $\alpha 146$ ka otvorenoj konformaciji, slično onoj koja je određena za ligande podgupe 2 [21]. Arg $\alpha 145$ je bio pomeren za $8 \AA$ prema rastvaraču, ali je i dalje bio u interakciji sa karboksilnom grupom nukleusa (slika 1.4) preko ugrađenih mostova sa molekulima vode. Na taj na;in je potvrđeno da pozitivno naelektrisan ostatak može da opstane na mestu vezujućem za jezgro [27, 28].

Oba pristupa proučavanju strukture enzim-supstrat kompleksa imaju određene prednosti i nedostatke. Na ovaj način se mogu dobiti važne informacije koje se odnose na mehanizam odvijanja enzimske reakcije hidrolize penicilina $G$, ali one moraju biti u skladu sa kinetičkim podacima i samo se takvi rezultati smatraju validnim. Da bi se utvrdila struktura enzim-supstrat kompleksa, korišćena su i oba navedena pristupa [21]:

- nemodifikovani enzim se tretira modifikovanim supstratom, odnosno penicilin G sulfoksidom (PGSO) i

- denaturisan modifikovani enzim se tretira penicilinom G.

Istaknuto je da je fleksibilnost ostataka Phe $\alpha 146$, Arg $\alpha 145$ i Phe $\beta 71$, koji reaguju sa tiazolidinskim prstenom, neophodna za vezivanje jezgra [19]. Kristalografske studije pokazuju da su hidrofobne interakcije i konformacijske osobine enzima PGA najverovatnije najvažniji faktori koji upravljaju u vezivanju enzima i liganada. Očigledno je da aromatični ostaci unutar aktivnog mesta najviše doprinose prepoznavanju supstrata i vezivanju istog. Otkriveno ja da su konformacije Arg $\alpha 145$, Phe $\alpha 146$ i Phe $\beta 71$ fleksibilne, i da bočni ostaci ovih aminokiselina mogu da zauzmu različite položaje u prisustvu liganda. Utvrđeno je da važnu ulogu u obrazovanju enzim-supstrat kompleksa imaju interakcije između proteina i penamskog prstena (spojeni $\beta$-laktamski i tiazolidinski prstenovi), pri čemu se ističe važnost Phe $\beta 71$. Uzajamna pomeranja između Phe $\beta 71$ i Phe a146 i prelaz između helatnih i spiralnih konformacija može da dozvoli supstratu pristup džepu koji određuje specifičnost enzima, čije je grlo stegnuto ostatkom Phe a146. Ovde je termin "spiralna" konformacija, koja je predstavljena da bi se naglasilo oslabljeno vezivanje liganda, upotrebljen da bi se razlikovao od "helatne" konformacije koja asocira na čvrsto vezivanje liganda za protein [25]. 


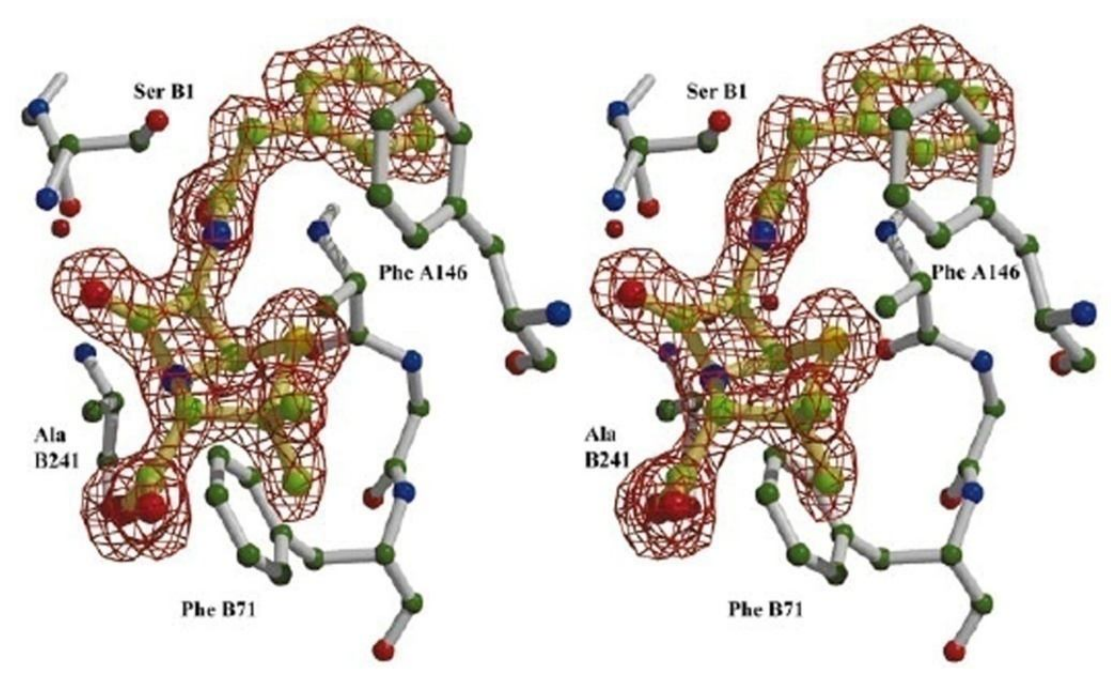

Slika 1.9. Trodimenzionalni izgled konačne $2 F_{o^{-}} F_{c}$ mape (obojena u crveno) elektronske gustine prikazane na $1 \sigma$ za kompleks penicilin G-modifikovana penicilinacilaza [25]

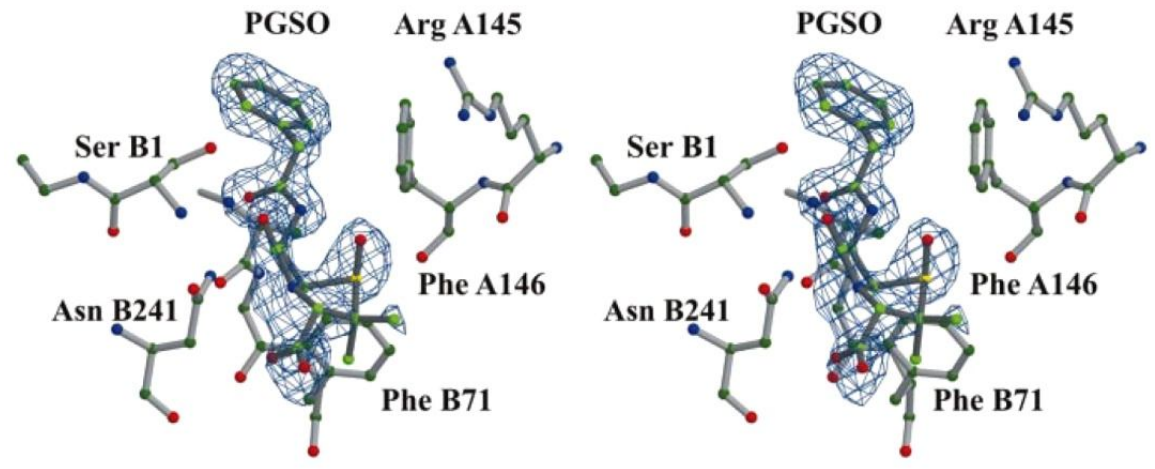

Slika 1.10. Trodimenzionalni izgled mape elektronske gustine PGSO vezanog za aktivno mesto u kompleks DIVLJI TIP-PGSO. $2 F_{o}-F_{c}$ mapa je obojena u plavo $i$ prikazana na $1 \sigma$ nivo. Jasnoće radi, elektronske gustine oko atoma proteina su izostavljene [25] 


\subsection{Kinetika enzimske hidrolize penicilina $G$}

Kinetika enzimske hidrolize PenG katalizovana enzimom PAC iz mutanta E.coli ATCC 11105 je proučavana u direktnom i povratnom smeru i određene su kinetičke konstante [29]. Proučavanje direktne i povratne reakcije i određivanje svih kinetičkih parametara, kao i jednačine kompletne brzine reakcije je neophodno da bi se predvideo rad bioreaktora u kome se izvodi ova enzimska reakcija [29].

Eksperimentalni rezultati pokazuju da na reakciju hidrolize PenG (direktnu reakciju) u prisustvu ovakvog enzima pod standardnim uslovima (100mM Na-fosfatni pufer, $\mathrm{pH} 7,8$ i na $37^{\circ} \mathrm{C}$ ) deluju tri vrste inhibicije:

- $\quad$ inhibicija supstratom, penicilinom $\mathrm{G}(\operatorname{Pen} \mathrm{G}) \mathrm{u}$ višku,

- nekompetitivna inhibicija produktom, 6-aminopenicilanskom kiselinom (6APA) i

- $\quad$ kompetitivna inhibicija produktom, fenilsirćetnom kiselinom (PAA) [30-32].

Početna brzina reakcije $\left(v_{\mathrm{o}}\right)$ se dobija iz sledeće jednačine koja je izvedena iz Mihaelis-Mentenovog modela za jednosupstratnu neinhibiranu enzimsku reakciju:

$$
v_{\mathrm{o}}=\frac{V_{\mathrm{M}}[S]}{K_{\mathrm{M}}+[S]}
$$

gde su: $V_{\mathrm{M}}$-maksimalna brzina reakcije, $K_{\mathrm{M}}$-Mihaelisova konstanta, $[S]$-koncentracija supstrata.

U slučaju inhibicije proizvodom reakcije, kada je proizvod $P$ nekompetitivni inhibitor, Mihaelis-Mentenova jednačina postaje:

$$
v_{\mathrm{i}}=\frac{V_{\mathrm{M}}[S]}{\left(1+\frac{[P]}{K_{\mathrm{iA}}}\right)\left(K_{\mathrm{M}}+[S]\right.}
$$

gde je $v_{\mathrm{i}}$-početna brzina inhibirane reakcije, $K_{\mathrm{iA}}$-konstanta nekompetitivne inhibicije.

Isto tako, kada je drugi proizvod reakcije, $Q$ kompetitivni inhibitor, MihaelisMentenova jednačina je:

$$
v_{\mathrm{i}}=\frac{V_{\mathrm{M}}[S]}{K_{\mathrm{M}}\left(1+\frac{[Q]}{K_{\mathrm{iB}}}\right)+[S]}
$$


gde je $[Q]$-koncentracija fenilsirćetne kiseline, $K_{\mathrm{iB}}$-konstanta kompetitivne inhibicije.

Konačno, za inhibiciju supstratom, Mihaelis-Mentenova jednačina je:

$$
\frac{1}{v_{\mathrm{i}}}=\frac{1}{V_{\mathrm{M}}}+\frac{[S]}{V_{\mathrm{M}} K_{\mathrm{S}}}
$$

gde je $K_{\mathrm{S}}$ konstanta inhibicije supstratom u višku.

Ako se uzmu u obzir sve inhibicije, jednačina koja se zasniva na tom mehanizmu reakcije može da se izrazi na sledeći način:

$$
v_{\mathrm{i}}=\frac{V_{\mathrm{M}}[S]}{\left(1+\frac{[P]}{K_{\mathrm{iA}}}\right) \cdot\left([S]+K_{\mathrm{M}}\left(1+\frac{[Q]}{K_{\mathrm{iB}}}\right)\right)+\frac{[S]^{2}}{K_{\mathrm{S}}}}
$$

Kinetika stacionarnog stanja za reakciju deacilacije PenG (za direktnu reakciju) u prisustvu PAC uključuje supstrat PenG i oba produkta 6-APA i PAA. Ovakav mehanizam reakcije se grafički može predstaviti kao na slici 1.11 [33-35].

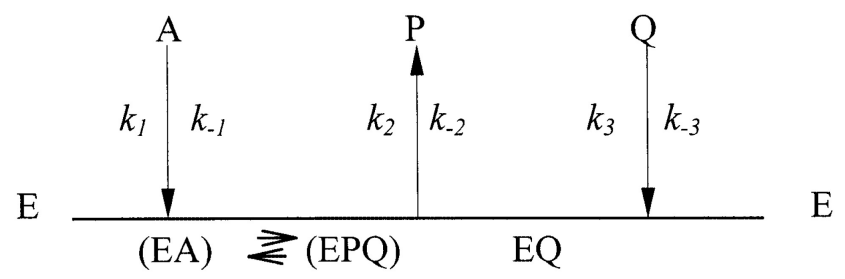

Slika 1.11. Grafičko predstavljanje mehanizma ukupne reakcije enzimske hidrolize PenG. E-PAC, A-Pen G, P-6 APA i Q-PAA [33-35]

Za konstante brzine reakcije i konstante ravnoteže važe sledeće jednačine:

$$
\begin{array}{ll}
k_{1}=V_{\mathrm{max}, \mathrm{r}} /\left(K_{\mathrm{iA}} E_{\mathrm{t}}\right) & k_{-1}=V_{\mathrm{max}, \mathrm{r}} / E_{\mathrm{t}} \\
1 / k_{2}=E_{\mathrm{t}} / V_{\mathrm{maxf}}-1 / k_{3} & k_{-2}=\left(k_{-1}+k_{2}\right) / K_{\mathrm{mP}} \\
k_{3}=K_{\mathrm{iQ}} V_{\mathrm{max}, \mathrm{r}} /\left(K_{\mathrm{mA}} E_{\mathrm{t}}\right) & k_{-3}=V_{\mathrm{max}, \mathrm{r}} /\left(K_{\mathrm{mA}} E_{\mathrm{t}}\right) \\
K_{\mathrm{iA}}=k_{-1} / k_{1} & K_{\mathrm{iQ}}=k_{3} / k_{-3}
\end{array}
$$

gde su:

$V_{\max , \mathrm{f(r)}}-$ maksimalna brzina reakcije u direktnom (povratnom) smeru, $K_{\mathrm{iA}(\mathrm{Q})}=$ konstanta inhibicije za $\mathrm{A}(\mathrm{Q})$, 
$\mathrm{E}_{\mathrm{t}}$-ukupna koncentracija enzima,
$K_{\mathrm{iQ}}=$ konstanta inhibicije za Q,
$K_{\mathrm{mA}(\mathrm{P})}=$ Michaelis-ova konstanta za A $(\mathrm{P})$.

Komponente EA, EPQ i EQ su kompleksi prelaznih stanja. Jednačina ukupne brzine reakcije (1.6) za reakciju hidrolize PenG je opisana kao [33-36]:

$$
v=\frac{V_{\mathrm{max}}\left(A-P Q / K_{\mathrm{e}}\right)}{A+K_{\mathrm{mA}}+P\left(K_{\mathrm{iA}} / K_{\mathrm{iP}}\right)+Q\left(K_{\mathrm{mA}} / K_{\mathrm{iQ}}\right)+P Q\left[K_{\mathrm{iA}} /\left(K_{\mathrm{iP}} K_{\mathrm{mQ}}\right)\right]+A P / K_{\mathrm{iP}}}
$$

gde je:

$v=$ početna brzina reakcije,

$\mathrm{A}, \mathrm{P}, \mathrm{Q}=$ koncentracije supstrata $\mathrm{A}$ i proizvoda reakcije, $\mathrm{P}$ i Q,

$V_{\max }=$ maksimalna brzina reakcije,

$K_{\mathrm{mQ}}=$ Michaelis-ova konstanta za Q,

$K_{\mathrm{e}}$-konstanta ravnoteže reakcije,

$K_{\text {iP }}=$ konstanta inhibicije za P.

Pošto je vrednost $K_{\mathrm{e}}$ vrlo velika, jednačina 1.6. se često pojednostavljuje sledećom jednačinom pod uslovom da su koncentracije proizvoda reakcije zanemarljive:

$$
v=\frac{V_{\max } A}{K_{m A}+A}
$$

Lako se uočava da oblik jednačine (1.7) odgovara obliku klasične MihaelisMentenove jednačine [29].

\subsection{Specifičnost penicilin-acilaze prema supstratu i njena primena}

\subsubsection{Specifičnost PAC iz Esherichia coli prema supstratu}

Penicilin-acilaza je sposobna da hidrolizuje različite amide opšte strukture: R-CONH-R'. Specifičnost prema supstratu je određena najviše acilnom polovinom R (zbog čega se naziv acilaza češće koristi nego amidaza) i PAC ima veći afinitet prema hidrofobnim grupama. Suprotno tome, R' ostatak (amino polovina) može znatno da 
varira i odlazeća grupa ima minimalan efekat na brzinu reakcije hidrolize [22]. "Slobodnija" specifičnost prema supstratu dovela je do različitih novijih primena ovog enzima kao biokatalizatora, uključujući razdvajanje nekih alkohola, hidroksiaminokarboksilnih kiselina i za protekciju fenilsirćetne grupe u sintezi peptida. Pored toga, PAC može da razdvaja racemske smeše nekih hiralnih jedinjenja i pokazuje umerenu stereohemijsku specifičnost između odgovarajućih enantiomera $u$ hidrolitičkom raskidanju fenilacetatne grupe iz $\alpha$-aminoalkilfosfornih kiselina, $\alpha-, \beta$ - i $\gamma$-aminokarboksilnih kiselina, šećera, amina, peptida i estara fenilsirćetne kiseline [37].

Interes za biokatalizatorima počiva na iskorišćavanju njihovih izvanrednih osobina kao što su regiospecifičnost i stereospecifičnost. Ova poslednja osobina nam pruža mogućnost primene biokatalizatora i za proizvodnju optički čistih jedinjenja. Biokatalitičko razdvajanje racemskih smeša se zasniva na specifičnosti enzima prema enantiomerima optički aktivnih molekula, u kojima jedan enantiomer iz racemske smeše ostaje neproreagovan, a drugi enantiomer se konvertuje u željeni čist produkt/intermedijar [37].

Pokazano je da izvanredna specifičnost PAC (poziciona i stereohemijska specifičnost) može uspešno da se koristi u biokatalitičkim procesima za proizvodnju čistih enantiomera iz [37]:

- $\quad$ racemskih metil estara 2-ariloksikarboksilnih kiselina (tabela 1.3),

- $\quad$ nekih rac 2-ariloksikarboksilnih kiselina i

- $\quad$ nesteroidnih antiinflamatornih lekova kao što su rac ketoprofen i rac suprofen.

Ispitivana je stereospecifičnost enzima u reakciji hidrolize optički aktivnih estara različite strukture i rezultati su dati u tabeli 1.3. Kao što se vidi, veliki stepeni konverzije $(\mathrm{C}>40 \%)$ i velika stereospecifičnost (ee $>80 \%$ ) su dobijeni za jedinjenja koje karakteriše $\mathrm{CH}_{3}$-grupa u $\alpha$-položaju i za jedinjenje koje ima sekundarni aromatični prsten na asimetričnom $\mathrm{C}$ atomu. Za takvo jedinjenje, koje ima aromatični prsten vezan za hiralni C atom, raskidu veze u (S)-estru većem od 99,9\% odgovara 47,9\% konverzija racemskog estra [38]. 
Tabela 1.3. Uticaj strukture supstrata na stepen konverzije i stereohemijsku selektivnost. C, konverzija (\%); ee, višak enantiomera (\%); E, stereohemijska specifičnost; R.S.D.\%, eksperimentalna greška $(n=2)$ [38].

\begin{tabular}{|c|c|c|c|c|c|c|c|}
\hline Racemat & $\Lambda$ & B & $\mathrm{R}$ & $C(\%)$ & R.S.D. \% & $e e^{\mathrm{a}}$ & $E$ \\
\hline 1 & $\mathrm{Cl}$ & $\mathrm{O}$ & $\mathrm{CII}_{3}$ & 50.6 & 2.97 & $81.1 \%(S)$ & 23 \\
\hline 2 & $\mathrm{Cl}$ & $\mathrm{O}$ & $\mathrm{C}_{2} \mathrm{I}_{5}$ & 5.4 & 0.46 & $39.0 \%(S)$ & 2.3 \\
\hline 3 & $\mathrm{Cl}$ & $\mathrm{O}$ & $\mathrm{C}_{6} \mathrm{H}_{3}$ & 47.9 & 2.75 & $>99.9 \%(S)$ & $>200$ \\
\hline 4 & $\mathrm{Cl}$ & $\mathrm{S}$ & $\mathrm{CH}_{3}$ & 19.7 & 4.8 & $4.3 \%(S)$ & 1.1 \\
\hline 5 & $\mathrm{Cl}$ & $\mathrm{NH}$ & $\mathrm{CH}_{3}$ & 6.7 & 2.2 & $66.4 \%(S)$ & 5.3 \\
\hline 6 & $\mathrm{Cl}$ & $\mathrm{CH}_{2}$ & $\mathrm{CH}_{3}$ & 10.5 & 0.64 & $38.2 \%(S)$ & 2.3 \\
\hline 7 & $\mathrm{Br}$ & $\mathrm{O}$ & $\mathrm{CH}_{3}$ & 46.7 & 0.73 & $82.9 \%(S)$ & 23 \\
\hline 8 & $\mathrm{~F}$ & $\mathrm{O}$ & $\mathrm{CH}_{3}$ & 28.2 & 0.42 & $17.1 \%(S)$ & 1.5 \\
\hline 9 & $\mathrm{CH}_{3}$ & $\mathrm{O}$ & $\mathrm{CH}_{3}$ & 22.7 & 0.25 & $85.3 \%(S)$ & 15 \\
\hline
\end{tabular}

${ }^{a}$ Brzo proreagovani enantiomer.

Interesantno je da promena supstituenta na $\alpha$-položaju iz metil u etil grupu dovodi do dramatične redukcije brzine konverzije i stereohemijske specifičnosti. Iz ovih podataka može se zaključiti da supstituent na aromatičnom prstenu igra veliku ulogu u brzini reakcije i specifičnosti enzima. Jedinjenja sa najjačim hidrofobnim i elektron-akceptorskim supstituentima su najbrže hidrolizovana. Prisustvo kiseonikovog atoma u $\alpha$-položaju je takođe važno za katalitičku aktivnost, jer je enzim slabo hidrolizovao i imao malu stereospecifičnost prema ostalim izoestrima [37].

\subsubsection{Specifičnost penicilin-acilaze iz Achromobacter sp. CCM 4824}

Interesantno je uporediti specifičnost penicilin-acilaze iz E. coli sa nekim drugim bakterijskim penicilin-acilazama. PAC iz bakterije Achromobacter sp. CCM 4824 pokazuje skoro dva puta veću hidrolitičku aktivnost prema ampicilinu, amoksicilinu i cefaleksinu u odnosu na penicilin G.

Ispitana je sposobnost hidrolize prirodnih i polusintetskih $\beta$-laktamskih antibiotika pod standardnim uslovima pomoću čiste PAC iz Achromobacter sp. Da bi se odredila relativna aktivnost na različitim supstratima, rađen je paralelan eksperiment sa PAC iz E. coli RE3 (pKA18). Podaci kolorimetrijskog ispitivanja su prikazani u tabeli 1.4. PAC iz Achromobacter sp. ima skoro dva puta veću hidrolitičku aktivnost sa 
polusintetskim antibiotikom ampicilinom (takođe i sa amoksicilinom i cefaleksinom) nego sa penicilinom G. Penicilin V je slabo hidrolizovan, dok se nikakva aktivnost nije pokazala sa cefalosporinom $\mathrm{C}$. Osnovna razlika između ovog novog enzima i poznate PAC je glavni supstrat na koji deluju. Rekombinantna PAC iz E. coli RE3 (pKA18) hidrolizuje polusintetski ampicilin, amoksicilin i cefaleksin sa dosta manjom aktivnošću u poređenju sa penicilinom G [39]. Sličan odnos između aktivnosti (ampicilin/penicilin G) je primećen i kod PAC iz E. coli ATCC 11105, A. faecalis ATCC 15246, B. megaterium ATCC 14945 i P. rettgeri PCM 1384 [40-42]. Iz tog razloga se ovi enzimi originalno nazivaju penicilin $G$ acilaze. Međutim, postoji nedostatak relevantnih uporedivih podataka iz literature o specifičnosti prema supstratima ostalih PAC [39]. 
Tabela 1.4. Specifičnost prema supstratu penicilin-acilaze (PAC) i ampicilin acilaze (AEH) dobijene iz različitih mikroorganizama. Pen G-penicilin G, Pen V-penicilin V, Amp-ampicilin, Amx-amoksicilin, Ceph-cefaleksin, DAOC G-deacetoksicefalosporin G, DAOC V-deacetoksicefalosporin V, NIPAB-6-nitro-3-fenilacetilamidobenzojeva kiselina [39].

\begin{tabular}{|c|c|c|c|c|c|c|c|c|c|}
\hline \multirow[b]{2}{*}{ Bakterija } & \multirow{2}{*}{$\begin{array}{c}\text { Tip } \\
\text { enzima }\end{array}$} & \multicolumn{8}{|c|}{ Relativna aktivnost (\%) } \\
\hline & & $\begin{array}{c}\text { Pen } \\
\text { G }\end{array}$ & $\begin{array}{c}\text { Pen } \\
\mathrm{V}\end{array}$ & Amp & Amx & Ceph & $\begin{array}{l}\mathrm{DAO} \\
\mathrm{C} \mathrm{G}\end{array}$ & $\begin{array}{l}\mathrm{DAO} \\
\mathrm{C} \mathrm{V}\end{array}$ & $\begin{array}{c}\text { NIPA } \\
\text { B }\end{array}$ \\
\hline $\begin{array}{l}\text { Achromobacter } \\
\text { sp. CCM } 2428\end{array}$ & PAC & 100 & 23 & 197 & 199 & 190 & 99 & 19 & 65 \\
\hline $\begin{array}{c}\text { E.coli } \\
\text { RE3(pKA18) }\end{array}$ & PAC & 100 & 12 & 51 & 38 & 61 & 95 & 6 & 32 \\
\hline $\begin{array}{c}\text { E.coli ATCC } \\
11105\end{array}$ & PAC & 100 & 7 & 19 & n.d. & n.d. & n.d. & n.d. & 48 \\
\hline $\begin{array}{c}\text { A.faecalis } \\
\text { ATCC } 15246\end{array}$ & PAC & 100 & 12 & 83 & n.a. & n.d. & n.d. & n.d. & n.d. \\
\hline $\begin{array}{l}\text { B.megaterium } \\
\text { ATCC } 14945\end{array}$ & PAC & 100 & 0 & 35 & n.d. & n.d. & n.d. & n.d. & n.d. \\
\hline $\begin{array}{c}\text { P.rettgeri PCM } \\
1384\end{array}$ & PAC & 100 & 13 & 25 & n.d. & n.d. & n.d. & n.d. & n.d. \\
\hline $\begin{array}{c}\text { P.melanogenu } \\
m \text { IFO } 12020\end{array}$ & $\mathrm{AEH}$ & 0 & 0 & 100 & 0 & 71 & n.d. & n.d. & n.d. \\
\hline $\begin{array}{l}\text { A.turbidans } \\
\text { ATCC } 9325\end{array}$ & $\mathrm{AEH}$ & n.d. & n.d. & 100 & 6 & 214 & n.d. & n.d. & n.d. \\
\hline
\end{tabular}

n.d. nije dostupno. Aktivnost PAC za penicilin G i AEH za ampicilin su uzete za 100\%. 


\subsection{Uticaj pH, temperature i koncentracije supstrata na aktivnost enzima PAC}

Karakterizacija enzima je neophodna da bi se svojstva enzima, koji vodi poreklo iz jednog organizma, uporedila sa onima iz drugih organizama. Enzimska kinetika analizira uticaj faktora na brzinu enzimske reakcije kao što su $\mathrm{pH}$, temperatura i koncentracija supstrata. Određivanje optimalne $\mathrm{pH}$ i optimalne temperature, kao i kinetičkog modela koji opisuje uticaj koncentracije supstrata na aktivnost enzima je veoma važno kada enzim treba da se upotrebi u industriji i vrednosti ovih parametara mogu da variraju u zavisnosti od porekla samog enzima i supstrata. Vrednosti Mihaelisove konstante, $K_{\mathrm{m}}$ za hidrolizu PenG koje su zabeležene u literaturi variraju u zavisnosti od porekla samog enzima [43].

Većina enzima poseduje karakterističnu $\mathrm{pH}$ vrednost pri kojoj je njihova aktivnost maksimalna. Ispod i iznad ove vrednosti, aktivnost je manja. Tercijarna struktura enzima, koja je odgovorna za njegovu katalitičku aktivnost, stabilizovana je vodoničnim vezama, hidrofobnim interakcijama i disulfidnim vezama. Usled promene koncentracije vodonikovih jona, dolazi do promene $\mathrm{u}$ jačini ovih interakcija, pa $\mathrm{i}$ do ireverzibilne denaturacije enzima. Ostali faktori koji su povezani sa uticajem $\mathrm{pH}$ vrednosti na enzimsku aktivnost zavise od kiselosti i baznosti samog enzima i samog supstrata [43].

Generalno, za enzim se vezuje samo jedan jonski oblik supstrata (neutralni ili naelektrisani oblik) čija koncentracija zavisi od $\mathrm{pH}$ vrednosti. Isto tako, za aktivnost enzima je odgovoran određeni aminokiselinski ostatak koji treba da bude $u$ disosovanom ili nedisosovanom obliku. U slučaju PAC iz E.coli, amino grupa serinskog ostatka (aktivni centar), koji je prisutan u $\beta$-subjedinici, odgovorna je za privlačenje $\mathrm{H}^{+}$jona od strane $\mathrm{OH}^{-}$grupe ovog ostatka [18]. Samo pod određenim uslovima kiseonikov atom iz $\mathrm{OH}$ grupe ostatka serina može da privuče $\mathrm{H}^{+}$proton i da se veže za amid penicilina $G$, odnosno aktivnost enzima direktno zavisi od pK vrednosti amino grupe iz esencijalnog serinskog ostatka.

Uticaj temperature, koji se javlja u svim hemijskim reakcijama, je takav da brzina reakcije koju katalizuje enzim raste eksponencijalno sa porastom temperature $u$ okviru određenog temperaturnog opsega u kome je enzim stabilan. Pošto su enzimi 
termolabilne supstance, po hemijskom sastavu prosti i složeni proteini, koji deluju na fiziološkim temperaturama.

Enzimska aktivnost penicilin-acilaze se kvantitativno određuje merenjem početne brzine hidolize PenG pri standardnim uslovima (određena koncentracija supstrata, određena vrednost $\mathrm{pH}$ sredine i temperatura). Uticaj početne koncentracije supstrata (PenG) se takođe ispituje preko početne brzine reakcije pri standardnim uslovima ( $\mathrm{pH}$ i temperatura). Izbor vremena trajanja reakcije se određuje tako da konverzije budu manje od $10 \%$. U tom slučaju koncentracije proizvoda reakcije su male, a mogući inhibirajući efekti proizvoda reakcije se mogu zanemariti.

Od važnosti je navesti neke kinetičke podatke određene za različite penicilinacilaze. Enzim iz B. megaterium ATCC 14945 se sastoji iz dve subjedinice, a svaka u sebi sadrži 245 i 537 aminokiselina, prosečnih molekulskih masa 26950 Da i 59070 Da. Parametri čiji je uticaj ispitivan na početnu brzinu reakcije hidrolize su [43]:

- uticaj temperature u opsegu od $25-60{ }^{\circ} \mathrm{C}$,

- uticaj pH u opsegu od 5-10 i

- uticaj koncentracije supstrata (Pen G) u opsegu od 0,5-10 mM.

Maksimalna brzina hidrolize je postignuta na $37^{\circ} \mathrm{C}$ u $200 \mathrm{mM} \mathrm{Na-fosfatnom} \mathrm{puferu,}$ pH 8,0 i dobijeni su sledeće vrednosti kinetičkih konstanti: $K_{\mathrm{m}}=1,83 \mathrm{mM}$ i $V_{\max }=$ $0,165 \cdot 10^{-3}\left(\mathrm{mM}_{\mathrm{PenG}} / \mathrm{min} \cdot \mathrm{IU}\right)$. Enzimska aktivnost je definisana kao početna brzina hidrolize PenG pod standardnim uslovima (Pen G 4\% (w/v) je pripremljen u fosfatnom puferu $0,2 \mathrm{M}$, pH 8,0 na $37^{\circ} \mathrm{C}$ ). Pri tome je IU jedinica definisana kao količina enzima koja katalizuje formiranje $1 \mu \mathrm{mol} / \mathrm{min}$ 6-aminopenicilanske kiseline (6-APA), pod standardnim uslovima. Određena optimalna $\mathrm{pH}$ vrednost za penicilin-acilazu iz $B$. megaterium na $37^{\circ} \mathrm{C}$ bila je 8,0 .

Sevidž i Kol (Savidge i Cole) (1975), proučavajući hidrolizu PenG, dobili su vrednosti Mihaelisove konstante, $K_{\mathrm{m}}$ 7,7 $\mathrm{mM}$ i 4,5 mM, redom, za penicilin-acilazu iz E.coli i $B$. megaterium. Budući da je konstanta $K_{\mathrm{m}}$ kvantitativna mera afiniteta enzima prema supstatu, vrednost dobijena za penicilin-acilazu iz B. megaterium ATCC 14945 $\left(K_{\mathrm{m}}=1,83 \mathrm{mM}\right)$ govori da PAC iz $B$. megaterium ima najveći afinitet prema penicilinu G [44]. 


\subsection{Proizvodnja penicilin-acilaze}

Za industrijsku primenu enzima veoma je važno da se oni ekonomično proizvode u dovoljnim količinama po pristupačnim cenama. Treba istaći da proizvodnja enzima ima određenu specifičnost u poređenju sa drugim mikrobiološkim procesima. Kao prvo, veliki broj industrijskih enzima je induktivno, pa je neophodno to imati u vidu pri sastavljanju hranljive podloge. Kao drugo, biosinteza velikog broja enzima suzbija se kataboličkom represijom. Pored toga, na ovom mestu treba naglasiti da proizvodnja enzima nije završena sintezom polipeptidnog lanca u ćeliji, već proces proizvodnje i aktivnost proizvedenog enzima u velikoj meri zavise od post-translacionih modifikacija, a kod ekstracelularnih i periplazmatičnih enzima i od transporta enzima kroz membranu u vanćelijski ili periplazmatičan prostor [26].

Penicilin-acilaza koja se najviše industrijski koristi proizvodi se iz E. coli kao periplazmatičan enzim, iako je mogu produkovati i drugi mikroorganizmi. U E. coli se produkuje kao inaktivni prekursor pre-proenzim koji se aktivira u procesima autokatalitičke proteolize u kojima se uklanjaju dve peptidne sekvence: jedna, Nkrajnja peptidna sekvenca potrebna za transport kroz membranu, i druga, koja maskira aktivni centar. Ovi procesi aktivacije odigravaju se uglavnom u toku transporta enzima kroz membranu u periplazmatični prostor. Penicilin-acilaza se produkuje na sličan način i u slučaju primene drugih proizvodnih mikroorganizama [26].

Postoje tri glavna regulaciona mehanizma u E. coli koja su uključena u sintezu PAC enzima $i$ to su: katabolička represija, indukcija fenilsirćetnom kiselinom i termoregulacija. Utvrđeno je da fenilsirćetna kiselina i njene soli indukuju produkciju penicilin-acilaze na nivou transkripcije, pa se nakon njihovog dodavanja u hranljivu podlogu postižu veći prinosi enzima. Hranljiva podloga se sastoji od izvora ugljenika (glukoze), izvora azota, faktora rasta i neorganskih soli, uglavnom kalcijuma jer enzim sadrži jon $\mathrm{Ca}^{2+}$ po molekulu enzima kao kofaktor. Veoma je važno da se održava dovoljno niska koncentracija glukoze u hranljivoj podlozi da ne bi došlo do značajnog smanjenja produkcije enzima usled kataboličke represije [26].

Gen koji kodira penicilin-acilazu iz divlje Escherichia coli je pac gen. Njegova ekspresija je indukovana fenilsirćetnom kiselinom i suzbijena glukozom i one utiču na ekspresiju gena na nivou transkripcije [45]. Sinteza penicilin-acilaze (PAC) pomoću 
Kluyvera cithrophila se takođe može indukovati fenilsirćetnom kiselinom i suzbiti glukozom [46]. Kada se produkcija vrši pomoću Providencia rettgeri, pac gen nije indukovan fenilsirćetnom kiselinom i ne podvrgava se kataboličkoj represiji pomoću glukoze, ali je suzbijen $\mathrm{C}_{4}$-dikarboksilnim kiselinama iz Krebsovog ciklusa, kao što su ćilibarna, fumarna i jabučna kiselina [47]. Pri produkciji PAC pomoću Alcaligenes faecalis, Arthrobacter viscosus i Bacillus megaterium, induktor je fenilsirćetna kiselina, ali se sinteza ne reguliše kataboličkom represijom. Što se tiče uticaja temperature kod svih mikroorganizama je primećeno da suviše visoka temperatura negativno utiče na proces biosinteze enzima.

Penicilin-acilaza se obično proizvodi u optimalnom temperaturnom intervalu od 24-30 ${ }^{\circ} \mathrm{C}$, ali ne i na $37^{\circ} \mathrm{C}$. Ovakav efekat temperature nije usled dezaktivacije enzima, pošto optimalna temperatura za njegovu aktivnost iznosi približno $40{ }^{\circ} \mathrm{C}$ [44]. Do negativnog uticaja povišene temperature na biosintezu enzima dolazi usled nastajanja suviše velike količine pre-proenzima i agregacije ovako neaktivnih molekula enzima pre delovanja intracelularnih proteaza koje uklanjaju nepotrebne aminokiselinske ostatke. Dakle, formiraju se inkluziona tela unutar ćelije usled čega se smanjuje prinos enzima na povišenim temperaturama [26]. Stoga je optimizacija i kontrola temperature veoma važna prilikom industrijske proizvodnje ovog enzima.

Faze u procesu proizvodnje PAC su:

1. sinteza prekursora enzima (pre-proenzim) koji sadrži signalni peptid, $\alpha$-jedinicu, peptid koji maskira aktivni centar i $\beta$-jedinicu,

2. transport prekursora enzima $u$ periplazmatični prostor i uklanjanje signalnog proteina (formira se proenzim),

3. proteolitičko odcepljivanje $\mathrm{N}$-terminalne $\beta$-jedinice $\mathrm{i}$

4. uklanjanje peptida koji zaklanja centar iz $\alpha$-subjedinice preko Cterminalne proteolitičke obrade proteazama u dva ili tri koraka [48].

Za hiperprodukciju PAC primenjuju se različite metode genetičkog inženjerstva za dobijanje vrsta koje su produktivnije i hiperosetljive na penicilin $\mathrm{G}$, kao što su:

1. klasične mutacije,

2. tehnike rekombinantne DNK,

3. post-translacione modifikacije.

Za svaku od ovih metoda je presudan izbor ćelije domaćina [1]. 


\section{STABILIZACIJA PENICILIN-ACILAZE}

Za industrijsku primenu enzima veoma su važni operativna stabilnost enzima kao i stabilnost pri lagerovanju [1]. Jedan od ključnih faktora za upotrebu enzima $u$ biotehnološkoj praksi je njihova stabilizacija nasuprot denaturaciji u ekstremnim uslovima kao što su visoka temperatura, kiseli i alkalni $\mathrm{pH}$ ili prisustvo organskih rastvarača [49]. Osnovni nedostatak penicilin-acilaze je njena mala stabilnost na povišenim temperaturama, u organskim rastvaračima kao i pri ostalim spoljnim uticajima u industrijskim uslovima. Zbog toga se primenjuju različite metode sa ciljem poboljšanja svojstava enzima, pre svega, njegove aktivnosti i stabilnosti u industrijskim uslovima [1].

Metode koje se koriste mogu biti metode molekularnog inženjerstva (mutageneza i usmerena evolucija) i ostale negenetske metode [26]. U negenetske metode spadaju:

- izolacija i selekcija mikroorganizama koji produkuju enzime boljih svojstava,

- upotreba različitih aditiva koji povećavaju stabilnost enzima,

- $\quad$ imobilizacija enzima na čvrste nosače i

- $\quad$ hemijska modifikacija enzima [1].

Sve gore navedene metodologije se uspešno primenjuju da bi se povećala stabilnost PAC u odnosu na temperaturu, $\mathrm{pH}$ i organske rastvarače [1].

\subsection{Mehanizam termalne dezaktivacije}

$\mathrm{U}$ industrijskoj primeni PAC naročito je prisutan problem njene male termalne stabilnosti. Naime, da bi se povećala brzina procesa i prostorno-vremenski prinos $\mathrm{u}$ reaktoru, potrebno je proces voditi na povišenim temperaturama, često iznad $60{ }^{\circ} \mathrm{C}$. Tako se brzina katalize PAC u toku hidrolize Pen G i Cep G povećava sa porastom temperature do $60{ }^{\circ} \mathrm{C}[50,51]$. Međutim, enzimska stabilnost je znatno niža na temperaturama iznad $40{ }^{\circ} \mathrm{C}$ i dolazi do denaturacije enzima. Iz tih razloga, stabilizacija PAC na temperaturama iznad $40{ }^{\circ} \mathrm{C}$ ima veliku važnost za njenu industrijsku primenu [52]. 
U industrijskim procesima termalno stabilni enzimi imaju velikih prednosti jer se tada proces može odvijati na povišenim temperaturama što daje sledeće prednosti:

- postiže se veća brzina reakcije i produktivnost,

- termodinamička ravnoteža se može pomeriti u pravcu nastajanja veće količine proizvoda reakcije,

- rastvorljivost supstrata $\mathrm{i}$ drugih reagenasa je obično veća na višim temperaturama,

- viskoznost reakcionog medijuma je manja i

- smanjen je rizik od mikrobiološke kontaminacije [1].

Prema tome, poslednjih godina stabilizaciji PAC je posvećena velika pažnja. Sistematično se ulažu veliki napori za izolovanje novih mikroorganizama koji sintetišu stabilne enzime. Primećena je termostabilna PAC iz A. faecalis, a njen gen je kloniran i njegova ekspresija je izvršena u E.coli .

Termalna dezaktivacija penicilin-acilaze je u skladu sa dvostepenim modelom ireverzibilne dezaktivacije, koja se odvija kroz dva stupnja. Prvo se odvija reverzibilna termalna dezaktivacija enzima do delimično denaturisanog oblika, $R$ a zatim ireverzibilna denaturacija do potpuno neaktivnog oblika, I:

$$
\mathrm{N} \rightleftarrows \mathrm{R} \rightarrow \mathrm{I}
$$

gde je $\mathrm{N}$ nativni, $\mathrm{R}$ reverzibilno denaturisani, a I ireverzibilno denaturisani, odnosno potpuno neaktivni oblik enzima [55]. Stabilizacione metode generalno teže usporavanju jednog ili drugog stupnja dezaktivacije. Reverzibilna denaturacija se najbolje sprečava imobilizacijom, dok aditivi poput ugljenih hidrata, površinski aktivnih supstanci, poliola i soli usporavaju irverzibilni stupanj [1].

Uvijena trodimenzionalna struktura globularnog proteina, kao što je enzim, je stabilizovana kovalentnim disulfidnim vezama i slabim nekovalentnim interakcijama uključujući vodonične veze, elektrostatičke, van der Valsove (van der Waals) i hidrofobne veze. Poboljšanje stukturne stabilnosti enzima može da se postigne jačanjem ovih kovalentnih i nekovalentnih interakcija u proteinskom molekulu [12]. 


\subsection{Stabilizacija penicilin-acilaze dodatkom različitih aditiva}

Stabilizacioni efekti soli su nespecifični i njihovi joni uglavnom doprinose isoljavanju enzima u vodenim rastvorima tako što smanjuju solvataciju molekula enzima. Usled toga dolazi do obrazovanja jačih hidrofobnih interakcija između bočnih aminokiselinskih ostataka u molekulu enzima i smanjenja rastvorljivosti enzima. U slučaju penicilin-acilaze, dve subjedinice se drže zajedno hidrofobnim silama. Na ovaj način, prisustvo soli kao što su $\left(\mathrm{NH}_{4}\right)_{2} \mathrm{SO}_{4}$ i $\mathrm{Na}_{2} \mathrm{SO}_{4}$ pomaže vezivanju ovih jedinica $\mathrm{u}$ nativnu formu, što doprinosi stabilnosti enzima [54].

Dodavanjem poliola takođe se često povećava stabilnost nativnih proteina. Stabilizacija PAC se povećava za $180 \%$ u prisustvu trehaloze nakon inkubacije na temperaturi od $60{ }^{\circ} \mathrm{C}$ u toku 30 minuta [55]. Enzim je dva puta stabilniji u prisustvu glukoze, dok je u prisustvu saharoze stabilniji čak četiri puta. Dekstran 11500 značajno povećava termalnu stabilnost enzima, i do 100 puta, na $55{ }^{\circ} \mathrm{C}$ [56]. Dodavanje dekstranskih polimera enzimskom rastvoru može izazvati istiskivanje molekula vode iz hidrofobnog dela globule enzima, zbog čega se formira kompaktniji hidrofobni molekul sa poboljšanom stabilnošću. Formiranjem vodoničnih veza između dekstrana i vode smanjuje se aktivnost vode u rastvoru enzima, zbog čega je molekul enzima stabilniji u dekstran-voda suspenziji nego u samoj vodi [1].

Upotreba organskih rastvarača ili njihovih vodenih rastvora poboljšava izvođenje enzimske sinteze $\beta$-laktamskih antibiotika $[57,58]$. Termodinamička ravnoteža može da se menja u smeru sinteze koristeći hidrofobne rastvarače u reakcionom medijumu. Pošto PAC gubi svoju aktivnost u organskim rastvaračima ili njihovim vodenim rastvorima, stabilizacija PAC u organskim rastvaračima zahteva pažnju da bi se ubrzala reakcija sinteze. Upotrebom etilenglikola ili glicerola kao organskih rastvarača koji su poznati kao stabilizatori enzima, poboljšava se sinteza ampicilina pri čemu ne dolazi do dezaktivacije enzima [59].

Najznačajnije poboljšanje do sada dobijene katalitičke aktivnosti enzima $u$ organskim rastvaračima rezultat je liofilizacije enzima u prisustvu inertnih supstanci, kao što su polimeri, šećeri i proste nepuferne soli. Jednostavnom liofilizacijom PAC u prisustvu nepuferne soli $(\mathrm{KCl})$, dobijen je liofilizat koji se pokazao kao izvanredno 
aktivan biokatalizator $\mathrm{u}$ organskom rastvaraču. Nađeno je da je PAC 750 puta reaktivnija u $n$-heksanu nakon liofilizacije u prisustvu $\mathrm{KCl}$, pri čemu se preparat sastoji iz 98 mas \% soli, 1 mas \% enzima i ostatak čini fosfatni pufer [60].

\subsection{Stabilizacija penicilin-acilaze hemijskom modifikacijom enzima}

Hemijska modifikacija enzima pomoću umrežavajućih agenasa predstavlja koristan metod za povećavanje termalne stabilnosti proteinskih molekula. Hemijskim umrežavanjem moguće je stabilizovati konformaciju nativnog enzima i smanjiti brzinu njegove termalne dezaktivacije. Glutaraldehid je agens koji se najčešće koristi za umrežavanje molekula enzima. Ipak, umrežavanjem enzima glutaraldehidom dobija se samo blago povećanje termostabilnosti. Poluvreme dezaktivacije enzima se na $40{ }^{\circ} \mathrm{C}$ povećava sa 30 na 90 minuta, ali na višim temperaturama njegova stabilnost ostaje nepromenjena [61].

Ispitana su tri različita efekta bis-imidoestara kao umrežavajućih agenasa na termostabilnost PAC. Primećena je 15 puta veća termostabilnost enzima nakon umrežavanja dimetiladipimidatom, a da se nisu promenile vrednosti kinetičkih konstanti, kao ni optimalna temperatura [62].

PAC katalizuje hidrolitičke reakcije pri blago alkalnim $\mathrm{pH}$ vrednostima $(7,5-8,0)$ i reakcije sinteze pri nižim $\mathrm{pH}$ vrednostima $(4,0-7,0)$. Prema tome, pri sintezi $\beta$ laktamskih antibiotika, koja se izvodi pri kiselim pH vrednostima, stabilnost enzima je od vitalnog značaja. Hemijskim umrežavanjem PAC dimetiladipimidatom povećava se i pH stabilnost enzima u intervalu od 3,0-9,0 [63]. Naime, ovako modifikovani enzim zadržao je u potpunosti početnu aktivnost pri inkubaciji pri $\mathrm{pH}$ vrednostima između 4,0-9,0 u toku 120 minuta [64].

Modifikacija površine proteina enzima makromolekulima se $\mathrm{u}$ nekim slučajevima takođe pokazala kao efikasan način za poboljšanje stabilnosti ovih biomolekula [65-68].

Uopšteno, efikasnost ove metode zavisi od izbora odgovarajućih uslova zasnovanih na:

(I) tipu, veličini, i strukturi enzima,

(II) strukturi i veličini modifikujućeg polimera i 
(III) tipu i uslovima za hemijsku reakciju uključenu u proceduru modifikacije [69].

Rastvorljivost u vodi, biokompatibilnost i netoksičnost mnogih polisaharida, kao i činjenica da je u prirodnim glikoenzimima uloga ugljenohidratnog dela upravo $\mathrm{u}$ stabilizaciji trodimenzionalne strukture proteinskog dela, favorizovali su korišćenje ugljenohidratnih polimera za modifikovanje enzima [70]. Na primer, kovalentno vezivanje dekstrana, polimerizovane saharoze i karboksimetilceluloze (CMC) za enzime se pokazalo uspešnim [52, 71-74].

Hemijska modifikacija ugljenim hidratima je uspešan metod za poboljšanje stabilnosti biokatalizatora zahvaljujući formiranju dodatnih inter- i intra- molekulskih mostova u glikozilovanom enzimskom molekulu [75]. Uopšteno, polisaharidi su efikasniji stabilizatori od mono- ili disaharida jer višetačkasto vezivanje takvih polihidroksila povećava krutost kao i hidrataciju enzimskog molekula [76].

Postupak modifikacije enzima polisaharidima se može objasniti na primeru dekstrana.

Perjodatna oksidacija je efikasna za uvođenje aldehidnih grupa na C-2 i C-4 poziciju D-glukoznog ostatka u dekstranu. Tako pripremljeni dekstran se vezuje za amino grupe ciljnog proteina kovalentnim vezama i hidroksilne grupe dekstrana mogu da intereaguju sa hidrofilnim grupama proteina, povećavajući stabilnost proteina (slika 2.1.) [77].

Dekstrani različitih molekulskih masa su oksidacijom prevedeni u derivate dialdehida i kovalentno su vezani za $\varepsilon$-amino grupe ostataka lizina i $\mathrm{N}$-terminalnih $\alpha$ amino grupa proteinskog molekula stvarajući pri tome Šifovu bazu (Schiff). Dekstrandialdehidno-modifikovana PAC imala je devet puta veće poluvreme dezaktivacije na $55^{\circ} \mathrm{C}$, a da je vrednost njene kinetičke konstante, $V_{\max }$ ostala nepromenjena [52].

Stabilnost PAC se može povećati i glikozilacijom kvaščevim mananima. Dialdehidni derivat manana je korišćen za umrežavanje PAC i dobijen je modifikovani enzim veće stabilnosti pri ekstremnim $\mathrm{pH}$ vrednostima i temperaturama. Hemijskom reakcijom aldehidnih grupa manana sa $\varepsilon$-amino grupama lizina molekula PAC formiraju se jedinjenja tipa Šifove baze koja su veoma stabilna [78]. Slično tome, zabeleženo je četvorostruko povećanje termostabilnosti i pH-stabilnosti enzima njegovim umrežavanjem sa karboksimetil-celulozom [79]. 

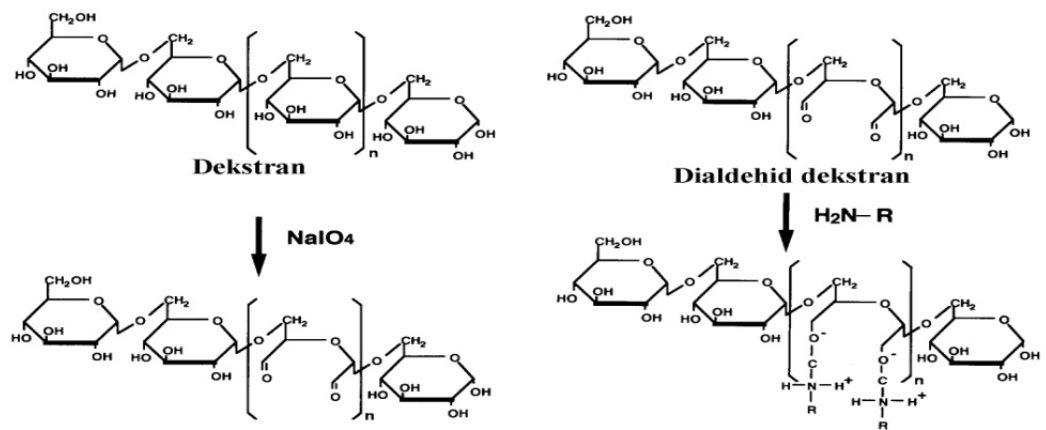

Dialdehid dekstran

(a)

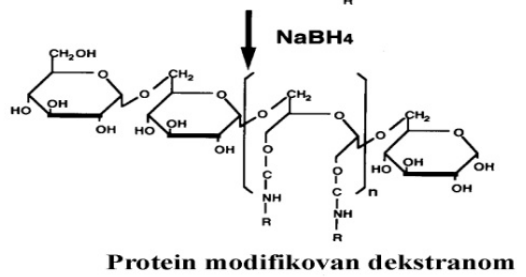

(b)

Slika 2.1. Modifikacija proteina dekstranom (a) Uvođenje dialdehidnih grupa u glukozne ostatke dekstrana perjodatnom metodom (b) Modifikacija proteina dialdehiddekstranom. $\mathrm{H}_{2} \mathrm{~N}$-R predstavlja protein [72]

Na osnovu datih podataka jasno je da se svojstva PAC potencijalno mogu poboljšati hemijskom modifikacijom različitim polisaharidima. Međutim, još uvek nije ispitana modifikacija PAC oksidovanim derivatima skroba, niti alginata, i nije ispitana mogućnost imobilizacije tako stabilizovanog enzima na čvrste nosače.

Stabilnost enzima se može značajno povećati i samo njihovom imobilizacijom. PAC je moguće imobilisati na različite nosače od prirodnih do sintetičkih polimera $\mathrm{i}$ uloženi su veliki napori da se poboljšaju kinetičke osobine imobilisanih enzima. Kako je imobilizacija penicilin-acilaze jedan od predmeta istraživanja ovog doktorata, imobilizaciji enzima će biti posvećena veća pažnja. 


\section{IMOBILIZACIJA ENZIMA}

\subsection{Definicija i svrha imobilizacije}

Primena enzima $u$ industriji je ograničena zbog visoke cene enzima, neekonomičnog načina primene i male stabilnosti. Imobilizacija enzima je postupak kojim se enzim u reakcionom sistemu odvaja od ostalih učesnika (reaktanata i proizvoda) tako što se fizički lokalizuje ili hemijski vezuje u određenom prostoru pri čemu zadržava svoju katalitičku aktivnost. Pri imobilizaciji, enzim se najčešće prevodi iz rastvornog u nerastvoran oblik.

Razlozi za imobilizaciju enzima su sledeći [80]:

1. postiže se višestruka upotreba biokatalizatora, što znači da imobilisani enzim može više puta da se vraća u proces. Nasuprot tome, slobodan enzim se može upotrebiti samo jednom i ne može se opet koristiti za sledeće procese;

2. postiže se veća stabilnost biokatalizatora u toku katalitičkog procesa i tokom lagerovanja. Imobilisani enzim je uglavnom otporniji na uticaje temperature i pH i može se duže vremena lagerovati, a da pri tome ne izgubi aktivnost;

3. omogućeno je kontinualno vođenje procesa tako što se reakcije katalizovane imobilisanim enzimima mogu izvoditi kontinualno u različitim reaktorima pa je moguća automatska kontrola procesa;

4. omogućena je lakša kontrola procesa, jer se reakcija može zaustaviti u bilo kom trenutku jednostavnim uklanjanjem biokatalizatora;

5. postiže se lako izdvajanje enzima iz reakcione smeše (filtracijom ili centrifugiranjem) tako da u proizvodima reakcije nema zaostalih proteina pa nema kontaminacije proizvoda;

6. snižava se cena koštanja enzima i celog tehnološkog postupka.

Jedan od osnovnih zahteva u industriji je obezbeđivanje kontinualnih tehnoloških procesa i trebalo bi da bude rešen razvojem imobilizacionih tehnika. Pri tome, trebalo bi da se očuvaju funkcionalne osobine enzima i postigne odgovarajuća stabilnost imobilisanog enzima u toku dugotrajnog perioda [81]. 
Jedan od važnih faktora imobilizacije enzima je izbor i dizajn nosača za imobilizaciju jer fizičke i hemijske osobine nosača u velikoj meri određuju aktivnost imobilisanog enzima $[82,83]$. Nosač treba da ima takav hemijski sastav da pokazuje veliki afinitet prema enzimima tako da se enzim vezuje pod blagim uslovima, ili fizičkom adsorpcijom ili hemijskim kovalentnim vezivanjem, koji neće dovesti do njegove denaturacije [84].

Svojstva imobilisanog enzima su određena svojstvima enzima i nosača. Interakcija između njih daje imobilisani enzim sa specifičnim hemijskim, biohemijskim, mehaničkim i kinetičkim osobinama (slika 3.1.) [85].

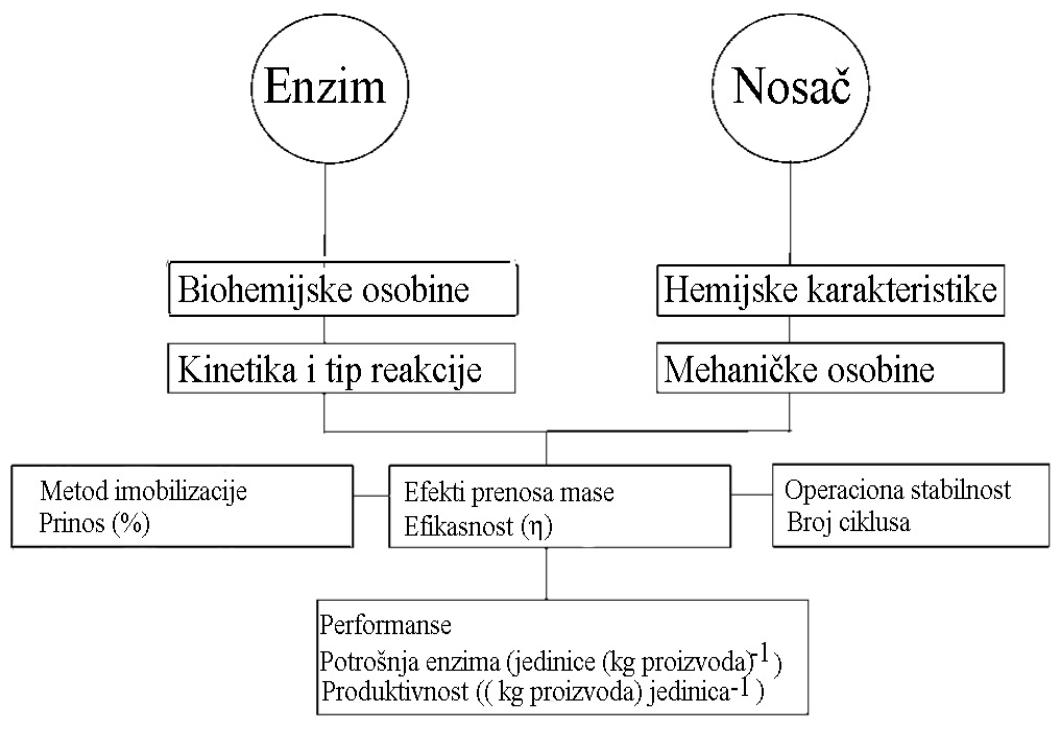

Slika 3.1. Osobine imobilisanih enzima su određene kombinacijom svojstava enzima $i$ nosača [26]

Najvažniji parametar ocene metode imobilizacije je prinos aktivnosti koji predstavlja odnos specifične aktivnosti imobilisanog i slobodnog enzima izražen u procentima i određuje se standardnim metodama u sistemu bez difuzionih limitacija (obično iznosi od $0-100 \%$, u retkim slučajevima je veći od 100\%). Ovaj parametar kvantitativno pokazuje koliko je enzim zadržao od početne aktivnosti u toku samog postupka imobilizacije. U realnim sistemima, pri izvođenju reakcije, imobilisani enzim dodatno gubi aktivnost zbog difuzionih otpora što se kvantitativno izražava faktorom efektivnosti, $\eta$. Međutim, stabilnost enzima se $u$ većini slučajeva povećava 
imobilizacijom čime se nadoknađuju gubici aktivnosti enzima usled ograničene difuzije pri izvođenju reakcije u sistemu sa imobilisanim enzimom i pretrpljenog hemijskog ili mehaničkog postupka imobilizacije. Produktivnost procesa, koja predstavlja količinu proizvedenog proizvoda po jedinici aktivnosti enzima (kg/IU), je sveukupna ocena imobilisanog sistema i ona se značajno povećava sa povećanjem broja upotreba biokatalizatora u šaržnom sistemu ili operativne stabilnosti u kontinualnom [26].

\subsection{Metode imobilizacije enzima [26]}

U širem smislu metode imobilizacije se dele u dve grupe: hemijske i fizičke metode. Hemijske metode se zasnivaju na stvaranju najmanje jedne hemijske veze između molekula enzima i nosača. Fizičke metode imobilizacije se zasnivaju na vezivanju molekula enzima za nosač vezama nekovalentnog tipa (dipol-dipol interakcije, elektrostatičke interakcije, vodonične veze) ili na mehaničkom smeštanju enzima u određeni deo prostora.

U užem smislu razlikuju se sledeće metode:

1. kovalentno vezivanje enzima za nosač- zasniva se na formiranju najmanje jedne hemijske veze između molekula enzima i nosača;

2. adsorpcija enzima na nosač- zasniva se na uspostavljanju slabih privlačnih sila između molekula enzima i nosača (dipol-dipol interakcije, elektrostatičke interakcije, vodonične veze i hidrofobne interakcije);

3. obuhvatanje enzima nosačem -razlikuju se dva oblika:

a) smeštanje enzima u polimerne gelove- enzim se smešta u mrežu gusto isprepletanih polimernih lanaca koji stvaraju gel pri čemu ta mreža treba da bude dovoljno porozna da kroz nju mogu da prolaze molekuli supstrata i proizvoda reakcije, ali da enzim ne može da prođe kroz mrežu i pređe u okolni rastvor;

b) umrežavanje enzima- zasniva se na intra- i intermolekulskom vezivanju molekula enzima i bifunkcionalnih agenasa; molekuli enzima se vezuju međusobno ili sa drugim proteinima preko bifunkcionalnog agensa $\mathrm{i}$ grade agregate nerastvorne $\mathrm{u}$ vodi; 
4. imobilizacija enzima u reverzne micele- reverzne micele su vodene kapljice obuhvaćene površinski aktivnom materijom i dispergovane u nepolarnom organskom rastvaraču; reverzne micele imaju mnogo veću graničnu površinu u odnosu na dvofazni sistem voda-organski rastvarač pa je i aktivnost enzima u ovim sistemima veća;

5. smeštanje enzima iza polupropustljive membrane ili u nju- enzim se smešta iza čvrste polupropustljive barijere (to jest unutar kapsula sfernog oblika) koja propušta supstrat i proizvode reakcije, a zadržava enzim (inkapsulacija) ili se enzim nalazi mehanički zarobljen, adsorbovan ili kovalentno vezan $\mathrm{u}$ porama membrane (imobilizacija enzima u membranama).

\subsection{Kovalentna imobilizacija}

Kovalentno vezivanje enzima na čvrste nosače se zasniva na stvaranju najmanje jedne hemijske veze između funkcionalnih grupa enzima i čvrstog nosača. Kao čvrsti nosači koristi se veliki broj neorganskih materijala (staklo, keramika, alumosilikati, oksidi metala), prirodnih polimera (celuloza, hitin, agaroza, skrob i drugi polisaharidi) kao i sintetičkih polimera i kopolimera (polimeri na bazi derivata akrilne kiseline, poliamidi, poliuretani, derivati na bazi polivinil alkohola i drugi). Enzimi se obično imobilišu preko amino grupe ( $\alpha$ - i $\varepsilon$-lizin), karboksilne grupe, sulfhidrilne grupe cisteina, imidazolne grupe (histidin), hidroksilne grupe (serin, treonin) ili fenolnog jezgra tirozina. Mali je broj grupa koje su toliko aktivne da se može odmah pristupiti njihovom povezivanju. Usled toga veoma retko se nosači koriste direktno za vezivanje enzima i u većini slučajeva treba prethodno aktivirati bilo enzim bilo nosač. U retkim slučajevima se pristupa aktivaciji enzima jer ovi postupci mogu dovesti do njegove denaturacije. Znatno češće se nosači pre kovalentnog vezivanja hemijski obrađuju aktivatorima i modifikujućim agensima. Metode kovalentnog vezivanja enzima su obično složene, zametne, skupe i sastoje se iz najmanje dve faze:

1. aktivacije ili modifikacije nosača i

2. vezivanja enzima za nosač $[26,80]$.

Kada se enzimi vezuju kovalentnim vezama, broj hemijskih veza između enzima i nosača treba da se kontroliše, da se konformacija enzima ne bi značajno 
promenila u toku imobilizacije, odnosno da imobilisani enzim zadrži što veću početnu aktivnost [86].

Generalno, enzim se može imobilisati jednotačkastom ili višetačkastom kovalentnom imobilizacijom. Kod jednotačkaste imobilizacije samo jedan (ili dva) aminokiselinska ostatka u molekulu enzima se kovalentno vezuju za nosač, dok kod višetačkaste kovalentne imobilizacije svaki molekul enzima se preko nekoliko ostataka vezuje za nosač [87]. Opšte je prihvaćeno da bi stabilizacija enzima trebalo da se postigne ukoliko se izvrši višetačkasto kovalentno vezivanje enzima za nosač i uglavnom ako su reaktivne grupe na nosaču izolovane od sopstvene površine preko kraćih "nožica“. Na ovaj način, svi ostaci molekula enzima koji su uključeni u imobilizaciju mogu da sačuvaju svoje relativne položaje, tako da je enzim fiksiran u svojoj aktivnoj konformaciji koja se ne menja čak ni pod uticajem spoljašnih uslova (toplote, organskih rastvarača ili nekih drugih agenasa). Prema tome, višetačkasto kovalentno imobilisani enzim bi trebalo da bude stabilniji u odnosu na jednotačkasto imobilisani enzim [88].

\subsection{Imobilizacija penicilin-acilaze}

Razvoj imobilisanih enzima koji su stabilni $\mathrm{u}$ dovoljno dugom periodu lagerovanja i industrijske primene je glavni izazov u industrijskoj biokatalizi i postao je predmet aktuelnih istraživanja. Enzimi mogu biti vezani za nosač fizičkim silama, koje su generalno suviše slabe da zadrže enzim vezan za nosač pod industrijskim uslovima kada se koriste velike koncentracije reaktanata i proizvoda kao i u rastvorima visoke jonske jačine. Kako je kovalentno vezivanja enzima za nosač stabilno, ova metoda se najčešće koristi za imobilizaciju penicilin-acilaze, naročito u industrijskim uslovima [89].

Organski polimerni nosači su najviše proučavani materijali zbog prisustva velikog broja funkcionalnih grupa, koje mogu da se vežu za enzim [90]. Polimerni organski materijali kao što su smole, organski gelovi i vlakna su konvencionalni nosači za imobilizaciju enzima. Međutim, ovi materijali imaju malu mogućnost regeneracije pa je njihova primena ograničena. Neorganski nosači kao što su porozni silikatni gelovi su strukturalno stabilniji, ekološki prihvatljiviji, i hemijski otporniji na organske 
rastvarače, kao i na dejstvo mikroorganizama od organskih nosača [91]. Oni su stabilni u širokom intervalu pH i imaju prednost što mogu lako da se regenerišu [92].

Mnogi nosači, i organski i neorganski, su već korišćeni za imobilizaciju PAC u industrijskim uslovima, ali u mnogim laboratorijama se još uvek pokušava imobilizacija PAC na novim tipovima nosača, sa ciljem poboljšanja katalitičke efikasnosti enzima i smanjenja cene koštanja biokatalitičkog procesa [93]. Imobilizacijom mogu da se poboljšaju svojstva penicilin-acilaze ili da se vreme njenog korišćenja produži jer je imobilisana penicilin-acilaza manje osetljiva na degradaciju, agregaciju ili denaturaciju [94]. Time se ujedno smanjuju troškovi enzima i postiže veća produktivnost procesa.

Aktivnost penicilin-acilaze se obično meri u benzilpenicilin jedinicama (BPU) ili samo jedinicama (U). Jedna BPU odgovara količini enzima koja oslobađa jedan $\mu$ mol fenilsirćetne kiseline po minuti iz penicilina G. BPU ima u literaturi različite vrednosti jer ne postoji saglasnost između koncentracije penicilina $\mathrm{G}, \mathrm{pH}$ i temperature reakcije prilikom izvođenja metode [95].

U savremenijim postupcima kao ocena efikasnosti imobilizacije penicilinacilaze razmatra se broj katalitičkih sačuvanih aktivnih mesta koji može da se meri titrimetrijski tzv. "titracijom aktivnog položaja". Na osnovu objavljenih rezultata, $1 \mu \mathrm{mol}$ penicilin-acilaze iz E. coli ATCC 11105 odgovara 3660 BPU, što je ekvivalentno katalitičkoj molekulskoj aktivnosti od $61 \mathrm{~s}^{-1}$ [95].

Postoji više kompanija koje se bave proizvodnjom 6-aminopenicilanske kiseline i polusintetskih penicilina kao što su DSM, Asahi Kasei Chemicals Corporation, Dr. Vig Medicaments, Unifar, Eli Lilly, Pfizer Inc. i drugi. U ovim kompanijama koristi se penicilin-acilaza imobilisana na različitim nosačima i to, uglavnom, kovalentnom imobilizacijom. Iako detalji nisu dostupni, uglavnom se kao nosači koriste Eupergit ${ }^{\circledR} \mathrm{C}$, aminovani poliakrilonitril, gelovi na bazi želatina i drugi. 


\subsubsection{Eupergit kao nosač za imobilizaciju enzima}

\subsubsection{Eupergit: hemijski sastav}

Eupergit je makroporozni kopolimer metakrilamida, glicidilmetakrilata i alilglicidil etra, umrežen $N, N^{\prime}$-metilen-bis(metakrilamidom), sa prosečnom veličinom čestica od $170 \mu \mathrm{m}$ i prečnikom pora $25 \mathrm{~nm}$ [96]. Eupergit je razvijen i komercijalizovan 70-tih godina XX veka (Rohm, Darmstadt, Nemačka) [97]. Eupergit je veoma hidrofilan i vezuje približno tri puta veću masu vode u odnosu na svoju masu [98]. Zbog svoje strukture, Eupergit je stabilan, i hemijski i mehanički, u celom pH opsegu, pri čemu niti bubri niti se kontrahuje čak ni pri drastičnim promenama $\mathrm{pH}$ vrednosti [97].

Enzimi se kovalentno vezuju za Eupergit direktnim nukleofilnim napadom slobodnih amino grupa na epoksidne grupe na nosaču. Procedura se izvodi pri neutralnim ili alkalnim $\mathrm{pH}$ i dobijene veze su dugoročno stabilne unutar $\mathrm{pH}$ opsega od 1 do 12. Preporučuje se velika koncentracija soli (do $1 \mathrm{M}$ fosfata), koja verovatno ispoljava efekat isoljavanja. Zbog velike gustine epoksidnih grupa na površini čestica nosača $(600 \mu \mathrm{mol}$ po g suvog Eupergit), molekul enzima može da formira višestruke veze ("višetačkasto vezivanje"), koje se smatraju glavnim faktorom doprinosa velikoj operacionoj stabilnosti enzima vezanih za Eupergit ${ }^{\circledR} \mathrm{C}$ [99]. Preostale epoksidne grupe mogu biti blokirane različitim reagensima (merkaptoetanolom, etanolaminom, glicinom, itd.) da bi se sprečile neželjene reakcije nosača i proteina [100].

\subsubsection{Imobilizacija penicilin-acilaze na Eupergit}

PAC iz E. coli je imobilisana na Eupergit (slika 3.2.). Klasičnom metodom imobilizacije na epoksidnom nosaču koja se zasniva na hemijskom vezivanju PAC preko amino grupa u rastvorima visoke jonske jačine. Utvrđeno je da se do 1300 BPU $(0,36 \mu \mathrm{mol})$ penicilin-acilaze brzo adsorbuje po g (vlažnog) Eupergit, što izgleda kao maksimalni kapacitet, jer se pri dodatku enzima, ne povećava količina vezanog enzima. Pri tome, pokazano je "titracijom aktivnog položaja" da su približno 85-90\% 
katalitičkih aktivnih mesta još uvek katalitički sposobni, što odgovara maksimalnoj gustini katalitičkih aktivnih mesta od $0,3 \mu \mathrm{mol}\left(1,8 \times 10^{7}\right)$ po g nosača. Međutim, eksperimentalno određeni prinos aktivnosti je mnogo manji usled smanjenja konformacione fleksibilnosti imobilisanog enzima. Ovaj gubitak aktivnosti se pripisuje i difuzionim ograničenjima. Zabeleženo je da su ovi preparati, ipak, mnogo aktivniji nego što se očekuje na osnovu informacija o proizvodu (581 naspram $200 \mathrm{BPU} / \mathrm{g}$ ), što se pripisuje korišćenju prečišćenijeg rastvora enzima [95, 96, 98].

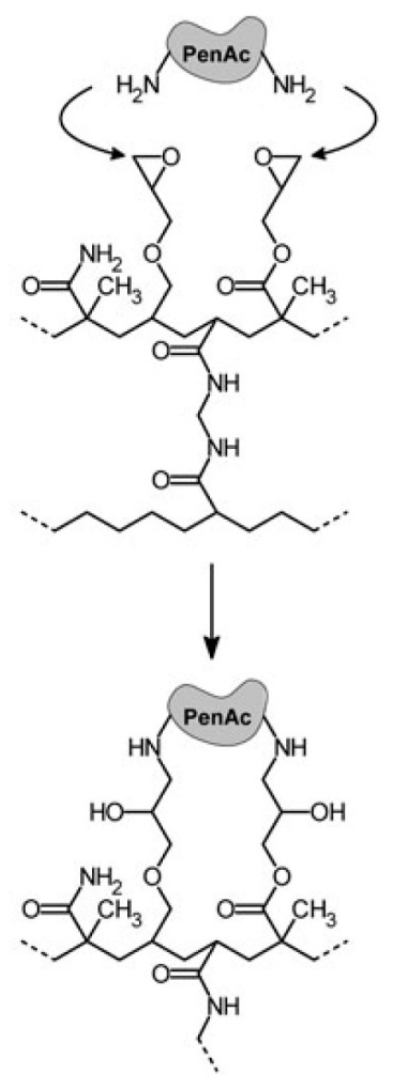

Slika 3.2. Kovalentno vezivanje PAC za Eupergit višestrukim vezama [101]

Utvrđeno je da je imobilisana penicilin-acilaza na Eupergit veoma stabilna pod operativnim uslovima, odnosno ona zadržava $60 \%$ svoje početne aktivnosti nakon korišćenja preko 800 puta u uzastopnim šaržnim ciklusima. Imobilizacija veoma prečišćene penicilin-acilaze daje manje stabilne preparate; međutim, modifikacijom preostalih epoksidnih grupa usled reakcije sa ditiotreitolom može da stabilizuje ovaj biokatalizator [97]. 


\subsubsection{Difuzione limitacije u Eupergit}

Glavni nedostatak Eupergit i, uopšte makroporoznih nosača, su difuzione limitacije koje smanjuju efikasnost biokatalizatora. Ovaj problem je još izraženiji u slučaju imobilizacije PAC i primene tako imobilisanog enzima u reakciji hidrolize penicilina G. Hidrolizom penicilina $G$ nastaje kiselina zbog čega dolazi do $\mathrm{pH}$ gradijenta u nosaču. Budući da $\mathrm{pH}$ utiče na enzimsku aktivnost, kao i na ravnotežu reakcije, $\mathrm{pH}$ gradijent povećava opšte efekte raspodele pojedinih komponenti reakcione smeše između nosača i rastvora [101-103]. Pronađeno je da su ovi uticaji pH gradijenta i difuzionih limitacija veoma značajni (slika 3.3.) i molekuli enzima u unutrašnjosti nosača pri rastojanju većem od $30 \mu \mathrm{m}$ od površine nosača jedva doprinose celokupnoj reakciji zbog ograničene difuzije molekula supstrata kroz česticu biokatalizatora [103]. pH gradijent se može smanjiti puferovanjem reakcione sredine, ali ovo rešenje nije atraktivno u industrijskim okolnostima [82, 103].

Pronađen je znatan gubitak aktivnosti penicilin-acilaze usled imobilizacije na Eupergit, čak i sa adekvatnim puferovanjem; uočeno je da se efekat povećava sa povećanjem količine imobilisanog enzima, odnosno gustine aktivnih mesta na nosaču. Kao što se očekuje, znatno povećanje aktivnosti (koje odgovara molekulskoj aktivnosti biokatalizatora od približno 50 transformacija $\mathrm{s}^{-1}$ ) je dobijeno kada se unapredi prenos mase drobljenjem čestica biokatalizatora do veličine $<5 \mu[98]$. 


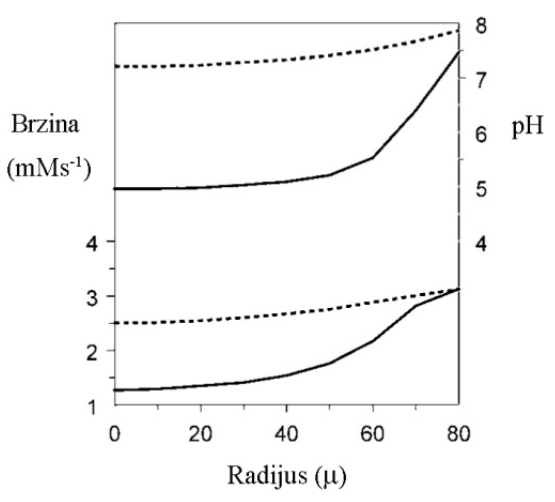

Slika 3.3. Hidroliza penicilina $G$ primenom imobilisane PAC na Eupergit: brzina reakcije i pH gradijenti u česticama Eupergit; (-) nepuferovan sistem $i$ (- - -) sa 200 mM fosfatnim puferom [102]

Već je ranije rečeno da penicilin-acilaza može da katalizuje i reakciju sinteze $\beta$ laktamskih antibiotika, pa je od značaja bilo ispitati efikasnost imobilisane PAC na Eupergit i u reakciji sinteze koja se po mehanizmu razlikuje od reakcije hidrolize. Utvrđeno je da su efekti difuzionih limitacija čak i veći u kinetički kontrolisanoj reakciji, kao što je sinteza $\beta$-laktamskih antibiotika, nego u ravnotežno-kontrolisanoj hidrolizi penicilina G. Dakle, nađeno je da je penicilin-acilaza na Eupergit mnogo manje efikasna u sintezi ampicilina i cefaleksina, izraženo u S/H odnosu (odnos brzine reakcije sinteze i hidrolize), nego slobodan enzim. U slučaju cefaleksina, na primer, početni $\mathrm{S} / \mathrm{H}$ odnos se smanjuje od $>30$ za slobodan enzim do približno 5 za imobilisani enzim na Eupergit pri gustini aktivnih mesta od 0,2 $\mu \mathrm{mol} / \mathrm{g}[98,102]$.

\subsubsection{Sepabeads kao nosač za imobilizaciju enzima}

\subsubsection{Sepabeads:hemijski sastav i osnovna svojstva}

Sepabeads (Resindion, Milan, Italija) je grupa sintetskih polimera bazirana na polimetakrilatu u koga su uvedene različite grupe. Proizvode se različiti tipovi ovog komercijalnog nosača, od kojih se najviše koriste Sepabeads EC-EP, Sepabeads ECEA i Sepabeads EC-HA (slika 3.4.). 
Osnovne karakteristike ovih nosača su:

- visoko porozna struktura i pravilna sferičnost čestica nosača,

- velika fizička i hemijska stabilnost i otpornost na dejstvo mikroorganizama,

- visok kapacitet vezivanja proteina,

- mala težnja ka bubrenju u rastvorima pa čak i pri velikoj jonskoj jačini,

- izvanredna mehanička stabilnost dobijena intenzivnim umrežavanjem i

- dostupnost u opsegu različitih veličina i stepena poroznosti [104].

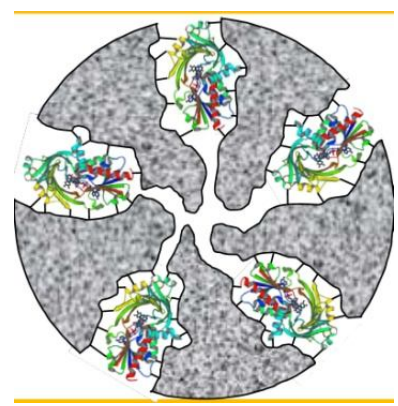

Slika 3.4. Mikroskopski izgled čestice Sepabeads EC-nosača [104]

Sepabeads EC-EP je polimetakrilatni nosač koji već ima ugrađene epoksidne funkcionalne grupe i nije potrebno da se izvrši aktivacija takvog nosača. Amino grupe enzima direktno reaguju sa epoksidnim grupama nosača u procesu kovalentne imobilizacije enzima na ovaj nosač (slika 3.5.).

Pokazano je da je reaktivnost epoksidnih grupa na nekom nosaču prema nukleofilnim grupama u molekulu enzima, kao što su hidroksilne, amino i sulfhidrilne grupe, mala u blagim reakcionim uslovima (neutralna sredina, niska jonska jačina) i to u skladu sa sledećim redosledom: sulfhidrilne grupe $>$ amino grupe $>$ hidroksilne grupe. Dakle, dok se reakcija sa hidroksilnim grupama odvija tek u jako baznoj sredini $(\mathrm{pH} 11)$, amino grupe mogu da reaguju na nižim $\mathrm{pH}$ vrednostima $(\mathrm{pH} 8)$, da bi sulfhidrilne grupe mogle da reaguju čak pri neutralnim $\mathrm{pH}$ vrednostima $(\mathrm{pH} 7)$.

Međutim, uspešna imobilizacija enzima na epoksidnim nosačima može da se odvija primenom izrazito hidrofobnih epoksidnih nosača, na primer Sepabeads EC-EP, i izvođenjem imobilizacije u prisustvu visokih koncentracija soli (1,25 M kalijum fosfatni pufer). Ovaj način kovalentne imobilizacije enzima na hidrofobnim 
epoksidnim nosačima je opisan u preglednom radu i može se označiti kao konvencionalni postupak [105]. Pretpostavljen je veoma interesantan dvostepeni mehanizam hemijskog vezivanja enzima na epoksidne nosače koji se sastoji od:

1) brze fizičke adsorpcije enzima na hidrofobni nosač i

2) hemijske reakcije između adsorbovanog enzima i epoksidnih grupa nosača.

Da bi se ovaj proces odvijao, neophodno je da nosač bude hidrofoban $\mathrm{i}$ da se imobilizacija odvija u rastvorima visoke jonske jačine.

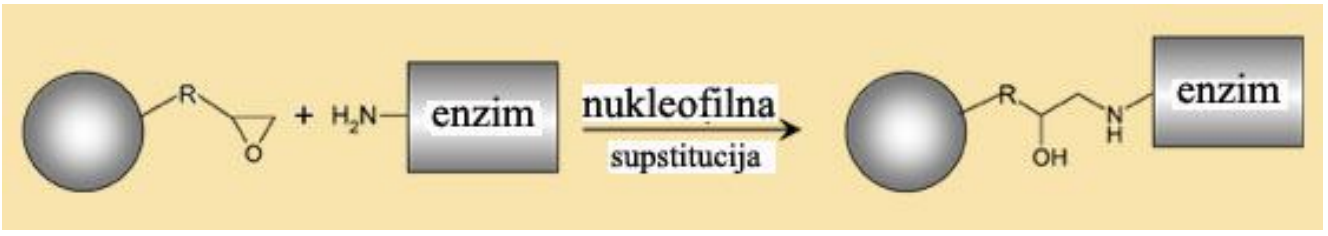

Slika 3.5. Šematski prikaz imobilizacije enzima na Sepabeads EC-EP nosač [104]

Sepabeads EC-EP (epoksidni nosač) može de se koristi za imobilizaciju/stabilizaciju enzima i preko višetačkastog kovalentnog vezivanja. Ovi nosači su komercijalno dostupni u dovoljnim količinama po relativno niskim cenama $\mathrm{i}$ pogodni su za industrijsku primenu. Takođe, nosač ima odgovarajuću strukturu pora i vrlo veliku zapreminsku gustinu epoksidnih grupa (oko $100 \mu \mathrm{mol} / \mathrm{cm}^{3}$ ). Ovakve karakteristike bi trebalo da omoguće veoma lako i čvrsto vezivanje enzima za nosač. Međutim, krajnja aktivnost, stabilnost i ostala svojstva imobilisanog enzima zavise od procedure izvođenja imobilizacije, pa je potrebno ispitati uslove imobilizacije i svojstva dobijenih biokatalizatora u svakom pojedinačnom slučaju [105].

$\mathrm{Na}$ primer, ispitivana je imobilizacija penicilin-acilaze na Sepabeads EC-EP nosaču i razvijen je postupak za dobijanje značajno stabilnijeg biokatalizatora [105]. Ovaj postupak, takođe, može biti primenjen i za Eupergit, ili za bilo koji nosač koji sadrži epoksidne grupe. Postupak se zasniva na naknadnom tretiranju prethodno dobijenog imobilizata po konvencionalnom postupku. Naime, enzim se imobiliše na nosač pod konvencionalnim uslovima u rastvoru visoke jonske jačine, a zatim se pre nego što se blokiraju neproreagovale grupe nosača, izloži dejstvu ekstremnih uslova 
(visok $\mathrm{pH}$, visoke temperature, duži periodi inkubacije, itd.). Time se može povećati broj obrazovanih veza između enzima i nosača pri čemu dolazi do značajne stabilizacije enzima jer su proreagovale i manje aktivne grupe nosača sa grupama u molekulu enzima. Pokazano je da se poluvreme dezaktivacije tako dobijenog imobilizata povećava 18 puta na $\mathrm{pH} 10$ i $20{ }^{\circ} \mathrm{C}$ u poređenu sa enzimom imobilisanim pod konvencionalnim uslovima ( $\mathrm{pH} 7$ i $20{ }^{\circ} \mathrm{C}$ ). Takođe je pokazano da blokiranje neproreagovalih epoksidnih grupa aminokiselinom, kao što je glicin, umesto merkaptoetanolom, isto tako povećava stabilnost biokatalizatora [105].

Sepabeads EC-EA i Sepabeads EC-HA nosači poseduju amino grupu koja je preko dve i šest metilenskih grupa, redom, vezana za polimetakrilatnu osnovu. Da bi se enzim imobilisao na njih, nosači se prethodno moraju aktivirati tako da se na njih uvedu reaktivne grupe, za koje se, onda, potencijalno mogu vezati amino grupe enzima.

Imobilizacija enzima na Sepabeads EC-EA i Sepabeads EC-HA može da se izvrši na mnogo načina.

Dakle, na nosač koji poseduje amino grupe ne može kao takav da se veže enzim, već je neophodna prethodna aktivacija nosača. Aktivacijom glutaraldehidom, na nosač se uvode karbonilne grupe za koje se mogu vezati amino grupe enzima pod određenim uslovima (slika 3.6.). Ovaj postupak imobilizacije koji se zasniva na prethodnoj aktivaciji amino-nosača glutaraldehidom ovde je nazvan glutaraldehidna metoda.

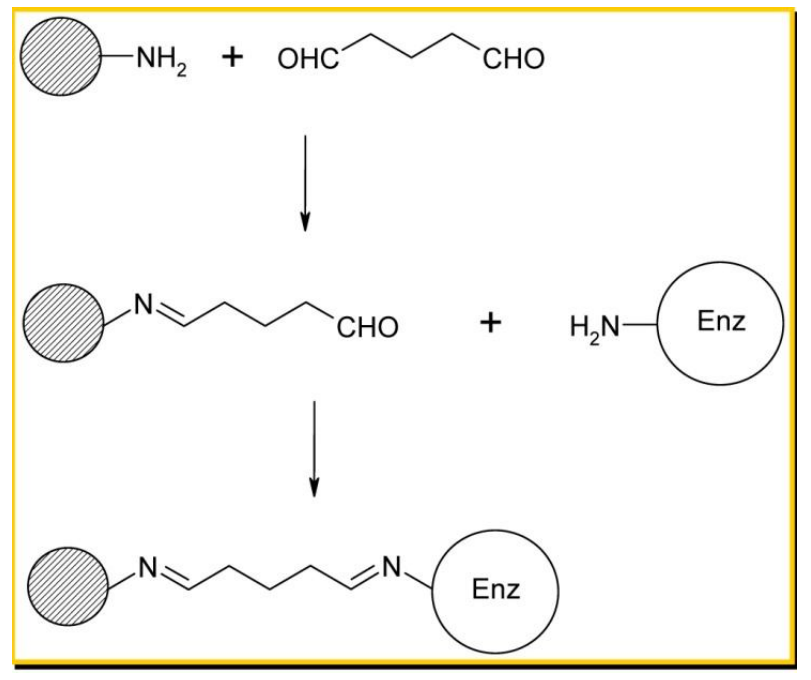

Slika 3.6. Postupak imobilizacije enzima na nosače sa amino grupama glutaraldehidnom metodom [104] 
Drugi postupak se zasniva na prethodnoj aktivaciji enzima. Naime, PAC se može hemijski modifikovati polisaharidima tako da se u molekul uvede ugljenohidratna frakcija, koja može značajno doprineti stabilizaciji molekula enzima, ali i povećanju reaktivnosti prema nosaču. U ovom postupku imobilizacije, hemijski modifikovana penicilin-acilaza se može vezati za nosač preko neproteinskog dela molekula, i to preko ugljenohidratne komponente tako što se prethodno oksiduje perjodatom. Perjodatna metoda imobilizacije podrazumeva oksidaciju hidroksilnih grupa iz ugljenohidratne frakcije enzima u karbonilne grupe. Nakon toga se enzim pod blagim uslovima, preko aldehidnih grupa, može hemijski vezati za amino grupe nosača (slika 3.7).

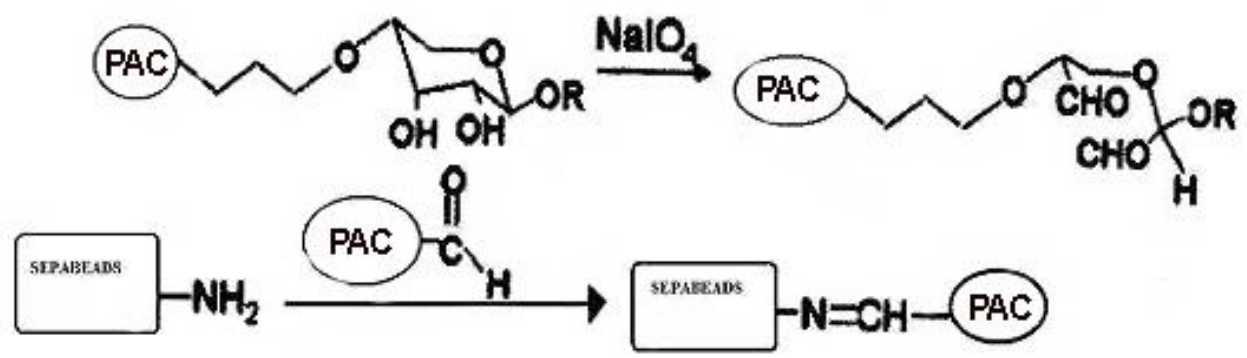

Slika 3.7. Perjodatna metoda vezivanja enzima za nosač

U ovom radu će biti izvršena imobilizacija slobodne penicilin-acilaze direktnim vezivanjem na Sepabeads EC-EP nosač konvencionalnom metodom, kao i na Sepabeads EC-EA i Sepabeads EC-HA nosače koji su prethodno aktivirani glutaraldehidnom metodom. Takođe, penicilin-acilaza koja je modifikovana različitim polisaharidima će biti imobilisana na Sepabeads EC-EA i Sepabeads EC-HA nosače. Tako dobijeni imobilizati će se okarakterisati i uporediće se njihova svojstva od značaja za odvijanje reakcije hidrolize prirodnog penicilina $G$ u cilju dobijanja 6-APA kao važnog prekursora polusintetskih antibiotika. 


\subsubsection{Amberlit XAD-7 kao nosač za imobilizaciju PAC}

Amberlit XAD-7 je porozna smola poli(metakrilni estar), sa specifičnom površinom od $450 \mathrm{~m}^{2} / \mathrm{g}$ i prosečnim prečnikom pora od $9 \mathrm{~nm}$. Prvenstveno je razvijen kao umereno hidrofilni materijal za kolonsku hromatografiju. Fizička adsorpcija penicilin-acilaze na Amberlitu XAD-7 nije stabilna, kao što se i očekuje. Zato su ispitani različiti postupci kovalentne imobilizacije enzima na ovoj smoli u cilju dobijanja stabilnijih imobilizata. Po jednom postupku, smola se aktivira aminoalkilacijom sa 1,2-diaminoetanom, a zatim sa glutaraldehidom [82, 106]. Nakon toga, PAC se može vezati za ovako aktiviran nosač preko amino grupa na uobičajen način (slika 3.8.).

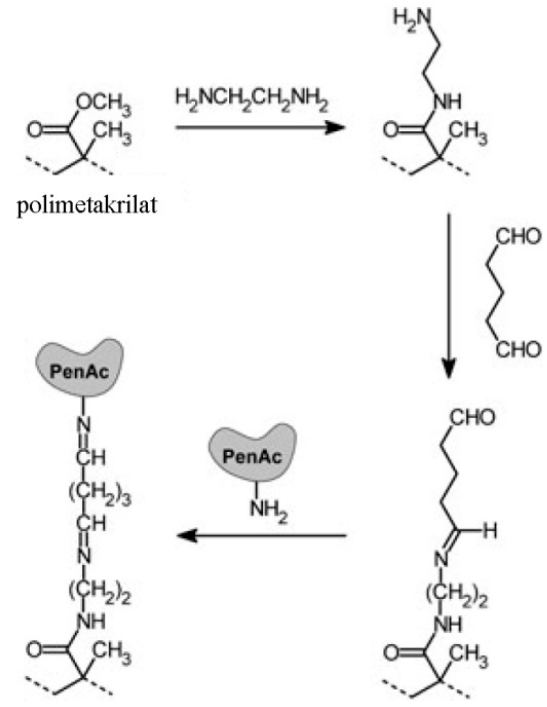

Slika 3.8. Aktivacija Amberlita XAD-7 $i$ kovalentno vezivanje penicilin-acilaze [82]

Kovalentno vezivanje penicilin-acilaze za slobodne aldehidne grupe $u$ aktiviranom nosaču daje preparate sa aktivnošću od 194 BPU/g (suve mase). Prinos aktivnosti je mali od svega 25\%. Primećeno je da se veća količina enzima (izražena preko broja enzimskih jedinica) vezuje kada se smanji veličina čestica nosača jer se povećava specifična površina nosača. Tako, na manjim česticama aktivnost raste do $400 \mathrm{BPU} / \mathrm{g}$, što odgovara prinosu aktivnosti od 33\%. Ovi rezultati ukazuju i na to da je 
difuzija supstrata (penicilina G) u pore nosača (oko $9 \mathrm{~nm}$ ) veoma spora i limitira brzinu reakcije. Ovo je potvrđeno i u ranijem, srodnom, radu da penicilin-acilaza prodire samo $25 \mu \mathrm{m}$ u sloj ispod površine XAD-7 čestica za 24 h usled ograničene difuzije. Isto tako, pri samoj imobilizaciji enzima primećeno je da se molekuli nehomogeno distribuiraju unutar čestice i da se uglavnom vezuju u spoljašnjoj ljusci, odnosno u blizini površine nosača. Ovo je nepoželjno jer je neophodno da molekuli enzima budu homogeno raspoređeni unutar čestice da bi se dobili ujednačeni i validni rezultati. Utvrđeno je da je potrebno imobilisati enzim u uslovima velike koncentracije enzima u toku dovoljno dugog vremena da bi se dobile uniformne čestice biokatalizatora ujednačenog sastava [82].

Isto tako je pokazano da ovi biokatalizatori nemaju dovoljnu stabilnost za industrijsku primenu. Postepeni gubitak aktivnosti usled ponovnog korišćenja biokatalizatora je pripisan hemijskoj nestabilnosti Šifove baze koja nastaje u reakciji između aldehidnih grupa smole i amino grupa enzima. Redukcijom Šifove baze natrijum-borohidridom ustvari se može povećati poluvreme dezaktivacije biokatalizatora na $>400 \mathrm{~h}$ na $37^{\circ} \mathrm{C}$ u operativnim uslovima [106].

\subsubsection{Prirodni polisaharidi kao nosači za imobilizaciju penicilin-acilaze}

\subsubsection{Agaroza kao nosač za imobilizaciju PAC}

Agaroza je linearan polisaharid (približne molekulske mase $12 \mathrm{kD}$ ) koji se dobija iz morskih algi i sastoji se od jedinica D-galaktoze i 3,6-anhidro-D-galaktoze koje su naizmenično raspoređene. Hemijski modifikovana agaroza, aldehid-agaroza, sadrži slobodne aldehidne grupe, za koje se enzim može kovalentno vezati preko svojih amino grupa ostataka lizina pri čemu se formira Šifova baza. Umreženi aldehid-agaroza gelovi su komercijalno dostupni iz različitih izvora [107].

Kovalentno vezivanje penicilin-acilaze, kao i različitih drugih enzima, za umreženu aldehid-agarozu je opsežno ispitano, uglavnom sa ciljem poboljšanja njene termalne stabilnosti i tolerancije prema organskim rastvaračima [108]. Penicilin-acilaza može da se do $600 \mathrm{BPU}$ vezuje $/ \mathrm{cm}^{3}$ gela, ali količina vezanog enzima je namerno ograničena na $10 \mathrm{BPU} / \mathrm{cm}^{3}$, da bi se izbegle difuzione limitacije. Stoga, višetačkastim 
vezivanjem penicilin-acilaze za aldehid-agarozu (prinos aktivnosti 80\%) može se povećati njena termalna stabilnost čak 2500 puta. Dalje povećanje termostabilnosti biokatalizatora i do tri puta može se postići redukcionom metilacijom preostalih slobodnih amino grupa, uzastopno, sa formaldehidom i natrijum-borohidridom [108].

Pretpostavljeno je da na stabilnost imobilisanog enzima u polarnim organskim rastvaračima veliki uticaj ima nagrađeno mikrookruženje enzima zbog čega se često modifikuje površina nosača da bi se nagradila hidrofilnija mikrosredina za enzim [109]. Takva mikrookolina se može formirati na različite načine. Jedan od primenjenih načina je tretiranje penicilin-acilaze višetačkasto vezane za glioksil-agarozu poliaminom (npr. amino-dekstran [110]), praćeno reakcijom sa dekstran-polialdehidom i redukcijom natrijum-borohidridom. Verovatno, oba koraka uključuju dalje umrežavanje enzima i nosača ovim reagensima. Stoga, molekuli enzima postaju čvrsto uključeni u okolinu sa velikom koncentracijom amino i hidroksilnih grupa. Ustvari, nađeno je da kada se ovi preparati inkubiraju u vodenim smešama od 70\% dimetilformamid ili $60 \%$ dioksana, imobilisani enzim zadrži oko $80 \%$ početne aktivnosti što ukazuje na značajnu stabilizaciju u odnosu na imobilisani enzim na glioksil-agarozi [109].

\subsubsection{Smeštanje u želatin}

Imobilizacija enzima ili ćelija smeštanjem u biopolimerne gelove, kao što je želatin, alginat ili hitozan, je jedan od najstarijih postupaka imobilizacije. Procedura je relativno jednostavna, ne zahteva modifikaciju nosača i odvija se pod blagim uslovima. Nedavno objavljena procedura za imobilizaciju celih ćelija ili izolovane penicilinacilaze u gel želatin-alginat odvija se na sledeći način [111]. Procedura je opisana na primeru dezintegrisanih ćelija $E$. coli koje sadrže penicilin-acilazu, ali se primenjuje u neizmenjenom obliku i za enzim izolovan iz ćelija. Dezintegrisane ćelije E. coli se suspenduju u vodenom rastvoru želatina i natrijum-alginata, i dobijena smeša se zatim ukapava u rastvor kalcijum-hlorida, koji umrežava alginat, da bi se formirale čvrste čestice. Čestice se dalje ispiraju puferom koji rastvara kalcijum-alginat da bi se formirala porozna struktura čestica želatina koje sadrže enzim. Dalje umrežavanje čestica primenom glutaraldehida može značajno da ih stabilizuje i da doprinese hemijskom vezivanju enzima za matriks [111]. 
Rezultujući biokatalizator nije imao zadovoljavajuću operativnu stabilnost za primenu u industrijskim uslovima. Naime, početna aktivnost čestica biokatalizatora se zadržava za vreme pet 9-časovnih ciklusa u reaktoru sa pakovanim slojem nakon čega naglo opada. Može se zaključiti da su vezivanja enzima umrežavanjem pomoću glutaraldehida nedovoljno stabilna; takođe je moguće da je broj slobodnih amino grupa u želatinu suviše mali za višetačkasto vezivanje enzima [111].

\subsubsection{Hitozan kao nosač za imobilizaciju enzima}

Hitozan je pogodan kao nosač za imobilizaciju velikog broja enzima jer poseduje gotova sva svojstva od značaja za tu namenu [112, 113]. Iako ne postoji univerzalni nosač za sve enzime, određene karakteristike su poželjne za sve materijale koji se koriste za imobilizaciju enzima. Neke od njih, koje poseduje i hitozan, su: veliki afinitet prema proteinima, dostupnost reaktivnih funkcionalnih grupa za direktnu reakciju sa enzimom ili hemijsku modifikaciju, hidrofilnost, mehanička stabilnost, laka priprema različitih geometrijskih oblika koji obezbeđuju pogodnu površinu za odabranu biotransformaciju. Pored toga, za primenu u prehrambenoj, farmaceutskoj industriji ili medicini potrebno je da materijali budu netoksični i biokompatibilni. Takođe, poželjno je da materijali budu biorazgradljivi i njihova primena ekonomična.

Hitozan je prirodni poliaminosaharid, derivat hitina, dobijen njegovim $\mathrm{N}$ deacetilovanjem (slika 3.9.) [114]. Hitin je jedan od najrasprostranjenijih organskih supstanci u prirodi i ulazi u sastav školjki, ljuskara, skeleta insekata i ćelijskog zida gljiva kojima daje čvrstoću i stabilnost. Dobija se u velikim količinama i po relativno niskim cenama iz ostataka morske hrane u industrijskim procesima. Hemijski, hitin se sastoji od $\beta(1 \rightarrow 4)$ povezanih 2-acetoamido-2-deoksi- $\beta$-D-glukoznih jedinica ili $N$ acetil-D-glukozamina stvarajući dugački linearni polimer nerastvoran u većini rastvarača [113]. 


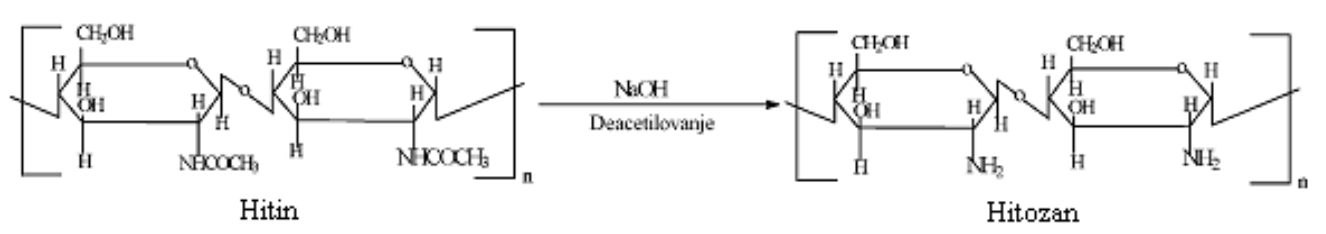

Slika 3.9. Dobijanje hitozana [114]

Hitozan,osnovni derivat hitina, dobija se alkalnim deacetilovanjem hitina pri čemu od stepena deacetilovanja zavise njegove kiselo-bazne osobine i rastvorljivost. On je zapravo heteropolimer sastavljen od N-acetil-D-glukozamina i D-glukozamina, pri čemu stepen deacetilovanja komercijalnog hitozana najčešće iznosi od 70-90 \% (slika 3.10) [112].

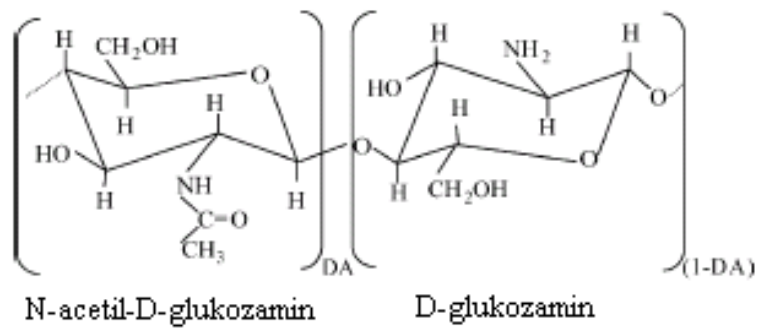

Slika 3.10. Struktura hitozana [112]

Hitozan poseduje jedinstvene hemijske i biološke karakteristike. On je linearni poliglukozoaminski lanac velike molekulske mase nerastvoran u vodi. Poseduje reaktivne amino i hidroksilne grupe, koje se mogu relativno lako hemijski modifikovati i na taj način omogućiti kovalentno vezivanje enzima pod blagim uslovima [113]. Zahvaljujući velikom broju hidroksilnih grupa koje sadrži pokazuje izraženo hidrofilni karakter [112]. Sa druge strane, amino grupe čine hitozan katjonskim polielektrolitom $(\mathrm{pKa} \approx 6,5)$, i jedan je od nekoliko pronađenih u prirodi. Amino grupe hitozanu daju jedinstvene karakteristike: rastvoran je u kiselim vodenim rastvorima $(\mathrm{pKa}<6,5)$ i kada je rastvoren poseduje pozitivno naelektrisane amino grupe koje prianjaju za negativno naelektrisanu površinu, zbog čega stvara agregate sa polianjonskim jedinjenjima ili helatne komplekse sa jonima teških metala. Obe ove karakteristike, rastvorljivost $\mathrm{u}$ 
kiselim vodenim rastvorima i agragacija sa polianjonima čine hitozan podložnim geliranju. Hitozan ima i posebne biološke karakteristike: biokompatibilnost, biorazgradljivost na bezopasne produkte, netoksičnost, fiziološku inertnost, veliki afinitet prema proteinima, kao i antitumornu i antifungalnu aktivnost. Sva ova svojstva daju ogroman potencijal hitozanu za primenu u raznim oblastima [113].

U imobilizaciji enzima materijali od hitozana se koriste $u$ obliku praha i gelova različitih geometrijskih konfiguracija. Priprema gelova hitozana zasniva se na činjenici da se on rastvara u većini organskih kiselina, kao što su mravlja, sirćetna, limunska i vinska [113]. Rastvaranjem dolazi do protonovanja amino grupe na drugom ugljenikovom atomu D-glukozamin jedinice, pri čemu on postaje katjonski polielektrolit [112]. Povećanje $\mathrm{pH}$ vrednosti dovodi do njegovog razelektrisavanja i smanjuje njegovu rastvorljivost. Na ovaj način mogu se dobiti hitozanske gel čestice, membrane, membrane kapsula, vlakna, šuplja vlakna i sunđeri. Da bi se poboljšala mehanička svojstva hitozana, on se može intramolekulski umrežavati bifukcionalnim agensima, kao što su: glutaraldehid, epihlorhidrin i glicidol [113].

\subsection{Imobilizacija penicilin-acilaze na hitozanskim mikročesticama}

Hitozanske mikročestice koje se koriste za imobilizaciju enzima mogu se dobiti primenom metode neutralizacije (ukapavanjem rastvora hitozana u rastvor alkalija, najčešće natrijum-hidroksida, pri čemu usled povećanja $\mathrm{pH}$ vrednosti dolazi do očvršćavanja mikročestica hitozana) ili jonotropskom gelirajućom metodom (ukapavanjem rastvora hitozana u rastvor anjonskog polielektrolita) [113]. Jedan od najčešće korišćenih očvršćavajućih agenasa za jonsko geliranje hitozana je natrijumtripolifosfat $\left(\mathrm{N}_{\mathrm{a}}-\mathrm{TPP}\right)$. Natrijum-tripolifosfat je netoksični polianjon koji reaguje sa hitozanom privlačenjem suprotno naelektrisanih molekula, tj. elektrostatičkim silama $\mathrm{i}$ formira u vodi nerastvoran kompleks [115].

Hitozanske mikročestice ne mogu se direktno koristiti za imobilizaciju PAC već se moraju prethodno aktivirati nekim aktivacionim agensom. Kako hitozan poseduje jednu amino grupu u glukoznoj jedinici, aktivacija se može lako izvršiti, pod blagim uslovima, korišćenjem glutaraldehida kao aktivacionog agensa [88]. Tretmanom 
umrežavanja hitozanskih mikročestica glutaraldehidom menjaju se hemijske i fizičke karakteristike hitozana. Formiraju se relativno jake čestice, ali manje elastičnosti i deformacione stabilnosti $\mathrm{u}$ odnosu na neaktivirane, zbog dopunskog povezivanja između polimernih lanaca hitozana [116]. Aktivacijom glutaraldehidom uvode se karbonilne grupe na hitozanske čestice sa kojima lako mogu da reaguju amino grupe PAC, formirajući stabilan imobilisani enzim (slika 3.11.) [88].

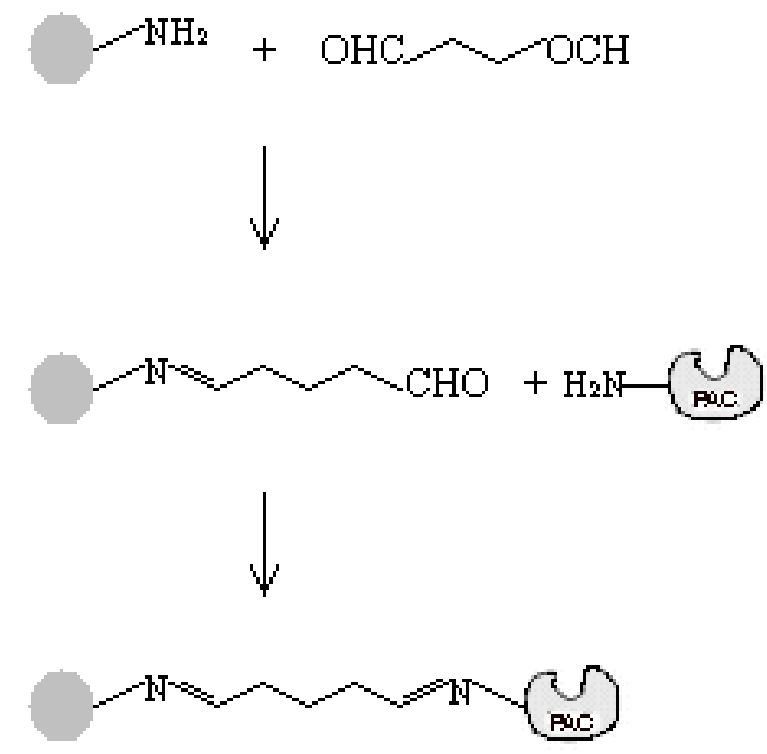

\section{Slika 3.11. Postupak imobilizacije PAC glutaraldehidnom metodom}

Amino grupe (N-terminalna i u ostatku lizina), rasprostranjene na površini PAC, su veoma rektivne i sa aldehidnim grupama na nosaču formiraju jedinjenja tipa Šifove baze, koja su veoma stabilna [87]. Broj kovalentnih veza između enzima i nosača zavisi od stepena aktivacije nosača (koncentracije aldehidnih grupa na površini) i koncentracije amino grupa u molekulu enzima. Takođe $\mathrm{pH}$ vrednost pri kojoj se vrši imobilizacija je važan parametar jer amino grupe lizina imaju pKa oko 10,5 i reaktivne su samo pri pH vrednostima većim od 10,0 [112]. PAC poseduje veliki broj ostataka lizina na površini molekula (slika 3.12.) [87]. 


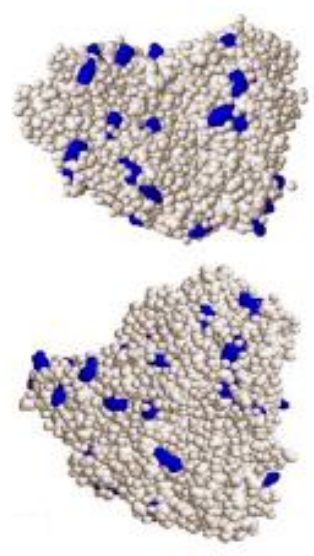

Slika 3.12. 3D struktura PAC. Plavom bojom su predstavljeni ostaci lizina [87]

Generalno, enzim se može imobilisati jednotačkastom ili višetačkastom kovalentnom imobilizacijom. Kod jednotačkaste imobilizacije samo jedan (ili dva) aminokiselinska ostatka u molekulu enzima se kovalentno vezuju za nosač, dok kod višetačkaste kovalentne imobilizacije svaki molekul enzima se preko nekoliko ostataka vezuje za nosač [87]. Opšte je prihvaćeno da bi stabilizacija enzima trebalo da se postigne ukoliko se izvrši višetačkasto kovalentno vezivanje enzima za nosač i uglavnom ako su reaktivne grupe na nosaču izolovane od sopstvene površine preko kraćih "nožica". Na ovaj način, svi ostaci molekula enzima koji su uključeni u imobilizaciju mogu da sačuvaju svoje relativne položaje, tako da je enzim fiksiran u svojoj aktivnoj konformaciji koja se ne menja čak ni pod uticajem spoljašnih uslova (toplote, organskih rastvarača ili nekih drugih agenasa). Prema tome, višetačkasto kovalentno imobilisani enzim bi trebalo da bude stabilniji u odnosu na jednotačkasto imobilisani enzim [88].

\subsubsection{Imobilizacija enzima u želatin-hitozan nosače}

Kasnih 80-tih godina XX veka opisana je procedura za smeštanje ćelija u umrežene gelove želatina i polimera koji sadrži slobodne amino grupe, kao što su hitozan, alginat ili polietilenimin [111]. Eventualno, čestice se stabilizuju umrežavanjem primenom glutaraldehida. Postoje indikacije koje ukazuju da je 
industrijski biokatalizator, penicilin $\mathrm{G}$ hidrolaza, poznata pod komercijalnim nazivom Separase $G$, upravo imobilisana na sličan način, ali su detalji nedostupni $[118,119]$. Isto tako, utvrđeno je da se penicilin-acilaza iz E.coli ponaša mnogo bolje u sintezi $\beta$ laktamskih antibiotika kada se imobiliše u želatin-hitozan nego u druge nosače [120]. Verovatno, ovaj rezultat obezbeđuje osnovu za razvoj komercijalnog biokatalizatora, tržišno označenog sa Assemblase, koji se koristi u enzimskoj sintezi polusintetskih $\beta$ laktamskih antibiotika [95]. Međutim, prostorno-vremenski prinos reaktora još uvek nije zadovoljavajući zbog čega je imobilizacija penicilin-acilaze još uvek aktuelna oblast istraživanja.

Iako su industrijski podaci uglavnom nedostupni, neki rezulatati istraživanja do sada objavljeni u literaturi ukazuju da je Assemblase čak lošiji biokatalizator za hidrolizu penicilina G od PAC imobilisane na Eupergit. Tako, molekulska aktivnost

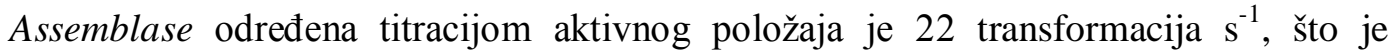
mnogo manje nego kod nativnog enzima (61 transformacija $\mathrm{s}^{-1}$ ) i takođe manje nego kod PAC imobilisane na Eupergit pri približno istoj količini vezanog enzima (31 transformacija s ${ }^{-1}$ ) [95].

Ovako veliki gubitak aktivnosti Assemblase pripisan je ograničenom prenosu mase supstrata i proizvoda reakcije kroz čestice biokatalizatora. Detaljnije proučavanje usmereno na raspodelu penicilin-acilaze unutar čestica je presudno za razumevanje prenosa mase. Da bi se utvrdila raspodela molekula enzima unutar čestica nosača izvođeni su različiti eksperimenti. Na primer, čestice Assemblase su prosejane u frakcije po veličini i izmerena je gustina aktivnih mesta u svakoj frakciji (slika 3.13.). Nađeno je da prosečna količina enzima unutar čestica opada sa porastom prečnika čestice, što je potvrđeno u eksperimentima hidrolize. Zaključeno je, na osnovu ovih rezultata, da je enzim uglavnom prisutan u plitkom omotaču na površini zrna [121]. Ovaj rezultat je nedavno potvrđen imunomarkiranjem [122]. 


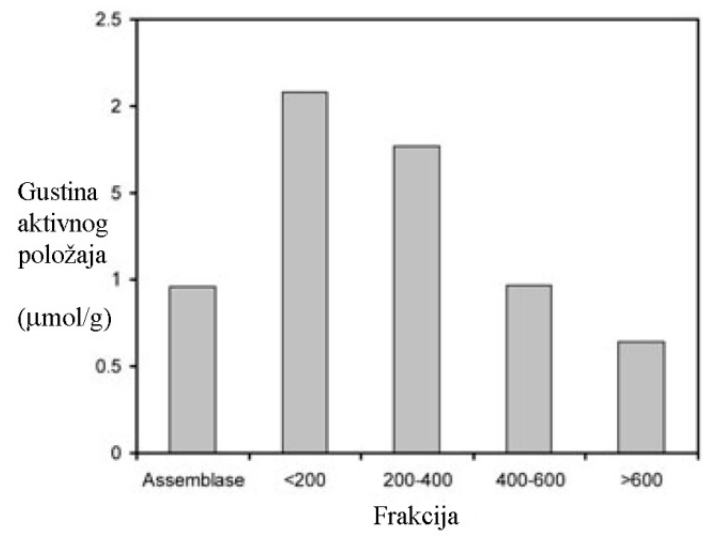

Slika 3.13. Gustina aktivnog položaja Assemblase i njegovih prosejanih frakcija [121]

Karakteristike Assemblase u sintezi cefaleksina iz (R)-fenilglicinamida i 7ADCA su detaljno ispitane i upoređene sa slobodnim enzimom. Assemblase je još manje efikasan katalizator u reakciji transesterifikacije što je procenjeno pomoću $\mathrm{S} / \mathrm{H}$ odnosa [123], nego slobodan enzim, što je opet pripisano difuzionim limitacijama. Naime, usled ograničene difuzije dublji slojevi enzima nisu u kontaktu sa nukleofilnim supstratom (7-ADCA), dok se molekuli proizvoda reakcije akumuliraju unutar čestica što rezultuje u povećanoj hidrolizi i smanjenoj transesterifikaciji. Važnost ovog uticaja zavisi od koncentracije enzima u nosaču i pH, kao što se očekuje i, na osnovu kinetičkog modela, optimalni reakcioni uslovi su predviđeni i dokazani [124].

Ostaje pitanje zašto se Assemblase ponaša, izraženo S/H odnosom, mnogo bolje u sintezi cefaleksina nego, na primer, penicilin-acilaza imobilisana na Eupergit, uprkos velikom prečniku pora drugog materijala. Razlog može da bude to što je enzim lociran u površinskom omotaču čestica Assemblase. Nadalje, verovatno je nepravilno oceniti Assemblase nosač kao čvrstu sredinu; njegov glavni sastojak je voda, koju vezuje labava umrežena matrica želatina i hitozana. Ali takođe, treba uzeti u obzir da PAC imobilisana u želatin-hitozan čestice (Assemblase) je samo 30\% efektivna u hidrolizi penicilina G [95], što je manje nego penicilin-acilaza vezana za Eupergit [98]. Budući da su difuzione limitacije primećene u oba sistema, ovo neslaganje ne može da bude logično pripisano samo difuzionim limitacijama u sistemu sa Assemblase česticama, tako da niska efikasnost biokatalizatora može da bude posledica primenjene procedure za njegovo dobijanje. 


\subsubsection{Biospecifična imobilizacija PAC na Konkanavalin A nosaču}

Konkanavalin A pripada klasi lektina, proteina koji reaguju sa specifičnim krajnjim ostacima šećera, zbog čega se koriste u proučavanju sastava ugljenih hidrata na ćelijskim površinama. Konkanavalin A se takođe koristi kao agens u imobilizaciji glikozilovanih enzima $[125,126]$.

Prirodna penicilin-acilaza iz E. coli nije glikozilovana i, stoga, kao slobodna ne reaguje sa konkanavalinom A. Međutim, slobodan enzim se može hemijski glikozilovati ako se modifukuje nekim polisaharidom. Na primer, sintetički glikokonjugat penicilin-acilaze se može dobiti u reakciji sa polialdehidom dobijenim iz manana. Nakon toga se izvrši redukcija rezultujućih Šifovih baza i neproreagovalih aldehidnih grupa [127]. Pre imobilizacije enzima za nosač je neophodno hemijski vezati konkanavalin A. Iz tog razloga se priprema nosača vrši u dva stupnja. Tako, ako se koristi celuloza kao nosač za imobilizaciju enzima, ona se prvo aktivira sa 1,3,5trihlortriazinom, a onda se konkanavalin A hemijski vezuje za ovako aktiviranu celulozu. Na osnovu literaturnih podataka, dobijen je nosač koji sadrži svega 1\% konkanavalina A i koji je mogao da veže male količine sintetičkog glikoproteina PACmanan. Aktivnost imobilisanog enzima je bila 18 BPU/g, koja odgovara prinosu aktivnosti od 74\% [127]. Dobijeni imobilizat je pokazao i veliku stabilnost tako da se javlja mali gubitak aktivnosti usled skladištenja ili ponovnog korišćenja biokatalizatora.

Ukratko, biospecifična imobilizacija penicilin-acilaze se pokazala izvodljivom, ali je procedura kompleksna i na ovaj način se mogu vezati male količine enzima. Ova metoda imobilizacije nije našla industrijsku primenu. 


\subsubsection{Neorganski nosači za imobilizaciju PAC}

\subsubsection{Modifikovani nosači na bazi silicijum-dioksida}

Silicijum-dioksid je veoma dobro proučen materijal koji može biti pripremljen u širokim opsezima veličine čestica i poroznosti. Veličina čestica hromatografskih silicijum-dioksid materijala je u opsegu od 5-100 $\mu \mathrm{m}$, sa prečnicima pora od 10-20 nm. Veća veličina čestica, koja bi bila poželjna za primenu kao nosača biokatalizatora, uzrokuje difuzione limitacije i pojavu koncentracionih gradijenata unutar čestice. Nedavno su dobijene čestice silicijum-dioksida sa bimodalnom strukturom pora, koja je karakteristična po međusobno povezanim kanalima makro-veličine sa mikroporoznom strukturom. Na ovaj način, obezbeđeno je da čestice nosača imaju veliku specifičnu površinu uz neometanu difuziju. Monolitni materijali koji ispunjavaju ovaj poslednji zahtev su nedavno razvijeni za primenu u katalizi i biokatalizi, dok su HPLC kolone zasnovane na monolitu već dugo komercijalno dostupne [128].

Imobilizacija penicilin-acilaze na aktiviranom silicijum-dioksid nosaču se uglavnom izvodi preko slobodnih amino grupa ostataka lizina na površini enzima. Enzim se kovalentno vezuje za aktivirani aminopropilsilicijum-dioksid, kao i silicijumdioksid funkcionalizovan oksiranom (slika 3.14.) [129]. Grupa istraživača je ispitivala imobilizaciju PAC na ovako tretiran silicijum-dioksid i utvrdili su da se oko $180 \mathrm{mg}$ enzima imobiliše po g mikročestica silicijum-dioksida (prečnika $5 \mu \mathrm{m}$ ), izražavajući aktivnost od oko $1250 \mathrm{BPU} / \mathrm{g}$. Ovi rezultati su slični sa onima dobijenim na Eupergit [130].
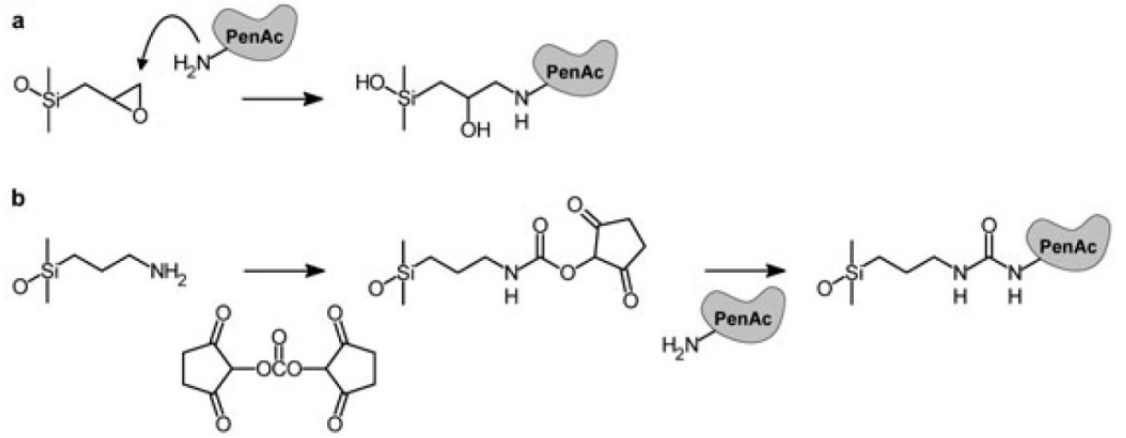

Slika 3.14. Šema imobilizacije penicilin-acilaze: a) na silicijum-dioksidu modifikovanim oksiranom i b) aminopropil silicijum-dioksidu [130] 
Penicilin-acilaza imobilisana na silicijum-dioksidu je primenjena za hidrolizu penicilina $\mathrm{G}$ u reaktoru u kome se ujedno odvija reakcija i separacija proizvoda pri čemu se pokazalo da biokatalizator ima zadovoljavajuću mehaničku stabilnost. Sveukupno, u prethodnim istraživanjima modifikovani silicijum-dioksid se pokazao kao obećavajući nosač za penicilin-acilazu jer ispunjava industrijske zahteve hemijske i mehaničke stabilnosti, dok je imobilisani enzim zadržao zadovoljavajuću aktivnost i stabilnost [129].

Modifikovani silicijum-dioksid se može pripremiti direktno iz odgovarajućih prekursora. Ima mnogo primera u literaturi koji se odnose na pripremu modifikovanih nosača na bazi silicijum-dioksida. Na primer, pokazano je da se aminopropilmodifikovani silicijum-dioksid gel može pripremiti hidrolizom smeše tetraetoksisilana i aminopropiltrimetoksisilana. Izmerena mala specifična površina $\left(165 \mathrm{~m}^{2} / \mathrm{g}\right)$ ukazivala je na veliki prečnik pora, reda $40 \mathrm{~nm}$. Sadržaj aminopropil grupa $-0,3 \mathrm{mmol} / \mathrm{g}$ je bio mnogo manji nego što se očekuje na osnovu sastava početne smeše $(1,9 \mathrm{mmol} / \mathrm{g})$. Očigledno, 85\% aminopropil grupa je nedostupno unutar matriksa silicijum-dioksida. Kasnija aktivacija glutaraldehidom i kovalentna imobilizacija penicilin-acilaze (slika 3.15.) daju biokatalizator umerene aktivnosti od $110 \mathrm{BPU} / \mathrm{g}$ (suve mase), takođe prinos aktivnosti je oko $80 \%$. Termalna stabilnost na $60{ }^{\circ} \mathrm{C}\left(\mathrm{t}_{0,5}=37 \mathrm{~min}\right)$ se dobro poredi sa penicilin-acilazom na Eupergit $\left(\mathrm{t}_{0,5}=10 \mathrm{~min}\right)$ [131].

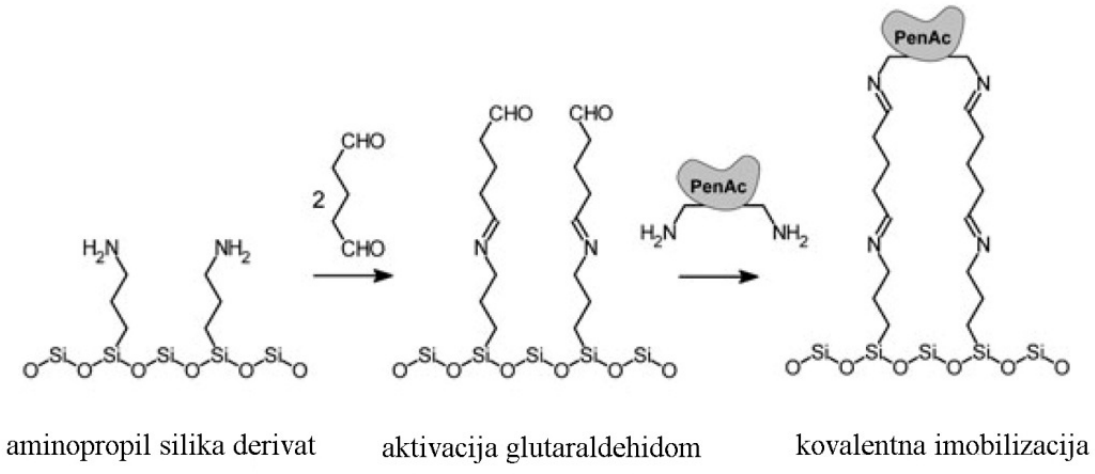

Slika 3.15. Aktivacija aminopropilsilicijum-dioksida $i$ kovalentno višetačkasto vezivanje penicilin-acilaze [131] 


\subsubsection{Smeštanje u matriks silicijum-dioksida}

Nasuprot imobilizaciji na površini silicijum-dioksida, enzimi mogu takođe biti smešteni unutar matriksa silicijum-dioksida, kao na primer lipaza [132]. Kada se ista procedura primeni na penicilin-acilaze, imobilisani enzim zadržava svega 10\% početne aktivnosti, što je pripisano difuzionim limitacijama u matriksu silicijum-dioksida. Ovo je lep primer kako se metode imobilizacije moraju optimizovati u slučaju svakog pojedinačnog enzima, pa čak i u slučaju istog enzima kada se koristi u različitim katalitičkim reakcijama. Primećeno je na osnovu ovih i drugih ispitivanja da dolazi do većeg gubitka aktivnosti imobilisanih PAC usled difuzionih limitacija nego kod ostalih enzima kao, na primer, lipaza [133].

\subsubsection{Imobilizacija PAC na molekulskim sitima}

\subsection{Raslojeni zeoliti kao nosači za imobilizaciju PAC}

Pore u zeolitima su suviše male $(0,5-1,2 \mathrm{~nm})$ da bi propustile penicilin-acilazu ili bilo koji drugi protein. Međutim, ljuštenjem slojevitih zeolita dobijaju se mikrokristalni slojevi silicijum-dioksida koji se gomilaju u mezo- i makroporozne agregate. Pošto su sastavljeni od pločica, ovi raslojeni zeoliti imaju ujedno veliku specifičnu površinu $\left(>600 \mathrm{~m}^{2} / \mathrm{g}\right)$ i velike pore, što ne može biti slučaj kod tradicionalnih mikroporoznih materijala. Veličina pora i uniformna distribucija silanol grupa, kao i lako obnavljanje i recikliranje raslojenih nosača kalcinacijom, podstaklo je interesovanje mnogih istraživača za moguću primenu raslojenih zeolita kao nosača za imobilizaciju enzima [134].

Eksperimenti se izvode sa raslojenim čistim silicijum-dioksidom ITQ-6 [135], koji je aktiviran 3-aminopropil(trietoksi)silanom i, nakon toga, glutaraldehidom. Penicilin-acilaza se kovalentno vezuje tako što reaguju slobodne amino grupe enzima sa aldehidnim grupama aktiviranog nosača. Konačno, nastale imino veze se mogu stabilizovati redukcijom do sekundarnih amina primenom natrijum-borhidrida (slika 3.16.) [136]. 


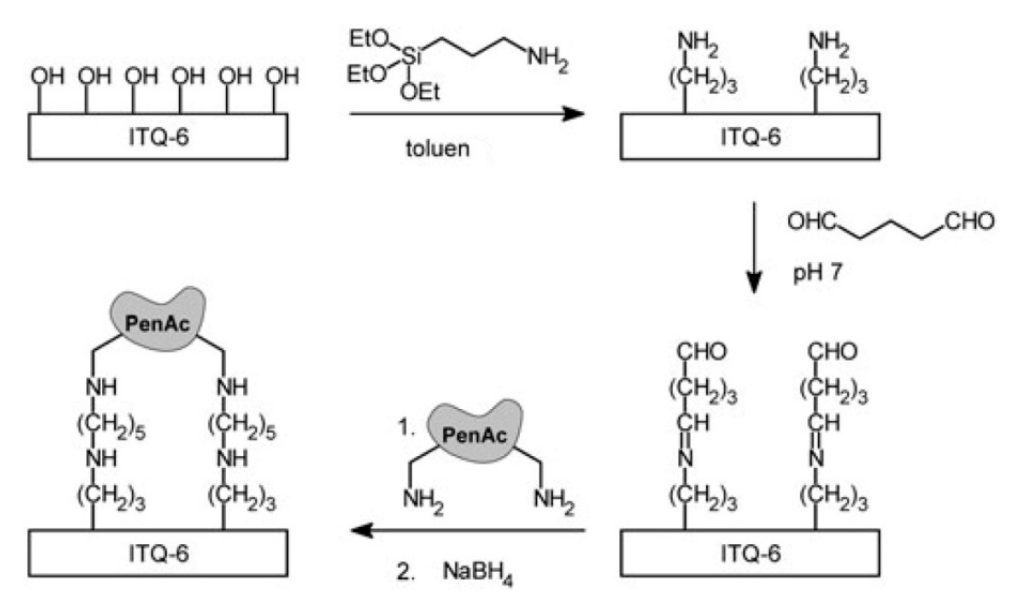

Slika 3.16. Kovalentna imobilizacija penicilin-acilaze na raslojenom zeolitu ITQ-6 [136]

$\mathrm{Na}$ ovaj način je PAC iz E. coli imobilisana na raslojenom zeolitu [136]. Aktivnost rezultujućeg preparata je bila 2440 BPU/g, što je do sada jedna od najvećih aktivnosti saopštenih u literaturi za imobilisanu penicilin-acilazu na čvrstom nosaču i može biti pripisana veoma povoljnim svojstvima nosača. $\mathrm{Na}$ osnovu poređenja poluvremena dezaktivacije imobilisanog i nativnog enzima na $\mathrm{pH} 8$ i $46{ }^{\circ} \mathrm{C}$ (koja su iznosila 18 h i 3 h, redom) može se zaključiti da se enzim šest puta stabilizuje u toku ove kovalentne imobilizacije. Zabeleženo je da hemijska nestabilnost nosača doprinosi gubitku aktivnosti, s obzirom da su O-Si-C veze poznate kao nestabilne na $\mathrm{pH}>7$.

U zaključku, kovalentna imobilizacija penicilin-acilaze na ITQ-6 daje veoma aktivan biokatalizator koji može biti privlačan za dobijanje polusintetskih antibiotika zbog velikih dimenzija pora. Praktična vrednost ove tehnike takođe značajno zavisi od mehaničke stabilnosti imobilisanog enzima u reaktoru sa pakovanim slojem, što još uvek nije dovoljno ispitano. 


\subsubsection{Imobilizacija PAC na lipidnim biokompozitnim filmovima na neorganskim nosačima}

U nekim istraživanjima koriste se lipidni filmovi kontrolisane debljine koji su presvučeni preko kvarca ili nekog drugog neorganskog materijala kao nosači za imobilizaciju enzima. Lipidni filmovi koji su se koristili za imobilizaciju penicilinacilaze uglavnom su se sastojali od stearinske kiseline ili oktadecilamina. Ovi lipidni filmovi imaju dvoslojnu strukturu pri čemu su lipidni slojevi odvojeni hidrofilnim kanalima, kao što je prikazano na slici 3.17. Interesantno je da su filmovi od stearinske kiseline (anjonski film) i oktadecilamina (katjonski film) u istom stepenu adsorbovali penicilin-acilazu. Ovaj rezultat je donekle neočekivan, s obzirom da su eksperimenti izvedeni na pH 6,5, što je dosta ispod izoelektrične tačke penicilin-acilaze (pI PAC je 8,1). Zato je pretpostavljeno da vezivanje enzima za nosač nije zasnovano na elektrostatičkim interakcijama. Ova pretpostavka je i eksperimentalno potvrđena povećanjem debljine sloja stearinske kiseline od $25 \mathrm{~nm}$ do $50 \mathrm{~nm}$, pri čemu se masa imobilisanog enzima takođe povećala dva puta pokazujući da se penicilin-acilaze ne imobiliše samo na površini filma nego i unutar lipidnih bislojeva [137].

Takođe je utvrđeno da je vezivanje enzima ireverzibilno. Naime, ne dolazi do spiranja enzima pri pH 6,5, niti 7,5. Ono što je izuzetno povoljno pri imobilizaciji penicilin-acilaze na lipidnim filmovima je da ona skoro potpuno zadržava početnu aktivnost i da se može ponovo koristi veliki broj puta u uzastopnim ciklusima sa malim gubitkom aktivnosti [137].

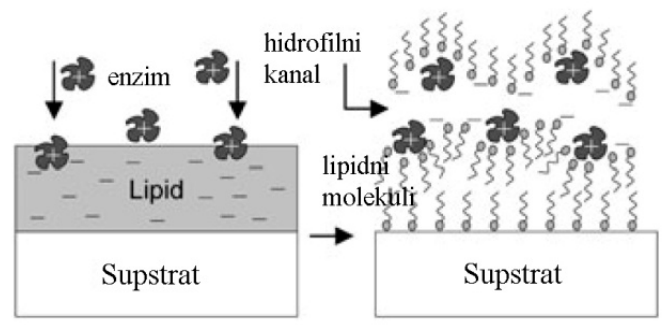

Slika 3.17. Šematsko predstavljanje adsorpcije penicilin-acilaze na lipidnom filmu [137] 


\subsubsection{Imobilizacija penicilin-acilaze bez primene nosača}

Imobilizacija enzima bez primene nosača je potencijalno korisna zbog smanjenih troškova nosača, koji u nekim slučajevima čak nadmašuju troškove enzima. Pored toga, postižu se znatno veće aktivnosti po jedinici biokatalizatora i izbegava rukovanje velikom masom neaktivnog materijala u toku reakcije. Nerastvorni enzimski preparati se pripremaju umrežavanjem enzima sa bifunkcionalnim reagensom. Takvi biokatalizatori mogu da se koriste u reaktorima sa pakovanim slojem, ali imaju suviše loše mehaničke karakteristike da bi se koristili u šaržnom reaktoru sa mešanjem. Značajne su dve tehnike za imobilizaciju penicilin-acilaze bez primene nosača: umreženi enzimski kristali i umreženi enzimski agregati [138].

\subsubsection{Umreženi enzimski kristali}

Umreženi enzimski kristali (CLECs, na engl. cross-linked enzyme crystals) se spominju još 1964. godine [139], ali njihov potencijal kao biokatalizatora procesa je postao očigledan tek ranih 90-tih godina [140, 141]. CLECs se proizvode u dvostepenom procesu: prvo se odvija kristalizacija enzima iz koncentrovanih rastvora, onda se dobijeni kristali umrežavaju bifunkcionalnim reagensom kao što je glutaraldehid. Kristalizacija enzima se smatra uskim grlom procesa, s obzirom da razvoj adekvatnog protokala zahteva vreme i intezivan rad. Treba primetiti, međutim, da je kristalizacija takođe efikasna procedura za prečišćavanje enzima, naročito u velikim razmerama [142].

CLECs biokatalizatori imaju veliku aktivnost, s obzirom da se sastoje od čistog proteina bez nosača, i veoma su stabilini kako mehanički tako i hemijski. U ovom sistemu molekuli enzima su sabijeni skoro do teorijske granice i stabilizacija se javlja kao posledica jakih intra- $\mathrm{i}$ intermolekulskih polarnih i hidrofobnih interakcija između ostataka aminokiselina [1]. CLECs su ekstremno stabilni, ne samo na visokim temperaturama, nego isto tako u odnosu na ostale denaturante, kao što su organski rastvarači [142-144]. Ovakav pristup je jedinstven među tehnologijama stabilizacije 
koji za rezultat daje istovremenu imobilizaciju i stabilizaciju bez smanjenja aktivnosti enzima. To znači da je proteinski matriks u isto vreme katalizator i nosač.

CLECs penicilin-acilaze (CLEC-EC) su neko vreme bile komercijalno dostupne (Altus Biologics, SAD) ali je proizvodnja nedavno prekinuta. Osnovna prednost ovih sistema je olakšan transport supstrata i proizvoda kroz biokatalizator u poređenju sa drugim oblicima imobilisanih enzima, kao posledica male veličine kristala (reda $15 \mu \mathrm{m}$, mereno duž najkraće ose) i otvorenih kanala (približno 3,5-5,0 nm) između pojedinačnih enzimskih molekula. Treba primetiti, međutim, da je prečnik pore Eupergit približno pet puta veći $(25 \mathrm{~nm})$, što može da bude posledica veličine čestica ovog materijala [145].

\subsubsection{Umreženi enzimski agregati}

Alternativa kristalizaciji je fizička agregacija proteinskih molekula u supermolekulske strukture i potom njihovo taloženje bez narušavanja prvobitne trodimenzionalne strukture proteina. Ovaj proces može biti indukovan dodatkom soli, organskih rastvarača ili nejonskih polimera rastvorima proteina [146]. Ustvari, taloženje proteina amonijum-sulfatom, polietilenglikolom, i nekim organskim rastvaračima kao što su alkoholi, se najčešće koristi kao metoda koncentrovanja i prečišćavanja rastvora proteina, ali kada se ovi čvrsti agregati prevashodno prevode u nerastvoran oblik hemijskim umrežavanjem, dobijaju se umreženi enzimski agregati (CLEAs, na engl. cross-linked enzyme aggregates) (slika 3.18.) [147]. 


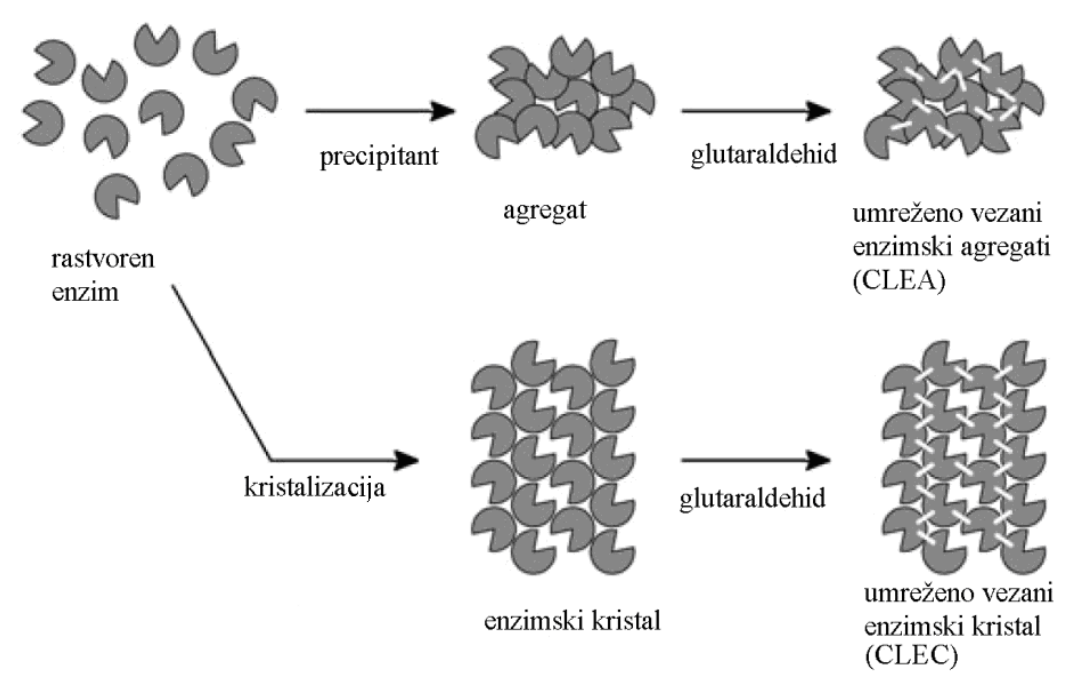

Slika 3.18. Poređenje formiranja umreženih enzimskih agregata (CLEAs) u odnosu na umrežene enzimske kristale (CLECs) [148]

Sistemi umreženih enzimskih agregata sa penicilin-acilazom (CLEAs-PAC) se pripremaju tako što se rastvoru enzima na $0{ }^{\circ} \mathrm{C}$ i $\mathrm{pH} 8,0$ lagano dodaje precipitant $\left(\mathrm{NH}_{4}\right)_{2} \mathrm{SO}_{4}$, PEG 8000 ili terc-butil alkohol. U sledećem koraku, agregirani molekuli PAC se podvrgavaju hemijskom umrežavanju glutaraldehidom. Poređenjem sa konvencionalno imobilisanom PAC i CLEC sistemom, ovi CLEA-PAC sistemi poseduju veliku specifičnu aktivnost, produktivnost, kao i veliki odnos sinteze i hidrolize $(\mathrm{S} / \mathrm{H})$, pa su pogodni za sintezu polusintetskih $\beta$-laktamskih antibiotika u vodenim sredinama. Šta više, oni su aktivni i stabilni u širokom opsegu polarnih i nepolarnih organskih rastvarača [1].

Ispitan je uticaj sredstva za taloženje na aktivnost dobijenog biokatalizatora. Ukoliko se kao taložni reagens koristi terc-butil alkohol, umreženi enzimski agregati zadržavaju do $80 \%$ prvobitne aktivnosti (T-CLEA, slika 3.11). Pri korišćenju poli(etilenglikola) dolazi do većih gubitaka aktivnosti enzima (ovako umreženi biokatalizator je označen na slici kao P-CLEA). Na osnovu titracije aktivnog položaja P-CLEA pokazano je da je ovaj gubitak aktivnosti podjednako posledica gubitka aktivnih položaja, kao i smanjenja konformacione fleksibilnosti enzima. Autori tvrde da stepen agregacije enzima ima krucijalnu ulogu na aktivnost umreženog enzima. Ovo 
mišljenje se zasniva na činjenici da je umrežena penicilin-acilaza koja je dobijena bez faze taloženja imala takođe veoma malu aktivnost (CLE, slika 3.19.) [148].

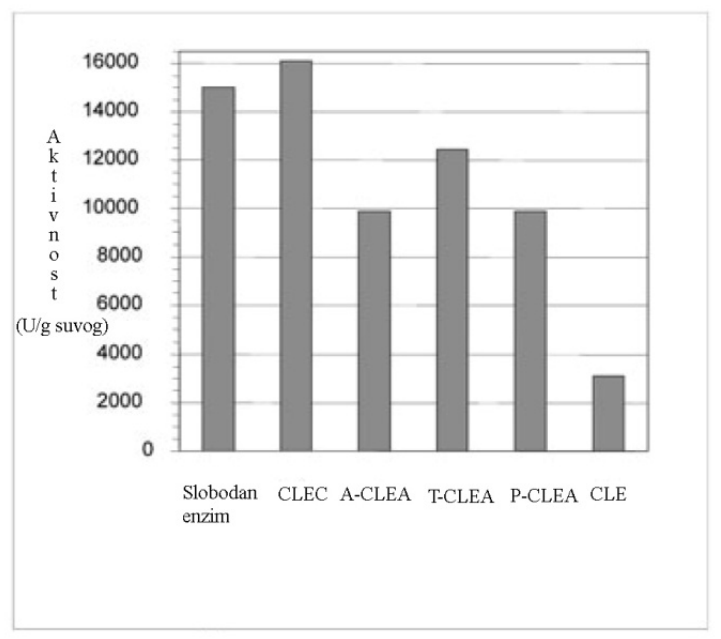

Slika 3.19. Aktivnost penicilin-acilaze-CLEAs pri hidrolizi penicilina G. Precipitanti: amonijum-sulfat (A-CLEA), terc-butil alkohol (T-CLEA), i PEG 8000 (P-CLEA); CLE je dobijen umreženim vezivanjem penicilin-acilaze u rastvoru [148]

\subsection{Umreženi enzimski agregati penicilin-acilaze kao katalizatori sinteze polusintetskih antibiotika}

Potencijal umreženih enzimskih agregata penicilin-acilaze (CLEAs-PAC) je ispitan u sintezi ampicilina iz (R)-fenilglicinamida i 6-APA, naročito sa aspekta odnosa brzine reakcije sinteze i hidrolize. Ovi sistemi su se pokazali kao bolji katalizatori u reakciji sinteze od umreženih enzimskih kristala penicilin-acilaze (CLECs-PAC). Naime, dobijen je odnos $\mathrm{S} / \mathrm{H}$ približno isti kao sa slobodnim enzimom, dok se sa CLECs-EC postiže samo polovina od te vrednosti. Značajno, S/H odnos sa CLEAs-EC kao katalizatorom čak opada manje sa povećanjem stepena konverzije reakcije u poređenju sa slobodnim enzimom. Dokazano je takođe da su ovi sistemi, naročito kada su dobijeni sa terc-butil alkoholom kao precipitantom, stabilni pod reakcionim uslovima. Ne dešava se spiranje enzima iz nosača u rastvor i početna aktivnost biokatalizatora se u celosti regeneriše ako se on izdvoji iz reakcione smeše pre nego što 
ampicilin počne da se taloži. U ovoj tački, približno $30 \%$ prvobitne aktivnosti biokatalizatora se izgubi, verovatno jer kristalizacija ampicilina uzrokuje narušavanje agregata biokatalizatora zbog čega je bitno da se proces sa imobilisanim sistemom zaustavi u određenom trenutku i biokatalizator izdvoji pre početka taloženja antibiotika [149].

\subsection{Sinteza ampicilina u mikrovodenim sistemima organskih rastvarača}

Očigledan način da se spreči odvijanje sporedne reakcije hidrolize u enzimskim reakcijama transesterifikacije je da se koristi organski rastvarač pri minimalnoj koncentraciji vode. Međutim, za razliku od lipaze, pokazano je da slobodna penicilinacilaza nije aktivna i stabilna u ovim sistemima. S druge strane, umreženi enzimski agregati penicilin-acilaze (CLEAs-EC) su pokazali, neočekivano, veliku stabilnost u hidrofilnim organskim rastvaračima, kao što je acetonitril, 2-etoksietiletar i terc-amil alkohol [148]. Naime, utvrđeno je da CLEAs-EC, iako mnogo manje efikasno, katalizuju reakciju sinteze ampicilina u sistemima polarnih organskih rastvarača. Nasuprot očekivanjima, međutim, poboljšanje u S/H odnosu je marginalno u poređenju sa reakcijom u vodi. Najveći prinosi ampicilina (do 86\%) su ostvareni u acetonitrilu pri malom sadržaju vode kada se kao biokatalizatori koriste umreženi agregati relativno nepoznate penicilin-acilaze iz Alcaligenes faecalis [150]. U ovim sistemima je ipak potrebna mala količina vode da bi se solvatizovale funkcionalne grupe enzima i utvrđeno je da je minimalna potrebna aktivnost vode, $a_{w}$, od 0,4-0,7, koja je $u$ istom intervalu kao i u sistemu sa penicilin-acilazom imobilisanom na Celite R-640 [150, $151]$.

Sveukupno može se zaključiti da su CLEAs-EC veoma aktivni i stabilni preparati sa velikom sintetičkom sposobnošću. Pokazan je njihov potencijal da stabilizuju penicilin-acilaze u nevodenoj sredini. Problem prilikom primene ovih enzimskih preparata u industriji može biti mala veličina čestica, koja ih čini težim za filtriranje nego tradicionalne imobilizate. Stoga, predmet savremenih istraživanja $u$ ovoj oblasti je poboljšanje filtracionih osobina CLEAs-EC bez gubitka aktivnosti. Nadalje, vredi primetiti da je ova metoda imobilizacije uspešno primenjena za različite enzime, uključujući lipaze, esteraze, nitrilaze, oksinitrilaze, fitaze, glukozo-oksidaze, 
galaktozo-oksidaze, katalaze, laktaze i alkohol-dehidrogenaze. Zaključeno je da će njihovo lako pripremanje i široka primenljivost, uključujući sirove enzimske preparate, i veliko zadržavanje aktivnosti i stabilnosti najzad dovesti do raspostranjene upotrebe CLEAs u industrijskim biotransformacijama [152-154].

\subsubsection{Tehnike imobilizacije u razvoju}

\subsubsection{Integrisano prečišća vanje i imobilizacija penicilin-acilaze}

Procedure za proizvodnju industrijskih biokatalizatora, iz ekonomskih razloga, treba da budu što je moguće jednostavnije. Stoga, prečišćavanju sirovog enzima, koji je često samo homogenizovana ćelijska masa, se pribegava samo u onim slučajevima kada je čistoća enzimskog preparata neophodna. Nažalost, to je slučaj penicilin-acilaze koja se koristi za proizvodnju lekova zbog čega je neophodno ukloniti primese ostalih proteina iz enzimskog preparata. Šta više, jedan od razloga što se kao metoda imobilizacije za ovaj enzim najviše koristi kovalentna imobilizacija je upravo zahtev za apsolutno čistim proizvodom bez primesa proteina jer i sam enzim ostaje kao kontaminirajuća primesa ukoliko nije čvrsto vezan za nosač. U cilju što rentabilnije proizvodnje i smanjenja troškova prečišćavanja enzima i proizvoda reakcije, savremena istraživanja su usmerena ka integraciji procesa prečišćavanja i imobilizacije penicilinacilaze [155].

Kao jedna od najboljih metoda prečišćavanja enzima pokazala se raspodela $u$ vodenim dvofaznim sistemima. Tako, prečišćena penicilin-acilaza se direktno dobija iz razorenih i prethodno obrađenih ćelija $E$. coli raspodelom u dvofaznom sistemu fosfatnih soli/poli(etilen glikol). Enzim se izdvaja u gornjoj fazi poli(etilenglikola) u prinosu od 79\% i faktorom prečišćavanja od 7,8 [155]. Istraživači i inženjeri su uspeli da ovaj postupak integrišu sa imobilizacijom enzima i na taj način omoguće ujedno izdvajanje enzima iz gornje faze i imobilizaciju enzima na čvrst nosač. Na taj način proces je zaokružen, u sistem se stalno dodaje sirovi enzim, enzim se raspodeljuje između faza pri čemu se gornja faza obogaćuje enzimom i usled dodavanja aktiviranih čestica nosača, imobilisani enzim se stalno izdvaja iz gornje faze i koristi u različitim procesima (slika 3.20.) [155]. 
$\mathrm{Na}$ osnovu uvida u literaturu dva tipa nosača su se koristila u stupnju imobilizacije pri ovom pristupu i to: Eupergit i aldehid-aktivirana agaroza. Aktivnost Eupergit imobilizata je bila prilično niska (približno $85 \mathrm{BPU} / \mathrm{g}$ ) i vreme koje je potrebno da se adsorbuje ova umerena količina enzima iz gornje faze je bilo $50 \mathrm{~h}$ [155]. Smatra se da se enzim sporo adsorbuje u prisustvu 12\% PEG zbog velike viskoznosti rastvora. Mala krajnja aktivnost imobilizata može biti uzrokovana preostalim proteinskim kontaminantima u gornjoj fazi. Aldehid-agaroza je adsorbovala penicilinacilazu iz gornje faze do konačne aktivnosti od približno 50 BPU/g, što nije loš rezultat uzimajući u obzir da je gustina aldehidnih grupa, pri $40-50 \mu \mathrm{mol} / \mathrm{cm}^{3}$, samo $30 \%$ gustine epoksidnih grupa u Eupergit [155].

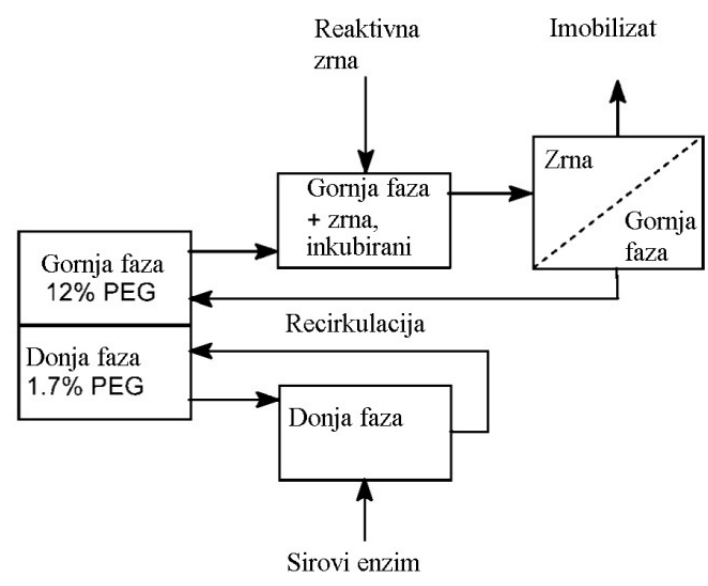

Slika 3.20. Integrisano prečišćavanje i kovalentna imobilizacija penicilin-acilaze [155]

U zaključku, razvijen je postupak integrisanog prečišćavanja i imobilizacije sirove penicilin-acilaze, ali se zahtevaju poboljšanja da bi se proces učinio praktično izvodljivim. 


\subsubsection{Kovalentno vezivanje penicilin-acilaze za temperaturno osetljive polimere}

Poli- $N$-izopropilakrilamid (poliNIPAM) je temperaturno osetljiv polimer: taloži se iz vodenih rastvora kada se greje iznad $32{ }^{\circ} \mathrm{C}$. Stoga, obrazovanjem konjugata poliNIPAM sa enzimima mogu se dobiti temperaturno osetljivi imobilizati koji se talože, i na taj način izdvajaju iz vodenih rastvora, pri malim promenama u temperaturi, pH ili jonskoj jačini [155]. Na taj način moguće je da se reakcija odvija u homogenom sistemu sa imobilisanim enzimom bez difuzionih limitacija tako što se podese parametri sredine kada je polimer rastvoran i da se na kraju reakcije promenom parametara, najčešće temperature, biokatalizator istaloži i na taj način odvoji iz reakcione smeše. Ovim se ujedno kombinuju prednosti imobilisanih enzima, kao što su separacija i reciklacija biokatalizatora, i homogenih sistema, kao što je smanjenje difuzionih limitacija [156].

Ivanov i saradnici su sintetisali reaktivni poliNIPAM derivat kopolimerizacijom NIPAM monomera i $N$-akroiloksisukcinimida, u odnosu 19:1, u kopolimer (slika 3.21.) sa molekulskom masom od $39 \mathrm{kDa}$. Sadržaj aktiviranih estarskih grupa u kopolimeru je bio približno 0,5 mol\%. Kada se penicilin-acilaza umrežila sa 35 puta većom količinom kopolimera, dobijeni imobilizat imao je $37 \%$ prvobitne aktivnosti. Na osnovu gel filtracione hromatografije utvrđeno je da se jedan molekul enzima modifikuje sa velikim brojem lanaca kopolimera [156].

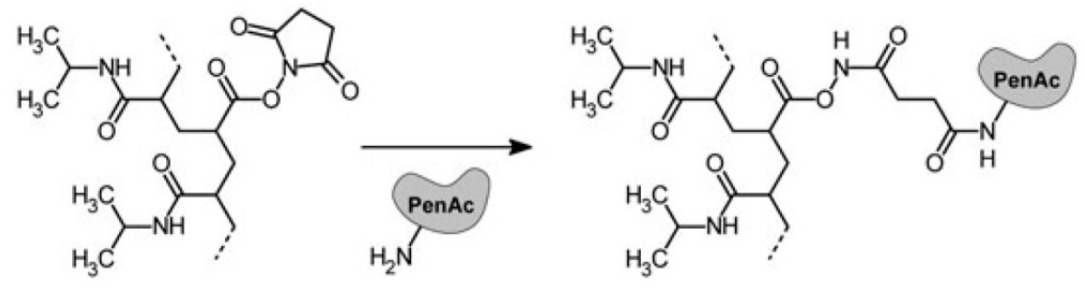

Slika 3.21. Vezivanje penicilin-acilaze za poliNIPAM-termoosetljivi polimer [156] 
Da bi se povećao sadržaj enzima u konjugatu, eksperimenti su se izvodili pri većem sadržaju enzima, na primer pri masenom odnosu kopolimera i enzima 3,5:1. Rezultujući konjugat je bio četiri puta aktivniji nego prethodni, iako je zadržao svega $24 \%$ početne aktivnosti jer je veća količina enzima imobilisana. Sadržaj proteina u polimernim frakcijama je bio 13 mas \% i, nažalost, zbog toga je termosenzitivnost ovih kopolimera bila manja. Dalje povećanje sadržaja proteina u kopolimeru uzrokuje da njegov odgovor na promene temperature i jonske jačine potpuno izostane. Verovatno, veliki udeo hidrofilnog enzima u kopolimeru remeti njegov termoodgovor, koji zavisi od odnosa hidrofilnih i hidrofobnih interakcija [156].

Imobilisani sistem sa sadržajem enzima u kopolimeru od $13 \%$ je ispitan $\mathrm{u}$ sintezi cefaleksina iz (R)-fenilglicinamida i 7-ADCA. Njegova transesterifikaciona efikasnost (S/H) je bila slična efikasnosti slobodnog enzima [156].

U zaključku, kovalentno vezivanje enzima u temperaturno osetljive polimere ima veliki potencijal za izvođenje reakcije hidrolize prirodnih penicilina i reakcije sinteze polusintetskih antibiotika. Ova metoda zahteva dalji razvoj da bi postala odgovarajuća za industrijsku praksu. Izgleda da je osnovni zahtev fino podešavanje stepena hidrofobnosti kopolimera da bi se uravnotežila hidrofilnost vezanog enzima [156].

\subsubsection{Magnetna biokatalizatorska zrna}

Da bi čestice biokatalizatora imale dobre filtracione karakteristike njihova veličina treba da bude najmanje od 0,1 do $0,2 \mathrm{~mm}$. S druge strane, prenos mase kroz velike čestice je veoma otežan, pa je često potrebno naći kompromis između zahteva za olakšanu separaciju biokatalizatora i za efikasan prenos mase. Uklanjanje čestica biokatalizatora iz reakcione smeše po završetku reakcije korišćenjem magnetnog polja bi bila dobra alternativa, čak i u prisustvu čvrstih proizvoda, pri čemu nema zahteva za potrebnom veličinom čestica. Mikročestični polimeri, koji imaju magnetna svojstva, su sada komercijalno dostupni i primenjuju se u prečišćavanju proteina i separaciji ćelija [157].

Prednosti imobilizacija enzima na nosačima sa magnetnim svojstvima su:

- olakšana separacija enzima upotrebom magnetnog polja i 
- mogućnost primene čestica znatno manjeg prečnika nego kod drugih vrsta nosača [158].

Nedavno su objavljeni radovi o kovalentnoj imobilizaciji penicilin-acilaze na različite tipove magnetnih mikročestica. Najbolji rezultati, od nekoliko tipova polimera, su dobijeni sa namagnetisanim, epoksi-aktiviranim poli(vinil alkohol) mikročesticama, sa prosečnim prečnikom čestice $1,8 \mu \mathrm{m}$ i specifičnom površinom od $84 \mathrm{~m}^{2} / \mathrm{g}$. Penicilinacilaza se kovalentno vezivala za epoksidne grupe preko 1,6-diaminoheksana i glutaraldehid međuagenasa. Maksimalna masa vezanog enzima bila je $28 \mathrm{mg} / \mathrm{g}$, što odgovara aktivnosti od $20 \mathrm{BPU} / \mathrm{g}$ i molekularnoj aktivnosti, $k_{\text {cat }}$ vrednosti od 20 transformacija $\mathrm{s}^{-1}$. Cefaleksin se sintetisao iz (R)-fenilglicinamida i 7-ADCA u prisustvu magnetnog biokatalizatora sa $\mathrm{S} / \mathrm{H}$ odnosom od oko 8 , što je između vrednosti slobodnog enzima i imobilisanog enzima na Eupergit (13 i 3, redom) [159].

Stoga, princip prevođenja biokatalizatora u namagnetisani oblik imobilizacijom na nosače sa magnetnim svojstvima da bi se olakšala separacija ima veliki potencijal za razvoj industrijskih biokatalizatora. Osnovni problem koji treba da se reši je malo opterećenje enzima na nosaču (mala količina imobilisanog enzima) zbog čega je aktivnost oko 10 puta manja nego kod prosečnog Eupergit imobilizata [159].

\subsubsection{Termodijaliza kroz katalitičku membranu}

Termodijaliza uključuje primenu temperaturne razlike preko membrane. Usled temperaturnog gradijenta olakšan je prenos mase u ovim sistemima što se pokazalo više puta kao osnovni problem pri primeni imobilisanih penicilin-acilaza u industrijskim uslovima. Takvi uslovi izazivaju protok rastvarača u kome je rastvoren supstrat od tople ka hladnoj strani, tako da se na taj način unapređuje prenos mase supstrata. Termodijaliza preko katalitičke membrane može da se koristi da bi se prevazišla difuziona ograničenja, kao što je prikazano na slici 3.22 [160].

U literaturi je opisano nekoliko ovakvih sistema u slučaju imobilizacije penicilin-acilaze. U jednom slučaju korišćena je membrana na bazi poliakrilamida, koji ima nekoliko slobodnih krajnjih grupa za kovalentno vezivanje enzima. Da bi se uvele dodatne funkcionalne grupe za višestruko hemijsko vezivanje molekula enzima, membrana se aktivira pogodnim estrom metakrilne kiseline u reakciji polimerizacije po 
tipu slobodnih radikala. Nakon toga, membrana se dodatno aktivira pomoću reakcije sa 1,6-diaminoheksanom i glutaraldehidom (slika 3.23). Konačno, penicilin-acilaza se kovalentno vezuje za aktiviranu membranu. Ispitan je uticaj količine vezanog enzima na membrani na aktivnost ovog sistema, ali prinos aktivnosti nije bio preko $11 \%$. Aktivnost membranski-vezanog biokatalizatora opada za 50\% posle prvog korišćenja, ali zatim ostaje stabilna pri produženom periodu ponovnog korišćenja [161].

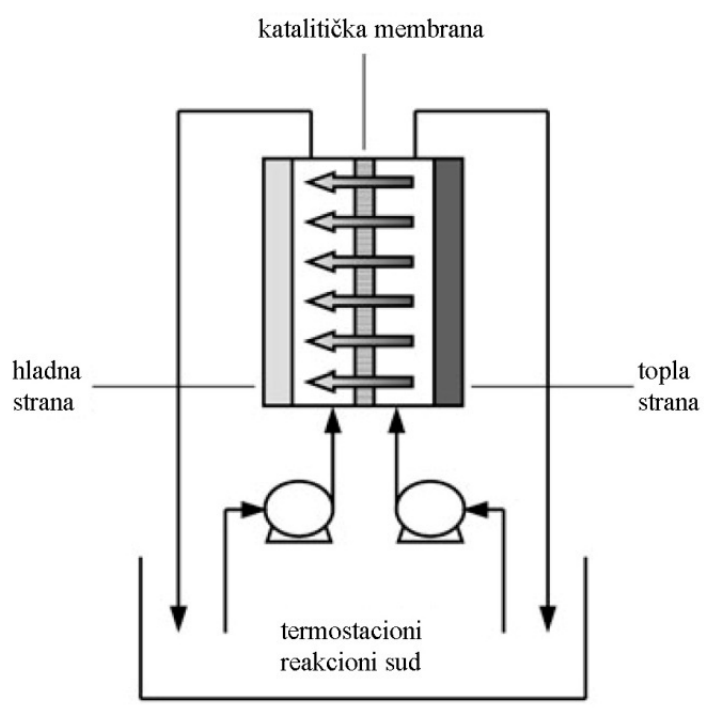

Slika 3.22. Šematski prikaz membranskog reaktora. Protok rastvarača je od tople ka hladnoj strani [160]

Reaktor za termodijalizu se sastojao od dve komore koje su bile odvojene katalitičkom membranom; termostatirana reakciona smeša kontinualno je cirkulisala kroz obe komore (slika 3.22.) [160, 162]. Primena membranskog reaktora sa termodijalizom ispitana je u sintezi cefaleksina iz (R)-fenilglicinamida i 7-ADCA. Kada su obe komore na istoj temperaturi, tok reakcije je bio veoma sličan onom katalizovanom penicilin-acilazom imobilisanom u gelu na bazi želatina (Assemblasse), što ukazuje na postojanje difuzionih limitacija u sistemu. Kada se primeni temperaturni gradijent od $30{ }^{\circ} \mathrm{C}$, tok reakcije liči na tok sa slobodnim enzimom, što ukazuje na sistem bez difuzionih limitacija. Ovaj pozitivan uticaj na prenos mase je pripisan temperaturnom gradijentu duž membrane. U sličnom proučavanju, kinetički parametri 
sinteze cefaleksina su se određivali u sistemu sa i bez temperaturnog gradijenta. Prividne vrednosti Mihaelisove konstante membranski vezanog biokatalizatora su, pod izotermnim uslovima, 3,5-4 puta veće od onih kod slobodnog enzima. Ovaj odnos se smanjuje do približno 1,6 kada se primeni temperaturni gradijent, što je takođe pokazatelj da temperaturni gradijent poboljšava prenos mase kroz membranu [160, $162]$.

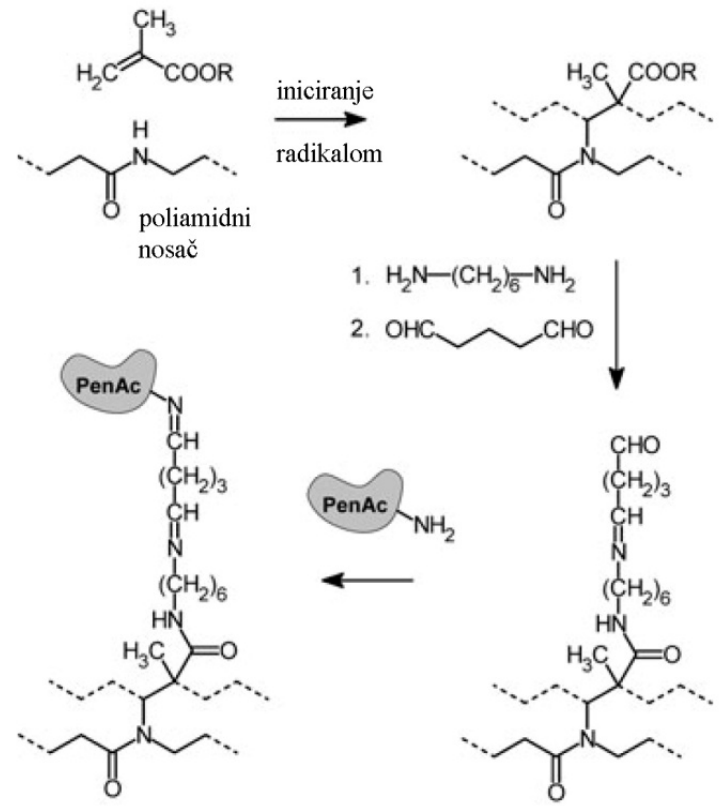

Slika 3.23. Aktivacija membrane na bazi poliakrilamida $i$ kovalentno vezivanje penicilin-acilaze [161]

Sistem sa imobilisanom penicilin-acilazom u membranskom reaktoru sa termodijalizom ima dosta potencijala, ali neki glavni problemi još uvek moraju da se reše za industrijsku primenu. Verovatno, prinos aktivnosti membranski vezanog enzima može biti poboljšan. Nažalost, temperaturna razlika i, stoga, dobitak u efikasnosti prenosa mase, je ograničen usled termalne nestabilnosti 7-ADCA i cefaleksina. Pored toga, nedostatak ovih sistema je malo opterećenje enzima na membrani zbog čega je $\mathrm{i}$ aktivnost biokatalizatora mala. Količina vezanog enzima može biti poboljšana primenom membrana u obliku šupljih vlakana koje imaju značajno veću površinu po 
jedinici zapremine. Takav dizajn takođe može da dozvoli i veće temperaturne razlike, usled smanjenja vremena zadržavanja komponenti u sistemu [160].

\subsubsection{Katalitički elektro-membranski reaktor}

Imobilisana penicilin-acilaza je generalno manje ili značajno manje efikasna $u$ hidrolizi penicilina $\mathrm{G}$ nego slobodan enzim. Osnovni razlog je akumulacija proizvoda reakcije, 6-aminopenicilanske kiseline, u česticama nosača što snižava konformacionu fleksibilnost penicilin-acilaze i, osim toga, uvećava inhibitorni uticaj sporednog proizvoda, fenilacetata. Pored primene temperaturnog gradijenta kroz membranu, jedan od načina da se utiče na transport reaktanta i proizvoda kroz pore nosača je da se primeni električno polje [163].

Elektro-membranski reaktor je šematski prikazan na slici 3.24. Penicilin-acilaza se imobiliše u poliakrilamidnu ploču polimerizacijom po tipu radikala smeše vodenog rastvora akrilamida, fosfatnog pufera i enzima. Rezultujuća katalitička membrana razdvaja komore reaktanata od komore proizvoda. Električno polje se primenjuje preko dve elektrode, koje su odvojene od komora reaktanata i proizvoda jonoizmenjivačkim membranama [163].

U odsustvu električnog polja sav prenos mase se odvija usled gradijenta koncentracije. Reakcija se verovatno odvija u membrani, i to u tankoj zoni okrenutoj prema komori reaktanata, slično konvencionalno imobilisanom biokatalizatoru, dok proizvodi difunduju nazad u komoru reaktanata. Uočeno je da odmah posle primene pozitivnog električnog polja, brzina reakcije raste (slika 3.25.). Prihvatljivo objašnjenje je separacija anjonskih proizvoda od protona: difuzija 6-APA i fenilacetatnog anjona izvan reakcione zone, nazad u komoru reaktanta, se ubrzava električnim poljem pošto su protoni privučeni ka komori proizvoda (slika 3.24c). Stoga, $\mathrm{pH}$ u reakcionoj zoni se održava konstantnim. Negativno polje (slika 3.24d), nasuprot, privlači anjonska jedinjenja (penicilin G, 6-APA i fenilacetat) dublje u membranu prema komori proizvoda. Početni rezultat je pad u brzini reakcije, što je prouzrokovano, verovatno, produžavanjem difuzionog puta svih komponenti. Neznatno napredovanje u brzini reakcije je samo primećeno pri velikoj jačini negativnog polja (slika 3.25). Čak i tad, reakcija je difuziono kontrolisana, kao što je pokazano malim povećanjem 
produktivnosti odmah posle petostrukog povećanja količine enzima u membrani, nasuprot onom što je primećeno kada se primeni pozitivno polje. Negativno polje takođe rezultira delimičnom separacijom 6-APA, koja se uglavnom akumulira u komori proizvoda, i nekonvertovanog penicilina $\mathrm{G}$, koji se uglavnom nalazi u komori reaktanata. Takva integracija reakcije i separacije proizvoda reakcije u istoj jedinici ima veliki potencijal za praktičnu primenu [163].

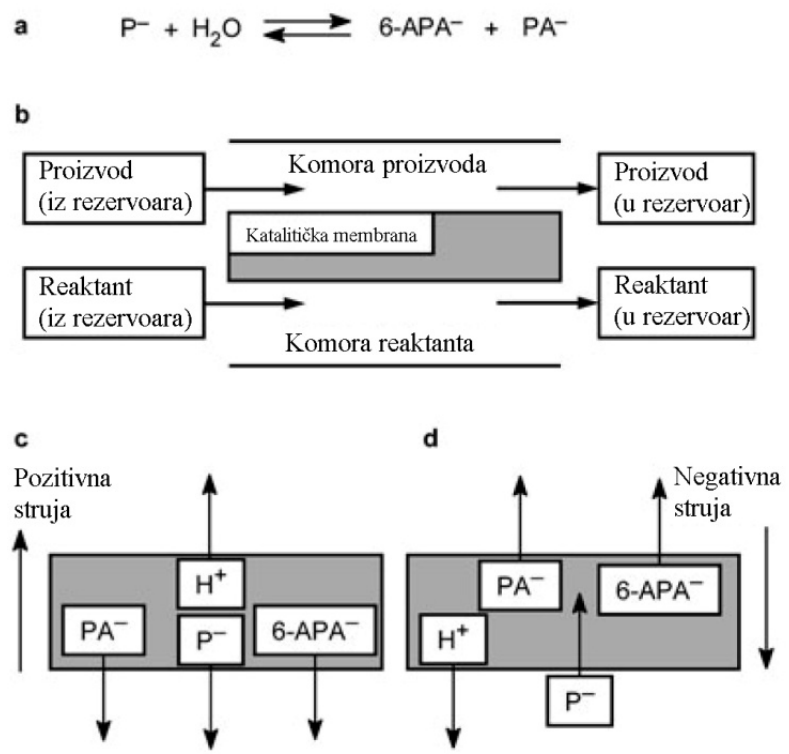

Slika 3.24. Princip rada elektro-membranskog reaktora (a) reakcija u jonskom obliku koja se odvija u reaktoru (b) pokretanje jona pod primenjenim pozitivnim (c) $i$ negativnim (d) poljem. $P^{-}$: anjon penicilina $G ; P A^{-}$, fenilacetatni anjon [163]

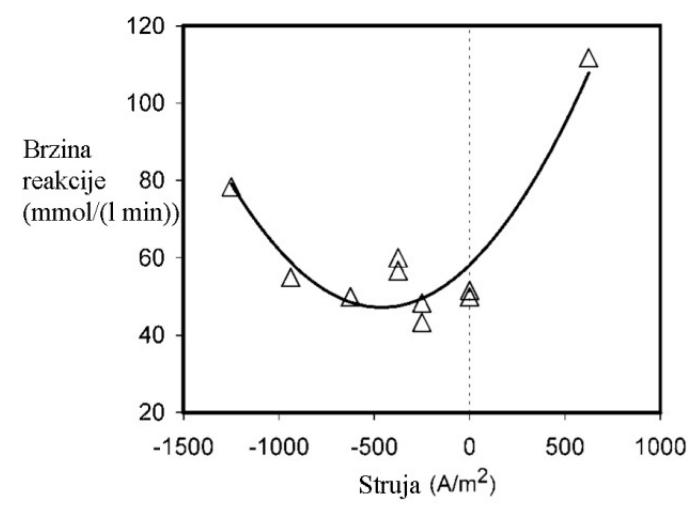

Slika 3.25. Brzina reakcije hidrolize penicilina $G$ u zavisnosti od gustine struje [163] 
Potencijalni nedostatak elektro-membranskog reaktora je zagrevanje membrane i rastvora u komorama, što može da uzrokuje dezaktivaciju penicilin-acilaze kao i degradaciju $\beta$-laktamskih jedinjenja. Porast temperature je naročito primećen u struji reaktanata, i jako je uglavnom umeren, raste i do $50{ }^{\circ} \mathrm{C}$ kada se toplota ne odvodi. Zbog toga je neophodno hlađenje reaktorskog sistema [164].

Brzina hidrolize penicilina $\mathrm{G}$ može biti značajno uvećana primenom električnog polja na enzim imobilisan u membrani, ali još treba da se pokaže da se postiže povećanje prostorno-vremenskog prinosa reaktora u poređenju sa konvencionalnim procesima. Pored toga, osnovni cilj da se pređe u oblast kinetički kontrolisane reakcije umesto difuziono kontrolisane nije postignut. Moguće je da ovaj cilj može da se postigne upotrebom više-komponentnog reaktora u cilju separacije komponenti, na primer, elektrodijalizom ili adsorpcijom [164].

\subsubsection{Separacija proizvoda reakcije u sistemu sa imobilisanim enzimom}

Pošto separacija željenog produkta od ostalih komponenata procesa u industriji još uvek predstavlja kritičnu tačku kada je reč o troškovima proizvodnje, predložena je alternativna metoda koja predstavlja primenu integrisanog uređaja za reakcijuseparaciju koga čini kolona za tečnu hromatografiju na čiji je nosač kovalentno imobilisana PAC. U ovakvom uređaju se sinhronizovano izvode reakcija hidrolize PenG i separacija produkata, 6-APA i PAA [8].

Izvršeno je više različitih vrsta kovalentnih imobilizacija na dva različita silikatna nosača sa različitim veličinama pora. Nosači su bili silikati sa mikročesticama i monolitni silikati. Na svakom od njih su bile ugrađene aminopropil- i epoksi-grupe posebno. Najbolje rezultate u smislu količine vezane PAC i aktivnosti imobilisanog enzima, stereospecifičnosti i separacije proizvoda hidrolize PenG postignuti su sa PAC imobilisanom na monolitnom silikatu u koga su uvedene epoksidne grupe (slika 3.26.) [8]. 


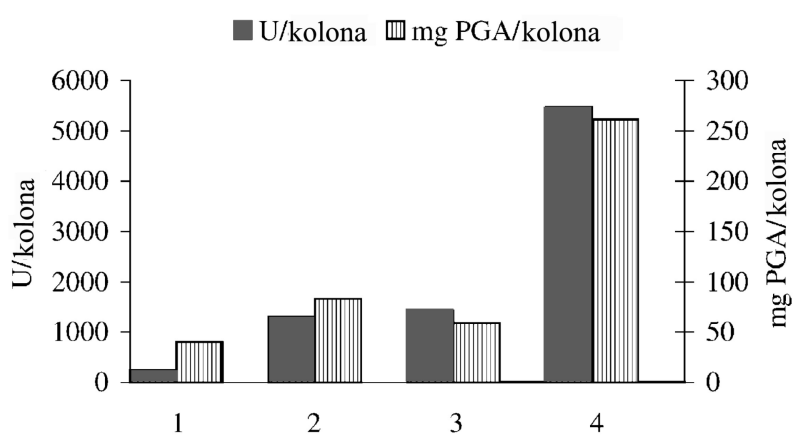

Slika 3.26. Sadržaj $i$ aktivnost PAC imobilisane na silikatu sa mikročesticama $i$ monolitnom silikatu (1) PAC imobilisana na aminopropil-silikatu mikročestica (2) PAC imobilisana na epoksi-silikatu mikročestica (3) PAC imobilisana na aminopropilmonolitnom silikatu. (4) PAC imobilisana na epoksi-monolitnom silikatu [8]

Generalno, u ovim ispitivanjima kao najbolji nosač za imobilizaciju enzima pokazao se epoksi-monolitni silikat iz sledećih razloga:

- epoksi-grupe formiraju stabilne kovalentne veze sa različitim grupama enzima (amino grupe) pod blagim uslovima $\mathrm{i}$

- same strukture monolitnog silikata u kome se odvija brži prenos mase između supstance unutar eluenta i aktivnih mesta unutar skeleta nosača, iz čega sledi da je ovaj materijal idealan nosač za imobilizaciju enzima.

Uspešno je izvedena reakcija hidrolize i potpuna separacija proizvoda reakcije na PAC-epoksi-mikročesicama silikata sa veličinom pora od $200 \AA$ (slika 3.27.) i zahvaljujući tome otvoreno je pitanje mogućnosti šire primene ovako imobilisanog enzima [8]. 


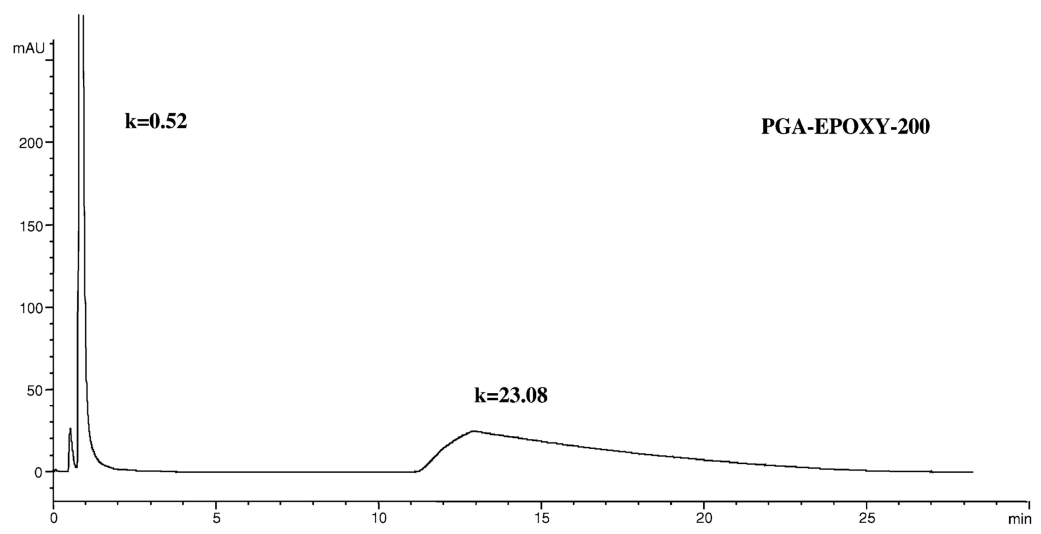

Slika 3.27. Hromatogram penicilina $G\left(1 \mathrm{mg} / \mathrm{cm}^{3}\right)$ na PAC epoksi-mikročesticama silikata prečnika pore od 200 A. Mobilna faza: $50 \mathrm{mM} \mathrm{KH}_{2} \mathrm{PO}_{4}, \mathrm{pH}$ 7,0; protok $0,8 \mathrm{~cm}^{3} / \mathrm{min}$; detekcija na 225nm. Faktor zadržavanja za 6-APA je 0,52 i za PAA je $23,08[8]$ 


\section{BIOREAKTORI ZA PROCESE SA IMOBILISANIM BIOKATALIZATORIMA}

Da bi sistemi sa imobilisanim biokatalizatorima mogli uspešno da se primenjuju, potrebno je obezbediti adekvatne bioreaktorske sisteme koji će omogućiti pogodne hidrodinamičke uslove $\mathrm{i}$ efikasan prenos mase $\mathrm{i}$ toplote do i od površine biokatalizatora. Naročito su zahtevni enzimi osetljivi na smicanje kada je potrebno obezbediti dobru zaštitu njihovom imobilizacijom u nosače. Uslovi strujanja i mešanja u reaktoru određuju raspodelu supstrata i produkata i utiču na brzinu reakcije. Uglavnom su za optimalne rezultate potrebni složeni reaktorski sistemi.

U imobilisanim sistemima koriste se uglavnom sledeći tipovi reaktora:

1. reaktor sa mešanjem

2. reaktor sa pakovanim slojem

3. reaktor sa fluidizovanim slojem

4. gas-lift reaktor i

5. membranski reaktor.

\subsection{Reaktor sa mešanjem}

Reaktor sa mešanjem je jedna od prvih vrsta reaktora koji su korišćeni u biotehnologiji. Sastoji se od posude sa jednom ili više mešalica, različitih oblika. U posudama se često nalaze odbojnici, koji omogućavaju bolje mešanje i sprečavaju nepoželjno stvaranje vrtloga tečnosti. Mogu biti šaržni i protočni kada se tečna faza kontinualno dovodi u reaktor, dok se gasna faza može opciono uvoditi.

Glavna karakteristika ove vrste reaktora je gotovo idealna izmešanost fluidne faze. Tok fluida je najčešće turbulentan sa neuniformnom raspodelom napona smicanja, najvećom u blizini mešalice, a najmanjom u blizini zidova reaktora. Helikoidne mešalice, mešalice u obliku sidra i sl. se koriste za mešanje osetljivih sistema, za razliku od turbinskih i propelerskih mešalica koje izazivaju veće smicajne napone. Glavni operacioni parametar u reaktoru sa mešanjem je rotaciona brzina mešanja. 
Kritična brzina rotacije (pri kojoj su čvrste čestice suspendovane u tečnoj fazi) zavisi od prečnika mešalice i karakteristika suspenzije (prečnik, gustina čestica, viskoznost i gustina tečnosti). Utrošak snage se može odrediti pomoću faktora snage koji je definisan kao [165]:

$$
\mathrm{Np}=\frac{P}{n^{3} d_{\mathrm{M}}{ }^{5} \rho}
$$

gde $P$ predstavlja snagu, Np-faktor snage (bezdimenziona snaga), $n$-brzinu rotacije mešalice, $d_{\mathrm{M}^{-}}$-prečnik mešalice, $\rho$-gustina.

Režim strujanja se određuje pomoću Rejnoldsovog broja (Re) koji je definisan kao:

$$
\operatorname{Re}=\frac{n d_{\mathrm{M}}^{2}}{v}
$$

gde je $v$ kinematska viskoznost fluida.

Faktor snage zavisi od režima strujanja do određene vrednosti i pri turbulentnom strujanju postaje konstantan.

Turbulentan tok i dobra izmešanost $\mathrm{u}$ reaktoru sa mešanjem dovodi do efikasnog prenosa mase između tečne i čvrste faze. U biološkim sistemima najčešće je ograničavajući faktor prenos kiseonika, pa je zato kontrolišući stupanj reakcije brzina prenosa kiseonika.

Sud sa mešanjem se može aproksimirati šaržnim reaktorom sa idealnim mešanjem, slika 4.1 .

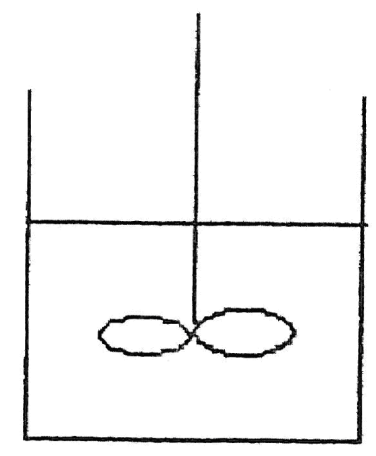

Slika 4.1. Šaržni reaktor sa mešanjem 
Kod ovog tipa reaktora reaktanti se najpre unesu u sud, a zatim uz, idealno mešanje, reaguju između sebe u određenom vremenskom periodu. Po završenoj reakciji, reakciona smeša se izbacuje iz suda. Ovo je nestacionaran proces u kome se sastav reakcione smeše menja sa vremenom. Međutim, u bilo kom trenutku sastav je isti po celoj zapremini reaktora.

U slučaju kinetike prvog reda molski bilans za penicilin $G$ u šaržnom reaktoru je:

$$
v_{\mathrm{i}}=-\frac{d[S]}{d t}=k_{1}[S]
$$

gde je $v_{\mathrm{i}}$-brzina hidrolize penicilina $\mathrm{G},[S]$-koncentracija penicilina $\mathrm{G}$ u trenutku $t, t-$ vreme odigravanja reakcije $\mathrm{u}$ šaržnom reaktoru, a $k_{1}$-konstanta brzine reakcije hidrolize penicilina.

Integraljenjem navedene jednačine dobija se izraz za koncentraciju penicilina $G$, $[S]$ u šaržnom reaktoru u zavisnosti od vremena reakcije $t$ :

$$
-\int_{\left[S_{0}\right]}^{[S]} \frac{d[S]}{[S]}=k_{1} \int_{0}^{t} d t \quad \Rightarrow \quad[S]=\left[S_{0}\right] \exp \left(-k_{1} t\right)
$$

gde je $\left[S_{0}\right]$ - početna koncentracija penicilina $\mathrm{G}$ u početnom trenutku $t=0$.

\subsection{Reaktor sa pakovanim slojem}

Reaktor sa pakovanim slojem je jednostavne konstrukcije, i predstavlja kolonu u kojoj se kao pakovanje koriste čestice biokatalizatora, a tečna faza kontinualno struji. Različite vrste materijala se mogu koristiti kao nosači u pakovanom sloju, obuhvatajući i one koji su osetljivi na abraziju. Neorganski materijali imaju prednost u ovim sistemima zbog dobrih mehaničkih svojstava mada u novije vreme sintetski polimeri imaju sve veći značaj. U literaturi su u ovim reaktorima najčešće korišćeni komercijalni imobilisani enzimi Lipozyme i Novozyme kod kojih su enzimi imobilisani na sintetskim jonoizmenjivačima.

Glavni parametar u ovom tipu reaktora je protok tečne faze. Uniformna raspodela tečnosti kroz uske kanale pakovanog sloja dovodi do dovoljno velike brzine i efikasnog prenosa mase, kako spoljašnjeg tako i unutrašnjeg. 
Neuniformna raspodela protoka dovodi do koncentracionih i temperaturnih gradijenata, što predstavlja najčešći problem kod reaktora sa pakovanim slojem. Jedan od načina da se prevaziđe ovaj problem je recirkulacija tečnosti, koja dovodi do boljeg prenosa toplote i mase.

Uslovi klipnog proticanja u reaktoru sa pakovanim slojem su pogodni za proizvodnju etanola, butanola i sl. Uopšteno govoreći, veća produktivnost se postiže pri klipnom proticanju $\mathrm{u}$ odnosu na protočne reaktore sa idealnim mešanjem za sve reakcije pozitivnog reda. U sistemima sa pakovanim slojem gde dolazi do proizvodnje gasovitih sastojaka (npr. $\mathrm{CO}_{2}$ u proizvodnji etanola), glavni problem je nagomilavanje mehura gasa što dalje dovodi do smanjenja produktivnosti.

Neke od primena ovog tipa reaktora su: tretman otpadnih vodadenitrifikacija imobilizacijom heterotrofnih bakterija (koristi se pesak kao pakovan sloj), kao i u proizvodnji piva (razvijeno i na industrijskom nivou).

Reaktor sa pakovanim slojem može se aproksimirati idealnim cevnim reaktorom (ICR), slika 4.2.

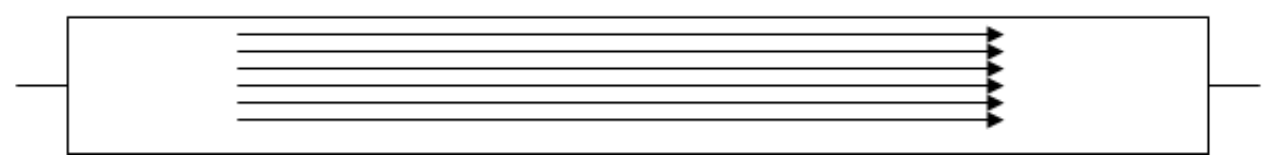

Slika 4.2. Idealni cevni reaktor.

U idealnom cevnom reaktoru (reaktoru sa klipnim proticanjem) sastav fluida se menja od tačke do tačke duž pravca proticanja. Stoga se materijalni bilans za određenu reakcionu komponentu mora postaviti za diferencijalni element zapremine, $\mathrm{d} V$.

Molski bilans za cevni reaktor za reakciju prvog reda:

$$
v_{\mathrm{i}}=-\frac{d F_{M}}{d(V / v)}=k_{1}[S]
$$

gde je $F_{\mathrm{M}}$-molski protok reakcione smeše $\left(F_{\mathrm{M}}=v \cdot[S]\right), v$-zapreminski protok reakcione smeše, $V$ - zapremina ICR-a $\left(V=v \tau_{c}\right.$, gde je $\tau_{c}$-vreme zadržavanja reakcione smeše u ICR-u), a ostale oznake su navedene ranije. 
Integraljenjem jednačine (4.5) od ulaza u reaktor i ulazne koncentracije $\left[S_{0}\right]$ do izlaza dobija se izraz za koncentraciju penicilina $\mathrm{G}$ na izlazu iz cevnog reaktora u zavisnosti od vremena zadržavanja u reaktoru:

$$
\begin{aligned}
& -\int_{[S]_{0}}^{[S]} \frac{d[S]}{[S]}=k_{1} \int_{0}^{\tau_{c}} d \tau_{c} \\
& {[S]=\left[S_{0}\right] \exp \left(-k_{1} \tau_{c}\right)}
\end{aligned}
$$




\section{SINTEZA $\beta$-LAKTAMSKIH ANTIBIOTIKA}

$\beta$-Laktamski antibiotici su jedni od najkorišćenijih faramaceutskih preparata zbog širokog antibakterijskog spektra dejstva i velike hemijske stabilnosti.

\subsection{Hemijska struktura prirodnih i polusintetskih penicilina i načini njihovog dobijanja}

Penicilini važe za najvažnije antibiotike sa aspekta obima njihove godišnje proizvodnje i potražnje, uprkos dostupnosti sve većeg broja alternativnih antibiotika [168]. Oni predstavljaju grupu beta-laktamskih antibiotika koji se koriste u lečenju infekcija izazvanih u prvom redu Gram-pozitivnim bakterijama. Penicilin ujedno podrazumeva i bilo kojeg predstavnika ove grupe. Svi penicilini dele zajedničku opštu molekulsku formulu: $\mathrm{R}-\mathrm{C}_{9} \mathrm{H}_{11} \mathrm{~N}_{2} \mathrm{O}_{4} \mathrm{~S}$, gde je $\mathrm{R}$ neki bočni niz. Oni spadaju u grupu antibiotika koji u svom molekulu sadrže, između ostalog, heterociklični prsten sa azotom. To su monokarboksilne kiseline sa dva heterociklična jezgra, od kojih je jedan petočlani-tiazolidinov, a drugi četvoročlani prsten koji odgovara jednom $\beta$-laktamu i u kome je supstituent različit za svaki tip penicilina (slika 5.1, tabela 5.1) [26].

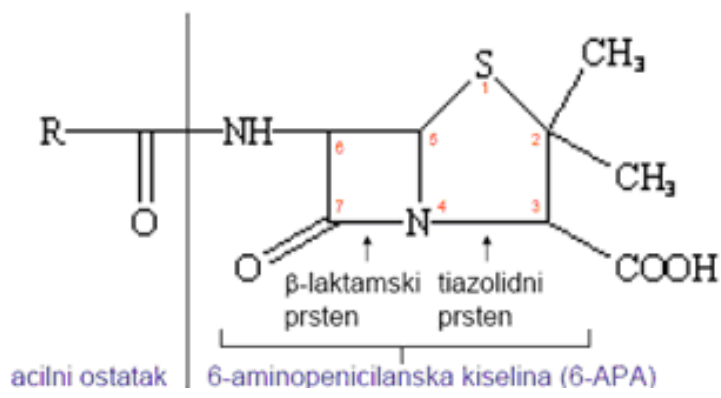

Slika 5.1 Šematski prikaz strukture jezgra penicilina 
Tabela 5.1. Različiti penicilini u zavisnosti od R ostatka

\begin{tabular}{llll}
\hline R-ostatak & Naziv R-ostatka & Naziv penicilina & $\begin{array}{l}\text { Molekulska } \\
\text { masa }\end{array}$ \\
\hline $\mathrm{CH}_{3}-\mathrm{CH}_{2} \mathrm{CH}=\mathrm{CHCH}_{2}-$ & 2-pentenil- & Penicilin F & 312,4 \\
$\mathrm{C}_{6} \mathrm{H}_{5} \mathrm{CH}_{2}{ }^{-}$ & benzil- & Penicilin G & 334,4 \\
$p$ - $\mathrm{OHC}_{2} \mathrm{H}_{4} \mathrm{CH}_{2-}$ & $p$-oksibenzil- & Penicilin X & 350,4 \\
$\mathrm{CH}_{3}\left(\mathrm{CH}_{2}\right)_{5} \mathrm{CH}_{2-}$ & $n$-heptil- & Penicilin K & 342,4 \\
$\mathrm{CH}_{3}\left(\mathrm{CH}_{2}\right)_{3} \mathrm{CH}_{2-}$ & $n$-amil- & Penicilin F' & 314,4 \\
$\mathrm{C}_{6} \mathrm{H}_{5} \mathrm{OCH}_{2-}$ & fenoksimetil- & Penicilin V & 350,4 \\
\hline
\end{tabular}

Prirodni penicilini se dobijaju mikrobiološkom fermentacijom uglavnom pomoću plesni Penicillium chrysogenum i poznato je da nije u pitanju jedno jedinjenje već serija penicilina koji u bočnom ostatku imaju različite grupe, što uslovljava promene biološke aktivnosti molekula [26]. Penicilin G (PenG) i penicilin V (PenV) spadaju u najvažnije prirodne peniciline koji se proizvode fermentacijom u velikom obimu. Međutim, samo mala količina ovih vrsta penicilina se koristi direktno $u$ terapeutske svrhe, dok se većina koristi za proizvodnju 6-aminopenicilanske kiseline (6-APA), polaznog jedinjenja za proizvodnju polusintetskih antibiotika [167]. Osnovni razlog je što prirodni penicilini, koji su dobijani fermentacijom, u medicinskoj praksi nisu davali uvek željene rezultate usled sve veće rezistencije patogenih mikroorganizama na prirodne peniciline. Iz tih razloga su činjeni različiti pokušaji, da se izmenom bočnog ostatka dođe do penicilina boljih svojstava kao što su veća stabilnost ili širi spektar delovanja. Isto se odnosi i na proizvodnju prirodnih cefalosporina. Polusintetski antibiotici ne pokazuju samo bolje karakteristike, kao što su povećana stabilnost, smanjena rezistencija mikroorganizama, lakša apsorpcija, već izazivaju i znatno manje sporednih efekata u poređenju sa penicilinom $\mathrm{G}$ ili penicilinom V [26].

Polusintetski penicilini i cefalosporini (amoksicilin, ampicilin, cefaleksin, cefadroksil, cefazolin i dr.) čine $65 \%$ sve razvijenije svetske proizvodnje antibiotika, koja je premašila 45,000 tona u 2000. godini [168, 169]. 
Polusintetski antibiotici se mogu dobiti na tri načina:

1. fermentacijom,

2. organskom sintezom $\mathrm{i}$

3. enzimskim tehnologijama.

Dobijanje polusintetskih antibiotika direktno mikrobiološkom fermentacijom, tj. dodatkom odgovarajućih prekursora (organske kiseline, njihove soli i njihovi derivati) u hranljivu podlogu, nije dalo očekivane rezultate.

Industrijska proizvodnja ovih lekova počela je 60-ih i 70-ih godina XX veka (ampicilin je patentiran 1961. godine, amoksiciln 1972; cefaleksin 1970; a cefadroksil 1977. godine). Ovi prvi konvencionalni hemijski procesi za dobijanje polusintetskih antibiotika su se odvijali na niskim temperaturama (niže od $-30^{\circ} \mathrm{C}$ ) i zahtevali su primenu organskih rastvarača i zaštitu bočnih grupa da bi se izbeglo stvaranje sporednih proizvoda. Pored toga, u ovim procesima proizvodi se velika količina otpada koji se ne može reciklirati $[170,171]$. Tada je predviđena mogućnost zamene hemijske enzimskom sintezom, prvenstveno radeći u vodenim rastvorima i pod fiziološkim uslovima [9].

Sinteza polusintetskih antibiotika katalizovana enzimima ima nekoliko prednosti u poređenju sa konvencionalnim hemijskim transformacijama:

(1) snažna hemijska aktivacija karboksilnih grupa u acil donorima koja se izvodi korišćenjem veoma toksičnih reagenasa ne mora da bude neophodna ili može bar da bude blaža (korišćenjem slobodnih kiselina ili estara);

(2) enzimska specifičnost čini nepotrebnom zaštitu karboksilnih grupa u jezgru antibiotika;

(3) veoma velika specifičnost i aktivnost enzima pod blagim uslovima izbegava rizik od racemizacije;

(4) ne postoji rizik od bilo kojih sporednih reakcija i

(5) nije potrebno da se koriste veoma toksični rastvarači koji se upotrebljavaju u konvencionalnim hemijskim procesima (npr. etilen-hlorid) [172].

Interes za efikasnijom enzimskom sintezom koja se smatra ekološki znatno „čistijom“ tehnologijom je u stalnom porastu. Glavni nedostatak enzimskog procesa je nizak sintetički prinos proizvoda. Korišćenje organskih rastvarača u enzimskoj organskoj sintezi privlači veliko interesovanje jer prinos u sintetskim reakcijama može 
biti poboljšan usled povećanja rastvorljivosti supstrata, smanjenja aktivnosti vode i promene $\mathrm{pK}$ vrednosti reaktanata (ovako povećavajući koncentraciju nenaelektrisanih, reaktivnih supstrata) [173].

Zbog male termalne stabilnosti $\beta$-laktamskog prstena, enzimska sinteza se generalno izvodi pod blagim uslovima, kao što su niska temperatura i $\mathrm{pH}$, daleko od optimuma aktivnosti enzima. Stoga je brzina reakcije sinteze veoma mala, kao i prinos i produktivnost [174].

Za dalji razvoj industrijske proizvodnje ovih antibiotika, koja se zasniva na korišćenju enzima, neophodno je optimizovati procesne parametre i izabrati odgovarajući dizajn bioreaktora. Polusintetski antibiotici se industrijski dobijaju kondenzacijom izmenjenog bočnog lanca (acil-donora) i $\beta$-laktamskog jezgra. Da bi se ova jezgra proizvela industrijski, upotrebljavaju se enzimske hidrolize prirodnih penicilina ili cefalosporina: penicilin $\mathrm{G}$ daje 6-aminopenicilinsku kiselinu (6-APA) ili cefalosporin $\mathrm{C}$ daje 7-aminocefalosporinsku kiselinu (7-ACA). 7Aminodezacetoksicefalosporinska kiselina (7-ADCA) se može još dobiti i hemijskom sintezom, odnosno proširivanjem prstena 6-APA, a može se koristiti i hemijska hidroliza prirodnog cefalosporina G ili adipil-7-ADCA [20, 169, 175].

Katalizator u sintetskoj reakciji je penicilin-acilaza, najčešće iz Escherichia coli. Osnovni problem pri izvođenju ove reakcije je kako pomeriti ravnotežu reakcije u pravcu sinteze i smanjiti odvijanje kompetitivne reakcije, hidrolize [176].

\subsection{Termodinamički kontrolisana sinteza}

Polusintetski antibiotici se mogu dobiti u enzimskim procesima koji mogu biti termodinamički ili hemijski kontrolisani. U termodinamički kontrolisanom enzimskom procesu reaktanti su 6-APA i slobodna karboksilna kiselina koja ima u bočnom lancu odgovarajuću alkil grupu $\left(\mathrm{R}_{1}\right)$. Ovo je tipična reverzibilna enzimska reakcija $\mathrm{i}$, u ovom slučaju, osnovni problem je kako pomeriti ravnotežu reakcije u pravcu sinteze antibiotika (slika 5.2.). Savremena istraživanja su usmerena na primenu mikrovodenih sistema organskih rastvarača u kojima je aktivnost vode mala, pa samim tim se smanjuje odvijanje povratne reakcije hidrolize antibiotika. Ispitane su PAC iz različitih 
mikroorganizama u prisustvu različitih organskih rastvarača, ali su dobijeni uspešni rezultati u samo par slučajeva [19].

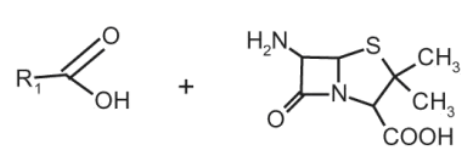

bočni lanac

\section{Sinteza}

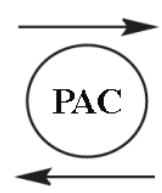

Hidroliza

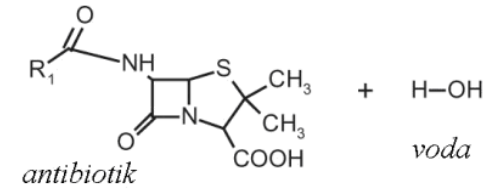

voda

Slika 5.2. Termodinamički kontrolisana sinteza polusintetskih penicilina, katalizovana penicilin-acilazom (PAC) [19]

Kada se koristi PAC iz E. coli za termodinamički kontrolisanu sintezu antibiotika, karboksilna grupa bočnog lanca mora biti neutralna, spremna za nukleofilini napad enzima, dok je, istovremeno, amino grupa $\beta$-laktamskog jezgra takođe neutralna, dostupna za nukleofilne interakcije. Međutim, u pH intervalu u kome je enzim aktivan ( $\mathrm{pH}$ 6-8), broj molekula supstrata sa odgovarajućim nabojem je neznatan. Enzim iz nekog drugog mikroorganizma može savladati ovu kinetičku prepreku (na primer, PAC iz Xanthomonas citri), ali je ipak prinos reakcije ograničen na osnovu konstante ravnoteže, odnosno termodinamički je nepovoljno formiranje amidnih veza u vodenoj sredini (kao što je pokazano za ampicilin i cefaleksin) $[177,178]$.

Isto tako, ispitivana je mogućnost sinteze cefaleksina $\mathrm{u}$ termodinamički kontrolisanoj sintezi korišćenjem PAC iz E. coli i $X$. citri, ali su proizvedene veoma niske koncentracije antibiotika (manje od $0,1 \mathrm{mM}$ na $\mathrm{pH} 5,5 ; 5-30{ }^{\circ} \mathrm{C}$ ). S druge strane, niska rastvorljivost fenilglicina u vodi narušava pomeranje ravnoteže prema sintezi [179].

U termodinamički kontrolisanoj sintezi, prinosi su određeni samo konstantom ravnoteže reakcije. U ovom slučaju, organski rastvarači igraju važnu ulogu, oni povećavaju prinose povećavanjem pKa karboksilne grupe i takođe smanjenjem koncentracije vode [180]. 
Naravno, različiti ko-rastvarači mogu biti korišćeni radi pomeranja ravnoteže [181-184]. Korišćena je PAC iz Kluyvera citrophila i utvrđeni su profili pH, temperature i ko-rastvarača (dietilformamida) za vreme šaržnih sinteza, dostižući prinos od $20 \mathrm{~g} / \mathrm{L}$ cefalotina [172].

Gubitak enzimske aktivnosti u prisustvu organskih rastvarača je drugi nedostatak termodinamički kontrolisanih procesa. Abian i saradnici $(2001,2002,2004)$ su opisali kako višetačkasto kovalentno vezivanje enzima za nosač, i prisustvo hidrofilne mikrookoline koja okružuje molekul može da stabilizuje enzim. Ista grupa je testirala ovaj koncept na različitim sintetskim reakcijama kao model sistemima. Ipak, uprkos nekim poboljšanjima koja su postignuta u termodinamički kontrolisanoj sintezi antibiotika, znatno veću primenu i potencijal još uvek ima kinetički kontrolisana reakcija sinteze polusintetskih antibiotika [185-187].

\subsection{Kinetički kontrolisana reakcija sinteze polusintetskih antibiotika}

U kinetički kontrolisanom procesu reaktanti su aktivirani prekursor acil donora (estar ili amid D-acil bočnog lanca antibiotika) i jedinjenje sa $\beta$-laktamskim jezgrom (6-APA), dok kao proizvodi reakcije nastaju antibiotik i alkohol ili derivat amonijuma (slika 5.3.). Primenom različitih acil donora mogu se dobiti različiti polusintetski penicilini. Cefalosporini se dobijaju kada se umesto 6-APA koristi 7-ACA ili 7-ADCA [19]. 


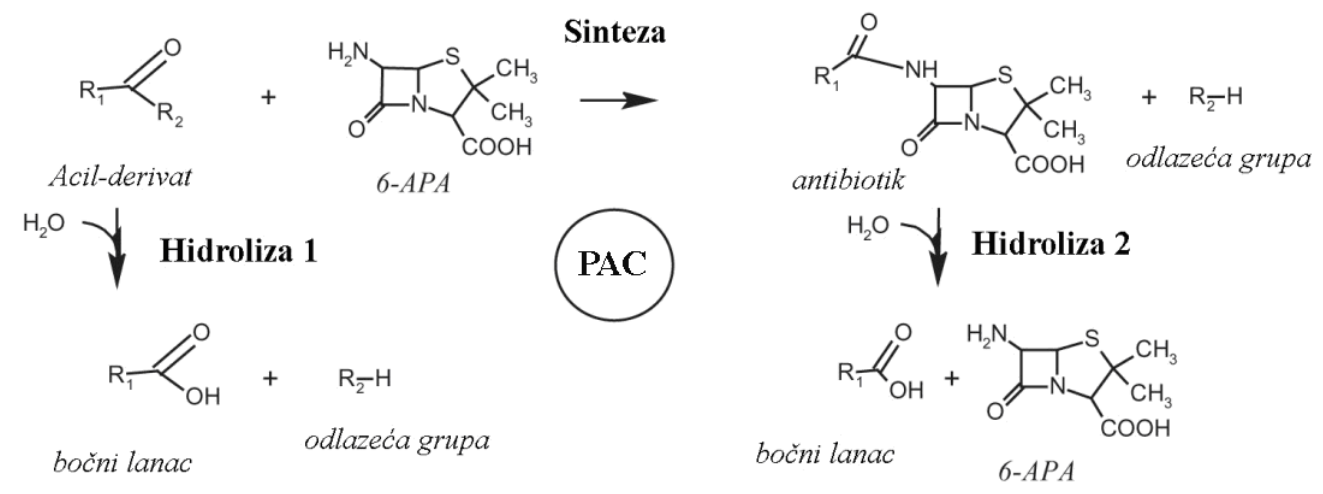

Slika 5.3. Kinetički kontrolisana sinteza. PAC se ponaša kao transferaza (za sintezu) $i$ kao hidrolaza, promovišući dve neželjene bočne reakcije (hidrolizu 1, bočnog lanca acil donor derivata, $i$ hidrolizu 2, antibiotika). Na primer, u sintezi ampicilina $R_{l^{-}}$ $\mathrm{COOH}=D_{D^{-}}(-)-$fenilglicin $(P G) ; z a$ amoksicilin, $\mathrm{R}_{l^{-}} \mathrm{COOH}=\mathrm{p}-\mathrm{OH}{ }_{-D^{-}}(--)-P G$, itd. Acil donor derivat može biti estar (npr., $\left.\mathrm{R}_{2}=--\mathrm{OCH}_{3}\right)$ ili amid $\left(\mathrm{R}_{2}=--\mathrm{NH}_{2}\right)$ [19]

U kinetički kontrolisanom procesu moguće je ostvariti mnogo veći prinos proizvoda nego u termodinamički kontrolisanom, ali je znatno teža optimizacija i kontrola procesa. Naime, kako se ne postiže ravnoteža već prinos proizvoda raste do neke maksimalne vrednosti, veoma je važno proces zaustaviti kada se postigne maksimalna konverzija. Reakcija počinje obrazovanjem prelaznog kompleksa, acilenzim intermedijara. Sada, PAC može da deluje kao transferaza ili kao hidrolaza, pri čemu se nuklofili, molekuli vode i $\beta$-laktamsko jezgro, takmiče u napadu na acil-enzim intermedijar. Zbog toga, podešavanjem parametara reakcije može se značajno uticati na njen tok i prinos antibiotika [19].

Parametri od krucijalnog značaja su:

(a) stepen zasićenosti aktivnog centra enzima nukleofilom,

(b) odnos (sinteza antibiotika/ hidroliza estra) i

(c) odnos (sinteza antibiotika/ hidroliza antibiotika).

Evidentno, dobijeni rezultati značajno zavise od katalitičkih osobina enzima ili osobina primenjenog enzimskog preparata [172].

Ispitane su različiti načini povećanja prinosa kinetički kontrolisanim reakcijama sinteze polusintetskih antibiotika. Neki od njih su bili sledeći: kristalizacija proizvoda u 
integrisanim reaktorima, primena $\mathrm{pH}$ gradijenta $\mathrm{u}$ toku šaržnog procesa, modulacija svojstava enzima kovalentnom imobilizacijom, povećanje afiniteta enzima prema acil donorima sa $\mathrm{C} \alpha$-substituentima preko mutageneze usmerene položajem, povećanje enantioselektivnosti PAC iz različitih mikroorganizama pomoću imobilizacije, primena membranskih neizotermnih reaktora, korišćenje dvofaznih sistema, ko-rastvarači, korastvarači i niske temperature ili čak primena zamrznutih medijuma $[24,57,104,152$, $154,171,173,176,188-195]$.

\subsection{Mehanizam enzimske sinteze $\beta$-laktamskih antibiotika}

Za neku enzimsku reakciju kaže se da se odvija po kinetički kontrolisanom mehanizmu kada biokatalizator može ujedno da deluje kao hidrolaza i kao transferaza. U ovom slučaju prinos proizvoda prolazi kroz maksimum i on, između ostalog, zavisi i od svojstava biokatalizatora. U kinetički kontrolisanoj sintezi ampicilina katalizovanoj penicilin-acilazom (PAC), ili estar ili amid reaguje sa $\beta$-laktamskim jezgrom, dajući antibiotik. U ovoj reakciji, poželjno je da se PAC ponaša kao transferaza. Ipak, enzim može da se ponaša i kao hidrolaza (slika 5.3), $\beta$-laktamsko jezgro i molekuli vode se nadmeću u nukleofilnom napadu na acil-enzim intermedijar.

U literaturi su detaljno proučeni mehanizmi sve tri reakcije prikazane na slici 5.3. (sinteza antibiotika, hidroliza bočno-lančanog prekursora i hidroliza antibiotika). Ipak, još uvek nije dovoljno proučena kinetika reakcije za velike koncentracije supstrata, i jedno važno pitanje još uvek ostaje otvoreno, da li vezivanje 6-APA za enzim može prethoditi acilirajućem koraku u sintetičkom putu [196].

Nekoliko autora je pretpostavilo da se 6-APA vezuje za enzim samo posle formiranja acil-enzim kompleksa; mehanizam je analogan mehanizmu serin-proteaza (posebno $\alpha$-himotripsina), sa kompetirajućim nukleofilima (na primer, za vreme sinteze peptida u vodenoj sredini) $[189,197-199]$. S druge strane, ispitivana je sinteza amoksicilina pri čemu je pretpostavljeno da acil-enzim kompleks može da bude formiran ili posle ili pre vezivanja 6-APA za enzim, ali je utvrđeno da se antibiotik sintetiše samo u prvom slučaju. Autori su utvrdili da velika koncentracija molekula vode (u vodenoj sredini) veoma favorizuje hidrolizu. Stoga, da bi se odvijala sinteza, 6APA treba već da bude u povoljnom položaju za nukleofilni napad [200, 201]. 
Prema nekim literaturnim podacima, $\beta$-laktamsko jezgro mora da se vezuje za enzim pre nukleofilnog napada na acil-enzim kompleks. Ova hipoteza je dalje testirana definišući odnos konstanti deaciliranja, $\left(\mathrm{k}_{\mathrm{H}} / \mathrm{k}_{\mathrm{S}}\right)_{\mathrm{app}},\left(\mathrm{k}_{\mathrm{H}} / \mathrm{k}_{\mathrm{S}}\right)_{\mathrm{app}}=\mathrm{C}_{\mathrm{NH}}\left(v_{\mathrm{AOH}} / v_{\mathrm{AN}}\right)$, koji bi bio invarijantan s obzirom na koncentraciju supstrata, u slučaju direktnog napada molekula slobodne 6-APA na acil-enzim kompleks. S druge strane, ako postoji acil-enzim-jezgro intermedijarni kompleks, odnos konstanti $\left(\mathrm{k}_{\mathrm{H}} / \mathrm{k}_{\mathrm{S}}\right)_{\text {app }}$ bi varirao sa koncentracijom 6APA. Kada su eksperimentalni podaci $\mathrm{C}_{\mathrm{NH}}\left(v_{\mathrm{AOH}} / v_{\mathrm{AN}}\right)$ prema $\mathrm{C}_{\mathrm{NH}}$ grafički prikazani, dobijena je linearna zavisnost $\left(\mathrm{k}_{\mathrm{H}} / \mathrm{k}_{\mathrm{S}}\right)_{\text {app }}$ prema $\mathrm{C}_{\mathrm{NH}}$, i zaključeno je da 6-APA mora da se vezuje za enzim pre deaciliranja. Ipak, u oba rada su prikazani rezultati samo za jednu fiksnu koncentraciju PGME [27, 202].

Ključno pitanje u pogledu deacilacionog koraka sinteze je mehanizam nukleofilnog napada $\beta$-laktamskog jezgra na acil-enzim intermedijar, u kompeticiji sa vodom. Da bi se desila bilo koja primetna sinteza, jedna (ili obe) od dve hipoteze bi trebalo da budu važeće:

(a) veći broj molekula bi bio nadoknađen značajnom razlikom u konstantama brzine deacilacije (jezgro naspram vode) za vreme ovog koraka. Ipak na osnovu prethodno opisanih rezultata $[27,202]$ može se odbaciti ova pretpostavka;

(b) prethodno i/ili olakšano vezivanje $\beta$-laktamskog jezgra za enzim pomaže jezgru da prevaziđe kompeticiju vodom [27, 202].

Dakle, još uvek nije usaglašeno pitanje da li se kompleks jezgra i enzima formira pre ili posle acil-enzim intermedijara.

Tačan uvid u mehanizam reakcije može se dobiti primenom metoda kristalografije X-zracima. Međutim, rastvorljivost $\beta$-laktamskih jezgara i PAC je slična, čineći njihovu ko-kristalizaciju neizvodljivom, kao i potapanje kristala proteina. Stoga, iako brojni radovi pokazuju kristalnu strukturu enzima u kompleksu vezanog sa bočnim lancima liganada, ne postoje dostupni podaci za formiranje enzim-( $\beta$-laktamskog) kompleksa [18, 21-23].

Ispitivan je uticaj zasićenja PAC sa 6-APA pre izvođenja sinteze amoksicilina. Nije registrovana značajnija razlika između $\mathrm{S} / \mathrm{H}$ odnosa na $\mathrm{pH} 7,0$, ali na $\mathrm{pH} 6,0$, selektivnost je rasla kada je PAC prethodno zasićena sa 6-APA. Ovo je druga indikacija da je vezivanje $\beta$-laktamskog jezgra za enzim bitno u celokupnom mehanizmu sinteze. Na nižim $\mathrm{pH}$, kada su manje neutralni Ser $\beta 1$ amini dostupni, 
važnost vezivanja jezgra za PAC postaje značajna. Stoga, potpuni kinetički mehanizam ovog sistema reakcija, vodeći računa o svim mogućim interakcijama, je dosta komplikovan [27, 202-204].

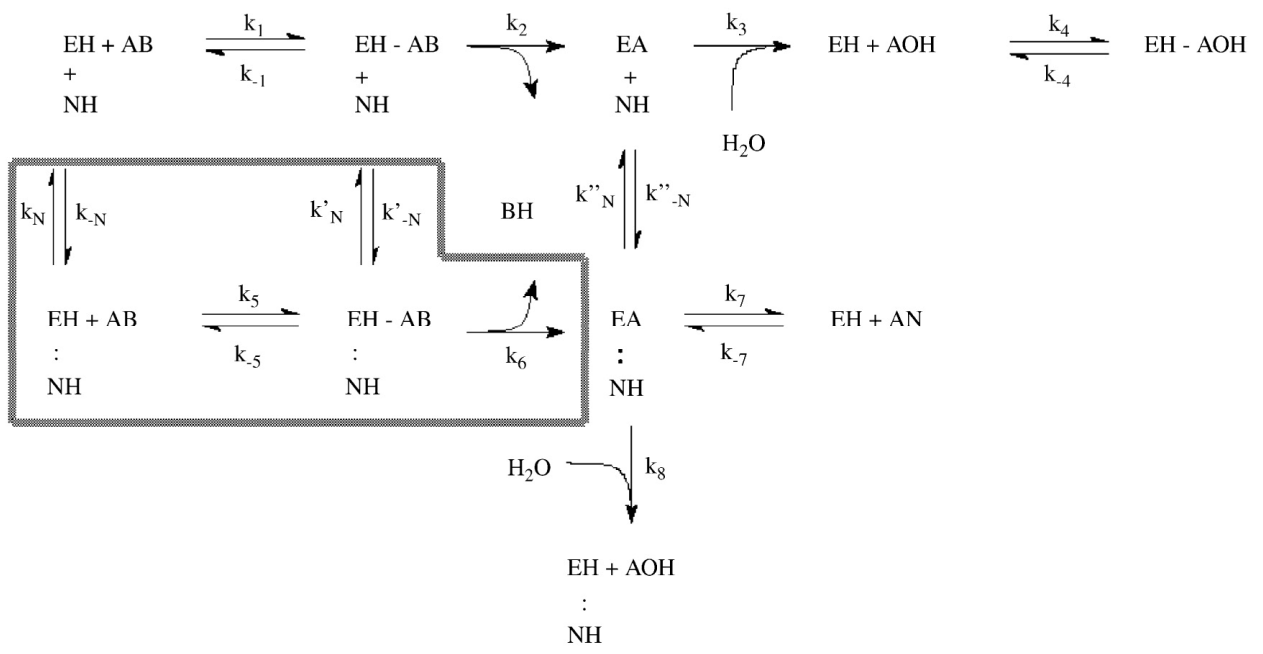

Slika 5.4. Šema mehanizma enzimske sinteze $\beta$-laktamskih antibiotika. Istaknuti deo slike ukazuje na korake koji nisu usaglašeni u literaturi [204]

Predloženo je nekoliko modela mehanizma enzimske sinteze $\beta$-laktamskih antibiotika. U odsustvu antibiotika, uzimajući u obzir samo početne brzine, modeli izvedeni iz slike 5.4, i ignorišući istaknuti deo mehanizma će imati $\mathrm{S} / \mathrm{H}$ :

$$
\left(\frac{\mathrm{S}}{\mathrm{H}}\right)_{C_{\mathrm{AN}}=0}=\left(\frac{v_{\mathrm{AN}}}{v_{\mathrm{AOH}}}\right)_{C_{\mathrm{AN}}=0}=\frac{P_{1} C_{\mathrm{NH}}}{P_{2}+P_{3} C_{\mathrm{NH}}}
$$

Gde su $\mathrm{P}_{1}, \mathrm{P}_{2}$ i $\mathrm{P}_{3}$ kinetičke konstane. Stoga, za sve ove modele, $\mathrm{S} / \mathrm{H}$ je invarijantan s obzirom na fenilglicinmetil estar (PGME) [27, 200, 205].

Pretpostavljeno je da acil-enzim kompleks može da bude formiran ili posle ili pre vezivanja 6-APA [200, 201]. Za brzinu sinteze antibiotika, $v_{\mathrm{s}}$, autori su koristili polu-empirijski model sa „particionim članom“ $\left(\mathrm{T}_{\max } \mathrm{X}\right)$ : 


$$
v_{\mathrm{S}}=\frac{k_{\mathrm{cat} 1} C_{\mathrm{AB}} C_{\mathrm{E} 0}}{K_{\mathrm{m} 1}\left(1+\frac{C_{\mathrm{AN}}}{k_{\mathrm{AN}}}+\frac{C_{\mathrm{AOH}}}{k_{\mathrm{AOH}}}\right)+C_{\mathrm{AB}}} T_{\max } X
$$

$\mathrm{Sa} 0 \leq \mathrm{T}_{\max }<1$ i X=C $\mathrm{C}_{\mathrm{NH}} /\left(\mathrm{K}_{\mathrm{EN}}+\mathrm{C}_{\mathrm{NH}}\right)$.

$\mathrm{T}_{\max }$ kvantifikuje količinu (6-APA)-acil-enzim kompleksa (EANH) koji ulazi u sintetički put. Stoga, 1-T $\mathrm{T}_{\max }$ je odnos EANH koji trpi nukleofilni napad vodom. Svi acil-enzimi, EA, koji već nemaju NH u poziciji, su hidrolizovani. Prateći ovaj poluempirijski pristup, S/H ima takođe funkcionalni oblik sličan jednačini 5.1. [200, 201].

Da bi ovi enzimski procesi bili ekonomični potrebno je omogućiti reciklaciju biokatalizatora, izvoditi reakciju u uslovima velike koncentracije supstrata i unaprediti kristalizaciju proizvoda.

Preduzete su brojne strategije usmerene ka poboljšanju efikasnosti sintetičke reakcije:

- optimizacija $\mathrm{pH}$, jonske jačine i temperature,

- korišćenje viška acil donora u odnosu na nukleofil,

- korišćenje korastvarača,

- regulacija termodinamičke aktivnosti vode,

- regeneracija acil donora korišćenjem metanola kao dodatnog nukleofila,

- primena vodenih dvofaznih sistema za „in situ“ ekstrakciju reakcionog proizvoda,

- odvijanje reakcije sinteze u zamrznutom rastvoru,

- stvaranje odgovarajuće mikrookoline enzima,

- menjanje katalitičkih osobina penicilin-acilaze hemijskom modifikacijom i imobilizacijom,

- smanjivanje rastvorljivosti proizvoda reakcije formiranjem inkluzionih kompleksa i

- primena velike koncentracije reaktanta [205].

U ovom doktoratu je kao biokatalizator korišćena penicilin-acilaza iz E. coli (DSM, Holandija). Bilo je veoma važno da se okarakteriše slobodan enzim da bi rezultati koji su dobijeni u sistemima sa modifikovanim i imobilisanim enzimom mogli 
da se porede. U tom cilju ispitan je uticaj različitih vrednosti $\mathrm{pH}$, temperature i početne koncentracije supstrata na aktivnost slobodne penicilin-acilaze iz E. coli kao i na aktivnost penicilin-acilaze imobilisane na različitim nosačima.

Izvršena je modifikacija penicilin-acilaze različitim polisaharidima u cilju poboljšanja njene stabilnosti. Ispitana je termostabilnost modifikovane penicilin-acilaze kao i njena aktivnost na različitim $\mathrm{pH}$ vrednostima $\mathrm{i}$ temperaturama. Takođe, modifikovana penicilin-acilaza je imobilisana na nosače od industrijskog značaja kao što su komercijalni Sepabeads EC-EA i Sepabeads EC-HA nosače, u cilju poboljšanja svojstava imobilizata i mogućnosti reciklacije. Dobijeni imobilizati su u potpunosti okarakterisani. Na osnovu pregleda literature može se uočiti da nema radova u kojima je ispitana mogućnost imobilizacije hemijski modifkovane PAC polisaharidima na čvrste nosače.

U okviru ove teze PAC je imobilisana na navedene nosače na dva konceptualno različita načina jer se jedan zasniva na prethodnoj aktivaciji nosača, dok se drugi zasniva na prethodnoj hemijskoj modifikaciji enzima.

Izvršena je imobilizacija slobodne penicilin-acilaze direktnim vezivanjem na Sepabeads EC-EP nosač konvencionalnom metodom, kao i na Sepabeads EC-EA i Sepabeads EC-HA nosače koji su prethodno aktivirani glutaraldehidnom metodom. Takođe, penicilin-acilaza koja je modifikovana različitim polisaharidima je imobilisana na Sepabeads EC-EA i Sepabeads EC-HA nosače. Tako dobijeni imobilizati su okarakterisani i upoređena su njihova svojstva od značaja za odvijanje reakcije hidrolize prirodnog penicilina $\mathrm{G}$ u cilju dobijanja 6-APA kao važnog prekursora polusintetskih antibiotika.

Ispitana je i imobilizacija PAC na hitozanskim mikročesticama koje su prethodno aktivirane glutaraldehidom, kako bi se odigrao proces kovalentnog vezivanja enzima za nosač. 


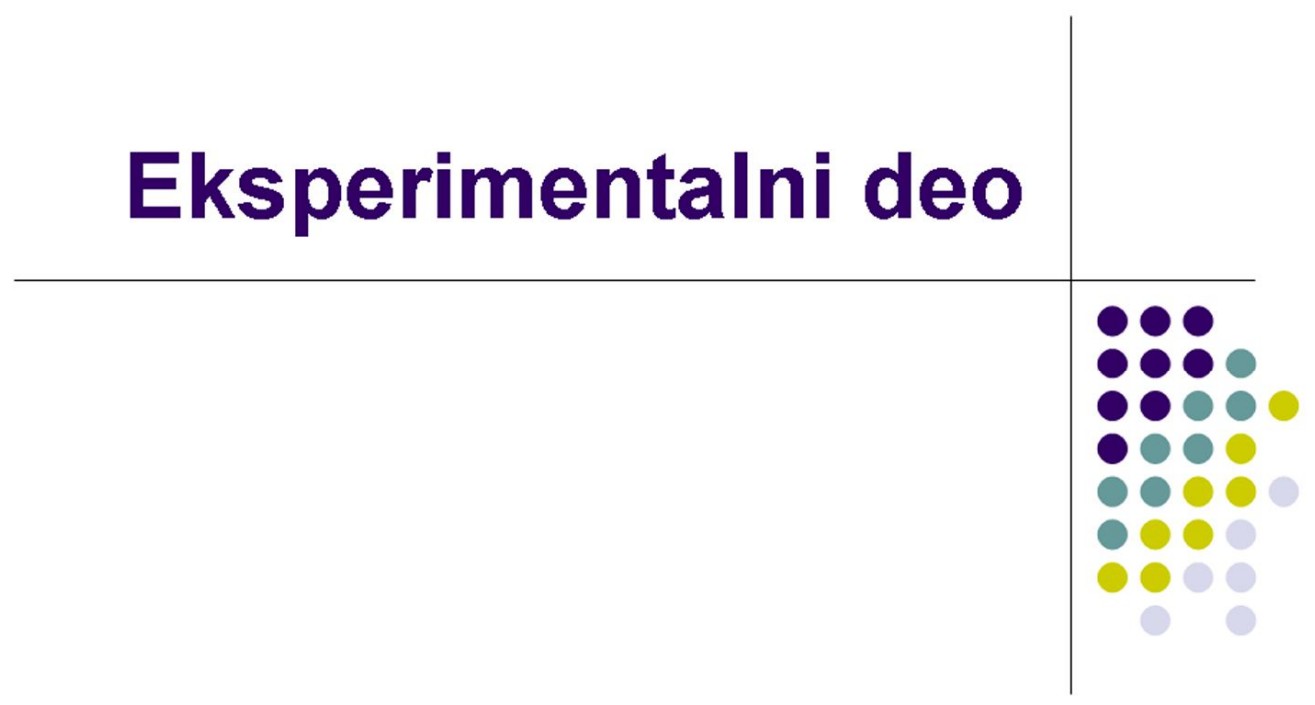




\section{MATERIJALI I METODE}

\subsection{MATERIJALI}

Kao biokatalizator korišćen je enzimski preparat slobodne penicilin-acilaze (PAC) iz Escherichia coli dobijen na poklon od kompanije DSM (Holandija).

Za određivanje sadržaja proteina korišćen je Folin Ciocalten reagens (Sigma, SAD).

Kao standard za određivanje sadržaja proteina korišćen je goveđi serum albumin (Sigma, SAD).

Kao supstrat korišćen je penicilin G (Sigma, SAD).

Za određivanje standardne enzimske aktivnosti korišćena je 6-aminopenicilanska kiselina (Sigma, SAD).

Kao hromogeni supstrat za određivanje sadržaja 6-aminopenicilanske kiseline korišćen je $p$ dimetilaminobenzaldehid (Sigma, SAD).

Kao nosači za kovalentnu imobilizaciju enzima korišćeni su:

-komercijalni polimetakrilatni nosači: Sepabeads EC-EP, Sepabeads EC-EA i Sepabeads EC-HA (svi od kompanije Resindion Mitsubishi Chemical Corporation, Italija) i

-hitozan (Acros organics, SAD).

Za aktiviranje nosača korišćen je glutaraldehid (Sigma, USA).

Za modifikaciju enzima korišćeni su skrob i alginat (Merck-Alkaloid, Makedonija), za čiju oksidaciju je korišćen natrijum-perjodat (BDH chemicals, Velika Britanija).

Ostale korišćene hemikalije su:

-metanol (Lachema, Češka),

-sirćetna kiselina (Lachema, Češka),

-natrijum-hidroksid (Lachema, Češka),

-etanol (96\%) (Moss, Beograd),

-tris (Sigma, SAD),

-hlorovodonična kiselina (Zorka, Šabac),

-natrijum-hidrogenfosfat (Lachema, Češka), 
-natrijum-dihidrogenfosfat (Lachema, Češka),

-kalijum-hidrogenfosfat (Lachema, Češka),

-kalijum-dihidrogenfosfat (Lachema, Češka),

-bakar-sulfat (Zorka, Šabac),

-natrijum-karbonat (Zorka, Šabac),

-kalijum-natrijum-tartarat (Zorka, Šabac),

-etilenglikol (Sigma, SAD),

-natrijum-acetat (Zdravlje, Leskovac),

-natrijum-tripolifosfat (Sigma, SAD),

-tween 80 (Sigma, SAD),

-natrijum-hidrogenkarbonat (Lachema, Češka),

-fenilmetilsulfonil fluorid (Merck, Nemačka),

-fenilsirćetna kiselina (Sigma, SAD) i

-kalijum-bromid (Sigma, SAD).

Sve hemikalije su imale čistoću p.a. 


\subsection{METODE}

\subsubsection{Karakterizacija slobodne penicilin-acilaze}

\subsubsection{Određivanje sadržaja proteina metodom po Loriju (Lowry) [206]}

Metoda po Loriju se zasniva na građenju obojenih proizvoda aromatičnih aminokiselina sa Folin Ciocalten reagensom u kombinaciji sa biuretskom reakcijom za peptidne veze. Koncentracija nastalih obojenih proizvoda se određuje spektrofotometrijski. Sa reagensom Folin Ciocalten pretežno reaguju aminokiseline koje sadrže hidroksilnu grupu fenolskog karaktera kao što su tirozin i triptofan. Velika osetljivost metode omogućuje da se odredi $10^{-5}$ do $10^{-4} \mathrm{~g}$ proteina u probi. Reakcija je jednostavna za izvođenje, ali njen nedostatak je specifičnost za tirozin tako da se intenzitet boje menja u zavisnosti od aminokiselinskog sastava proteina. Takođe, na razvijanje boje utiče veliki broj supstanci. Zbog toga je potrebno imati u vidu da pri određivanju standardne krive korišćeni rastvarač treba da sadrži iste komponente kao i uzorci koji se analiziraju. Prilikom određivanja sadržaja proteina u komercijalnom preparatu penicilin-acilaze u ovom radu kao standardni protein korišćen je goveđi serum albumin.

Postupak određivanja je sledeći:

1) Priprema reagenasa:

- reagens A: 2\% rastvor natrijum-karbonata u 0,1 M natrijum-hidroksidu;

- reagens B: 1\% rastvor bakar-sulfata u destilovanoj vodi;

- reagens C: $2 \%$ rastvor kalijum-natrijum tartarata u destilovanoj vodi;

- reagens D: priprema se mešanjem $1 \mathrm{~cm}^{3}$ reagensa $B$ i $1 \mathrm{~cm}^{3}$ reagensa $C$, a zatim se pomešani rastvori dopune reagensom A do $100 \mathrm{~cm}^{3}$ ukupne zapremine. Priprema se neposredno pred upotrebu i

- reagens F: Folin Ciocalten reagens. 
2) Određivanje standardne krive za određivanje sadržaja proteina.

Standardna kriva se određuje pre svake serije eksperimentalnih merenja. Standardni rastvori u opsegu od 0,1 do $0,5 \mathrm{mg} / \mathrm{cm}^{3} \mathrm{mogu}$ se dobiti razblaživanjem osnovnog rastvora koncentracije $1 \mathrm{mg} / \mathrm{cm}^{3}$ koji se priprema rastvaranjem $10 \mathrm{mg}$ standardnog proteina $\mathrm{u} 10 \mathrm{~cm}^{3}$ vode. $U$ epruvete se dodaju određene zapremine osnovnog rasvora mikropipetom $\left(0,1-0,5 \mathrm{~cm}^{3}\right) \mathrm{i}$ destilovana voda $\left(0,9-0,5 \mathrm{~cm}^{3}\right)$ tako da ukupna zapremina bude $1 \mathrm{~cm}^{3}$. U rastvore se zatim dodaje $2 \mathrm{~cm}^{3}$ reagensa D i nakon mešanja rastvori se ostavljaju da odstoje 10 min na sobnoj temperaturi. Posle toga, dodaje se $0,2 \mathrm{~cm}^{3}$ reagensa $\mathrm{F}$ i sadržaj epruvete se dobro promeša. Tako pripremljeni uzorci treba da odstoje 45 min na sobnoj temperaturi da se razvije plava boja čija se apsorbancija meri spektrofotometrijski na $500 \mathrm{~nm}$. Iz očitanih vrednosti dobija se standardna kriva koja predstavlja zavisnost apsorbancije od koncentracije standardnog proteina.

Paralelno se priprema uzorak enzima koncentracije $0,01 \mathrm{~cm}^{3} / \mathrm{cm}^{3}$ i priprema se po istom postupku kao i uzorci za standardnu krivu. Slepa proba je $1 \mathrm{~cm}^{3}$ vode, $2 \mathrm{~cm}^{3}$ reagensa D i $0,2 \mathrm{~cm}^{3}$ reagensa F. Iz očitane apsorbance na osnovu standardne krive određuje se sadržaj proteina u uzorku.

\subsubsection{Određivanje aktivnosti slobodne penicilin-acilaze [207]}

Penicilin-acilaza je enzim koji katalizuje hidrolizu penicilina G. Proizvodi ove reakcije su fenilsirćetna kiselina (PAA) i 6-aminopenicilanska kiselina (6-APA).

Enzimska katalitička reakcija se izvodi u 0,1 M natrijum-fosfatnom puferu pH 7,92 i na $37^{\circ} \mathrm{C}$, a vreme trajanja reakcije je 3 minuta. Standardna koncentracija supstrata (PenG) koja se uzima za određivanje aktivnosti slobodnog enzima je 2,0 mas \%. Reakcija se zaustavlja etanolom.

Enzimska aktivnost se određuje merenjem količine proizvoda 6-APA spektrofotometrijskom metodom koristeći p-dimetilaminobenzaldehid (PDAB) kao bojeni indikator. U kiselim uslovima amino grupe iz 6-APA reaguju sa PDAB formirajući zeleno-žuto obojenu Šifovu bazu koja ima karakterističnu apsorpciju na 415 nm. Prisustvo PenG u sistemu ne ometa merenje sadržaja 6-APA i ne treba da se izdvoji iz sistema. 


\section{Postupak određivanja aktivnosti slobodnog enzima je sledeći:}

U svaki balon se stavi $2,5 \mathrm{~cm}^{3}$ standardnog rastvora penicilina G (2,0\%(w/v) PenG u 0,1 M natrijum fosfatnom puferu, $\mathrm{pH}$ 7,92) i baloni se u tresilici ostave u toku 10 minuta da bi se termostatirali na temperaturi od $37^{\circ} \mathrm{C}$.

Naprave se rastvori enzima različitih koncentracija $u$ istom fosfatnom puferu da bi se $u$ svaki balon dodao $1 \mathrm{~cm}^{3}$ rastvora enzima određene koncentracije. Enzim koji se ispituje se nalazi u tečnom stanju tako da je ovde koncentracija izražena zapreminskim udelom. U ovom radu su se koncentracije enzima kretale u intervalu od $0,03-0,15 \mathrm{~cm}^{3} / \mathrm{cm}^{3}$, a iznosile su: 0,$03 ; 0,045 ; 0,06$; 0,$075 ; 0,09 ; 0,12$ i $0,15 \mathrm{~cm}^{3} / \mathrm{cm}^{3}$.

U određeni balon se dodaje $1 \mathrm{~cm}^{3}$ određene koncentracije enzima i istovremeno se uključuje štoperica. Sadržaj u balonima se sve vreme meša u tresilici pri konstantnom broju obrtaja. Nakon tačno 3 minuta, reakcija se prekida dodavanjem $2,5 \mathrm{~cm}^{3}$ etanola.

\section{Određivanje sadržaja 6-APA u uzorcima:}

Kada je završena i poslednja reakcija, iz svakog balona se uzima po $1 \mathrm{~cm}^{3}$ uzorka i stavlja u određenu epruvetu.

$\mathrm{U} 1 \mathrm{~cm}^{3}$ uzorka se dodaju rastvori A, B i C u zapreminskom odnosu prema uzorku (A: B: $\mathrm{C}=2: 1: 0,5)$, odnosno $1 \mathrm{~cm}^{3}$ uzorka $+2 \mathrm{~cm}^{3} \mathrm{~A}+1 \mathrm{~cm}^{3} \mathrm{~B}+0,5 \mathrm{~cm}^{3} \mathrm{C}$.

Pri tome je:

- rastvor A je 20 zap. \% sirćetna kiselina u destilovanoj vodi;

- rastvor B je 0,5\% (w/v) natrijum-hidroksid u destilovanoj vodi;

- rastvor C je 0,5\% (w/v) PDAB u metanolu.

Kada se uzorcima doda rastvor C, oni se ostave da odstoje 20 minuta na sobnoj temperaturi da bi se razvila boja i tek se onda meri apsorbanca na $415 \mathrm{~nm}$. Slepu probu čini $1 \mathrm{~cm}^{3}$ pufera, $2 \mathrm{~cm}^{3}$ rastvora $\mathrm{A}, 1 \mathrm{~cm}^{3}$ rastvora $\mathrm{B}$ i $0,5 \mathrm{~cm}^{3}$ rastvora $\mathrm{C}$.

Sadržaj 6-APA u svakom uzorku se određuje pomoću napravljene standardne krive koja predstavlja zavisnost apsorbancije od koncentracije 6-APA. 
1 IU je definisana kao količina enzima koja proizvodi $1 \mu$ mol 6-APA po minuti pod standardnim uslovima (2,0\% (w/v) PenG u 0,1 M natrijum fosfatnom puferu, $\mathrm{pH} 7,92$ na $37^{\circ} \mathrm{C}$ ).

\subsubsection{Određivanje uticaja temperature na aktivnost slobodne penicilin- acilaze}

$\mathrm{Na}$ osnovu dobijene zavisnosti brzine enzimske reakcije (aktivnosti enzima) od koncentracije supstrata (PenG) za radnu koncentraciju enzima od $0,006 \mathrm{~cm}^{3} / \mathrm{cm}^{3}$ pod standardnim uslovima, nalazi se radna koncentracija supstrata pri kojoj se postiže zasićenje enzima supstratom. Odabrana radna koncentracija supstrata je 2,0\% (w/v) PenG u $0,1 \mathrm{M}$ fosfatnom puferu $\mathrm{pH} 7,92$ na $37^{\circ} \mathrm{C}$.

Ispitivanje uticaja temperature određivano je u opsegu od $20-75{ }^{\circ} \mathrm{C}$ sa odabranom koncentracijom supstrata. Svaki balon u kome se nalazi 2,5 $\mathrm{cm}^{3}$ supstrata radne koncentracije je stavljen u tresilicu najmanje 30 minuta da se termostatira na određenoj temperaturi. Zatim se izvodi enzimska reakcija sa $1 \mathrm{~cm}^{3}$ enzima radne koncentracije i određuje sadržaj 6-APA po istim postupcima opisanim u odeljku 6.2.1.2. Svi eksperimenti su rađeni u duplikatu.

\subsubsection{Određivanje uticaja pH na aktivnost slobodne penicilin-acilaze}

Ispitivan je uticaj $\mathrm{pH}$ vrednosti reakcione sredine $\mathrm{u}$ opsegu od 4,5-9,3. Korišćeni puferi $(0,1 \mathrm{M})$ sa određenim $\mathrm{pH}$ vrednostima su bili:

-acetatni pufer (pH 4,5 i pH 5,5),

-fosfatni pufer (pH 6,2, $\mathrm{pH} 7,3$ i pH 7,9) i

-tris/HCl pufer ( $\mathrm{pH} 8,6$ i $\mathrm{pH} 9,3)$.

Za pripremanje rastvora enzima i supstrata radnih koncentracija, i enzim i supstrat su rastvoreni u određenom puferu određene $\mathrm{pH}$ vrednosti koji su namenjeni za svaki balon u tresilici posebno. Enzimska reakcija počinje tako što se sadržaju balona u tresilici $\left(2,5 \mathrm{~cm}^{3}\right.$ rastvora supstrata radne koncentracije u određenom puferu određene $\mathrm{pH}$ vrednosti) doda $1 \mathrm{~cm}^{3}$ rastvora enzima radne koncentracije u istom puferu iste $\mathrm{pH}$ vrednosti po istom postupku opisanom u odeljku 6.2.1.2, što važi i za određivanje sadržaja 6-APA. Svi eksperimenti su ponovljeni dva puta. 


\subsubsection{Određivanje termostabilnosti slobodne penicilin-acilaze}

Termostabilnost slobodne PAC je ispitivana na temperaturi od $50{ }^{\circ} \mathrm{C}$ u toku $5 \mathrm{~h}$. $\mathrm{U}$ seriju balona je sipano po $1 \mathrm{~cm}^{3}$ rastvora PAC u $0,1 \mathrm{M}$ natrijum-fosfatnom puferu $\mathrm{pH}$ 7,92 radne koncentracije $0,006 \mathrm{~cm}^{3} / \mathrm{cm}^{3}$. Baloni su stavljeni u vodeno kupatilo na $50^{\circ} \mathrm{C}$. Prvi balon je izvađen u nultom trenutku (posle nekoliko sekundi) i tretiran kao početni uzorak, dok su ostali baloni izvađeni u određenim pravilnim vremenskim intervalima (nakon 1 h, 2 h, 3 h, 4 h i 5 h).

Posle vodenog kupatila, svi baloni su stavljeni u tresilicu na $37{ }^{\circ} \mathrm{C}$, oko $30 \mathrm{~min}$, da se termostatiraju. Posle 30 min u svaki balon je dodato $2,5 \mathrm{~cm}^{3} 2 \%$ (w/v) PenG u 0,1M fosfatnom puferu $\mathrm{pH} 7,92 \mathrm{uz}$ istovremeno uključivanje štoperice. Reakcija traje 3 min i zaustavlja se dodavanjem $2,5 \mathrm{~cm}^{3}$ etanola.

Sadržaj 6-APA je određen postupkom opisanim u odeljku 6.2.1.2.

Dva modela su korišćena za modelovanje eksperimentalnih rezultata i to: model dezaktivacije prvog reda i model sa početnom lag fazom pre dezaktivacije. U ovim modelima, prevođenje potpuno aktivnog slobodnog enzima $(E)$ u potpuno neaktivni kranji enzimski oblik $(D)$ u jednom koraku može se predstaviti kao:

$$
E \stackrel{k_{D}}{\longrightarrow} D
$$

Ovaj mehanizam vodi do kinetičkog modela I reda, gde preostala enzimska aktivnost, $A$ u vremenu $t$ može da se odredi iz sledeće jednačine:

$$
A=100 \% \cdot e^{-k_{\mathrm{D}} t}
$$

gde je $k_{\mathrm{D}}$ konstanta dezaktivacije prvog reda.

Model sa početnom lag fazom pre dezaktivacije može da se formuliše $j$-nom (6.2) uz dodatni uslov:

$$
A=100 \% \text { za } t \leq t_{\mathrm{D}}
$$


Jednačina 6.2. se primenjuje za $t>t_{\mathrm{D}}$, gde je $t_{\mathrm{D}}$ vreme trajanja početne lag faze u kojoj nema dezaktivacije enzima.

Najbolji kvantitativni pokazatelj stabilnosti enzima je poluvreme dezaktivacije, $t_{1 / 2}$, koje predstavlja vreme za koje se dezaktivira polovina početne količine enzima. Ono se može izračunati iz konstante brzine dezaktivacije $\left(k_{\mathrm{D}}\right)$ na osnovu jednačine 6.2:

$$
t_{1 / 2}=\frac{\ln 2}{k_{\mathrm{D}}}
$$

Isto tako može se odrediti faktor stabilizacije enzima $(F)$ kao odnos poluvremena dezaktivacije imobilisanog $\left(t_{1 / 2_{\mathrm{IE}}}\right)$ i slobodnog enzima $\left(t_{1 / 2_{\mathrm{SE}}}\right)$

$$
F=\frac{t_{1 / 2_{\mathrm{IE}}}}{t_{1 / 2_{\mathrm{SE}}}}
$$

$\mathrm{U}$ ovim kinetičkim modelima promenljivi parametri su $k_{\mathrm{D}}$ i $t_{\mathrm{D}}$ koji se određuju nelinearnom Levenberg-Markuard regresionom metodom za najmanja odstupanja korišćenjem MAT-LAB programa.

\subsubsection{Određivanje kinetičkih konstanti slobodne penicilin-acilaze}

Ispitana je kinetika hidrolize Pen G slobodnom PAC i u pet eksperimentalnih serija ispitani su inhibitorni uticaji supstrata u višku i proizvoda reakcije.

\subsection{Određivanje konstanti inhibicije supstratom u višku}

U prvoj eksperimentalnoj seriji određen je uticaj supstrata (Pen G) u višku na brzinu reakcije hidrolize. U seriju balona je stavljeno po $2,5 \mathrm{~cm}^{3}$ standardnog rastvora penicilina $\mathrm{G}$ različitih koncentracija $(0,01 ; 0,02 ; 0,03 ; 0,04 ; 0,05 ; 0,06 ; 0,07 ; 0,08 ; 0,10$; 0,$12 ; 0,14 ; 0,16 ; 0,18 ; 0,20 ; 0,22 ; 0,24$ M Pen G u 0,1 M natrijum-fosfatnom puferu, 
pH 7,92) i baloni su u tresilici ostavljeni u toku $30 \mathrm{~min}$. da bi se termostatirali na temperaturi od $37^{\circ} \mathrm{C}$.

$\mathrm{U}$ svaki balon se dodaje po $1 \mathrm{~cm}^{3}$ rastvora slobodnog enzima koncentracije $0,006 \mathrm{~cm}^{3} / \mathrm{cm}^{3}$ i istovremeno se uključuje štoperica. Sadržaj u balonima se sve vreme meša u tresilici pri konstantnom broju obrtaja. Nakon tačno 3 minuta reakcija se prekida dodavanjem $2,5 \mathrm{~cm}^{3}$ etanola.

Da bi se odredio sadržaj 6-aminopenicilanske kiseline iz svakog balona se uzima po $1 \mathrm{~cm}^{3}$ supernatanta i sadržaj 6-APA se određuje po metodi opisanoj $\mathrm{u}$ poglavlju 6.2.1.2. Svi eksperimenti su rađeni u duplikatu.

\subsection{Određivanje konstanti inhibicije 6-aminopenicilanske i fenilsirćetne} kiseline

Ispitivanje uticaja proizvoda hidrolize Pen G je vršeno u četiri serije od po četiri balona u kojima se nalazilo po $2,5 \mathrm{~cm}^{3}$ standardnog rastvora penicilina $\mathrm{G}$ različitih koncentracija $(0,01 ; 0,02 ; 0,05$ i 0,10 M Pen G u 0,1 M natrijum-fosfatnom puferu, $\mathrm{pH}$ 7,92). U svaku seriju je dodata različita koncentracija PAA ili 6-APA i to tako da su koncentracije iznosile: $1 \% ; 1,5 \% ; 1,75 \%$ i 2 mas \%. Baloni su zatim ostavljeni u tresilici u toku 30 minuta da bi se termostatirali na temperaturi od $37^{\circ} \mathrm{C}$.

U slučaju ispitivanja inhibicije slobodnog enzima napravljeni su uzorci po istom postupku samo je u svaki balon dodato po $1 \mathrm{~cm}^{3}$ rastvora slobodnog enzima koncentracije $0,006 \mathrm{~cm}^{3} / \mathrm{cm}^{3}$. Sadržaj u balonima je sve vreme mešan u tresilici pri konstantnom broju obrtaja. Nakon tačno 3 minuta reakcija se prekida dodavanjem $2,5 \mathrm{~cm}^{3}$ etanola. 


\subsubsection{Imobilizacija penicilin-acilaze na komercijalne polimetakrilatne Sepabeads nosače}

\subsubsection{Imobilizacija penicilin-acilaze na Sepabeads EC-EP konvencionalnom metodom}

Enzim se imobiliše kovalentno na polimetakrilatni nosač u koga su prethodno uvedene epoksidne funkcionalne grupe po postupku koji je preporučio proizvođač ovog komercijalnog nosača (Resindion Mitsubishi Chemical Corporation, Italija). U ovom slučaju, enzim se imobiliše direktno za epoksidne grupe nosača u rastvoru visoke jonske jačine, bez prethodne aktivacije enzima ili nosača.

Postupak imobilizacije je bio sledeći:

Naprave se rastvori enzima određenih koncentracija (u intervalu od 0,0025$0,04 \mathrm{~cm}^{3} / \mathrm{cm}^{3}$ ) u 1,25 M kalijum-fosfatnom puferu $\mathrm{pH} 8,0$. U ovom radu napravljeno je osam različitih rastvora enzima čije su koncentracije iznosile: 0,$0025 ; 0,005 ; 0,01$; 0,$02 ; 0,025 ; 0,03 ; 0,035$ i $0,04 \mathrm{~cm}^{3} / \mathrm{cm}^{3}$.

U svakom balonu se nalazi po $10 \mathrm{~cm}^{3}$ rastvora enzima u koji se suspenduje po 0,5 g nosača. Baloni sa takvim sadržajem se ostave 48 sati u tresilici uz konstantno mešanje (pri konstantnom broju obrtaja) na $25^{\circ} \mathrm{C}$. Posle $48 \mathrm{~h}$, uzorci se filtriraju čime se zaustavlja proces imobilizacije.

U filtratima se nalazi izvesna količina nevezanog enzima čiji se sadržaj određuje spektrofotometrijskom metodom na $210 \mathrm{~nm}$ uz pomoć standardne krive koja predstavlja zavisnost apsorbancije od koncentracije enzima (slika 6.1.). Pri tome se u krajnjem proračunu vezane količine enzima na nosač uzimaju u obzir izmerene zapremine filtrata.

Imobilisani enzimi su ostavljeni u frižideru na $4{ }^{\circ} \mathrm{C}$ do daljih ispitivanja.

Da bi se odredio procenat vezanog enzima, izračunava se maseni prinos imobilizacije $\left(\eta_{\text {enz }}\right)$ koji predstavlja odnos mase vezanog enzima $\left(P_{\mathrm{g}}\right)$ i mase enzima $\mathrm{u}$ početnom rastvoru za imobilizaciju $\left(P_{0}\right)$ :

$$
\eta_{\mathrm{enz}}=\frac{P_{g}}{P_{0}} \times 100
$$




\subsubsection{Imobilizacija penicilin-acilaze na Sepabeads EC-EA i Sepabeads EC-HA konvencionalnom metodom)}

Imobilizacija penicilin-acilaze na Sepabeads EC-EA i Sepabeads EC-HA je izvršena i u ovom slučaju po konvencionalnom postupku koji je preporučio proizvođač nosača. Ova imobilizacija se zasniva na hemijskom vezivanju penicilin-acilaze za Sepabeads EC-EA i Sepabeads EC-HA pri čemu je prethodno potrebno izvršiti aktivaciju nosača. Nosači se tretiraju glutaraldehidom da bi se uvele aldehidne grupe za koje se vezuju $\mathrm{NH}_{2}$ grupe enzima.

Aktivacija nosača se izvodi na sledeći način.

Određena masa nosača ( $5 \mathrm{~g})$ se suspenduje u $20 \mathrm{~cm}^{3} 2 \%$ rastvora glutaraldehida i ostavi u tresilici $1 \mathrm{~h}$ na $25^{\circ} \mathrm{C}$. Nakon toga, nosač se odvoji od glutaraldehida i ispere sa $25 \mathrm{~cm}^{3} 20 \mathrm{mM}$ kalijum-fosfatnog pufera $\mathrm{pH} 8$ kako bi se uklonio nevezani glutaraldehid. Zatim se nosač suši 1 h, čime je postupak aktivacije nosača završen.

Imobilizacija enzima se zatim izvodi na sledeći način.

Naprave se rastvori enzima određenih koncentracija ( $u$ intervalu od 0,0025$0,04 \mathrm{~cm}^{3} / \mathrm{cm}^{3}$ ) u $20 \mathrm{mM}$ kalijum-fosfatnom puferu $\mathrm{pH} 8,0$. U ovom radu napravljeno je sedam različitih rastvora enzima čije su koncentracije iznosile: 0,$0025 ; 0,005 ; 0,01$; 0,$025 ; 0,03 ; 0,035 ; 0,04 \mathrm{~cm}^{3} / \mathrm{cm}^{3}$. Ako se zna da sadržaj proteina u enzimskom preparatu određen po metodi opisanoj u poglavlju 6.2 .1 .1 . iznosi $56,13 \mathrm{mg} / \mathrm{cm}^{3}$, onda ove koncentracije odgovaraju sledećim koncentracijama proteina: 0,$14 ; 0,28 ; 0,56$; 1,$40 ; 1,68 ; 1,96 ; 2,24 \mathrm{mg} / \mathrm{cm}^{3}$.

$\mathrm{U}$ svakom balonu se nalazi po $10 \mathrm{~cm}^{3}$ rastvora enzima određene koncentracije $\mathrm{u}$ koje se suspenduje po 0,5 g nosača. Baloni sa takvim sadržajem se ostave $20 \mathrm{~h} \mathrm{u}$ tresilici uz konstantno mešanje (pri konstantnom broju obrtaja) na $25{ }^{\circ} \mathrm{C}$. Posle $20 \mathrm{~h}$, uzorci se filtriraju čime se zaustavlja proces imobilizacije.

U filtratima se nalazi izvesna količina nevezanog enzima čiji se sadržaj određuje spektrofotometrijskom metodom na $210 \mathrm{~nm}$ uz pomoć standardne krive (slika 6.1.) koja predstavlja zavisnost apsorbancije od koncentracije enzima. Ovo je bilo potrebno stoga što se nije mogla koristiti Lorijeva metoda za određivanje sadržaja 
enzima $\mathrm{u}$ filtratu jer rastvor nakon imobilizacije stvara zamućenje sa Lorijevim reagensima. Sadržaj enzima određen je direktno spektrofotometrijskom metodom bez bojenja na $210 \mathrm{~nm}$ kako je poznato da proteni apsorbuju u datoj UV oblasti.

Imobilisani enzimi su ostavljeni u frižideru na $4{ }^{\circ} \mathrm{C}$ do daljih ispitivanja.

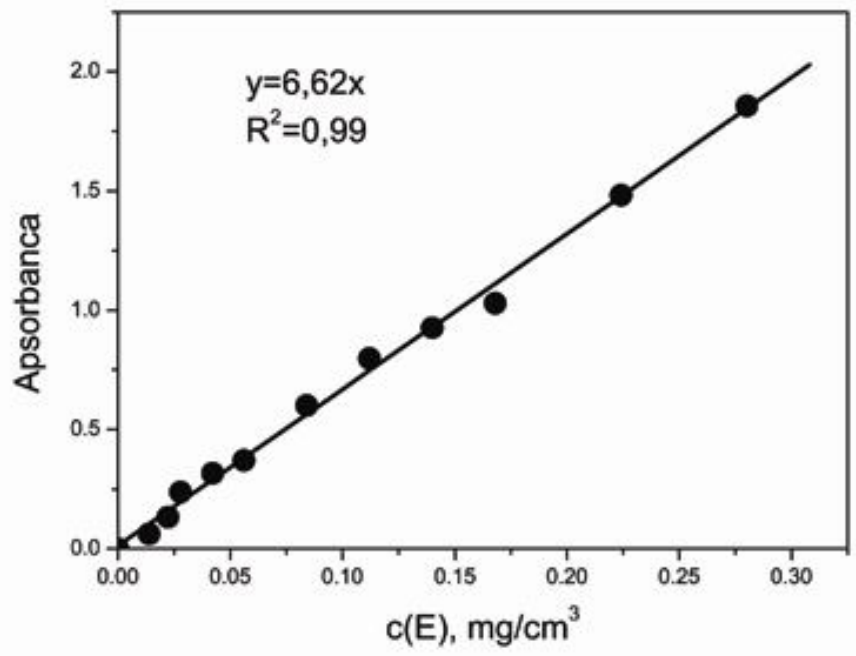

Slika 6.1. Tipična standardna kriva za određivanje koncentracije enzima $(210 \mathrm{~nm})$

\subsubsection{Određivanje stepena hidrofobnosti nosača}

Da bi dobijene aktivnosti imobilisanih enzima mogle da se izraze po masi suvog nosača, određen je stepen hidrofobnosti nosača, jer se vlažan nosač suspenduje u rastvoru enzima za imobilizaciju.

Stepen hidrofobnosti, $f$, je odnos mase vlažnog nosača i mase nosača osušenog do konstantne vrednosti.

\subsubsection{Određivanje aktivnosti imobilisane penicilin-acilaze}

Aktivnost imobilisane PAC je ispitivana $\mathrm{u}$ rastvoru supstrata radne koncentracije $(2,0 \%(\mathrm{w} / \mathrm{v})$ PenG u 0,1 M fosfatnom puferu $\mathrm{pH} 7,92)$. Baloni sa po $3,5 \mathrm{~cm}^{3}$ rastvora su termostatirani na radnoj temperaturi od $37^{\circ} \mathrm{C}$.

Po 0,1 g suvih imobilizata sa različitim količinama vezanog enzima dobijenih iz eksperimenta pod 6.2.2.1 ili 6.2.2.2 je dodato u svaki balon uz istovremeno uključivanje 
štoperice na 3 minuta trajanja reakcije pri čemu se sadržaj balona u tresilici konstantno meša. Nakon tačno 3 minuta, reakcija se zaustavlja dodavanjem $2,5 \mathrm{~cm}^{3}$ etanola. Uzorak koji se uzima za analizu sadržaja 6-APA je $1 \mathrm{~cm}^{3}$ supernatanta. Procedura određivanja sadržaja 6-APA je po metodi opisanoj u poglavlju 6.2.1.2.

Da bi se uporedile aktivnosti slobodne i imobilisane PAC, izračunat je prinos aktivnosti imobilizacije $\left(\eta_{\text {akt }}\right)$ koji predstavlja odnos specifične aktivnosti imobilisanog enzima $\left(S A_{\mathrm{IE}}\right)$ i specifične aktivnosti slobodnog enzima $\left(S A_{\mathrm{SE}}\right)$ :

$$
\eta_{\mathrm{akt}}=\frac{S A_{I E}}{S A_{S E}} \times 100
$$

\subsubsection{Određivanje uticaja temperature na aktivnost imobilisane penicilin-acilaze}

Izabrano je da radna koncentracija supstrata iznosi 2,0\% (w/v) PenG u 0,1 M fosfatnom puferu $\mathrm{pH} 7,92$. Usvojeno je na osnovu prethodnih rezultata da radni imobilizat bude sa aktivnošću od $72 \mathrm{IU} / \mathrm{g}$ nosača (suvog).

Uticaj temperature je ispitan $\mathrm{u}$ istom intervalu kao $\mathrm{u}$ poglavlju 6.2.1.3. na sledeći način.

$\mathrm{U}$ balone se odmeri po $3,5 \mathrm{~cm}^{3}$ rastvora supstrata izabrane radne koncentracije i sačeka se najmanje 30 minuta da se balon u tresilici termostatira na određenoj temperaturi. U svaki balon je sipano po $0,1 \mathrm{~g}$ suvog radnog imobilizata uz istovremeno uključivanje štoperice. Reakcija i određivanje sadržaja 6-APA su vođeni po istim procedurama kao u prethodnim ogledima (poglavlje 6.2.1.2.).

\subsubsection{Određivanje uticaja $\mathrm{pH}$ na aktivnost imobilisane penicilin-acilaze}

Radni imobilizat je bio isti kao u prethodnom poglavlju 6.2.2.5., dok je rastvor supstrata radne koncentracije i dalje 2,0\% (w/v) ali u puferu odgovarajuće $\mathrm{pH}$ vrednosti za svaki uzorak posebno. Napravljeni su identični puferi sa $\mathrm{pH}$ vrednostima kao u poglavlju 6.2.1.4. Reakcija se izvodi na temperaturi od $37{ }^{\circ} \mathrm{C}$. U svaki balon je odmereno po $3,5 \mathrm{~cm}^{3}$ rastvora supstrata radne koncentracije i uzorci su termostatirani 
oko 30 minuta. Nakon toga, u uzorke je sipano po $0,1 \mathrm{~g}$ suvog imobilizata uz uključivanje štoperice. Reakcija i određivanje sadržaja 6-APA su vođeni po istim procedurama kao u prethodnim ogledima (poglavlje 6.2.1.2.).

\subsubsection{Određivanje termostabilnosti imobilisane penicilin-acilaze}

Termostabilnost imobilisane PAC je ispitivana na isti način kao što je opisano u poglavlju 6.2.1.5. U seriju balona je sipano po $0,1 \mathrm{~g}$ suvog radnog imobilizata i suspendovano u $1 \mathrm{~cm}^{3}$ 0,1 M natrijum-fosfatnom puferu $\mathrm{pH}$ 7,92. Baloni su stavljeni u vodeno kupatilo na $50{ }^{\circ} \mathrm{C}$. Prvi balon je izvađen u nultom trenutku (posle nekoliko sekundi) i tretiran kao početni uzorak, dok su ostali baloni izvađeni u određenim pravilnim vremenskim intervalima (nakon $1 \mathrm{~h}, 2 \mathrm{~h}, 3 \mathrm{~h}, 4 \mathrm{~h}$ i 5 h).

Posle vodenog kupatila, svi baloni su stavljeni u tresilicu na $37^{\circ} \mathrm{C}$, oko $30 \mathrm{~min}$, da se termostatiraju. Posle 30 min u svaki balon je dodato $2,5 \mathrm{~cm}^{3} 2 \%$ (w/v) PenG u 0,1M fosfatnom puferu $\mathrm{pH} 7,92 \mathrm{uz}$ istovremeno uključivanje štoperice. Reakcija traje 3 min i zaustavlja se dodavanjem $2,5 \mathrm{~cm}^{3}$ etanola.

Sadržaj 6-APA se određuje po metodi opisanoj u poglavlju 6.2.1.2.

\subsubsection{Karakterizacija i imobilizacija penicilin-acilaze modifikovane derivatima polisaharida}

6.2.3.1. Modifikacija penicilin-acilaze derivatima polisaharida

PAC je modifikovana derivatima polisaharida po metodi 2. Određena masa polisaharida (skroba ili alginata) (1g) je rastvoren u $100 \mathrm{~cm}^{3}$ destilovane vode i $1,07 \mathrm{~g}$ čvrstog natrijum-perjodata $\left(\mathrm{NaIO}_{4}\right)$ je dodato u rastvor. Reakciona smeša se meša na tamnom mestu na $4{ }^{\circ} \mathrm{C}$ u trajanju od $48 \mathrm{~h}$. Nakon toga $1 \mathrm{~cm}^{3}$ etilenglikola se doda $\mathrm{i}$ reakciona smeša se ostavi da odstoji još 1 h na $4{ }^{\circ} \mathrm{C}$. Dobijeni polisaharid-dialdehid dijalizuje se u crevu za dijalizu prema vodi preko noći na tamnom i hladnom mestu da bi se uklonio višak aldehida male molekulske mase, kao i višak etilenglikola i natrijum- 
perjodata. Na taj način se izvrši perjodatna oksidacija polisaharida i njegovo prevođenje $\mathrm{u}$ aldehidne derivate.

Reakcija konjugacije PAC sa aldehidnim derivatima polisaharida se izvodila po sledećem postupku. Penicilin-acilaza $\left(2,5 \mathrm{~cm}^{3}\right)$ se pomeša sa $2,5 \mathrm{~cm}^{3} 10 \mathrm{mM}$ natrijumfosftanog pufera $\mathrm{pH}$ 7,0 i doda se $5 \mathrm{~cm}^{3}$ rastvora oksidisanog polisaharida. Reakciona smeša se ostavi na $4{ }^{\circ} \mathrm{C}$, na tamnom mestu 7 dana. Time je izvršena modifikacija enzima. Modifikovani enzim se ultrafiltracijom kroz YM 100 membranu (100 kDa, Milipore Corporation, Bedford, MA, SAD) odvoji od neproreagovalog enzima $(\approx 80 \mathrm{kDa})$ i oksidisanog polisaharida.

$\mathrm{Na}$ osnovu literaturnih podataka, Šifove baze formirane između penicilinacilaze i oksidisanog polisaharida su veoma stabilne, tako da nije bilo potrebno izvršiti dodatnu redukciju korišćenjem $\mathrm{NaBH}_{4}$ [208].

\subsubsection{Oksidacija enzima modifikovanog polisaharidima}

Nakon izvršene modifikacije enzima derivatom skroba ili alginata vršena je njegova dodatna oksidacija perjodatom u višku radi povećanja broja aldehidnih grupa ugljenohidratne komponente enzima. Postupak je sledeći: za oksidaciju je neophodno dodati $5 \mu \mathrm{mol} \mathrm{NaIO}_{4}$ po $1 \mathrm{mg}$ enzima. U čaši u kojoj je vršena modifikacija skrobom nalazi se $2,5 \mathrm{~cm}^{3}$ enzima tj. 140,32 $\mathrm{mg}$ enzima, tako da je za njegovu modifikaciju potrebno $14 \mathrm{~cm}^{3} 50 \mathrm{mmol}$ rastvora perjodata u Na-acetatnom puferu $\left(0,21 \mathrm{~g} \mathrm{NaIO}_{4} \mathrm{u}\right.$ $20 \mathrm{~cm}^{3}$ Na-acetatnog pufera).

Smeša modifikovanog enzima i rastvora perjodata je ostavljena u frižideru $6 \mathrm{~h}$. Nakon toga je dodat etilenglikol pri čemu je preporučena količina $0,04 \mathrm{~cm}^{3}$ etilenglikola na $6 \mathrm{~cm}^{3}$ perjodata, konkretno u ovom slučaju dodaje se $0,1 \mathrm{~cm}^{3}$ etilenglikola.

$\mathrm{Na}$ ovaj način izvršena je dodatna oksidacija skroba vezanog za penicilinacilazu. 


\subsubsection{Određivanje sadržaja aktiviranog polisaharida u konjugatu PAC} [209]

Sadržaj aktiviranog polisaharida u konjugatu PAC je određen fenol-sulfatnom metodom. Standardna kriva se pripremala na sledeći način: $2 \mathrm{~cm}^{3}$ rastvora koji sadrži različite mase rastvorenog polisaharida je pomešano $\mathrm{sa} 0,05 \mathrm{~cm}^{3} 80 \%$ fenola. Zatim je $\mathrm{u}$ uzorke dodato $5 \mathrm{~cm}^{3}$ koncentrovane sumporne kiseline. Uzorci su ostavljeni da odstoje $10 \mathrm{~min}$ i nakon toga su stavljani u vodeno kupatilo na $30{ }^{\circ} \mathrm{C} 20 \mathrm{~min}$. Apsorbanca je očitana na $490 \mathrm{~nm}$. Uzorak konjugovane PAC je tretiran po istom postupku i iz očitane apsorbance određen je sadržaj polisaharida u konjugatu PACderivat polisaharida. Tipične standardne krive za određivanje sadržaja aktiviranog skroba i alginata su prikazane na slikama 6.2. i 6.3.

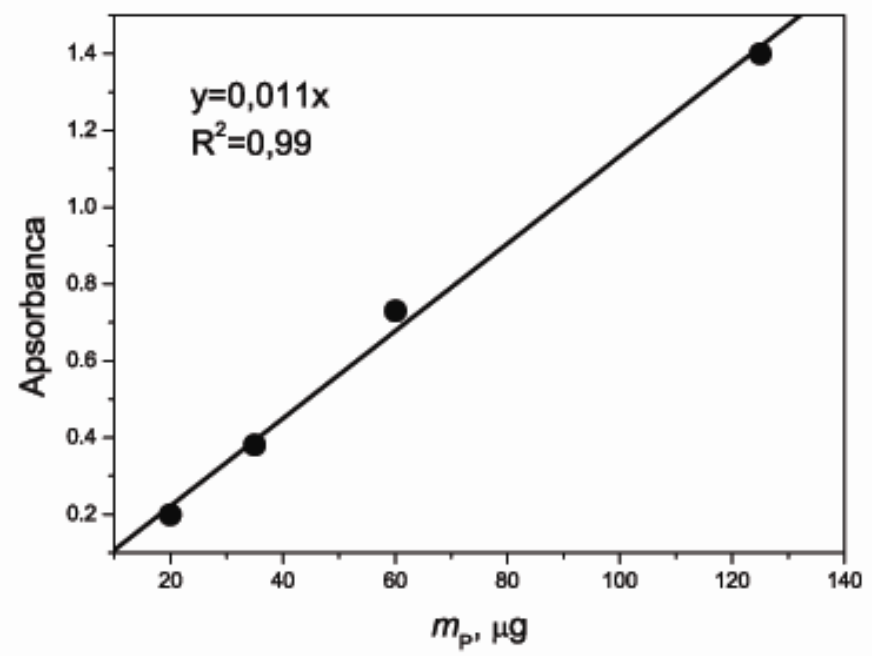

Slika 6.2. Standardna kriva za određivanje sadržaja aktiviranog skroba (490 nm) 


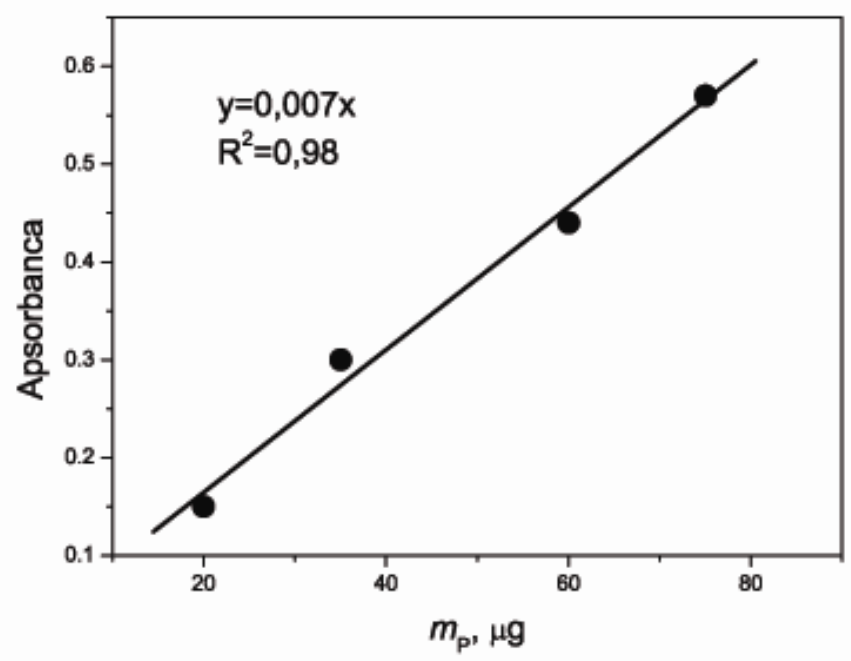

Slika 6.3. Standardna kriva za određivanje sadržaja aktiviranog alginata $(490 \mathrm{~nm})$

\subsubsection{Određivanje uticaja temperature na aktivnost modifikovane penicilin-acilaze}

Uticaj temperature na aktivnost modifikovane PAC je određivan istim postupkom kao u poglavlju 6.2.1.3.

\subsubsection{Određivanje uticaja pH na aktivnost modifikovane penicilin-acilaze}

Uticaj $\mathrm{pH}$ na aktivnost modifikovane PAC je određen istim postupkom kao u poglavlju 6.2.1.4.

\subsubsection{Određivanje stabilnosti modifikovane penicilin-acilaze}

Termostabilnost modifikovane PAC je određena istim postupkom kao u poglavlju 6.2.1.5. 
.... 6.2.3.7. Imobilizacija modifikovane penicilin-acilaze na komercijalne Sepabeads EC-HA i

Sepabeads EC-EA nosače

Mogućnost imobilizacije modifikovane PAC je takođe ispitivana na komercijalnim nosačima Sepabeads EC-HA i Sepabeads EC-EA na sledeći način. Čaša u kojoj se nalazi oksidisan, modifikovan enzim se dopuni do $50 \mathrm{~cm}^{3}$ natrijum-acetatnim puferom $\mathrm{pH}$ 5,0. Naprave se rastvori modifikovanog enzima određenih koncentracija tako da koncentracija enzima bude u intervalu od 0,0025 do $0,04 \mathrm{~cm}^{3} / \mathrm{cm}^{3}$ u $50 \mathrm{mM}$ natrijum-acetatnom puferu $\mathrm{pH}$ 5,0. U ovom radu napravljeno je sedam koncentracija koje su iznosile $0,0025,0,005,0,01,0,025,0,03,0,035,0,04 \mathrm{~cm}^{3} / \mathrm{cm}^{3}$.

Imobilizacija se sastojala od vezivanja oksidovane modifikovane PAC za amino-Sepabeads nosače u natrijum-acetatnom puferu na $\mathrm{pH} 5,0$ i na $4{ }^{\circ} \mathrm{C}$ u toku $48 \mathrm{~h}$. $\mathrm{U}$ tom cilju u sedam čaša od $100 \mathrm{~cm}^{3}$ se sipa po $10 \mathrm{~cm}^{3}$ rastvora enzima različite koncentracije i 0,5 g suvog Sepabeads EC-EA ili Sepabeads EC-HA nosača. Čaše su ostavljene u frižider da stoje $48 \mathrm{~h}$, nakon čega se uzorci filtriraju i time se završava proces imobilizacije. U filtratima je određena količina nevezanog enzima spektrofotometrijskom metodom na $210 \mathrm{~nm}$ uz pomoć standardne krive koja predstavlja zavisnost apsorbancije od koncentracije enzima. Slepa proba se pravi kao $1 \mathrm{~cm}^{3}$ pufera (Na-acetatni pufer $\left.\mathrm{pH}=5,0\right), 2 \mathrm{~cm}^{3}$ rastvora $\mathrm{A}, 1 \mathrm{~cm}^{3}$ rastvora $\mathrm{B}, 0,5 \mathrm{~cm}^{3}$ rastvora C. Na slici 6.4, 6.5 i 6.6. prikazane su tipične standardne krive za određivanje koncentracije enzima. 


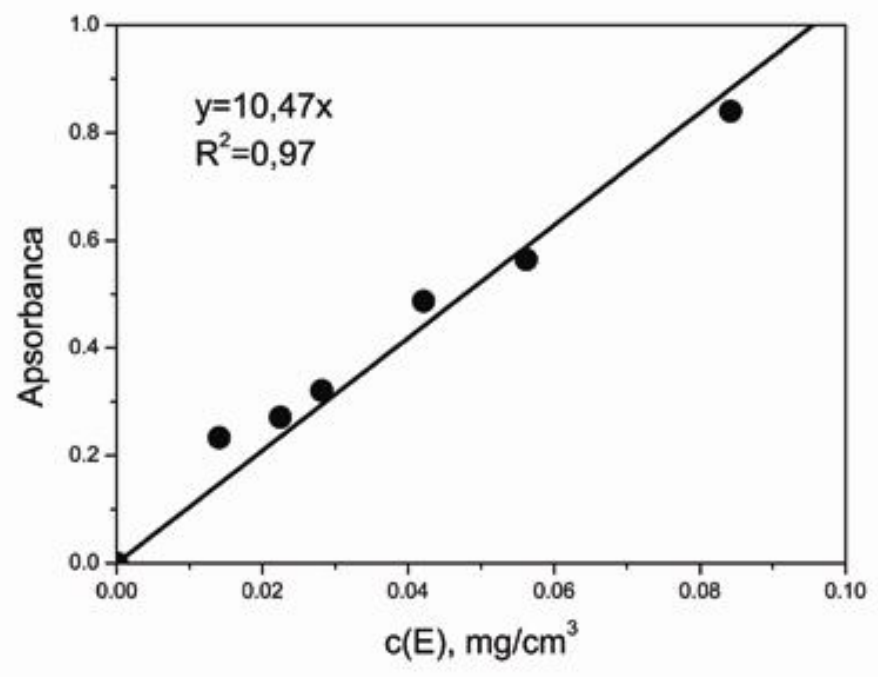

Slika 6.4. Standardna kriva za određivanje koncentracije enzima PAC oksidovane i modifikovane derivatom skroba

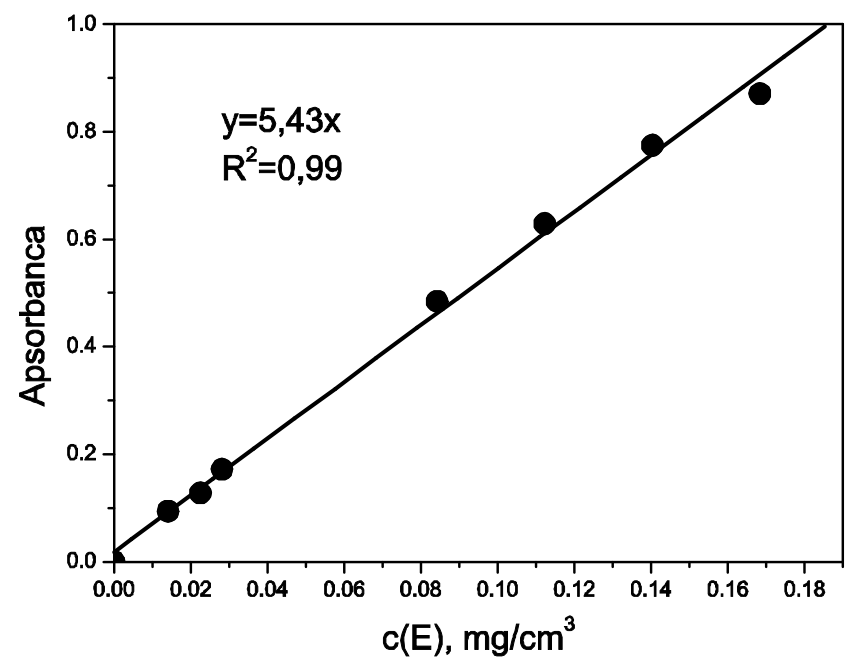

Slika 6.5. Standardna kriva za određivanje koncentracije enzima PAC modifikovane derivatom skroba 


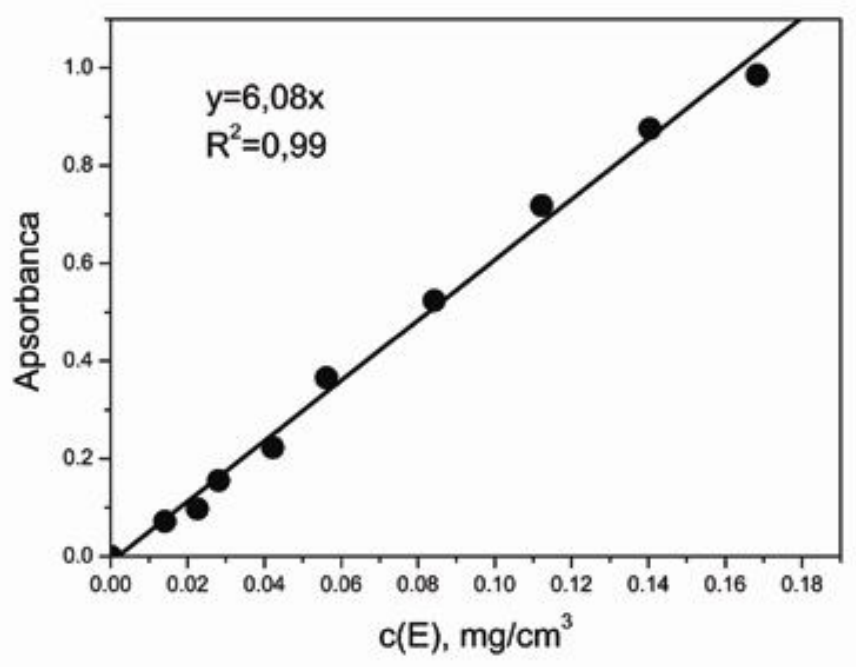

Slika 6.6. Standardna kriva za određivanje koncentracije enzima PAC modifikovane derivatom alginata

6.2.3.8. Određivanje aktivnosti modifikovane i imobilisane penicilin-acilaze

Aktivnost imobilisane modifikovane PAC je određena po istom postupku kao u poglavlju 6.2.2.4.

\subsubsection{Određivanje uticaja temparature na aktivnost modifikovane $i$ imobilisane penicilin-acilaze}

Uticaj temperature na aktivnost imobilisane modifikovane PAC je određena kao u poglavlju 6.2.2.5.

\subsubsection{Određivanje uticaja pH na aktivnost modifikovane i imobilisane} penicilin-acilaze

Uticaj $\mathrm{pH}$ na aktivnost imobilisane modifikovane PAC je određena kao $\mathrm{u}$ poglavlju 6.2.2.6. 


\subsubsection{Određivanje stabilnosti modifikovane i imobilisane penicilin- acilaze}

Termostabilnost imobilisane modifikovane PAC je određena kao u poglavlju 6.2.2.7.

\subsubsection{Imobilizacija penicilin-acilaze na hitozanske mikročestice dobijene elektrostatičkom ekstruzijom}

\subsubsection{Priprema i aktivacija hitozanskih mikročestica}

Hitozanske mikročestice su dobijene postupkom elektrostatičke ekstruzije, odnosno ekstruzijom uz dejstvo jakog elektrostatičkog polja između igle kroz koju se ukapava rastvor hitozana i rastvora natrijum-tripolifosfata (Na-TPP) u kome se odvija očvršćavanje hitozanskih mikročestica. Na slici 6.7. prikazana je šema aparature za dobijanje sferičnih čestica malih dimenzija primenom elekrostatičkog polja koja je korišćena u ovom radu. 


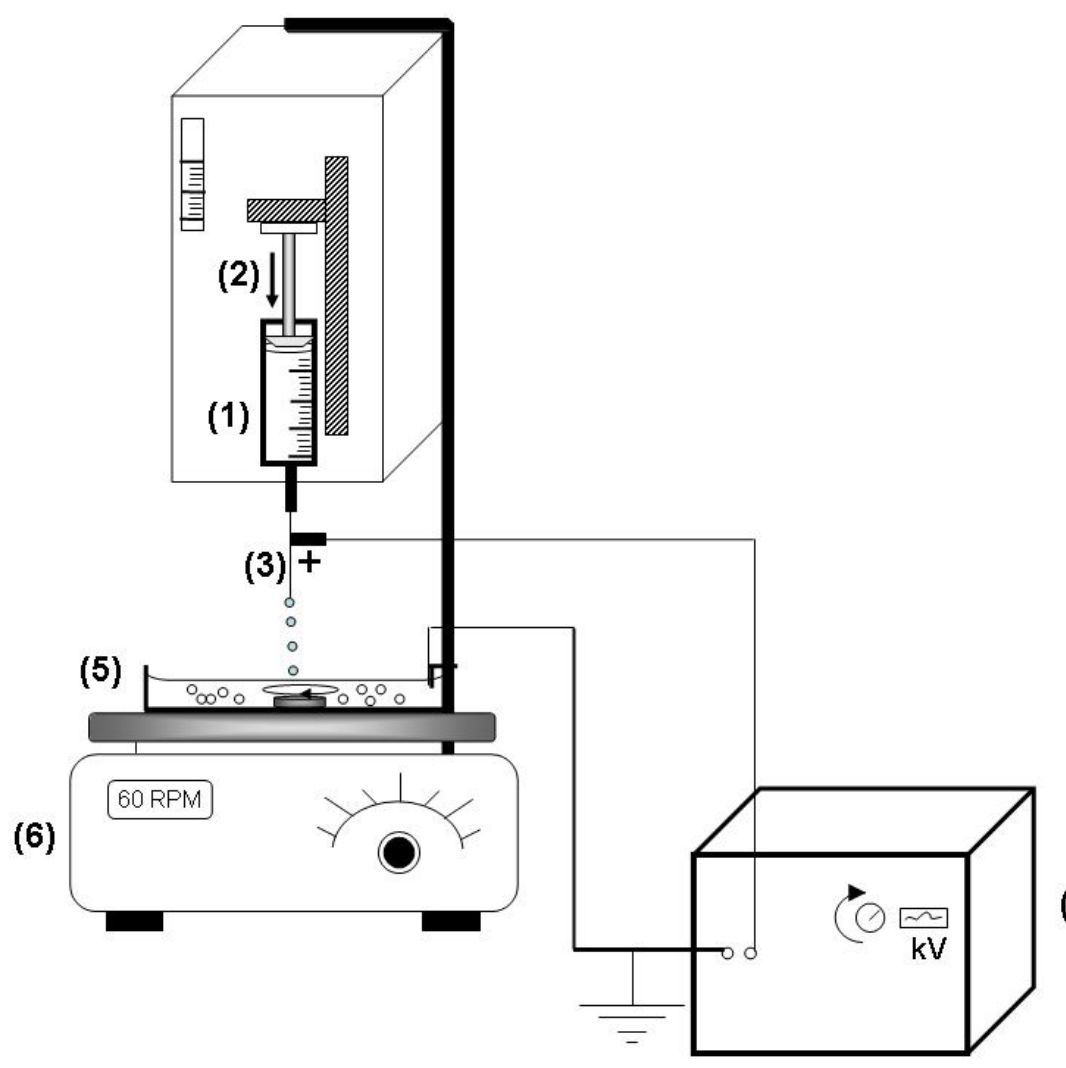

(4)

Slika 6.7. Šematski prikaz eksperimentalne aparature za dobijanje hitozanskih mikročestica: (1) rastvor hitozana se propušta pumpom (2) kroz iglu 21 G (3) povezanu sa generatorom visokog napona (4). Dobijene kapi se skupljaju u rastvoru za geliranje, $10 \%$ natrijum-tripolifosfatu (TPP) (5), koji se meša na magnetnoj mešalici (200 rpm) (6)

Aparatura se sastoji od pumpe koja potiskuje rastvor hitozana kroz špric sa iglom, plastičnog šprica zapremine $10 \mathrm{~cm}^{3}$ sa iglom prečnika $21 \mathrm{G}$ (gauge), generatora visokog napona (Model 30 R, Bertan Associates, Inc., SAD) i rastvora natrijumtripolifosfata, koji se meša na magnetnoj mešalici. Iz generatora visokog napona izvedena je pozitivna elektroda povezana sa iglom, a u rastvor Na-TPP uronjena je uzemljena elektroda. Na ovaj način se dovodi pozitivan jednosmeran napon na vrh igle konstantne vrednosti. Rastvor hitozana potiskivan je pumpom kroz špric do vrha igle konstantnim protokom i dolazi do otkidanja kapi pod dejstom gravitacione i elektrostatičke sile u obliku mlaza naelektrisanih čestica, malih dimenzija. Hitozanske 
mikročestice padaju u rastvor natrijum-tripolifosfata koji se meša na magnetnoj mešalici pri $200 \mathrm{o} / \mathrm{min}$ i spontano geliraju u dodiru sa Na-TPP.

Ispitani su uslovi za dobijanje hitozanskih mikročestica različitih karakteristika koje su korišćene za imobilizaciju enzima i pri tom je variran po jedan od sledećih parametara u svakoj seriji dobijanja čestica:

1. koncentacija rastvora hitozana $(1,0 \%, 1,5 \%, 2,0 \mathrm{w} / \mathrm{v} \%)$;

2. rastojanje vrha igle od površine Na-TPP $(2,5 \mathrm{~cm}, 5 \mathrm{~cm}, 7,5 \mathrm{~cm})$;

3. primenjeni napon $(2,9 \mathrm{kV}, 3,7 \mathrm{kV}, 4,4 \mathrm{kV})$.

\section{Postupak dobijanja hitozanskih mikročestica je sledeći:}

Pripremi se rastvor hitozana odgovarajuće koncentracije u 2\% sirćetnoj kiselini i $1 \%$ Tween 80 i rastvori se homogenizuju mešanjem na magnetnoj mešalici. Napravi se $40 \mathrm{~cm}^{3} 10 \mathrm{w} / \mathrm{v} \%$ rastvora natrijum-tripolifosfata u destilovanoj vodi.

Podesi se odgovarajuće rastojanje vrha igle od površine Na-TPP i odgovarajuća konstantna vrednost napona, a zatim se istiskuje $20 \mathrm{~cm}^{3}$ rastvora hitozana pumpom kroz špric sa iglom. Dobijene hitozanske čestice se ostave $24 \mathrm{~h}$ da se mešaju na magnetnoj mešalici kako bi u potpunosti očvrsle.

Posle očvršćavanja, hitozanske mikročestice se izdvoje vakuum filtracijom na Bihnerovom levku i isperu sa $200 \mathrm{~cm}^{3}$ destilovane vode. Nakon toga, hitozanske mikročestice se suspenduju u $0,1 \mathrm{M}$ natrijum-fosfatnom puferu, $\mathrm{pH} 8,0$ i ostave na $8{ }^{\circ} \mathrm{C}$ do daljih ispitivanja.

\section{Postupak aktivacije hitozanskih mikročestica se izvodi na sledeći način:}

Hitozanske mikročestice su tretirane glutaraldehidom da bi se uvele aldehidne grupe za koje se mogu kovalentno vezati amino grupe enzima. Dobijene hitozanske mikročestice, izdvojene su iz rastvora filtriranjem i ostavljene su da se prosuše $30 \mathrm{~min}$. na sobnoj temperaturi.

Po 2 g čestica je suspendovano u balonima, zavisno od koncentracije glutaraldehida kojim se čestice aktiviraju, u 7,68 cm $3,7,04 \mathrm{~cm}^{3}, 6,4 \mathrm{~cm}^{3}, 5,76 \mathrm{~cm}^{3}$ ili $5,12 \mathrm{~cm}^{3}$ natrijum-fosfatnog pufera $(0,1 \mathrm{M}, \mathrm{pH} 8,0)$. Baloni su ostavljeni u tresilici da 
se termostatiraju 30 minuta na $28{ }^{\circ} \mathrm{C}$. Nakon toga u svaki balon je redom dodato $0,32 \mathrm{~cm}^{3}, 0,96 \mathrm{~cm}^{3}, 1,6 \mathrm{~cm}^{3}, 2,24 \mathrm{~cm}^{3}$ ili $2,88 \mathrm{~cm}^{3} 25 \%$ rastvora glutaraldehida tako da koncentracije glutaraldehida u balonu budu $1 \%, 3 \%, 5 \%, 7 \%$ ili 9 zap.\%, redom. Baloni su ostavljeni da se mešaju u tresilici pri konstantom broju obrtaja 30 minuta na $28^{\circ} \mathrm{C}$ da bi se izvršila aktivacija mikročestica. Posle pola sata, aktivirane mikročestice su filtrirane na filter papiru i isprane sa $150 \mathrm{~cm}^{3}$ destilovane vode da bi se odstranio višak neproreagovalog glutaraldehida. Čestice su ostavljene da se prosuše $30 \mathrm{~min}$ na sobnoj temperaturi. Ovim se završava postupak aktivacije hitozanskih mikročestica.

\subsubsection{Imobilizacija penicilin-acilaze na hitozanskim mikročesticama}

Napravljen je rastvor enzima koncentracije $0,01 \mathrm{~cm}^{3} / \mathrm{cm}^{3}$ u $0,1 \mathrm{M}$ natrijumfosfatnom puferu ( $\mathrm{pH} \mathrm{8,0).} \mathrm{U} \mathrm{seriju} \mathrm{balona} \mathrm{je} \mathrm{dodato} \mathrm{po} 10 \mathrm{~cm}^{3}$ rastvora enzima date koncentracije i po 1 g prosušenih aktiviranih hitozanskih mikročestica. Baloni su stavljeni u tresilicu uz konstantno mešanje $22 \mathrm{~h}$ na $28^{\circ} \mathrm{C}$ da bi se izvršila imobilizacija.

Posle $22 \mathrm{~h}$ uzorci su fitrirani na filter papiru, pri čemu se filtrat sakuplja radi analize nevezanih proteina i meri njegova zapremina. Imobilisani enzim je prosušen 30min. na sobnoj temperaturi i korišćen u daljem radu.

\subsubsection{Određivanje aktivnosti imobilisane penicilin-acilaze}

Aktivnost PAC imobilisane na hitozanskim mikročesticama je određena po istom postupku kao u poglavlju 6.2.2.4.

\subsubsection{Titracija aktivnog položaja}

Titracija aktivnog položaja se zasniva na efikasnoj ireverzibilnoj inhibiciji PAC inhibitorom proteaza rastuće koncentracije i ispitivanjem preostale enzimske aktivnosti sve do potpune inhibicije $[93,96]$. Molarna koncentracija ireverzibilnog inhibitora koja dovodi do potpune inhibicije PAC ekvivalentna je molarnoj koncentraciji aktivnih mesta u molekulu enzima. Titracija aktivnog položaja slobodne i imobilisane PAC se izvodi inkubiranjem $0,1 \mathrm{~cm}^{3}$ slobodne PAC ili $0,2 \mathrm{~g}$ imobilisane PAC sa različitim 
sadržajem enzima, preko noći na $\mathrm{pH} 8,0$ i $4{ }^{\circ} \mathrm{C}$ sa različitim koncentracijama rastvora fenilmetilsulfonilflurida (PMSF) da bi se postigla postepena inhibicija aktivnog enzima [210]. Posle $12 \mathrm{~h}$, ispituje se preostala aktivnost enzima u reakciji hidrolize penicilina G standardnim postupkom.

Prikazuje se zavisnost preostale aktivnosti PAC od količine upotrebljenog PMSF i eksperimentalni podaci se modeluju linearnom zavisnošću. Količina PMSF koja je potrebna za potpunu inhibiciju enzima se dobija ekstrapolacijom prave do preseka sa apscisom i odgovara molarnoj koncentraciji aktivnih položaja u molekulu enzima.

\subsubsection{Karakterizacija hitozanskih mikročestica}

Prečnik hitozanskih mikročestica sa imobilisanom PAC određen je slučajnim odabirom 50 hitozanskih mikročestica korišćenjem mikroskopa (Imager.A1, Zeiss, Švajcarska) povezanog sa digitalnom video kamerom (Zeiss, AxioCam MRc, Švajcarska). Iz ovih podataka se izračunavao srednji prečnik mikročestica i standardna devijacija. Morfologija liofilizovanih mikročestica je analizirana korišćenjem Skenirajućeg elektronskog mikroskopa (JEOL JSM5800 SEM and TESCAN Vega TS 5130MM, Velika Britanija) sa rezolucijom na $30 \mathrm{kV}$. Hemijska karakterizacija neaktiviranih i aktiviranih hitozanskih mikročestica kao i imobilisanih uzoraka se vrši Furijeovom transformacionom infracrvenom spektroskopskopijom (FT-IR) korišćenjem Bomem MB 100 FT-IR spektrofotometra (SpectraLab Scientific Inc, Kanada). 10 mg uzorka se pomeša i spraši sa 100 mg kalijum-bromida i komprimuje u tabletice pod pritiskom od 11 t, u trajanju oko 1 min, pomoću Graseby Specac Model: 15,011. Spektri su dobijeni u rasponu talasnog broja od $400-4000 \mathrm{~cm}^{-1}$, na $25{ }^{\circ} \mathrm{C}$ i na $4 \mathrm{~cm}^{-1}$ rezolucije spektra.

\subsubsection{Određivanje uticaja temperature na aktivnost imobilisane penicilin-acilaze}

Uticaj temperature na aktivnost imobilisane penicilin-acilaze na hitozanskim mikročesticama je određen istim postupkom kao u poglavlju 6.2.2.5. 


\subsubsection{Određivanje uticaja $\mathrm{pH}$ na aktivnost imobilisane penicilin-acilaze}

Uticaj $\mathrm{pH}$ na aktivnost imobilisane penicilin-acilaze na hitozanskim mikročesticama je određen istim postupkom kao u poglavlju 6.2.2.6.

\subsubsection{Operativna stabilnost imobilisane penicilin-acilaze}

Da bi se odredila operativna stabilnost imobilisanog enzima, isti uzorci imobilisanog enzima su korišćeni u uzastopnim eksperimentima hidrolize penicilina $G$, kako je opisano u poglavlju 6.2.4.3. Posle svake reakcije određivan je sadržaj 6-APA, a čestice imobilisanog enzima su filtrirane na filter papiru. Imobilisani enzim je ispran sa $50 \mathrm{~cm}^{3}$ destilovane vode da bi se otklonili zaostali supstrat i proizvodi reakcije.

Imobilisani enzim je sušen pola sata na sobnoj temperaturi. Preostala količina imobilisanog enzima je izmerena na analitičkoj vagi i reakcija se ponavlja po istoj proceduri (poglavlje 6.2.4.3).

\subsubsection{Određivanje kinetike otpuštanja enzima sa hitozanskih mikročestica}

Kinetika otpuštanja enzima sa hitozanskih mikročestica je određivana $u$ natrijum-fosfatnom puferu na tresilici u toku $120 \mathrm{~h}$. U svaki balon se doda po $50 \mathrm{~cm}^{3}$ 0,1 M natrijum-fosfatnog pufera $(\mathrm{pH} 7,92)$ i suspenduje $2 \mathrm{~g}$ izmerenog imobilizata. Periodično se uzima po $3 \mathrm{~cm}^{3}$ uzorka iz svakog balona i meri se apsorbanca na $210 \mathrm{~nm}$. $\mathrm{Na}$ osnovu izmerene apsorbance određuje se sadržaj otpuštenog enzima korišćenjem standarne krive za enzim (slika 6.1).

Nakon merenja apsorbance uzeti uzorci se vraćaju u balone. 


\subsubsection{Određivanje kinetičkih konstanti imobilisane penicilin-acilaze}

\subsection{Određivanje konstanti inhibicije supstratom u višku}

Konstanta inhibicije supstratom $\mathrm{u}$ višku se određuje po postupku opisanom u poglavlju 6.2.1.5.1. pri čemu se u svaki balon umesto $1 \mathrm{~cm}^{3}$ rastvora slobodne PAC dodaje po 0,153 g imobilisanog enzima dobijenog iz eksperimenta opisanog $\mathrm{u}$ poglavlju 6.2.4.2.

\subsection{Određivanje konstanti inhibicije 6-aminopenicilanske $i$ fenilsirćetne kiseline}

Konstante inhibicije 6-aminopenicilanske kiseline i fenilsirćetne kiseline su određene kao što je opisano u poglavlju 6.2.1.5.2. pri čemu se u svaki balon umesto $1 \mathrm{~cm}^{3}$ rastvora slobodne PAC dodaje po $1 \mathrm{~cm}^{3} 0,1 \mathrm{M}$ natrijum-fosfatnog pufera, $\mathrm{pH} 7,92$ i suspenduje 0,153 g imobilisanog enzima dobijenog iz eksperimenta opisanog $\mathrm{u}$ poglavlju 6.2.4.2.

\subsubsection{Određivanje brzine reakcije u reaktoru sa pakovanim slojem}

Aktivnost PAC imobilisane na hitozanskim mikročesticama ispitivana je u reaktoru sa pakovanim slojem. Kao reaktor sa pakovanim slojem korišćeno je kućište za filter zapremine $1 \mathrm{~cm}^{3}$ i prečnika $1 \mathrm{~cm}$. Eksperimentalni sistem se sastojao od rezervoara sa reakcionom smešom, peristaltičke pumpe koja je obezbedila proticanje fluida, reaktora i rezervoara sa izlaznom smešom (slika 6.8.). Sistem je bio na sobnoj temperaturi, masa mikročestica pakovanja je bila $0,1 \mathrm{~g}$ odnosno zapremina $0,3 \mathrm{~cm}^{3}$.

Prvo je izvršena kalibracija pumpe propuštanjem određene zapremine destilovane vode i merenjem vremena isticanja. Dobijene su sledeće vrednosti:

za očitanu vrednost podeoka 0,22 : protok $=0,30 \mathrm{~cm}^{3} / \mathrm{min}$, za očitanu vrednost podeoka 0,29 : protok $=0,53 \mathrm{~cm}^{3} / \mathrm{min}$, za očitanu vrednost podeoka 0,44 : protok $=1,03 \mathrm{~cm}^{3} / \mathrm{min}$. 
Zatim, pri gore određenim protocima, kroz pakovan sloj reaktora propuštano je $3,5 \mathrm{~cm}^{3}$ reakcione smeše $\left(0,05 \mathrm{~g}\right.$ penicilina $\mathrm{G}+3,5 \mathrm{~cm}^{3}$ natrijum-fosfatnog pufera, $\mathrm{pH}=7,92)$ i sakupljani su uzorci. Treba napomenuti takođe da su za svaki od tri protoka korišćene nove mikročestice u reaktoru (nakon završetka rada sa jednim protokom, pumpa je isključena, reaktor ispražnjen i napunjen novim mikročesticama). Svaki eksperiment je ukupno trajao četiri vremena zadržavanja pri čemu su uzorci uzimani za period od trećeg do četvrtog vremena zadržavanja. Za protok $0,30 \mathrm{~cm}^{3} / \mathrm{min}$ eksperiment je ukupno trajao 12 min pri čemu je uzorak uziman od 9-12. min. Za protok $0,53 \mathrm{~cm}^{3} /$ min eksperiment je ukupno trajao 8 min pri čemu je uzorak uziman od 6 8.min. Za protok od $1,03 \mathrm{~cm}^{3} /$ min eksperiment je ukupno trajao 4 min pri čemu je uzorak uziman od 3-4. min. Koncentracija 6-aminopenicilanske kiseline je određivana po metodi opisanoj u poglavlju 6.2.1.2.

U drugoj eksperimentalnoj seriji, eksperimentalni reaktor sa pakovanim slojem je primenjen u režimu recirkulacije tečnosti (slika 6.8.b). Postupak je bio isti, s tom razlikom što se proizvod sakupljao u istoj čaši u kojoj se nalazi i početni rastvor reakcione smeše. Ovaj sistem se predstavlja idealnim cevnim reaktorom koji je vezan na red sa rezervoarom sa idealnim mešanjem. Ukupna zapremina reakcione smeše je bila $4 \mathrm{~cm}^{3}$. Kao i u slučaju reaktora sa pakovanim slojem, korišćeni su isti protoci: $0,30 \mathrm{~cm}^{3} / \mathrm{min}, 0,53 \mathrm{~cm}^{3} / \mathrm{min}$ i $1,03 \mathrm{~cm}^{3} / \mathrm{min}$. 


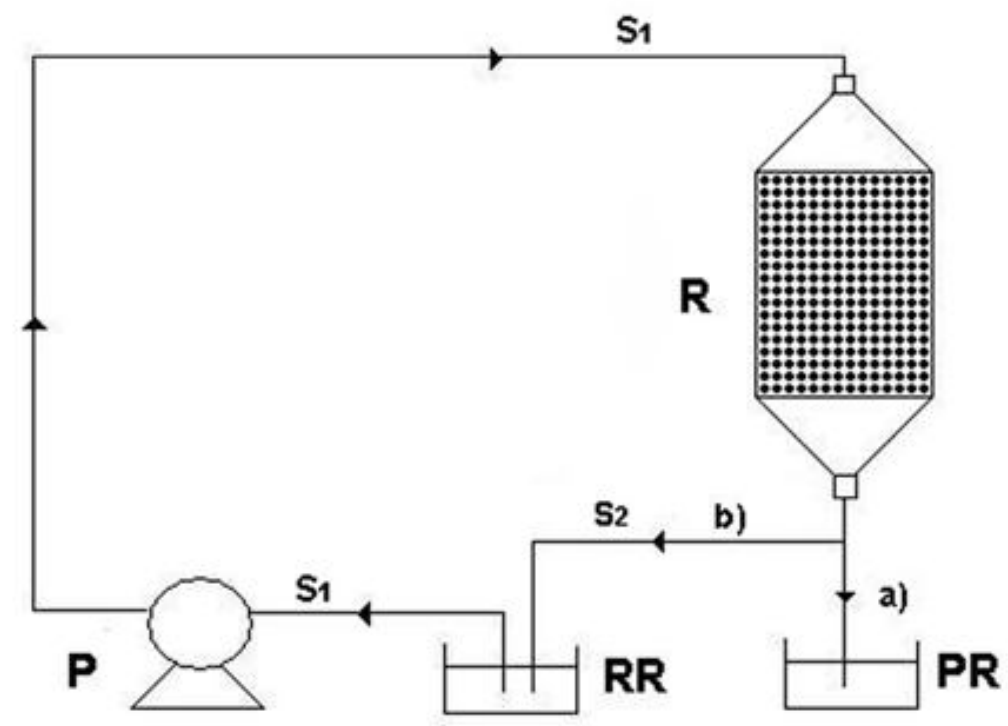

Slika 6.8. Šema bioreaktorskog sistema sa pakovanim slojem bez recirkulacije tečnosti (protok a) $i$ sa recirkulacijom tečnosti (protok b): $R$ : reaktor sa pakovanim slojem; $R R$ : rezervoar sa reaktantima; PR: rezervoar sa proizvodima; $P$ : pumpa 


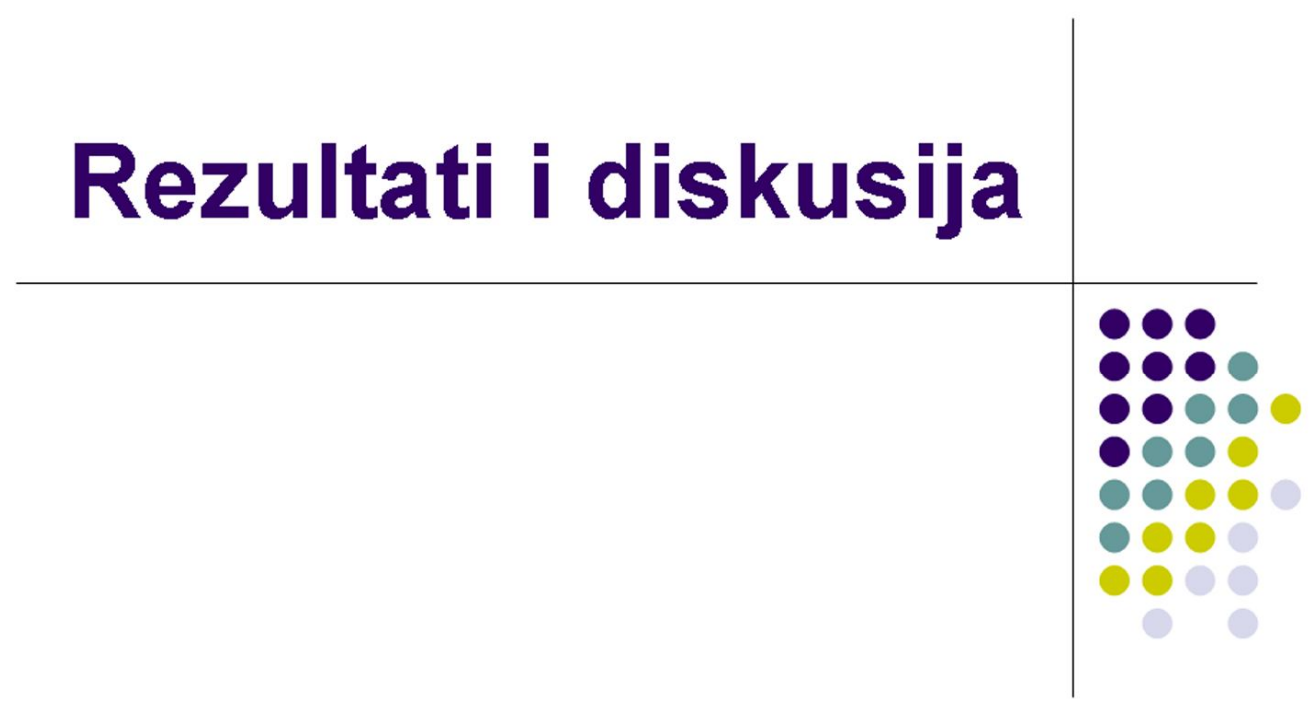




\section{KARAKTERIZACIJA SLOBODNE PENICILIN-ACILAZE}

Cilj ovog dela rada je bio da se okarakteriše slobodan enzim, komercijalna penicilin-acilaza iz Escherichia coli tj. da se odredi njena aktivnost, $\mathrm{pH}$ i temperaturni profil, kao i termalna stabilnost. Takođe, ispitana je početna kinetika reakcije hidrolize prirodnog penicilina $\mathrm{G}$ koja je katalizovana ovim enzimom. $U$ tom cilju ispitani su uticaji početne koncentracije supstrata (Pen G) i proizvoda reakcije (6-APA i PAA) na početnu brzinu reakcije. Na osnovu dobijenih rezultata utvrđeni su inhibitorni uticaji supstrata i proizvoda reakcije kao i vrsta inhibicije. Ova svojstva enzima su veoma važne kada enzim treba da se koristi u industriji i ona variraju u zavisnosti od porekla enzima. Zbog toga je karakterizacija enzima neophodna da bi se svojstva enzima, koji vodi poreklo iz jednog organizma, uporedila sa svojstvim enzima iz drugih organizama. Isto tako, u ovom radu su ta svojstva odeđena u cilju njihovog poređenja sa svojstvima imobilisanih enzima, jer je samo na taj način moguće proceniti efikasnost upotrebljene metode imobilizacije.

\subsection{Ispitivanje sadržaja enzima u komercijalnom enzimskom preparatu}

Komercijalni enzimski preparat (DSM, Holandija) je proizveden u tečnom stanju. Kako je čistoća enzimskog preparata veoma važan faktor pri ispitivanju svojstava enzima, prvo je ispitan sadržaj proteina (čistog enzima) u komercijalnom preparatu po metodi opisanoj u poglavlju 6.2.1.1. Kao standardni protein korišćen je goveđi serum albumin (BSA). Utvrđeno je da $0,01 \mathrm{~cm}^{3}$ komercijalnog enzimskog preparata ima apsorbancu od 0,385. Na osnovu toga je određeno da sadržaj proteina u komercijalnom enzimskom preparatu iznosi $56,13 \mathrm{mg} / \mathrm{cm}^{3}$. U prilogu je data standardna prava na osnovu koje je određen sadržaj proteina (slika P-7.1). 


\subsection{Ispitivanje specifične aktivnosti slobodne penicilin-acilaze}

Aktivnost enzima je određivana pre svake serije eksperimentalnih merenja po metodi opisanoj u poglavlju 6.2.1.2. Iz nagiba dobijenih linearnih zavisnosti aktivnosti enzima od početne mase enzima određivana je specifična aktivnost enzimskog preparata. Ove vrednosti su se kretale u intervalu od 1,87-2,28 IU/mg enzima. Na slici 7.1 prikazana je jedna od dobijenih zavisnosti aktivnosti enzima od početne mase enzima u uzorku komercijalnog preparata različitih koncentracija. Kako je dobijena odgovarajuća linearnost (koeficijent linearnosti ove zavisnosti je 0,993), specifična aktivnost slobodnog enzima ( $\mathrm{SA}_{\mathrm{SE}}$ ), koja predstavlja nagib prave, je precizno određena i u ovoj eksperimentalnoj seriji iznosila je 2,27 IU/mg enzima.

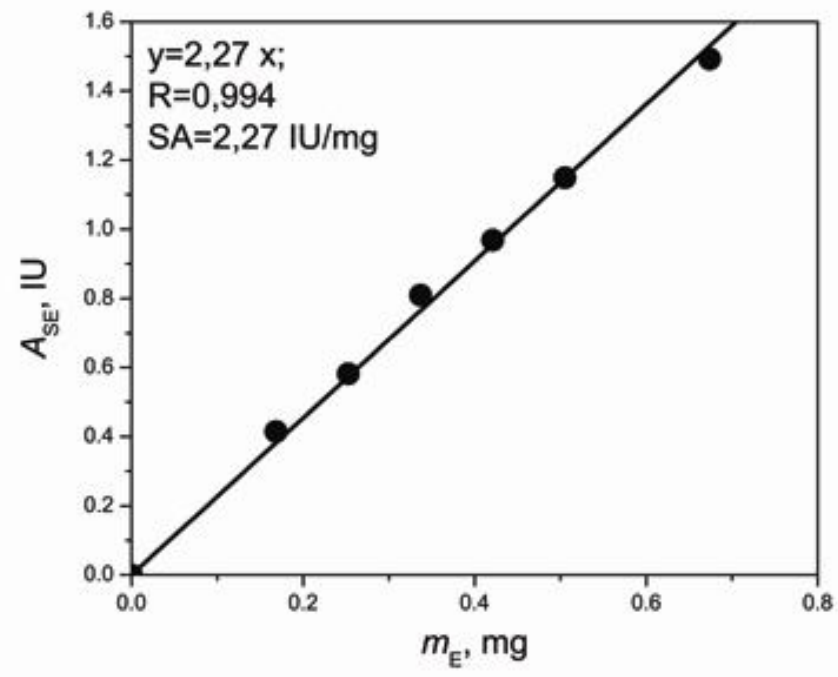

Slika 7.1. Zavisnost aktivnosti PAC izražene u IU od mase enzima u komercijalnom enzimskom preparatu

\subsection{Ispitivanje uticaja temperature na aktivnost slobodne penicilin-acilaze}

$\mathrm{U}$ radu je ispitan uticaj temperature na aktivnost enzima u intervalu od 21 do $75^{\circ} \mathrm{C}$ po metodi opisanoj u poglavlju 6.2.1.3. i rezultati su prikazani na slici 7.2. Ovde je aktivnost izražena kao relativna aktivnost (\%) u odnosu na optimalnu koja se uzima 
kao 100\%. Pri niskim temperaturama aktivnost slobodne PAC raste sa porastom temperature, dok pri visokim temperatura ova aktivnost opada. Porast brzine enzimske reakcije sa temperaturom u skladu je sa poznatom Arenijusovom jednačinom i kinetičkom teorijom, dok na visokim temperaturama dolazi do pada aktivnosti verovatno zato što se molekul PAC denaturiše i na kraju izgubi svoju biokatalitičku aktivnost. Uočava se da je optimalna temperatura za ovaj enzim $37{ }^{\circ} \mathrm{C}$. Dobijena vrednost optimalne temperature je približno ista kao vrednosti objavljene u literaturi za isti enzim iz E. coli koje su se kretale u opsegu od $40-45{ }^{\circ} \mathrm{C}[150,211,212]$.

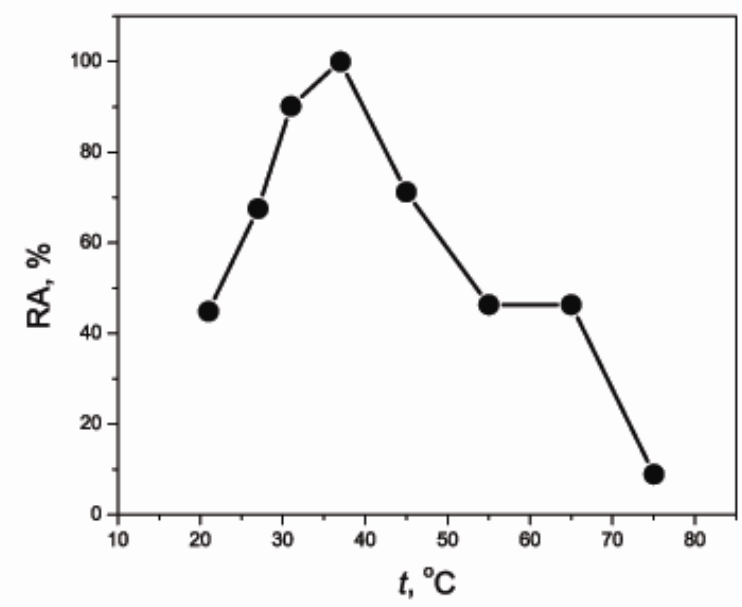

Slika 7.2. Zavisnost relativne aktivnosti (RA) PAC od temperature (reakcioni uslovi: radna koncentracija enzima od $0,06 \mathrm{~cm}^{3} / \mathrm{cm}^{3}$ i supstrata od 2,0\% (w/v) PenG u 0,1 M fosfatnom puferu $\mathrm{pH} 7,92 \mathrm{na} 37^{\circ} \mathrm{C}$ )

\subsection{Ispitivanje uticaja pH vrednosti na aktivnost slobodne penicilin-acilaze}

Ispitan je uticaj $\mathrm{pH}$ vrednosti na aktivnost enzima po metodi opisanoj u poglavlju 6.2.1.4., pri čemu se ispitivana $\mathrm{pH}$ vrednost kretala od 4,50 do 9,30. Na slici 7.3. se vidi da enzim zadržava svoju aktivnost $\mathrm{u}$ širokom intervalu $\mathrm{pH}$ vrednosti koje se kreću od 6,20 do 8,60, dok na vrednostima ispod 6,20 i iznad 8,60 aktivnost naglo opada. 


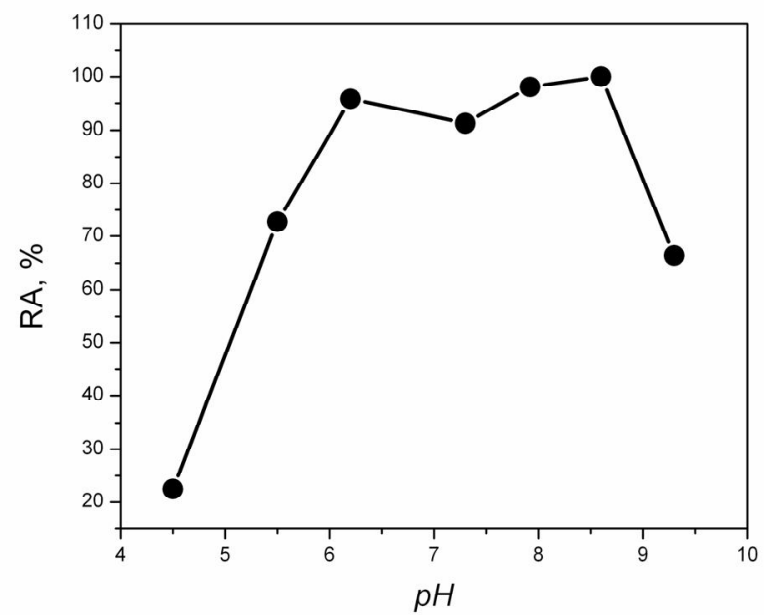

Slika 7.3. Zavisnost relativne aktivnosti PAC od $\mathrm{pH}$ vrednosti. Uslovi reakcije: $37{ }^{\circ} \mathrm{C}$, 3 min, 0,1 M puferi: acetatni puferi ( $p H 4,5$ i pH 5,5), fosfatni puferi ( $p H$ 6,2, pH 7,3 $i$ pH 7,9) i tris/HCl puferi (pH 8,6 i pH 9,3)

U literaturi su objavljene optimalne $\mathrm{pH}$ vrednosti slobodne penicilin acilaze iz E. coli od 7,5 i 8,0 [150, 213], što je u skladu sa rezultatima dobijenim u ovom radu.

\subsection{Ispitivanje stabilnosti slobodne penicilin-acilaze}

Ispitana je termalna stabilnost pencilin-acilaze na temperaturi $50{ }^{\circ} \mathrm{C}$ po metodi opisanoj u poglavlju 6.2.1.5. Rezultati su prikazani na slici 7.4. pri čemu simboli predstavljaju eksperimentalno dobijene vrednosti, dok puna linija predstavlja vrednosti dobijena na osnovu kinetičkog modela dezaktivacije I reda (j-na 6.2). 


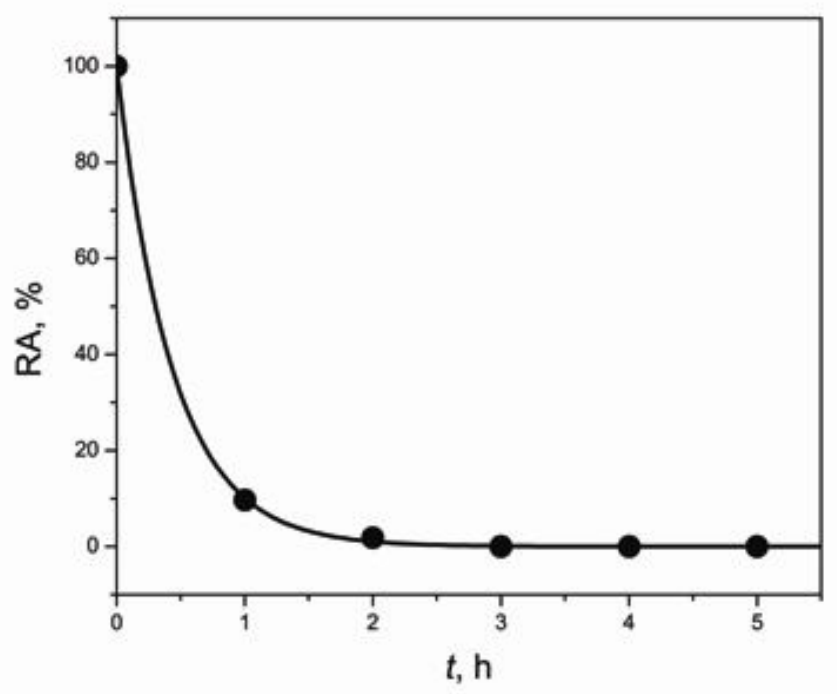

Slika 7.4. Zavisnost relativne aktivnosti PAC od vremena na $50{ }^{\circ}$ C. PAC se termostatira na $50{ }^{\circ} \mathrm{C}$ u različitim vremenskim periodima, a zatim se ispituje aktivnost tretiranog enzima u standardnoj reakciji hidrolize penicilina G. Uslovi reakcije: 0,1 M natrijum-fosfatni pufer $(\mathrm{pH}=7,92), t=37^{\circ} \mathrm{C}, 3 \mathrm{~min}$

Na osnovu modela dobijena je vrednost konstante brzine dezaktivacije za slobodnu penicilin-acilazu od $2,320 \mathrm{~h}^{-1}$. Izračunato poluvreme dezaktivacije slobodne PAC iznosi 0,30 h. Lako se uočava da se eksperimentalni rezultati valjano opisuju datim kinetičkim modelom $(\mathrm{STD}<1 \%)$ i da nema potrebe za korišćenjem kompleksnijih kinetičkih modela sa većim brojem parametara.

\subsection{Ispitivanje početne kinetike hidrolize penicilina $G$ slobodnom penicilin-acilazom u šaržnom sistemu}

\subsubsection{Ispitivanje inhibicije supstratom u višku}

Prilikom ispitivanja uticaja koncentracije penicilina $G$, na početnu brzinu reakcije varirana je koncentracija supstrata u intervalu od 0,01 do 0,24 M u 0,1 M fosfatnom puferu $\mathrm{pH}=7,92$. Dobijena zavisnost prikazana je na slici 7.5. Rezultati su 
prikazani kao relativna brzina reakcije koja predstavlja odnos brzine reakcije (za određene koncentracije Pen G) i maksimalne brzine reakcije i izražena je u procentima.

Iz prikazanih rezultata (slika 7.5.) se uočava da aktivnost slobodne PAC raste sa povećanjem koncentracije Pen G do koncentracije od 0,1 M. Sa daljim povećanjem koncentracije Pen G aktivnost slobodne PAC opada. Na osnovu predstavljenih rezultata može se zaključiti da do inhibicije slobodnog enzima dolazi pri koncentracijama supstrata većim od $0,1 \mathrm{M}$.

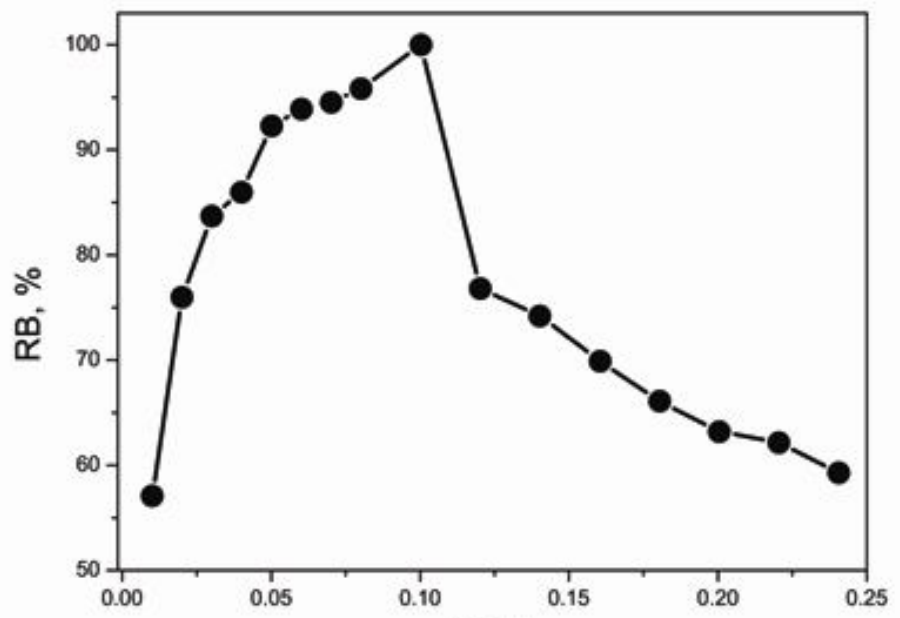

[S], M

Slika 7.5. Zavisnost relativne brzine reakcije (RB) katalizovane slobodnom PAC od koncentracije Pen G. Reakcioni uslovi: koncentracija Pen G od 0,01 do 0,24 M, koncentracija enzima $0,006 \mathrm{~cm}^{3} / \mathrm{cm}^{3}, 0,1 \mathrm{M}$ natrijum-fosfatni pufer pH 7,92, temperatura $37^{\circ} \mathrm{C}$

$\mathrm{Na}$ osnovu dobijenih rezultata nacrtan je Lajnviver-Berkov dijagram za slobodnu PAC za koncentracije supstrata od 0,01 do 0,1 M. Dijagram je prikazan na slici 7.6b. 


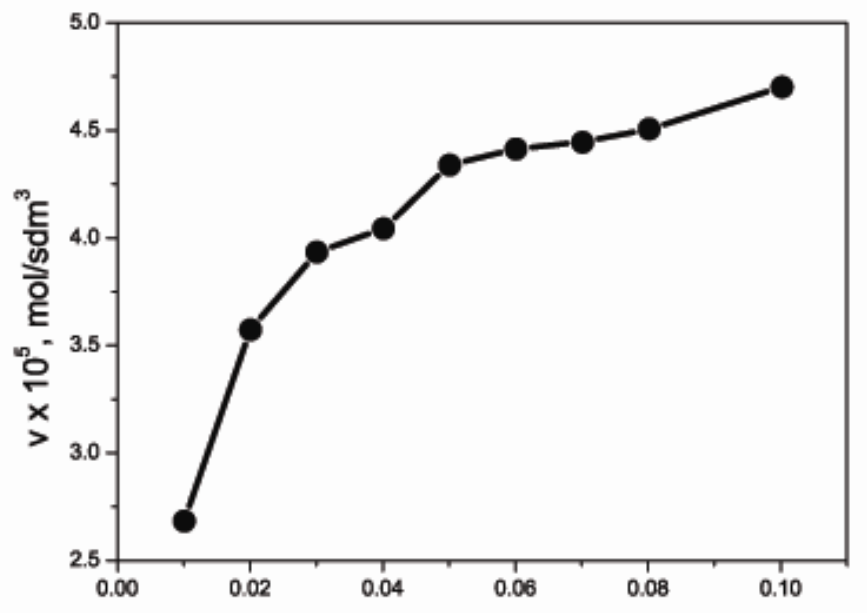

[S]

a)

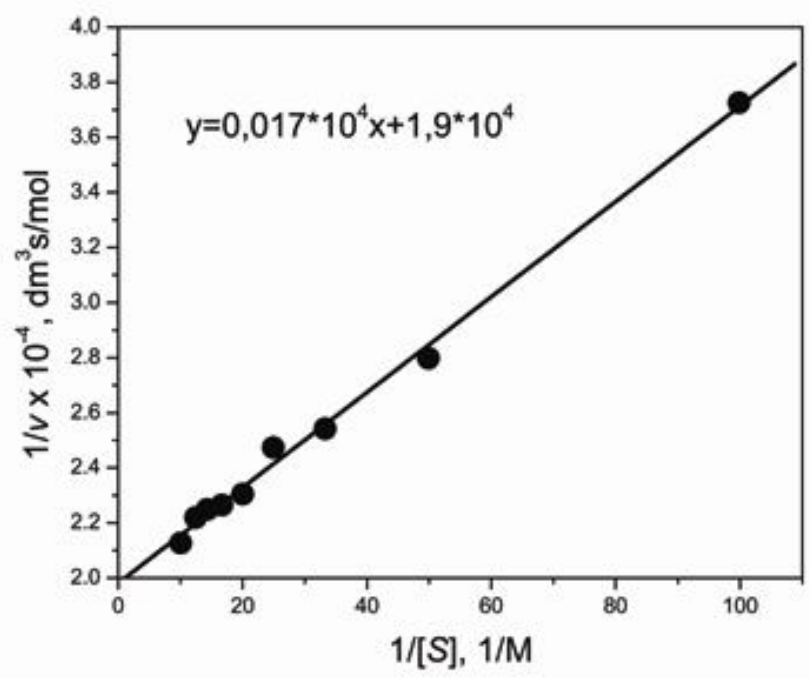

b)

Slika 7.6. a) Zavisnost početne brzine reakcije katalizovane slobodnom PAC od koncentracije Pen G. Reakcioni uslovi: koncentracija Pen G od 0,01 do 0,1 M, koncentracija enzima $0,006 \mathrm{~cm}^{3} / \mathrm{cm}^{3}, 0,1 \mathrm{M}$ natrijum-fosfatni pufer pH 7,92, temperatura $37^{\circ} \mathrm{C}$

b) Lajnviver-Berkov dijagram recipročnih vrednosti početne brzine hidrolize Pen $G i$ koncentracije supstrata za reakciju katalizovanu slobodnom PAC. Dijagram je određen na osnovu vrednosti prikazanih na slici 7.6 a) 
$\mathrm{Na}$ osnovu prikazanih rezultata na slici 7.6. dobijaju se vrednosti maksimalne početne brzine reakcije $\left(V_{\mathrm{M}}\right)$ i Mihaelis-Mentenove konstante $\left(K_{\mathrm{M}}\right)$ za slobodnu PAC, koje su iznosile redom $5,13 \cdot 10^{-5} \mathrm{~mol} /\left(\mathrm{dm}^{3} \mathrm{~s}\right)$ i $9,14 \cdot 10^{-3} \mathrm{~mol} / \mathrm{dm}^{3}$. Za PAC iz Escherichia coli i Bacilus megaterium u literaturi su dobijene vrednosti za $K_{\mathrm{M}}$ od 7,7mM i 4,5 mM [214], dok je za PAC iz Bacilus megaterium ATCC 14945 dobijena vrednost za $K_{\mathrm{M}}$ od 1,83 $\mathrm{mM}$ [43]. Budući da je $K_{\mathrm{m}}$ kvantitativna mera afiniteta enzima prema supstratu, vrednost dobijena za penicilin-acilazu iz B. megaterium ATCC 14945 govori da PAC iz B. megaterium ima najveći afinitet prema penicilinu G.

Takođe, prikazan je i dijagram zavisnosti recipročne vrednosti brzine reakcije od koncentracije supstrata u višku od 0,12 do 0,24 M za slobodnu PAC. Rezultati su prikazani na slici 7.7 . 


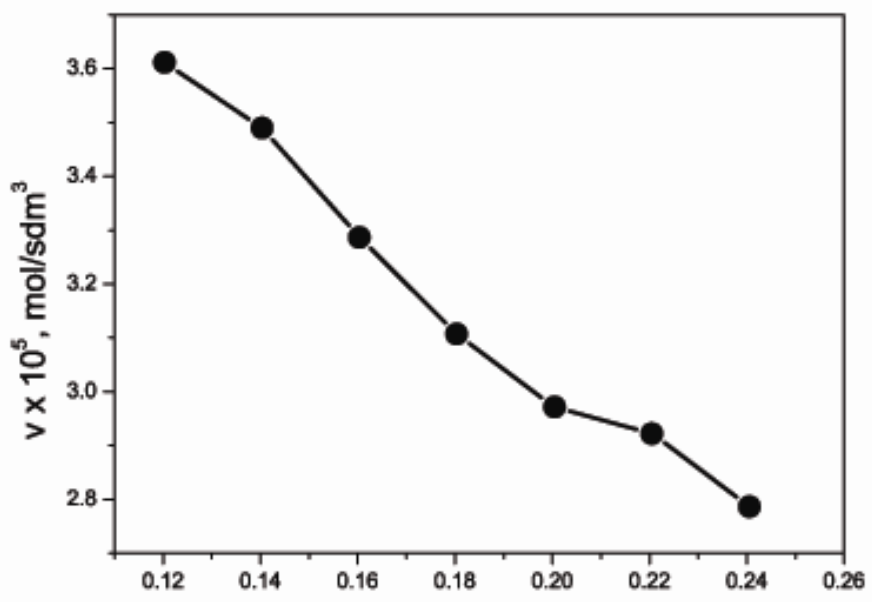

[S]

a)

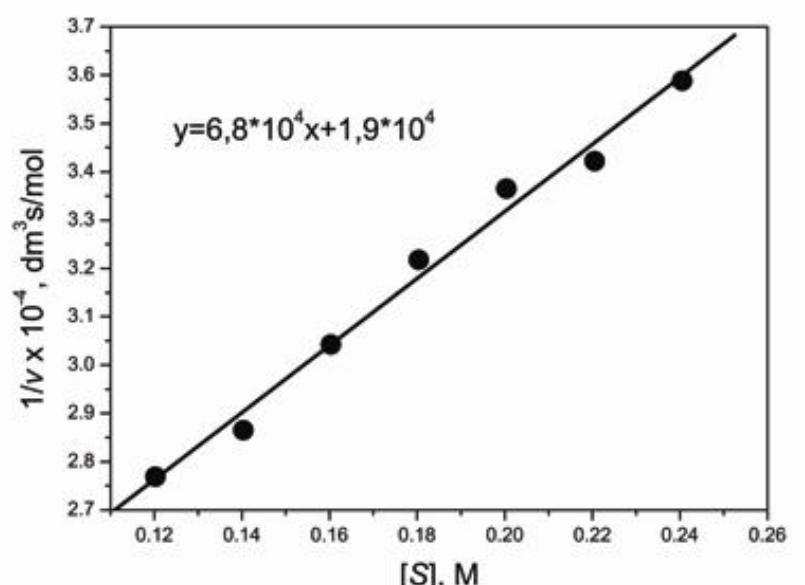

b)

Slika 7.7. a) Zavisnost početne brzine reakcije katalizovane slobodnom PAC od koncentracije Pen G. Reakcioni uslovi: koncentracija Pen $G$ od 0,12 do 0,24 M, koncentracija enzima $0,006 \mathrm{~cm}^{3} / \mathrm{cm}^{3}, 0,1 \mathrm{M}$ natrijum-fosfatni pufer pH 7,92, temperatura $37^{\circ} \mathrm{C}$; b) Zavisnost recipročne vrednosti početne brzine reakcije od koncentracije supstrata u slučaju slobodne PAC. Dijagram je određen na osnovu vrednosti prikazanih na slici 7.7 a) 
Na osnovu jednačine 1.4. i prikazanih rezultata na slici 7.7. dobijena je vrednost konstante inhibicije supstratom u višku $\left(K_{\mathrm{s}}\right)$ za slobodnu PAC od 0,286 $\mathrm{mol} / \mathrm{dm}^{3}$. Prema tome, vrednost $K_{\mathrm{M}}\left(9,14 \cdot 10^{-3} \mathrm{~mol} / \mathrm{dm}^{3}\right)$ slobodne PAC je oko 31 puta niža, nego odgovarajuća vrednost $K_{\mathrm{S}}\left(0,286 \mathrm{~mol} / \mathrm{dm}^{3}\right)$, ukazujući na relativno slabu inhibiciju penicilinom G.

\subsubsection{Ispitivanje početne kinetike u prisustvu proizvoda reakcije}

Hidroliza penicilina $G$ pomoću enzima penicilin-acilaze može biti inhibirana proizvodima reakcije: 6-aminopenicilanskom kiselinom (6-APA) i fenilsirćetnom kiselinom (PAA).

\subsubsection{Ispitivanje uticaja početne koncentracije 6-aminopenicilanske kiseline na} početnu brzinu reakcije.

Da bi se utvrdilo da li dolazi do inhibicije reakcije jednim od proizvoda reakcije, 6-APA, ispitana je zavisnost početne brzine reakcije od početne koncentracije supstrata u prisustvu različitih koncentracija 6-APA koje su iznosile: 1\%, 1,5\%, 1,75\% i $2 \% \mathrm{w} / \mathrm{v}$. Dobijeni rezultati su prikazani na slici 7.8. za slobodnu PAC. 


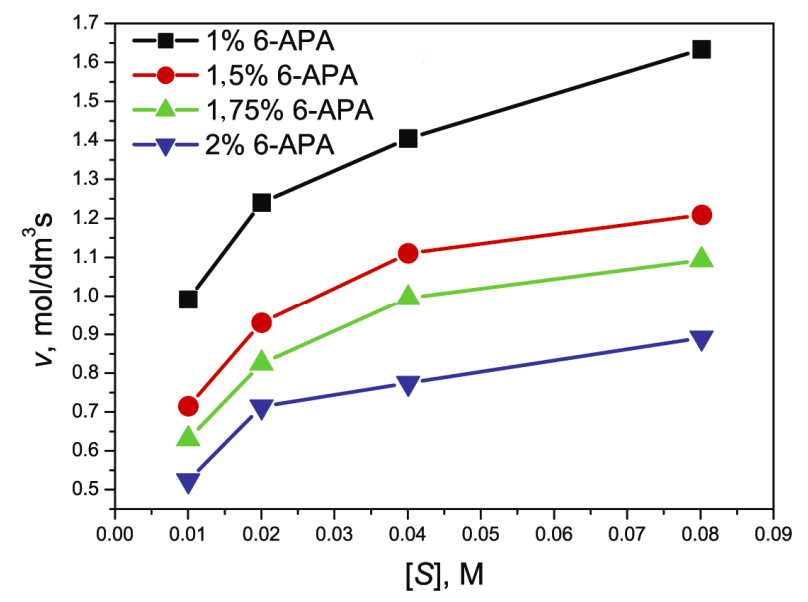

Slika 7.8. Uticaj koncentracija inhibitora 6-APA na zavisnost početne brzine reakcije od koncentracije Pen G za slobodnu PAC. Uslovi odigravanja reakcije: koncentracija Pen G od 0,01 do 0,08 M, koncentracija inhibitora 6-APA od 1\% do 2\%, 3min., $37^{\circ} \mathrm{C}$, 0,1 M natrijum-fosfatni pufer ( $\mathrm{pH} 7,92)$

Iz prikazanih zavisnosti (slika 7.8.) uočava se da proizvod reakcije 6-APA inhibira reakciju hidrolize penicilina G u slučaju slobodne PAC. U cilju utvrđivanja vrste inhibicije prikazan je Lajnviver-Berkov dijagram za slobodnu PAC (slika 7.9.).

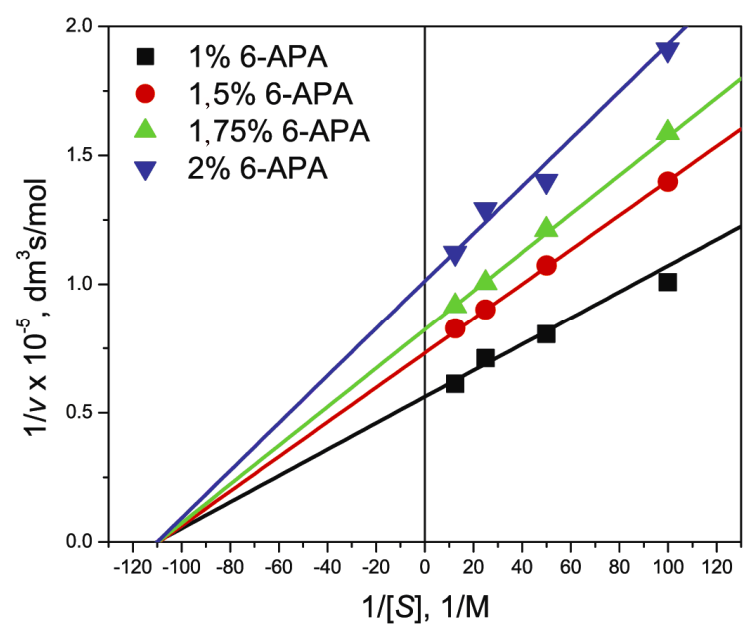

Slika 7.9. Lajnviver-Berkov dijagram za slobodnu PAC и slučaju 6-APA kao inhibitora 
Sa Lajnviver-Berkovog dijagrama se uočava da je u pitanju klasična nekompetitivna inhibicija PAC proizvodom reakcije (6-APA). U cilju kvantitativnog određivanja jačine inhibicije određena je konstanta inhibicije za slobodnu PAC (slika 7.10.).

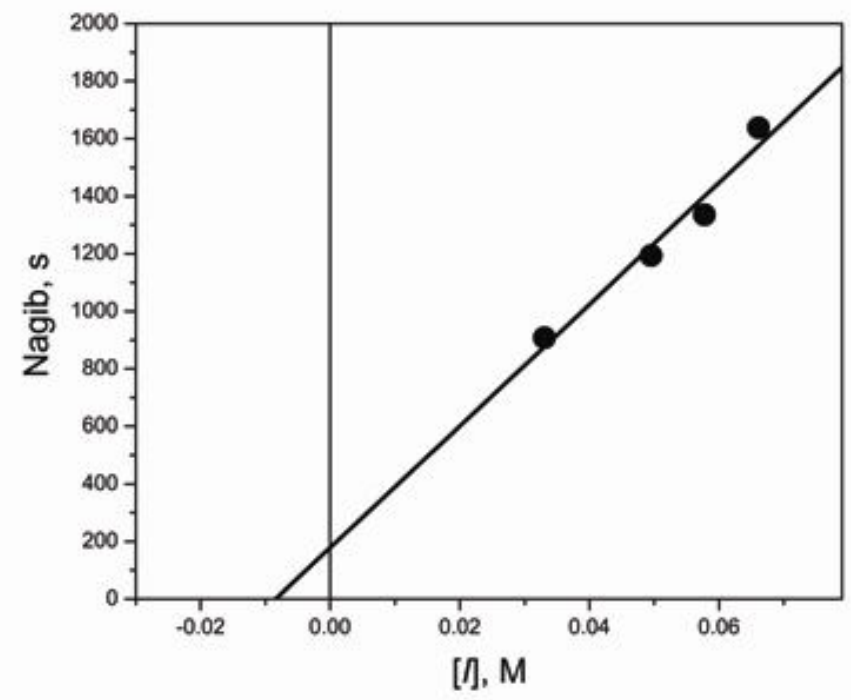

Slika 7.10. Zavisnost nagiba iz Lajnviver-Berkovog dijagrama od koncentracije inhibitora (6-APA) za slobodnu PAC

$\mathrm{Na}$ osnovu slike 7.10. dobijena je vrednost konstante inhibicije za slobodnu PAC od $8,45 \cdot 10^{-3}$ M. Inhibitor (6-APA) se vezuje za enzim i na taj način smanjuje početnu brzinu reakcije koja se postiže sa datom početnom količinom supstrata. Što je koncentracija inhibitora (6-APA) veća, brzina reakcije je manja.

\subsubsection{Ispitivanje uticaja početne koncentracije fenilsirćetne kiseline na početnu brzinu reakcije}

Da bi se utvrdilo da li dolazi do inhibicije reakcije drugim proizvodom reakcije, PAA, ispitana je zavisnost početne brzine reakcije od početne koncentracije supstrata u prisustvu različitih koncentracija PAA koje su iznosile: 1\%, 1,5\%, 1,75\% i $2 \% \mathrm{w} / \mathrm{v}$.

Dobijeni rezultati su prikazani na slici 7.11. 


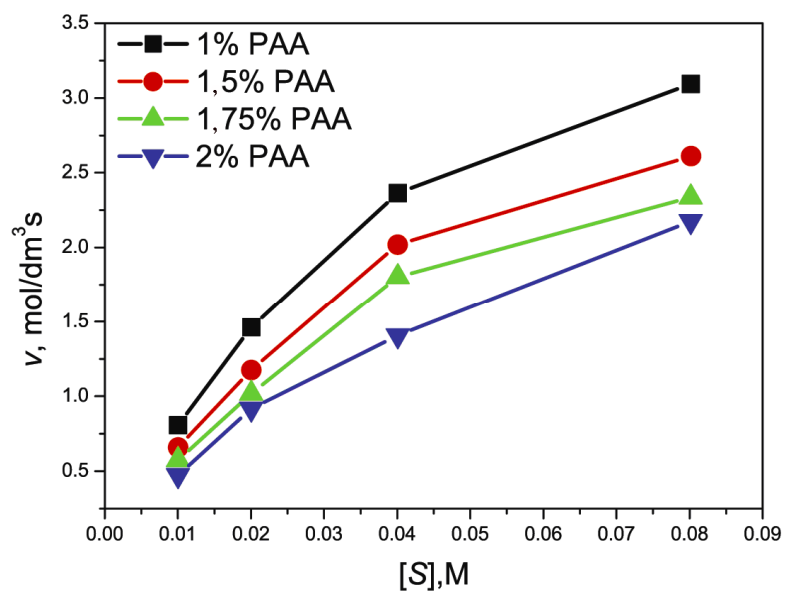

Slika 7.11. Uticaj različitih koncentracija inhibitora PAA na zavisnost brzine reakcije od koncentracije Pen G za slobodnu PAC. Uslovi odigravanja reakcije: koncentracija Pen G od 0,01 do 0,08 M, koncentracija inhibitora PAA od $1 \%$ do 2\%, 3min., $37^{\circ} \mathrm{C}$, 0,1M natrijum-fosfatni pufer $(\mathrm{pH} 7,92)$

Iz prikazane zavisnosti (slika 7.11.) uočava se da proizvod reakcije PAA inhibira reakciju hidrolize penicilina G u slučaju slobodne PAC. U cilju utvrđivanja vrste inhibicije prikazan je Lajnviver-Berkov dijagram za slobodnu PAC (slika 7.12.)

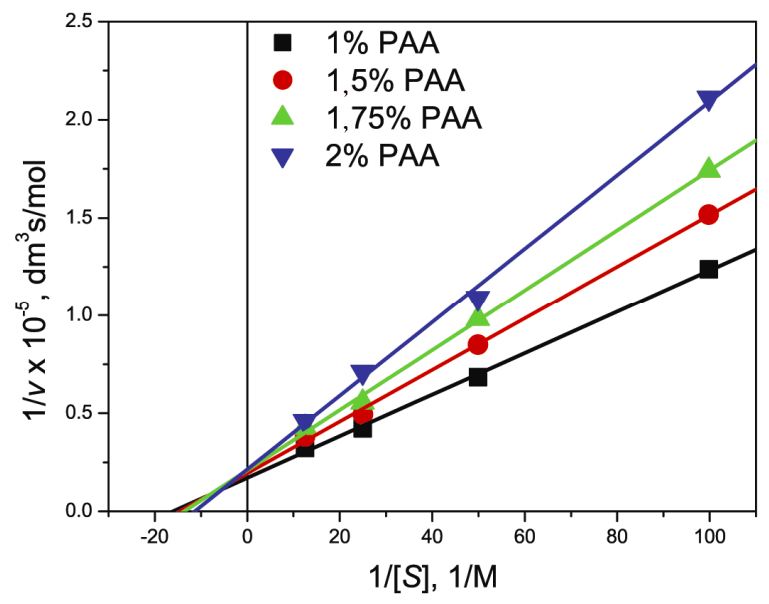

Slika 7.12. Lajnviver-Berkov dijagram za slobodnu PAC u slučaju PAA kao inhibitora 
Sa Lajnviver-Berkovog dijagrama se uočava da je u pitanju klasična kompetitivna inhibicija enzima proizvodom reakcije (PAA). U cilju kvantitativnog određivanja jačine inhibicije određena je konstanta inhibicije za slobodnu PAC (slika 7.13.).

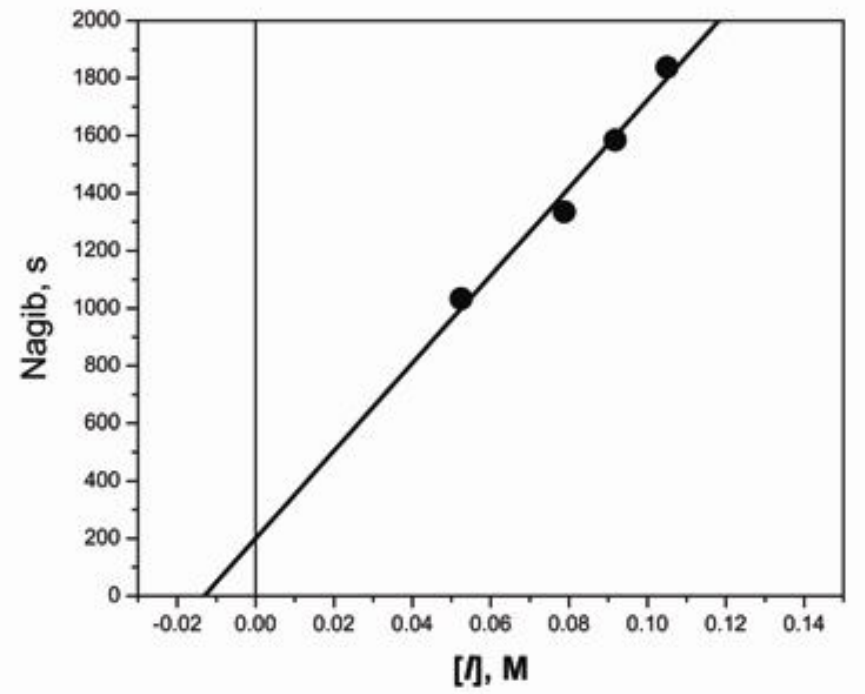

Slika 7.13. Zavisnost nagiba iz Lajnviver-Berkovog dijagrama od koncentracije inhibitora (PAA) za slobodnu PAC

Na osnovu slike 7.13 određena je dobijena je vrednost konstante inhibicije za slobodnu PAC od $11,7 \cdot 10^{-3}$.

Svi rezultati određivanja kinetičkih konstanti su sumirani u tabeli 7.1.

Tabela 7.1. Vrednosti $V_{\mathrm{M}}, K_{\mathrm{M}}$, konstante inhibicije i kritične koncentracije penicilina G, kao i konstante inhibicije u slučaju 6-APA i PAA kao inhibitora

\begin{tabular}{lllllll}
\hline & $\begin{array}{lllll}V_{\mathrm{M}} \cdot 10^{5}, \\
\mathrm{~mol} / \mathrm{dm}^{3} \mathrm{~s}\end{array}$ & $\begin{array}{c}K_{\mathrm{M}} \cdot 10^{3}, \\
\mathrm{M}\end{array}$ & $\begin{array}{l}K_{\mathrm{s}}, \\
\mathrm{M}\end{array}$ & $\begin{array}{l}\text { Kritična } \\
\text { koncentracija } \\
\text { Pen G, M }\end{array}$ & $\begin{array}{l}K_{\mathrm{iA}} \cdot 10^{3}, \\
\mathrm{M}\end{array}$ & $\begin{array}{l}K_{\mathrm{iB}} \cdot 10^{3}, \\
\mathrm{M}\end{array}$ \\
\hline $\begin{array}{l}\text { Slobodna } \\
\text { PAC }\end{array}$ & 5,13 & 9,14 & 0,286 & 0,1 & 8,45 & 11,7 \\
\hline
\end{tabular}


Pokazano je da slobodnu PAC inhibira supstrat u višku i oba proizvoda reakcije, pri čemu je 6-APA nekompetitivni, a PAA kompetitivni inhibitor. Takođe, može da se zaključi da je 6-APA jači inhibitor nego PAA.

\subsubsection{Kinetički izraz za reakciju katalizovanu slobodnom penicilin acilazom u šaržnom sistemu}

$\mathrm{Na}$ osnovu dobijenih kinetičkih rezultata proizilazi da je sistem sa slobodnom PAC podložan inhibiciji supstratom u višku, kao i da oba proizvoda reakcije deluju inhibitorno. Utvrđeno je da je 6-APA nekompititivni, dok je PAA kompetitivni inhibitor slobodne PAC.

$\mathrm{Na}$ osnovu dobijenih kinetičkih konstanti jednačina početne brzine reakcije $\mathrm{u}$ slučaju slobodne PAC je prema jednačini 1.5:

$$
v_{\mathrm{i}}=\frac{5,13 \cdot 10^{-5}[\mathrm{~S}]}{\left(1+\frac{[\mathrm{P}]}{8,45 \cdot 10^{-3}}\right) \cdot\left([\mathrm{S}]+9,14 \cdot 10^{-3}\left(1+\frac{[\mathrm{Q}]}{11,7 \cdot 10^{-3}}\right)\right)+\frac{[\mathrm{S}]^{2}}{0,286}}
$$

gde je $v_{\mathrm{i}}$ početna brzina reakcije $(\mathrm{M} / \mathrm{s}),[\mathrm{S}]$ koncentracija supstrata Pen $\mathrm{G}(\mathrm{M}),[\mathrm{Q}]$ koncentracija fenilsirćetne kiseline $(\mathrm{M}),[P]$ koncentracija 6-aminopenicilanske kiseline (M) 


\section{Zaključak}

U ovom delu rada je izvršena karakterizacija slobodnog enzima penicilinacilaze iz Escherichia coli, komercijalnog enzimskog preparata proizvođača DSM (Holandija).

$\mathrm{Na}$ osnovu dobijenih rezultata određena su sledeća svojstva komercijalnog enzimskog preparata:

1. Sadržaj proteina u komercijalnom enzimskom preparatu je $56,13 \mathrm{mg} / \mathrm{cm}^{3}$.

2. Specifična aktivnost slobodnog enzima pod standardnim uslovima $(2 \%(\mathrm{w} / \mathrm{v})$ PenG u 0,1 M Na-fosfatnom puferu $\mathrm{pH} 7,92, \mathrm{t}=37^{\circ} \mathrm{C}$ ) iznosi 2,27 IU $/ \mathrm{mg}$ čistog enzima.

3. Optimalna $\mathrm{pH}$ vrednost slobodne penicilin-acilaze pod standardnim uslovima (2\% (w/v) PenG u 0,1 M Na-fosfatnom puferu $\left.\mathrm{pH} 7,92, \mathrm{t}=37^{\circ} \mathrm{C}\right)$ iznosi 8,60, dok je enzim aktivan u širem intervalu $\mathrm{pH}$ vrednosti od 6,2 do 8,6.

4. Optimalna temperatura slobodne penicilin-acilaze pod standardnim uslovima (2\% (w/v) PenG u 0,1 M Na-fosfatnom puferu $\mathrm{pH}=7,92)$ iznosi $37^{\circ} \mathrm{C}$.

5. Konstanta brzine dezaktivacije slobodne penicilin-acilaze je 2,320 $\mathrm{h}^{-1}$, a poluvreme dezaktivacije iznosi $0,30 \mathrm{~h}$.

$\mathrm{Na}$ osnovu rezultata koji su dobijeni $\mathrm{u}$ toku ispitivanja uticaja početne koncentracije supstrata (Pen G) i proizvoda reakcije (6-APA i PAA) na početnu brzinu reakcije u slučaju slobodne PAC mogu se izvesti sledeći zaključci.

1. Do inhibicije supstratom u višku dolazi pri koncentracijama supstrata većim od $0,1 \mathrm{M}$.

2. Proizvod reakcije 6-APA inhibira reakciju hidrolize penicilina G slobodnom PAC. Na osnovu dobijenih rezultata utvrđeno je da je u pitanju klasična nekompetitivna inhibicija, a vrednost konstante inhibicije je $8,45 \cdot 10^{-3} \mathrm{M}$.

3. Proizvod reakcije PAA takođe inhibira reakciju hidrolize penicilina G slobodnom PAC. Na osnovu dobijenih rezultata utvrđeno je da je u pitanju klasična kompetitivna inhibicija, sa konstantom inhibicije od $11,7 \cdot 10^{-3} \mathrm{M}$. 


\section{IMOBILIZACIJA PENICILIN-ACILAZE NA KOMERCIJALNE POLIMETAKRILATNE SEPABEADS NOSAČE KONVENCIONALNOM METODOM}

Cilj ove doktorske teze je bio da se razvije efikasan imobilisani sistem sa PAC na komercijalnim polimetakrilatnim nosačima i to Sepabeads EC-EP, Sepabeads EC-EA i Sepabeads EC-HA. Ovo podrazumeva razvoj metode imobilizacije i optimizaciju uslova imobilizacije sa aspekta masenog prinosa imobilizacije i prinosa aktivnosti. Ovi nosači su interesantni jer imaju odlična svojstva za potencijalnu industrijsku primenu i, na osnovu literaturnih podataka, dobijaju se stabilni biokatalizatori velike specifične aktivnosti u slučaju imobilizacije na ove nosače. U ovom delu rada je prvo ispitana mogućnost primene konvencionalne metode imobilizacije koju je preporučio proizvođač nosača u slučaju penicilin-acilaze.

Sepabeads EC-EP nosač ima ugrađene epoksidne funkcionalne grupe, tako da se enzim imobiliše na njega tako što amino grupe enzima direktno reaguju sa epoksidnim grupama nosača. Sepabeads EC-EA i Sepabeads EC-HA nosači poseduje amino grupu koja je preko dve i šest metilenskih grupa, redom, vezana za polimetakrilatnu osnovu. Da bi se enzim imobilisao na njih, nosači se prethodno moraju aktivirati, npr. sa glutaraldehidom, tako da se na njih uvode aldehidne grupe, za koje se, sada, potencijalno mogu vezati amino grupe enzima.

U radu su imobilizati dobijeni po ovim konvencionalnim metodama okarakterisani, određena je optimalna temperatura, $\mathrm{pH}$ i termalna stabilnost, kao i prinos imobilizacije i aktivnosti. Rezultati su upoređeni i prodiskutovani.

\subsection{Imobilizacija penicilin-acilaze na Sepabeads EC-EP}

Penicilin-acilaza se može kovalentno imobilisati na komercijalni polimetakrilatni nosač, Sepabeads EC-EP (slika 8.1.), koji već ima ugrađene epoksidne funkcionalne grupe, čak i bez prethodne aktivacije nosača. Enzim se imobiliše na ovaj nosač tako što amino grupe enzima direktno reaguju sa epoksidnim grupama nosača. 


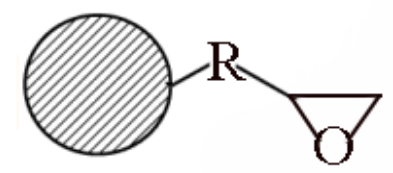

Slika 8.1. Sepabeads EC-EP nosač

\subsubsection{Ispitivanje uticaja uslova imobilizacije na svojstva imobilisane penicilin- acilaze na Sepabeads EC-EP}

Ispitan je uticaj početne koncentracije enzima $u$ intervalu od 0,0025 do $0,040 \mathrm{~cm}^{3} / \mathrm{cm}^{3}$ na masu i aktivnost imobilisanog enzima. Kako je u prvom delu rada određen sadržaj proteina u enzimskom preparatu, koji iznosi $56,13 \mathrm{mg} / \mathrm{cm}^{3}$, mogu se odrediti i početne koncentracije proteina u rastvoru za imobilizaciju. One su se nalazile $\mathrm{u}$ intervalu od 0,140 do $2,245 \mathrm{mg} / \mathrm{cm}^{3}$. Imobilizacija je vršena po metodi opisanoj $\mathrm{u}$ poglavlju 6.2.2.1.

Stepen hidrofobnosti nosača, f je određen po metodi opisanoj u poglavlju 6.2.2.3. i njegova vrednost je iznosila 3,58. On predstavlja odnos početne mase vlažnog nosača i osušenog nosača do konstantne mase. Tako da se rezultati mogu izraziti po masi suvog nosača.

Ispitan je uticaj početne koncentracije enzima $u$ intervalu od 0,140 do $2,245 \mathrm{mg} / \mathrm{cm}^{3}$ na masu imobilisanog enzima i rezultati su prikazani na slici 8.2 . Lako se uočava da sa povećanjem početne koncentracije rastvora enzima za imobilizaciju gotovo linearno raste i masa imobilisanog enzima. Najveća masa vezanog enzima $\left(P_{\mathrm{g}}\right)$ je bila 133,6 mg proteina/g suvog nosača pri čemu je maseni procenat imobilizacije iznosio 96,9\%. Ova masa vezane penicilin-acilaze za Sepabeads EC-EP je veća od vrednosti pronađenih u literaturi za druge enzime. Na primer, istom metodom imobilizacije za lipazu B iz Candida antartica na Sepabeads EC-EP dobijena je vrednost $P_{\mathrm{g}}$ od 117,9 mg/g suvog nosača [215]. Za lipazu iz Candida rugosa dobijena je vrednost $P_{\mathrm{g}}$ od 109,2 $\mathrm{mg} / \mathrm{g}$ suvog nosača [216]. Za fruktoziltransferazu imobilisanu na Sepabeads EC-EP3 i Sepabeads EC-EP5 dobijene su znatno manje vrednosti $P_{\mathrm{g}}$ od $31,4 \mathrm{mg} / \mathrm{g}$ suvog nosača i od 54,7 mg/g suvog nosača [217], redom, što je verovatno 
posledica različitih svojstava enzima koji se imobilišu, naročito različite koncentracije funkcionalnih grupa na površini molekula enzima koje su dostupne za vezivanje sa nosačem.

Interesantno je da se i maseni procenat imobilizacije povećava sa povećanjem početne koncentracije enzima što je prikazano na slici 8.2. Maseni prinos imobilizacije $\left(\eta_{\text {enz }}\right)$ se naglo povećava sa povećanjam početne koncentracije enzima do oko $0,56 \mathrm{mg} / \mathrm{cm}^{3}$ kada dostiže oko $95 \%$ i nakon toga se zadržava oko te vrednosti $(96,7 \pm 1,4 \%)$. Dobijena vrednost $\eta_{\text {enz }}$ je veća od vrednosti koje su dobijene za lipazu iz Candida rugosa imobilisanu na Sepabeads EC-EP (78\%) primenom iste metode imobilizacije [216].

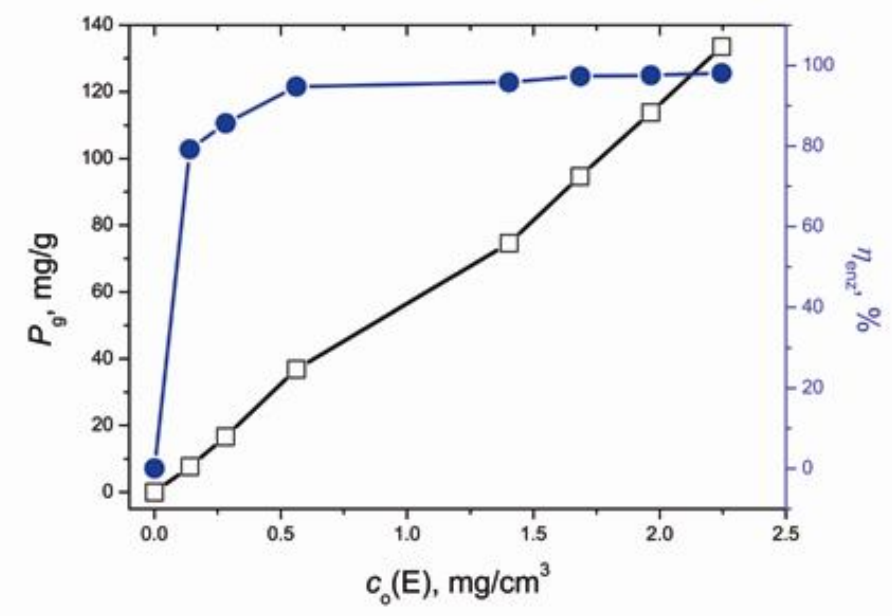

Slika 8.2. Uporedni dijagram zavisnosti mase vezane $P A C\left(P_{g}\right)$ i masenog prinosa imobilizacije $\left(\eta_{\text {enz }}\right)$ od početne koncentracije PAC $\left(c_{o}\right)$. Uslovi imobilizacije: $0,5 \mathrm{~g}$ Sepabead EC-EP nosača, $48 \mathrm{~h}, 25^{\circ} \mathrm{C}, 1,25$ M kalijum-fosfatni pufer $(\mathrm{pH} 8,0)$

Sa aspekta primene imobilisanog enzima mnogo je značajnija aktivnost imobilisanog enzima od mase imobilisanog enzima. Na slici 8.3. je prikazana zavisnost aktivnosti imobilisanog enzima od mase vezane PAC i lako se uočava da aktivnost imobilisanog enzima skoro linearno raste sa povećanjem mase vezane PAC. 


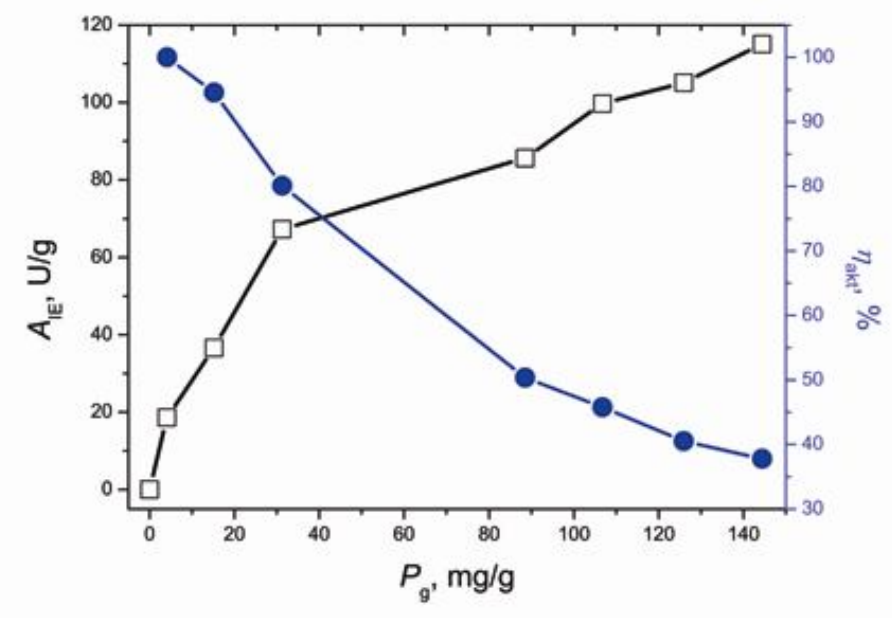

Slika 8.3. Uporedni dijagram zavisnosti aktivnosti imobilisane PAC $\left(A_{I E}\right)$ i prinosa aktivnosti $\left(\eta_{\text {akt }}\right)$ od mase vezane PAC $\left(P_{g}\right)$. Uslovi imobilizacije: 0,5 g Sepabeads ECEP nosača, $48 \mathrm{~h}, 25^{\circ} \mathrm{C}, 1,25 \mathrm{M}$ kalijum-fosfatni pufer $(\mathrm{pH} 8,0)$

Da bi uporedili aktivnosti slobodnog i imobilisanog enzima, izračunat je prinos aktivnosti imobilizacije ( $\eta_{\mathrm{akt}}$ ) (jednačina 6.7.). Za date mase vezanog enzima, prinos aktivnosti je iznosio od $\approx 100 \%$ za najmanju masu vezanog enzima $(4,03 \mathrm{mg} / \mathrm{g})$ do $37,8 \%$ za masu vezanog enzima od 144,4 mg/g. Za D-aminokiselinsku oksidazu iz Trigonopsis variabilis imobilisanu na Sepabeads EC-EP dobijena je maksimalna vrednost $\eta_{\text {akt }}$ od $50 \%$, što je znatno manje od maksimalne vrednosti $\eta_{\text {akt }}$ dobijene u ovom radu [218]. U najboljem slučaju, imobilisana PAC zadržava 100\% aktivnosti slobodne PAC. Ovaj rezultat ukazuje da su primenjeni komercijalni nosač (Sepabeads EC-EP) i metoda imobilizacije izuzetno odgovarajući za imobilizaciju penicilin-acilaze iz E. coli jer enzim zadržava aktivnost u velikom procentu.

\subsubsection{Ispitivanje uticaja temperature na aktivnost penicilin-acilaze imobilisane na Sepabeads EC-EP}

Uticaj temperature na aktivnost imobilisanog enzima je ispitan po metodi opisanoj u poglavlju 6.2.2.5., pri kojoj se koristio imobilisani enzim čija je aktivnost 
85,6 IU/g nosača, odnosno čiji je prinos aktivnosti $\eta_{\text {akt }}$ iznosio 50,3\%. Standardni uslovi za ovaj ogled su bili: radna koncentracija supstrata iznosila je 2\% (w/v) PenG u 0,1 M natrijum-fosfatnom puferu $\mathrm{pH} 7,92$, dok se temperatura menjala $\mathrm{u}$ intervalu od $21-75^{\circ} \mathrm{C}$.

Na slici 8.4. prikazan je uporedni dijagram zavisnosti aktivnosti slobodne PAC i imobilisane PAC od temperature, koji je pogodniji za uočavanje nastalih razlika $\mathrm{u}$ temperaturnom profilu između ove dve formulacije enzima. Optimalna temperatura imobilisanog enzima je $41{ }^{\circ} \mathrm{C}$ i malo se pomerila ka višim temperaturama u odnosu na onu za slobodni enzim koja je iznosila $37{ }^{\circ} \mathrm{C}$, ali je interval temperature u kome je imobilisani enzim aktivan ostao uzak. Slično, za penicilin-acilazu iz Streptomyces lavendulae imobilisanu na Sepabeads EC-EP 303 u reakciji hidrolize penicilina V dobijeno je povećanje optimalne temperature od $5{ }^{\circ} \mathrm{C}$ u odnosu na optimalnu temperaturu slobodne PAC [219], kao i u drugom radu, gde je zabeleženo povećanje optimalne temperature nakon imobilizacije fitaze na Sepabeads EC-EP od $8{ }^{\circ} \mathrm{C}$ [220]. Sa druge strane, optimalna temperatura imobilisane lipaze na Sepabeads EC-EP je bila niža nego što je optimalna temperatura slobodne lipaze [216]. Može se zaključiti da imobilizacija nije doprinela stabilizaciji enzima kakva je očekivana i da je interval temperature u kome imobilisani enzim zadržava svoju aktivnost ostao uzak.

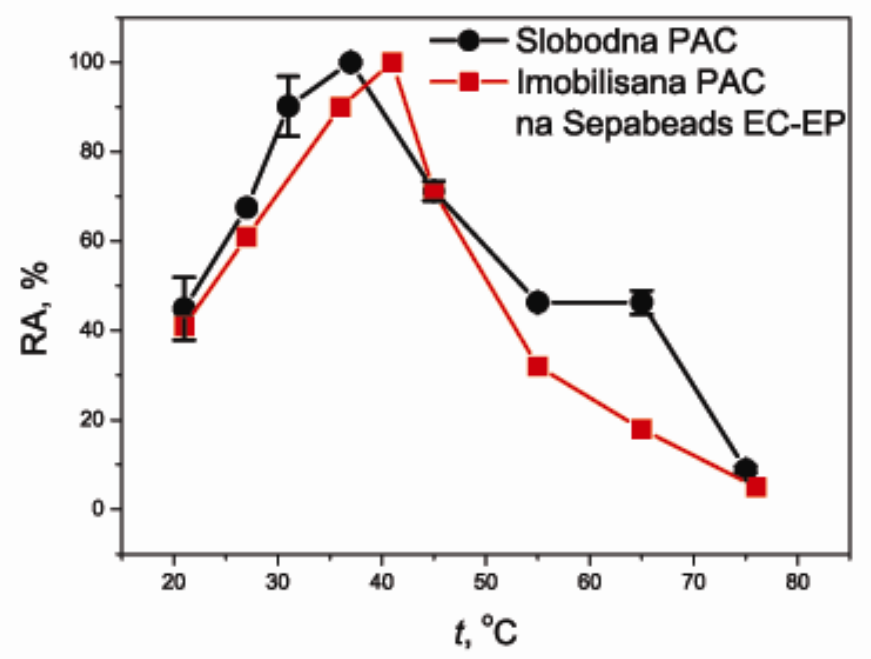

Slika 8.4. Zavisnost relativne aktivnosti (RA) slobodne $i$ imobilisane $P A C$ od temperature. Uslovi reakcije: 0,1 Mnatrijum-fosfatni pufer ( $\mathrm{pH}$ 7,92), $3 \mathrm{~min}$ 


\subsubsection{Ispitivanje uticaja $\mathrm{pH}$ na aktivnost penicilin-acilaze imobilisane na Sepabeads EC-EP}

Zavisnost aktivnosti imobilisanog enzima od $\mathrm{pH}$ vrednosti je ispitan metodom opisanom u poglavlju 6.2.2.6., pri čemu se koristio imobilisani enzim čija je aktivnost bila 85,6 IU/g nosača, odnosno čiji je prinos aktivnosti iznosio 50,3\%. Standardni uslovi za ovaj ogled su bili: radna koncentracija supstrata iznosi 2\% (w/v) PenG u 0,1M puferima različitih $\mathrm{pH}$ vrednosti (od 4,50-9,30) na temperaturi od $37^{\circ} \mathrm{C}$. Na slici 8.5. su prikazani $\mathrm{pH}$ profili dobijeni za slobodni i imobilisani enzim. Primećuje se da se za imobilisani enzim nešto promenio $\mathrm{pH}$ profil, što je vrlo moguće, zbog promenjene mikrookoline enzima. Dobijeni pH optimum za imobilisani enzim je nešto uži i pomeren je ka alkalnoj sredini. Imobilizacija enzima doprinosi stabilnosti enzima u alkalnoj sredini. Sveukupno, može se zaključiti da se $\mathrm{pH}$ profil enzima neznatno menja nakon imobilizacije na komercijalnom epoksidnom nosaču (Sepabeads EC-EP) što je i očekivano jer je površina nosača nenaelektrisana, pa efekti raspodele jona vodonika ne dolaze do izražaja. Slično, pH optimum za imobilisanu penicilin-acilazu iz Streptomyces lavendulae na Sepabeads EC-EP je bio za $1,5 \mathrm{pH}$ jedinicu niži nego što je pH optimum slobodne penicilin-acilaze [219]. Sa druge strane, za lipazu i fitazu imobilisanu na Sepabeads EC-EP dobijeni su isti pH optimumi kao i za slobodne enzime [216, 220]. Ovi rezultati ukazuju na neophodnost optimizacije postupka imobilizacije na neki nosač u slučaju svakog pojedinačnog enzima, pa čak i istog enzima različitog mikrobiološkog porekla. 


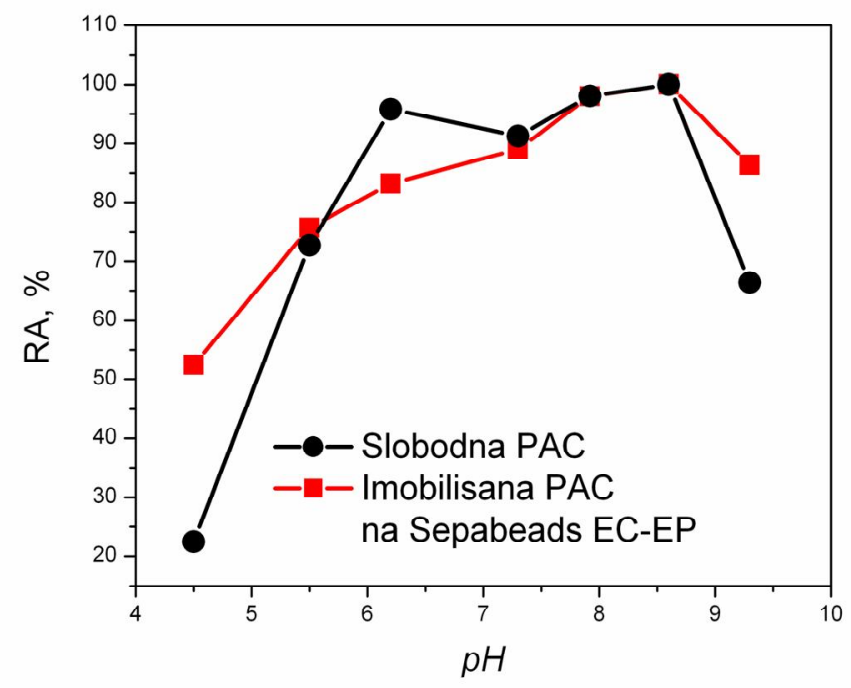

Slika 8.5. Zavisnost relativne aktivnosti (RA) imobilisanei slobodne PAC od pH vrednosti. Uslovi reakcije: $37^{\circ} \mathrm{C}, 3 \mathrm{~min}, 0,1 \mathrm{M}$ puferi: acetatni puferi $(\mathrm{pH} 4,5 \mathrm{i} \mathrm{pH}$ 5,5), fosfatni puferi (pH 6,2, pH 7,3 i pH 7,9) i tris/HCl puferi (pH 8,6 i pH 9,3)

\subsubsection{Ispitivanje uticaja imobilizacije penicilin-acilaze na Sepabeads EC-EP na stabilnost biokatalizatora}

Jedan od osnovnih ciljeva imobilizacije enzima je njegova stabilizacija. Zbog toga je ispitana termalna stabilnost enzima na $50{ }^{\circ} \mathrm{C}$ po metodi opisanoj u poglavlju 6.2.2.7. Rezultati su prikazani na slici 8.6.

Sa slike 8.6. se vidi da imobilizacija enzima na Sepabeads EC-EP doprinosi njegovoj stabilizaciji. Da bi se rezultati izrazili kvantitativno, eksperimentalni rezultati su modelovani kinetičkim modelom inaktivacije prvog reda (jednačina 6.2.). Na osnovu modela dobijena je vrednost konstante brzine inaktivacije $\left(k_{\mathrm{D}}\right)$ za imobilisan enzim od $0,41 \mathrm{~h}^{-1}$. Na osnovu toga se zaključuje da se slobodna PAC $\left(k_{\mathrm{D}}=2,32 \mathrm{~h}^{-1}\right)$ značajno brže inaktivira od imobilisane PAC.

Izračunato poluvreme inaktivacije PAC imobilisane na Sepabeads EC-EP iznosi 1,7 h (jednačina 6.4.) Na osnovu dobijenih rezultata, može se izračunati da se enzim stabilizovao 5,67 puta (jednačina 6.5.). Dobijeni faktor stabilizacije (F) je bolji od 
faktora stabilizacije od 1,7 koji je dobijen za D-aminokiselinsku oksidazu imobilisanu na Sepabeads EC-EP čija termostabilnost je takođe ispitana na $50{ }^{\circ} \mathrm{C}$. Isto tako, i u slučaju L-aspartat $\alpha$-dekarboksilaze iz Escherichia coli i saharoza fosforilaze, čije termostabilnosti su ispitane na $80{ }^{\circ} \mathrm{C}$ i $60{ }^{\circ} \mathrm{C}$, redom, nije došlo do poboljšanja termostabilnosti nakon imobilizacije na Sepabeads EC-EP [218, 221, 222]. Međutim, faktor stabilizacije određen u ovom radu još uvek nije dovoljan za potencijalnu industrijsku primenu ovako imobilisanog enzima.

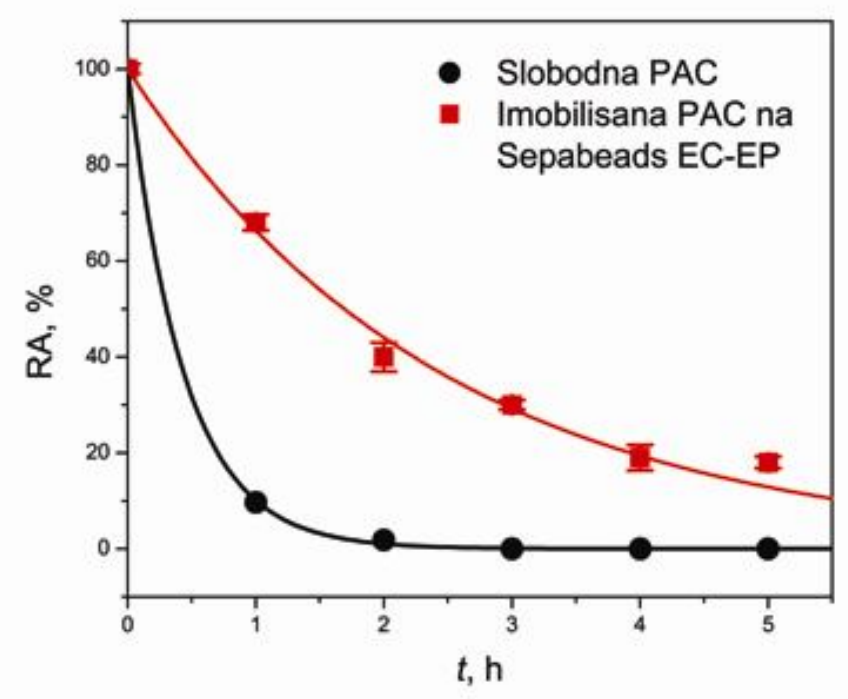

Slika 8.6. Zavisnost relativne aktivnosti slobodne PAC i imobilisane na Sepabeads ECEP od vremena. Biokatalizatori su se termostatirali $n a 50^{\circ} \mathrm{C}$ u različitim vremenskim periodima, a zatim se ispitivala aktivnost tretiranih biokatalizatora u standardnoj reakciji. Uslovi reakcije: 0,1 M natrijum-fosfatni pufer $(\mathrm{pH}=7,92), t=37^{\circ} \mathrm{C}, 3 \mathrm{~min}$

\subsection{Imobilizacija penicilin-acilaze na Sepabeads EC-EA i Sepabeads EC-HA}

Penicilin-acilaza je imobilisana na komercijalnim polimetakrilatnim nosačima Sepabeads EC-EA i Sepabeads EC-HA primenom konvencionalnog postupka koji je preporučio sam proizvođač ovih nosača i koji je primenjen u slučaju velikog broja enzima. Sepabeads EC-EA i Sepabeads EC-HA poseduju amino grupu koja je preko 
dve i šest metilenskih grupa vezana za polimetakrilatnu osnovu (slika 8.7.). Da bi se enzim imobilisao na ove nosače, oni se prethodno aktiviraju glutaraldehidom, tako da se na njih uvode aldehidne gupe, za koje se mogu vezati amino grupe enzima.

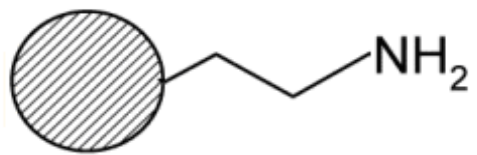

a)

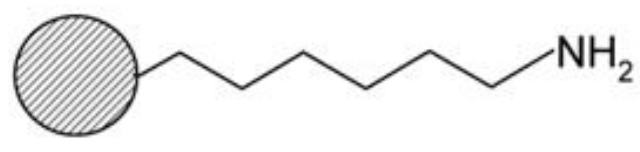

b)

Slika 8.7. Šematski prikaz amino grupa na komercijalnim nosačima: a) Sepabeads ECEA $i$ b) Sepabeads EC-HA

\subsubsection{Ispitivanje uticaja uslova imobilizacije na svojstva imobilisane penicilin- acilaze na Sepabeads EC-EA i Sepabeads EC-HA}

Za vezivanje enzima na nosače korišćena je konvencionalna metoda imobilizacije opisana u poglavlju 6.2.2.2. Varirana je početna koncentracija enzima u rastvoru za imobilizaciju u intervalu od 0,0025 do $0,040 \mathrm{~cm}^{3} / \mathrm{cm}^{3}$. Kako je u prvom delu rada određen sadržaj proteina u enzimskom preparatu, koji iznosi $56,13 \mathrm{mg} / \mathrm{cm}^{3}$, mogu se odrediti i početne koncentracije enzima u rastvoru za imobilizaciju. One su se nalazile $\mathrm{u}$ intervalu od $0,140 \mathrm{do} 2,245 \mathrm{mg} / \mathrm{cm}^{3}$. Određene su mase vezanog enzima $\mathrm{i}$ to indirektno na osnovu koncentracije zaostalog enzima $u$ filtratu (metoda opisana $u$ poglavlju 6.2.2.2.) i aktivnost biokatalizatora u zavisnosti od mase vezanog enzima (metoda opisana u poglavlju 6.2.2.4.). Rezultati su prikazani na slikama 8.8. i 8.9.

Određen je i stepen hidrofobnosti nosača, f i dobijene su vrednosti 3,33 i 2,33 za Sepabeads EC-EA i Sepabeads EC-HA redom. Stepen hidrofobnosti Sepabeads ECEA je neznatno manji u odnosu na stepen hidrofobnosti Sepabeads EC-EP (f=3,58), dok se Sepabeads EC-HA pokazao kao manje hidrofilan nosač od prethodnih. 


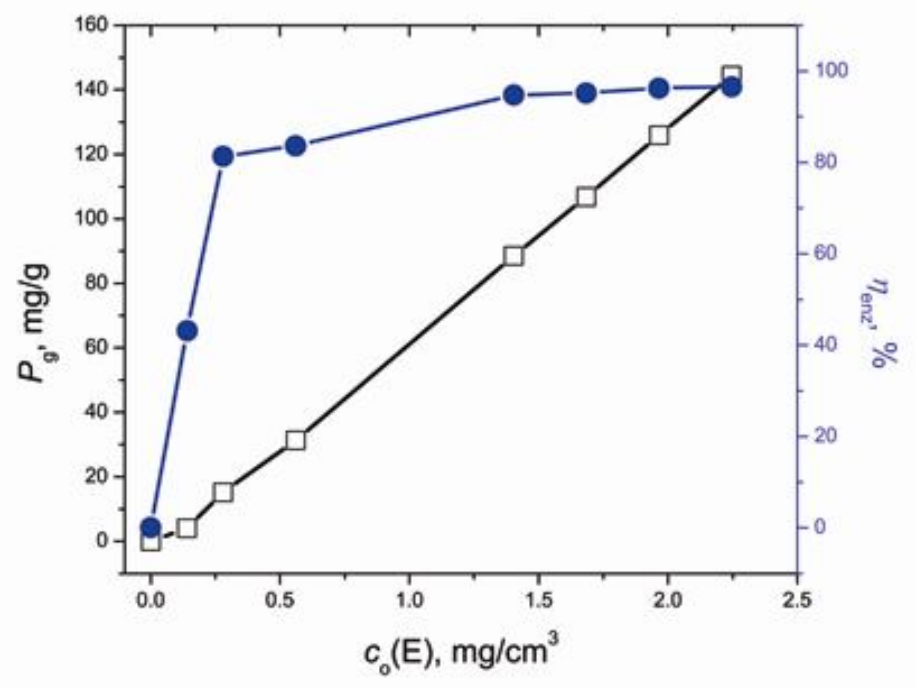

a)

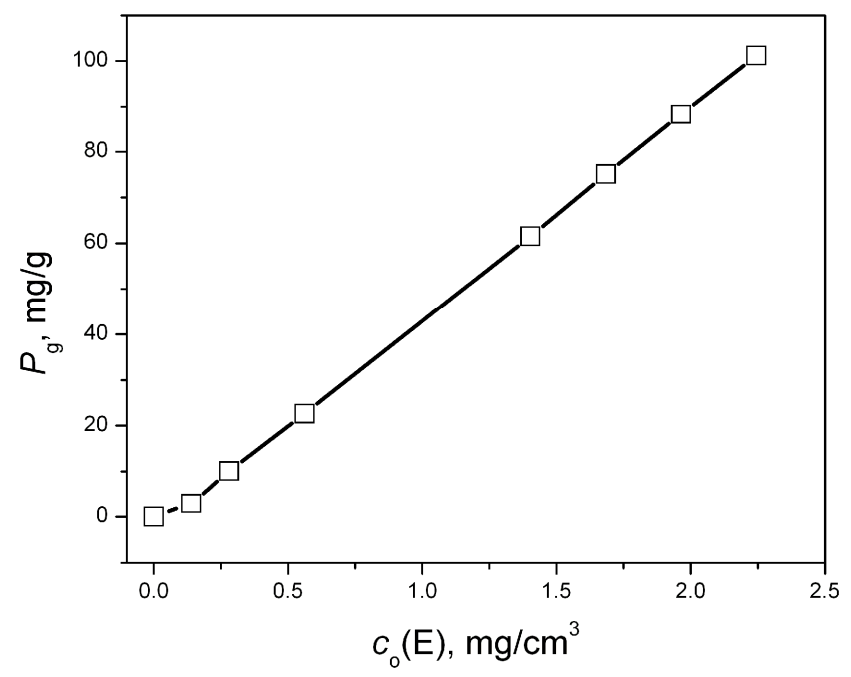

b)

Slika 8.8. Uporedni dijagram zavisnosti mase vezane $P A C\left(P_{g}\right)$ i masenog prinosa imobilizacije ( $\left.\eta_{\text {enz }}\right)$ od početne koncentracije PAC ( $\left.c_{o}\right)$ za a) Sepabeads EC-EA $i b$ ) Sepabeads EC-HA. Uslovi imobilizacije: 0,5 g nosača, $20 \mathrm{~h}, 25^{\circ} \mathrm{C}, 20 \mathrm{mM}$ kalijumfosfatni pufer (pH 8,0)

Na osnovu rezultata sa slike 8.8. vidi se da masa vezanog enzima raste gotovo linearno sa porastom početne koncentracije enzima i da maksimalna masa vezanog 
enzima iznosi oko $145 \mathrm{mg} / \mathrm{g}$ suvog Sepabeads EC-EA. Što se tiče masenog prinosa imobilizacije, pri malim koncentracijama enzima dolazi do njegovog naglog skoka da bi pri većim koncentracijama dostigao neku konstantnu vrednost $(93,3 \pm 3,8 \%)$. Na Sepabeads EC-HA se vezuje manje PAC, za iste početne koncentracije enzima u rastvoru, što se može pripisati manjoj hidrofilnosti ovog nosača. Može se zaključiti da je kapacitet vezivanja proteina za oba nosača prilično veliki. Ove vrednosti su znatno veće od vrednosti maksimalne mase vezanog enzima od $99,9 \mathrm{mg} / \mathrm{g}$ suvog nosača i 70mg/g suvog nosača koje su dobijene za lipazu i $\alpha$-glukozidazu imobilisane na Sepabeads EC-EA, redom [216, 223]. Isto tako, masa vezane PAC na Sepabeads ECHA postignuta u ovom radu veća je od vrednosti $P_{\mathrm{g}} \mathrm{u}$ slučaju lipaze imobilisane na isti nosač koja je iznosila 90,9 mg/g [216].

Skoro ista masa vezane PAC koja je postignuta za Sepabeads EC-EA u ovom radu dobijena je pri imobilizaciji PAC na Amberlite XAD7 gde je imobilisano 145,4 mg proteina/g suvog nosača [103]. Nasuprot tome, za benzoilformat-dekarboksilaza imobilisanu na Sepabeads EC-EA dobjena je nešto veća vrednost $P_{\mathrm{g}}(153,2 \mathrm{mg} / \mathrm{g}$ suvog nosača). Takođe, u poređenju vezivnog kapaciteta sva tri ispitana Sepabeads nosača u ovom radu može se zaključiti da Sepabeads EC-EA vezuje najviše enzima. Ovo je lako objasniti u poređenju sa Sepabeads EC-EP nosačem, koji ima značajno manju koncentraciju funkcionalnih grupa $(0,11 \mathrm{mmol} / \mathrm{g})$ od Sepabeads EC-EA nosača $(0,6 \mathrm{mmol} / \mathrm{g})$. Međutim, interesantno je da Sepabeads EC-EA vezuje veću količinu enzima i od nosača koji ima veću koncentraciju reaktivnih grupa, kao što je Sepabeads EC-HA $(0,7 \mathrm{mmol} / \mathrm{g})$. Moguće tumačenje je da je afinitet Sepabeads EC-HA nosača prema izrazito hidrofilnoj penicilin-acilazi najmanji zbog najmanje hidrofilnosti i, usled toga, nepovoljnih efekata raspodele. Naime, koncentracija hidrofilnog enzima kao što je PAC biće nešto manja u blizini nosača zbog njegove manje hidrofilnosti, a samim tim uslovi za formiranje veza između enzima i nosača su znatno nepovoljniji. Ovome svakako negativno doprinosi i dužina ugljovodoničnog lanca kojom je povezana funkcionalna grupa sa polimetakrilatnom osnovom. Pošto Sepabeads EC-HA ima veću dužinu lanca nego Sepabeads EC-EA može da se zaključi da povećanje dužine lanca nepovoljno utiče na masu vezanog enzima i zbog sternih smetnji. 


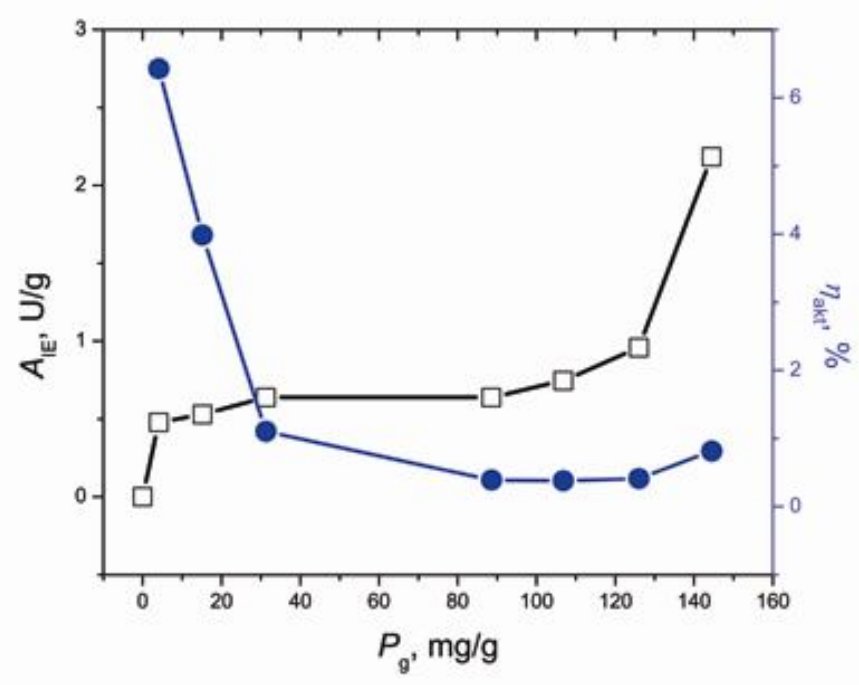

a)

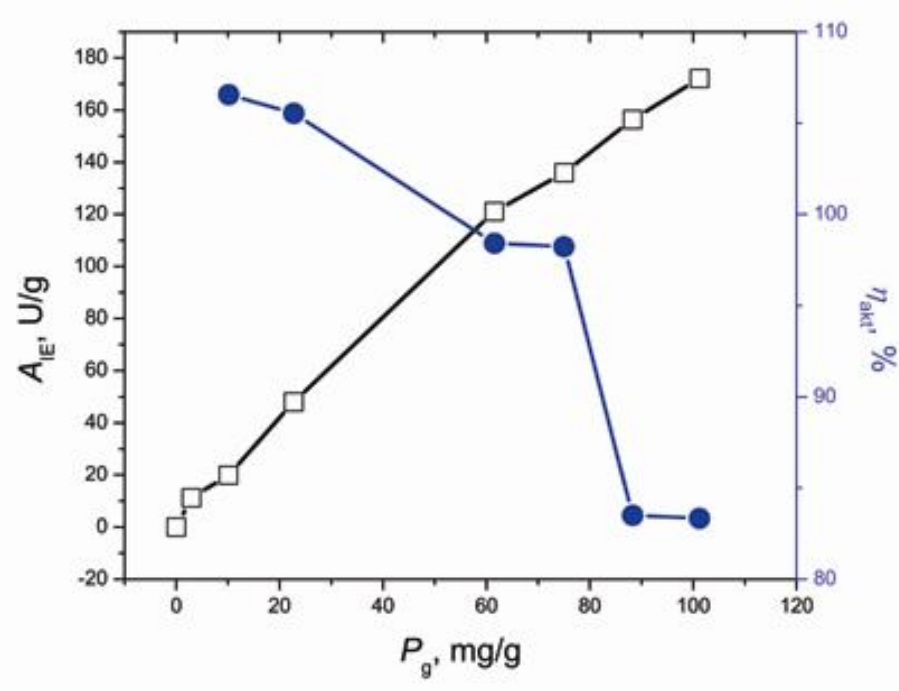

b)

Slika 8.9. Uporedni dijagram zavisnosti aktivnosti imobilisane PAC $\left(A_{I E}\right)$ i prinosa aktivnosti $\left(\eta_{a k t}\right)$ od mase vezane PAC $\left(P_{g}\right)$ za a) Sepabeads EC-EA $i$ b) Sepabeads ECHA . Uslovi imobilizacije: 0,5 g Sepabeads EC-EA nosača, $20 \mathrm{~h}, 25{ }^{\circ} \mathrm{C}, 20 \mathrm{mM}$ kalijum-fosfatni pufer ( $p H$ 8,0) 
Na slici 8.9. su prikazane zavisnosti aktivnosti imobilisanih enzima i prinosa aktivnosti imobilizacije od mase vezanog enzima na nosačima. U slučaju Sepabeads EC-EA nosača, uočava se da se aktivnost imobilisanog enzima ne menja značajnije sa porastom mase vezanog enzima. Ona iznosi od 0,47 do 2,18 IU/g suvog nosača, za mase vezanog enzima od 4 do $145 \mathrm{mg} / \mathrm{g}$, tako da se postiže prosečna aktivnost od oko $0,74 \pm 0,07 \mathrm{IU} / \mathrm{g}$. Ovo je verovatno zbog toga što pri većim količinama vezanog enzima na nosaču dolazi do sternih smetnji i difuzionih limitacija. Poznato je da se sa povećanjem mase vezanog enzima povećava i vrednost Tileovog modula, odnosno da se povećava otpor pora prema prenosu mase supstrata i proizvoda reakcije. Isto tako, moguće je da dolazi do formiranja više slojeva enzima na nosaču tako da se pojedini molekuli enzima isključuju iz sfere odvijanja reakcije. Što se tiče prinosa aktivnosti, sa slike se vidi da se kreće u intervalu od 1 do $7 \%$, što je izuzetno niska vrednost. Najveći prinos aktivnosti se postiže pri najmanjoj masi vezanog enzima, a zatim sa njenim porastom opada. To znači da dolazi do velikih gubitaka aktivnosti u toku imobilizacije i da ovaj nosač i metoda nisu podesni za imobilizaciju datog enzima.

Međutim, potpuno drugačiji trend imaju zavisnosti prikazane na dijagramu 8.9b koje su dobijene za imobilizaciju PAC na Sepabeads EC-HA nosač. Lako se uočava da aktivnost imobilisanog enzima raste sa porastom mase vezanog enzima. Prinos aktivnosti je izuzetno veliki i iznosio je $99,1 \pm 11,1 \%$. Može se zaključiti da je dati nosač izuzetno povoljan za imobilizaciju PAC. U ovom slučaju je ostvaren znatno veći prinos aktivnosti nego pri imobilizaciji na Sepabeads EC-EA jer je PAC udaljenija od površine nosača, zbog veće dužine lanca preko koje je amino grupa vezana za polimetakrilatnu osnovu Sepabeads EC-HA nosača, pa je smanjena mogućnost difuzionih limitacija i veća je fleksibilnost konformacije enzima.

\subsubsection{Ispitivanje uticaja temperature na aktivnost penicilin-acilaze imobilisane na Sepabeads EC-EA i Sepabeads EC-HA}

Ispitan je i uticaj temperature na aktivnost imobilisanih enzima na oba nosača po metodi opisanoj u poglavlju 6.2.2.5. i pri tome je temperatura varirana u intervalu od 21 do $75^{\circ} \mathrm{C}$. Rezultati su prikazani na slici 8.10. 


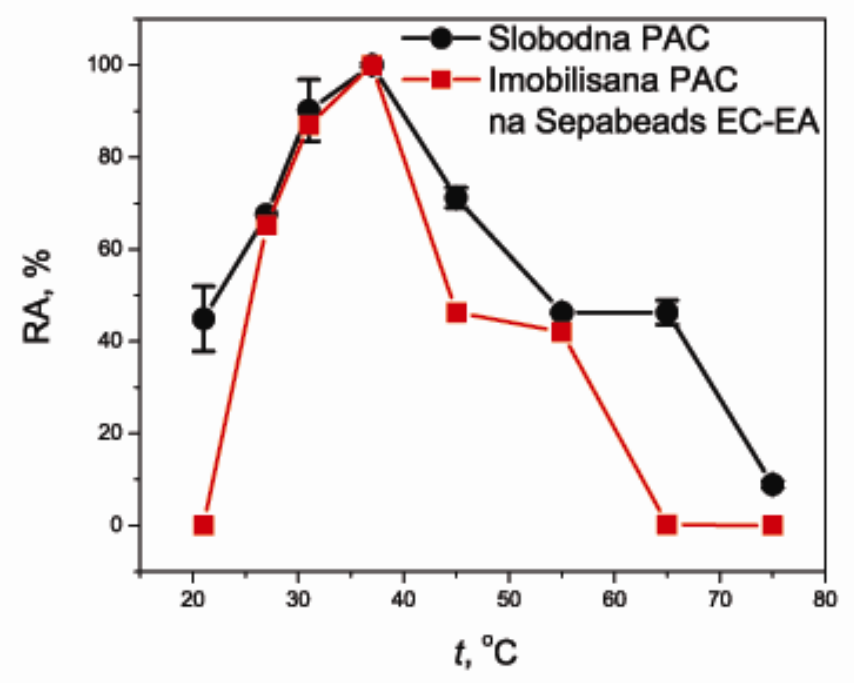

a)

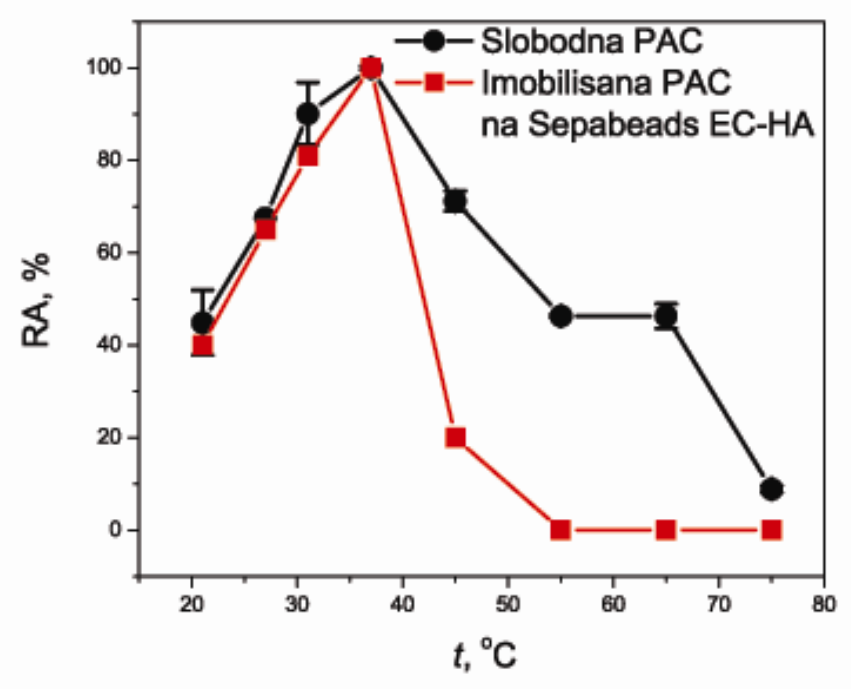

b)

Slika 8.10. Zavisnost relativne aktivnosti (RA) imobilisane PAC od temperature za a) Sepabeads EC-EA $i$ b) Sepabeads EC-HA. Uslovi reakcije: 0,1 M natrijum-fosfatni pufer $\mathrm{pH}$ 7,92, 3 min 
Sa slike 8.10. se vidi da se temperaturni optimumi slobodne i imobilisanih PAC poklapaju u sva tri slučaja i iznose $37{ }^{\circ} \mathrm{C}$. Takođe se vidi da je temperaturni profil imobilisanih PAC čak uži od temperaturnog profila slobodne PAC, što ukazuje na to da nije došlo do značajnije stabilizacije enzima posle imobilizacije na oba nosača. Slični rezultati su dobijeni u literaturi za enzime imobilisane na Sepabeads EC-EA nosač. Tako, imobilizacija lipaze na ovaj nosač nije uticala na temperaturni optimum, dok je u slučaju imobilizacije $\alpha$-glukozidaze došlo do povećanja temperaturnog optimuma $u$ odnosu na slobodan enzim za $10{ }^{\circ} \mathrm{C}[216,223]$. U slučaju imobilizacije lipaze na Sepabeads EC-HA, u literaturi je pokazano da dolazi do povećanja optimalne temperature za $8{ }^{\circ} \mathrm{C}$ u odnosu na slobodnu lipazu [216].

\subsubsection{Ispitivanje uticaja $\mathrm{pH}$ na aktivnost penicilin-acilaze imobilisane na Sepabeads EC-EA i Sepabeads EC-HA}

Ispitan je uticaj $\mathrm{pH}$ vrednosti na aktivnost imobilisanih enzima po metodi opisanoj u poglavlju 6.2.2.6., pri čemu se ispitivana $\mathrm{pH}$ vrednost kretala u intervalu od 4,50 do 9,30. Rezultati su prikazani na slici 8.11.

Sa slike 8.11. se vidi da je pH optimum PAC imobilisane na Sepabeads EC-EA nosaču, u odnosu na pH optimum slobodne PAC, pomeren ka kiseloj sredini i iznosi 5,5. Kako se hidroliza penicilina pomoću PAC izvodi u alkalnoj sredini, ovakvom imobilizacijom se nije postigao željeni cilj, jer se dobija biokatalizator koji je aktivniji u kiselim sredinama. Sa ovog aspekta imobilizacija PAC na Sepabeads EC-EP je pogodnija jer nakon imobilizacije dolazi do pomeranja $\mathrm{pH}$ optimuma ka alkalnoj sredini. U slučaju imobilizacije $\alpha$-glukozidaze na Sepabeads EC-EA pH optimum imobilisanog i slobodnog enzima je ostao isti dok u slučaju imobilizacije lipaze dolazi do pomeranja optimuma ka baznoj sredini [216, 223]. Sa druge strane, PAC imobilisana na Sepabeads EC-HA ima isti pH optimum kao i slobodna PAC, dok je profil nešto uži nego kod slobodnog enzima. Ovo ukazuje na to da data metoda imobilizacije nije doprinela poboljšanju pH optimuma u oba slučaja. 


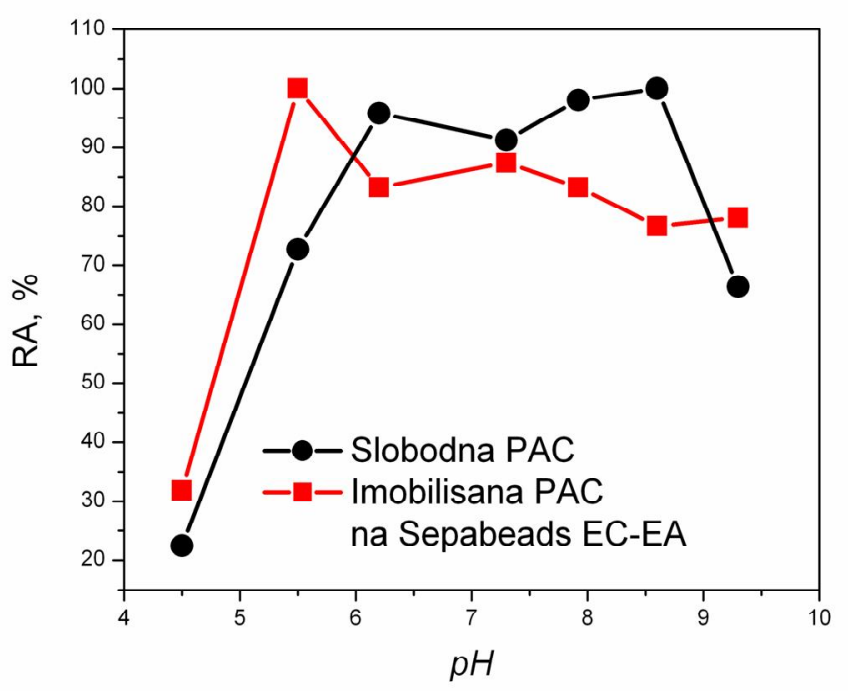

a)

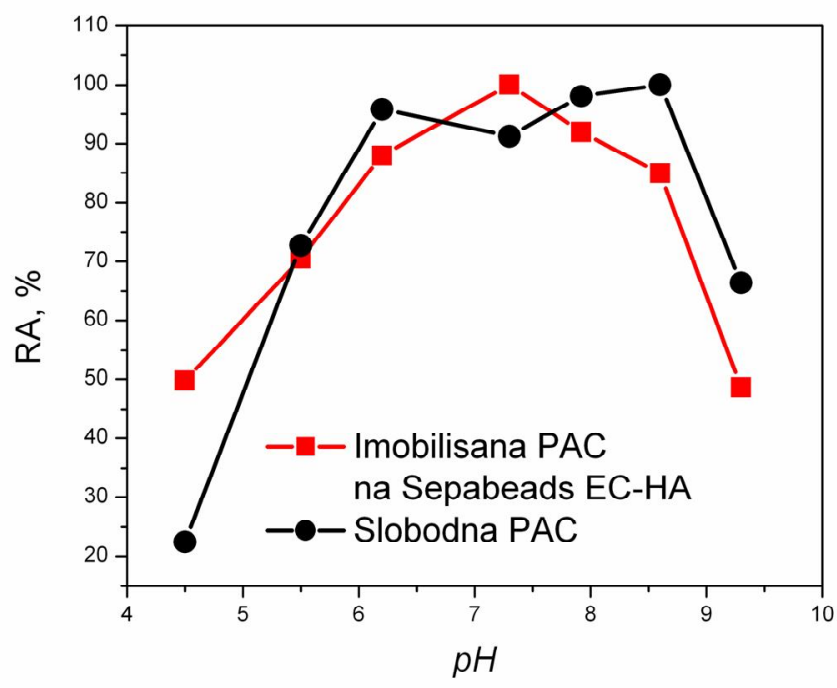

b)

Slika 8.11. Zavisnost relativne aktivnosti (RA) slobodne $i$ imobilisane $P A C$ od $p H$ vrednosti za a) Sepabeads EC-EA i b) Sepabeads EC-HA. Uslovi reakcije: $37^{\circ} \mathrm{C}$, $3 \mathrm{~min}$, 0,1 M puferi: acetatni puferi ( $p H 4,5$ i pH 5,5 ), fosfatni puferi (pH 6,2, pH 7,3 i pH 7,9) i tris/HCl puferi ( $p H$ 8,6 i pH 9,3) 


\subsubsection{Ispitivanje uticaja imobilizacije penicilin-acilaze na Sepabeads EC-EA i} Sepabeads EC-HA na stabilnost biokatalizatora

Ispitana je termalna stabilnost imobilisanih enzima na $50{ }^{\circ} \mathrm{C}$ po metodi opisanoj u poglavlju 6.2.2.7 i rezultati su prikazani na slici 8.12.

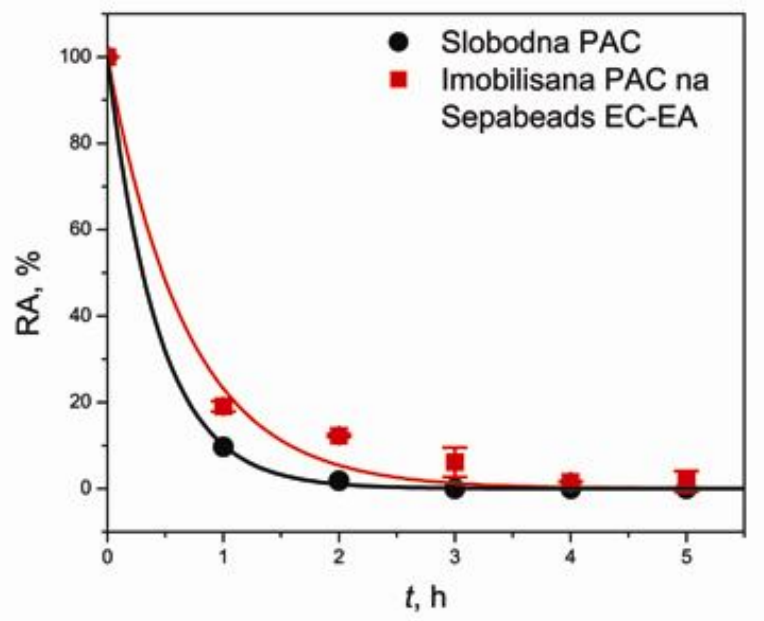

a)

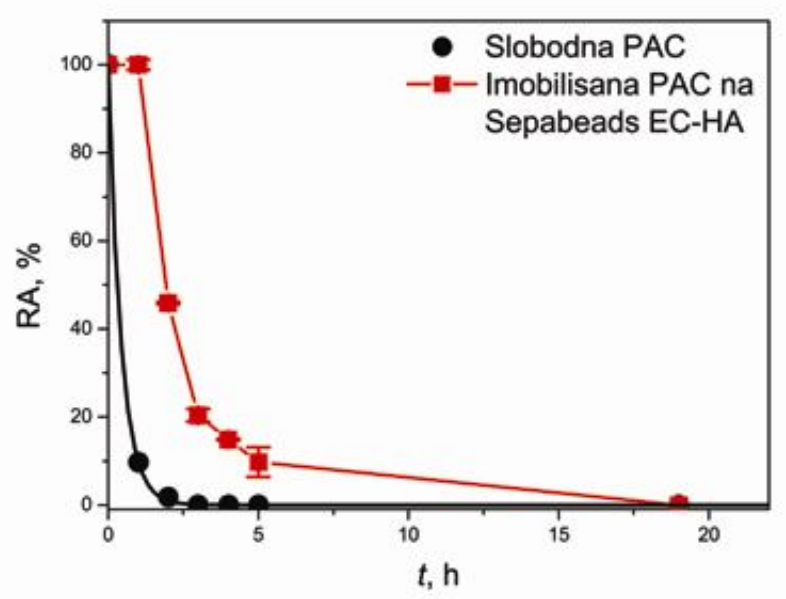

b)

Slika 8.12. Zavisnost relativne aktivnosti od vremena za slobodnu PAC i imobilisanu na a) Sepabeads EC-EA $i$ b) Sepabeads EC-HA. Biokatalizatori se termostatiraju na $50^{\circ} \mathrm{C}$ u različitim vremenskim periodima, a zatim se ispituje aktivnost tretiranih biokatalizatora u standardnoj reakciji. Uslovi reakcije: 0,1 M natrijum-fosfatni pufer $(p H=7,92), t=37^{\circ} \mathrm{C}, 3 \mathrm{~min}$ 
Sa slike 8.12. se vidi da imobilizacija enzima na Sepabeads EC-EA neznatno doprinosi njegovoj stabilizaciji, dok je u slučaju Sepabeads EC-HA nosača, stabilizacioni efekat nešto veći. PAC imobilisana na Sepabeads EC-HA pokazuje određeno vreme stabilnosti pre nego što počne da se smanjuje aktivnost biokatalizatora ukazujući na to da je kinetika dezaktivacije nešto kompleksnija nego što predviđa pretpostavljeni jednostepeni kinetički model.

Da bi se rezultati kvantitativno uporedili, modelovani su kinetičkim modelima dezaktivacije prvog reda bez i sa početnim lag periodom pre dezaktivacije (jednačine 6.2. i 6.3.). Dobijene vrednosti za konstantu brzine dezaktivacije, $k_{\mathrm{D}}$ i poluvreme dezaktivacije na osnovu modela prikazane su u Tabeli 8.1. i upoređene su sa vrednostima određenim za slobodan enzim.

Tabela 8.1. Vrednosti kinetičkih konstanti dezaktivacije za slobodan enzim i PAC imobilisane na Sepabeads EC-EP, Sepabeads EC-EA i Sepabeads EC-HA nosačima.

\begin{tabular}{ccccc}
\hline & $\boldsymbol{k}_{\mathbf{D}}, \mathbf{h}^{-\mathbf{1}}$ & $\boldsymbol{t}_{\mathbf{1 / 2}}, \mathbf{h}$ & $\begin{array}{c}\text { Stabilizacioni } \\
\text { faktor, } \boldsymbol{F}\end{array}$ & $\boldsymbol{t}_{\mathbf{D}}, \mathbf{h}$ \\
\hline Slobodna PAC & 2,32 & 0,30 & 1 & - \\
PAC imobilisana na & 0,41 & 1,7 & 5,67 & - \\
$\begin{array}{c}\text { Sepabeads EC-EP } \\
\text { PAC imobilisana na }\end{array}$ & 1,47 & 0,47 & 1,6 & - \\
$\begin{array}{c}\text { Sepabeads EC-EA } \\
\text { PAC imobilisana na } \\
\text { Sepabeads EC-HA }\end{array}$ & 0,77 & 1,9 & 6,33 & 0,89 \\
\hline
\end{tabular}

$\mathrm{Na}$ osnovu dobijenih vrednosti se zaključuje da se slobodna PAC brže dezaktivira od imobilisanih PAC. Stabilizacija PAC imobilizacijom na Sepabeads ECEA je znatno manja od stabilizacije koja se postiže imobilizacijom na Sepabeads ECHA ili na Sepabeads EC-EP kada se enzim stabilizovao 5,67 puta.

Može se zaključiti da je Sepabeads EC-HA nosač znatno pogodniji za imobilizaciju PAC nego Sepabeads EC-EA jer dolazi do neznatnih gubitaka aktivnosti $\mathrm{u}$ toku imobilizacije i dobijeni biokatalizator je znatno termalno stabilniji od slobodne 
PAC, dok u slučaju imobilizacije na Sepabeads EC-EA dolazi do velikih gubitaka aktivnosti u toku imobilizacije i iako je dobijeni biokatalizator nešto termalno stabilniji od slobodne PAC, znatno je nestabilniji nego biokatalizator dobijen imobilizacijom PAC na Sepabeads EC-HA. 


\section{Zaključak}

U ovom delu rada je izvršeno ispitivanje imobilizacije PAC na komercijalne polimetakrilatne nosače Sepabeads EC-EP, Sepabeads EC-EA i Sepabeads EC-HA.

$\mathrm{Na}$ osnovu dobijenih rezultata mogu se izvesti sledeći zaključci:

1. Masa vezane PAC raste gotovo linearno sa povećanjem početne koncentracije enzima u rastvoru za imobilizaciju. Maksimalna masa vezane PAC se postiže vezivanjem na Sepabeads EC-EA (145 mg/g suvog nosača), dok je za Sepabeads EC-EP i Sepabeads EC-HA nešto manja (133,6 mg/g suvog nosača i $101 \mathrm{mg} / \mathrm{g}$ suvog nosača, redom). Pri imobilizaciji se postižu maksimalni maseni prinosi imobilizacije od $96,7 \pm 1,4 \%, 93,3 \pm 3,8 \%$ i $95,7 \pm 1,2 \%$ za Sepabeads ECEP, Sepabeads EC-EA i Sepabeads EC-HA, redom, ukazujući da se gotovo sva početna količina PAC vezuje za nosače. Maseni prinosi imobilizacije naglo rastu sa povećanjem početne koncentracije enzima u rastvoru za imobilizaciju i pri koncentraciji PAC od $0,28 \mathrm{mg} / \mathrm{cm}^{3}$ iznose $85,6 \%, 82 \%$ i $79 \%$ za navedena tri nosača, redom.

2. Aktivnost imobilisanog enzima se značajno menja sa porastom mase vezanog enzima. Najveći prosečan prinos aktivnosti se dobija imobilizacijom PAC na Sepabeads EC-HA od 95,9 $\pm 11,1 \%$. Imobilizacijom na Sepabeads EC-EP se dobija dosta manji prosečan prinos aktivnosti od $64,2 \pm 26,6 \%$, dok se imobilizacijom na Sepabead EC-EA dobija najmanji prosečan prinos aktivnosti

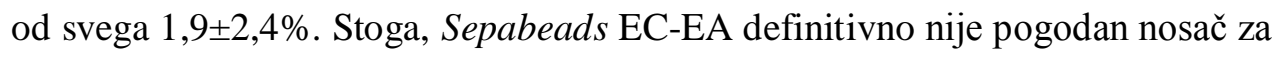
imobilizaciju PAC.

3. Imobilizacijom PAC na Sepabeads EC-EP dolazi do malog pomeranja optimalne temperature ka višim temperaturama, dok imobilizacijom na Sepabeads EC-EA i Sepabeads EC-HA temperaturni optimum ostaje isti kao kod slobodne PAC, dok je u sva tri slučaja došlo do sužavanja temperaturnog profila, tako da se može zaključiti da imobilizacija PAC na Sepabeads nosače nije dovela do poboljšanja temperaturne stabilnosti biokatalizatora. 
4. Najpovoljnija promena $\mathrm{pH}$ profila se dobija nakon imobilizacije PAC na Sepabeads EC-EP jer je pH optimum pomeren ka alkalnoj sredini u kojoj se i izvodi reakcija hidrolize Pen G pomoću PAC. Imobilizacijom na Sepabeads EC-EA pH optimum se pomera ka kiseloj sredini, što je nepovoljno, stoga i sa ovog aspekta Sepabeads EC-EA nosač nije pogodan za imobilizaciju PAC. U slučaju imobilizacije PAC na Sepabeads EC-HA, ne dolazi do promene pH optimuma a profil je nešto uži u odnosu na slobodnu PAC.

5. Pri ispitivanju termalne stabilnosti enzima na $50{ }^{\circ} \mathrm{C}$, utvrđeno je da imobilizacijom PAC na Sepabeads EC-HA dolazi do najvećeg povećanja stabilnosti (6,33 puta), zatim imobilizacijom na Sepabeads EC-EP (5,67 puta), a najmanje povećanje stabilnosti se postiže imobilizacijom na Sepabeads EC-EA (svega 1,6 puta).

Dobijeni rezultati ukazuju na to da je Sepabeads EC-HA nosač najpodesniji za imobilizaciju PAC, zatim Sepabeads EC-EP, dok je Sepabeads EC-EA nepodesan za imobilizaciju ovog enzima. 


\section{KARAKTERIZACIJA I IMOBILIZACIJA PENICILIN-ACILAZE MODIFIKOVANE DERIVATIMA POLISAHARIDA}

Kako u slučaju prethodnih imobilizacija PAC na komercijalne Sepabeads nosače nije postignuta očekivana stabilizacija biokatalizatora, cilj ovog dela rada je bio da se ispitaju mogućnosti stabilizacije enzima prethodnom hemijskom modifikacijom, a zatim i imobilizacije tako stabilizovanog enzima na ove nosače. Modifikacija enzima je izvedena uvođenjem ugljeno-hidratne komponente u molekul jer je poznato da su prirodni glikoproteini stabilniji od običnih protein-enzima. Modifikacija je izvršena derivatima dva polisaharida, $i$ to derivatima jednog neutralnog polisaharida, skroba, i jednog anjonskog polisaharida, alginata.

Modifikacija derivatima skroba je izvršena na dva načina.

Prvi način se zasniva na dvostrukoj oksidaciji skroba i izvodio se po sledećem postupku. Najpre je skrob oksidovan perjodatom do aldehidnih derivata za čije karbonilne grupe je vezana penicilin-acilaza. Zatim je izvršena još jedna oksidacija derivata skroba-PAC u cilju dobijanja više karbonilnih grupa, preko kojih se sada ovaj konjugat može hemijski vezati za nosače Sepabeads EC-EA i Sepabeads EC-HA (metoda 1).

U drugom načinu je izvršena samo jedna oksidacija skroba pomoću perjodata i dobijen je aldehidni derivat skroba za koji se može vezati enzim i tako dobijen konjugat je vezan za nosače Sepabeads EC-EA i Sepabeads EC-HA (metoda 2).

$\mathrm{S}$ obzirom da je u toku rada utvrđeno da metoda 2 daje bolje rezultate, modifikacija derivatima alginata je vršena samo ovom metodom. Dobijeni konjugat derivat alginata-PAC je imobilisan na nosače Sepabeads EC-EA i Sepabeads EC-HA.

Dobijeni konjugati derivat skroba-PAC i derivat alginata-PAC, kao i njihovi imobilizati na Sepabeads EC-EA i Sepabeads EC-HA su okarakterisani tj. određena je njihova aktivnost, temperaturni i pH profil, kao i termostabilinost. Rezultati su prodiskutovani i upoređeni, kako međusobno, tako i sa prethodnim rezultatima imobilizacije. 


\subsection{Karakterizacija i imobilizacija penicilin-acilaze modifikovane derivatom skroba}

\subsubsection{Imobilizacija penicilin-acilaze modifikovane derivatom skroba po metodi 1}

\subsubsection{Imobilizacija penicilin-acilaze modifikovane derivatom skroba na Sepabeads EC-EA i Sepabeads EC-HA po metodi 1}

U radu je ispitan novi postupak stabilizacije enzima koji se zasniva na imobilizaciji oksidovanog i modifikovanog enzima (metoda 1). Naime, ispitan je postupak imobilizacije PAC na nosače od industrijskog značaja, Sepabeads EC-EA i Sepabeads EC-HA, koji se zasniva na oksidaciji enzima modifikovanog derivatom skroba i zatim hemijskom vezivanju tako modifikovane PAC na nosače (metode opisane u poglavlju 6.2.3.2. i 6.2.3.7.). Ovim je omogućeno vezivanje enzima na nosače preko ugljeno-hidratnog dela uvedenog u molekul umesto preko funkcionalnih grupa koje su od značaja za njegovu katalitičku aktivnost.

9.1.1.1.1. Ispitivanje uticaja uslova imobilizacije na svojstva skrob-penicilin-acilaze imobilisane na Sepabeads EC-EA i Sepabeads EC-HA po metodi 1

U ovom delu rada je skrob-PAC imobilisana na Sepabeads EC-EA i Sepabeads EC-HA. Kao i u prethodnim slučajevima, varirana je početna koncentracija enzima u rastvoru za imobilizaciju od 0,0025 do $0,040 \mathrm{~cm}^{3} / \mathrm{cm}^{3} \mathrm{tj}$. od 0,140 do $2,245 \mathrm{mg} / \mathrm{cm}^{3}$. Određena je masa vezane modifikovane PAC za nosače indirektno, na osnovu koncentracije nevezane PAC u filtratu, i aktivnost tako dobijenih biokatalizatora. Rezultati su prikazani na slikama 9.1. i 9.2.

Kada se skrob-PAC na ovakav način imobiliše na Sepabeads EC-EA, sa slike 9.1. se vidi da masa vezanog enzima na nosač raste gotovo linearno sa povećanjem početne koncentracije enzima u rastvoru. Pri tome se dobija približno ista masa vezanog enzima na nosač kao i kod konvencionalno imobilisanog enzima i to $144 \mathrm{mg} / \mathrm{g}$ suvog nosača, za početnu koncentraciju enzima od $2,25 \mathrm{mg} / \mathrm{cm}^{3}$. Što se tiče masenog prinosa 
imobilizacije, pri malim koncentracijama enzima dolazi do njegovog naglog skoka da bi pri većim koncentracijama dostigao neku konstantnu vrednost $(91,5 \pm 4,7 \%)$. I u ovom slučaju kao i kod slobodnog enzima, nešto manja količina modifikovane PAC se vezuje na Sepabeads EC-HA (slika 9.2b), što se može pripisati manjoj hidrofilnosti ovog nosača. U ovom slučaju masa vezanog modifikovanog enzima na nosač je približno ista kao kod imobilizacije nemodifikovanog enzima i iznosi $100 \mathrm{mg} / \mathrm{g}$ suvog nosača za početnu koncentraciju $2,25 \mathrm{mg} / \mathrm{cm}^{3}$.

Sa slike 9.2. se vidi da je aktivnost imobilisanog biokatalizatora na Sepabeads EC-EA slična aktivnosti konvencionalno imobilisanog enzima, iako su primenjene potpuno različite hemijske metode imobilizacije. Aktivnost imobilisane skrob-PAC po metodi 1 iznosi od 0,64 do $25 \mathrm{IU} / \mathrm{g}$ suvog nosača, za mase vezanog enzima od 8$125 \mathrm{mg} / \mathrm{g}$, što odgovara prinosu aktivnosti od 4 do $10 \%$. Ove vrednosti su nešto veće $u$ poređenju sa aktivnostima dobijenim u slučaju prethodne konvencionalne metode (0,47-2,18 IU/g suvog nosača), ali su još uvek male. Definitivno, ovaj nosač nije podesan za imobilizaciju PAC, možda zbog velike hidrofilnosti, jer je poznato da dolazi do denaturacije proteina na hidrofilnim površinama. Hidrofilnost nosača je pogodna sa aspekta afiniteta nosača prema proteinima, ali ne i sa aspekta aktivnosti. Moguće da i dužina lanca preko koje je vezana funkcionalna grupa nosača nije dovoljno velika da ublaži konformacione promene do kojih dolazi u molekulu enzima pri vezivanju. Međutim, u ovom slučaju nisu postignute veće aktivnosti imobilisane modifikovane PAC ni na Sepabeads EC-HA nosaču (2,5 do 11 IU/g suvog nosača za mase vezanog enzima $10-100 \mathrm{mg} / \mathrm{g}$ ), što odgovara prinosu aktivnosti od 4-12\%. Značajno veće aktivnosti imobilisane PAC na Sepabeads EC-HA nosaču su postignute konvencionalnom glutaraldehidnom metodom, kao što je prikazano u poglavlju 8.2.1. 


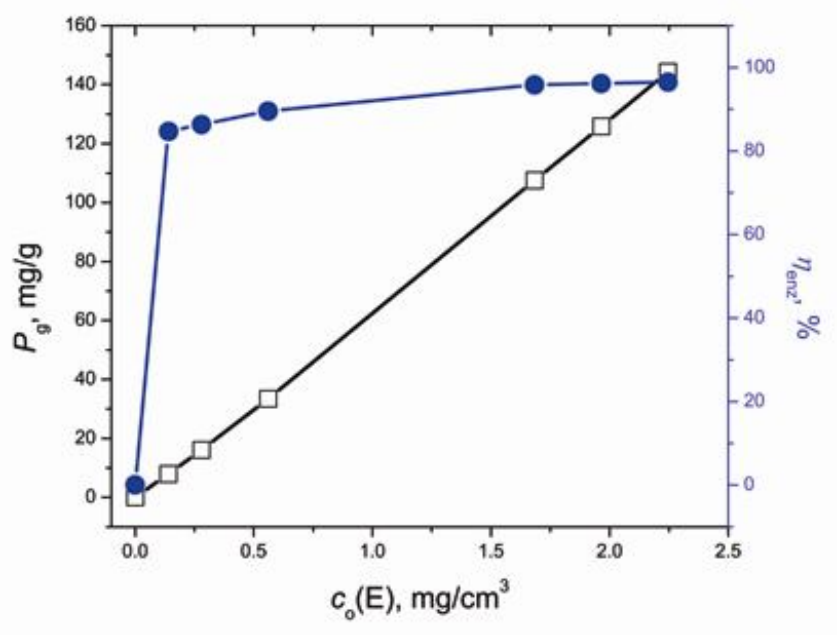

a)

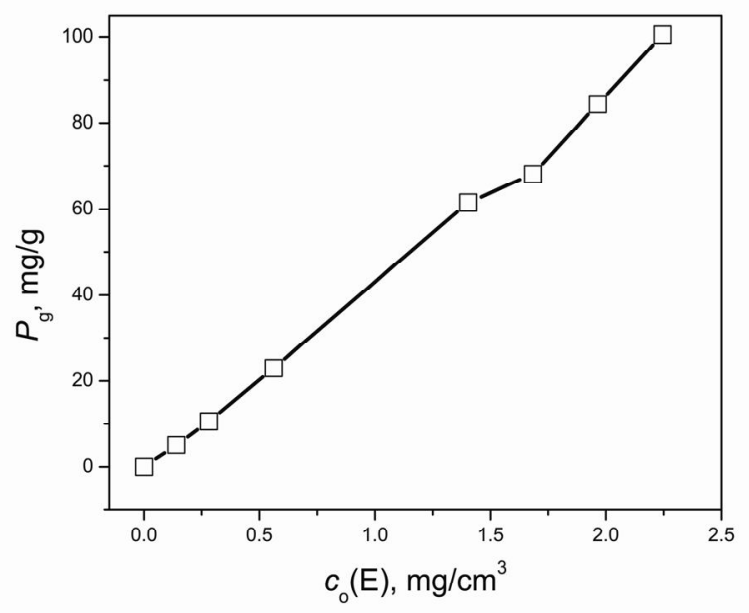

b)

Slika 9.1. Uporedni dijagram zavisnosti mase vezane skrob-PAC po metodi $1\left(P_{g}\right)$ od početne koncentracije enzima $\left(c_{o}\right)$ i masenog prinosa imobilizacije $\left(\eta_{\text {enz }}\right)$ od početne koncentracije enzima $\left(c_{o}\right)$ za a) Sepabeads EC-EA $i$ b) Sepabeads EC-HA. Uslovi imobilizacije: 0,5 g Sepabeads EC-EA nosača, $48 \mathrm{~h}, 8{ }^{\circ} \mathrm{C}, 50 \mathrm{mM}$ natrijum-acetatni pufer $(p H 5,0)$ 


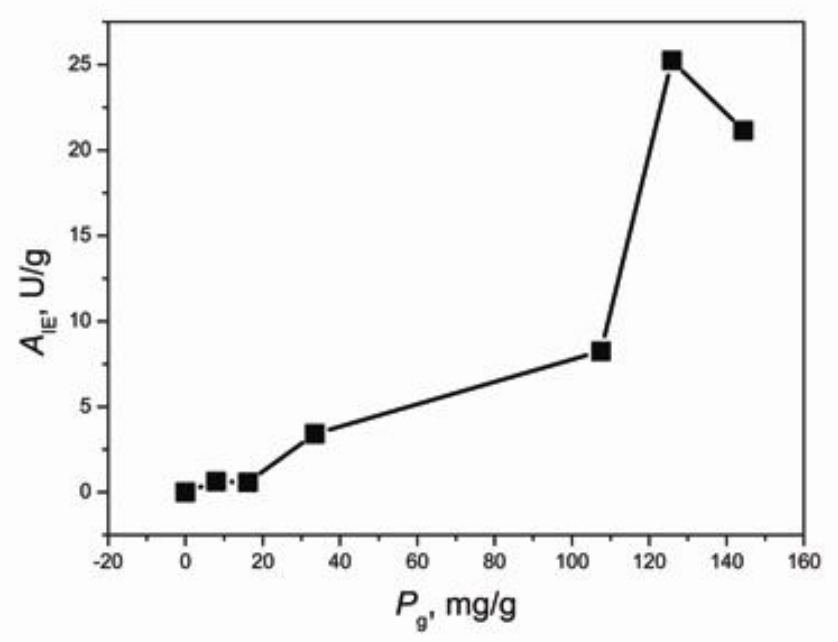

a)

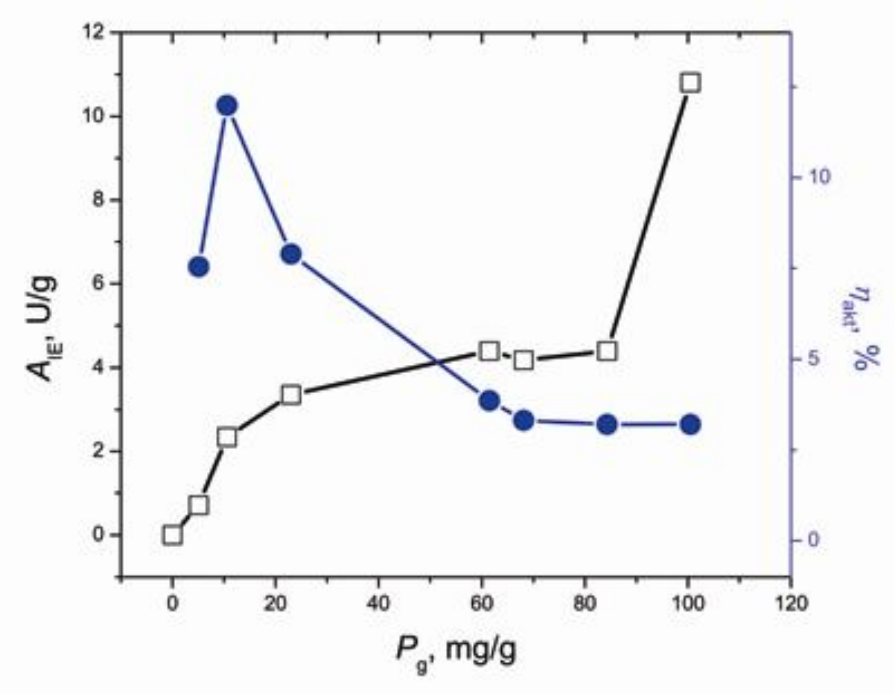

b)

Slika 9.2. Zavisnosti aktivnosti imobilisane skrob-PAC $\left(A_{I E}\right)$ i prinosa aktivnosti $\left(\eta_{\text {akt }}\right)$ od mase vezanog enzima $\left(P_{g}\right)$ po metodi 1 za a) Sepabeads EC-EA $i$ b) Sepabeads ECHA. Uslovi imobilizacije: 0,5 g Sepabeads EC-EA nosača, $48 \mathrm{~h}, 8{ }^{\circ} \mathrm{C}, 50 \mathrm{mM}$ natrijumacetatni pufer $(\mathrm{pH} 5,0)$ 
Može se zaključiti da je postignuta veoma mala aktivnost imobilisanog enzima, što je možda posledica odabrane metode imobilizacije koja se zasniva na tretiranju enzima oksidacionim sredstvima, pa je moguće da je enzim inaktiviran usled suviše intenzivne oksidacije.

\subsection{Ispitivanje uticaja temperature na aktivnost skrob-penicilin-acilaze} imobilisane na Sepabeads EC-EA i Sepabeads EC-HA po metodi 1

Ispitan je uticaj temperature na aktivnost enzima po metodi opisanoj u poglavlju 6.2.3.9. pri čemu je temperatura varirana $u$ intervalu od 20 do $75{ }^{\circ} \mathrm{C}$. Rezultati su prikazani na slici 9.3 .

$\mathrm{Na}$ slici 9.3. se uočava da skrob-PAC imobilisana na Sepabeads EC-EA i Sepabeads EC-HA po metodi 1 zadržava istu optimalnu temperaturu kao i slobodna i konvencionalno imobilisana PAC, od $37{ }^{\circ} \mathrm{C}$. Temperaturni profili su u oba slučaja suženi $\mathrm{u}$ odnosu na temperaturni profil slobodne PAC, dok $\mathrm{u}$ odnosu na konvencionalno imobilisanu PAC profil je dosta sužen i nešto širi u slučaju imobilizacije na Sepabeads EC-EA i Sepabeads EC-HA po metodi 1, redom. 


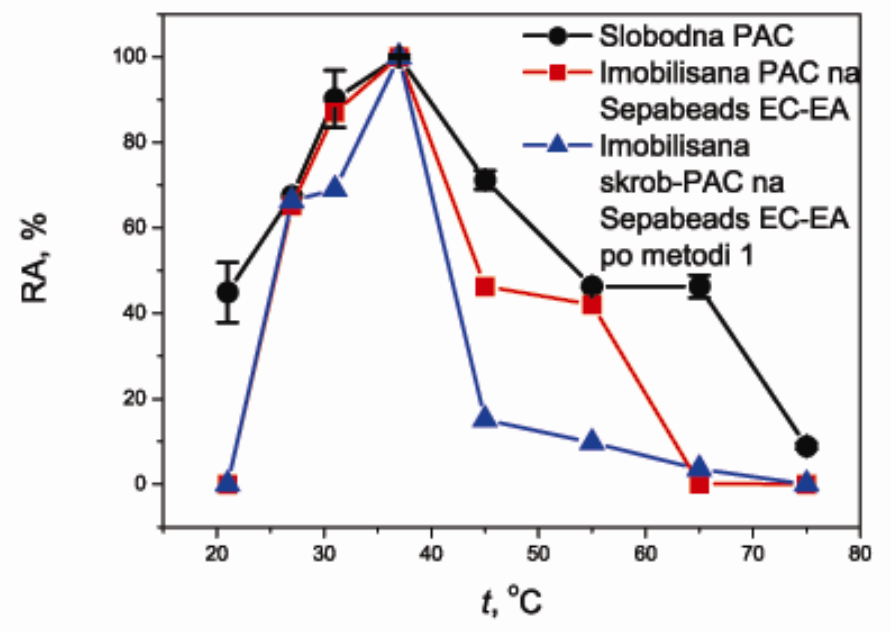

a)

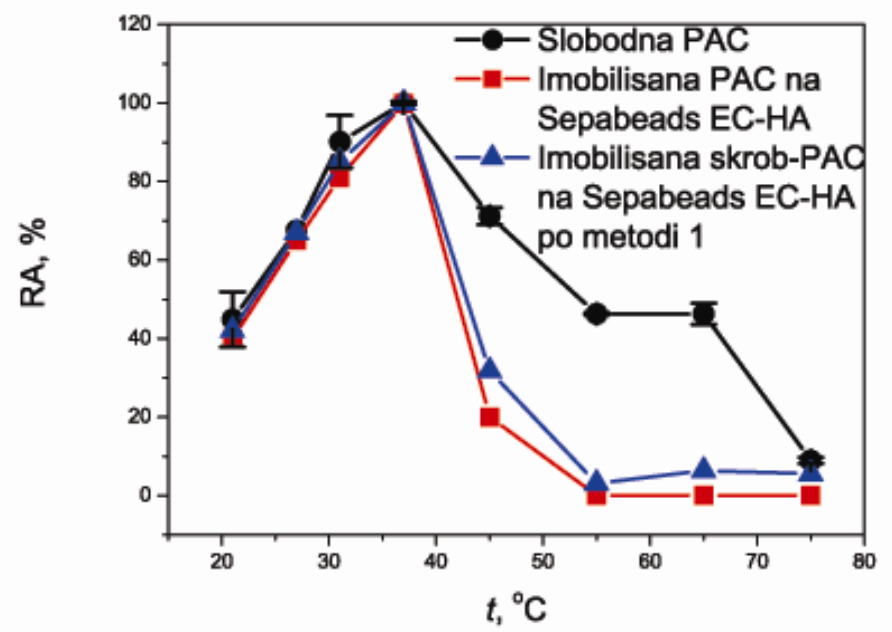

b)

Slika 9.3. Zavisnost relativne aktivnosti (RA) od temperature za slobodnu PAC, konvencionalno imobilisane PAC, imobilisane skrob-PAC po metodi 1 na a) Sepabeads EC-EA $i$ b) Sepabeads EC-HA. Uslovi reakcije: 0,1 M natrijum-fosfatni pufer ( $p H$ 7,92), $3 \mathrm{~min}$ 
9.1.1.1.3. Ispitivanje uticaja pH vrednosti na aktivnost skrob-penicilin-acilaze imobilisane na Sepabeads EC-EA i Sepabeads EC-HA po metodi 1

Ispitan je uticaj $\mathrm{pH}$ vrednosti na aktivnost skrob-PAC imobilisane po metodi opisanoj u poglavlju 6.2.3.10., pri čemu se ispitivana $\mathrm{pH}$ vrednost kretala $\mathrm{u}$ intervalu od 4,50 do 9,30. Rezultati su prikazani na slici 9.4.

Sa slike 9.4. se vidi da su pH profili skrob-PAC imobilisane po metodi 1 na Sepabeads EC-EA i Sepabeads EC-HA pomereni ka višim i nižim pH vrednostima, redom, $\mathrm{u}$ odnosu na $\mathrm{pH}$ profil konvencionalno imobilisane PAC i optimalna $\mathrm{pH}$ vrednost u oba slučaja iznosi 6,2. Međutim, i dalje su njihovi profili u odnosu na slobodnu PAC pomereni ka kiseloj sredini i značajno su uži.

Očigledno je da i sa ovog aspekta ova metoda nije podesna za modifikaciju i imobilizaciju enzima. 


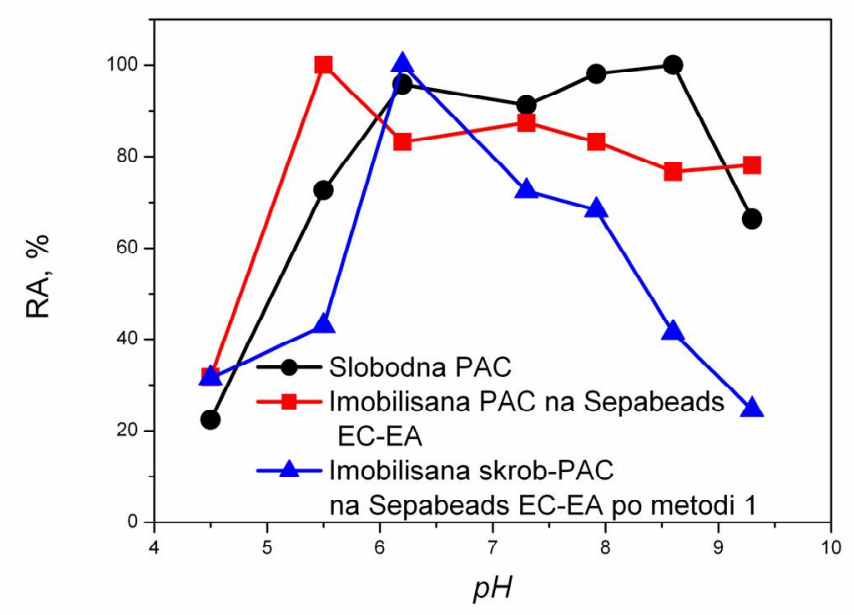

a)

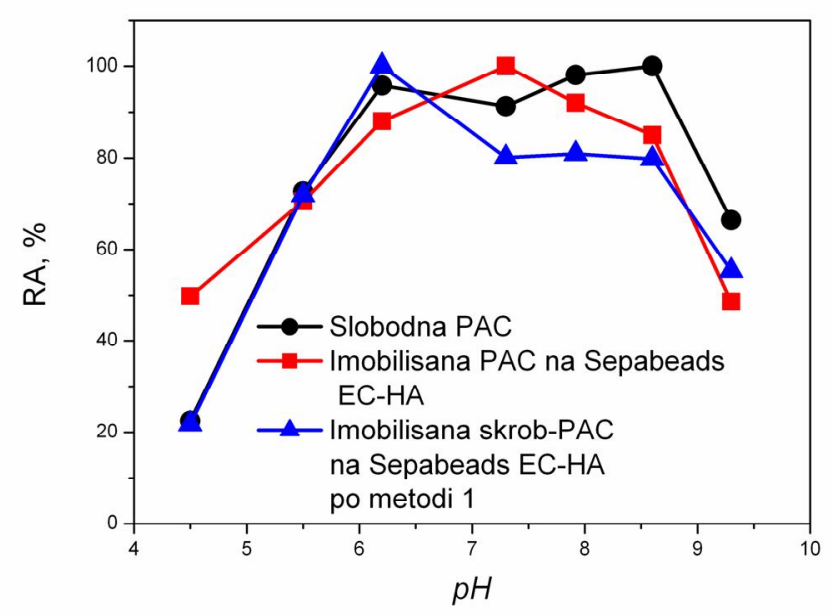

b)

Slika 9.4. Zavisnost relativne aktivnosti (RA) od pH vrednosti za slobodnu PAC, konvencionalno imobilisane PAC, imobilisane skrob-PAC po metodi 1 na a) Sepabeads EC-EA $i$ b) Sepabeads EC-HA. Uslovi reakcije: $37{ }^{\circ} \mathrm{C}, 3 \mathrm{~min}, 0,1 \mathrm{M}$ puferi: acetatni puferi (pH 4,5 i pH 5,5), fosfatni puferi ( $p H$ 6,2, pH 7,3 i pH 7,9) i tris/HCl puferi (pH 8,6 i pH 9,3) 
9.1.1.1.4. Ispitivanje uticaja imobilizacije skrob-penicilin-acilaze (metoda 1) na termalnu stabilnost biokatalizatora

Praćene su kinetike dezaktivacije modifikovane PAC imobilisane po metodi 1 na Sepabeads EC-EA i Sepabeads EC-HA na $50{ }^{\circ} \mathrm{C}$ (metoda opisana u poglavlju 6.2.3.11.). Na slici 9.5. su prikazani rezultati gde simboli predstavljaju eksperimentalne vrednosti, a pune linije predviđanja kinetičkog modela (jednačina 6.2.).

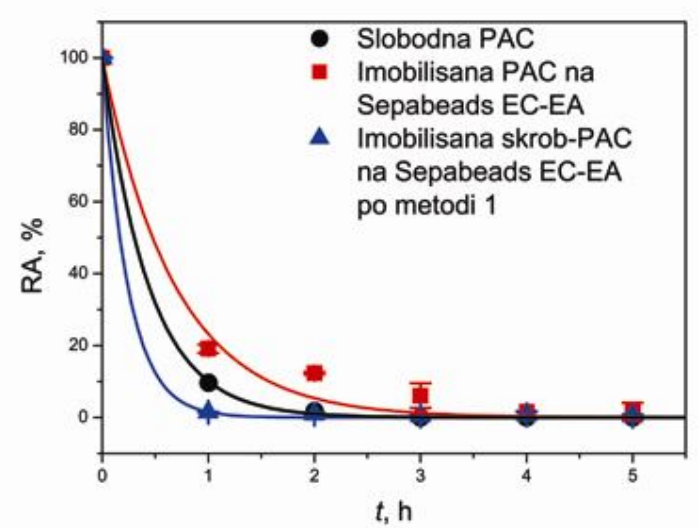

a)

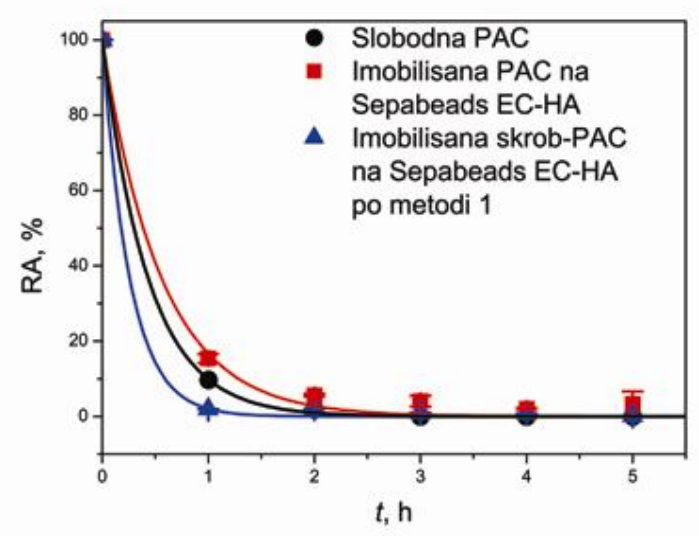

b)

Slika 9.5. Zavisnost relativne aktivnosti od vremena za slobodnu, konvencionalno imobilisanu i imobilisanu skrob-PAC na a) Sepabeads EC-EA $i$ b) Sepabeads EC-HA po metodi 1. Biokatalizatori se termostatiraju na $50{ }^{\circ} \mathrm{C}$ u različitim vremenskim periodima, a zatim se ispituje aktivnost tretiranih biokatalizatora $u$ standardnoj reakciji. Uslovi reakcije: 0,1 M natrijum-fosfatni pufer $(\mathrm{pH}=7,92), t=37^{\circ} \mathrm{C}, 3 \mathrm{~min}$ 
Sa slike 9.5. se vidi da je ovako imobilisan modifikovan enzim manje stabilan čak i od slobodnog enzima. Na osnovu kinetičkog modela dezaktivacije dobijene su vrednosti konstanti brzine dezaktivacije, $k_{\mathrm{D}}$ i poluvremena dezaktivacije $t_{1 / 2}$ (Tabela 9.1.).

Na osnovu dobijenih rezultata, može se zaključiti da se slobodan enzim kao i konvencionalno imobilisani enzimi sporije dezaktiviraju nego modifikovana imobilisana PAC. Slobodan enzim je stabiliniji 1,80 i 1,68 puta od modifikovane PAC imobilisane na Sepabeads EC-EA i Sepabeads EC-HA, redom (jednačina 6.5.).

Može se zaključiti da navedeni postupak imobilizacije nije doprineo ni stabilizaciji enzima, tako da je ova metoda nepodesna za imobilizaciju enzima. Navedeni postupak je čak prouzrokovao destabilizaciju enzima verovatno zbog promene konformacije u toku hemijskog tretmana. Modifikovana PAC imobilisana na Sepabeads EC-HA je neznatno stabilnija nego imobilisana na Sepabeads EC-EA, što nije od značaja.

Tabela 9.1. Vrednosti kinetičkih konstanti dezaktivacije za slobodan enzim i PAC i skrob-PAC (metoda 1) imobilisane na Sepabeads EC-EA i Sepabeads EC-HA nosače

\begin{tabular}{|c|c|c|c|c|}
\hline Biokatalizator & $k_{\mathrm{D}}, \mathrm{h}^{-1}$ & $t_{1 / 2}, h$ & $\mathbf{F}$ & $t_{\mathrm{d}}$ \\
\hline Slobodna PAC & 2,32 & 0,30 & 1,0 & 0 \\
\hline Imobilisana PAC na & 1,46 & 0,47 & 1,6 & 0 \\
\hline \multicolumn{5}{|l|}{ Sepabeads EC-EA } \\
\hline Imobilisana PAC na & 0,77 & 1,90 & 6,33 & 0,89 \\
\hline \multicolumn{5}{|l|}{ Sepabeads EC-HA } \\
\hline Imobilisana skrob-PAC & 4,18 & 0,17 & 0,55 & 0 \\
\hline \multicolumn{5}{|l|}{ na Sepabeads EC-EA po } \\
\hline \multicolumn{5}{|l|}{ metodi 1} \\
\hline Imobilisana skrob-PAC & 3,89 & 0,19 & 0,63 & 0 \\
\hline \multicolumn{5}{|l|}{ na Sepabeads EC-HA po } \\
\hline metodi 1 & & & & \\
\hline
\end{tabular}




\subsubsection{Karakterizacija penicilin-acilaze modifikovane derivatom skroba}

Skrob se oksiduje perjodatom do aldehida skroba, koji se zatim vezuje preko karbonilne grupe za amino grupu PAC da bi formirao ugljenohidratne delove $\mathrm{u}$ molekulu enzima, kao što je šematski prikazano na slici 9.6.

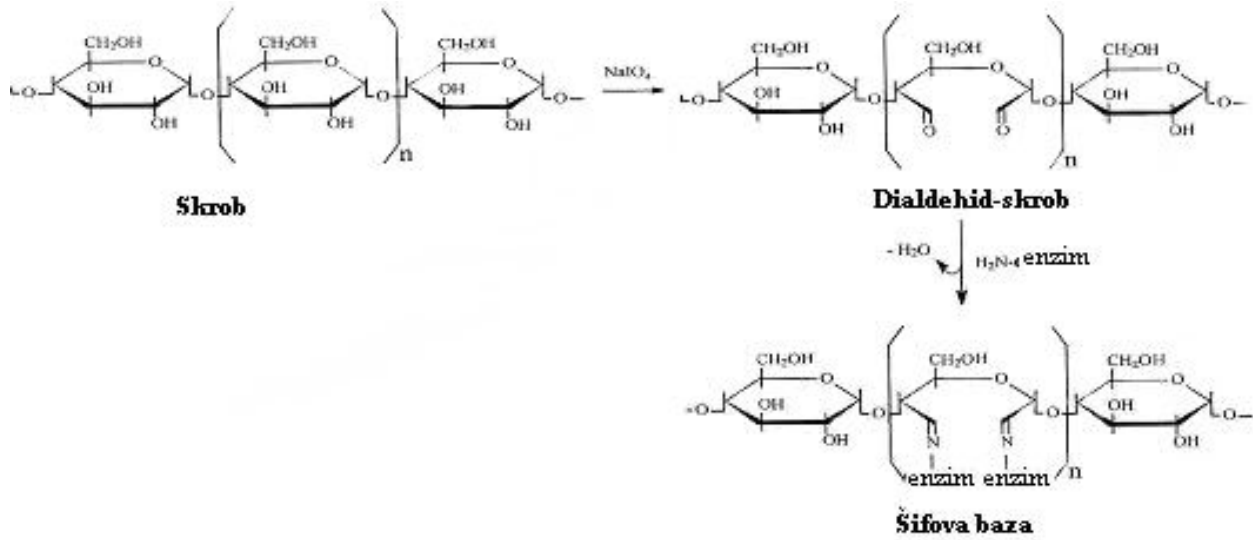

Slika 9.6. Šematski prikaz modifikacije PAC skrobom

Utvrđeno je da pripremljeni novi glikoenzim, PAC modifikovana aldehidnim derivatima skroba (skrob-PAC), sadrži 47\% ugljenohidratnog dela, određeno po metodi opisanoj u poglavlju 6.2.3.3. Skrob-PAC kompleks zadržava oko 95\% prvobitne aktivnosti odgovarajuće količine slobodne PAC. Ovaj rezultat je uporediv ili bolji od rezultata iz literature za druge hemijski modifikovane enzime ovom metodom, prikazanih u tabeli 9.2. Interesantno je da u literaturi nema podataka o hemijskoj modifikaciji PAC skrobom, iako je modifikacija ovog enzima drugim polisaharidima kao što su manan, pektin ili dekstran doprinela značajnoj stabilizaciji enzima pri čemu je aktivnost ovako modifikovanih enzima čak bila veća od aktivnosti nativne PAC [236]. 
Tabela 9.2. Pregled literaturnih vrednosti specifične aktivnosti hemijski modifikovanih enzima dobijenih za različite enzime u poređenju sa rezultatima dobijenim u ovom radu

\begin{tabular}{|c|c|c|}
\hline Konjugat & Specifična aktivnost, \% & Referenca \\
\hline Skrob-PAC & 95 & Ovaj rad \\
\hline Alginat-amilaza & 50 & [224] \\
\hline Dekstran-PAC & 110,3 & [236] \\
\hline Manan-PAC & 143,1 & [236] \\
\hline Pektat-PAC & 103,8 & [236] \\
\hline Hitozan-celulaza & 39,8 & [225] \\
\hline $\begin{array}{l}\alpha \text {-amilaza- } \beta \text {-ciklodekstrin- } \\
\text { karboksimetilceluloza }\end{array}$ & 90 & [226] \\
\hline Invertaza-pektin & 57 & [227] \\
\hline $\begin{array}{l}\text { Superoksid dizmutaza- } \\
\text { manan }\end{array}$ & 52 & [228] \\
\hline$\alpha$-amilaza- & 54 & [74] \\
\hline karboksimetilceluloza & & \\
\hline Tripsin- & 62 (esterolitička) & [69] \\
\hline karboksimetilceluloza & 42 (proteolitička) & \\
\hline
\end{tabular}

\subsubsection{Ispitivanje uticaja temperature na aktivnost penicilin-acilaze modifikovane derivatom skroba po metodi 2.}

Kako je osnovni cilj hemijske modifikacije PAC bila njena stabilizacija, prvo je ispitan uticaj temperature i pH na njenu aktivnost i rezultati su upoređeni sa slobodnim enzimom. Ispitan je uticaj temperature na aktivnost skrob-PAC po metodi opisanoj u poglavlju 6.2.3.4. pri čemu je temperatura varirana u intervalu $20-75{ }^{\circ} \mathrm{C}$. Rezultati su prikazani na slici 9.7 .

Što se tiče temperaturnog profila, skrob-PAC zadržava istu optimalnu temperaturu od $37{ }^{\circ} \mathrm{C}$ kao i slobodna PAC. Takođe, u literaturi postoje podaci da za celulazu modifikovanu hitozanom ne dolazi do promene optimalne temperature, dok do 
povećanja optimalne temperature za $8{ }^{\circ} \mathrm{C}$ dolazi u slučaju modifikacije invertaze pektinom i himotripsina ciklodekstrinom, a u slučaju modifikacije tripsina različitim $\beta$ ciklodekstrinima to povećanje iznosi $5-10{ }^{\circ} \mathrm{C}[225,227,229,230]$. Temperaturni profil skrob-PAC na višim temperaturama je neznatno širi nego temperaturni profil slobodne PAC. Može se zaključiti da nije postignuta željena stabilizacija enzima, ali svakako, pre iznošenja nekog opšteg zaključka, bilo je od važnosti ispitati i $\mathrm{pH}$ profil i termalnu stabilnost modifikovanog enzima.

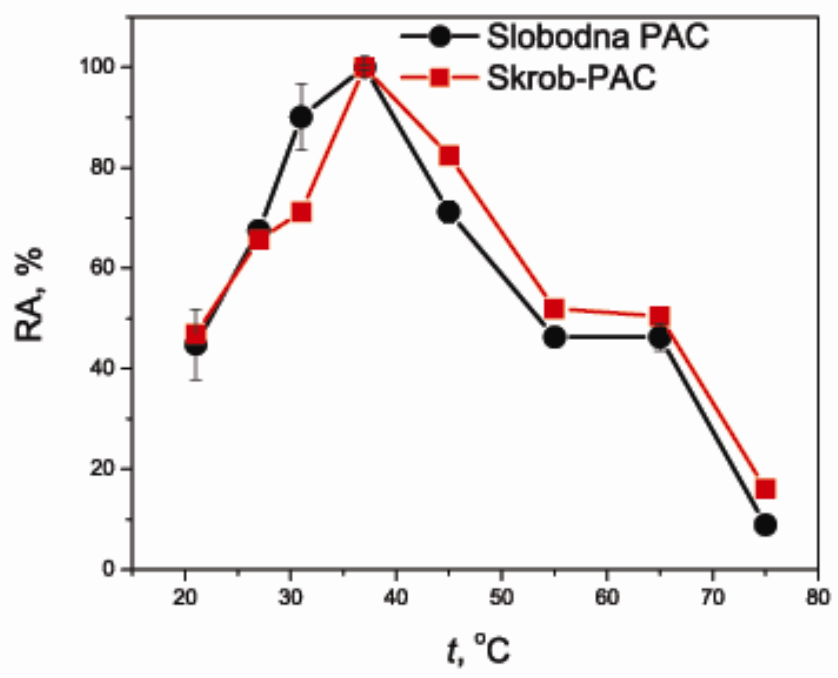

Slika 9.7. Zavisnost relativne aktivnosti (RA) skrob-PAC od temperature. Uslovi reakcije: 0,1 Mnatrijum-fosfatni pufer ( $p H=7,92), 3$ min

\subsubsection{Ispitivanje uticaja $\mathrm{pH}$ na aktivnost penicilin-acilaze modifikovane derivatom skroba po metodi 2}

Ispitan je uticaj $\mathrm{pH}$ vrednosti na aktivnost skrob-PAC po metodi opisanoj $\mathrm{u}$ poglavlju 6.2.3.5., pri čemu se ispitivana $\mathrm{pH}$ vrednost kretala u intervalu između 4,509,30. Rezultati su prikazani na slici 9.8. 


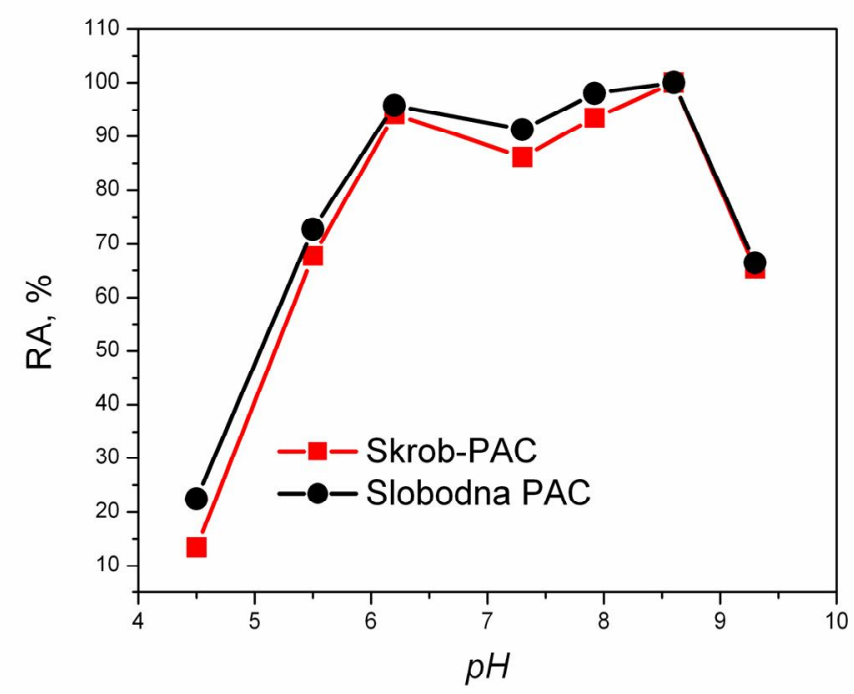

Slika 9.8. Zavisnost relativne aktivnosti skrob-PAC od pH vrednosti. Uslovi reakcije: $37{ }^{\circ} \mathrm{C}, 3 \mathrm{~min}, 0,1 \mathrm{M}$ puferi: acetatni puferi ( $\mathrm{pH}$ 4,5 i pH 5,5), fosfatni puferi ( $\mathrm{pH}$ 6,2, pH 7,3 i pH 7,9) i tris/HCl puferi (pH 8,6 i pH 9,3)

Sa slike 9.8. se vidi da optimalna pH vrednost skrob-PAC iznosi 8,60 , dok je slobodan enzim aktivan $\mathrm{u}$ širem intervalu $\mathrm{pH}$ vrednosti od 6,2 do 8,6. $\mathrm{pH}$ profil skrobPAC približno je isti kao i pH profil slobodne PAC. Skoro zanemarljive razlike u $\mathrm{pH}$ profilima ukazuju da nije došlo do značajnijih promena u samoj strukturi enzima nakon modifikacije. Za celulazu modifikovanu hitozanom dobijen je sličan rezultata [225]. 


\subsubsection{Ispitivanje uticaja modifikacije penicilin-acilaze derivatom skroba na termalnu stabilnost biokatalizatora}

Ispitana je kinetika dezaktivacije skrob-PAC na temperaturi $50{ }^{\circ} \mathrm{C}$ po metodi opisanoj u poglavlju 6.2.3.6. Rezultati su prikazani na slici 9.9.

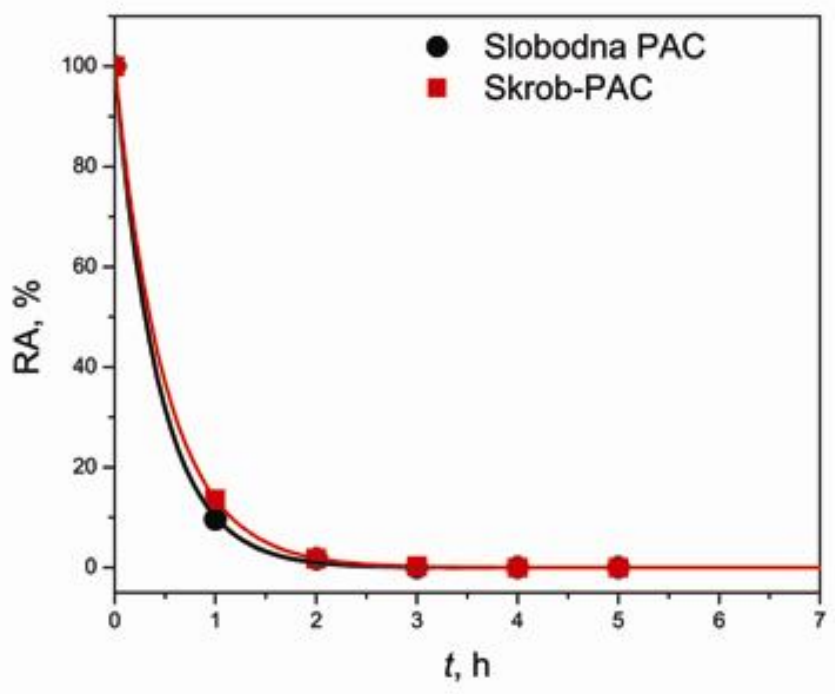

Slika 9.9. Zavisnost relativne aktivnosti skrob-PAC $i$ slobodne PAC od vremena.

Biokatalizatori se termostatiraju na $50{ }^{\circ} \mathrm{C}$ u različitim vremenskim periodima, a zatim se ispituje aktivnost tretiranih biokatalizatora u standardnoj reakciji. Uslovi reakcije: 0,1 M natrijum-fosfatni pufer ( $p H$ 7,92), $t=37^{\circ} \mathrm{C}, 3 \mathrm{~min}$

Na osnovu kinetičkog modela dezaktivacije prvog reda (jednačina 6.2) dobijena je vrednost konstante brzine dezaktivacije za skrob-PAC od 1,99 $\mathrm{h}^{-1}$, dok je za slobodan enzim 2,32 $\mathrm{h}^{-1}$. Izračunato poluvreme dezaktivacije skrob-PAC iznosi $0,35 \mathrm{~h}$, a za slobodnu PAC je 0,30 h. Na osnovu dobijenih rezultata može da se zaključi da hemijska modifikacija enzima stabilizuje enzim u odnosu na slobodan, ali neznatno $(\mathrm{F}=1,2)$. Nasuprot ovim rezultatima, u literaturi je zabeleženo da dolazi do značajnijeg poboljšanja termostabilnosti enzima nakon modifikacije polisaharidima (Tabela 9.3.). 
Tabela 9.3. Pregled literaturnih vrednosti faktora stabilizacije (F) hemijski modifikovanih enzima na različitim temperaturama

\begin{tabular}{llll}
\hline Konjugat & $\mathbf{F}$ & $\mathbf{T},{ }^{\circ} \mathrm{C}$ & Referenca \\
\hline Skrob-PAC & 1,2 & 50 & Ovaj rad \\
$\alpha$-amilaza- $\beta$ - & 5,0 & 75 & {$[226]$} \\
ciklodekstrin- & & & \\
karboksimetilceluloza & & 65 & {$[231]$} \\
Hitozan-invertaza & 60,0 & 65 & {$[227]$} \\
Invertaza-pektin & 576,0 & $45-60$ & {$[52]$} \\
Dekstran-PAC & $1,16-8,62$ & 50 & {$[78]$} \\
Manan-PAC & 16 & 40 & {$[79]$} \\
Karboksimetilceluloza- & 4 & & {$[74]$} \\
PAC & & 55 & {$[230]$} \\
$\alpha$-amilaza- & 6 & $45-60$ & \\
karboksimetilceluloza & & & \\
$\beta$-ciklodekstrin-tripsin & $9,4-6,0$ & & \\
\hline
\end{tabular}

\subsubsection{Imobilizacija penicilin-acilaze modifikovane derivatom skroba po metodi 2}

\subsubsection{Imobilizacija penicilin-acilaze modifikovane derivatom skroba po metodi 2 na Sepabeads EC-EA i Sepabeads EC-HA}

U cilju dobijanja aktivnijeg i stabilnijeg biokatalizatora u radu je ispitan i sličan postupak modifikacije i imobilizacije, tako da se samo skrob tretira perjodatom da bi se preveo u dialdehid skroba, a tek nakon toga se dodaje enzim koji se za njega hemijski vezuje (metode opisane u poglavlju 6.2.3.1. i 6.2.3.7.). Na taj način se enzim ne izlaže intenzivnoj oksidaciji. Tako modifikovan skrob-PAC konjugat se vezuje za Sepabeads EC-EA i Sepabeads EC-HA. 
9.1.3.1.1. Ispitivanje uticaja uslova imobilizacije na svojstva skrob-penicilin-acilaze imobilisane na Sepabeads EC-EA i Sepabeads EC-HA po metodi 2

U ovom delu rada je modifikovana PAC imobilisana na Sepabeads EC-EA, pri čemu je početna koncentracija enzima u rastvoru za imobilizaciju varirana u intervalu od 0,0025 do $0,040 \mathrm{~cm}^{3} / \mathrm{cm}^{3}$ tj. od 0,140 do $2,245 \mathrm{mg} / \mathrm{cm}^{3}$. I ovde je određivana masa vezanog modifikovanog enzima za nosače indirektno, na osnovu koncentracije zaostalog enzima $\mathrm{u}$ filtratu, $\mathrm{i}$ aktivnost tako dobijenih biokatalizatora $\mathrm{u}$ zavisnosti od početne koncentracije enzima u rastvoru za imobilizaciju kao što je prethodno opisano. Rezultati su prikazani na slikama 9.10. i 9.11. 


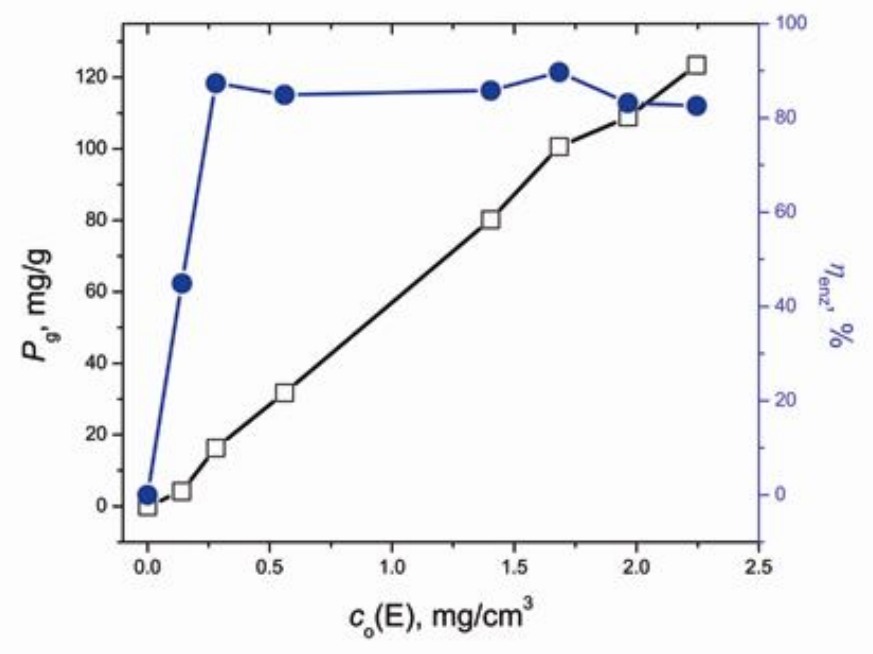

a)

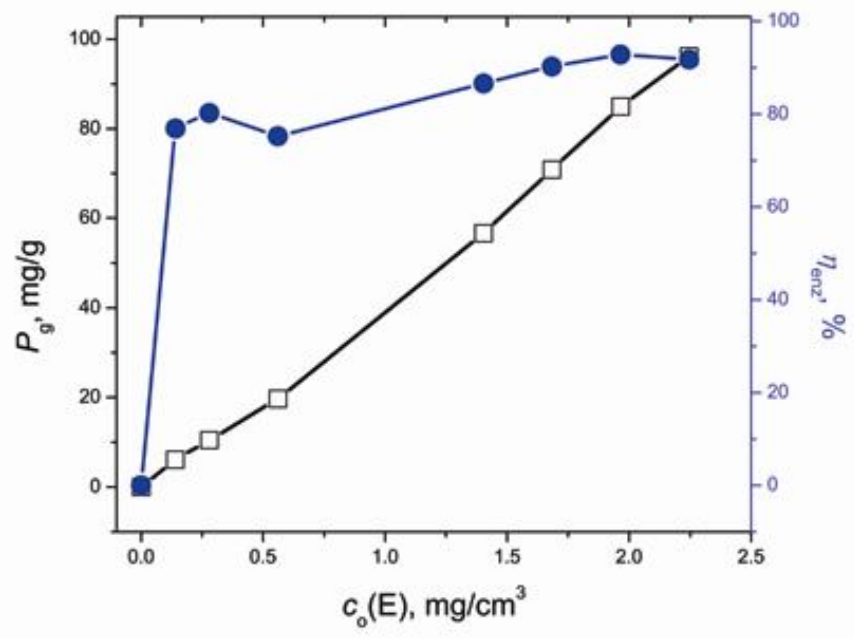

b)

Slika 9.10. Uporedni dijagram zavisnosti mase vezane skrob-PAC po metodi $2\left(P_{g}\right) i$ masenog prinosa imobilizacije ( $\eta_{\text {enz }}$ ) od početne koncentracije enzima $\left(c_{o}\right)$ za a) Sepabeads EC-EA $i$ b) Sepabeads EC-HA. Uslovi imobilizacije: 0,5 g nosača, 48 , $8^{\circ} \mathrm{C}, 50 \mathrm{mM}$ natrijum-acetatni pufer $(\mathrm{pH} 5,0)$ 


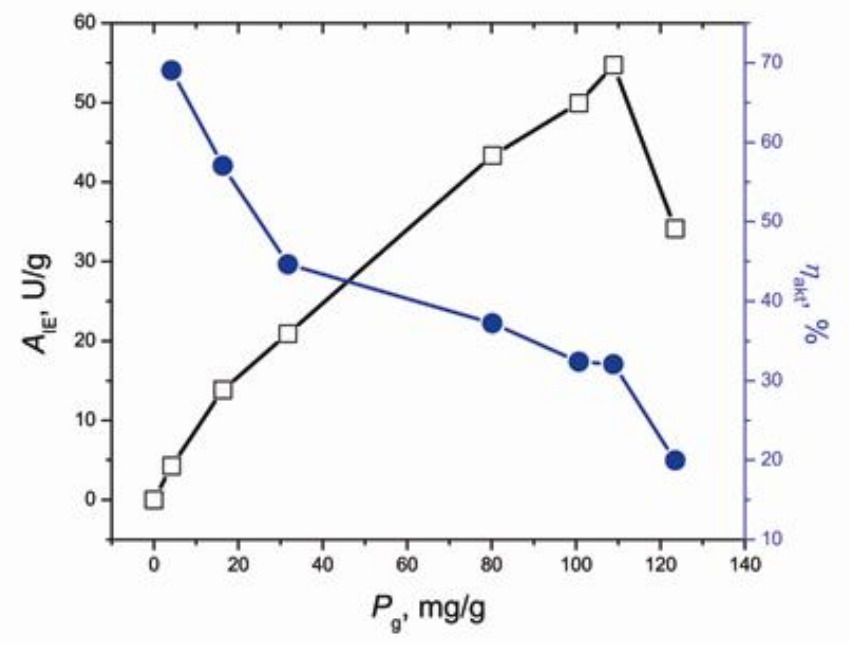

a)

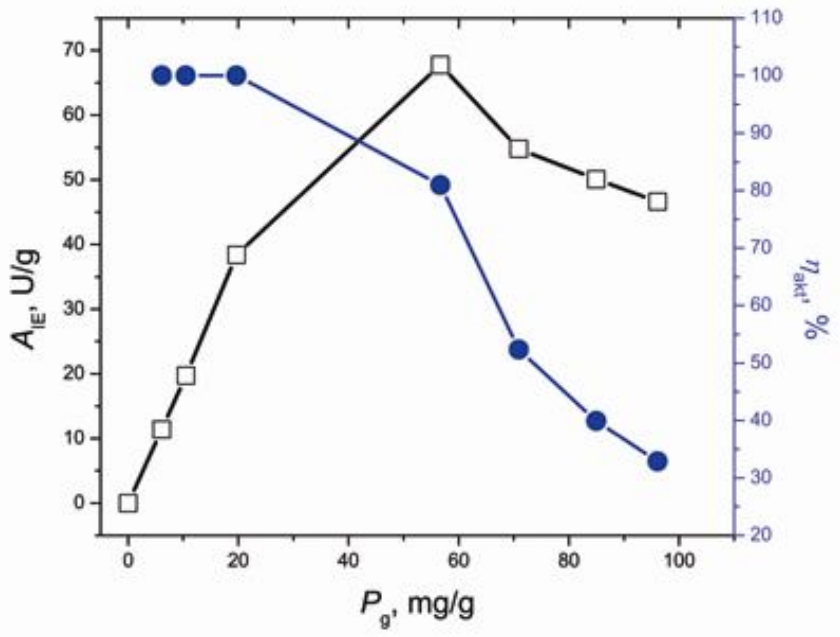

b)

Slika 9.11. Uporedni dijagram zavisnosti aktivnosti imobilisane skrob-PAC po metodi $2\left(A_{I E}\right)$ i prinosa aktivnosti ( $\left.\eta_{a k t}\right)$ od mase vezane PAC $\left(P_{g}\right)$ za a) Sepabeads EC-EA i b) Sepabeads EC-HA. Uslovi imobilizacije: 0,5 g nosača, $48 \mathrm{~h}, 8^{\circ} \mathrm{C}, 50 \mathrm{mM}$ natrijumacetatni pufer (pH 5,0)

Sa slike 9.10. se vidi da se postiže maksimalna masa vezanog enzima od oko $123 \mathrm{mg} / \mathrm{g}$ i $96 \mathrm{mg} / \mathrm{g}$ suvog nosača Sepabeads EC-EA i Sepabeads EC-HA, redom, za početnu koncentraciju enzima u rastvoru od $2,25 \mathrm{mg} / \mathrm{cm}^{3}$, i da masa vezanog enzima raste gotovo linearno sa porastom početne koncentracije enzima, kao što je dobijeno i u 
svim prethodnim slučajevima. U odnosu na konvencionalno imobilisan enzim, za nosače se vezuje nešto manja količina enzima. Maseni prinosi imobilizacije iznose 85,6 $\pm 2,7 \%$ i 90,4\% $\pm 2,72$ za Sepabeads EC-EA i Sepabeads EC-HA, ukazujući ipak na veliku količinu enzima koji se veže za nosač.

Kao i u prethodnim slučajevima, pri malim početnim koncentracijama enzima, dolazi do naglog porasta masenog prinosa, tako da se za veoma male početne koncentracije enzima od $0,14 \mathrm{mg} / \mathrm{cm}^{3}$ i $0,28 \mathrm{mg} / \mathrm{cm}^{3}$ već postiže maseni prinos od $77 \%$ i $87,4 \%$, u slučaju imobilizacije na Sepabeads EC-HA i Sepabeads EC-EA, redom. Slično, za invertazu hemijski modifikovanu hitozanom i naknadno imobilisanu na hitinski nosač obložen alginatom dobijen je maseni prinos imobilizacije od 85\% [232].

$\mathrm{Na}$ slici 9.11. prikazane su zavisnosti aktivnosti imobilisanog enzima i prinosa aktivnosti imobilizacije od mase vezanog enzima na nosaču. Sa slike se vidi da se sa imobilisanim i modifikovanim enzimom po metodi 2 postiže aktivnost biokatalizatora od 4,3 do 54,7 i od 11,4 do 67,8 IU/g suvog nosača, za mase vezanog enzima od 4-123 i $6-96 \mathrm{mg} / \mathrm{g}$ suvog nosača Sepabeads EC-EA i Sepabeads EC-HA, redom. Postiže se dva i šest puta veća aktivnost nego kod imobilisane skrob-PAC po metodi 1 za ova dva nosača, redom, i to pri manjim masama vezanog enzima za nosač u slučaju imobilizacije na Sepabeads EC-EA. To se najbolje može uočiti preko prinosa aktivnosti koji iznose čak oko 70\% i 100\% za Sepabeads EC-EA i Sepabeads EC-HA, redom, što je značajan rezultat u poređenju sa literaturnim podacima. Poznato je da hemijski imobilisani enzimi gube značajan deo početne akivnosti u postupku imobilizacije, ali evidentno je da je u ovom slučaju enzim zadržao značajnu početnu aktivnost. Razlog je primenjena metoda imobilizacije, gde se enzim vezuje za nosač preko uvedene ugljenohidratne komponente, a ne preko proteinskog dela molekula. Ovaj rezultat je bolji od rezultata objavljenih $\mathrm{u}$ literaturi za druge enzime ali primenom istog principa imobilizacije. Knežević i saradnici (2006) su za lipazu imobilisanu na Eupergit C preko ugljenohidratnog dela dobili prinos aktivnosti od 43,3\%, dok su Prodanović i saradnici (2001) za invertazu imobilisanu na makroporozni glicidilmetakrilat preko ugljenohidratnog dela dobili prinos aktivnosti od 45\% [233, 234]. 


\subsection{Ispitivanje uticaja temperature na aktivnost skrob-penicilin-acilaze} imobilisane na Sepabeads EC-EA i Sepabeads EC-HA po metodi 2

Ispitan je uticaj temperature na aktivnost enzima po metodi opisanoj u poglavlju 6.2.3.9. pri čemu je temperatura varirana u intervalu $20-75^{\circ} \mathrm{C}$. Rezultati su prikazani na slici 9.12.

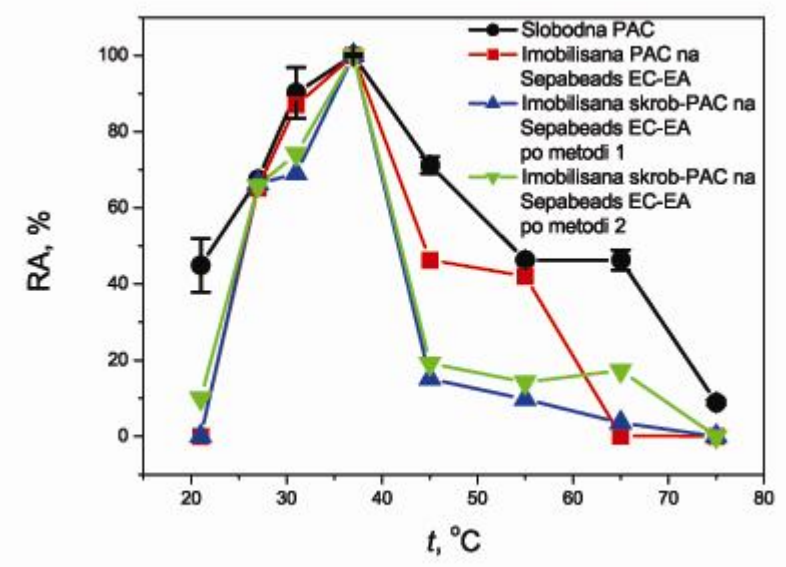

a)

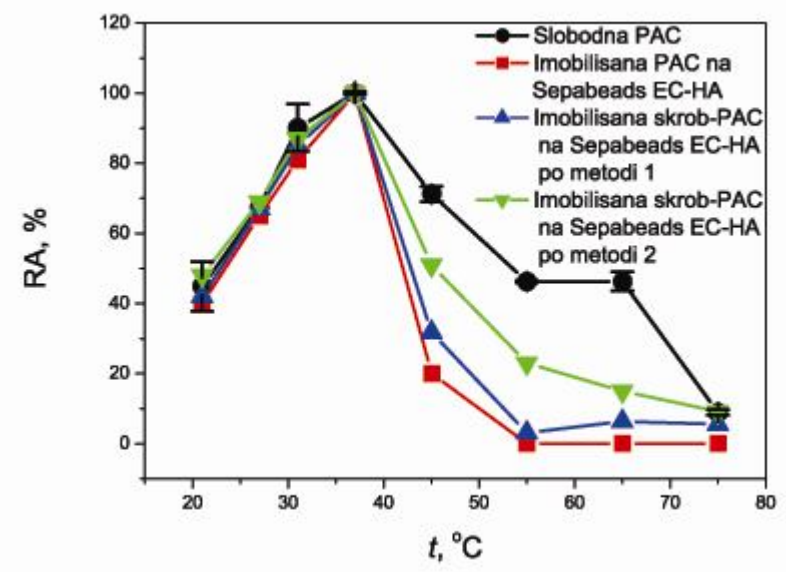

b)

Slika 9.12. Zavisnost relativne aktivnosti (RA) od temperature za slobodnu PAC, konvencionalno imobilisane PAC, imobilisane skrob-PAC po metodi 1 i po metodi 2 na a) Sepabeads EC-EA i b) Sepabeads EC-HA. Uslovi reakcije: 0,1 M natrijum-fosfatni pufer $(p H=7,92), 3$ min 
Sa slika se uočava da u oba slučaja enzim zadržava istu optimalnu temperaturu od $37{ }^{\circ} \mathrm{C}$ kao i slobodna, konvencionalno imobilisana PAC i imobilisana skrob-PAC po metodi 1, dok su njihovi profili uži nego temperaturni profil slobodne PAC.

Za modifikovanu invertazu je dobijeno povećanje optimalne temperature za $10^{\circ} \mathrm{C}$ nakon imobilizacije [232].

9.1.3.1.3. Ispitivanje uticaja pH vrednosti na aktivnost skrob-penicilin-acilaze imobilisane na Sepabeads EC-EA i Sepabeads EC-HA po metodi 2

Ispitan je uticaj $\mathrm{pH}$ vrednosti na aktivnost imobilisanog enzima po metodi opisanoj u poglavlju 6.2.3.10., pri čemu se ispitivana $\mathrm{pH}$ vrednost kretala u intervalu između 4,50-9,30. Rezultati su prikazani na slici 9.13.

$\mathrm{Na}$ slici 9.13. se vidi da se $\mathrm{pH}$ profili imobilisane skrob-PAC po metodi 2 pomeraju ka baznoj sredini u odnosu na $\mathrm{pH}$ profil imobilisane skrob-PAC po metodi 1 u oba slučaja i konvencionalno imobilisane PAC u slučaju imobilizacije na Sepabeads EC-EA. Optimalna pH vrednost biokatalizatora za Sepabeads EC-EA iznosi 8,60, tako da se nije promenila u odnosu na optimalnu vrednost slobodnog enzima. Dok je optimalna pH vrednost biokatalizatora za Sepabeads EC-HA 7,3 dakle nepromenjena u odnosu na optimalnu vrednost konvencionalno imobilisane PAC. Biokatalizatori su aktivni $\mathrm{u}$ intervalu $\mathrm{pH}$ vrednosti od 7,3 do 8,6, dok je za slobodan enzim interval optimalnih vrednosti bio od 6,2 do 8,6, što pokazuje da je optimalni $\mathrm{pH}$ opseg imobilizacijom, nažalost, sužen. 


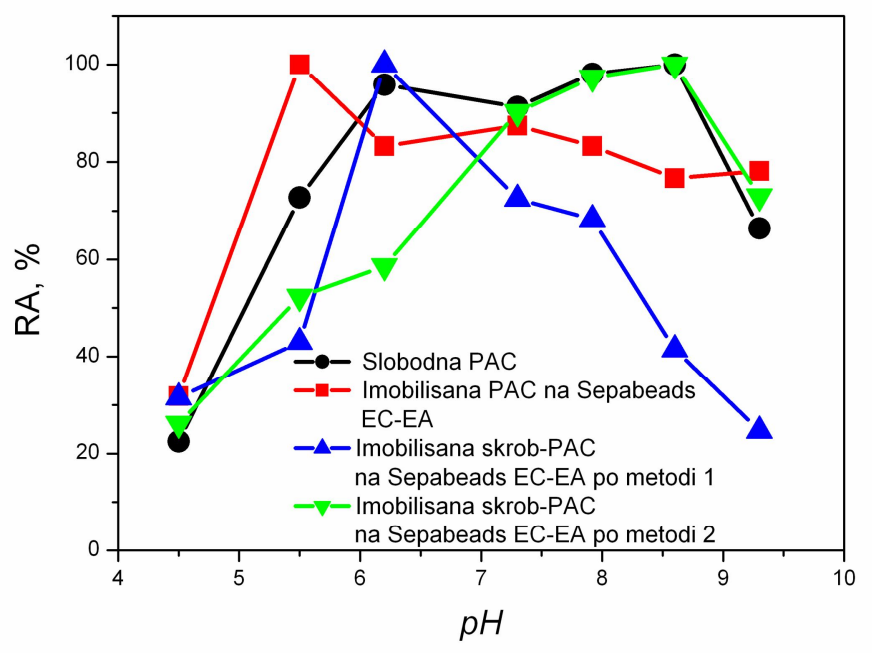

a)

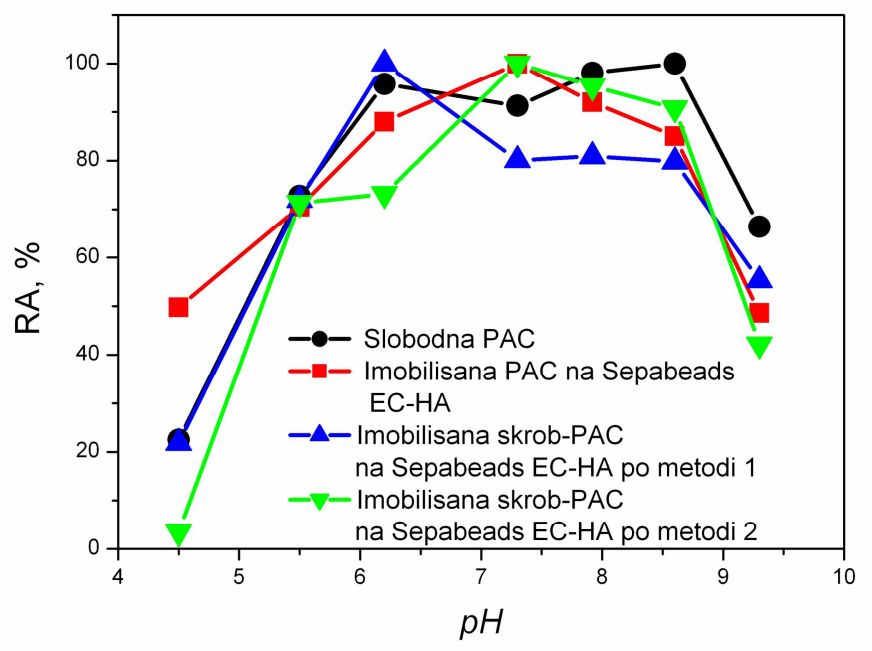

b)

Slika 9.13. Zavisnost relativne aktivnosti (RA) od pH vrednosti za slobodnu PAC, konvencionalno imobilisane PAC, imobilisane skrob-PAC po metodi 1 i po metodi 2 na a) Sepabeads EC-EA $i$ b) Sepabeads EC-HA. Uslovi reakcije: $37{ }^{\circ} \mathrm{C}, 3 \mathrm{~min}, 0,1 \mathrm{M}$ puferi: acetatni puferi (pH 4,5 i pH 5,5), fosfatni puferi (pH 6,2, pH 7,3 i pH 7,9) $i$ tris/HCl puferi (pH 8,6 i $p H$ 9,3) 
9.1.3.1.4. Ispitivanje uticaja imobilizacije skrob-penicilin-acilaze (metoda 2) na termalnu stabilnost biokatalizatora

Kao i u prethodnim slučajevima, ispitana je stabilnost skrob-PAC imobilisane na Sepabeads EC-EA i Sepabeads EC-HA po metodi 2 na $50{ }^{\circ} \mathrm{C}$, praćenjem kinetike dezaktivacije biokatalizatora. Rezultati su prikazani na slici 9.14. i pri tome je izvršeno modelovanje rezultata primenom kinetičkog modela dezaktivacije prvog reda (jednačina 6.2.) i primenom modela sa početnom lag fazom (jednačina 6.3.).

Sa slike se vidi da je ovaj biokatalizator dosta stabilniji u odnosu na slobodan, konvencionalno imobilisan i imobilisan modifikovan enzim po metodi 1.

$\mathrm{Na}$ osnovu modela dobijene su vrednosti konstanti brzine dezaktivacije, $k_{\mathrm{D}} \mathrm{i}$ poluvremena dezaktivacije $t_{1 / 2}$ (Tabela 9.4.).

Tabela 9.4. Vrednosti kinetičkih konstanti dezaktivacije za slobodan enzim i skrob-PAC imobilisane na Sepabeads EC-EA i Sepabeads EC-HA nosače po metodi 2

\begin{tabular}{lcccc}
\hline Biokatalizator & $\boldsymbol{k}_{\mathbf{D}}, \mathrm{h}^{-1}$ & $\boldsymbol{t}_{\mathbf{1 / 2}}, \mathrm{h}$ & $\boldsymbol{F}$ & $\boldsymbol{t}_{\mathbf{D}}$ \\
\hline Slobodna PAC & 2,32 & 0,30 & 1 & \\
$\begin{array}{l}\text { Imobilisana skrob-PAC na } \\
\text { Sepabeads } \text { EC-EA po metodi } 2\end{array}$ & 0,34 & 2,00 & 6,67 & \\
$\begin{array}{l}\text { Imobilisana skrob-PAC na } \\
\text { Sepabeads } \text { EC-HA po metodi 2 }\end{array}$ & 0,39 & 2,83 & 9,43 & 0,95 \\
\hline
\end{tabular}

Iz dobijenih rezultata može da se zaključi da ovakva metoda imobilizacije PAC dosta doprinosi stabilizaciji enzima. 


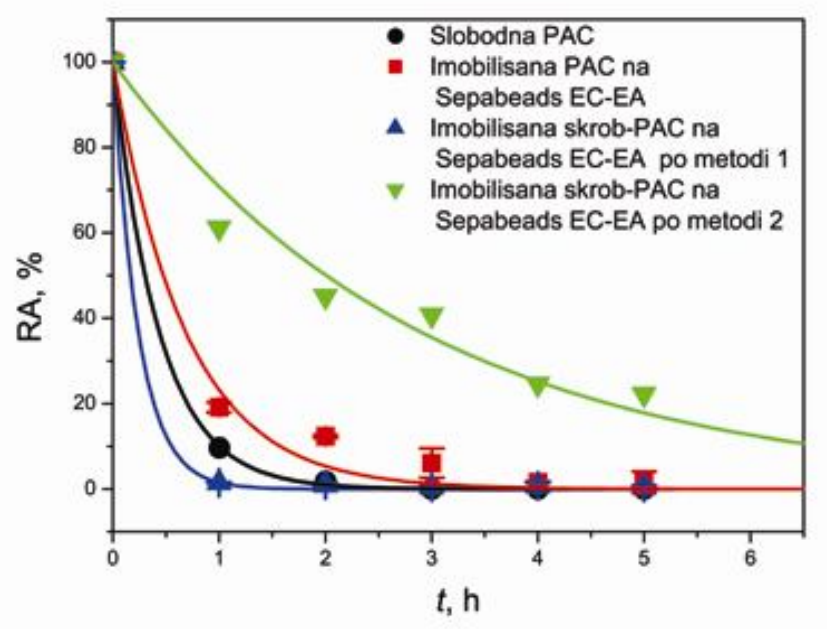

a)

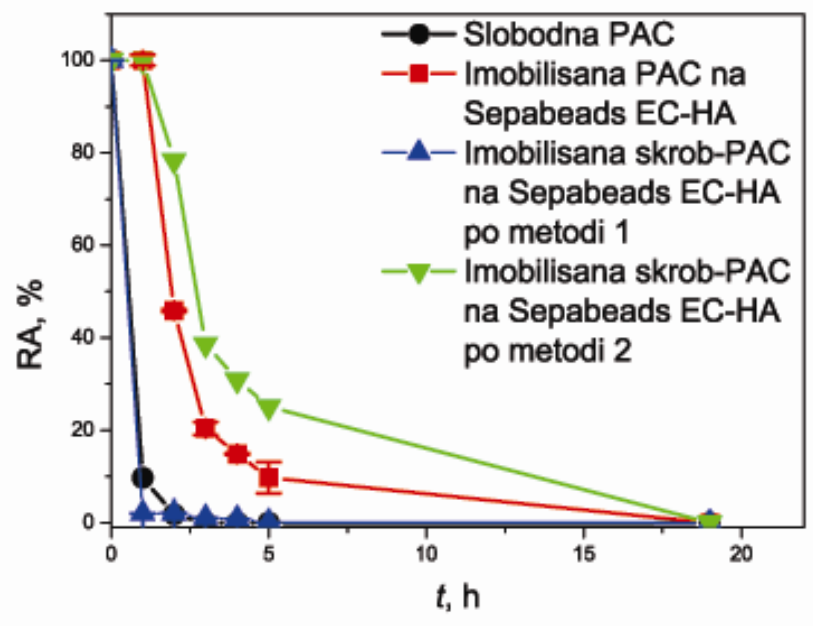

b)

Slika 9.14. Zavisnost relativne aktivnosti od vremena za slobodnu, konvencionalno imobilisanu i imobilisanu skrob-PAC na a) Sepabeads EC-EA $i$ b) Sepabeads EC-HA po metodama 1 i 2 . Biokatalizatori se termostatiraju na $50{ }^{\circ} \mathrm{C}$ u različitim vremenskim periodima, a zatim se ispituje aktivnost tretiranih biokatalizatora $u$ standardnoj reakciji. Uslovi reakcije: 0,1 M natrijum-fosfatni pufer $(\mathrm{pH}=7,92), t=37^{\circ} \mathrm{C}, 3 \mathrm{~min}$ 
U literaturi je zabeleženo da modifikovana invertaza nakon imobilizacije ima 4 puta veću termostabilnost na $65^{\circ} \mathrm{C}$ nego slobodna invertaza, lipaza imobilisana preko ugljenohidratnog dela je dva puta stabilnija na $75{ }^{\circ} \mathrm{C}$ nego konvencionalno imobilisana i 18 puta nego slobodna lipaza, dok invertaza adsorbovana preko ugljenohidratnog dela na Sepiolite je 8 puta stabilnija na $60{ }^{\circ} \mathrm{C}$ nego konvencionalno adsorbovana invertaza $[232,233,235]$.

U ovom radu je pokazano da je modifikacijom i imobilizacijom penicilinacilaze po metodi 2 dobijen biokatalizator koji je stabilizovan u odnosu na slobodan enzim. Takođe, on zadržava i značajnu početnu aktivnost od 70\% i 100\% za Sepabeads EC-EA i Sepabeads EC-HA, redom, što je posledica primenjene metode modifikacije i imobilizacije enzima. Može se zaključiti da je ovaj postupak podesan za stabilizaciju enzima [208].

\subsection{Karakterizacija i imobilizacija penicilin-acilaze modifikovane derivatom alginata}

\subsubsection{Karakterizacija penicilin-acilaze modifikovane derivatom alginata po metodi 2}

U ovom delu rada ispitana je mogućnost modifikacije PAC derivatom alginata da bi se dobila sintetisana glikozilovana PAC za koju se očekuje da će biti stabilnija od slobodne PAC. PAC je modifikovana po metodi opisanoj u poglavlju 6.2.3.1. Alginat se oksiduje perjodatom do aldehida alginata, koji se zatim vezuje preko karbonilne grupe za amino grupu PAC da bi formirao ugljenohidratne delove u molekulu enzima.

Utvrđeno je da pripremljeni novi glikoenzim, PAC modifikovana aldehidnim derivatima alginata (alginat-PAC), sadrži 53\% ugljenohidratnog dela, pri čemu zadržava oko 93\% prvobitne aktivnosti odgovarajuće količine slobodne PAC. Ovaj rezultat je bolji od rezultata iz literature (vidi tabelu 9.1, poglavlje 9.1.1). Sličan rezultat su dobili Mislovičova i saradnici, koji su utvrdili da je sadržaj ugljenohidratnog dela 55\% u istom derivatu [236]. U odnosu na kompleks skrob-PAC, alginat-PAC ima nešto veći sadržaj ugljenohidratnog dela i neznatno manju aktivnost. 


\subsubsection{Ispitivanje uticaja temperature na aktivnost penicilin-acilaze modifikovane} derivatom alginata po metodi 2

Ispitan je uticaj temperature na aktivnost alginat-PAC po metodi opisanoj $\mathrm{u}$ poglavlju 6.2.3.4. pri čemu je temperatura varirana u intervalu $20-75{ }^{\circ} \mathrm{C}$. Rezultati su prikazani na slici 9.15 .

Može se uočiti da alginat-PAC zadržava istu optimalnu temperaturu od $37{ }^{\circ} \mathrm{C}$ kao i slobodna PAC, međutim temperaturni profil alginat-PAC je uži nego temperaturni profil slobodne PAC.

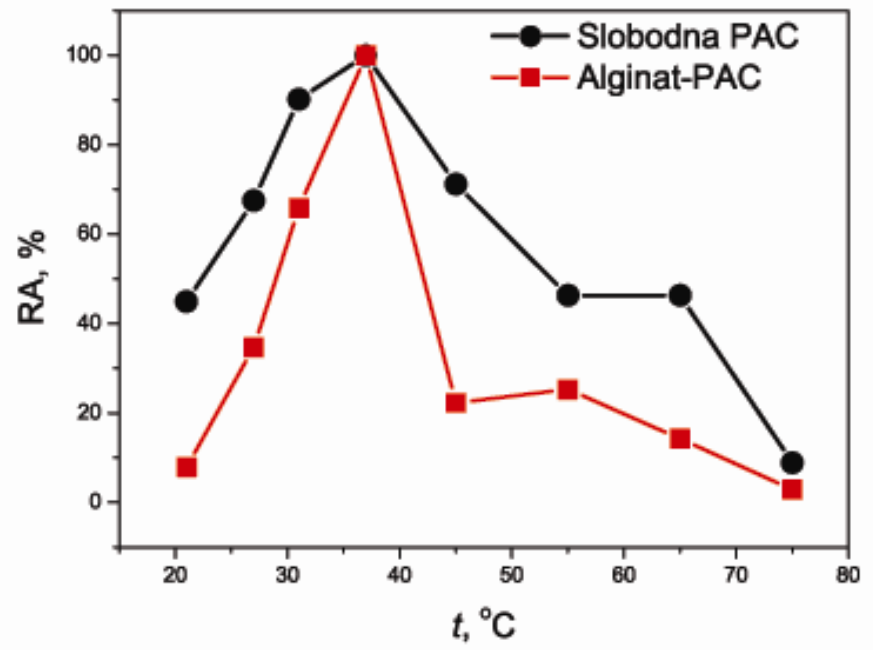

Slika 9.15. Zavisnost relativne aktivnosti slobodne PAC i alginat-PAC od temperature. Uslovi reakcije: 0,1 M natrijum-fosfatni pufer $(\mathrm{pH}=7,92), 3 \mathrm{~min}$ 


\subsubsection{Ispitivanje uticaja $\mathrm{pH}$ na aktivnost penicilin-acilaze modifikovane derivatom alginata po metodi 2}

Ispitan je uticaj $\mathrm{pH}$ vrednosti na aktivnost alginat-PAC po metodi opisanoj $\mathrm{u}$ poglavlju 6.2.3.5. pri čemu se ispitivana $\mathrm{pH}$ vrednost kretala u intervalu između 4,509,30. Rezultati su prikazani na slici 9.16.

Sa slike se vidi da optimalna $\mathrm{pH}$ vrednost alginat-PAC iznosi 8,60, dok je enzim aktivan u širem intervalu $\mathrm{pH}$ vrednosti od 6,2 do 8,6. $\mathrm{pH}$ profil alginat-PAC je približno isti kao i pH profil slobodne PAC. Skoro zanemarljive razlike u $\mathrm{pH}$ profilima ukazuju da nije došlo do značajnijih promena u samoj strukturi enzima nakon modifikacije.

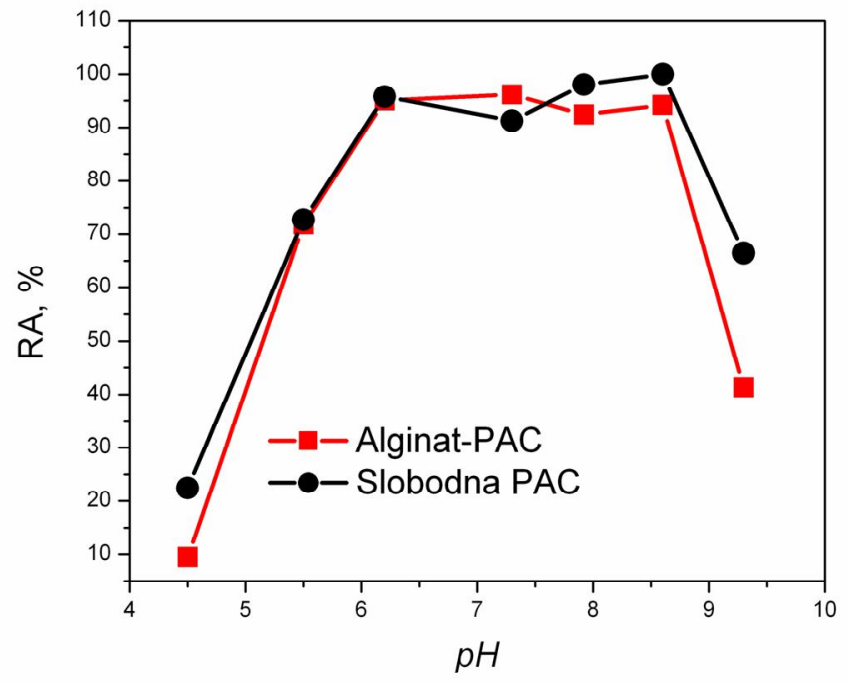

Slika 9.16. Zavisnost relativne aktivnosti slobodne PAC $i$ alginat-PAC od pH vrednosti. Uslovi reakcije: $37{ }^{\circ} \mathrm{C}, 3 \mathrm{~min}, 0,1 \mathrm{M}$ puferi: acetatni puferi $(\mathrm{pH} 4,5$ i $\mathrm{pH}$ 5,5), fosfatni puferi (pH 6,2, pH 7,3 i pH 7,9) i tris/HCl puferi (pH 8,6 i pH 9,3) 


\subsubsection{Ispitivanje uticaja modifikacije penicilin-acilaze derivatom alginata na termalnu stabilnost biokatalizatora po metodi 2}

Ispitana je kinetika dezaktivacije alginat-PAC na temperaturi $50{ }^{\circ} \mathrm{C}$ po metodi opisanoj u poglavlju 6.2.3.6. Eksperimentalni rezultati i predviđanja kinetičkog modela dezaktivacije prvog reda (jednačina 6.2.) su prikazani na slici 9.17.

Sa slike 9.17. se vidi da je alginat-PAC izgubila gotovo potpuno aktivnost odmah nakon tretmana na $50{ }^{\circ} \mathrm{C}$ u periodu od $1 \mathrm{~h}$. Primena kinetičkog modela dezaktivacije je stoga nepouzdana ali je radi poređenja sa ostalim biokatalizatorima određena konstanta dezaktivacije od 50,65 $\mathrm{h}^{-1}$ koja je davala najbolja slaganja predviđanja modela sa eksperimentalnim rezultatima. Poluvreme dezaktivacije je onda iznosilo 0,014 h, a za slobodnu PAC je 0,30 h. Iako bi radi preciznijeg određivanja parametara modela bilo potrebno dodati eksperimentalne tačke u periodu do vremena od $1 \mathrm{~h}$, dobijeni kinetički parametri jasno ukazuju da hemijska modifikacija derivatom alginata nije dovela do stabilizacije PAC i da je modifikacija derivatom skroba pogodnija jer dovodi do stabilizacije PAC. Ove razlike u ponašanju PAC modifikvane alginatom i skrobom mogu biti usled toga što je alginat anjonski polisaharid, dok je skrob nejonski. Očigledno da dodatno negativno naelektrisanje u molekulu enzima negativno utiče na ukupnu preraspodelu naelektrisanja u molekulu enzima i njegovu konformaciju, koje su u direktnoj vezi sa katalitičkim svojstvima i stabilnosti enzima. 


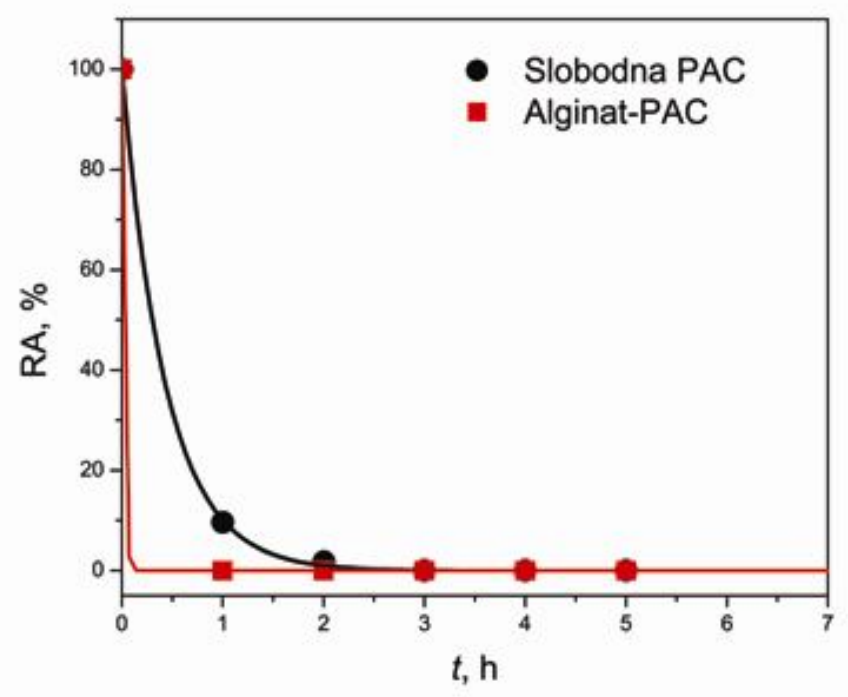

Slika 9.17. Zavisnost relativne aktivnosti slobodne PAC $i$ alginat-PAC od vremena. Alginat-PAC se termostatira na $50{ }^{\circ} \mathrm{C}$ u različitim vremenskim periodima, a zatim se ispituje aktivnost tretirane alginat-PAC u standardnoj reakciji. Uslovi reakcije: 0,1 M natrijum-fosfatni pufer $(\mathrm{pH}=7,92), t=37^{\circ} \mathrm{C}, 3 \mathrm{~min}$

\subsubsection{Imobilizacija penicilin-acilaze modifikovane derivatom alginata po metodi 2}

U cilju dobijanja aktivnijeg i stabilnijeg biokatalizatora u radu je ispitan i postupak imobilizacije alginat-PAC na istim komercijalnim nosačima koji su ispitivani i u prethodnim istraživanjima. Pošto je prilikom imobilizacije skrob-PAC utvrđeno da metoda 2 daje bolje rezultate, u ovom delu rada je vršena imobilizacija alginat-PAC samo ovom metodom. U literaturi ne postoje podaci o imobilizaciji PAC modifikovane derivatom alginata, tako da je u ovom radu imobilizacija alginat-PAC prvi put ispitana.

\subsubsection{Imobilizacija penicilin-acilaze modifikovane derivatom alginata na Sepabeads EC-EA i Sepabeads EC-HA po metodi 2}

U ovom delu rada ispitana je imobilizacija alginat-PAC na Sepabeads EC-EA i Sepabeads EC-HA nosače. Alginat je tretiran perjodatom da bi se preveo u dialdehid 
alginata, a tek nakon toga je dodata PAC koja se za njega hemijski vezuje. Na taj način se PAC ne izlaže intenzivnoj oksidaciji. Tako modifikovan alginat-PAC konjugat se vezuje za Sepabeads EC-EA i Sepabeads EC-HA.

9.2.2.1.1. Ispitivanje uticaja uslova imobilizacije na svojstva alginat-penicilin-acilaze imobilisane na Sepabeads EC-EA i Sepabeads EC-HA po metodi 2

U ovom delu rada je modifikovana PAC imobilisana na Sepabeads EC-EA i Sepabeads EC-HA, pri čemu je početna koncentracija enzima u rastvoru za imobilizaciju varirana $\mathrm{u}$ intervalu od 0,0025 do $0,040 \mathrm{~cm}^{3} / \mathrm{cm}^{3}$ tj. od 0,140 do $2,245 \mathrm{mg} / \mathrm{cm}^{3}$. I u ovom slučaju određivana je masa vezanog modifikovanog enzima za nosač indirektno, na osnovu koncentracije zaostalog enzima u filtratu i na osnovu aktivnosti tako dobijenih biokatalizatora. Rezultati su prikazani na slikama 9.18. i 9.19. 


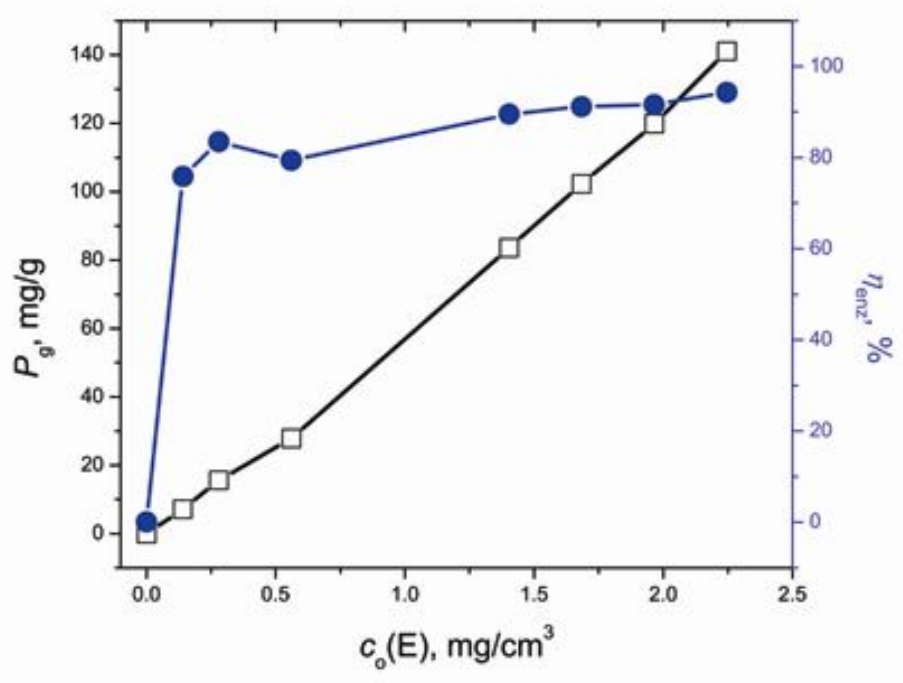

a)

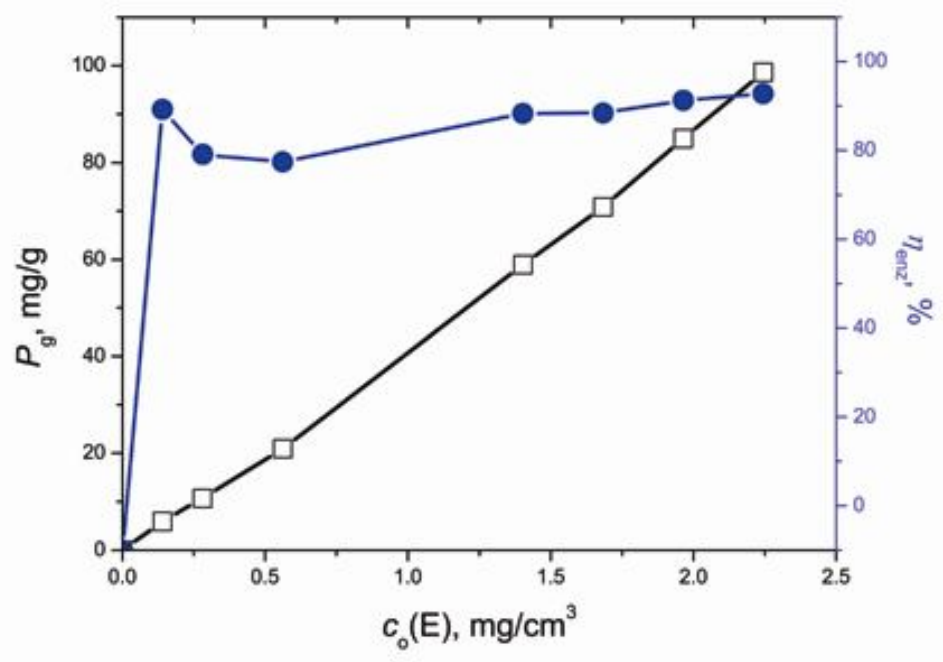

b)

Slika 9.18. Uporedni dijagram zavisnosti mase vezane alginat-PAC po metodi $2\left(P_{g}\right) i$ masenog prinosa imobilizacije ( $\left.\eta_{\text {enz }}\right)$ od početne koncentracije enzima $\left(c_{o}\right)$ za a) Sepabeads EC-EA $i$ b) Sepabeads EC-HA. Uslovi imobilizacije: 0,5 g nosača, 48 h, $8^{\circ} \mathrm{C}, 50 \mathrm{mM}$ natrijum-acetatni pufer $(\mathrm{pH} 5,0)$ 


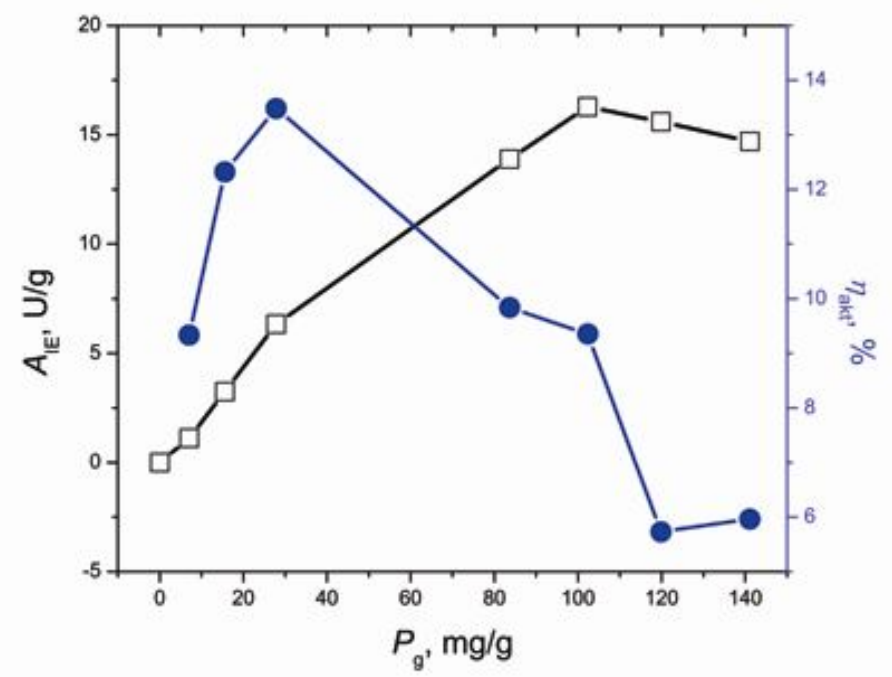

a)

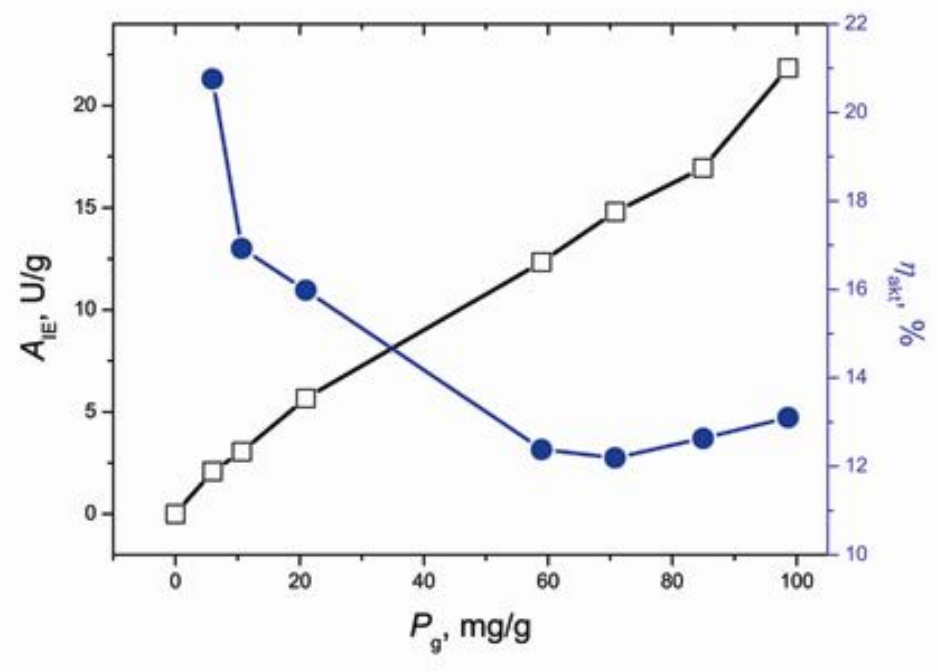

b)

Slika 9.19. Uporedni dijagram zavisnosti aktivnosti $\left(A_{I E}\right)$ imobilisane alginat-PAC po metodi 2 i prinosa aktivnosti ( $\eta_{\text {akt }}$ ) od mase vezane PAC $\left(P_{g}\right)$ za a) Sepabeads EC-EA $i$ b) Sepabeads EC-HA. Uslovi imobilizacije: 0,5 g nosača, $48 \mathrm{~h}, 8^{\circ} \mathrm{C}, 50 \mathrm{mM}$ natrijumacetatni pufer (pH 5,0) 
Sa slike 9.18. se vidi da se postiže maksimalna masa vezanog enzima od oko $141 \mathrm{mg} / \mathrm{g}$ i 99 mg/g suvog nosača za Sepabeads EC-EA i Sepabeads EC-HA, redom, za najveću ispitivanu početnu koncentraciju enzima u rastvoru od $2,25 \mathrm{mg} / \mathrm{cm}^{3}$, i da masa vezanog enzima raste gotovo linearno sa porastom početne koncentracije enzima. U odnosu na imobilisanu skrob-PAC po metodi 2 , za nosač se vezuje nešto više enzima što se može protumačiti da dolazi jednim delom i do jonske adsorpcije enzima. Maseni prinos imobilizacije iznosio je $85,7 \pm 9,3 \%$ i $88,6 \% \pm 6,2$ za Sepabeads EC-EA i Sepabeads EC-HA, redom, ukazujući na veliku količinu enzima koja se veže za nosač. Kao i u prethodnim slučajevima, pri malim početnim koncentracijama enzima, dolazi do naglog porasta masenog prinosa, tako da se za početnu koncentraciju enzima od $0,14 \mathrm{mg} / \mathrm{cm}^{3}$ postiže maseni prinos od $75,8 \%$ i $90,9 \%$ za Sepabeads EC-EA i Sepabeads EC-HA, redom. Dobijeni rezultati su približno isti kao u slučaju nemodifikovanog enzima imobilisanog na Sepabeads EC-EA i Sepabeads EC-HA konvencionalnom metodom.

$\mathrm{Na}$ slici 9.19. prikazane su zavisnosti aktivnosti imobilisanog enzima i prinosa aktivnosti imobilizacije od mase vezanog enzima na nosačima. Sa slike se vidi da se sa imobilisanim i modifikovanim enzimom postiže aktivnost biokatalizatora od 1,1 do $16,3 \mathrm{IU} / \mathrm{g}$ i od 2,1 do 21,8 IU/g suvog nosača, za mase vezanog enzima od 7 do $141 \mathrm{mg} / \mathrm{g}$ i od 6 do $99 \mathrm{mg} / \mathrm{g}$ suvog nosača za Sepabeads EC-EA i Sepabeads EC-HA, redom. Može se uočiti da se postiže znatno manja aktivnost nego kod imobilisane skrob-PAC po metodi 2. U ovom slučaju je i prinos aktivnosti znatno manji i iznosi maksimalno $13,5 \%$ i $20,7 \%$ za Sepabeads EC-EA i Sepabeads EC-HA, redom. Dobijena aktivnost i prinos aktivnosti su znatno manji nego u slučaju imobilizacije skrob-PAC, pa može da se zaključi da modifikacija PAC derivatom alginata nepovoljno deluje na njenu aktivnost i da je modifikacija derivatom skroba pogodnija.

\subsection{Ispitivanje uticaja temperature na aktivnost alginat-penicilin-acilaze} imobilisane na Sepabeads EC-EA i Sepabeads EC-HA po metodi 2

Ispitan je uticaj temperature na aktivnost imobilisanog enzima po metodi opisanoj u poglavlju 6.2.3.9. pri čemu je temperatura varirana u intervalu $20-75{ }^{\circ} \mathrm{C}$. Rezultati su prikazani na slici 9.20. 
Sa slike se uočava da enzim u oba slučaja zadržava istu optimalnu temperaturu od $37{ }^{\circ} \mathrm{C}$, kao i slobodna, konvencionalno imobilisana PAC i imobilisana skrob-PAC po metodi 2 .

I ovde su temperaturni profili u oba slučaja uži nego temperaturni profil slobodne PAC.

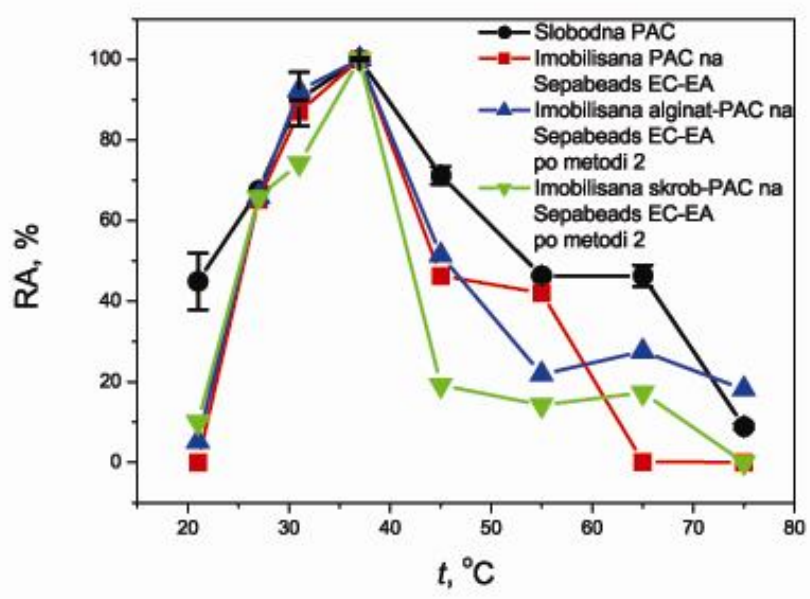

a)

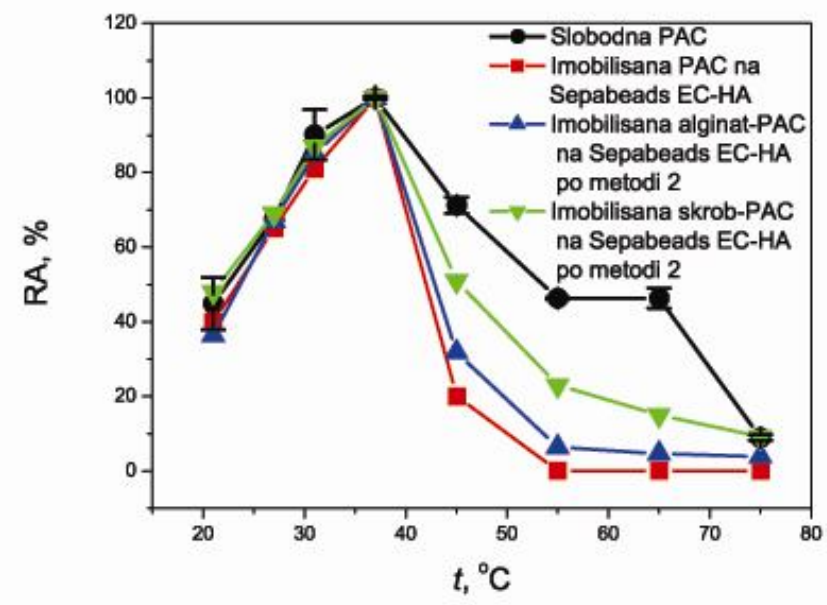

b)

Slika 9.20. Zavisnost relativne aktivnosti (RA) od temperature za slobodnu PAC, konvencionalno imobilisane PAC, imobilisane skrob-PAC $i$ alginat-PAC na a) Sepabeads EC-EA $i$ b) Sepabeads EC-HA. Uslovi reakcije: 0,1 M natrijum-fosfatni pufer $(p H=7,92), 3$ min 
9.2.2.1.3. Ispitivanje uticaja pH vrednosti na aktivnost alginat-penicilin-acilaze imobilisane na Sepabeads EC-EA i Sepabeads EC-HA po metodi 2

Ispitan je uticaj $\mathrm{pH}$ vrednosti na aktivnost alginat-PAC imobilisane na Sepabeads EC-EA i Sepabeads EC-HA po metodi 6.2.3.10., pri čemu se ispitivana pH vrednost kretala u intervalu između 4,50-9,30. Rezultati su prikazani na slici 9.21.

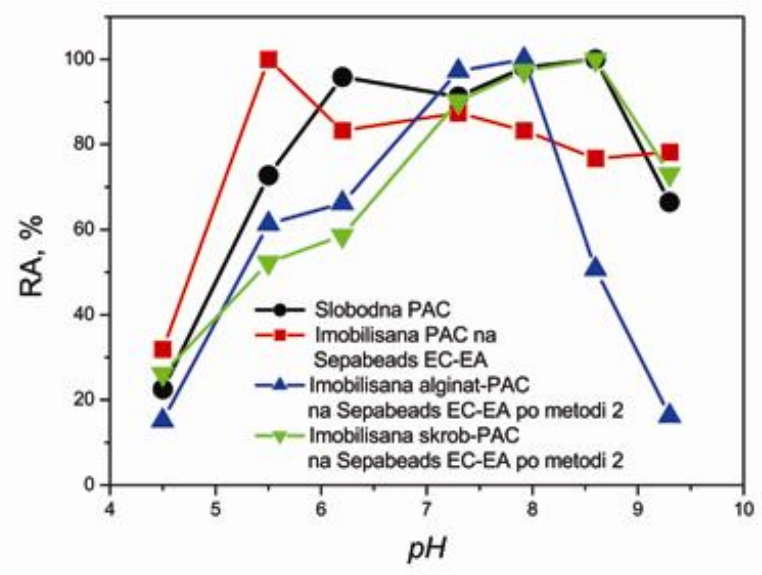

a)

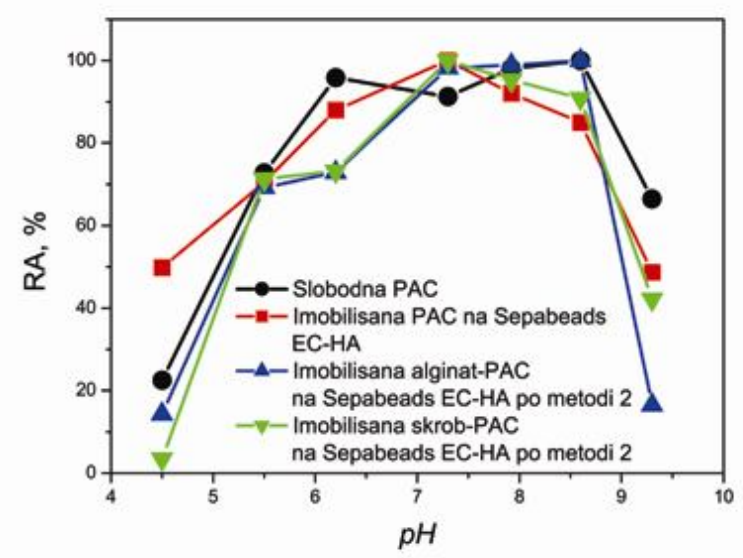

b)

Slika 9.21. Zavisnost relativne aktivnosti (RA) od $p H$ vrednosti slobodnu PAC, konvencionalno imobilisane PAC, imobilisane skrob-PAC $i$ alginat-PAC na a) Sepabeads EC-EA $i$ b) Sepabeads EC-HA. Uslovi reakcije: $37^{\circ} \mathrm{C}, 3 \mathrm{~min}, 0,1 \mathrm{M}$ puferi: acetatni puferi (pH 4,5 i pH 5,5 ), fosfatni puferi (pH 6,2, pH 7,3 i pH 7,9) i tris/ HCl puferi (pH 8,6 i pH 9,3) 
Na slici 9.21. se vidi da je optimalna $\mathrm{pH}$ vrednost alginat-PAC imobilisane na Sepabeads EC-EA iznosila 7,9, tako da je nešto manja nego optimalna vrednost slobodnog enzima i skrob-PAC imobilisane po metodi 2 na Sepabeads EC-EA. S druge strane, $\mathrm{pH}$ optimum alginat-PAC imobilisane na Sepabeads EC-HA je isti kao i kod slobodne PAC ( $\mathrm{pH} \mathrm{8,6).} \mathrm{Biokatalizator} \mathrm{je} \mathrm{aktivan} \mathrm{u} \mathrm{intervalu} \mathrm{pH}$ vrednosti od 7,3 do 8,0 i od 7,3 do 8,6 za Sepabeads EC-EA i Sepabeads EC-HA, redom, dok je slobodan enzim bio aktivan od 6,2 do 8,6 , tako da je u oba slučaja $\mathrm{pH}$ profil biokatalizatora sužen u odnosu na $\mathrm{pH}$ profil slobodnog enzima.

\subsection{Ispitivanje uticaja imobilizacije alginat-penicilin-acilaze na termalnu stabilnost biokatalizatora}

Kao i u prethodnim slučajevima, ispitana je stabilnost alginat-PAC imobilisane na Sepabeads EC-EA i Sepabeads EC-HA po metodi 2 na $50{ }^{\circ} \mathrm{C}$ (metoda opisana u poglavlju 6.2.3.11.), praćenjem kinetike dezaktivacije biokatalizatora. Rezultati su prikazani na slici 9.22. i pri tome je izvršeno modelovanje rezultata po modelu prvog reda (jednačina 6.2.).

Sa slike se vidi da su u oba slučaja biokatalizatori nestabilniji u odnosu na konvencionalno imobilisanu PAC i imobilisanu skrob-PAC po metodi 2. U poređenju sa slobodnim enzimom, samo je u slučaju imobilizacije alginatom modifikovane PAC na Sepabeads EC-HA postignuta neznatna stabilizacija enzima.

$\mathrm{Na}$ osnovu modela (jednačina 6.2.) se dobija konstanta brzine dezaktivacije imobilisane alginat-PAC na Sepabeads EC-EA i Sepabeads EC-HA po metodi 2, koja iznosi $5,0 \mathrm{~h}^{-1}$ i 1,68 $\mathrm{h}^{-1}$, redom. Iz jednačine 6.4. se dobija da je poluvreme dezaktivacije biokatalizatora $0,14 \mathrm{~h}$ i $0,41 \mathrm{~h}$, redom, dok je za slobodan enzim iznosilo 0,30 h. Može se zaključiti da je slobodan enzim oko 2,14 puta stabilniji od alginat-PAC imobilisane na Sepabeads EC-EA, a da je alginat-PAC imobilisana na Sepabeads EC-HA 1,37 puta stabilnija od slobodnog enzima. Odavde može da se zaključi da ova metoda ne doprinosi stabilizaciji enzima u slučaju imobilizacije na Sepabeads EC-EA.

$\mathrm{Na}$ osnovu dobijenih rezultata može se zaključiti da je hemijska modifikacija destabilizovala enzim, ali da je njegovom imobilizacijom na Sepabeads EC-HA došlo 
do određene stabilizacije. Alginat-PAC imobilisana na Sepabeads EC-HA je nešto stabilinija nego slobodna, a značajno stabilnija od neimobilisane alginat-PAC na $50{ }^{\circ} \mathrm{C}$. Takođe, alginat-PAC imobilisana na Sepabeads EC-HA je 2,92 puta stabilnija nego alginat-PAC imobilisana na Sepabeads EC-EA, pa može da se zaključi da je Sepabeads EC-HA i u ovom slučaju pogodniji nosač za imobilizaciju alginat-PAC.

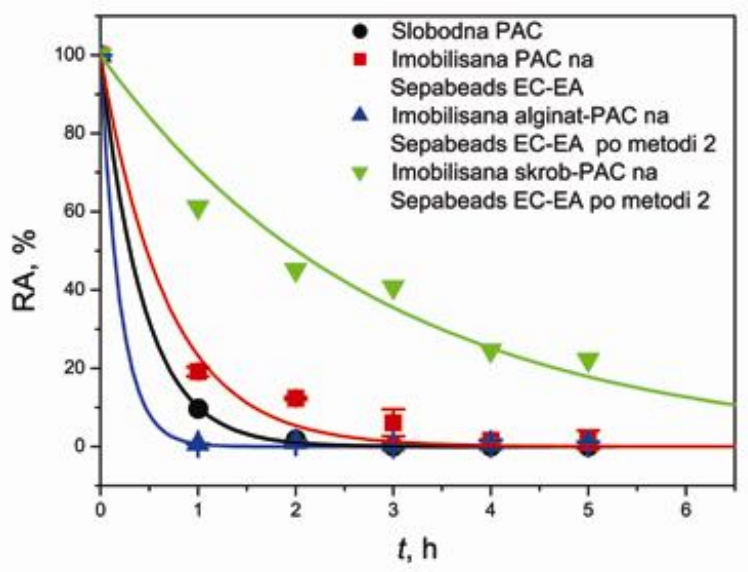

a)

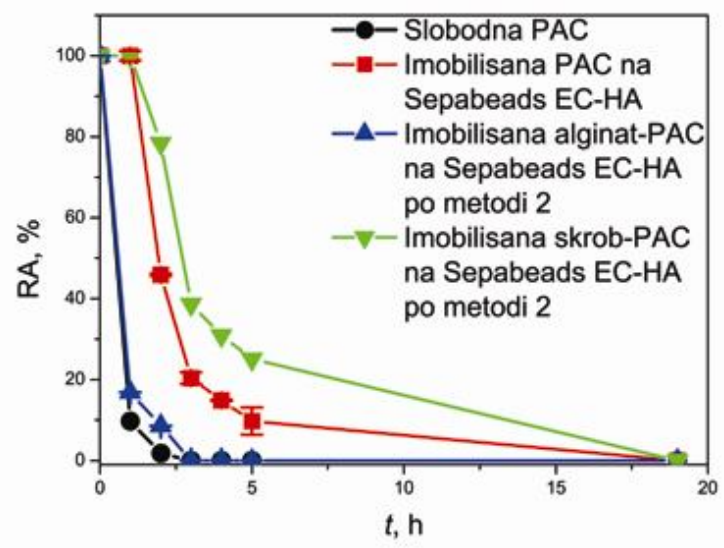

b)

Slika 9.22. Zavisnost relativne aktivnosti od vremena za slobodnu, konvencionalno imobilisanu i imobilisanu skrob-PAC i alginat-PAC po metodi 2 na a) Sepabeads ECEA $i$ b) Sepabeads EC-HA. Biokatalizatori se termostatiraju na $50{ }^{\circ} \mathrm{C}$ u različitim vremenskim periodima, a zatim se ispituje aktivnost tretiranih biokatalizatora $u$ standardnoj reakciji. Uslovi reakcije: 0,1 M natrijum-fosfatni pufer ( $p H=7,92)$, $t=37^{\circ} \mathrm{C}, 3 \mathrm{~min}$ 


\subsection{Poređenje biokatalizatora na bazi modifikovanih PAC}

1. Maksimalne mase vezanog enzima za početnu koncentraciju enzima od $2,25 \mathrm{mg} / \mathrm{cm}^{3}$ za sve postupke su upoređene u tabeli 9.5. Što se tiče masenog prinosa imobilizacije, pri malim koncentracijama enzima dolazi do njegovog naglog skoka, a srednje vrednosti masenih prinosa ukazuju da se gotovo sva početna količina enzima vezuje za nosač (Tabela 9.5.).

Tabela 9.5. Vrednosti maksimalne mase vezanog enzima i masenih prinosa imobilizacije

\begin{tabular}{|c|c|c|c|}
\hline Biokatalizator & $\begin{array}{c}\boldsymbol{m}_{\max }, \mathrm{mg} / \mathrm{g} \\
\text { suvog nosača }\end{array}$ & $\begin{array}{c}\eta_{\text {enz0.14 }} \\
\%\end{array}$ & $\begin{array}{c}\eta_{\text {enz srednje }} \\
\%\end{array}$ \\
\hline Imobilisana & 144 & 84,7 & $91,5 \pm 4,7$ \\
\hline \multicolumn{4}{|l|}{ Sepabeads EC-EA po metodi 1} \\
\hline Imobilisana & 90 & 79,0 & $94,9 \pm 0,86$ \\
\hline \multicolumn{4}{|l|}{ Sepabeads EC-HA po metodi 1} \\
\hline Imobilisana skrob-PAC & 123 & 45,0 & $85,6 \pm 2,7$ \\
\hline \multicolumn{4}{|l|}{ Sepabeads EC-EA po metodi 2} \\
\hline Imobilisana skrob-PAC & 96 & 77,0 & $90,4 \pm 2,72$ \\
\hline \multicolumn{4}{|l|}{ Sepabeads EC-HA po metodi 2} \\
\hline Imobilisana alginat-PAC na & 141 & 75,8 & $85,7 \pm 9,3$ \\
\hline \multicolumn{4}{|l|}{ Sepabeads EC-EA po metodi 2} \\
\hline Imobilisana alginat-PAC na & 99 & 90,9 & $88,6 \% \pm 6,2$ \\
\hline Sepabeads EC-HA po metodi 2 & & & \\
\hline
\end{tabular}

2. U tabeli 9.6. su prikazane vrednosti aktivnosti i prinosa aktivnosti imobilisane modifikovane PAC. 
Tabela 9.6. Vrednosti aktivnosti i prinosa aktivnosti imobilisane modifikovane PAC

\begin{tabular}{llll}
\hline Biokatalizator & $\boldsymbol{A}_{\mathrm{IE}}, \mathrm{U} / \mathrm{g}$ & $\boldsymbol{P}_{\mathbf{g}, \mathrm{mg} / \mathrm{g}}$ & $\eta_{\mathbf{a k t}}, \%$ \\
& & & \\
\hline Imobilisana skrob-PAC na Sepabeads EC-EA & $0,64-25$ & $8-125$ & $4-10$ \\
po metodi 1 & & & \\
Imobilisana skrob-PAC na Sepabeads EC-HA & $2,5-11$ & $10-100$ & $12-4$ \\
po metodi 1 & & & \\
Imobilisana skrob-PAC na Sepabeads EC-EA & $4,2-54,7$ & $4-123$ & $70-20$ \\
$\begin{array}{l}\text { po metodi } 2 \\
\text { Imobilisana skrob-PAC na Sepabeads EC-HA }\end{array}$ & $11,4-67,8$ & $6,1-96,1$ & $100-33$ \\
po metodi 2 & & & \\
Imobilisana alginat-PAC na Sepabeads EC- & $1,1-16,3$ & $7-141$ & $13,5-6,0$ \\
EA po metodi 2 & & & \\
Imobilisana alginat-PAC na Sepabeads EC- & $2,1-21,8$ & $5,9-98,6$ & $20,8-12,1$ \\
HA po metodi 2 & & & \\
\hline
\end{tabular}

3. Pregled optimalnih $\mathrm{pH}$ vrednosti je prikazan u tabeli 9.7. 
Tabela 9.7. Optimalne $\mathrm{pH}$ vrednosti modifikovane i imobilisane PAC

\begin{tabular}{lc}
\hline Biokatalizator & $\boldsymbol{p H}$ \\
\hline Skrob-PAC & 8,6 \\
Alginat-PAC & 8,6 \\
Imobilisana skrob-PAC na Sepabeads EC-EA & 6,2 \\
po metodi 1 & \\
Imobilisana skrob-PAC na Sepabeads EC-HA & 6,2 \\
po metodi 1 & \\
Imobilisana skrob-PAC na Sepabeads EC-EA & 8,6 \\
po metodi 2 & \\
Imobilisana skrob-PAC na Sepabeads EC-HA & 7,3 \\
po metodi 2 & \\
Imobilisana alginat-PAC na Sepabeads EC- & 8,0 \\
EA po metodi 2 & 8,6 \\
Imobilisana alginat-PAC na Sepabeads EC- \\
HA po metodi 2
\end{tabular}

4. U tabeli 9.8. su prikazane konstante brzine dezaktivacije, poluvremena dezaktivacije i faktori stabilizacije slobodne PAC, konjugata PAC, konvencionalno imobilisane PAC i imobilisanih konjugata PAC po metodama $1 \mathrm{i}$ 2 koji su dobijeni na osnovu modela. 
Tabela 9.8. Parametri modela dobijeni na osnovu kinetičkog modela dezaktivacije prvog reda (jednačine 5.1. i 5.2.) slobodne PAC, konjugata PAC, konvencionalno imobilisane PAC i imobilisanih konjugata PAC po metodama 1 i 2

\begin{tabular}{lcccc}
\hline Biokatalizator & $\boldsymbol{k}_{\mathbf{D}}, \mathrm{h}^{-1}$ & $\boldsymbol{t}_{\mathbf{1} / 2}, \mathrm{~h}$ & $\mathbf{F}$ & $\boldsymbol{t}_{\mathbf{d}}$ \\
\hline Slobodna PAC & 2,32 & 0,30 & 1 & 0 \\
Skrob-PAC & 1,99 & 0,35 & 1,16 & 0 \\
Alginat-PAC & 50,65 & 0,01 & 0,03 & \\
Imobilisana PAC na Sepabeads EC- & 1,46 & 0,47 & 1,6 & 0 \\
EA & & & & \\
Imobilisana PAC na Sepabeads EC- & 0,77 & 1,90 & 6,33 & 0,89 \\
HA & & & & \\
Imobilisana skrob-PAC na & 4,18 & 0,17 & 0,55 & 0 \\
Sepabeads EC-EA po metodi 1 & & & & \\
Imobilisana skrob-PAC na & 3,89 & 0,19 & 0,63 & 0 \\
Sepabeads EC-HA po metodi 1 & & & & \\
Imobilisana skrob-PAC na & 0,34 & 2,00 & 6,67 & 0 \\
Sepabeads EC-EA po metodi 2 & & & & \\
Imobilisana skrob-PAC na & 0,39 & 2,83 & 9,43 & 0,95 \\
Sepabeads EC-HA po metodi 2 & & & & \\
Imobilisana alginat-PAC na & 5,0 & 0,14 & 0,47 & 0 \\
Sepabeads EC-EA po metodi 2 & & & & \\
Imobilisana alginat-PAC na & 1,68 & 0,41 & 1,37 & 0 \\
Sepabeads EC-HA po metodi 2 & & & & \\
\hline
\end{tabular}




\section{Zaključak}

U ovom delu rada je izvršena modifikacija penicilin-acilaze iz E.coli u cilju njegove stabilizacije uvođenjem ugljeno-hidratne komponente (skroba i alginata), pri čemu su korišćene dve metode njegove modifikacije. Izvršena je karakterizacija dobijenih modifikovanih PAC. Pored toga ispitana je kovalentna imobilizacija modifikovanih PAC na komercijalnim polimetakrilatnim nosačima Sepabeads EC-EA i Sepabeads EC-HA, pri čemu su ispitani $\mathrm{pH}$ i temperaturni profili i termostabilnost tako dobijenih biokatalizatora. Sva svojstva dobijenih biokatalizatora su upoređena sa svojstvima slobodnog enzima.

Na osnovu dobijenih rezultata mogu se izvesti sledeći zaključci:

1. Skrob-PAC i alginat-PAC sadrže 47\% i 53\% ugljenohidratnog dela i zadržavaju oko 95\% i 93\% prvobitne aktivnosti odgovarajuće količine slobodne PAC, redom.

2. Masa vezanog enzima za nosač raste gotovo linearno sa povećanjem početne koncentracije enzima u rastvoru za imobilizaciju.

3. Najveću aktivnost i prinos aktivnosti je pokazala skrob-PAC imobilisana na Sepabeads EC-HA po metodi 2 (Tabela 9.6).

4. Optimalna temperatura svih konjugata i imobilisanih konjugata je ista kao i slobodne PAC i iznosi $37^{\circ} \mathrm{C}$.

5. $\mathrm{pH}$ profili skrob-PAC $\mathrm{i}$ alginat-PAC su približno isti kao i $\mathrm{pH}$ profil slobodne PAC, dok su $\mathrm{pH}$ profili imobilisanih konjugata suženi u odnosu na $\mathrm{pH}$ profil slobodne PAC.

6. Najstabilniji biokatalizator je skrob-PAC imobilisana po metodi 2 na Sepabeads EC-HA, sa poluvremenom dezaktivacije od $2,83 \mathrm{~h}$, tako da je u odnosu na slobodnu PAC stabilizovana 9,43 puta.

Iz dobijenih rezultata može da se zaključi da je skrob-PAC imobilisana na Sepabeads EC-HA po metodi 2 biokatalizator najboljih svojstava jer je najstabilnija, a i ima najveću aktivnost i prinos aktivnosti. 


\section{IMOBILIZACIJA PENICILIN-ACILAZE NA HITOZANSKE MIKROČESTICE DOBIJENE ELEKTROSTATIČKOM EKSTRUZIJOM}

Cilj ovog dela rada je bio da se ispita imobilizacija enzima na hitozanskim mikročesticama koje su dobijene primenom tehnike elektrostatičke ekstruzije. Hitozan kao nosač za ovu imobilizaciju izabran je zbog niske cene jer je jedan od najrasprostranjenijih, obnovljivih polisaharida dobijen hemijskim $N$-deacetilovanjem hitina. Pored toga, on sadrži slobodne amino grupe koje se pod blagim uslovima mogu aktivirati glutaraldehidom, čime se uvode aldehidne grupe za koje se vezuje amino grupe enzima. Variranjem parametara procesa određeni su optimalni uslovi imobilizacije. Dobijeni rezultati su analizirani sa aspekta stabilnosti, aktivnosti imobilisanog enzima i efikasnosti imobilizacije.

Potom je ispitana početna kinetika reakcije hidrolize prirodnog penicilina $G$ koja je katalizovana penicilin-acilazom iz Escherichia coli imobilisanom na hitozanskim mikročesticama (hitozan-PAC). U tom cilju ispitani su uticaji početne koncentracije supstrata (penicilina G) i proizvoda reakcije (6-aminopenicilanske kiseline $\mathrm{i}$ fenilsirćetne kiseline) na početnu brzinu reakcije. $\mathrm{Na}$ osnovu dobijenih rezultata utvrđen je inhibitorni uticaj supstrata i proizvoda reakcije, kao i vrsta inhibicije.

Najzad, radi razmatranja mogućnosti primene imobilisane PAC u realnim sistemima, ispitivana je početna kinetika hidrolize Pen $\mathrm{G} \mathrm{u}$ dva reaktorska sistema: protočnom reaktoru sa pakovanim slojem i protočnom reaktoru sa pakovanim slojem sa recirkulacijom reakcione smeše. U ovom delu rada, cilj je bio da se odrede najpogodniji kinetički modeli koji opisuju brzinu reakcije u ovim sistemima, a zatim da se na osnovu dobijenih kinetičkih konstanti i uporede efikasnosti hidrolize. 


\subsection{Optimizacija imobilizacije penicilin-acilaze korišćenjem elektrostatičke ekstruzije}

Prva serija eksperimenata je izvedena da bi se odredili optimalni uslovi za proizvodnju uniformnih hitozanskih mikročestica sa velikim zadržavanjem aktivnosti PAC. Tabela 10.1. prikazuje vrednosti prečnika hitozanskih mikročestica, maseni prinos proteina $\mathrm{i}$ prinos aktivnosti za različite uslove izvođenja elektrostatičke ekstruzije (*eksperimentalni podaci za prečnike mikročestica su upoređeni sa njihovim vrednostima predviđenim teorijskim modelom (jednačina 10.2.). Izračunata vrednost

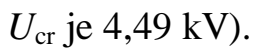

Uočava se da prečnik mikročestica zavisi od primenjenog napona i rastojanja elektroda, koji određuju jačinu elektrostatičkog polja i sile koja deluje na kapi, dok je uticaj koncentracije hitozana zanemarljiv. Na primer, kako primenjeni napon raste od 0 do $4,4 \mathrm{kV}$, srednji prečnik mikročestice se smanjio 2,5 puta od približno 1,55 do 0,61 mm (Tabela 10.1). Standardna devijacija se takođe smanjuje na većim primenjenim naponima, usled sferičnijeg oblika mikročestica i uniformnije raspodele veličine. Kako se napon povećava iznad 4,7 kV (koji je kritični napon u ovom slučaju), formira se nestabilni mlaz koji dovodi do bimodalne raspodele veličine mikročestica. Uticaj rastojanja elektroda na prečnik mikročestica je sličan. Na primer kako se smanjuje rastojanje elektroda od 7 do 2,5 cm, jačina elektrostatičkog polja raste, pa rezultujući prečnik mikročestica opada od 1,16 do $0,61 \mathrm{~mm}$ (Tabela 10.1).

Da bi potpuno opisali i optimizovali tehniku elektrostatičke ekstruzije eksperimentalni podaci prečnika mikročestica su upoređeni sa izračunatim vrednostima dobijenim iz teorijskog modela (rezultati su prikazani u Tabeli 10.1.). 
Tabela 10.1. Uticaj primenjenog napona $(U)$, rastojanje elektroda $(h)$ i koncentracije hitozana $\left(C_{\mathrm{p}}\right)$ na prečnik hitozanskih čestica $\left(d_{\mathrm{p}}\right)$, maseni prinos imobilizacije $\left(\eta_{\mathrm{enz}}\right)$ i prinos aktivnosti ( $\left.\eta_{\mathrm{akt}}\right)$ (dobijeni optimalni uslovi su podebljani).

\begin{tabular}{|c|c|c|c|c|c|c|c|}
\hline \multirow[t]{2}{*}{$\bar{U}, \mathrm{kV}$} & \multirow[t]{2}{*}{$\boldsymbol{h}, \mathrm{cm}$} & \multirow[t]{2}{*}{$C_{\mathrm{p}}, \%$} & \multirow{2}{*}{$\begin{array}{l}\boldsymbol{d}_{\mathbf{p}}, \\
\mathrm{mm}\end{array}$} & \multicolumn{2}{|c|}{ Standardna devijacija } & \multirow[t]{2}{*}{$\eta_{\mathrm{enz},} \%$} & \multirow[t]{2}{*}{$\eta_{\text {akt }}, \%$} \\
\hline & & & & $\mathrm{mm}$ & $\%$ & & \\
\hline \multicolumn{8}{|c|}{ Uticaj primenjenog napona } \\
\hline 0 & 2,5 & 1,5 & 1,55 & $\pm 0,10$ & 12,9 & 82,2 & 57,5 \\
\hline 2,9 & 2,5 & 1,5 & 1,05 & $\pm 0,07$ & 13,3 & 77,6 & 57,5 \\
\hline 3,7 & 2,5 & 1,5 & 0,75 & $\pm 0,03$ & 8,0 & 77,2 & 67,3 \\
\hline 4,4 & 2,5 & 1,5 & 0,61 & $\pm 0,02$ & 6,6 & 72,9 & 71,8 \\
\hline \multicolumn{8}{|c|}{ Uticaj rastojanja elektrode } \\
\hline 4,4 & 2,5 & 1,5 & $\mathbf{0 , 6 1}$ & $\pm 0,02$ & 6,6 & 72,9 & 71,8 \\
\hline 4,4 & 5,0 & 1,5 & 1,14 & $\pm 0,02$ & 3,5 & 55,3 & 42,5 \\
\hline 4,4 & 7,0 & 1,5 & 1,16 & $\pm 0,09$ & 15,5 & 61,0 & 36,7 \\
\hline \multicolumn{8}{|c|}{ Uticaj koncentracije hitozana } \\
\hline 4,4 & 2,5 & 1,0 & 0,57 & $\pm 0,03$ & 10,5 & 63,8 & 66,4 \\
\hline 4,4 & 2,5 & 1,5 & 0,61 & $\pm 0,02$ & 6,6 & 72,9 & 71,8 \\
\hline 4,4 & 2,5 & 2,0 & 0,62 & $\pm 0,07$ & 22,6 & 86,5 & 79,3 \\
\hline \multicolumn{8}{|c|}{ Teorijske vrednosti* } \\
\hline 0 & 2,5 & 1,5 & 1,96 & $\pm 0,14^{*}$ & $16,5^{*}$ & - & - \\
\hline 2,9 & 2,5 & 1,5 & 1,63 & $\pm 0,21$ & 30,6 & - & - \\
\hline 3,7 & 2,5 & 1,5 & 1,34 & $\pm 0,21$ & 39,9 & - & - \\
\hline 4,4 & 2,5 & 1,5 & 0,67 & $\pm 0,02$ & 6,6 & - & - \\
\hline
\end{tabular}

Dobijanje čestica u prisustvu električnog polja može se analizirati teorijom elektrostatičke disperzije polimernih rastvora. Teorija objašnjava uticaj primenjenog elektrostatičkog potencijala i različitih fizičko-hemijskih faktora na veličinu čestice. Za našu eksperimentalnu aparaturu kritični napon, $U$ cr je funkcija unutrašnjeg prečnika igle, $d \mathrm{c}$ i površinskog napona rastvora polimera $\gamma_{0} \mathrm{u}$ obliku: 


$$
U \mathrm{cr}=\sqrt{\frac{d_{c} \gamma_{0}}{k_{g} \varepsilon_{0}}}
$$

Uticaj primenjenog napona $U$ na prečnik kapi $d$ je dat sledećom jednačinom:

$$
\begin{aligned}
& d(\mathrm{U}) \cong d_{0}\left[1-\left(\frac{U}{U_{c r}}\right)^{2}\right]^{\frac{1}{3}} \\
& d_{0}=\left(\frac{3 d_{c} \gamma}{\rho g}\right)^{\frac{1}{3}}
\end{aligned}
$$

gde je $d_{0^{-}}$prečnik kapi pri $U=0(\mathrm{~mm})$, dok je $\gamma_{0}$-površinski napon rastvora hitozana $\left(\mathrm{mN} \mathrm{m}^{-1}\right), U_{\mathrm{cr}-}$ kritični napon $(\mathrm{kV}), \rho$ - gustina rastvora hitozana $\left(\mathrm{kg} \mathrm{m}^{-3}\right), g$ gravitaciono ubrzanje, $k_{\mathrm{g}}$-bezdimenzioni parametar koji zavisi od geometrije sistema. Ovo ukazuje na to da jednostavnim ukapavanjem bez primenjenog napona mogu da se dobiju samo velike čestice (oko $2 \mathrm{~mm}$ ). Takođe, teorijski pristup predviđa da veličina mikročestica je uglavnom funkcija primenjenog napona, površinskog napona polimera, veličine igle i geometrije elektrode.

Vrednosti parametara u jednačinama (10.1.) i (10.2.) korišćenih za izračunavanje teorijskih vrednosti su: $d_{\mathrm{c}}=0,724 \mathrm{~mm}, \gamma_{0}=69 \mathrm{mN} / \mathrm{m}$ (mereno na $25^{\circ} \mathrm{C}$ ), $k=0,28$ (za aparaturu sa jednom iglom), $\varepsilon_{0}=8,85 \times 10^{-12} \mathrm{C}^{2} / \mathrm{Nm}^{2}, \mathrm{i} \rho=1000 \mathrm{~kg} / \mathrm{m}^{3}$. Izračunata vrednost dobijena za $U$ cr od $4,49 \mathrm{kV}$ se dobro slaže sa eksperimentalno određenom vrednošću $(4,7 \mathrm{kV})(\mathrm{STD}=3,3 \%)$. Teorijski model predviđa da nije moguće dobiti manje hitozanske čestice od približno $1,96 \mathrm{~mm}$ samo dejstvom gravitacije bez primenjenog napona što je eksperimentalno potvrđeno do određenog stepena $\left(d_{\mathrm{p}}=1,55 \mathrm{~mm}\right)$. Drugi teorijski rezultati prečnika čestica za odgovarajući napon se $\mathrm{u}$ određenoj meri slažu sa eksperimentalnim, ali su im vrednosti veće za sve potencijale, naročito za $3,7 \mathrm{kV}$.

Ispitani operacioni parametri elektrostatičke ekstruzije takođe utiču na maseni prinos imobilizacije i prinos aktivnosti (Tabela 10.1). Može da se primeti da uvođenje elektrostatičkog potencijala smanjuje maseni prinos enzima, dok prinos aktivnosti raste do $71,8 \%$. Sa druge strane, sa porastom rastojanja elektroda, iako jačina polja opada, 
dužina puta kroz vazduh raste, dajući i niži maseni prinos imobilizacije i niži prinos aktivnosti. Konačno, koncentracija hitozana ima pozitivan uticaj i na maseni prinos i na prinos aktivnosti tako da koncentracija od $2 \%$ daje prinose od 86,5 i 79,3\%, redom. Tako visok maseni prinos imobilizacije ukazuje na to da je kapacitet za vezivanje proteina veoma dobar. U radu je izvršen pokušaj i da se koristi 2,5\% hitozan, ali se oblik čestica deformisao što je onemogućilo njihovu dalju primenu. Osim toga, variranje koncentracije hitozana nije značajnije uticalo na prinos aktivnosti $(\mathrm{STD}=7,0 \%)$, ali čestice dobijene korišćenjem 1,5\% hitozana su pokazale malu raspodelu veličine i pravilnije sferičan oblik nego one dobijene korišćenjem $2 \%$ hitozana, pa je ova koncentracija izabrana kao optimalna.

Dakle, optimalni uslovi za imobilizaciju PAC su: primenjeni napon od 4,4 kV, rastojanje elektroda od 2,5 cm i 1,5\% rastvor hitozana. Mikročestice dobijene pod ovim uslovima su bile pravilnog sferičnog oblika sa srednjim prečnikom od oko $600 \mu \mathrm{m}$ i imale su aktivnost od $123 \mathrm{U} / g$ suvog nosača, što odgovara prinosu aktivnosti od 71,8\% za PAC. Ovi rezultati ukazuju da primenjeni nosač (hitozanske mikročestice) i metoda imobilizacije su odgovarajući za imobilizaciju PAC iz Escherichia coli uzimajući u obzir da je hemijsko vezivanje enzima često povezano sa neizbežnim gubitkom aktivnosti usled promene prirodne konformacije i aktivnog položaja. U poređenju sa skrob-PAC imobilisanom na Sepabeads EC-HA po metodi 2 koja je imala prinos imobilizacije od $90,4 \pm 2,72 \%$ i prinos aktivnosti od $100 \%$, PAC imobilisana na hitozanske mikročestice ima nešto manji prinos aktivnosti i prinos imobilizacije.

\subsection{Karakterizacija penicilin-acilaze imobilisane na hitozanske mikročestice}

Hitozanske mikročestice su bile pravilnog sferičnog oblika i glatke površine, srednjeg prečnika od 0,61 mm. Morfologija nemodifikovanih i aktiviranih hitozanskih mikročestica sa imobilisanom PAC su analizirane korišćenjem skenirajuće elektronske mikroskopije i dobijeni mikrografi su prikazani na slici 10.1. Može da se primeti da se mikrostruktura hitozanskih mikročestica promenila posle aktiviranja i imobilizacije PAC. Mikročestica sa imobilisanom PAC je porozna, mogu se uočiti uniformne sferične pore, ukazujući na to da se reakcija aktivacije glutaraldehidom (umrežavanje) ravnomerno odvijala kroz zapreminu mikročestice. 

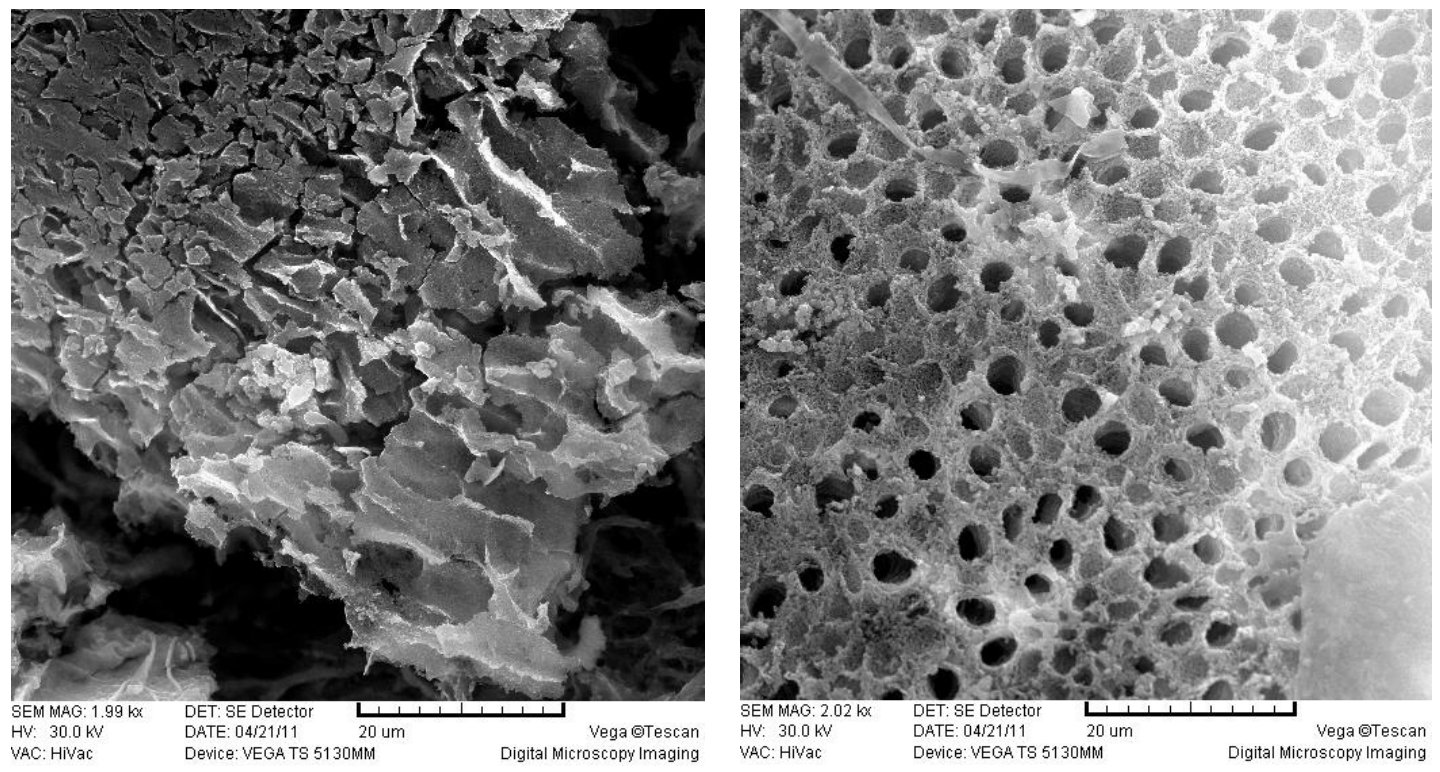

a)

b)
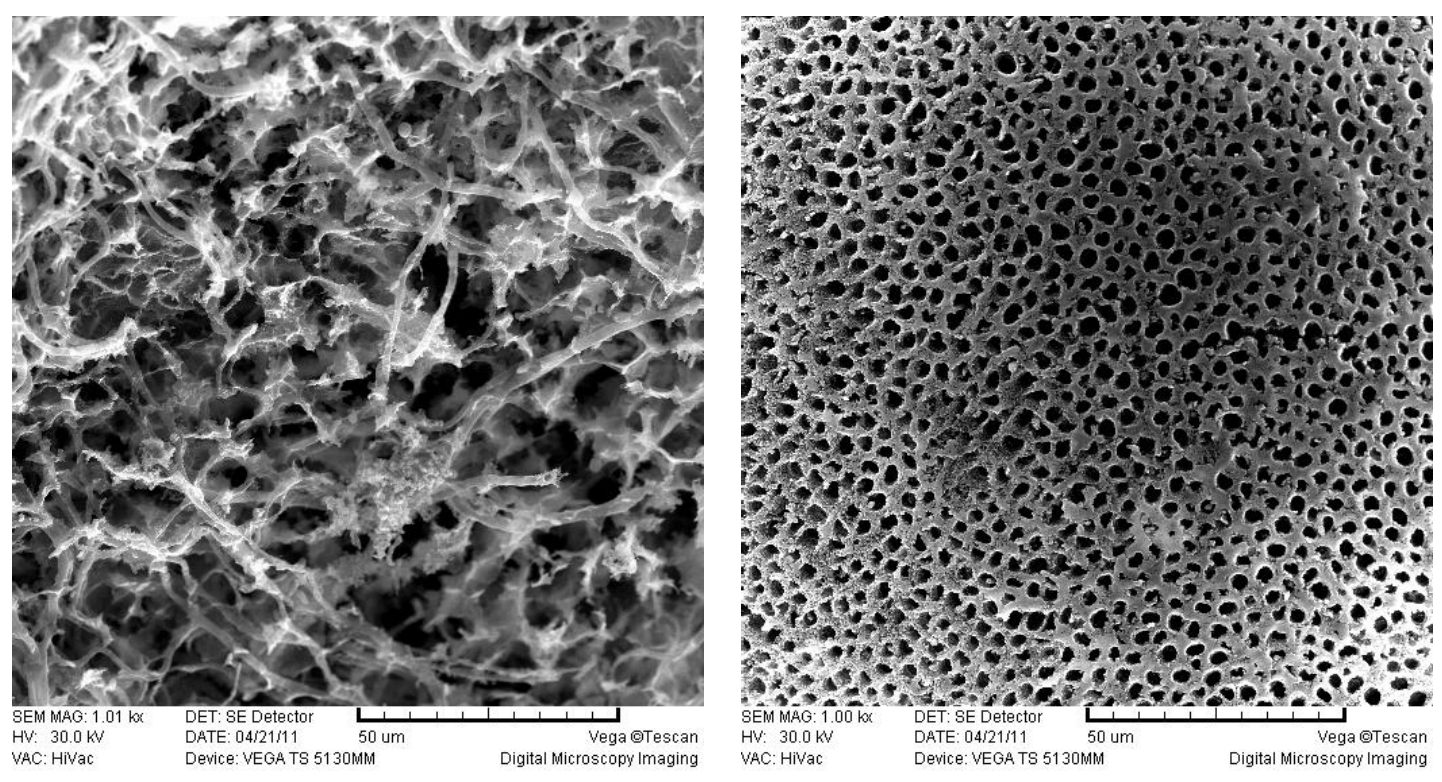

c)

d)

Slika 10.1. SEM mikrografi površine a) $i$ c) neaktivirane mikročestice (skala 20 i $50 \mu m$, redom) b) $i$ d) umrežene mikročestice sa imobilisanom PAC (skala 20 i $50 \mu \mathrm{m}$, redom)

FT-IR analiza je korišćena za hemijsku karakterizaciju dobijenih mikročestica i i to nemodifikovanih kao i aktiviranih hitozanskih čestica sa $1 \%$ i $9 \%$ rastvorom 
glutaraldehida (Hit-GA-1 i Hit-GA-9, redom). Isto tako urađena je hemijska karakterizacija aktiviranih hitozanskih mikročestica sa imobilisanim enzimom (PACHit-GA-9). FT-IR spektar različitih uzoraka je prikazan na slici 10.2.

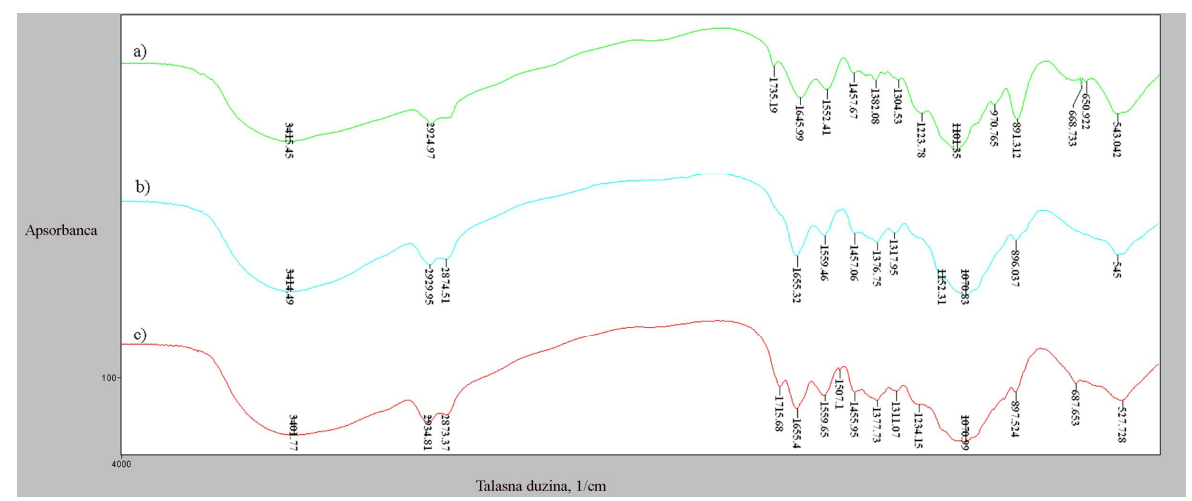

a)

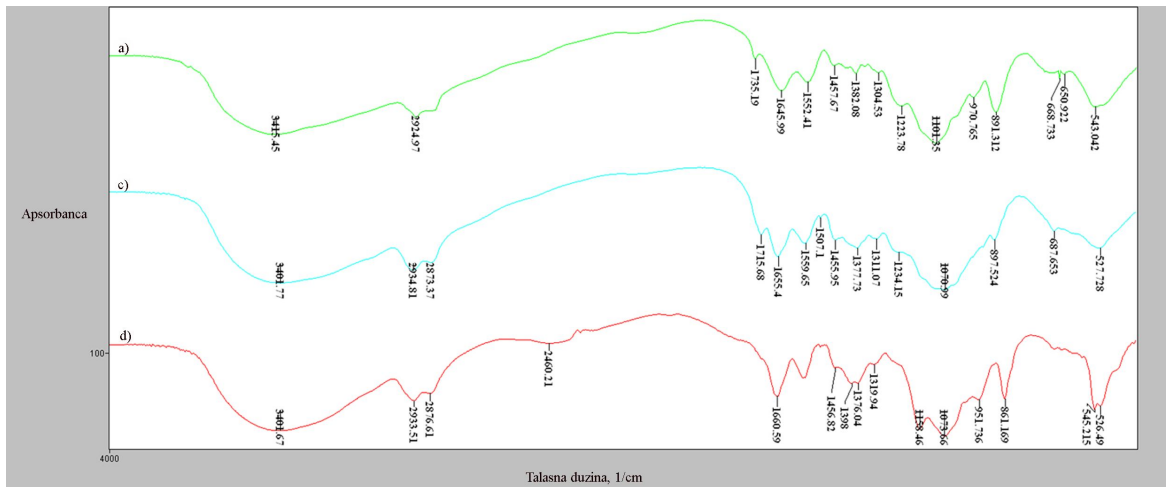

b)

Slika 10.2. Uporedni FT-IR spektar a) nemodifikovane hitozanske mikročestice (kriva a), hitozanske mikročestice aktivirane sa $1 \%$ glutaraldehidom (kriva b) $i$ hitozanske mikročestice aktivirane sa 9\% glutaraldehidom (kriva c) $i$ b) nemodifikovane hitozanske mikročestice (kriva a), hitozanske mikročestice aktivirane sa 9\% glutaraldehidom (kriva c) i imobilisana PAC na hitozanskim mikročesticama aktiviranim sa 9\% glutaraldehidom (kriva d) 
FT-IR spektar hitozana pokazuje karakterističnu vezu na 1646 (amidna traka I), 1552 (amidna traka II) i 1382 (amidna traka III). Uočljivi pik na $1101 \mathrm{~cm}^{-1}$ (vibracije $\mathrm{C}-\mathrm{O}-\mathrm{C})$ i $891 \mathrm{~cm}^{-1}$ (C-O vibracija) su karakteristični za njegovu ugljenohidratnu strukturu. Široke apsorpcione trake na $3415 \mathrm{~cm}^{-1}$ i $2925 \mathrm{~cm}^{-1}$ su prouzrokovane simetričnom amin $\mathrm{N}-\mathrm{H}$ vibracijom. Hemijsko aktiviranje hitozana može da se objasni formiranjem Šifove baze kao što je potvrđeno pojavom pika na $1655 \mathrm{~cm}^{-1}$ povezano sa nastajanjem imino grupe u nukleofilnoj reakciji amino grupe hitozana sa aldehidnom grupom aktivirajućeg agensa. Međutim, FT-IR spektri hitozana aktiviranog različitim koncentracijama glutaraldehida (1 i 9\%) pokazuju gotovo istu apsorpciju na $1655 \mathrm{~cm}^{-1}$, ukazujući na to da $1 \%$ glutaraldehid obezbeđuje dovoljno aldehidnih grupa na površini hitozanskih mikročestica koje mogu da se vezuju za PAC (Slika 10.2a). Pikovi na 1560 i $1716 \mathrm{~cm}^{-1}$ usled etilenskih i slobodnih-aldehidnih veza, redom, su se pojavili posle aktiviranja hitozana 9\% glutaraldehidom, ukazujući na nešto drugačiju strukturu glutaraldehida na nosaču posle aktiviranja kada su korišćene različite koncentracije ( $1 \mathrm{i}$ $9 \%$ ). Na osnovu uvida u literaturu jasno je da struktura glutaraldehida na nosaču nakon aktivacije još uvek nije dovoljno objašnjena, tako da je moguće da se formiraju polimeri, monomeri i dimeri glutaraldehida i da oni nisu ravnomerno rspoređeni po površini nosača [158].

Uspešna imobilizacija PAC na aktivirane čestice potvrđena je FTIR spektroskopijom. U spektru sa imobilisanom PAC jasno se uočavaju sve trake karakteristične za prisustvo enzima. Traka na $1660 \mathrm{~cm}^{-1}$, ujedno i najistaknutija traka proteina, posledica je $-\mathrm{C}=\mathrm{O}$ valencionih $\mathrm{i}-\mathrm{NH}$ deformacionih vibracija amidne veze (slika 10.2.b). Dodatno, nakon što se PAC imobiliše, očigledno je povećanje intenziteta pika na $1377 \mathrm{~cm}^{-1}$ vezano za prisustvo $\mathrm{CH}_{3}$ u amidnoj grupi i amidnoj II vezi (1560 $\mathrm{cm}^{-1}$ ), ukazujući na prisustvo PAC na čestici. Razlike su takođe očigledne u oblasti između 860 i $1660 \mathrm{~cm}^{-1}$, vezano za apsorpciju C-O i C-O-C grupa, gde spektar imobilisanog enzima pokazuje široke i nedovoljno dobro definisane pikove. 


\subsection{Ispitivanje uticaja uslova imobilizacije na svojstva penicilin-acilaze imobilisane na hitozanske mikročestice}

Imobilizacija enzima se često izvodi sa velikim viškom nosača. Sa praktične tačke gledišta, priprema biokatalizatora sa maksimalnim sadržajem enzima i aktivnosti je od velike važnosti. U pokušaju da se više enzima vezuje na hitozanske mikročestice, ispitan je uticaj sadržaja enzima u rastvoru za imobilizaciju u opsegu od 64,1$1025,2 \mathrm{U} / \mathrm{g}$ suvog nosača $\left(0,14-2,24 \mathrm{mg} / \mathrm{cm}^{3}\right)$ na masu $\left(P_{\mathrm{g}}\right)$ i aktivnost imobilisanog enzima $\left(A_{\mathrm{IE}}\right)$. Povećanje sadržaja PAC u početnom rastvoru za imobilizaciju dovodi do skoro linearnog povećanja mase vezanog enzima, dok aktivnost imobilisanog enzima dostiže maksimalnu vrednost od 263,6 U/g suvog nosača, i onda opada (slika 10.3). Pod svim ispitanim eksperimentalnim uslovima dobijeni su veliki prinosi vezivanja proteina od 62-95\% (slika 10.4). Sa druge strane, prinosi aktivnosti opadaju sa porastom količine enzima tako da se najveći prinos od oko $95 \%$ postiže za najniže količine enzima (slika 10.4). Do pada aktivnosti verovatno dolazi usled ograničenja prenosa mase u reakciji hidrolize pri većim sadržajima proteina, kao i inhibicije proizvodom ili potpunom dezaktivacijom frakcija molekula enzima. Optimalni početni odnos aktivnosti PAC i suvog nosača u rastvoru za imobilizaciju je bio 769 U/g.

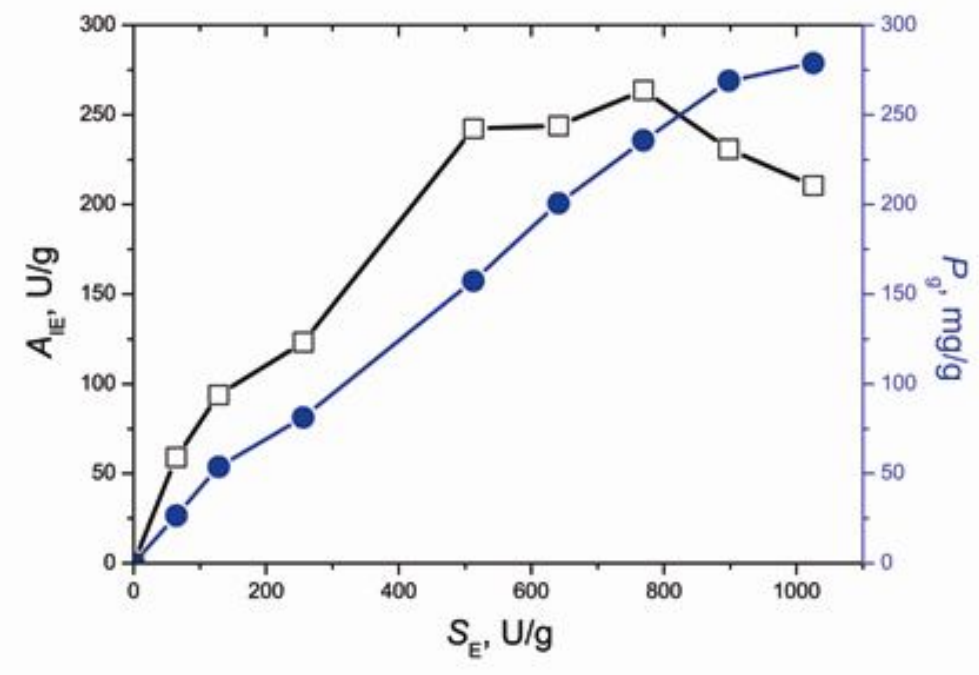

Slika 10.3. Uticaj sadržaja enzima (broj unetih jedinica aktivnosti po masi nosača, $S_{\mathrm{E}}$ ) pri imobilizaciji na količinu i aktivnost imobilisanog enzima 


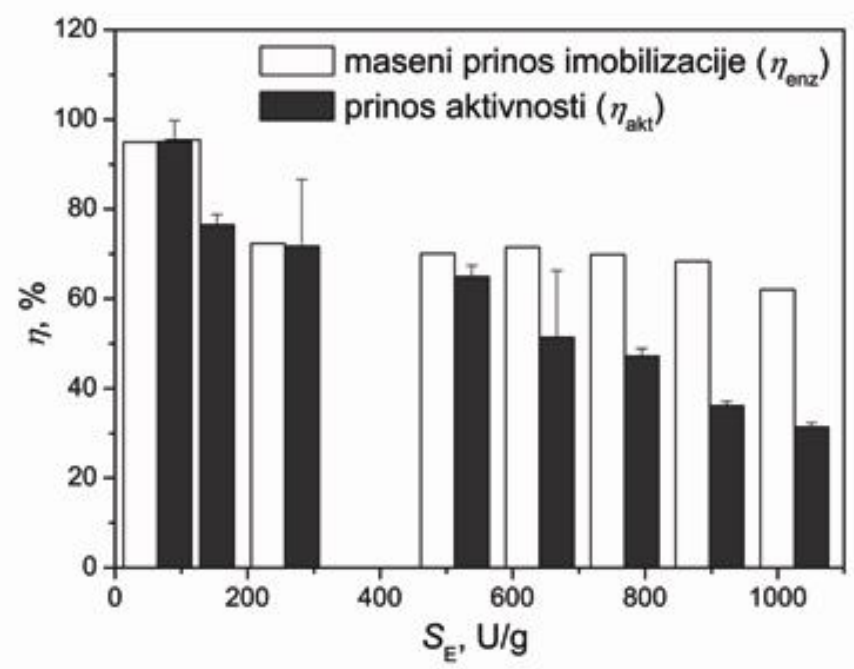

Slika 10.4. Uticaj sadržaja enzima (broj unetih jedinica aktivnosti po masi nosača, $S_{\mathrm{E}}$ ) pri imobilizaciji na maseni prinos imobilizacije i prinos aktivnosti

Da bi se odredio uzrok dobijenog pada aktivnosti imobilisanog enzima, izvršeno je određivanje koncentracije aktivnih centara enzima u imobilisanim uzorcima sa različitim sadržajem proteina metodom titracije. Ova metoda je posebno korisna jer omogućava direktnu procenu količine aktivnog enzima po jedinici mase biokatalizatora, kao i značaj difuzionih limitacija supstrata [93, 96]. Izmerena je i početna koncentracija aktivnih centara po jedinici zapremine slobodne PAC koja je uzeta kao referentni uzorak. Rezultati su prikazani na slici 10.5. i u Tabeli 10.2. Vidljiva je linearna zavisnost između količine katalitički kompetentnih aktivnih centara koji su se vezali za hitozan i početne količine aktivnih centara u rastvoru za imobilizaciju. Maksimalno vezivanje je $0,176 \mathrm{~mol} / \mathrm{g}$ ili približno 1,06 x $10^{17}$ aktivnih centara/g suvih čestica. Suprotno tome, prosečna molekulska aktivnost imobilizata opada od 49 do $20 \mathrm{~s}^{-1}$ sa povećanjem količine unetih aktivnih centara pri imobilizaciji i najveće vrednosti se postižu kada se unose najmanje količine aktivnih centara, sugerišući pad katalitičke aktivnosti po aktivnom centru usled imobilizacije pri većem sadržaju vezanog enzima. Dakle, utvrđeno je da se enzim vezuje za nosač i da broj katalitički kompetentnih aktivnih centara raste sa povećanjem količine vezanog enzima, ali da ti centri nisu dostupni u reakciji sa realnim supstratom. Pri većem sadržaju 
enzima, molekulska aktivnost imobilisane PAC je približno $40 \%$ od slobodne PAC, ukazujući na pojavu difuzionih limitacija u imobilisanom sistemu. To je očekivano $\mathrm{s}$ obzirom da se reakcija odvija u šaržnom reaktoru sa blagim mešanjem, pri čemu se mešanje održava na minimumu, samo da bi čestice ostale suspendovane. Dalja ispitivanja korišćenjem različitih tipova reaktora su još uvek neophodna da bi se poboljšala katalitička efikasnost i prenos mase u imobilisanom sistemu. Optimizacijom sadržaja količine imobilisanog enzima može se dobiti biokatalizator sa velikom katalitičkom efikasnošću od oko $250 \mathrm{U} / \mathrm{g}$ suvih hitozanskih mikročestica (molekulska aktivnost imobilisane PAC je približno $70 \%$ od slobodne PAC).

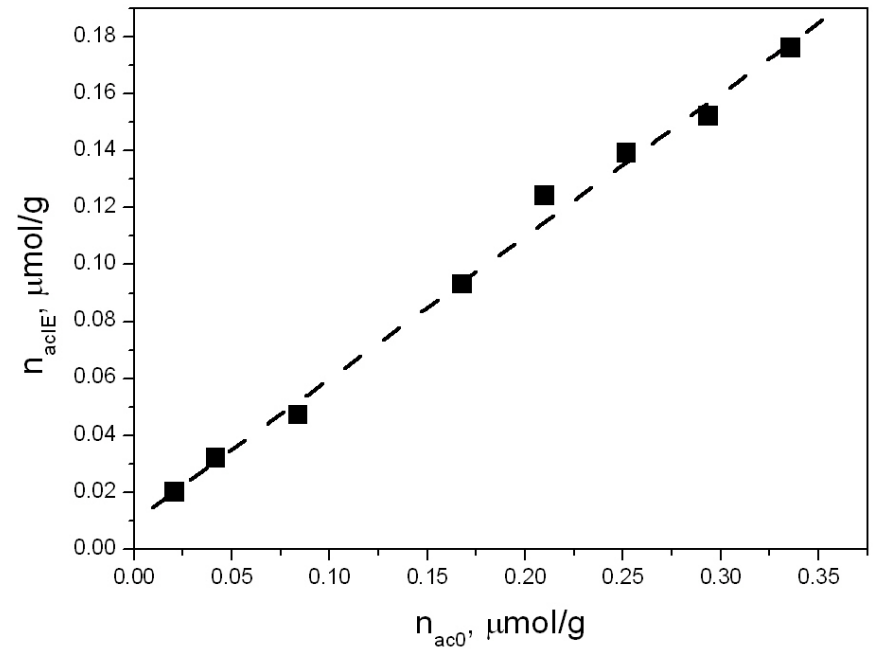

Slika 10.5. Zavisnost količine katalitički kompetentnih aktivnih centara koji su se vezali za hitozan $n_{\mathrm{acIE}}$ od početne količine aktivnih centara u rastvoru za imobilizaciju $n_{\mathrm{ac} 0}$ 
Tabela 10.2. Rezultati imobilizacije PAC na hitozanske čestice aktivirane sa $1 \%$ glutaraldehidom pri različitim količinama enzima

\begin{tabular}{|c|c|c|c|c|c|c|c|}
\hline Preparat & $\begin{array}{l}A_{0} \\
(\mathrm{U} / \mathrm{g})\end{array}$ & $\begin{array}{l}\boldsymbol{A}_{\mathrm{IE}} \\
(\mathrm{U} / \mathrm{g})\end{array}$ & $\eta_{\text {akt }}(\%)$ & $\begin{array}{l}\boldsymbol{n}_{\mathrm{ac0}} \\
(\mu \mathrm{mol} / \mathrm{g})\end{array}$ & $\begin{array}{l}\boldsymbol{n}_{\mathrm{acIE}} \\
(\mu \mathrm{mol} / \mathrm{g})\end{array}$ & $\begin{array}{l}\text { Prinos }^{b} \\
(\%)\end{array}$ & $\begin{array}{l}\text { Molekulska } \\
\text { aktivnost }^{\mathrm{c}} \\
\left(\mathrm{s}^{-1}\right)\end{array}$ \\
\hline Slobodna & - & $128^{\mathrm{a}}$ & & $0,042^{\mathrm{a}}$ & & & $51^{\mathrm{a}}$ \\
\hline \multicolumn{8}{|l|}{ PAC } \\
\hline IE-1 & 64,1 & 59,0 & 95,1 & 0,021 & 0,020 & 98,0 & 49 \\
\hline IE-2 & 128,1 & 93,9 & 76,4 & 0,042 & 0,032 & 85,8 & 49 \\
\hline IE-3 & 256,3 & 123,3 & 71,7 & 0,084 & 0,047 & 74,1 & 44 \\
\hline IE-4 & 512,6 & 242,3 & 64,9 & 0,168 & 0,093 & 75,9 & 43 \\
\hline IE-5 & 640,6 & 243,8 & 51,4 & 0,210 & 0,124 & 79,6 & 33 \\
\hline IE-6 & 768,9 & 263,6 & 47,2 & 0,252 & 0,139 & 75,8 & 32 \\
\hline IE-7 & 897,1 & 230,9 & 36,1 & 0,294 & 0,152 & 72,5 & 25 \\
\hline IE-8 & 1025,2 & 210,6 & 31,4 & 0,336 & 0,176 & 69,9 & 20 \\
\hline \multicolumn{8}{|c|}{$\begin{array}{l}A_{0^{-}} \text {aktivnost PAC unete u rastvor za imobilizaciju po gramu suvog nosača; } A_{\mathrm{IE}^{-}} \text {aktivnost } \\
\text { imobilisanog enzima po gramu suvog nosača određena standardnom metodom; } \eta \text { - prinos aktivnosti } \\
\text { imobilizacije definisan jednačinom } 6.7 \text {.; }{ }^{\mathrm{a}} \text { Aktivnost i koncentracija aktivnih centara po } \mathrm{cm}^{3} \text { slobodne } \\
\text { PAC; } n_{\mathrm{ac} 0} \text {-početna količina aktivnih centara enzima unetih pri imobilizaciji; } n_{\text {acIE- }} \text { količina aktivnih } \\
\text { centara određena na imobilisanom enzimu, }{ }^{b} \text { prinos imobilizacije određen preko aktivnih centara kao } \\
\text { količina imobilisanih aktivnih centara/(količina početnih aktivnih centara- količina preostalih aktivnih } \\
\text { centara u filtratu i rastvoru posle ispiranja) X } 100 \% \text {; }{ }^{c} \text { molekulska aktivnost (mol proizvoda po mol }\end{array}$} \\
\hline
\end{tabular}

\subsection{Ispitivanje uticaja koncentracije glutaraldehida}

Hitozanske čestice, dobijene pri primenjenom naponu od 4,4 kV, rastojanju elektroda od 2,5 $\mathrm{cm}$ i koncentraciji hitozana od 1,5\%, su aktivirane različitim koncentracijama glutaraldehida (od 1\% do 9\%) da bi se odredio optimalan odnos aktivnog agensa i nosača. Uticaj koncentracije glutaraldehida na masu vezane PAC, aktivnost imobilisane PAC i na prečnik čestice je prikazan na slikama 10.6. i 10.7. 


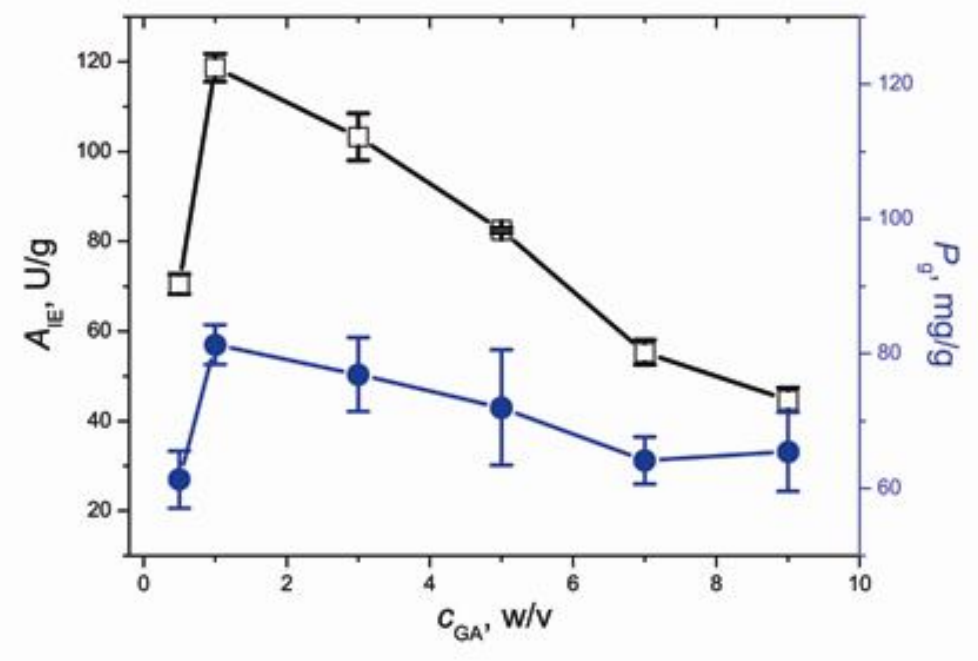

Slika 10.6. Uticaj koncentracije glutaraldehida $c_{\mathrm{GA}}$ na aktivnost $A_{\mathrm{IE}} i$ masu $P_{\mathrm{G}}$ imobilisane PAC (Količina enzima u rastvoru za imobilizaciju je bila $256 \mathrm{U} / \mathrm{g}$ suvih hitozanskih mikročestica dobijenih pod optimalnim uslovima elektrostatičkom ekstruzijom)

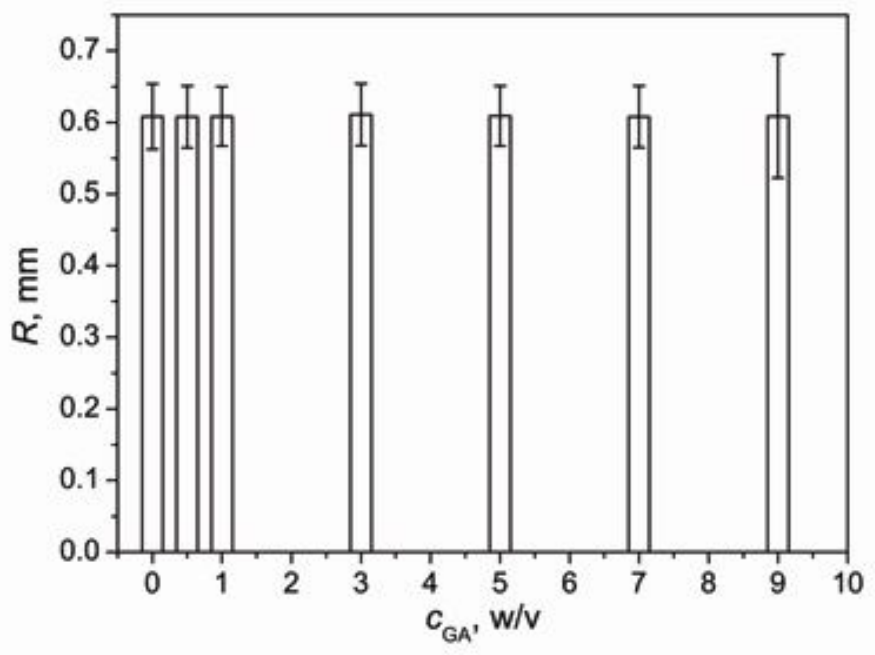

Slika 10.7. Uticaj koncentracije glutaraldehida $c_{\mathrm{GA}}$ na prečnik mikročestica, $R$ 
Aktivnost imobilisane PAC u početku raste sa koncentracijom glutaraldehida do

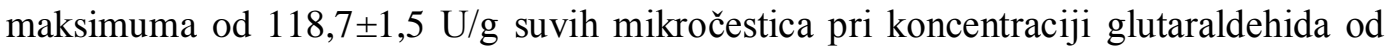
1\%. Nakon ove koncentracije, aktivnost imobilisane PAC je opadala tako da je pri

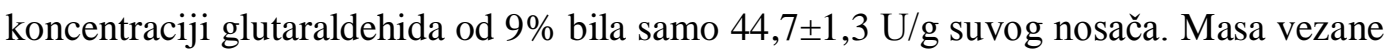
PAC ima isti trend kao aktivnost imobilisane PAC, dostižući maksimum od 81,3 mg/g pri koncentraciji glutaraldehida od $1 \%$. Ovaj trend može da se objasni sa dva suprotna uticaja: pri niskim koncentracijama glutaraldehida kako ova koncentracija raste, broj vezivnih položaja (aldehidnih grupa) prisutnih u mikročestici za vezivanje sa amino grupama PAC takođe raste. Međutim, pri većim koncentracijama glutaraldehida stepen intra- intermolekulskog umrežavanja samih molekula enzima takođe raste, negativno utičući na vezivanje enzima. Ovo ukazuje na to da $1 \%$ glutaraldehid obezbeđuje dovoljno aldehidnih grupa na površini hitozanskih mikročestica koje mogu da se vezuju za PAC. Optimalna koncentracija glutraldehida koja je određena u ovom radu je slična vrednostima dobijenim $\mathrm{u}$ istraživanjima prikazanim u literaturi u rasponu od 1,0 do 2,5\% u zavisnosti od specifičnog sistema za imobilizaciju (hitozanskog gela, enzimske i imobilizacione procedure) [153, 237-239].

Nije primećen značajni uticaj koncentracije glutaraldehida $u$ ispitanom opsegu od $1-9 \%(\mathrm{w} / \mathrm{v})$ na prečnik mikročestica, koji je bio približno $0,61 \mathrm{~mm}$ (STD 0,5\%) (slika 10.6). Rezultat se slaže sa onim dobijenim u detaljnom istraživanju uticaja aktivacije glutraldehidom u imobilizaciji PAC na hitozanske čestice jednostavnim ukapavanjem. U ovom istraživanju gustina $(1,0023 \pm 0,006 \mathrm{~g} / \mathrm{mL})$ i prečnik $(0,2084 \pm 0,004 \mathrm{~cm})$ hitozanskih mikročestica se ne menja posle aktivacije [162]. Uglavnom, mikročestice hitozana aktivirane $1 \%$ glutaraldehidom su pokazale veliki kapacitet za vezivanje enzima i veću aktivnost u poređenju sa hitozanskim mikročesticama aktiviranim sa $9 \%$ glutaraldehidom. Međutim, ovaj rezultat ne ukazuje neminovno na veću stabilnost i produktivnost biokatalizatora. Stoga, bilo je neophodno nezavisno ispitati operativnu stabilnost svih uzoraka imobilisanog enzima. 
10.5. Ispitivanje uticaja temperature na aktivnost penicilin-acilaze imobilisane na hitozanske mikročestice

Po analogiji na prethodna istraživanja, ispitan je uticaj temperature na aktivnost PAC-Hit-GA-1 i PAC-Hit-GA-9 po metodi opisanoj u poglavlju 6.2.4.6. pri čemu je temperatura varirana u intervalu $20-75^{\circ} \mathrm{C}$. Rezultati su prikazani na slici 10.8 .

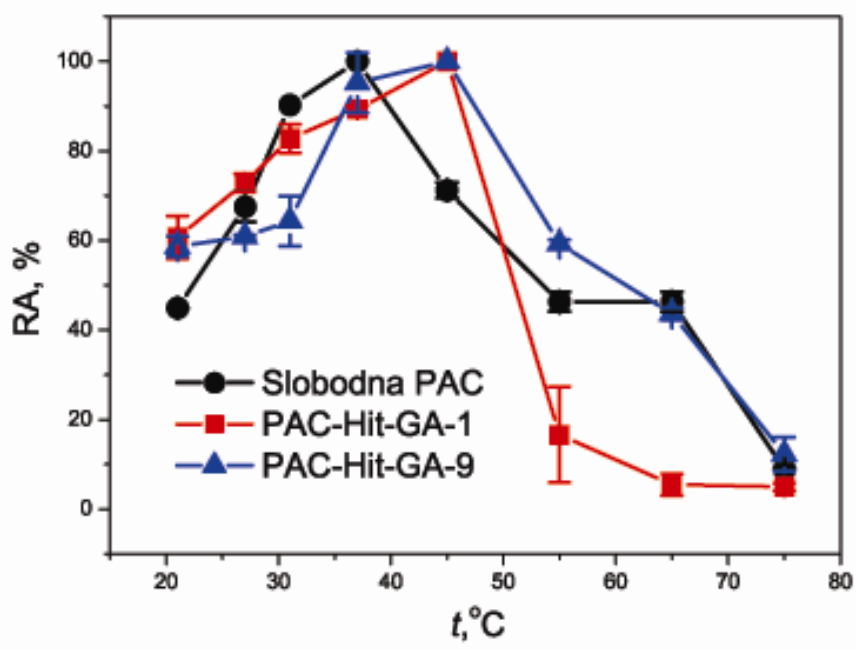

Slika 10.8. Zavisnost relativne aktivnosti slobodne PAC, PAC-Hit-GA-1 i PACHit-GA-9 od temperature. Uslovi reakcije: 0,1 M natrijum-fosfatni pufer ( $p H$ 7,92), 3 min. Maksimalna vrednost aktivnosti pri određenoj temperaturi je predstavljala $100 \%$

Imobilisani uzorci (PAC-Hit-GA-1 i PAC-Hit-GA-9) su imali sličan temperaturni profil, ali im je optimum bio veći u poređenu sa slobodnom PAC. Pokazalo se da se optimalna temperatura reakcije pomerila od $37{ }^{\circ} \mathrm{C}$ za slobodnu PAC do $45{ }^{\circ} \mathrm{C}$ za oba imobilisana uzorka, ukazujući na značajno bolju termalnu stabilnost PAC imobilisane na hitozanske mikročestice. Slični rezultati su objavljeni u literaturi, gde je pokazano da imobilizacija PAC utiče na njen temperaturni profil [81, 240]. 


\subsection{Ispitivanje uticaja $\mathrm{pH}$ na aktivnost penicilin-acilaze imobilisane na hitozanske mikročestice}

Kao i u slučaju prethodnih imobilizata, ispitan je uticaj $\mathrm{pH}$ vrednosti na aktivnost imobilisanih uzoraka (PAC-Hit-GA-1 i PAC-Hit-GA-9) po metodi opisanoj u poglavlju 6.2.4.7. pri čemu se ispitivana $\mathrm{pH}$ vrednost kretala u intervalu od 4,50 do 9,30. Rezultati su prikazani na slici 10.9.

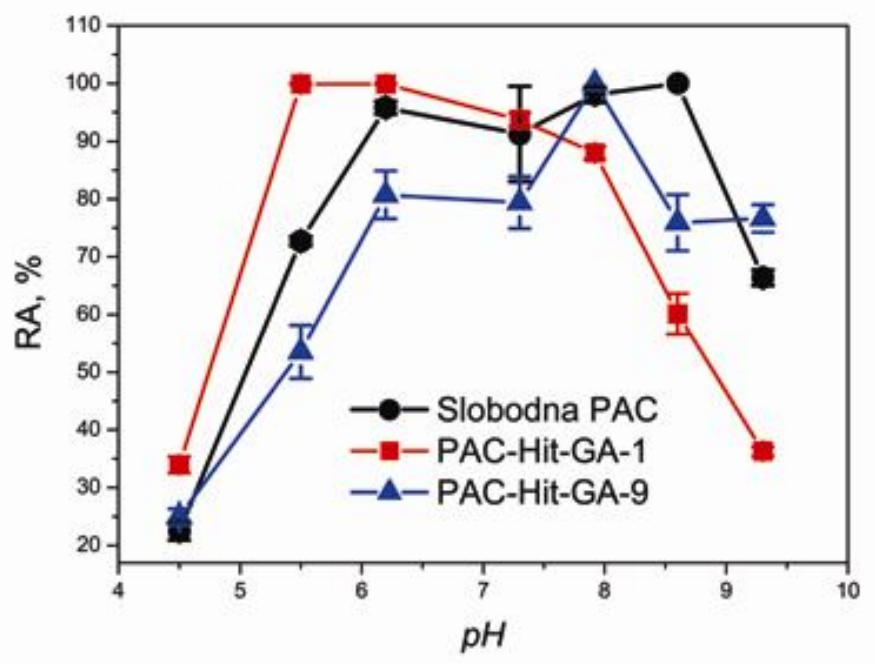

Slika 10.9. Zavisnost relativne aktivnosti slobodne PAC, PAC-Hit-GA-1 i PAC-HitGA-9 od pH vrednosti. Uslovi reakcije: $37{ }^{\circ} \mathrm{C}, 3 \mathrm{~min}, 0,1 \mathrm{M}$ puferi: acetatni puferi ( $\mathrm{pH}$ 4,5 i pH 5,5 ), fosfatni puferi ( $p H$ 6,2, $p H$ 7,3 i pH 7,9) i tris/HCl puferi (pH 8,6 i pH 9,3). Maksimalna vrednost aktivnosti pri određenoj $\mathrm{pH}$ je predstavljala 100\%

Sa slike 10.8. se vidi da je slobodna PAC bila stabilna u opsegu $\mathrm{pH}$ od 6,2-8,6 sa optimalnom $\mathrm{pH}$ od 8,6, dok se optimum pomerio ka kiseloj sredini za oba imobilisana uzorka. Uzorci PAC-Hit-GA-1 su bili sasvim stabilni u pH opsegu od 5,58,0 sa optimalnim $\mathrm{pH}$ pomerenim ka kiseloj sredini 5,5-6,2. Kod PAC-Hit-GA-9 je takođe došlo do pomeranje optimalne $\mathrm{pH}$ od oko 0,6 jedinica ka nižoj $\mathrm{pH}$ sredini, pokazujući da se matriks ponašao kao polikatjon. Usled toga što je hitozan pozitivno naelektrisan nosač, $\mathrm{pH}$ vrednost u mikrookolini hitozana je nešto veća nego u dubini 
rastvora, tako da se pH optimum imobilisanog enzima očekivano pomera ka kiseloj sredini u odnosu na slobodan. Ova pojava se obično primećuje kada su enzimi kovalentno vezani za naelektrisane nosače, kao što je to u ovom slučaju [240, 241]. Ipak, ovaj uticaj je manje značajan za PAC-Hit-GA-9, verovatno usled većeg stepena umrežavanja hitozanskih mikročestica.

\subsection{Ispitivanje stabilnosti imobilisanog enzima nakon višekratne upotrebe}

Stabilnosti PAC u operativnim uslovima je od presudnog značaja za njeno moguće korišćenje kao industrijskog biokatalizatora. Iz ovog razloga, operativna stabilnost oba imobilizata PAC-Hit-GA-1 i PAC-Hit-GA-9 je ispitana u seriji uzastopnih reakcija hidrolize penicilina $\mathrm{G}$ na $37{ }^{\circ} \mathrm{C}$ korišćenjem $200 \mathrm{mg}$ imobilisane PAC u uslovima kontinualnog mešanja (100 rpm ili 400 rpm). Na kraju svake šarže (1 h), biokatalizatori su filtrirani, oprani, osušeni i dodati u novu reakcionu smešu.

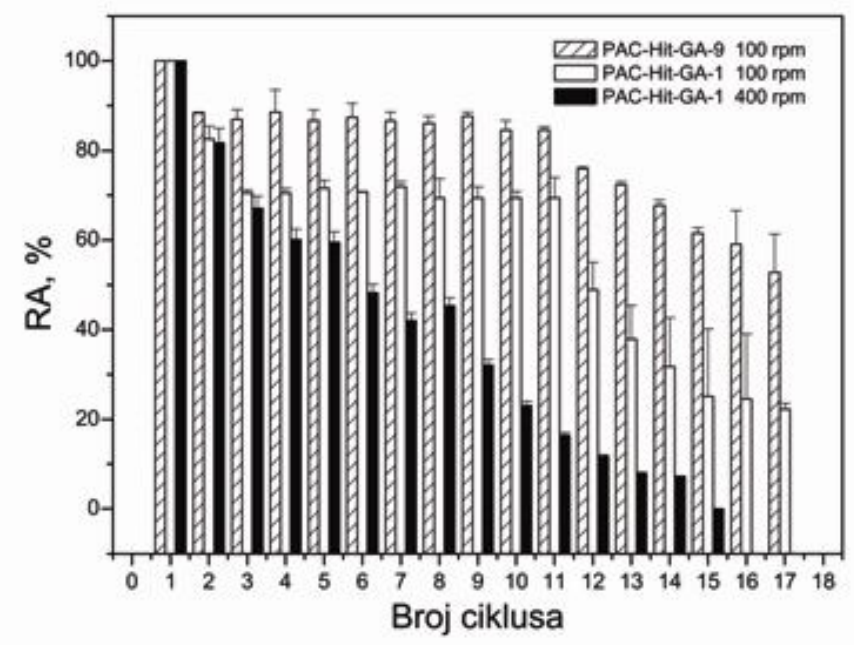

Slika 10.10. Relativna aktivnost PAC-Hit-GA-9 (100 rpm), PAC-Hit-GA-1 (100 rpm) i PAC-Hit-GA-1 (400 rpm) kao funkcija broja ciklusa $\left(37{ }^{\circ} \mathrm{C}, 1 \mathrm{~h}\right.$-ciklus, 200mg biokatalizatora, $\mathrm{pH} 7,92$ )

Dva profila stabilnosti za PAC-Hit-GA-9 i PAC-Hit-GA-1 pri brzini mešanja od 100 rpm koji su prikazani na slici 10.10. imaju slične karakteristike: aktivnost u 
početku pada posle jednog ili dva ciklusa, ostaje konstantna u toku 10-11 uzastopnih ciklusa, a onda gubitak aktivnosti postaje značajan. U slučaju PAC-Hit-GA-9, biokatalizator može da izvodi jedanaest reakcionih ciklusa sa malim padom aktivnosti (oko 15\%) posle čega aktivnost postepeno opada, pokazujući poluvreme od 9,34 h koje odgovara 9 ciklusa. Slično, PAC-Hit-GA-1 je zadržao oko $70 \%$ početne aktivnosti posle 11 uspešnih ciklusa i posle toga je pokazao pad aktivnosti, dajući poluvreme reakcije od 3,13 h što se može izraziti kao 3 uzastopne šarže od po 1 h. Značajan pad enzimske aktivnosti je možda prouzrokovan denaturaciom ili inhibicijom enzima proizvodom. Međutim, spiranje enzima sa nosača u toku vremena takođe može značajno da utiče na smanjenje stabilnosti enzima. Da bi se dalje ispitali razlozi za dobijenu dezaktivaciju, isti eksperiment je ponovljen sa svežim PAC-Hit-GA-1 u šaržnom reaktorskom sistemu pri većoj brzini mešanja od $400 \mathrm{rpm}$ i rezultat je takođe prikazan na slici 10.10. (crne kolone). U ovom slučaju dobijen je drugačiji, više izražen trend opadanja aktivnosti biokatalizatora, koji je sada izložen većim brzinama mešanja, pokazujući eksponencialni pad aktivnosti biokatalizatora. Na brzini mešanja od 400rpm samo 7,1\% aktivnosti ostaje posle 14 ponovljenih ciklusa za PAC-Hit-GA-1 u poređenju sa $31,7 \%$ dobijenih pri brzini od $100 \mathrm{rpm}$.

\subsection{Ispitivanje kinetike otpuštanja penicilin-acilaze sa mikročestica}

Moguće spiranje PAC sa hitozanskih mikročestica je takođe ispitano merenjem sadržaja enzima u supernatantima u toku vremena dve eksperimentalne serije sa PACHit-GA-1 i PAC-Hit-GA-9 pri brzini mešanja od 400 rpm. Rezultati su predstavljeni na slici 10.11 . 


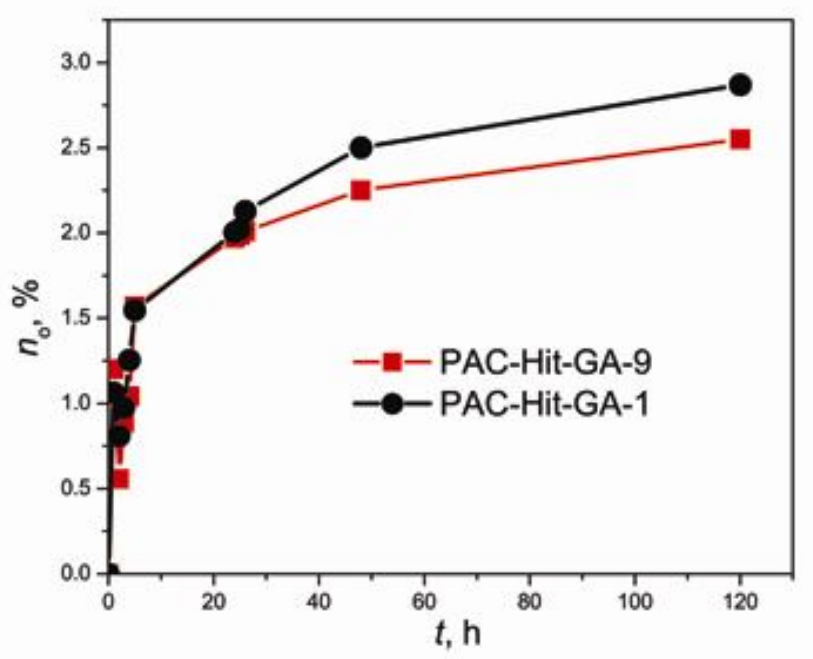

Slika 10.11. Kinetika spiranja PAC sa nosača za PAC-Hit-GA-1 i PAC-Hit-GA-9 na $37^{\circ} \mathrm{C}$ i pri brzini mešanja od $400 \mathrm{rpm}$

Može se uočiti da profili spiranja enzima sa nosača u toku vremena pokazuju blagi trend rasta u količini otpuštenog enzima sa vremenom za oba imobilizata. Povećanje spiranja enzima je manje za PAC-Hit-GA-9, gde je primećen gubitak enzima od samo oko 2,6\% posle $120 \mathrm{~h}$. Međutim, u oba slučaja je spiranje enzima zapravo minorno, ukazujući da gubitak aktivnosti imobilisanog enzima pri uzastopnom korišćenju ne može da se tumači kao posledica otpuštanja enzima sa nosača. Stoga je primarni uzrok verovatno dezaktivacija enzima mešanjem ili inhibicijom supstratom ili proizvodima. Veća stabilnost PAC-Hit-GA-9 može da se pripiše boljim mehaničkim karakteristikama hitozanskih čestica sa većim stepenom umrežavanja [159, 242].

\subsection{Ispitivanje početne kinetike hidrolize penicilina $G$ penicilin-acilazom imobilisanom na hitozanske mikročestice u šaržnom sistemu}

\subsubsection{Ispitivanje inhibicije supstratom u višku}

Ispitivan je uticaj koncentracije penicilina $\mathrm{G}$, na relativnu brzinu reakcije pri čemu je varirana koncentracija supstrata u intervalu od 0,01 do $0,24 \mathrm{M}$ u $0,1 \mathrm{M}$ 
fosfatnom puferu $\mathrm{pH}=7,92$. Dobijena zavisnost prikazana je na slici 10.12. uz uporednu zavisnost određenu za slobodnu PAC.

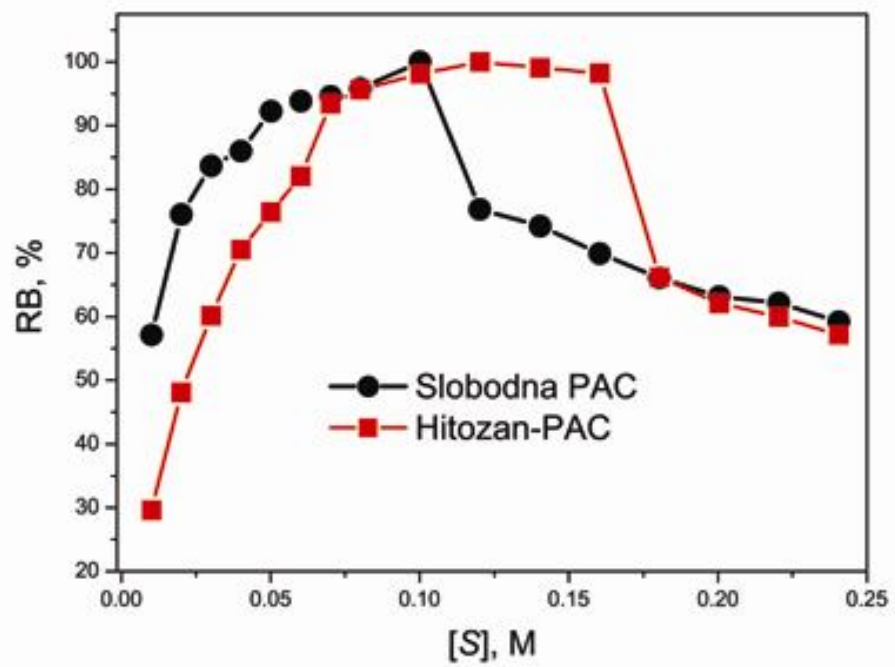

Slika 10.12. Zavisnost relativne brzine reakcije od koncentracije Pen $G$ za slobodnu PAC i PAC-Hit-GA-1

Aktivnost imobilisane PAC raste sa povećanjem koncentracije supstrata do koncentracije od 0,12 M. Međutim, sa daljim povećanjem koncentracije supstrata do 0,16 M, aktivnost PAC ostaje približno konstantna posle čega počinje naglo da opada. $\mathrm{Na}$ osnovu predstavljenih rezultata može da se zaključi da u slučaju imobilisane PACHit-GA-1 do inhibicije dolazi pri koncentracijama supstrata većim od 0,16 M, dok do inhibicije slobodne PAC dolazi pri koncentracijama supstrata većim od 0,1 M. Dakle, imobilizacija enzima pomera inhibiciju ka većim koncentracijama supstrata. Ovakav uticaj može da se objasni efektom raspodele supstrata u sistemu sa imobilisanom PAC. Koncentracija supstrata u dubini rastvora je veća od koncentracije supstrata u blizini nosača sa enzimom, pa zbog toga do inhibicije imobilisane PAC dolazi pri većim koncentracijama supstrata nego u slučaju slobodne PAC.

$\mathrm{Na}$ osnovu dobijenih rezultata nacrtan je Lajnviver-Berkov dijagram za imobilisanu PAC za koncentracije supstrata od 0,01 do 0,12 M, dijagram je prikazan na slici 10.13. 


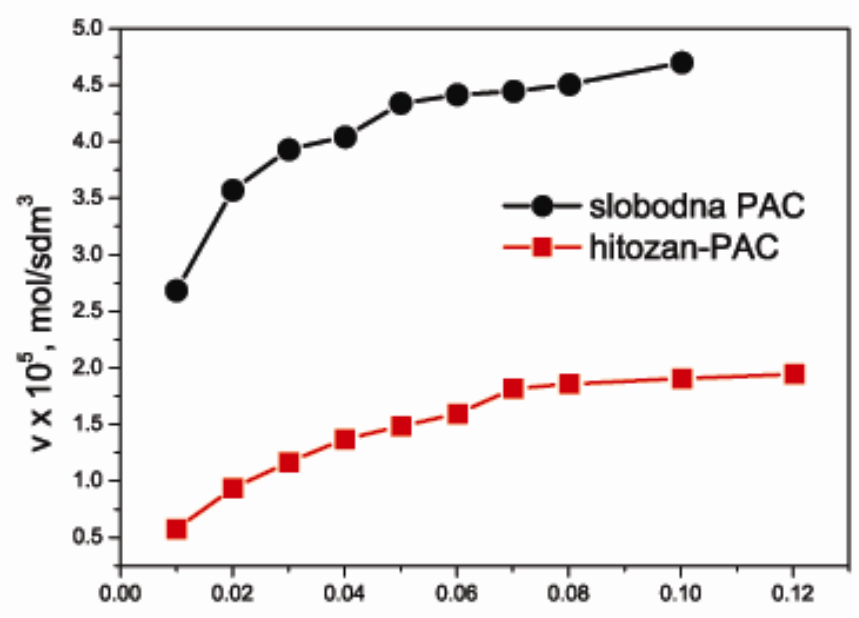

[S]

a)

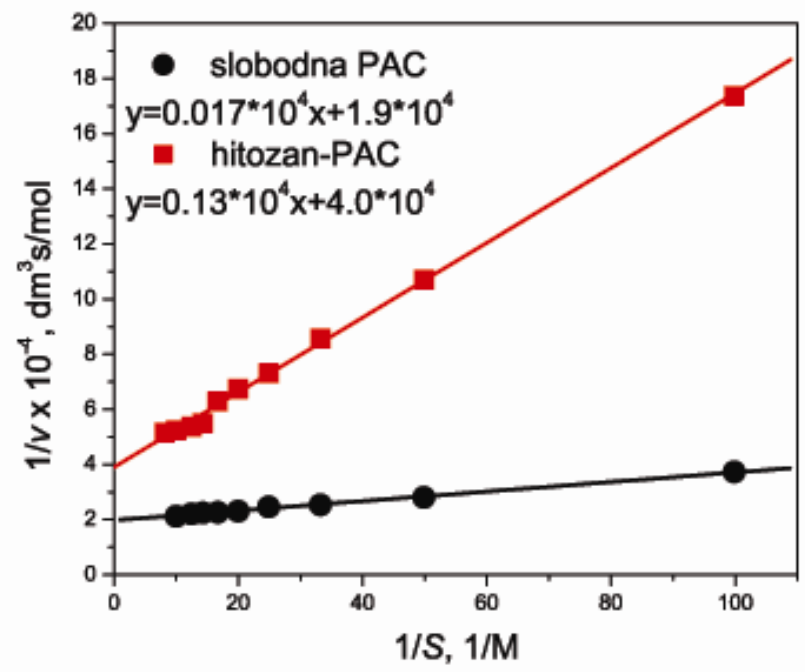

b)

Slika 10.13. a) Zavisnost početne brzine reakcije katalizovane slobodnom PAC $i$ hitozan-PAC od koncentracije Pen G. Reakcioni uslovi: koncentracija Pen G od 0,01 do 0,12 M, koncentracija enzima $0,006 \mathrm{~cm}^{3} / \mathrm{cm}^{3}$ ili $0,1 \mathrm{~g}$ imobilisane PAC, 0,1 M natrijum-fosfatni pufer $\mathrm{pH} 7,92$, temperatura $37^{\circ} \mathrm{C}$

b) Lajnviver-Berkov dijagram recipročnih vrednosti početne brzine hidrolize Pen $G i$ koncentracije supstrata za reakciju katalizovanu slobodnom PAC $i$ hitozan-PAC. Dijagram je određen na osnovu vrednosti prikazanih na slici 10.13 a) 
Dobijena je vrednost $K_{\mathrm{M}}$ za imobilisanu PAC od $32,6 \cdot 10^{-3} \mathrm{M}$, dok je za slobodnu PAC iznosila $9,14 \cdot 10^{-3} \mathrm{M}$. Do povećanja vrednosti $K_{\mathrm{M}}$ nakon imobilizacije PAC dolazi verovatno zbog difuzionih limitacija prenosu supstrata u blizini čestice, sternih smetnji aktivnog položaja od strane nosača, i gubitka fleksibilnosti PAC koja je neophodna za vezivanje supstrata kod imobilisane PAC. Stoga, imobilisana PAC ima vidljivo niži afinitet ka supstratu od slobodne PAC. U literaturi je takođe zabeležen porast $K_{\mathrm{M}}$ posle imobilizacije enzima [150, 243-246]. Za PAC imobilisanu na poli(vinil acetat-ko-diviil benzen) čestice dobijena je vrednost $K_{\mathrm{m}}$ od $0,033 \mathrm{mmol} / \mathrm{cm}^{3}$ [246]. Ova vrednost je približno ista kao vrednost određena u ovom radu $\left(32,6 \cdot 10^{-3} \mathrm{M}\right)$, verovatno jer imobilisani enzimi imaju isti afinitet prema supstratu. Uz to, vrednosti $K_{\mathrm{m}}$ u literaturi za PAC imobilisanu na različite nosače su bile $4,17 \mathrm{mmol} / \mathrm{dm}^{3}$, $11,36 \mathrm{mmol} / \mathrm{dm}^{3}$ i $3,18 \mathrm{mmol} / \mathrm{dm}^{3}[50,244,247]$. Ove vrednosti su niže od $K_{\mathrm{m}}$ vrednosti dobijene u ovom radu, verovatno usled većih difuzionih limitacija prenosu supstrata u filmu oko hitozanskih mikročestica.

Na slici 10.14 prikazani su dijagrami zavisnosti početne brzine reakcije i recipročne vrednosti brzine reakcije od koncentracije supstrata u višku od 0,18 do 0,24M za imobilisanu hitozan-PAC. 


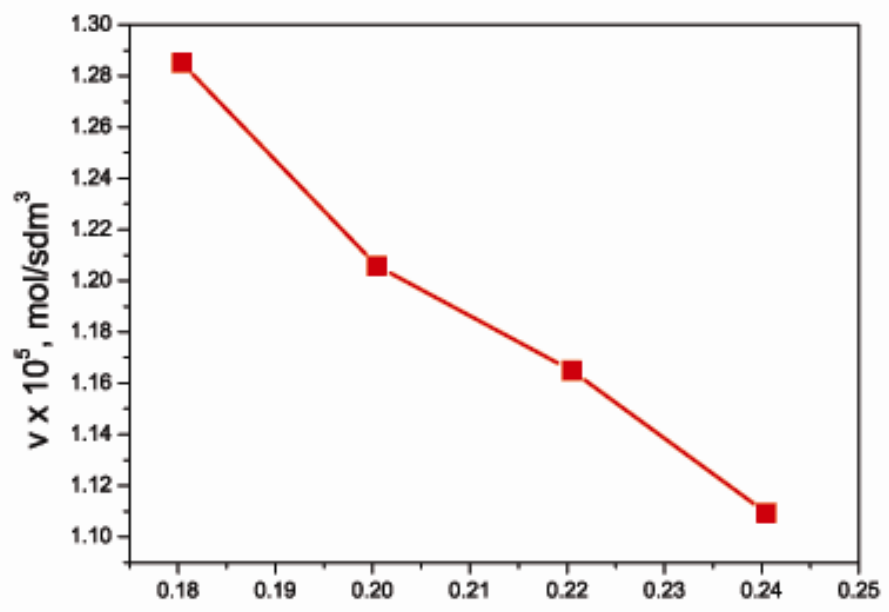

[S]

a)

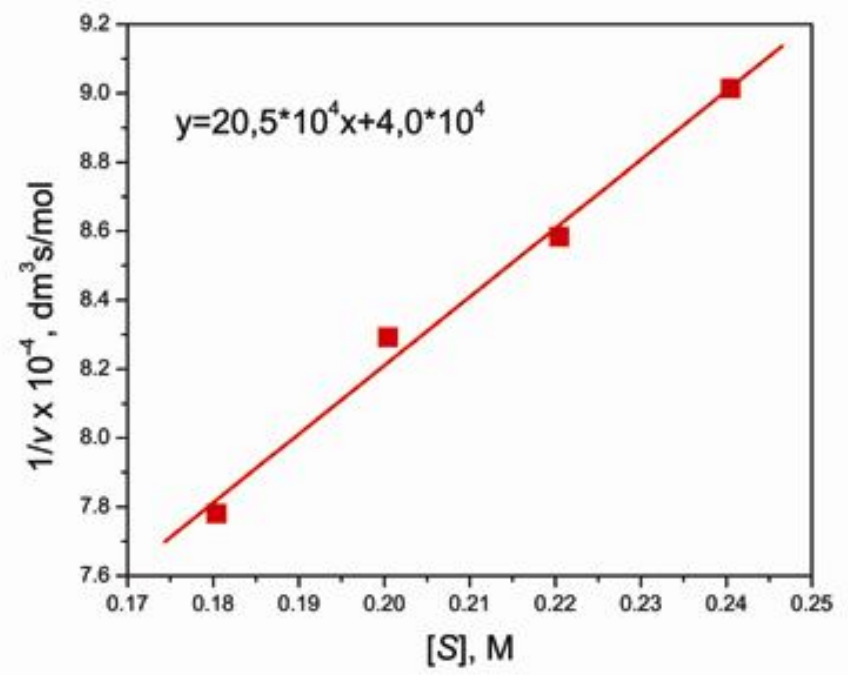

b)

Slika 10.14. a) Zavisnost početne brzine reakcije katalizovane imobilisanom PAC od koncentracije Pen G. Reakcioni uslovi: koncentracija Pen God 0,18 do 0,24 M, 0,1 g imobilisane PAC, 0,1 M natrijum-fosfatni pufer $p H$ 7,92, temperatura $37^{\circ} \mathrm{C}$

b) Zavisnost recipročne vrednosti početne brzine reakcije od koncentracije supstrata $u$ slučaju imobilisane PAC. Dijagram je određen na osnovu vrednosti prikazanih na slici $10.14 a)$ 
Na osnovu jednačine 1.4. i prikazanih rezultata na slici 10.14. dobija se vrednost konstante inhibicije supstratom u višku $K_{\mathrm{s}}$ od 0,199 M, za imobilisanu hitozan-PAC.

Prema tome, vrednosti $K_{\mathrm{M}}$ slobodne i imobilisane PAC od $9,14 \cdot 10^{-3} \mathrm{M}$ i $32,6 \cdot 10^{-3} \mathrm{M}$ su oko 31 i 6 puta niže, redom, nego odgovarajuće vrednosti $K_{\mathrm{S}}$ od 0,286 M i 0,199 M, redom, ukazujući na relativno slabu inhibiciju penicilinom G. Strukturne promene u PAC nastale u procesu imobilizacije i niža pristupačnost supstrata aktivnom položaju imobilisane PAC prouzrokovale su smanjenje afiniteta PAC prema supstratu. Takođe, smanjena je i aktivnost PAC i difuzija supstrata ka PAC je otežana glutaraldehidom koji je korišćen za aktiviranje hitozanskih mikročestica. Zbog toga, vrednost $V_{\mathrm{M}}$ imobilisane PAC $\left(2,45 \cdot 10^{-5} \mathrm{~mol} / \mathrm{dm}^{3} \mathrm{~s}\right)$ je dva puta niža nego $V_{\mathrm{M}}$ slobodne PAC $\left(5,13 \cdot 10^{-5} \mathrm{~mol} / \mathrm{dm}^{3} \mathrm{~s}\right)$.

\subsubsection{Ispitivanje početne kinetike u prisustvu proizvoda reakcije}

U ovom radu je pokazano da je hidroliza penicilina G pomoću slobodnog enzima penicilin-acilaze bila inhibirana proizvodima reakcije: 6-aminopenicilanskom kiselinom (6-APA) i fenilsirćetnom kiselinom (PAA). U ovom delu rada je ispitivan efekat ovih proizvoda na aktivnost PAC imobilisane na hitozanske mikročestice aktiviranih sa $1 \%$ glutaraldehidom.

\subsubsection{Ispitivanje uticaja početne koncentracije 6-aminopenicilanske kiseline na početnu brzinu reakcije}

Da bi se utvrdilo da li dolazi do inhibicije imobilisane hitozan-PAC proizvodom reakcije 6-APA, ispitana je zavisnost početne brzine hidrolize Pen G od početne koncentracije supstrata u prisustvu različitih koncentracija 6-APA koje su bile u opsegu od $1 \%$ do $2 \%$ w/v. Dobijeni su rezultati prikazani na slici 10.15 . 


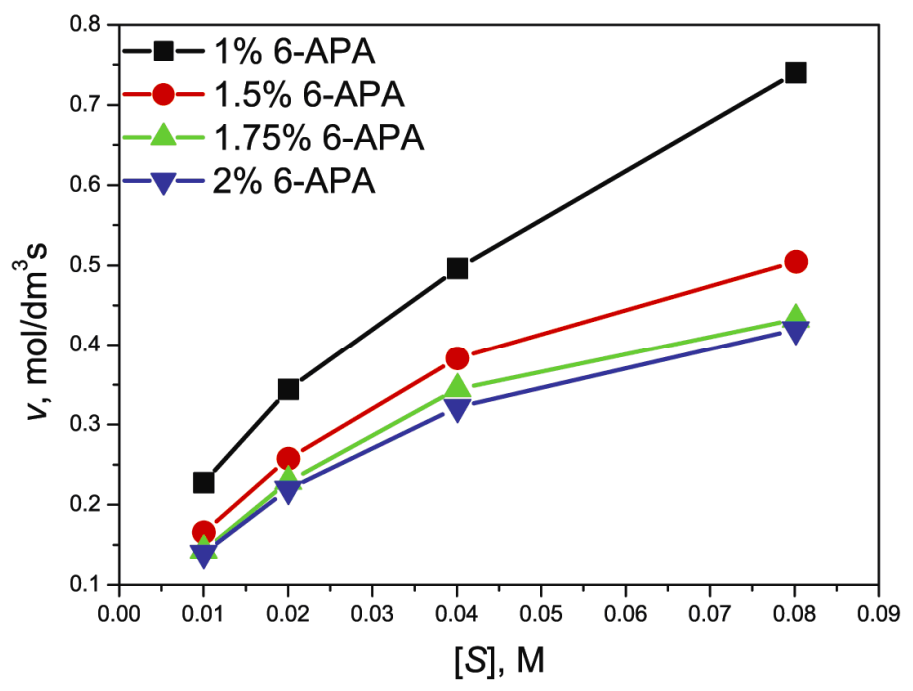

Slika 10.15. Uticaj različitih koncentracija inhibitora 6-APA na zavisnost početne brzine reakcije od koncentracije Pen $G$ za imobilisanu PAC na hitozanske mikročestice. Uslovi odigravanja reakcije: koncentracija Pen $G$ od 0,01 do 0,08 $\mathrm{M}$, koncentracija inhibitora 6-APA $1 \%$ do $2 \%$, 3min., $37^{\circ} \mathrm{C}, 0,1 \mathrm{M}$ natrijum-fosfatni pufer (pH 7,92), $1 \%$ glutaraldehid

Iz prikazanih zavisnosti uočava se da proizvod reakcije 6-APA inhibira reakciju hidrolize penicilina G i u slučaju imobilisane PAC. U cilju utvrđivanja vrste inhibicije prikazan je Lajnviver-Berkov dijagram za imobilisanu PCA na slici 10.16. 


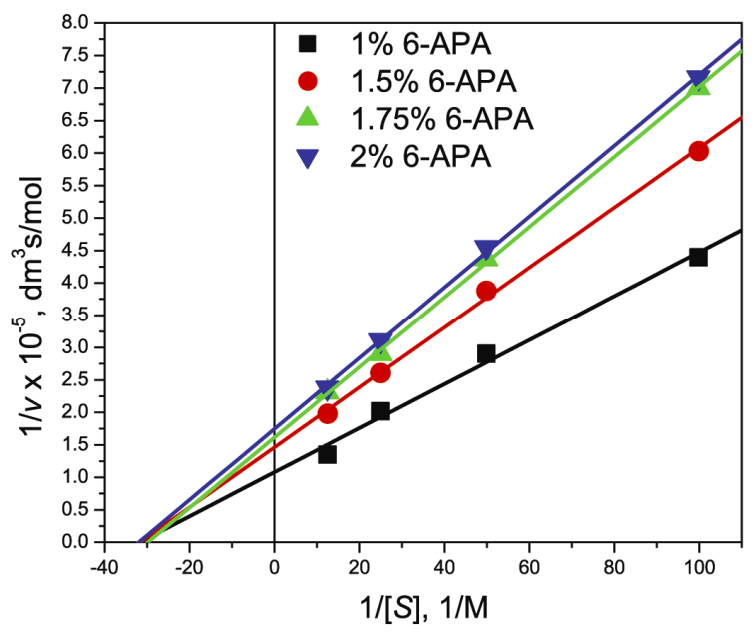

Slika 10.16. Lajnviver-Berkov dijagram za imobilisanu PAC na hitozanske mikročestice u slučaju 6-APA kao inhibitora

Sa Lajnviver-Berkovog dijagrama se uočava da je u pitanju klasična nekompetitivna inhibicija PAC proizvodom reakcije (6-APA). U cilju kvantitativnog određivanja jačine inhibicije određena je konstanta inhibicije za imobilisanu PAC (slika 10.17.).

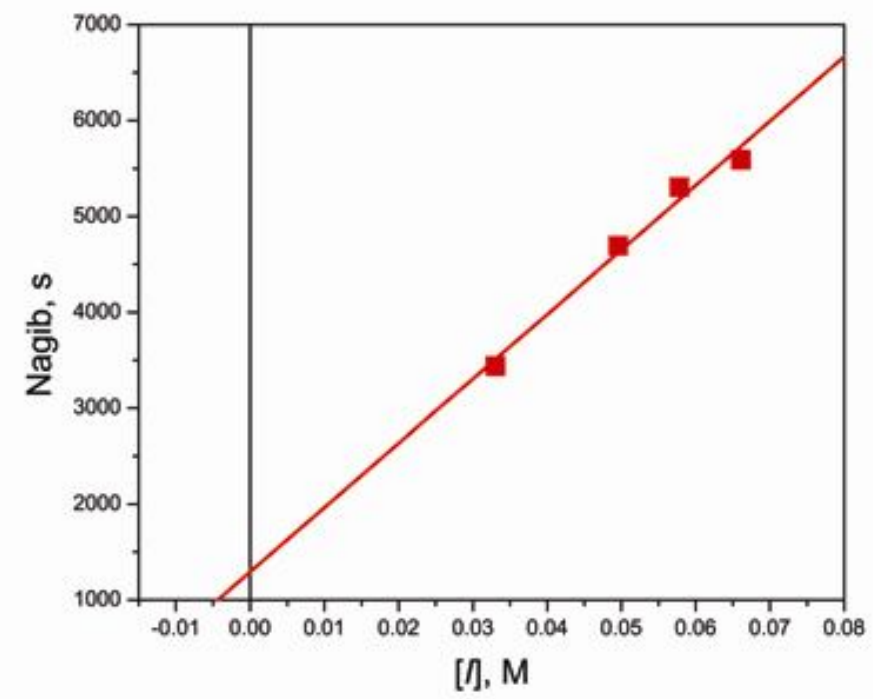

Slika 10.17. Zavisnost nagiba iz Lajnviver-Berkovog dijagrama od koncentracije inhibitora (6-APA) za imobilisanu PAC na hitozanske mikročestice aktivirane 1\% GA 
$\mathrm{Na}$ osnovu ovog dijagrama dobijena je vrednost konstante inhibicije od $19,43 \cdot 10^{-3} \mathrm{M}$ za imobilisanu PAC.

Što je konstanta inhibicije $K_{\mathrm{iA}}$ manja dejstvo inhibitora će biti veće, odnosno enzim ima veći afinitet prema inhibitoru. Prema tome, na osnovu dobijenih vrednosti konstanti inhibicije $K_{\mathrm{iA}}$ za slobodnu $\left(8,45 \cdot 10^{-3} \quad \mathrm{M}\right)$ i imobilisanu PAC $\left(19,43 \cdot 10^{-3} \mathrm{M}\right)$ može da se zaključi da je inhibicija jača u slučaju slobodne PAC i da se imobilizacijom smanjuje inhibicija 2,3 puta. Do ovih razlika u uticaju inhibitora dolazi usled efekta raspodele supstrata i inhibitora u sistemu sa imobilisanom PAC, pa je potrebna veća koncentracija inhibitora da bi se postigao isti stepen inhibicije kao u sistemu sa slobodnom PAC.

\subsubsection{Ispitivanje uticaja početne koncentracije fenilsirćetne kiseline na početnu brzinu reakcije}

Da bi se utvrdilo da li dolazi do inhibicije imobilisane hitozan-PAC proizvodom reakcije fenilsirćetnom kiselinom (PAA) kao jednim od proizvoda reakcije, ispitana je zavisnost početne brzine hidrolize Pen $\mathrm{G}$ od početne koncentracije supstrata u prisustvu različitih koncentracija PAA koje su bile u opsegu od $1 \%$ do $2 \%$ w/v.

Dobijeni su rezultati prikazani na slici 10.18 . 


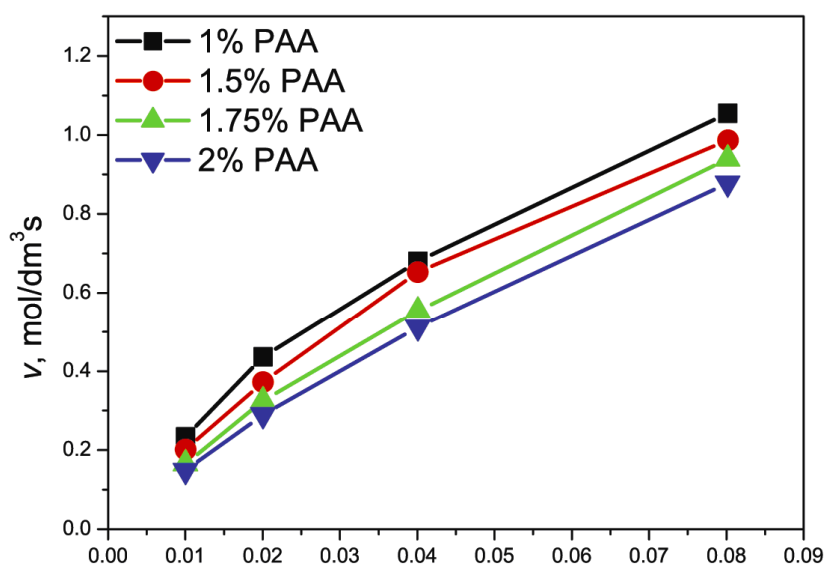

$[S], M$

Slika 10.18. Uticaj različitih koncentracija inhibitora PAA na zavisnost brzine reakcije od koncentracije Pen $G$ za imobilisanu PAC na hitozanskim mikročestica. Uslovi odigravanja reakcije: koncentracija Pen G od 0,01 do 0,08 M, koncentracija inhibitora PAA od $1 \%$ do $2 \%$, 3min., $37^{\circ} \mathrm{C}, 0,1$ M natrijum-fosfatni pufer $(\mathrm{pH} 7,92)$

Iz prikazane zavisnosti uočava se da proizvod reakcije PAA inhibira reakciju hidrolize penicilina G i u slučaju imobilisane PAC. U cilju utvrđivanja vrste inhibicije prikazan je Lajnviver-Berkov dijagram za imobilisanu PAC na slici 10.19.

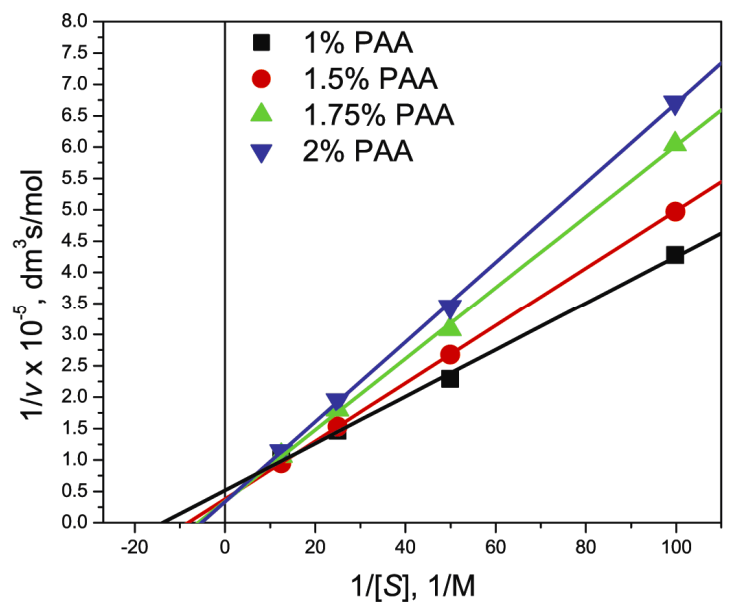

Slika 10.19. Lajnviver-Berkov dijagram za imobilisanu PAC na hitozanske mikročestice aktivirane 1\% GA u slučaju PAA kao inhibitora 
Sa Lajnviver-Berkovog dijagrama se uočava da je u pitanju klasična kompetitivna inhibicija enzima proizvodom reakcije (PAA). U cilju kvantitativnog određivanja jačine inhibicije određena je konstanta inhibicije za imobilisanu PAC (slika 10.20.).

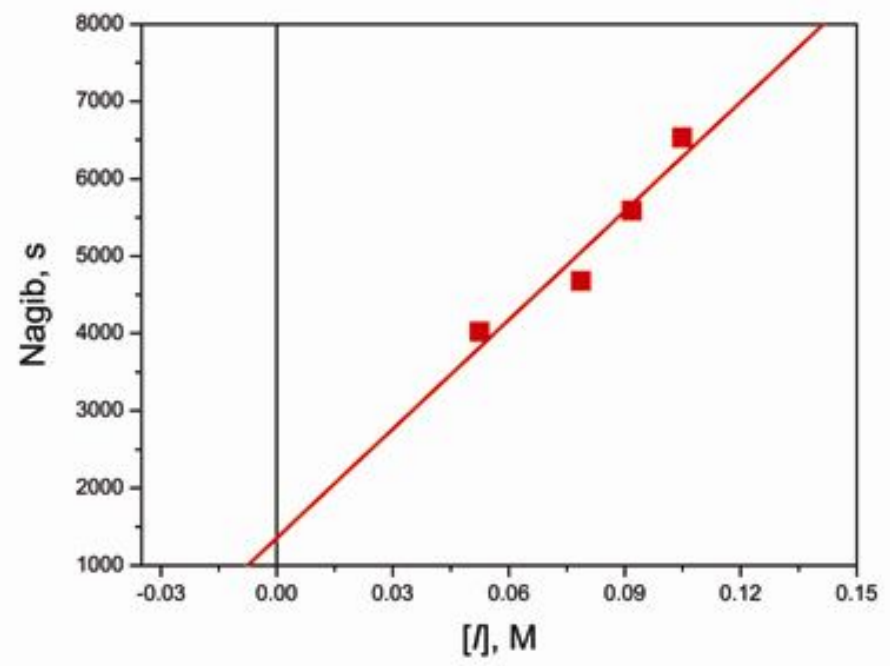

Slika 10.20. Zavisnost nagiba iz Lajnviver-Berkovog dijagrama od koncentracije inhibitora (PAA) za imobilisanu PAC na hitozanske mikročestice aktivirane 1\% GA

$\mathrm{Na}$ osnovu ovog dijagrama dobijena je vrednost konstante inhibicije od $28,4 \cdot 10^{-3} \mathrm{M}$ za imobilisanu PAC na hitozanske mikročestice.

Što je konstanta inhibicije $K_{\mathrm{iB}}$ manja dejstvo inhibitora je veće, odnosno enzim ima veći afinitet prema inhibitoru. Prema tome, na osnovu dobijenih vrednosti konstanti inhibicije $K_{\mathrm{iB}}$ za slobodnu i imobilisanu PAC $\left(11,7 \cdot 10^{-3} \mathrm{M}\right.$ i $28,4 \cdot 10^{-3} \mathrm{M}$, redom ) i ovde može da se zaključi da je inhibicija jača u slučaju slobodne PAC i da se imobilizacijom smanjuje inhibicija 2,4 puta. Odnosno zbog efekata raspodele inhibitora u sistemu sa imobilisanom PAC potrebna je veća koncentracija inhibitora da bi se postigao isti stepen inhibicije kao u sistemu sa slobodnom PAC.

U tabeli 10.3 prikazani su svi kinetički parametri uporedo za slobodnu i imobilisanu PAC na hitozanske mikročestice. Dobijeni rezultati ukazuju da je imobilisan sistem PAC-aktivirane hitozanske mikročestice pogodan za imobilizaciju PAC jer umanjuje negativne inhibitorne uticaje. Takođe je pokazano i da i slobodnu i imobilisanu PAC inhibira supstrat u višku i oba proizvoda reakcije, pri čemu je 6-APA nekompetitivni, a PAA je kompetitivni inhibitor. Ovi rezultati se slažu sa rezultatima 
objavljenim u literaturi [29, 50, 244, 246, 247]. Za imobilisanu PAC na poli(vinil acetat-ko-diviil benzen) česticama dobijene su vrednosti $\quad$ za $\quad K_{\mathrm{iA}} \quad$ i $\quad K_{\mathrm{iB}} \quad$ od $0,009 \mathrm{mmol} / \mathrm{cm}^{3}$ i $0,013 \mathrm{mmol} / \mathrm{cm}^{3}$, redom [246]. Ove vrednosti su niže nego $K_{\mathrm{iA}}$ i $K_{\mathrm{iB}}$ vrednosti dobijene u ovom radu, stoga, u ovom slučaju uticaj inhibitora na naš biokatalizator je manji. Takođe, u literaturi su objavljene i vrednosti $K_{\mathrm{iA}}$ i $K_{\mathrm{iB}}$ za PAC imobilisanu na različite nosače: $100,7 \mathrm{mmol} / \mathrm{dm}^{3}$ i $68,6 \mathrm{mmol} / \mathrm{dm}^{3}$ [247], odnosno $76,1 \mathrm{mmol} / \mathrm{dm}^{3}$ i $90 \mathrm{mmol} / \mathrm{dm}^{3}$, redom [50]. Ove vrednosti su veće od $K_{\mathrm{iA}}$ i $K_{\mathrm{iB}}$ vrednosti koje su dobijene u ovom radu, pa može da se zaključi da je uticaj inhibitora (6-APA i PAA) na naš biokatalizator veći.

Takođe, može da se zaključi da je 6-APA jači inhibitor nego PAA i da je slobodna PAC pod većim uticajem inhibitora nego imobilisana PAC. Prikazani rezultati ukazuju da su kinetičke karakteristike imobilisane PAC bolje nego slobodne PAC.

Tabela 10.3. Vrednosti $V_{\mathrm{M}}, K_{\mathrm{M}}, K_{\mathrm{s}}$, kritične koncentracije penicilina G pri kojima dolazi do inhibicije, konstante inhibicije u slučaju 6-APA $\left(K_{\mathrm{iA}}\right)$ i PAA $\left(K_{\mathrm{iB}}\right) \cdot k a o$ inhibitora za slobodnu i imobilisanu PAC na hitozanske mikročestice.

\begin{tabular}{|c|c|c|c|c|c|c|}
\hline & $\begin{array}{l}V_{\mathrm{M}} \cdot \mathbf{1 0 ^ { 5 }}, \\
\mathrm{mol} / \mathbf{d m}^{3} \mathrm{~s}\end{array}$ & $\begin{array}{l}K_{\mathrm{M}} \cdot \mathbf{1 0 ^ { 3 }}, \\
\mathrm{M}\end{array}$ & $K_{\mathrm{s}}, \mathbf{M}$ & $\begin{array}{l}\text { Kritična } \\
\text { koncentracija } \\
\text { Pen G, M }\end{array}$ & $\begin{array}{l}K_{\mathrm{iA}} \cdot \mathbf{1 0}^{\mathbf{3}}, \\
\mathrm{M}\end{array}$ & $\begin{array}{l}K_{\mathrm{iB}} \cdot \mathbf{1 0}^{\mathbf{3}}, \\
\mathrm{M}\end{array}$ \\
\hline Slobodna & 5,13 & 9,14 & 0,286 & 0,1 & 8,45 & 11,7 \\
\hline \multicolumn{7}{|l|}{ PAC } \\
\hline Hitozan- & 2,45 & 32,6 & 0,199 & 0,16 & 19,43 & 28,4 \\
\hline PAC & & & & & & \\
\hline
\end{tabular}

10.9.3. Kinetički izraz za reakciju katalizovanu slobodnom i imobilisanom penicilin-acilazom u šaržnom sistemu

Na osnovu dobijenih kinetičkih rezultata (Tabela 10.3) proizilazi da su oba sistema sa slobodnom i imobilisanom PAC podložni inhibiciji supstratom u višku, kao i da oba proizvoda reakcije deluju inhibitorno. Utvrđeno je da je 6-APA nekompititivni, dok je PAA kompetitivni inhibitor slobodne i imobilisane PAC. 
$\mathrm{Na}$ osnovu dobijenih kinetičkih konstanti jednačina početne brzine u slučaju slobodne PAC je, kao što je već navedeno:

$$
v_{\mathrm{i}}=\frac{5,13 \cdot 10^{-5}[S]}{\left(1+\frac{[P]}{8,45 \cdot 10^{-3}}\right) \cdot\left([S]+9,14 \cdot 10^{-3}\left(1+\frac{[Q]}{11,7 \cdot 10^{-3}}\right)\right)+\frac{[S]^{2}}{0,286}}
$$

a u slučaju imobilisane PAC jednačina početne brzine je:

$$
v_{\mathrm{i}}=\frac{2,45 \cdot 10^{-5}[\mathrm{~S}]}{\left(\left(1+\frac{[\mathrm{P}]}{19,4 \cdot 10^{-3}}\right) \cdot\left([\mathrm{S}]+32,6 \cdot 10^{-3}\left(1+\frac{[\mathrm{Q}]}{28,4 \cdot 10^{-3}}\right)\right)+\frac{[\mathrm{S}]^{2}}{0,199}\right.} \quad[\mathrm{M} / \mathrm{s}]
$$

oznake predstavljaju ranije navedene parametre: $[S]$-koncentracija supstrata (penicilina G) (M), $[P]$-koncentracija 6-aminopenicilanske kiseline $(\mathrm{M}),[Q]-$ koncentracija fenilsirćetne kiseline (M).

\subsection{Ispitivanje kinetike hidrolize penicilina $G$ penicilin-acilazom imobilisanom na hitozanske mikročestice u reaktoru sa pakovanim slojem}

Kinetika hidrolize penicilina G katalizovana PAC imobilisanom na hitozanskim mikročesticama aktiviranih $1 \% \mathrm{GA}$ je dalje ispitana u reaktoru sa pakovanim slojem. $\mathrm{U}$ tom cilju određivana je koncentracija nastalog proizvoda (6-APA) u različitim vremenskim intervalima. Na dobijene eksperimentalne rezultate primenjena su dva kinetička modela: ukupni model kinetike sa inhibicijom koji uzima u obzir inhibitorni uticaj supstrata i proizvoda reakcije i model kinetike prvog reda kod kog se inhibitorni efekti zanemaruju.

\subsubsection{Ukupni model kinetike sa inhibicijom}

U ovom delu rada je na eksperimentalne rezultate hidrolize Pen G imobilisanom PAC u reaktoru sa pakovanim slojem primenjen ukupan model kinetike koji uključuje 
inhibitorne efekte supstrata i proizvoda, u opštem slučaju dat jednačinom 1.5. Pri tome je pretpostavljeno da se reaktor sa pakovanim slojem može predstaviti modelom idealnog cevnog reaktora (ICR). Da bi utvrdili da li dati model pokazuje dobro slaganje sa eksperimentalnim rezultatima u slučaju primene integralne metode potrebno je integraliti ovu jednačinu.

$$
v_{\mathrm{i}}=-\frac{d[S]}{d t}=\frac{V_{\mathrm{M}}[S]}{\left(1+\frac{[P]}{K_{\mathrm{iA}}}\right) \cdot\left([S]+K_{\mathrm{M}}\left(1+\frac{[Q]}{K_{\mathrm{iB}}}\right)\right)+\frac{[S]^{2}}{K_{\mathrm{S}}}}
$$

Razdvajanjem promenljivih dobija se jednačina koja se može integraliti:

$$
-\int_{\left[S_{0}\right]}^{[S]}\left[\frac{\left(1+\frac{[P]}{K_{\mathrm{iA}}}\right) \cdot\left([S]+K_{\mathrm{M}}\left(1+\frac{[Q]}{K_{\mathrm{iB}}}\right)\right)+\frac{[S]^{2}}{K_{\mathrm{S}}}}{[S]}\right] d[S]=V_{\mathrm{M}} \int_{0}^{t} d t
$$

gde je $\left[S_{0}\right]-$ početna koncentracija supstrata u trenutku $t=0,[S]$ - koncentracija supstrata $\mathrm{u}$ trenutku t, $V_{\mathrm{M}}-$ maksimalna vrednost početne brzine reakcije, $K_{\mathrm{M}}$ - MihaelisMentenova konstanta, $K_{\mathrm{iA}}$ - konstanta nekompetitivne inhibicije, $K_{\mathrm{iB}}$ - konstanta kompetitivne inhibicije, $K_{\mathrm{S}}$ - konstanta inhibicije supstratom u višku.

Zamenom $[P]=\left[S_{0}\right]-[S]$ i $[Q]=\left[S_{0}\right]-[S]$ u jednačinu (10.5.) dobija se:

$$
-\int_{\left[S_{0}\right]}^{[S]}\left[\frac{\left(1+\frac{\left[S_{0}\right]-[S]}{K_{i A}}\right) \cdot\left([S]+K_{\mathrm{M}}\left(1+\frac{\left[S_{0}\right]-[S]}{K_{i B}}\right)\right)+\frac{[S]^{2}}{K_{S}}}{[S]}\right] d[S]=V_{\mathrm{M}} \int_{0}^{t} d t
$$

Integraljenjem j-ne (10.6.) dobija se krajnji izraz zavisnosti koncentracije supstrata $[S]$ od vremena t u implicitnom obliku:

$$
\begin{aligned}
& V_{\mathrm{M}} \mathrm{t}=\left([S]-\left[S_{0}\right]\right)\left(K_{M}\left(\frac{1}{K_{i A}}+\frac{1}{K_{i B}}\right)-1+\left(\frac{2 K_{M}}{K_{i A} K_{i B}}-\frac{1}{K_{i A}}\right)\left[\mathrm{S}_{0}\right]\right)- \\
& \ln \frac{[S]}{\left[S_{0}\right]}\left(\frac{K_{M}}{K_{i A} K_{i B}}\left[S_{0}\right]^{2}+K_{M}\left(\frac{1}{K_{i A}}+\frac{1}{K_{i B}}\right)\left[S_{0}\right]+K_{M}\right)-\frac{1}{2}\left(\frac{K_{M}-K_{i B}}{K_{i A} K_{i B}}+\frac{1}{K_{S}}\right)\left([S]^{2}-\left[S_{0}\right]^{2}\right)
\end{aligned}
$$


Zamenom dobijenih kinetičkih konstanti za hitozan-PAC u jednačinu 10.7. dobija se krajnji izraz:

$2,45 \cdot 10^{-5} \mathrm{t}=\left([\mathrm{S}]-\left[S_{0}\right]\right)\left(1,83+66,92\left[\mathrm{~S}_{0}\right]\right)-\ln \frac{[S]}{\left[S_{0}\right]}\left(59,2\left[\mathrm{~S}_{0}\right]^{2}+2,83\left[\mathrm{~S}_{0}\right]+0,032641\right)-$

$6,38\left([\mathrm{~S}]^{2}-\left[S_{0}\right]^{2}\right)$

Jednačina 10.8. može da se reši numerički.

Eksperimentalno određene koncentracije Pen G na izlazu iz reaktora u toku vremena su prikazane na slici 10.21. zajedno sa rezultatima dobijenim primenom ukupnog modela sa inhibicijom u integralnom obliku (jednačina 10.8).

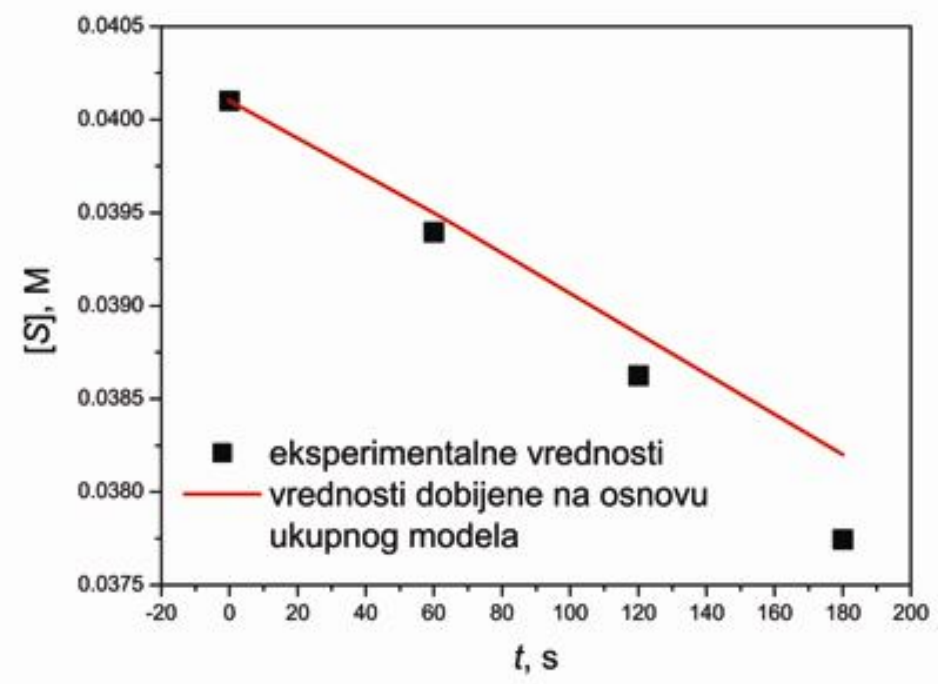

Slika 10.21. Zavisnost koncentracije penicilina $G$ od vremena u reaktoru sa pakovanim slojem hitozanskih mikročestica sa imobilisanom PAC određena eksperimentalno $i$ primenom modela sa inhibicijom

Na osnovu dobijenih rezultata može da se zaključi da primena ukupnog modela sa inhibicijom daje dosta dobro slaganje sa eksperimentalnim rezultatima (STD $\leq$ $0,8 \%$ ). Međutim, može se uočiti da model predviđa malo sporiju hidrolizu nego što je to eksperimentalno određeno. 


\subsubsection{Model kinetike prvog reda}

Hidroliza u reaktoru sa pakovanim slojem mikročestica je vođena do niskog stepena reagovanja (10\%) što daje mogućnost da se pri modelovanju eksperimentalnih rezultata inhibitorni uticaji supstrata i proizvoda reakcije zanemare. Jednačina brzine hidrolize se u tom slučaju svodi na kinetiku prvog reda:

$$
\begin{aligned}
& {[P]=[Q] \approx 0, \quad[S] \approx\left[S_{0}\right]} \\
& -\frac{d\lfloor S\rfloor}{d t}=k_{1}[S]
\end{aligned}
$$

Integraljenjem jednačine (10.9) od početnog trenutka $t=0$ i početne koncentracije supstrata $\left[S_{0}\right]$ do vremena $t$ i koncentracije $[S]$ dobija se:

$$
\ln \frac{[S]}{\left[S_{0}\right]}=-k_{1} t
$$

Eksperimentalni rezultati kao i linearna zavisnost koja daje najmanja odstupanja su prikazani na slici 10.22 . 


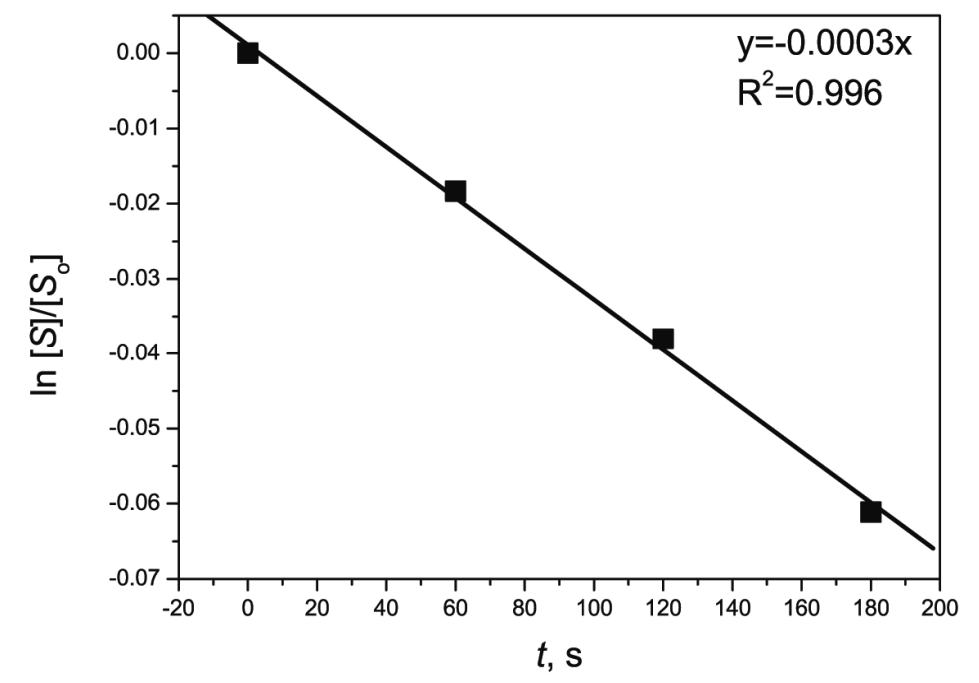

Slika 10.22. Zavisnost $\ln [S] /\left[S_{0}\right]$ od vremena

Lako se uočava da je dobijena zavisnost linearna $\left(R^{2}=0,996\right)$ što ukazuje da eksperimentalni rezultati pokazuju dobro slaganje sa kinetikom prvog reda. Vrednost konstante brzine reakcije određena je iz nagiba dobijene prave i iznosi: $k_{1}=3 \cdot 10^{-4} \mathrm{~s}^{-1}$. $\mathrm{Na}$ slici 10.23. prikazani su eksperimentalni rezultati i predviđanja modela kinetike prvog reda. 


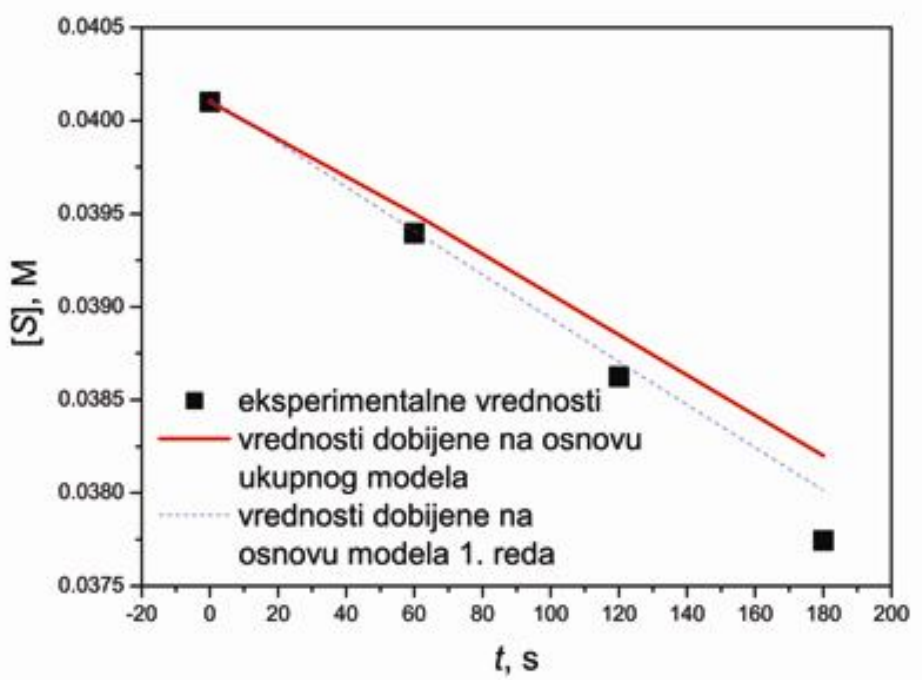

Slika 10.23. Zavisnost koncentracije supstrata od vremena u reaktoru sa pakovanim slojem hitozanskih mikročestica sa imobilisanom PAC određena eksperimentalno, primenom modela sa inhibicijom i modela 1. reda

Uočava se da je dobijeno dosta dobro slaganje predviđanja modela i eksperimentalnih podataka. Pri tome i u ovom slučaju model predviđa sporiju hidrolizu od eksperimentalno izmerene, ali daje bolje slaganje sa eksperimentalnim podacima od ukupnog kinetičkog modela.

\subsection{Ispitivanje kinetike hidrolize penicilina $G$ penicilin-acilazom imobilisanom na hitozanske mikročestice u reaktoru sa pakovanim slojem sa recirkulacijom}

Enzimska reakcija hidrolize penicilina $\mathrm{G}$ ispitana je i u reaktoru sa pakovanim slojem hitozanskih mikročestica sa imobilisanom PAC sa recirkulacijom koji je opisan i šematski prikazan u poglavlju 6.2.4.11. Sistem se može aproksimirati kao idealni cevni reaktor (sa vremenima zadržavanja $\tau_{\mathrm{C}}: 3 \mathrm{~min}, 2 \mathrm{~min}$, i $1 \mathrm{~min}$ ) vezan na red sa rezervoarom sa idealnim mešanjem (sa vremenima zadržavanja $\tau_{\mathrm{M}}: 13 \mathrm{~min}, 7,55 \mathrm{~min}$, $4 \mathrm{~min})$. 


\subsubsection{Model kinetike hidrolize u sistemu sa recirkulacijom}

Da bi se opisala kinetika hidrolize u sistemu sa recirkulacijom, potrebno je poznavati kinetiku reakcije u reaktoru sa pakovanim slojem. Pošto je u prethodnim istraživanjma pokazano da model kinetike I reda u opsegu eksperimentalnih merenja bolje opisuje kinetiku hidrolize Pen G u protočnom reaktoru sa pakovanim slojem nego kinetika sa inhibicijom kao i zbog složenosti jednačine modela kinetike sa inhibicijom, $\mathrm{u}$ ovom delu rada je usvojena kinetika I reda sa konstantom brzine od $3 \cdot 10^{-4} \mathrm{~s}^{-1} \mathrm{za}$ opisivanje reakcije hidrolize u reaktoru. $\mathrm{Na}$ taj način, kinetički model koji opisuje enzimsku hidrolizu penicilina $\mathrm{G}$ u reaktoru sa pakovanim slojem imobilisanih čestica biokatalizatora sa recirkulacijom zasniva se na dve osnovne pretpostavke:

1) eksperimentalni sistem se sastoji iz reaktora sa pakovanim slojem koji se predstavlja modelom ICR vezanog na red sa rezervoarom sa idealnim mešanjem (slika 10.24);

2) hidroliza penicilina G se odvija samo u ICR i može se opisati kinetikom I reda sa konstantom brzine od $3 \cdot 10^{-4} \mathrm{~s}^{-1}$.

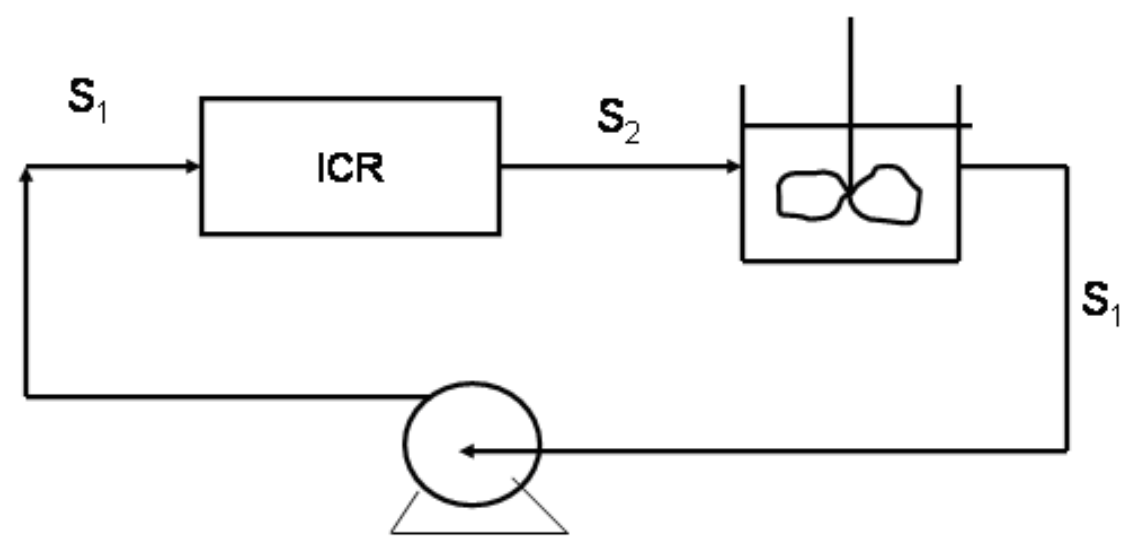

Slika 10.24. Reaktor sa pakovanim slojem sa recirkulacijom

Na osnovu navedenih pretpostavki mogu da se napišu sledeće projektne jednačine za reaktor sa pakovanim slojem i za rezervoar sa idealnim mešanjem:

$$
-\frac{d\left[S_{2}\right]}{d t}=f([S]) \Rightarrow\left[S_{2}\right]=f\left(\tau_{c},\left[S_{1}\right]\right)
$$




$$
\mathrm{V} \frac{d\left[S_{1}\right]}{d t}=v\left(\left[S_{2}\right]-\left[S_{1}\right]\right)
$$

Jednačina (10.12) se primenom jednačine (10.11) može napisati u obliku:

$$
\frac{d\left[S_{1}\right]}{d t}=\frac{\left[S_{2}\right]-\left[S_{1}\right]}{\tau_{M}}=\frac{f\left(\tau_{C}, S_{1}\right)-\left[S_{1}\right]}{\tau_{M}}
$$

Rešavanjem jednačina dobija se:

$$
\frac{d\left[S_{1}\right]}{f\left(\tau_{\mathrm{c}},\left[S_{1}\right]\right)-\left[S_{1}\right]}=\frac{d t}{\tau_{\mathrm{M}}}
$$

odnosno:

$$
t=\tau_{\mathrm{M}} \int_{\left[S_{o}\right]}^{[s]} \frac{d\left[S_{1}\right]}{f\left(\tau_{\mathrm{c}},\left[S_{1}\right]\right)-\left[S_{1}\right]}
$$

U slučaju kinetike prvog reda izlazna koncentracija supstrata $\left[S_{2}\right]$ je određena sledećom jednačinom:

$$
\left[S_{2}\right]=\left[S_{1}\right] e^{-k \tau_{c}}
$$

Uvođenjem jednačine 10.16. u jednačinu 10.12. dobija se:

$$
\frac{d\left[S_{1}\right]}{d t}=\frac{\left[S_{1}\right] e^{-k \tau_{\mathrm{c}}}-\left[S_{1}\right]}{\tau_{\mathrm{M}}}
$$

Razdvajanjem promenljivih dobija se jednačina koja se može integraliti:

$$
\int_{\left[S_{\mathrm{o}}\right]}^{[S]} \frac{d\left[S_{1}\right]}{\left[S_{1}\right]}=-\int_{o}^{t} \frac{\left(1-e^{-k \tau_{\mathrm{c}}}\right)}{\tau_{\mathrm{M}}} d t \Rightarrow t=-\int_{\left[S_{\mathrm{o}}\right]}^{[s]} \frac{\tau_{\mathrm{M}} d\left[S_{1}\right]}{\left[S_{1}\right]\left(1-e^{-k \tau_{\mathrm{c}}}\right)}
$$


Nakon integraljenja dobija se krajnji izraz koji daje zavisnost koncentracije supstrata u toku vremena:

$$
t=-\frac{\tau_{\mathrm{M}}}{\left(1-e^{-k \tau_{\mathrm{c}}}\right)} \ln \frac{[S]}{\left[S_{\mathrm{o}}\right]}
$$

odnosno:

$$
\ln \frac{[S]}{\left[S_{\mathrm{o}}\right]}=-\frac{\left(1-e^{-k \tau_{\mathrm{c}}}\right)}{\tau_{\mathrm{M}}} t
$$

Jednačina 10.20. se može napisati u eksplicitnom obliku zavisnosti koncentracije supstrata $[\mathrm{S}]$ od vremena:

$$
[S]=\left[S_{0}\right] \cdot e^{-\left(1-e^{-k \tau c}\right) \frac{t}{\tau_{M}}}
$$

dobijena zavisnost predstavlja prividnu kinetiku prvog reda sa konstantom $K$, odnosno

$$
[S]=\left[S_{0}\right] \cdot e^{-K t}
$$

Pri čemu je $\quad K=\frac{1-e^{-k \tau_{C}}}{\tau_{M}}$

$\mathrm{U}$ tabeli 10.4. su prikazane vrednosti konstante $\mathrm{K}$ i koncentracije pencilina $\mathrm{G}$ eksperimentalne vrednosti i vrednosti dobijene na osnovu ukupnog modela (jednačina $\left.10.24 \mathrm{za}\left[S_{0}\right]=0,04 \mathrm{M}\right)$. Korišćenjem jednačine (10.23) izračunate su vrednosti prividne konstante brzine $K$ korišćenjem konstane brzine reakcije za reaktor sa pakovanim slojem $k=3 \cdot 10^{-4} \mathrm{~s}^{-1}$. Može da se primeti da se dobija odlično slaganje pretpostavke modela i eksperimentalnih rezultata $(\mathrm{STD}<2 \%)$. 
Tabela 10.4. Vrednosti konstante $\mathrm{K}$ za $k=3 \cdot 10^{-4} \mathrm{~s}^{-1}$ i koncentracije pencilina $\mathrm{G}$ (eksperimentalne vrednosti i vrednosti dobijene na osnovu ukupnog modela)

\begin{tabular}{llll}
\hline Protok $\left(\mathbf{c m}^{3} / \mathbf{m i n}\right)$ & $\mathbf{1 , 0 3}$ & $\mathbf{0 , 5 3}$ & $\mathbf{0 , 3 0}$ \\
\hline$\tau_{\mathrm{C}}(\min )$ & 1,0 & 2,0 & 3,0 \\
$\tau_{\mathrm{M}}(\min )$ & 4,0 & 7,5 & 13,0 \\
$\mathrm{~K} \cdot 10^{4}\left(\mathrm{~s}^{-1}\right)$ & 0,74 & 0,78 & 0,67 \\
{$[S]_{\text {eksp. }}(\mathrm{mM})$} & 39,7 & 39,5 & 39,2 \\
{$[S]_{\text {uk.mod. }}(\mathrm{mM})$} & 39,5 & 38,8 & 38,2 \\
\hline
\end{tabular}

Ovaj eksperimentalni sistem je efikasan u slučaju izvođenja reakcije sa imobilisanim enzimom jer upotreba povratnog toka predstavlja pogodan način približavanja proticanju sa idealnim mešanjem u reaktoru sa pakovanim slojem čestica biokatalizatora, pri laminarnom režimu i malim smicanjem. Odnos konstanti brzine u sistemu sa recirkulacijom $(K)$ i u idealnom cevnom reaktoru $(k)$ je:

$$
\frac{K}{k}=\frac{\left(1-e^{-k \tau_{C}}\right)}{k \tau_{M}}
$$

Iz jednačine (10.23) se uočava da se podešavanjem vremena u ICR-u odnosno vremena zadržavanja u ICR-u $\left(\tau_{\mathrm{C}}\right)$ i zapremine odnosno vremena zadržavanja u rezervoaru $\left(\tau_{\mathrm{M}}\right)$ mogu dobiti značajno veće brzine hidrolize u sistemu sa recirkulacijom u odnosu na ICR sa jednim prolazom. U eksperimentalnom sistemu sa tri primenjena protoka konstanta brzine u sistemu sa recirkulacijom je bila manja od konstante brzine reakcije u ICR-u. 


\section{Zaključak}

Cilj ovog dela rada je bio ispitivanje mogućnosti imobilizacije penicilin-acilaze, na česticama od hitozana za potencijalnu primenu u farmaciji i medicini. Kako je cena ovog enzima visoka, hitozan kao nosač za imobilizaciju je izabran zbog niske cene i jednostavnog procesa imobilizacije, što daje mogućnost uvećanja razmera procesa.

Ispitana je kovalentna imobilizacija ovog enzima na hitozanskim mikročesticama koje su dobijene postupkom elektrostatičke ekstruzije. Određeni su optimalni uslovi imobilizacije i aktivnost i stabilnost imobilisane penicilin-acilaze.

Ispitana je i početna kinetika reakcije hidrolize prirodnog penicilina $G$, kao i uticaj početne koncentracije supstrata (Pen G) i proizvoda reakcije (6-APA i PAA) u slučaju imobilisane PAC. Kinetika reakcije hidrolize penicilina G pomoću imobilisane PAC je zatim ispitana u dva reaktorska sistema: sistemu sa pakovanim slojem i sistemu sa pakovanim slojem uz recirkulaciju reakcione smeše. $\mathrm{Na}$ dobijene rezultate primenjeni su kinetički modeli i upoređena je efikasnost odvijanja enzimske reakcije u oba reaktorska sistema.

$\mathrm{Na}$ osnovu rezultata koji su dobijeni $\mathrm{u}$ toku ispitivanja uticaja uslova imobilizacije na svojstva imobilisane PAC na hitozanskim mikročesticama mogu se izvesti sledeći zaključci:

-optimalni parametri pri dobijanju hitozanskih mikročestica elektrostatičkom ekstruzijom su:

- 4,4 kV primenjeni napon na elektrostatičkom ekstruderu

- 2,5 cm rastojanje vrha igle od površine rastvora natrijum-tripolifosfata

- 1,5\% koncentacija rastvora hitozana

Pri ovim uslovima, dobijaju se mikročestice sledećih karakteristika:

-pravilan sferičan oblik

-srednji prečnik od oko $600 \mu \mathrm{m}$

-prinos aktivnosti od 71,8\% za PAC od 123 U/g suvog nosača

-promenjena mikrostruktura hitozanskih mikročestica se promenila nakon aktiviranja

-ravnomerno aktiviranje mikročestica po čitavoj zapremini 
Dobijeni rezultati ukazuju da su primenjeni nosač i metoda imobilizacije odgovarajući za imobilizaciju PAC.

$\mathrm{Na}$ osnovu rezultata koji su dobijeni u toku ispitivanja aktivnosti i stabilnosti imobilizata mogu se izvesti sledeći zaključci:

-maksimalna aktivnost je iznosila 263,6 U/g suvog nosača

-maksimalan prinos imobilizacije je bio $95 \%$

-maksimalan prinos aktivnosti je bio $95 \%$

-optimalni odnos PAC i suvog nosača u rastvoru za imobilizaciju je bio $769 \mathrm{U} / \mathrm{g}$

-optimalna koncentracija glutaraldehida za aktiviranje hitozanskih mikročestica iznosila je $1 \%$

-imobilisana PAC je pokazala bolju termalnu stabilnost od slobodne PAC i optimalna temperatura se povećala za $8{ }^{\circ} \mathrm{C}$

-optimalna $\mathrm{pH}$ vrednost imobilisane PAC se pomerila ka kiseloj sredini u odnosu na optimalnu pH slobodne PAC

-posle 11 uzastopnih ciklusa PAC-Hit-GA-1 i PAC-Hit-GA-9 su zadržali oko $70 \%$ i $85 \%$ početne aktivnosti, redom

-otpuštanje enzima sa površine nosača je bilo zanemarljivo, pri čemu je ono bilo niže kod PAC-Hit-GA-9 mikročestica nego kod PAC-Hit-GA-1 usled većeg stepena umrežavanja i boljih mehaničkih karakteristika.

$\mathrm{Na}$ osnovu rezultata koji su dobijeni u toku ispitivanja uticaja početne koncentracije supstrata (Pen G) i proizvoda reakcije (6-APA i PAA) na relativnu brzinu reakcije u slučaju imobilisane PAC mogu se izvesti sledeći zaključci.

-do inhibicije supstratom u višku dolazi pri koncentracijama supstrata većim od 0,16 M, pri čemu je konstanta inhibicije iznosila 0,199,

-proizvodi reakcije 6-APA i PAA su inhibirali reakciju hidrolize penicilina G i u slučaju imobilisane PAC. U pitanju je bila nekompetitivna i kompetitivna inhibicija, a konstante inhibicije su iznosile 0,0194 M i 0,0284 M.

$\mathrm{Na}$ osnovu rezultata koji su dobijeni tokom ispitivanja kinetike reakcije hidrolize penicilina $\mathrm{G}$ pomoću imobilisanog enzima u dva reaktorska sistema mogu se izvesti sledeći zaključci

-U prvoj eksperimentalnoj seriji ispitana je početna kinetika hidrolize penicilina

G katalizovane PAC imobilisanom na hitozanskim mikročesticama $u$ 
protočnom reaktoru sa pakovanim slojem. Na dobijene rezultate primenjeni su modeli kinetike prvog reda i ukupni kinetički model sa inhibicijom. Oba modela su dala zadovoljavajuće slaganje sa eksperimentalnim podacima pri čemu je model prvog reda sa konstantom brzine od $3 \cdot 10^{-4} \mathrm{~s}^{-1}$ bolje opisao eksperimentalne podatke.

-U drugoj eksperimentalnoj seriji ispitana je početna kinetika hidrolize penicilina G katalizovane PAC imobilisanom na hitozanskim mikročesticama $\mathrm{u}$ reaktoru sa pakovanim slojem uz recirkulaciju reakcione smeše. Radi opisivanja kinetike hidrolize Pen G u ovom sistemu izveden je kinetički model koji se zasniva na pretpostavci hidrolize kinetikom prvog reda $\mathrm{u}$ idealnom cevnom reaktoru koji je redno vezan za rezervoar sa idealnim mešanjem u kome se reakcija ne odvija. Izvedeni kinetički model predstavlja kinetiku prvog reda sa pseudo-konstantom u kojoj figurišu konstanta brzine hidrolize i vremena zadržavanja u cevnom reaktoru i rezervoaru. Podešavanjem vremena zadržavanja u cevnom reaktoru i rezervoaru sa mešanjem u ovom sistemu je moguće postići veće početne brzine hidrolize. 


\section{Zaključna razmatranja}




\section{ZAKLJUČAK}

U ovom radu je prvi put primenjena originalna metoda za imobilizaciju penicilin-acilaze na nosače od komercijalnog značaja koja se zasniva na prethodnoj modifikaciji enzima derivatima skroba i alginata $i$, zatim, hemijskom vezivanju tako modifikovane penicilin-acilaze na nosače koji sadrže amino grupe kao funkcionalne (Sepabeads EC-EA, Sepabeads EC-HA). Takođe, razvijen je originalni postupak imobilizacije penicilin-acilaze na hitozanskim česticama koje su dobijene elektrostatičkom ekstruzijom. Hitozanske čestice sa imobilisanim enzimom dobijene pod optimalnim uslovima su ispitane u reakciji hidrolize penicilina $\mathrm{G}$ u reaktoru sa pakovanim slojem sa i bez recirkulacije. Detaljno je proučena i kinetika ove enzimski katalizovane reakcije.

- Ispitivanjem imobilizacije PAC na Sepabeads nosače (Sepabeads EC-EP, Sepabeads EC-EA i Sepabeads EC-HA) dobijeni su sledeći rezultati:

○ gotovo sva početna količina PAC se vezuje za nosače,

○ prinos aktivnosti imobilisane PAC zavisi od tipa Sepabeads nosača i najveći je za PAC imobilisanu na Sepabeads EC-HA nosač,

○ temperaturna stabilnost biokatalizatora se ne poboljšava imobilizacijom, a najpovoljnija promena $\mathrm{pH}$ profila se dobija nakon imobilizacije PAC na Sepabeads EC-EP,

o termalna stabilnost enzima na $50{ }^{\circ} \mathrm{C}$ se povećava imobilizacijom a najveće povećanje se dobija imobilizacijom PAC na Sepabeads EC-HA,

- Sepabeads EC-HA nosač je podesniji za imobilizaciju PAC od Sepabeads EC-EP i Sepabeads EC-EA nosača.

- Ispitivanje imobilizacije modifikovane penicilin-acilaze na Sepabeads EC-EA i Sepabeads EC-HA dobijeni su sledeći rezultati:

- imobilizacijom modifikovane PAC dobija se biokatalizator boljih karakteristika nego kada se vrši imobilizacija modifikovane i oksidovane PAC, 
○ imobilisana skrob-PAC ima bolje karakteristike od imobilisane alginatPAC,

○ optimalna temperatura se ne menja u odnosu na slobodnu PAC dok su $\mathrm{pH}$ profili suženi u odnosu na $\mathrm{pH}$ profil slobodne PAC,

- skrob-PAC imobilisana na Sepabeads EC-HA po metodi 2 je biokatalizator najboljih svojstava jer je najstabilniji, a ima i najveću aktivnost i prinos aktivnosti.

- Ispitivanjem optimalnih uslova za dobijanje hitozanskih mikročestica elektrostatičkom ekstruzijom i imobilizaciju PAC na ove čestice dobijeni su sledeći rezultati:

○ prečnik mikročestica zavisi od primenjenog napona i rastojanja elektroda dok je uticaj koncentracije hitozana i glutaraldehida zanemarljiv,

- maseni prinos imobilizacije i prinos aktivnosti zavise od operacionih parametara elektrostatičke ekstruzije i koncentracije hitozana,

- mikrostruktura hitozanskih mikročestica se menja posle aktiviranja i imobilizacije PAC,

- masa vezane i aktivnost imobilisane PAC zavise od koncentracije glutaraldehida, pri čemu su ovi parametri bolji kada se aktivacija izvrši $1 \%$ glutaraldehidom,

○ imobilizacijom dolazi do poboljšanja termalne stabilnosti PAC,

○ imobilizacijom optimalna $\mathrm{pH}$ vrednost PAC se pomera ka kiseloj sredini,

- sa imobilisanom PAC može da se izvodi jedanaest reakcionih ciklusa sa malim padom aktivnosti,

o imobilisana PAC se zanemarljivo otpušta sa hitozanskih mikročestica u toku vremena sa blagim trendom rasta.

- Ispitivanjem početne kinetike hidrolize penicilina G penicilin-acilazom imobilisanom na hitozanske mikročestice u šaržnom sistemu i u reaktoru sa pakovanim slojem sa i bez recirkulacije dobijeni su sledeći rezultati: 
○ kinetika hidrolize penicilina $G$ je kompleksna i uključuje inhibiciju supstratom u višku i proizvodima reakcije (6-aminopenicilanskom i fenilsirćetnom kiselinom) tako da zahteva razmatranje odgovarajućeg reaktorskog sistema za izvođenje reakcije sa velikom efikasnošću,

- imobilizacija PAC na hitozanske mikročestice je jedno od rešenja jer umanjuje inhibitorne uticaje supstrata i proizvoda reakcije, pa je ovaj biokatalizator odgovarajući za dobijanje 6-APA,

○ pokazano je da reaktor sa pakovanim slojem sa recirkulacijom može da obezbedi odgovarajući reaktorski sistem sa malim smicanjem i većom brzinom hidrolize nego u idealnom cevnom reaktoru

$\mathrm{Na}$ osnovu pregleda do sada objavljenih eksperimentalnih podataka i rezultata prikazanih u okviru ove doktorske disertacije ostvaren je značajan doprinos u poboljšanju stabilnosti penicilin-acilaze i definisani su optimalni procesni parametri i odgovarajući režim rada bioreaktora za odvijanje hidrolize penicilina G u sistemu sa imobilisanim enzimom. Zaključci i rezultati izneti u disertaciji su bitni za dalji razvoj imobilisanih sistema sa penicilin-acilazom iz Escherichia coli. 


\section{LITERATURA}

[1] Rajendhran, J., Gunasekaran, P. (2004) Recent Biotechnological Interventions for Developing Improved Penicillin G Acylases, Journal of Bioscience and Bioengineering, 97(1), 1-13.

[2] Valle, F., Balbas, P., Merino, E., Bolivar, F. (1991) The role of penicillin amidases in nature and in industry, Trends in Biochemical Science, 16, 36-40.

[3] Deshpande, B.S., Ambedkar, S.S., Sudhakaran, V.K., Shewale, J.G. (1994) Molecular biology of $\beta$-lactam acylases, World Journal of Microbiology and Biotechnology, 10, 129-138.

[4] Norouzian, D., Javadpour, S., Moazami, N., Akbarzadeh, A. (2002) Immobilization of whole cell penicillin G acylase in open gelatin matrix, Enyzme and Microbial Technology, 30, 26-29.

[5] Vandammc, E.J. (1988) Immobilized biocatalysts and antibiotic production: biochemical, genetical and biotechnical aspects, Marcel Dekker, New York, 261-286.

[6] Shewale, J.G., Sudhakaran, V.K. (1997) Penicillin V acylase: its potential in the production of 6-aminopenicillanic acid, Enzyme and Microbial Technology, 20, 402410.

[7] Massolini, G., Temporini, C., Calleri, E. (2008) Penicilin G Acylase as chiral selector in LC and CE: Exploring the origins of enantioselectivity, Journal of Chromatography B, 875 (1), 20-29.

[8] Calleri, E., Massolini, G., Lubda, D., Temporini, C., Loiodice, F., Caccialanza, G. (2004) Evaluation of a monolithic epoxy silica support for penicillin $G$ acylase immobilization, Journal of Chromatography A, 1031, 93-100.

[9] Cole, M. (1969) Hydrolysis of penicillins and related compounds by the cell-bound penicillin acylase of Escherichia coli, Biochemical Journal, 115, 733-739.

[10] Barbero, J.L., Buesa, J.M., Buitrago, G.G., Mendez, E., Perez-Aranda, A., Garcia, J.L. (1986) Complete nucleotide sequence of the penicillin acylase from Kluyvera citrophila, Gene, 49, 69-80. 
[11] Klei, H.E., Daumy, G.O., Kelly, J.A. (1995) Purification and preliminary crystallographic studies of penicillin G acylase from Providencia rettgeri, Protein Science, 4, 433-441.

[12] Verhaert, R.M.D., Riemens, A.M., Laan, J., Duin, J., Quax, W.J. (1997) Molecular cloning and analysis of the gene encoding the thermostable penicillin $\mathrm{G}$ acylase from Alcaligenes faecalis, Applied and Environmental Microbiology, 63, 3412-3418.

[13] Ohashi, H., Katsuta, Y., Nagashima, M., Kamei, T., Yano, M. (1989) Expression of the Arthrobacter viscosus penicillin acylase gene in Escherichia coli and Bacillus subtilis, Applied and Environmental Microbiology, 55, 351-356.

[14] Chiang, C., Bennett, R.E. (1967) Purification and properties of penicillin acylases from Bacillus megaterium, Journal of Bacteriology, 93, 302-308.

[15] Rajendhran, J., Krishnakumar, V., Gunasekaran, P. (2002) Optimization of a fermentation medium for the production of penicillin $G$ acylase from Bacillus sp., Letters in Applied Microbiology, 35, 523-527.

[16] Prieto, M.A., Diaz, E., Garcia, J.L. (1996) Molecular characterization of the 4hydroxyphenylacetate catabolic pathway of Escherichia coli $\mathrm{W}$ : engineering a mobile aromatic degradative cluster, Journal of Bacteriology, 178, 111-120.

[17] Brannigan, J.A., Dodson, G., Duggleby, H.J., Moody, P.C., Smith, J.L., Tomchick, D.R., Murzin, A.G. (1995) A protein catalytic framework with an N-terminal nucleophile is capable of self-activation, Nature, 378, 416-419.

[18] Duggleby, H.J., Tolley, S.P., Hill, C.P., Dodson, E.J., Dodson., G., Moody, P.C. (1995) Penicillin acylase has a single-amino-acid catalytic centre, Nature, 373, 264268.

[19] Giordano, R.C., Ribeiro, M.P.A., Giordano, R.L.C. (2006) Kinetics of $\beta$-lactam antibiotics synthesis by penicillin $\mathrm{G}$ acylase (PGA) from the viewpoint of the industrial enzymatic reactor optimization, Biotechnology Advances, 24, 27-41.

[20] Shewale, J.G., Deshpande, B.S., Sudhakaran, V.K., Ambedkar, S.S. (1990) Penicillin acylases: application and potentials, Process Biochemistry, 25, 97-103.

[21] Done, S.H., Brannigan, J.A., Moody, P.C., Hubbard, R.E. (1998) Ligand-induced Conformational Change in Penicillin Acylase, Journal of Microbiology and Biotechnology, 284, 463-475. 
[22] Alkema, W.B.L., Hensgens, C.M.H., Kroezinga, E.H.K., de Vries, E., Floris, R., van der Laan, J-M. (2000) Characterization of the $\beta$-lactam binding site of penicillin acylase of Escherichia coli by structural and site directed mutagenesis studies, Protein Engineering, 13, 857-863.

[23] Alkema, W.B.L., Dijkhuis, A-J., Vries, E., Janssen, D.B. (2002) The role of hydrophobic active-site residues in substrate specificity and acyl transfer activity of penicillin acylase, European Journal of Biochemistry, 269, 2093-2100.

[24] Alkema, W.B.L., Hensgens, C.M.H., Snijder, H.J., Keizer, E., Dijkstra B.W., Janssen, D.B. (2004) Structural and kinetic studies on ligand binding in wild-type and active-site mutants of penicillin acylase, Protein Engineering Design and Selection, 17, 473-480.

[25] McVey, C.E., Walsh, M.A., Dodson, G.G., Wilson, K.S., Brannigan, J.A. (2001) Crystal structures of penicillin acylase enzyme-substrate complexes: structural insights into the catalytic mechanism, Journal of Molecular Biology, 313, 139-145.

[26] Knežević-Jugović, Z., Enzimsko inženjerstvo, Tehnološko-metalurški fakultet, Beograd, 2008.

[27] Kasche, V., Haufler, U., Zollner, R. (1984) Kinetic studies on the mechanism of the penicillin acylase-catalyzed synthesis of ampicillin and benzylpenicillin, HoppeSeyler's Physiological Chemistry, 365, 1435-1443.

[28] Svedas, V.K., Savchenko, M.V., Belster, A.I., Guranda, D.F. (1996) Enantioselective penicillin acylase-catalyzed reactions: factors governing substrate and sterospecificity of the enzyme, Annals of New York Academy of Sciences 799, 659669.

[29] Kheirolomoom, A., Ardjmand, M., Fazelinia, H., Zakeri, A. (2001) Clarification of penicillin G acylase reaction mechanism, Process Biochemistry, 36, 1095-1101.

[30] Warburton, D., Dunnill, P., Lilly, MD. (1973) Conversion of benzylpenicillin to 6aminopenicillanic acid in a batch reactor and continuous feed stirred tank reactor using immobilized penicillin amidase, Biotechnology and Bioengineering, 15,13-25.

[31] Self, DA., Kay, G., Lilly, MD., Dunill, P. (1969) The conversion of benzylpenicillin to 6-aminopenicillanic acid using an insoluble derivative of penicillin amidase, Biotechnology and Bioengineering, 11, 337-348. 
[32] Balasingham, K., Warburton, D., Dunill, P., Lilly, MD. (1972) The isolation and kinetics of penicillin amidase from Escherichia coli, Biochimica et Biophysica Acta, $276,250-256$.

[33] Cleland, WW. (1963) The kinetics of enzyme-catalyzed reactions with two or more substrates or products. I. Nomenclature and rate equations, Biochimica et Biophysica Acta, 67, 104-137.

[34] Cleland, WW. (1963) The kinetics of enzyme-catalyzed reactions with two or more substrates or products. II. Inhibition:nomenclature and theory, Biochimica et Biophysica Acta, 67, 173-187.

[35] Cleland, WW. (1963) The kinetics of enzyme-catalyzed reactions with two or more substrates or products. III. Prediction of initial velocity and inhibition patterns by inspection, Biochimica et Biophysica Acta, 67, 188-196.

[36] Segel, IH. (1993) Ordered uni bi and ordered bi uni systems. In: Enzyme kinetics, behavior and analysis of rapid equilibrium and steadystate enzyme systems, Wiley, New York, 544-560.

[37] Calleri, E., Temporini, C., Massolini, G., Caccialanza, G. (2004) Penicillin G acylase-based stationary phases: analytical applications, Journal Of Pharmaceutical And Biomedical Analysis, 35, 243-258.

[38] Massolini, G., Calleri, E., Lavecchia, A., Loiodice, F., Lubda, D., Temporini, C., Fracchiolla, G., Tortorella, P., Novellino, E., Caccialanza, G. (2003) Enantioselective hydrolysis of some 2-aryloxyalkanoic acid methyl esters and isosteric analogues using a penicillin G acylase-based HPLC monolithic silica column, Analytical Chemistry, 75, $535-542$.

[39] Škrob, F., Bečka, S., Plháčková, K., Fotopulosová, V., Kyslík, P. (2003) Novel penicillin $\mathrm{G}$ acylase from Achromobacter sp. CCM 4824, Enzyme and Microbial Technology, 32, 738-744.

[40] Kutzbach, C., Rauenbusch, E. (1974) Preparation and general properties of crystalline penicillin acylase from Escherichia coli ATCC 11105, Hoppe Seylers Z Physiology and Chemistry,354, 45-53.

[41] Robak, M., Szewczuk, A. (1981) Penicillin amidase from Proteus rettgeri, Acta Biochimica Polonica, 28, 275-284. 
[42] Baker, W.L., (1992) Co-existence of $\beta$-lactamase and penicillin acylase in bacteria detection and quantitative determination of enzyme activities, Journal of Applied Bacteriology, 73, 14-22.

[43] Souza, V.R., Silva, A.C.G., Pinotti, L.M., Sobreiro, H., Araújo, S., Giordano, R.L.C. (2005) Characterization of the Penicillin G Acylase from Bacillus megaterium ATCC 14945, Brazilian Archives of Biology and Technology, 48, 105-111.

[44] Savidge, T.A., Cole, M. (1975) Penicillin acylase (bacterial), Methods in Enzymology, 43, 705-721.

[45] Merino, E., Balbas, P., Recillas, F., Becerril, B., Valle, F., Bolivar, F. (1992) Carbon regulation and the role in nature of the Escherichia coli penicillin acylase (pac) gene, Molecular Microbiology, 6, 2175-2182.

[46] Rao, A., Garcia, J. L. (1997) Identification of the pac promoter from Kluyvera citrophila, FEMS Microbiology Letters, 151, 9-16.

[47] Daumy, G.O., McColl, A.S., Apostolakos, D. (1982) Repression of penicillin G acylase of Proteus rettgeri by tricarboxylic acid cycle intermediates, Journal of Bacteriology, 152, 104-110.

[48] Chou, C.P., Lin, W., Kuo, B., Yu, C. (2000) Genetic strategies to enhance penicillin acylase production in Escherichia coli, Enzyme and Microbial Technology, 27, 766-773.

[49] Ozturk, D.C., Kazan, D., Erarslan, A. (2002) Stabilization and functional properties of Escherichia coli penicillin G acylase by covalent conjugation of anionic polysaccharide carboxymethycellulose, World Journal of Microbiology and Biotechnology, 18, 881-888.

[50] Erarslan, A., Terzi, I., Guray, A., Bermek, E. (1991) Purification and kinetics of penicillin G acylase from a mutant strain of Escherichia coli ATCC 11105, Journal of Chemical Technology and Biotechnology, 51, 27-40.

[51] Erarslan, A. (1993) The hydrolysis of cephalosporin G by free and immobilised penicillin G acylase from a mutant of Escherichia coli ATCC 11105, Process Biochemistry, 28, 311-318.

[52] Kazan, D., Ertan, H., Erarslan, A. (1997) Stabilization of Escherichia coli penicillin $G$ acylase against thermal inactivation by cross-linking with dextran dialdehyde polymers, Applied Microbiology and Biotechnology, 48, 191-197. 
[53] Mozhaev, V.V. (1993) Mechanism-based strategies for protein thermostabilization, Trends in Biotechnology, 11, 88-95.

[54] De Cordt, S., Hendrickx, M., Maesmans, G., Tobback, P. (1994) The influence of polyalcohols and carbohydrates on the thermostability of $\alpha$-amylase, Biotechnology and Bioengineering, 43, 107-114.

[55] Azevedo, A.M., Fonseca, L.P., Prazeres, D.M.F. (1999) Stability and stabilization of penicillin acylase, Journal of Chemical Technology and Biotechnology, 74, 11101116.

[56] Kazan, D., Erarslan, A. (1999) Effect of dextran polymers on the stability of soluble Escherichia coli penicillin acylase, Journal of Chemical Technology and Biotechnology, 74, 1157-1164.

[57] Travascio, P., Zito, E., Portaccio, M., Diano, N., Grano, V., Di Martino, S., Bertolini, T., Rossi, S., Mita, D.G. (2002) Enzyme reaction engineering: effect of methanol on the synthesis of antibiotics catalyzed by immobilized penicillin $\mathrm{G}$ acylase under isothermal and non-isothermal conditions, Biotechnology Progress, 18, 975-985. [58] Illanes, A., Anjari, S., Arrieta, R., Aguirre, C. (2002) Optimization of yield in kinetically controlled synthesis of ampicillin with immobilized penicillin acylase in organic media, Applied Biochemistry and Biotechnolog, 97, 165-179.

[59] Illanes, A., Fajardo, A. (2001) Kinetically controlled synthesis of ampicillin with immobilized penicillin acylase in the presence of organic cosolvents, Journal of Molecular Catalysis. B: Enzymatic, 11, 587-595.

[60] Lindsay, J.P., Clark, D.S., Dordick, J.S. (2002) Penicillin amidase is activated for use in nonaqueous media by lyophilizing in the presence of potassium chloride, Enzyme and Microbial Technology 31, 193-197.

[61] Erarslan, A., Kocer, H. (1992) Thermal inactivation kinetics of penicillin G acylase obtained from a mutant derivative of Escherichia coli ATCC 11105. Journal of Chemical Technology and Biotechnology, 55, 79-84.

[62] Erarslan, A., Ertan, H. (1995) Thermostabilization of penicillin G acylase obtained from a mutant of E. coli ATCC 11105 by bisimidoesters as homobifunctional crosslinking agents, Enzyme and Microbial Technology, 17, 629-635.

[63] Kazan, D., Ertan, H., Erarslan, A. (1996) Stabilization of penicillin G acylase against $\mathrm{pH}$ by chemical crosslinking, Process Biochemistry, 31, 135-140. 
[64] Ertan, H., Kazan, D., Erarslan, A. (1997) Cross-linked stabilization of Escherichia coli penicillin $\mathrm{G}$ acylase against $\mathrm{pH}$ by dextran-dialdehyde polymers, Biotechnology Techniques, 11, 225-229.

[65] Marshall J.J., (1978) Manipulation of the properties of enzymes by covalent attachment of carbohydrate, Trends in Biochemical Sciences, 3, 79-83.

[66] Veronese, F.M., Caliceti, P., Schiavon, O., Sartore, L., in: Harris, J.M., Ed. Poly ethylene glycol: Chemistry, Biochemical and Biomedical Application Plenum, New York, 1992, p. 127.

[67] Katre, N.V. (1993) The conjugation of proteins with polyethylene glycol and other polymers: Altering properties of proteins to enhance their therapeutic potential, Advanced Drug Delivery Reviews, 10, 91-114.

[68] Inada, Y., Matsushima, A., Kodera, Y., Nishimura, H. (1990) Review :

Polyethylene Glycol(PEG)-Protein Conjugates: Application to Biomedical and

Biotechnological Processes Journal of Bioactive and Compatible Polymers, 5, 343-364. [69] Villalonga, R., Villalonga, M.L., Gomez, L. (2000) Preparation and functional properties of trypsin modified by carboxymethylcellulose, Journal of Molecular Catalysis B: Enzymatic 10, 483-490.

[70] Pazur, J.H., Knull, H.R., Simpson, D.L. (1970) Glycoenzymes: A note on the role for the carbohydrate moieties, Biochemical and Biophysical Research Communications, 40, 110-116.

[71] Marshall, J.J., Rabinowitz, M.L. (1975) Enzyme stabilization by covalent attachment of carbohydrate, Archives of Biochemistry and Biophysics, 167, 777-779.

[72] Yamagata, Y., Arakawa, K., Yamaguchi, M., Kobayashi, M., Ichishima, E. (1994) Functional changes of dextran-modified alkaline proteinase from alkalophilic Bacillus sp, Enzyme and Microbial Technology, 16, 99-103.

[73] Srivastava, R.A.K. (1991) Studies on stabilization of amylase by covalent coupling to soluble polysaccharides, Enzyme and Microbial Technology 13, 164-170.

[74] Villalonga, R., Gomez, L., Ramýrez, H.L., Villalonga, M.L. (1999) Stabilization of $\alpha$-amylase by chemical modification with carboxymethylcellulose, Journal of Chemical Technology and Biotechnology, 74, 635-638. 
[75] Fernandez-Lafuente, R., Rosell, C.M., Rodriguez, V., Guisan, J.M. (1995) Strategies for enzyme stabilization by intramolecular crosslinking with bifunctional reagents. Enzyme and Microbial Technology, 17, 517-523.

[76] Venkatesh, P., Sundaram, P.V. (1998) Modulation of stability properties of bovine trypsin after in vitro structural changes with a variety of chemical modifiers, Protein Engineering, 11, 691-698.

[77] Yamagata, Y., Arakawa, K., Yamaguchi, M., Kobayashi, M., lchishima, E. (1994) Functional changes of dextran-modified alkaline proteinase from alkalophilic Bacillus sp, Enzyme and Microbial Technology, 16, 99-103.

[78] Masarova, J., Mislovicova, D., Gemeiner, P., Michalkova, E. (2001) Stability enhancement of Escherichia coli penicillin G acylase by glycosylation with yeast mannan, Biotechnology and Applied Biochemistry, 34, 127-133.

[79] Ozturk, D.C., Kazan, D., Erarslan, A. (2002) Stabilization and functional properties of Escherichia coli penicillin G acylase by covalent conjugation of anionic polysaccharide carboxymethylcellulose, World Journal of Microbiology and Biotechnology, 18, 881-888.

[80] Knežević, Z., Imobilizacija lipaze iz Candida rugosa na polimernim nosačima i na vlaknima od regenerisane celuloze u dijalizatoru, doktorska disertacija, Tehnološkometalurški fakultet, Beograd, 2003.

[81] Pastorino, L., Berzina, T.S., Troitsky, V.I., Bernasconi, E., Nicolini, C. (2002) Application of monolayer engineering for immobilization of penicillin $G$ acylase, Colloids and Surfaces B: Biointerfaces, 23, 289-293.

[82] Dias, F., Correia, A.C., Baptista, F.O. (1999) Activity and batch operational stability of Candida rugosa lipase immobilized in different hydrophilic polyurethane foams during hydrolysis in a biphasic medium, Bioprocess Engineering, 21, 517-524.

[83] Bajpai, A.K., Bhanu, S. (2003) Immobilization of $\alpha$-amylase in vinylpolymerbased interpenetrating polymer networks, Colloid and Polymer Science, 282, $76-83$.

[84] Petri, A., Gambicorti, T., Salvadori, P. (2004) Covalent immobilization of chloroperoxidase on silica gel and propertiesof the immobilized biocatalyst, Journal of Molecular Catalysis B: Enzymatic, 27, 103-106. 
[85] Tischer, W., Kasche, V. (1999) Immobilized enzymes: crystals or carriers, Trends in Biotechnology, 17, 326-335.

[86] Gao, B., Wang, X., Shen, Y. (2006) Studies on characters of immobilizing penicillin $\mathrm{G}$ acylase on a novel composite support $\mathrm{PEI} / \mathrm{SiO}_{2}$, Biochemical Engineering Journal, 28, 140-147.

[87] Lopez-Gallego, F., Montes, T., Fuentes, M., Alonso, N. (2005) Improved stabilization of chemically aminated enzymes via multipoint covalent attachment on glyoxyl supports, Journal of Biotechnology, 116, 1-10.

[88] Adriano, W. S., Filho, E.H.C., Silval, J.A., Giordano, R.L.C., Gonçalves, L.R.B. (2005) Stabilization of Penicilin G Acylase by immobilization on gluteraldehydeactivated chitosan, Brazilian Journal of Chemical Engineering, 22, 529-538.

[89] Carleysmith, S.W, Dunnill, P., Lilly, M.D. (1980) Kinetic behavior of immobilized Penicillin acylase, Biotechnology and Bioengineering, 22, 735-756.

[90] Chong, A.S.M., Zhao, X.S. (2004) Design of large-pore mesoporous materials for immobilization of penicillin G acylase biocatalyst, Catalysis Today, 93-95, 293-299.

[91] Chong, A.S.M., Zhao, X.S. (2004) Functionalized nanoporous silicas for the immobilization of penicillin acylase, Applied Surface Science 237, 398-404.

[92] Ren, L., He, J., Zhang, S., Evans, D.G., Duan, X. (2002) Immobilization of penicillin $\mathrm{G}$ acylase in layered double hydroxides pillared by glutamate ions, Journal of Molecular Catalysis B: Enzymatic 18, 3-11.

[93] Ren, L., He, J., Evans, D.G., Duan, X., Ma, R. (2001) Some factors affecting the immobilization of penicillin $\mathrm{G}$ acylase on calcined layered double hydroxides, Journal of Molecular catalysis B: Enzymatic, 16, 65-71.

[94] He, J., Li, X., Evans, D.G., Duan, X., Li, C. (2000) A new support for the immobilization of penicillin acylase, Journal of Molecular Catalysis B: Enzymatic 11, 45-53.

[95] van Langen, L.M., Janssen, M.H.A., Oosthoek, N.H.P., Pereira, S.R.M., Švedas, V.K., Rantwijk, F.V., Sheldon, R.A. (2002) Active Site Titration as a Tool for the Evaluation of Immobilization Procedures of Penicillin Acylase, Biotechnology and Bioengineering, 79, 224-228.

[96] Rohm GmbH, Immobilisation of Enzymes on Eupergit C and Eupergit C $250 \mathrm{~L}$, Eupergit Information Sheet, Document code INFO EP 3/E, 1995. 
[97] Katchalski-Katzir, E., Kraemer, D.M. (2000) Eupergit C: A Carrier for immobilization of enzymes of industrial potential. Journal of Molecular Catalysis B: Enzymatic, 10, 157-176.

[98] Janssen, M.H.A., van Langen, L.M., Pereira, S.R.M., van Rantwijk, F., Sheldon, R.A. (2002) Evaluation of the performance of immobilized penicillin $G$ acylase using active-site titration, Biotechnology and Bioengineering, 78, 425-432.

[99] Mateo, C., Fernandez-Lorente, G., Abian, O., Fernandez-Lafuente, R., Guisan, J.M. (2000) Multifunctional Epoxy Supports: A New Tool To Improve the Covalent Immobilization of Proteins. The Promotion of Physical Adsorptions of Proteins on the Supports before Their Covalent Linkage, Biomacromolecules, 1, 739-745.

[100] Kramer, D. M., Lehmann, K., Pennewiss, H., Plainer, H. (1979) Oxirane acrylic beads for protein immobilization: a novel matrix for biocatalysis and biospecific adsorption, $26^{\text {th }}$ International IUPAC Symposium on macromolecules.

[101] van der Wielen, L.A.M., van Buel, M.J., Straathof, A.J.J., Luyben, K.Ch.A.M. (1997) Modelling the enzymatic deacylation of penicillin G: Equilibrium and kinetic considerations, Biocatalysis and Biotransformation, 15, 121-146.

[102] Spieß, A., Schlothauer, R.-C., Hinrichs, J., Scheidat, B., Kasche, V. (1999) pH Gradients in Immobilized Amidases and Their Influence on Rates and Yields of $\beta$ Lactam Hydrolysis, Biotechnology and Bioengineering, 62, 267-277.

[103] Spieß, A., Kasche, V. (2001) Direct Measurement of pH Profiles in Immobilized Enzyme Carriers during Kinetically Controlled Synthesis Using CLSM, Biotechnology Progress, 17, 294-303.

[104] Reklamni materijal Sepabeads, Mitsubishi Chemical Corporation [105] Mateo, C., Abian, O., Fernandez-Lorente, G., Pedroche, J., Fernandez-Lafuente, R., Guisan, J.M. (2002) Epoxy sepabeads: A novel epoxy support for stabilization of industrial enzymes via very intense multipoint covalent attachment, Biotechnology progress, 18, 629-634.

[106] Bianchi, D., Golini, P., Bortolo, R., Cesti, P. (1996) Immobilization of penicillin $\mathrm{G}$ acylase on aminoalkylated polyacrylic supports, Enzyme and Microbial Technology, $18,592-596$. 
[107] Guisan, J. M. (1988) Aldehyde-agarose gels as activated supports for immobilization-stabilization of enzymes, Enzyme and Microbial Technology, 10, 375 382.

[108] Fernandez-Lafuente, R., Rosell, C.M., Alvaro, G., Guisan, J.M. (1992) Additional stabilization of penicillin $\mathrm{G}$ acylase-agarose derivatives by controlled chemical modification with formaldehyde, Enzyme and Microbial Technology 14, 489495.

[109] Fernandez-Lafuente, R., Rosell, C.M., Caanan-Haden, L., Rodes, L., Guisan, J.M. (1999) Facile synthesis of artificial enzyme nano-environments via solid-phase chemistry of immobilized derivatives: Dramatic stabilization of penicillin acylase versus organic solvents, Enzyme and Microbial Technology, 24, 96-103.

[110] Guisan, J.M., Rodriguez, V., Rosell, C. M., Soler, G., Bastida, A., FernandezLafuente, R., in: Immobilization of Enzymes and Cells (Ed.: G. F. Bickerstaff), Humana Press, Totowa, 1997, 777-779.

[111] Norouzian, D., Javadpour, S., Moazami, N., Akbarzadeh, A. (2002) Immobilization of whole cell penicillin $\mathrm{G}$ acylase in open pore gelatin matrix, Enzyme and Microbial Technology, 30, 26-29.

[112] Rodrigues, D. S., Mendesa, A. A., Adriano, W. S., Goncalves, L.R.B., Giordano, R.L.C. (2008) Multipoint covalent immobilization of microbial lipase on chitosan and agarose activated by different methods, Journal of Molecular Catalysis B: Enzymatic, $51,100-109$.

[113] Krajewska, B. (2004) Application of chitin- and chitosan-based materials for enzyme immobilizations: a review, Enzyme and Microbial Technology, 35, 126-139.

[114] Majeti, N., Kumar, R.V. (2000) A review of chitin and chitosan applications, Reactive and Functional Polymers, 46, 1-27.

[115] Meera, G., Abraham, T.E. (2006) Polyionic hydrocolloids for the intestinal delivery of protein drugs: Alginate and chitosan-a review, Journal of Controlled Release, 114, 1-14.

[116] Guibal, E. (2005) Heterogeneous catalysis on chitosan-based materials: a review, Progress in Polymer Science, 30, 71-109.

[117] Harder, A., de Haan, B. R., van der Plaat, J.B. (1988) (Gist-brocades B. V.), European Patent 222462, Chemical Abstracts, 108, 93124e. 
[118] Kulhanek, M., Tadra, M. (1968) Products of acylase and $\beta$-Lactamase hydrolysis of some penicillins, Folia Microbiologica, 13, 340-345.

[119] Verhaert, R.M.D., van der Laan, J.M., van Duin, J., Quax, W.J. (1997) Molecular cloning and analysis of the gene encoding the thermostable penicillin $\mathrm{G}$ acylase from Alcaligenes faecalis, Applied and Environmental Microbiology, 63, 3412-3418. [120] E. de Vroom (1997) (Gist-brocades B. V.), Patent WO 9704086, Chemical Abstracts, 126, 183181x.

[121] Van Roon, J. L., Joerink, M., Rijkers, M.P.W.M., Tramper, J., Schroen, C.G.P.H., Beeftink, H.H. (2003) Enzyme distribution derived from macroscopic particle behavior of an industrial immobilized penicillin- $G$ acylase, Biotechnology Progress, 19, 1510-1518.

[122] Van Roon, J.L., Groenedijk, E., Kieft, H., Schroen, C.G.P.H., Tramper, J., Beeftink, H.H. (2005) Novel approach to quantify immobilized-enzyme distributions, Biotechnology and Bioengineering, 89, 660-669.

[123] Bruggink, A., Roos, E.C., de Vroom, E. (1998) Penicillin Acylase in the Industrial Production of $\beta$-Lactam Antibiotics, Organic Process Research and Development, 2, 128-133.

[124] Schroen, C.G.P.H., Fretz, C.B., De Bruin, V.H., Berendsen, W., Moody, H.M., Roos, E.C., Van Roon, J.L., Kroon, P.J., Strubel, M., Janssen, A.E.M., Tramper, J. (2002) Modelling of the enzymatic kinetically controlled synthesis of cephalexin: Influence of diffusion limitation, Biotechnology and Bioengineering, 80, 331-340. [125] Saleemuddin, M., Husain, Q. (1991) Concanavalin A: A useful ligand for glycoenzyme immobilization-A review, Enzyme and Microbial Technology, 13, 290295.

[126] Saleemuddin, M. (1999) Bioaffinity based immobilization of enzymes, Advances in Biochemical Engineering/Biotechnology, 64, 203-226.

[127] Mislovičova, D., Masarova, J., Vikartovska, A., Gemeiner, P., Michalkova, E. (2004) Biospecific immobilization of mannan-penicillin G acylase neoglycoenzyme on Concanavalin A-bead cellulose, Journal of Biotechnology, 110, 11-19.

[128] de Lathouder, K.M., Bakker, J., Kreutzer, M.T., Kapteijn, F., Moulijn, J. A., Wallin, S. A. (2004) Structured reactors for enzyme immobilization: advantages of tuning the wall morphology, Chemical Engineering Science, 59, 5027-5033. 
[129] Calleri, E., Massolini, G., Lubda, D., Temporini, C., Loiodice, F., Caccialanza, G. (2004) Evaluation of a monolithic epoxy silica support for penicillin G acylase immobilization, Journal of Chromatography, 1031, 93-100.

[130] Calleri, E., Temporini, C., Massolini, G., Caccialanza, G. (2004) Penicillin G acylase-based stationary phases: analytical applications, Journal of pharmaceutical and biomedical analysis, 35, 243-258.

[131] Basso, A., de Martin, L., Ebert, C., Gardossi, L., Linda, P., Sibilla, F. (2003) Organically modified xerogels as novel tailor-made supports for covalent immobilisation of enzymes (penicillin G acylase), Tetrahedron Letters, 44, 5889-5891. [132] Reetz, M.T. (1997) Entrapment of Biocatalysts in Hydrophobic Sol-Gel Materials for Use in Organic Chemistry, Advanced Materials, 9, 943-954.

[133] Basso, A., de Martin, L., Ebert, C., Gardossi, L., Tomat, A., Casarci, M., Rosi, O. L. (2000) A novel support for enzyme adsorption: properties and application of aerogels in low water media, Tetrahedron Letters, 41, 8627-8630.

[134] Corma, A., Fornes, V., Rey, F. (2002) Delaminated Zeolites: An Efficient support fot Enzymes, Advanced Materials, 14, 71-74.

[135] Corma, A., Diaz, U., Domine, M.E., Fornes, V. (2000) New Aluminosilicate and Titanosilicate Delaminated Materials Active for Acid Catalysis and Oxidation Reactions Using $\mathrm{H}_{2} \mathrm{O}_{2}$, Journal of the American Chemical Society, 122, 2804-2809.

[136] Corma, A., Fornes, V., Jorda, J.L., Rey, F., Fernandez-Lafuente, R., Guisan, J.M., Mateo, C. (2001) Electrostatic and covalent immobilisation of enzymes on ITQ-6 delaminated zeolitic materials, Chemical Communications 419-420

[137] Phadtare, S., Parekh, P., Gole, A., Patil, M., Pundle, A., Prabhune, A., Sastry, M. (2002) Penicillin G Acylase-Fatty Lipid Biocomposite Films Show Excellent Catalytic Activity and Long Term Stability/Reusability, Biotechnology Progress, 18, 483-488.

[138] Cao, L., van Langen, L., Sheldon, R.A. (2003) Immobilised enzymes: carrierbound or carrier-free?, Current Opinion in Biotechnology, 14, 387-394.

[139] Quiocho, F.A., Richards, F.M. (1964) Intermolecular cross linking of a protein in the crystalline state: carboxypeptidase-A Proceedings of the National Academy of Sciences of the United States of America, 52, 833-839.

[140] Clair, N.L.S., Navia, M.A. (1992) Cross-linked Enzyme Crystals as Robust Biocatalysts, Journal of American Chemical Society, 114, 7314-7316. 
[141] Clair, N.L.S., Navia, M.A, (1992) (Vertex Pharmaceuticals, Inc.), Patent WO 9202617, Chemical Abstracts, 116, 230759x

[142] Lee, T.S., Turner, M.K., Lye, G.J. (2002) Mechanical Stability of Immobilized Biocatalysts (CLECs) in Dilute Agitated Suspensions, Biotechnology Progress, 18, 43 50 .

[143] Govardhan, C. (1999) Crosslinking of enzymes for improved stability and performance, Current Opinion in Biotechnology, 10, 331-335.

[144] Sobolov, S. B., Bartoszko-Malik, A., Oeschger, T., Montelbans, M. (1994) Cross-Linked Enzyme Crystals of Fructose Diphosphate Aldolase: Development as a Biocatalyst for Synthesis, Tetrahedron Letters, 35, 7751-7754.

[145] Navia, M.A., Clair, N.L.S., Griffith, J.P. (1993) Cross-Linked Enzyme Crystals (CLECs) as Immobilised Enzyme Particles. In Stability and Stabilisation of Enzymes; Van den Tweel, W.J., Harder, A., Buiteclear, R.M., Eds.; Elsevier: New York, 63-72.

[146] Brown, D.L., Glatz C.E. (1987) Aggregate breakage in protein precipitation, Chemical Engeenering Science, 42, 1831-1839.

[147] Rothstein, F. (1994) In Protein Purification Process Engineering; Harrison, R. G., Ed.; Marcel Dekker, Inc.: New York, 115-208.

[148] Cao, L., Van Rantwijk, F., Sheldon, R.A. (2000) Cross-Linked Enzyme Aggregates: A Simple and Effective Method for the Immobilization of Penicillin Acylase, Organic Letters, 2, 1361-1364.

[149] Cao, L., Van Langen, L.M., Van Rantwijk, F., Sheldon, R.A. (2001) Cross-linked aggregates of penicillin acylase: robust catalysts for the synthesis of $\beta$-lactam antibiotics, Journal of Molecular Catalysis B: Enzymatic 11, 665-670.

[150] Van Langen, L.M., Oosthoek, N.H.P., Van Rantwijk, F., Sheldon, R.A. (2003) Penicillin Acylase Catalysed Synthesis of Ampicillin in Hydrophilic Organic Solvents, Advanced Synthesis and Catalysis, 345, 797-801.

[151] de Martin, L., Ebert, C., Garau, G., Gardossi, L., Linda, P. (1999) Penicillin G amidase in low-water media: immobilisation and control of water activity by means of celite rods, Journal of Molecular Catalysis B: Enzymatic, 6, 437-445.

[152] Sheldon, R.A., Schoevaart, R., van Langen, L.M. (2003) CLEAs: An effective technique for enzyme immobilisation Speciality Chemicals Magazine, 40-42 (ISSN 0262-2262, DMG World Media) 
[153] Schoevaart, R., Wolbers, M.W., Golubovic, M., Ottens, M., Kieboom, A.P.G., van Rantwijk, F., van der Wielen, L.A.M.R., Sheldon, A. (2004) Preparation, Optimization, and Structures of Cross-Linked Enzyme Aggregates (CLEAs), Biotechnology and Bioengineering, 87, 754-762.

[154] Mateo, C., Palomo, J.M., Van Langen, L.M., Van Rantwijk, F., Sheldon, R.A. (2004) A new, mild cross-linking methodology to prepare cross-linked enzyme aggregates, Biotechnology and Bioengineering, 86, 273-276.

[155] Guan, Y.H., Lilley, T.H., Brook, A.H. (2001) Production of immobilized penicillin acylase using aqueous polymer systems for enzyme purification and in situ immobilization, Enzyme and Microbial Technology, 28, 218-224.

[156] Ivanov, A.E., Edink, E., Kumar, A., Galaev, I.Y., Arendsen, A.F., Bruggink, A., Mattiasson, B. (2003) Conjugation of Penicillin Acylase with the Reactive Copolymer of N-isopropylacrylamide: A step Toward a Thermosensitive Industrial Biocatalyst, Biotechnology Progress, 19, 1167-1175.

[157] http://www.magneticmicrosphere.com

[158] Wang, W., Deng, L., Peng, Z. H., Xiao, X. (2007) Study of epoxydized magnetic hydroxyl particles as a carrier for immobilizing penicillin $G$ acylase, Enzyme and Microbial Technology 40, 255-261.

[159] Bozhinova, D., Galunsky, B., Yueping, G., Frazreb, M., Koster, R., Kasche, V. (2004) Evaluation of magnetic polymer micro-beads as carriers of immobilised biocatalysts for selective and stereoselective transformations, Biotechnology Letters, $26,343-350$.

[160] Schroen, C.G.P.H., Mohy Eldin, M.S., Janssen, A.E.M.G., Mita, D., Tramper, J. (2001) Cephalexin synthesis by immobilised penicillin G acylase under non-isothermal conditions: reduction of diffusion limitation, Journal of Molecular catalysis B: Enzymatic, 15, 163-172.

[161] Eldin, M.S.M., Schroen, C.G.P.H., Jansen, A.E.M., Mita, D.G., Tramper, J. (2000) Immobilization of penicillin G acylase onto chemically grafted nylon particles, Journal of Molecular Catalysis B: Enzymatic, 10, 445-451.

[162] Travascio, P., Zito, O., De Maio, A., Schroen, C.G.P.H., Durante, D., De Luca, P., Bencivenga, U., Mita, D.G. (2002) Advantages of using non-isothermal bioreactors 
for the enzymatic synthesis of antibiotics: The penicillin $\mathrm{G}$ acylase as enzyme model, Biotechnology and Bioengineering, 79, 334-346.

[163] Pribyl, M., Chmelikova, R., Hasal, P., Marek, M. (2003) Penicillin G hydrolysis in an electro-membrane reactor with immobilized penicillin G acylase, Enzyme and Microbial Technology, 33, 793-801.

[164] Zadražil, A., Chmelikova, R., Hasal, P. (2003) Continuous penicillin G hydrolysis in an electro-membrane reactor with immobilized penicillin $G$ acylase, Biotechnology Letters, 25, 485-490.

[165] Obradović, B., Nedović, A.V., Bugarski, B., Willaert, G.R, Vunjak Novaković, G. (2004) Immobilised Cell Bioreactors, Fundamentals of Cell Immobilisation Biotechnology, Kluwer Academic Publishers, 411-436.

[166] Penalva, M.A., Rowlands, R.T., Turner, G. (1998) The optimization of penicillin biosynthesis in fungi, Trends in Biotechnology, 16, 483-489.

[167] Valle, F., Balbas, P., Merino, E., Bolivar, F. (1991) The role of penicillin amidases in nature and in industry, Trends in Biochemical Sciences, 16, 36-40.

[168] Elander, R.P. (2003) Industrial production of $\beta$-lactam antibiotics, Applied Microbiology and Biotechnology, 61, 385-392.

[169] Bruggink, A., Roy, P.D. (2001) Industrial synthesis of semi-synthetic antibiotics. In: A. Bruggink, editor. Synthesis of $\beta$-lactam antibiotics. Dordrecht: Kluwer;. 12-54. [170] Ospina, S., Barzana, E., Ramirez, O.T., Lopez-Munguia, A. (1996) Effect of pH in the synthesis of ampicillin by penicillin acylase, Enzyme and Microbial Technology, $19,462-469$.

[171] Youshko, M.I., Langen, L.M., Vroom, E., Rantwijk, F., Sheldon, R.A., Svedas, V. K. (2002) Penicillin acylase catalyzed ampicillin synthesis using a pH gradient: a new approach to optimization, Biotechnology and Bioengineering, 78, 589-593.

[172] Fernandez-Lafuente, R., Rosell, C.M., Piatkowska, B., Guisan, J.M. (1996) Synthesis of antibiotics (cephaloglycin) catalyzed by penicillin G acylase: Evaluation and optimization of different synthetic approaches, Enzyme and Microbial Technology, 19, 9-14.

[173] Kim, M.G., Lee, S.B. (1996) Penicillin acylase-catalyzed synthesis of $\beta$-lactam antibiotics in water-methanol mixtures: effect of cosolvent content and chemical nature 
of substrate on reaction rates and yields, Journal of Molecular Catalysis B: Enzymatic, $1,201-211$.

[174] Cao, L., van Langen, L.M., Van Rantwijk, F., Sheldon, R.A. (2001) Cross-linked aggregates of penicillin acylase: robust catalysts for the synthesis of $\beta$-lactam antibiotics, Journal of Molecular Catalysis B: Enzymatic, 11, 665-670.

[175] Schroen, C.G.P.H., Nierstrasz, V.A., Bosma, R., Dijskstra, Z.J., Vandesandt, E.J.A-X., Beeftink, H.H., Tramper, J. (2002) Process design for adipyl-7-ADCA hydrolysis, Biotechnology Progress, 18, 745-751.

[176] Van Langen, L.M., de Vroom, E., van Rantwijk, F., Sheldon, R. (1999) Enzymatic synthesis of $\beta$-lactam antibiotics using penicillin $\mathrm{G}$ acylase in frozen media, Federation of European of Biochemical Societies Letters 456, 89-92.

[177] Svedas, V.K., Margolin, A.L., Borisov, I.L., Berezin, I.V. (1980) Kinetics of enzymatic synthesis of benzylpenicillin, Enzyme and Microbial Technology, 2, 313317.

[178] Blinkovsky, A.M., Markaryan A.N. (1993) Synthesis of $\beta$-lactam antibiotics containing $\alpha$-aminophenylacetyl group in the acyl moiety catalyzed by $\mathrm{D}(-)$ phenylglycyl- $\beta$-lactamide amidohydrolase, Enzyme and Microbial Technology, 15, 965-973.

[179] Schroen, C.G.P.H., Nierstrasz, V.A., Kroon, P.J., Bosma, R., Janssen, A.E.M., Beeftink, H.H.E., Tramper, J. (1999) Thermodynamically controlled synthesis of $\beta$ lactam antibiotics Equilibrium concentrations and side-chain properties, Enzyme and Microbial Technology, 24, 498-506.

[180] Fernandez-Lafuente, R., Rosell, C. M., Guisan, J. M. (1998) The presence of methanol exerts a strong and complex modulation of the synthesis of different antibiotics by immobilized Penicillin G acylase, Enzyme and Microbial Technology, $23,305-310$.

[181] Fernandez-Lafuente, R., Rossel, C.M., Guisan, J.M. (1991) Enzyme reaction engineering: synthesis of antibiotics catalyzed by stabilized penicillin $\mathrm{G}$ acylase in the presence of organic cosolvents, Enzyme and Microbial Technology, 13, 898-905.

[182] Fernandez-Lafuente, R., Rossel, C.M., Guisan, J.M. (1995) The use of stabilized penicillin acylase derivatives improves the design of kinetically controlled synthesis. Journal of Molecular Catalysis. A: Chemical, 101, 91-97. 
[183] Fernandez-Lafuente, R.F., Rossel, C.M., Guisan, J.M. (1996) Dynamic reaction design of enzymes biotransformations in organic media: equilibrium-controlled synthesis of antibiotics by penicillin G acylase, Biotechnology and Applied Biochemistry, 24, 139-143.

[184] Diender, M.B., Straathof, A.J.J., Van der Wielen, L.A.M.S., Ras, C., Heijnen, J.J. (1998) Feasibility of the thermodynamic controlled synthesis of amoxicillin. Journal of Molecular Catalysis. A: Chemical, 5, 249-253.

[185] Abian, O., Mateo, C., Fernandez-Lorente, G., Palomo, J.M., Fernandez-Lafuente, R., Guisan, J.M. (2001) Stabilization of immobilized enzymes against water-soluble organic cosolvents and generation of hyperhydrophilic micro-environments surrounding enzyme molecules, Biocatalysis and Biotransformation, 19, 489-503.

[186] Abian, O., Wilson, L., Fernandez-Lorente, G., Palomo, J.M., Fuentes, M., Fernandez-Lafuente, R., Guisan, J.M., Re, D., Tam, A., Daminatti, M. (2002) Preparation of hydrophilic microenvironments (polymeric salts) surrounding enzyme molecules New enzyme derivatives to be used in any reaction medium, Journal of Molecular Catalysis B: Enzymatic, 19, 295-303.

[187] Abian, O., Mateo, C., Fernandez-Lorente, G., Guisan, J.M., Fernandez-Lafuente, R. (2004) Thermodinamically controlled synthesis of amide bonds catalyzed by highly organic solvent-resistant penicillin acylase derivatives, Biotechnology Progress, 20,117-121.

[188] Schroen, C.G.P.H., Nierstrasz, V.A., Bosma, R., Kroon, P.J., Tjeerdsma, P.S., Devroom, E., VanderLaan, J.M., Moody, H.M., Beeftink, H.H., Janssen, A.E.M, Tramper, J. (2002) Integrated reactor concepts for the enzymatic kinetic synthesis of cephalexin, Biotechnology and Bioengineering, 80,144-155.

[189] Youshko, M.I., Svedas, V.K. (2000) Kinetics of ampicillin synthesis catalyzed by penicillin $\mathrm{G}$ acylase form $E$. coli in homogeneous and heterogeneous systems Quantitative characterization of nucleophile reactivity and mathematical modeling of the process, Biochemistry Moscow, 65, 367-375.

[190] Youshko, M.I., Langen, L.M., Vroom, E., Rantwijk, F., Sheldon, R.A., Svedas, V.K. (2001) Highly efficient synthesis of ampicillin in "aqueous solution-precipitate" systems: repetitive addition of substrates in a semicontinuous process, Biotechnology and Bioengineering, 73, 426-430. 
[191] Rocchietti, S., Urrutia, A.S.V., Pregnolato, M., Tagliani, A., Guisan, J.M., Fernandez-Lafuente, R., Terreni, M. (2002) Influence of the enzyme derivative preparation and substrate structure on the enantioselectivity of penicillin $G$ acylase, Enzyme and Microbial Technology, 31, 89-93.

[192] Hernandez-Justiz, O., Fernandez-Lafuente, R., Terreni, M., Guisan, J.M. (1998) Use of aqueous two-phase systems for in situ extraction of water soluble antibiotics during their synthesis by enzymes immobilized on porous supports, Biotechnology and Bioengineering, 59, 73-79.

[193] Wei, D-Z., Zhu, J-H., Cao, X-J. (2002) Enzymatic synthesis of cephalexin in aqueous two-phase systems, Biochemical Engineering Journal, 11, 95-99.

[194] Illanes, A., Cabrera, Z., Wilson, L., Aguirre, C. (2003) Synthesis of cephalexin in ethylene glycol with glyoxil-agarose immobilized penicillin acylase: temperature and pH optimization, Process Biochemistry, 39, 111-117.

[195] Illanes, A., Anjari, M.S., Altamirano, C., Aguirre, C. (2004) Optimization of cephalexin synthesis with immobilized penicillin acylase in ethylene glycol medium at low temperatures, Journal of Molecular Catalysis B: Enzymatic, 30, 94-103.

[196] Ribeiro, M.P.A., Ferreira, A.L.O., Giordano, R.L.C., Giordano, R.C., Selectivity of the enzymatic synthesis of ampicillin by E. coli PGA in the presence of high concentrations of substrates, Journal of Molecular Catalysis B: Enzymatic 33 (2005) 81-86.

[197] Youshko, M.I., Chilov, G.G., Scheerbakova, T.A., Svedas, V.K. (2002) Quantitative characterization of the nucleophile reactivity in penicillin acylasecatalyzed acyl transfer reactions, Biochimica et Biophysica Acta-Proteins and Proteomics, 1599, 134-140.

[198] Schroen, C.G.P.H., Nierstrasz, V.A., Moody, H.M., Hoogschagen, H.M., Kroon, O.J., Bosma, R., Beeftink, H.H., Janssen, A.E.M., Tramper, J. (2001) Modeling of the Enzymatic Kinetic Synthesis of Cephalexin-Influence of Substrate Concentration and Temperature, Biotechnology and Bioengineering, 73, 171-178.

[199] Alkema, W.B.L., de Vries, E., Floris, R., Janssen, D.B. (2003) Kinetics of enzyme acylation and deacylation in the penicillin acylase-catalyzed synthesis of $\beta$ lactam antibiotics, European Journal of Biochemistry, 270, 3675-3683. 
[200] Goncalves, L.R.B., Fernandez-Lafuente, R., Guisan, J.M., Giordano, R.L.C. (2000) A Kinetic Study of Synthesis of Amoxicillin Using Penicillin G Acylase Immobilized on Agarose, Applied Biochemistry and Biotechnology, 84-86, 931-945. [201] Goncalves, L.R.B., Fernandez-Lafuente, R., Guisan, J.M., Giordano, R.L.C. (2003) Inhibitory effects in the side reactions occurring during the enzymatic synthesis of amoxicillin: p-hydroxyphenylglycine methyl ester and amoxicillin hydrolysis, Biotechnology and Applied Biochemistry, 38, 77-85.

[202] Goncalves, L.R.B., Fernandez-Lafuente, R., Guisan, J.M., Giordano, R.L.C. (2002) The role of 6-aminopenicillanic acid on the kinetics of amoxicillin enzymatic synthesis catalyzed by penicillin $\mathrm{G}$ acylase immobilized onto glyoxyl-agarose, Enzyme and Microbial Technology, 31, 464-471.

[203] Kasche, V. (1986) Mechanism and yields in enzyme catalysed equilibrium and kinetically controlled synthesis of $\beta$-lactam antibiotics, peptides and other condensation products, Enzyme and Microbial Technology, 8, 4-16.

[204] Goncalves, L.R.B., Sousa, R.J., Fernandez-Lafuente, R., Guisan, J.M., Giordano, R.L.C., Giordano, R.C. (2002) Enzymatic Synthesis of Amoxicillin Avoiding Limitations of the Mechanistic Approach for Reaction Kinetics, Biotechnology and Bioengineering, 80, 622-631.

[205] Youshko, M.I., Van Langen, L.M., de Vroom, E., Moody, H.M., Rantwijk, F., Sheldon, R.A., Švedas, V.K. (2000) Penicillin acylase-catalyzed synthesis of ampicillin in ,aqueous solution-precipitate“ systems. High substrate concentration and supersaturation effect, Journal of Molecular Catalysis B: Enzymatic, 10, 509-515.

[206] Lowry, O.H., Rosebrough, N.J., Farr, A.L., Randall, R.J. (1951) Protein measurement with the folin phenol reagent, Journal of Biological Chemistry, 193, 265 275.

[207] Shewale, J.G., Kumar, K.K., Ambekar, G.R. (1987) Evaluation of 6aminopenicillanic acid by p-dimethylaminobenzaldehyde, Biotechnology Techniques, 1, 69-72.

[208] Žuža, M., Milosavić, N., Knežević-Jugović, Z. (2009) Immobilization of modified penicillin G acylase on Sepabeads carriers, Chemical Papers, 63 (2), 117-124. 
[209] Dubois, M., Gilles, K. A., Hamilton, J. K., Rebers, P. A., Smith, F. (1956). Colorimetric method for determination of sugars and related substances, Analytical Chemistry, 28, 350-356.

[210] van Roon, J.L., Joerink, M., Rijkers, M.P.W.M., Tramper, J., Schroen, C.G.P.H., Beeftink, H.H. (2003) Enzyme Distribution Derived from Macroscopic Particle Behavior of an Industrial Immobilized Penicillin-G Acylase, Biotechnology Progress, $19,1510-1518$.

[211] Wang, A., Zhou, C., Du, Z., Liu, M., Zhu, S., Shen, S., Ouyang, P. (2009) Enhancement of microwave-assisted covalent immobilization of penicillin acylase using macromolecular crowding and glycine quenching, Journal of Bioscience and Bioengineering, 107, 219-224.

[212] Eldin, M.S.M., Santucci, M., Rossi, S., Bencivenga, U., Canciglia, P., Gaeta, F.S., Tramper, J., Janssen, A.E.M., Schroen, C.G.P.H., Mita, D.G. (2000) Nonisothermal cephalexin hydrolysis by penicillin $\mathrm{G}$ acylase immobilized on grafted nylon membranes, Journal of Molecular Catalysis B: Enzymatic, 8, 221-232.

[213] Shah, P., Sridevi, N., Prabhune, A., Ramaswamy, V. (2008) Structural features of Penicillin acylase adsorption on APTES functionalized SBA-15, Microporous and Mesoporous Materials, 116, 157-165.

[214] Savidge, T.A., Cole, M. (1975) Penicillin-acylase (bacterial), Methods in Enzymology, 43, 705-721.

[215] Hilterhaus, L., Minow, B., Muller, J., Berheide, M., Quitmann, H., Katzer, M., Thum, O., Antranikian, G., Zeng, A.P., Liese, A. (2008) Practical application of different enzymes immobilized on sepabeads, Bioprocess and Biosystem Engineering $31,163-171$.

[216] Prlainović, N.Ž., Knežević-Jugović, Z.D., Mijin, D.Ž., Bezbradica, D.I. (2011) Immobilization of lipase from Candida rugosa on Sepabeads: the effect of lipase oxidation by periodates, Bioprocess and Biosystems Engineering, 34 (7), 803-810.

[217] Ghazi, I., De Segura, A.G., Fernandez-Arrojo, L., Alcalde, M., Yates, M., RojasCervantes, M.L., Plou, Ballesteros, A. (2005) Immobilisation of fructosyltransferase from Aspergillus aculeatus on epoxy-activated Sepabeads EC for the synthesis of fructo-oligosaccharides, Journal of Molecular Catalysis B: Enzymatic, 35, 19-27. 
[218] Dib, I., Nidetzky, B. (2008) The stabilizing effects of immobilization in D-amino acid oxidase from Trigonopsis variabilis, BMC Biotechnology, 8 (72) 1-11.

[219] Hormigo, D., Mata, I.D.L., Castillon, M.P., Acebal, C., Arroyo, M. (2009) Kinetic and microstructural characterization of immobilied penicillin acylase from Streptomyces lavendulae on Sepabeads EC-EP, Biocatalysis and biotransformation, 27 (4), 271-281.

[220] Celem, E.B., Önal, S. (2009) Immobilization of phytase on epoxy-activated Sepabead EC-EP for the hydrolysis of soymilk phytate, Journal of Molecular Catalysis B: Enzymatic, 61, 150-156.

[221] Konst, P. M., Franssen, M.C.R., Scott, E.L., Sanders, J:P.M. (2009) A study on the applicability of L-aspartate a-decarboxylase in the biobased production of nitrogen containing chemicals, Green Chemistry, 11, 1646-1652.

[222] Cerdobbel, A., Desmet, T., Winter, K.D., Maertens, J., Soetaert, W. (2010) Increasing the thermostability of sucrose phosphorylase by multipoint covalent immobilization, Journal of Biotechnology 150, 125-130.

[223] Ahmed, K.S.O.H, Milosavić, N.B., Popović, M.M., Prodanović, R.M., Knežević, Z.D., Jankov, R.M. (2007) Preparation and studies on immobilized $\alpha$-glucosidase from beaker's yeast Saccharomyces cerevisiae, Journal of Serbian Chemical Society, 72 (12) 1255-1263.

[224] Gómez, L., Ramírez, H.L., Villalonga, R. (2001) Modification of $\alpha$-amylase by sodium alginate, Acta Biotechnologica, 21(3), 265-273.

[225] Darias, R., Villalonga, R. (2001) Functional stabilization of cellulase by covalent modification with chitosan, Journal of Chemical Technology and Biotechnology, 76, 489-493.

[226] Darias, R., Herrera, I., Fragoso, A., Cao, R., Villalonga, R. (2002) Supramolecular interactions mediated thermal stabilization for $\alpha$-amylase modified with a $\beta$-cyclodextrin-carboxymethylcellulose polymer, Biotechnology Letters, 24, $1665-1668$.

[227] Gomez, L., Villalonga, R. (2000) Functional stabilization of invertase by covalent modification with pectin, Biotechnology Letters, 22, 1191-1195. 
[228] Valdivia, A., Perez, Y., Dominguez, A., Caballero, J., Hernandez, Y., Villalonga, R. (2006) Improved pharmacological properties for superoxide dismutase modified with mannan, Biotechnology and Applied Biochemistry, 44, 159-165.

[229] Fernández, M., Fragoso, A., Cao, R., Villalonga, R. (2003) Improved functional properties of trypsin modified by monosubstituted amino- $\beta$-cyclodextrins, Journal of Molecular Catalysis B: Enzymatic, 21, 133-141.

[230] Villalonga, R., Fernandez, M., Fragoso, A., Cao, R., Mariniello, L., Porta, R. (2003) Thermal stabilization of trypsin by enzymic modification with $\beta$-cyclodextrin derivatives, Biotechnology and Applied Biochemistry, 38, 53-59.

[231] Gomez, L., Ramýrez H.L., Villalonga, R. (2000) Stabilization of invertase by modification of sugar chains with chitosan, Biotechnology Letters 22, 347-350.

[232] Gomez, L., Ramýrez, H.L., Villalonga, M.L., Hernandez, J., Villalonga, R. (2006) Immobilization of chitosan-modified invertase on alginate-coated chitin support via polyelectrolyte complex formation, Enzyme and Microbial Technology, 38, 22-27. [233] Knezevic, Z., Milosavic, N., Bezbradica, D., Jakovljevic, Z., Prodanovic, R. (2006) Immobilization of lipase from Candida rugosa on Eupergit ${ }^{\circledR}$ C supports by covalent attachment, Biochemical Engineering Journal, 30, 269-278.

[234] Prodanović, R., Jovanović, S., Vujičić, Z. (2001) Immobilization of invertase on a new type of macroporous glycidyl methacrylate, Biotechnology Letters, 23, 11711174 .

[235] Prodanović, R.M., Simić, M.B., Vujičić, Z.M. (2003) Immobilization of periodate oxidized invertase by adsorption on Sepiolite, Journal of Serbian Cheical Society 68 (11) 819-824.

[236] Mislovičova, D., Masarova, J., Bucko, M., Gemeiner, P. (2006) Stability of penicillin $\mathrm{G}$ acylase modified with various polysaccharides, Enzyme and Microbial Technology, 39, 579-585.

[237] Lathouder, K., Smeltink, M.W., Straathof, A.J.J., Paasman, M.A., Sandt, E.J.A.X., Kapteijn, F., Moulijn, J.A. (2008) Hydrogel coated monoliths for enzymatic hydrolysis of penicillin G, Journal of Industrial Microbiology and Biotechnology, 35, 815-824. 
[238] Adriano, W.S., Filho, E.H.C., Silva, J.A., Goncalves, L.R.B. (2005) Optimization of penicillin $\mathrm{G}$ acylase multipoint immobilization on to glutaraldehyde-chitosan beads, Biotechnology and Applied Biochemistry, 41, 201-207.

[239] Jin, X., Wu, Q., Chen, Q., Chen, C-X., Lin, X-F. (2008) Immobilization of penicillin $\mathrm{G}$ acylase on a composite carrier with a biocompatible microenvironment of chitosan, Journal of Chemical Technology and Biotechnology, 83, 1710-1716.

[240] Zhang, L., Zhu, X., Zheng, S., Sun, H. (2009) Photochemical preparation of magnetic chitosan beads for immobilization of pullulanase, Biochemical Engineering Journal, 46, 83-87.

[241] Wang, A., Wang, H., Zhu, S., Zhou, C., Du, Z., Shen, S. (2008) An efficient immobilizing technique of penicillin acylase with combining mesocellular silica foams support and $p$-benzoquinone cross linker, Bioprocess and Biosystems Engineering, 31, 509-517.

[242] Biró, E., Németh, Á.S., Sisak, C., Feczkó, T., Gyenis, J. (2008) Preparation of chitosan particles suitable for enzyme immobilization, Journal of Biochemical and Biophysical Methods, 70, 1240-1246.

[243] Bryjak, J., Noworyta, A. (1993) Kinetic behavior of penicillin acylase immobilized on acrylic carrier, Bioprocess and Biosystems Engineering, 9, 37-42.

[244] Erarslan, A., Guray, A. (1991) Kinetic investigation of penicillin G acylase from a mutant strain of Escherichia coli ATCC 11105 immobilized on oxirane-acrylic beads, Journal of Chemical Technology and Biotechnology, 51, 181-195.

[245] Lee, S.B., Riu, D.Y. (1982) Reaction kinetics and mechanisms of penicillin amidase: A comparative study by computer simulation, Enzyme and Microbial Technology, 4, 35-38.

[246] Jianguo, L., Wei, C., Shuai, W., Fan, O. (2001) Studies of poly(vinyl acetate-codiviyl benzene) beads as a carrier for the immobilization of penicillin acylase and the kinetics of immobilized penicillin acylase, Reactive and Functional Polymers, 48, 7584.

[247] Ospina, S.S., Munguia, A.L., Gonzalez, R.L., Quintero, R. (1992) Characterization and use of a penicillin acylase biocatalyst, Journal of Chemical Technology and Biotechnology, 53, 205-213. 


\section{PRILOG}

\section{DEO III- REZULTATI I DISKUSIJA}

\section{Poglavlje 7.}

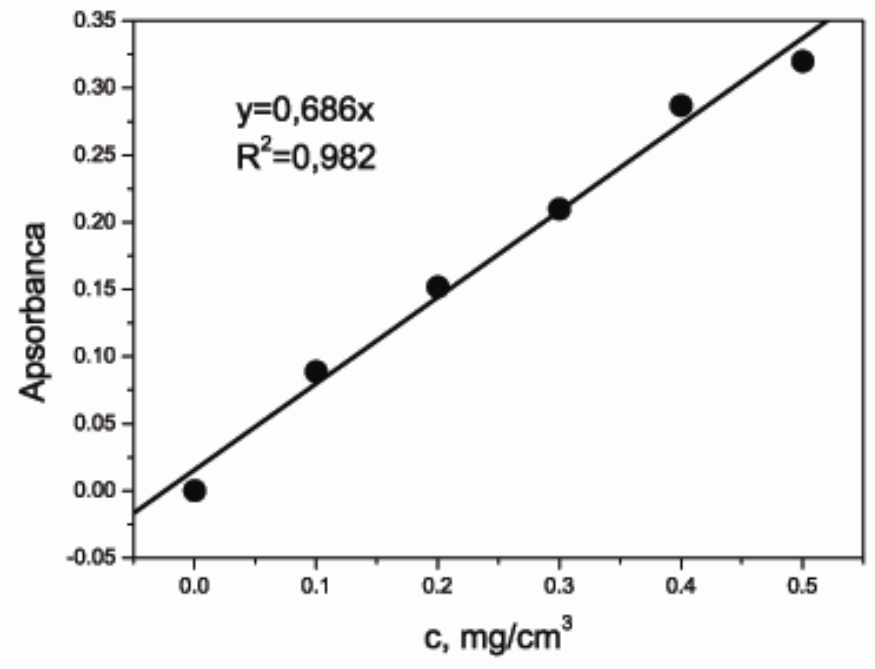

Slika P-7.1. Standardna kriva sadržaja BSA proteina u rastvoru određena metodom po Loriju 


\section{Spisak instrumenata}
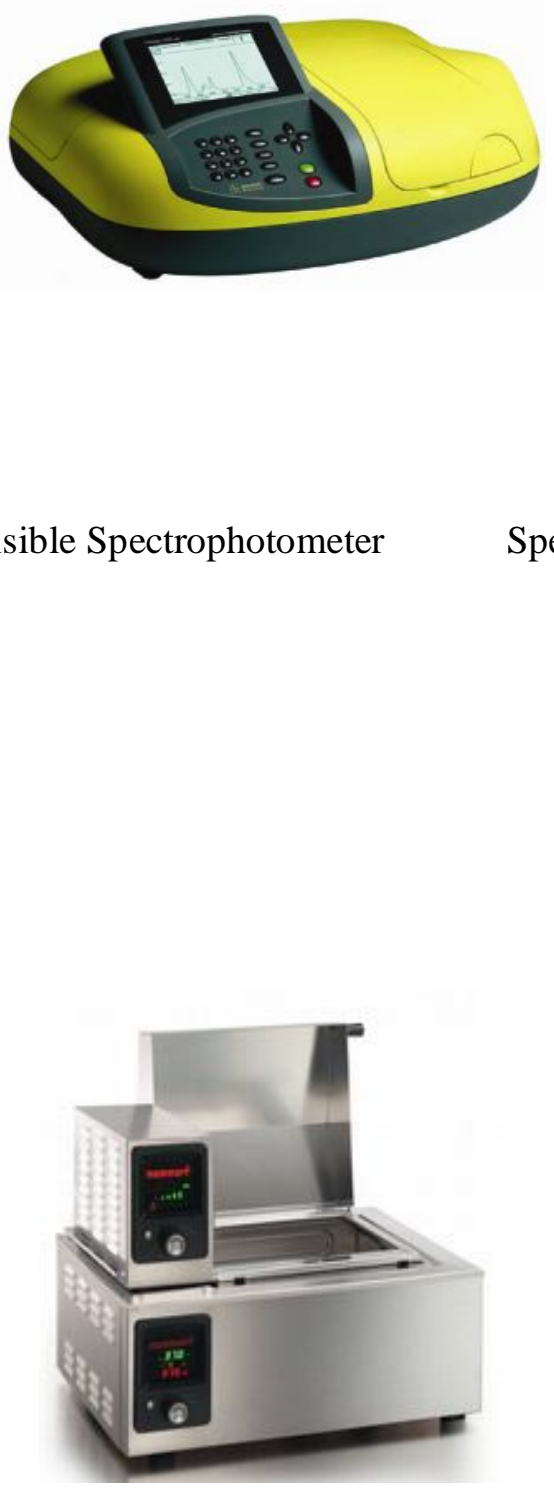


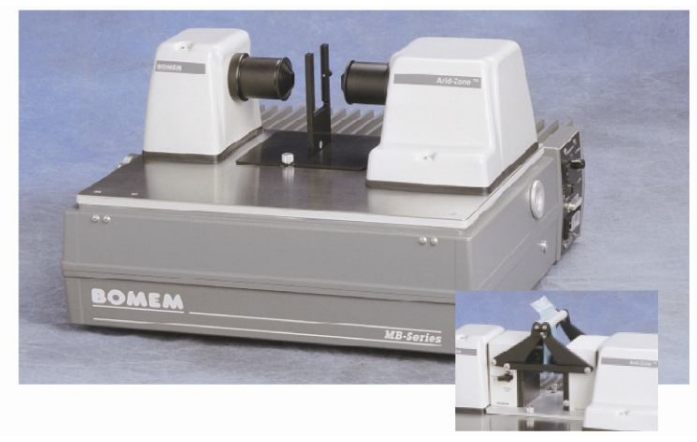

Bomem MB 100

Instrument za FT-IR analizu

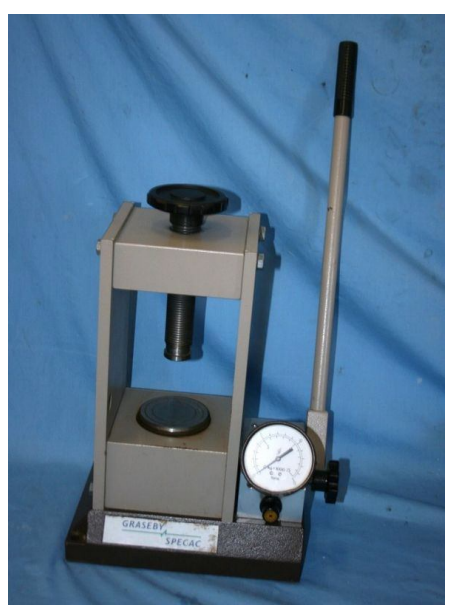

Graseby Specac Model: 15,011 Presa za tabletice za FT-IR analizu 


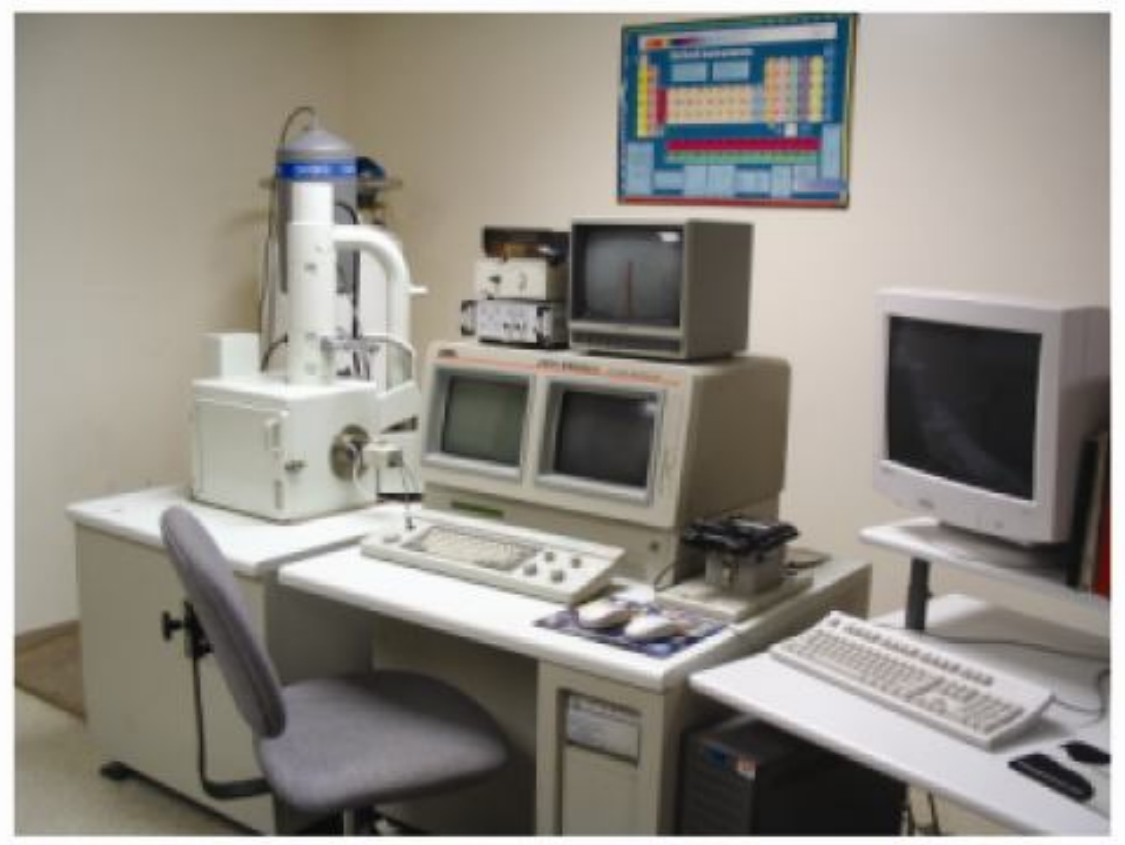

JEOL JMS-5800

Skenirajući elektronski mikroskop 


\section{Biografija autora}

Milena Žuža, diplomirani inženjer tehnologije za biohemijsko inženjerstvo i biotehnologiju, rođena je 20. 11. 1980. godine u Sarajevu. Osnovnu školu „Josif Pančić“" i V beogradsku gimnaziju, prirodno-metematički smer, završila je u Beogradu sa odličnim uspehom. 1999. godine upisala je studije na Tehnološko-metalurškom fakultetu u Beogradu i diplomirala 08.10.2004. godine sa ocenom na diplomskom radu 10 (deset) i prosečnom ocenom u toku studija 9,25.

U toku 2003. godine boravila je na stručnom usavršavanju u Nemačkoj, Institut für Chemische Verfahrenstechnik, TU Clausthal-Zellerfeld. Dobila je Specijalno priznanje za 2005. godinu za izuzetan uspeh u toku studija od Srpskog hemijskog društva, dok je 2001. i 2004. godine dobila Nagradu za najbolje studente u generaciji od Fondacije „Panta S. Tutundžić““.

2004. godine upisala je doktorske studije na TMF-u u Beogradu. Položila je sve ispite doktorskih studija sa prosečnom ocenom 10 (deset). 2008. i 2009. godine pohađala je međunarodne letnje škole "Advanced Biomedical Technologies for Treatment of Osteochondral Defects“ i „Stem Cells and Regenerative Medicine”, u Piranu (Slovenija) i položila je završne ispite ovih škola (4 ECTS). 2011. godine je završila obuku „Priprema projektnih predloga” i kurs „Akademske istraživačke veštine".

Kao stipendista Ministarstva nauke za doktorske studije bila angažovana na projektu „Dodaci hrani dobijeni biotehnološkim putema” (bth 1008) a kao istraživačsaradnik na projektima: „Razvoj biotehnoloških postupaka za proizvodnju aditiva i novih formulacija za prehrambenu industriju“ (TR-20064), „Razvoj novih inkapsulacionih i enzimskih tehnologija za proizvodnju biokatalizatora i biološki aktivnih komponenata hrane u cilju povećanja njene konkurentnosti, kvaliteta $\mathrm{i}$ bezbednosti" (III 46010) i „Development of enzyme processes for production of egg white protein hydrolysates" (Eureka E! 6750). Od školske 2006/2007. godine, angažovana je na izvođenju vežbi iz predmeta: Industrijski enzimski procesi, Farmaceutska biotehnologija, Enzimsko inženjerstvo i Biotehnološki praktimum. 
Прилог 1.

Изјава о ауторству

Потписани-а Милена Жужа

број индекса $\quad$ D $9 / 04$

Изјављујем

да је докторска дисертација под насловом

Развој имобилисаних система са пеницилин-ацилазом из Escherichia coli за добијање полусинтетских пеницилина

- резултат сопственог истраживачког рада,

- да предложена дисертација у целини ни у деловима није била предложена за добијање било које дипломе према студијским програмима других високошколских установа,

- да су резултати коректно наведени и

- да нисам кршио/ла ауторска права и користио интелектуалну својину других лица.

Потпис докторанда

у Београду, 24.05.2012.

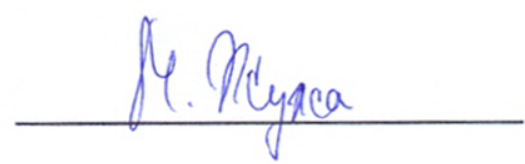




\section{Прилог 2.}

Изјава о истоветности штампане и електронске верзије докторског рада

Име и презиме аутора Број индекса Студијски програм Наслов рада

Ментор
Милена Жужа

D $9 / 04$

Биохемијско инжењерство и биотехнологија Развој имобилисаних система са пеницилин-ацилазом из Escherichia coli за добијање полусинтетских пеницилина

Потписани/а Др Зорица Кнежевић-Југовић, ванредни професор

Изјављујем да је штампана верзија мог докторског рада истоветна електронској верзији коју сам предао/ла за објављивање на порталу Дигиталног репозиторијума Универзитета у Београду.

Дозвољавам да се објаве моји лични подаци везани за добијање академског звања доктора наука, као што су име и презиме, година и место рођења и датум одбране рада.

Ови лични подаци могу се објавити на мрежним страницама дигиталне библиотеке, у електронском каталогу и у публикацијама Универзитета у Београду.

\section{Потпис докторанда}

у Београду, 24.05.2012.

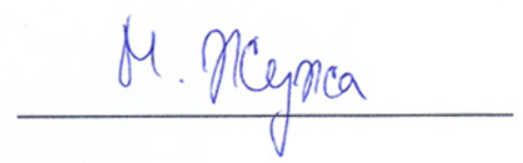




\section{Прилог 3.}

\section{Изјава о коришћењу}

Овлашћујем Универзитетску библиотеку „Светозар Марковић“ да у Дигитални репозиторијум Универзитета у Београду унесе моју докторску дисертацију под насловом:

Развој имобилисаних система са пеницилин-ацилазом из Escherichia coli за добијање полусинтетских пеницилина

која је моје ауторско дело.

Дисертацију са свим прилозима предао/ла сам у електронском формату погодном за трајно архивирање.

Моју докторску дисертацију похрањену у Дигитални репозиторијум Универзитета у Београду могу да користе сви који поштују одредбе садржане у одабраном типу лиценце Креативне заједнице (Creative Commons) за коју сам се одлучио/ла.

1. Ауторство

2. Ауторство - некомерцијално

3. Ауторство - некомерцијално - без прераде

4. Ауторство - некомерцијално - делити под истим условима

5. Ауторство - без прераде

6. Ауторство - делити под истим условима

(Молимо да заокружите само једну од шест понуђених лиценци, кратак опис лиценци дат је на полеђини листа).

Потпис докторанда

У Београду, $24.05 \cdot 2012$.

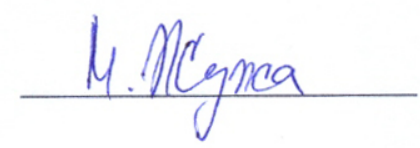

